Antonio Nereu Cavalcanti Filho

Contribuição ao controle tecnológico de concretos estruturais de cimento Portland em ambientes marítimos 
Antonio Nereu Cavalcanti Filho

\title{
Contribuição ao controle tecnológico de concretos estruturais de cimento Portland em ambientes marítimos
}

\author{
Dissertação apresentada à Escola Politécnica da \\ Universidade de São Paulo para obtenção do \\ título de Mestre em Engenharia Civil
}

São Paulo

2010 
Antonio Nereu Cavalcanti Filho

\section{Contribuição ao controle tecnológico de concretos estruturais de cimento Portland em ambientes marítimos}

Dissertação apresentada à Escola Politécnica da Universidade de São Paulo para obtenção do título de Mestre em Engenharia Civil

Área de Concentração:

Engenharia de Construção Civil e Urbana

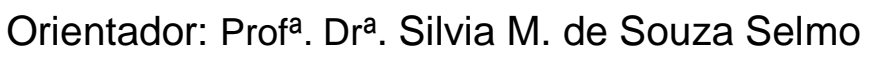


Aos meus queridos pais

"Você deixou seus sonhos para que eu sonhasse.

Derramou lágrimas para que eu fosse feliz.

Você perdeu noites de sono para que eu dormisse tranqüilo.

Acreditou em mim, apesar dos meus erros. Jamais esqueça que eu levarei para sempre um pedaço do seu ser dentro do meu próprio ser."

(Augusto Cury)

Sem vocês este trabalho não seria possível Amo vocês! 


\section{AGRADECIMENTOS}

À Escola Politécnica da Universidade de São Paulo através do Departamento de Engenharia Civil, pela infra-estrutura para obtenção do título de Mestre em Engenharia Civil.

À Coordenação de Aperfeiçoamento de Pessoal de Nível Superior (CAPES), pelo financiamento da bolsa de estudo para o desenvolvimento desta pesquisa.

Ao Centro de Estatística Aplicada (CEA) do IME-USP, pelo suporte estatístico.

Às empresas construtoras Hema e Enger, que apoiaram esta pesquisa.

À todos da Tecncon - Tecnologia do Concreto e Engenharia Ltda., pelo apoio na realização do programa experimental em João Pessoa/PB, em especial a meu tio Achilles, meu irmão Guilherme, Janiélson, Biapino (Sula), José Francisco (Zezo), Israel, Márcio e Klyvia.

À Prof ${ }^{a}$. Dr ${ }^{a}$. Silvia M. de Souza Selmo, pelo apoio em São Paulo, amizade, orientação, ensinamentos, dedicação e seriedade durante esses três anos de convivência.

Aos professores Paulo Helene e Gibson Meira, pela participação no exame de qualificação e contribuições importantes para o desenvolvimento desta dissertação.

Aos professores Maria Alba Cincotto, Selmo Chapira Kuppermann, Antonio Domingues de Figueiredo e Kai Loh Uemoto pelos conhecimentos adquiridos no curso de pós-graduação.

Aos funcionários e colaboradores mais próximos, pela presteza e apoio de alguns afazeres desta pesquisa, em especial à Aline dos Santos, ao Mário e ao Adilson.

À amiga Daniele Cafange, por toda a amizade desde o primeiro dia de pós-graduação, pelo apoio dado nesse período em São Paulo, pelas horas de estudo, pelo auxílio nos ensaios realizados em São Paulo e pelas várias caronas.

Aos amigos do curso de pós-graduação: Waleska, Tais, Gilberto, Sérgio (Serjão) e Tibério.

Aos amigos de apartamento Filipe e Pedro, pelo companheirismo, pelas palavras de apoio nas horas difíceis, pelas conversas na "padoca" e pela grande amizade feita para toda a vida.

Às queridas amigas de João Pessoa, que sempre me deram apoio nessa fase e mesmo com a distância estiveram presentes, Jossuely, Joana, Janayra, Manoela e Sandra.

À minha namorada Adriana, que suportou a saudade e a distância. Esteve sempre ao meu lado nos momentos mais difíceis no decorrer desta dissertação, incentivando e auxiliando a conclusão deste trabalho.

Ao meu irmão Guilherme, fica aqui o meu eterno agradecimento à sua amizade, as dúvidas de inglês tiradas, às conversas, pelo MSN, sobre o mestrado, concreto e principalmente sobre o futuro. Este trabalho também é seu.

À Nereu e Marise, meus amados pais pelo carinho, apoio, compreensão e por serem os melhores professores, pois me ensinam conhecimentos sobre a vida. Vocês foram responsáveis pelos maiores incentivos, garantindo meu equilíbrio emocional para a realização desta dissertação. E por serem exemplo de trabalho, dedicação, perseverança, dignidade e amor. 
CAVALCANTI FILHO, A. N. Contribuição ao controle tecnológico de concretos estruturais de cimento Portland, em ambientes marítimos. 2010. Dissertação (Mestrado) - Escola Politécnica da Universidade de São Paulo, São Paulo, 2010.

\section{RESUMO}

A durabilidade dos edifícios em concreto armado só pode ser alcançada se for atendido um conjunto de requisitos e critérios nas etapas de projeto, execução e manutenção, nas quais os materiais envolvidos precisam ser adequadamente especificados, produzidos e empregados, de acordo com as respectivas rotinas dessas etapas. Assim, o requisito genérico de proteção das armaduras de aço carbono, para a durabilidade de estruturas, é contemplado por vários critérios, desde a etapa de projeto. Esta dissertação trata dos critérios pertinentes à qualidade do concreto e visou contribuir para a evolução de procedimentos para o controle tecnológico de concretos estruturais de cimento Portland, em atmosferas marítimas e urbanas, em clima tropical, com vistas à proteção de armaduras de aço carbono. O programa experimental estudou três lotes diferentes de concretos estruturais, semelhantes quanto a especificações básicas de abatimento: $10 \pm 2 \mathrm{~cm}$, de $\mathrm{f}_{\mathrm{ck}} 30 \mathrm{MPa}$ e para ambiente classe III da NBR 6118 (2003). O objetivo foi caracterizar e analisar a influência de propriedades físicas do estado fresco sobre o estado endurecido de concretos, dentro da faixa de consistência citada, com ênfase nas propriedades relacionadas ao teor de ar das misturas e suas respectivas resistências à carbonatação e ao ingresso de íons cloreto. A amostragem, os ensaios no estado fresco e a moldagem dos corpos-de-prova foram realizados durante três concretagens conduzidas em duas obras de edifícios de múltiplos andares, na cidade de João Pessoa/PB. As composições e a produção dos lotes ficaram a cargo da central dosadora e fornecedora do concreto em cada obra. O lote inicial serviu para o treinamento da equipe, em campo e laboratório, com amostragem de seis caminhões. Os outros dois lotes, identificados como 1 e 2 , foram caracterizados em condições bastante semelhantes, sempre pela mesma equipe, e representados pela amostragem de cinco e seis caminhões, respectivamente. As propriedades medidas no estado fresco foram: abatimento do tronco de cone pela ABNT NBR NM 67 (1998); teor de ar por método pressométrico da ABNT NBR 47 (2002); massa específica pela ABNT NBR 9833 (2008); relação água/materiais secos por analogia à ABNT NBR 9605 (1992); e compactabilidade dos concretos adensado e não adensado, por adaptação da BS EN 12350-4 (2008). Para o estudo das propriedades no estado endurecido, os corpos-de-prova eram cilíndricos, com $10 \mathrm{~cm}$ de diâmetro e $20 \mathrm{~cm}$ de altura, e foram maturados por dois métodos adaptados do Tipo A da ASTM C 684 (1999). Certas propriedades foram ainda caracterizadas para condições normais de cura da ABNT NBR 5738 (2003). As propriedades estudadas no estado endurecido foram: resistência à compressão pela ABNT NBR 5739 (2007); resistência à tração por compressão diametral pela ABNT NBR 7222 (1994); absorção de água por capilaridade pela ABNT NBR 9779 (1995); absorção de água total e índice de vazios pela ABNT NBR 9778 (2005); resistência à carbonatação em câmara com $\mathrm{CO}_{2}$ (5\%; UR $65 \pm 10 \%$; $23 \pm 3{ }^{\circ} \mathrm{C}$ ); e resistência à penetração de cloretos e $\mathrm{CO}_{2}$, por três ciclos de um dia de molhagem e 27 dias de secagem, entre sete e 91 dias. De modo complementar, foram moldados corpos-de-prova específicos de aço e concreto, para medidas de potencial de circuito aberto, com vistas à continuidade de pesquisas sobre envelhecimento acelerado._A maioria das propriedades foram medidas por duas repetições, constando os resultados individuais em apêndices. A análise inicial dos resultados dos três lotes foi descritiva e resumiu em tabelas 0 valor médio, desvio padrão, valor máximo, valor mínimo, a amplitude e o coeficiente de variação de cada lote. As propriedades de cada lote também foram comparadas por análise de 
variância e, ao final, foram correlacionadas de modo conjunto, independentemente do lote de origem. Nesse caso, foram destacadas as melhores correlações entre propriedades, independentemente dos materiais constituintes de cada concreto. Entre as propriedades do estado fresco, destacaram-se as seguintes: a) o abatimento do tronco de cone apresentou correlação forte e inversa $\left(r^{2}=-0,802\right.$, para lotes 1 e 2) com resistência à compressão após um dia de cura acelerada em temperatura moderada, em método similar ao Tipo A da ASTM C 684 (1999); b) o teor de ar pelo método pressométrico apresentou correlações de razoáveis a fortes com a resistência à compressão a 28 dias $\left(r^{2}=-0,698\right.$, para lotes 1 e 2$)$, com a resistência à tração por compressão diametral por cura acelerada a sete dias $\left(r^{2}=-0,818\right.$, para lotes 1 e 2$)$, com a profundidade de carbonatação em câmara de $\mathrm{CO}_{2}\left(r^{2}=0,699\right.$, para lotes 1 e 2) e com a profundidade de penetração de cloretos por três ciclos de imersão e secagem $\left(r^{2}=0,625\right.$, para lotes 1 e 2); c) as medidas de compactabilidade do concreto adensado, ainda que realizadas em condições de campo, apresentaram várias correlações moderadas com outras propriedades do estado fresco e endurecido. No estado endurecido, destacaram-se as seguintes correlações: a) $r^{2}$ da ordem de $-0,75$ para a resistência à compressão a um dia dos concretos dos lotes 1 e 2, com cura acelerada de 0/24 horas em temperatura moderada, e a profundidade de carbonatação em câmara de $\mathrm{CO}_{2}(5 \%)$ e a de penetração de cloretos por três ciclos de imersão e secagem, ambas analisadas a 91 dias, tendo os corpos-de-prova recebido cura inicial acelerada de $24 / 48 \mathrm{~h}$, em temperatura moderada, seguida de imersão normal por até sete dias; b) $r^{2}$ de $-0,682$ entre a resistência à tração por compressão diametral, com cura acelerada de $24 / 48 \mathrm{~h}$ em temperatura moderada seguida de cura normal por até sete dias, e a profundidade de ingresso de íons cloreto, para os três lotes submetidos aos ciclos citados; c) valores de $r^{2}$ entre 0,521 e - 0,561 para as correlações entre a absorção de água por capilaridade, em corpos-de-prova submetidos à cura inicial acelerada em temperatura moderada por $24 / 48 \mathrm{~h}$ e em temperatura normal por até sete dias, e a resistência à carbonatação para os lotes submetidos aos ciclos citados. Assim, esta pesquisa conclui e propõe que, além do teor de ar no estado fresco, as resistências à compressão e à tração por compressão diametral entre um e sete dias, por cura acelerada do Tipo A da ASTM C 684 (1999) ou por duração adaptada da mesma, sejam propriedades que passem a ser avaliadas em concretos, com vistas a melhorar e controlar a sua resistência a agentes agressivos. Nesta pesquisa, a microestrutura nas primeiras idades do concreto mostrou ser mais determinante da rede de conexão de poros e do transporte de agentes agressivos do que a microestrutura em idades mais avançadas de hidratação; e trabalhos futuros devem confirmar esta interpretação. Espera-se que estes resultados possam estimular novas práticas de qualificação de concretos em estudos de dosagem ou no ato do recebimento de concretos pré-misturados, especialmente em ambientes mais agressivos às armaduras, com vistas à futura evolução de procedimentos da ABNT NBR 12655 (2006).

Palavras chave: Concreto, Controle tecnológico, Cloretos, Carbonatação, Durabilidade, Armaduras 
CAVALCANTI FILHO, A. N. Contribution to field quality control of Portland cement structural concretes in maritime environments. 2010. Master's thesis - Escola Politécnica da Universidade de São Paulo, São Paulo, 2010.

\section{ABSTRACT}

Durability of reinforced concrete buildings can only be achieved if a set of requirements and criteria is met in the design, execution and maintenance phases, in which the materials must be properly specified, manufactured and employed, according to the respective procedures of these phases. Therefore, the general requirement of protection of carbon steel reinforcements, for structural durability, is contemplated by several criteria as early as the design phase. This thesis addresses the relevant criteria concerning concrete quality and its objective was to contribute to the evolution of technological control procedures for Portland cement structural concretes, in urban and maritime atmospheres in tropical climate, aiming at the protection of carbon steel reinforcements. The experimental program studied three different batches of structural concrete that were similar in terms of slump test basic specifications: $10 \pm 2 \mathrm{~cm}, \mathrm{f}_{\mathrm{ck}}=$ $30 \mathrm{MPa}$ and class III of ABNT NBR 6118 (2003) environmental classification. The goal was to characterize and analyze the influence of physical properties of fresh concrete on hardened concrete, within the previously mentioned consistency range, with emphasis on those properties related to air content of the mixtures and their respective carbonation and chloride ion penetration resistances. Sampling, fresh concrete tests and specimen molding were conducted during three cast-in-place concretes in two construction sites of multi-storey buildings in the city of João Pessoa, state of Paraíba, in Brazil. The batch plant supplying the concrete for each construction site was responsible for batch composition and production. The initial batch was used to train the team, in the field and laboratory, with a sample of six trucks. The other two batches, identified as 1 and 2, were characterized under very similar conditions, always by the same team, and the samples consisted of five and six trucks, respectively. The properties measured in fresh concrete were: slump test according to Brazilian norm ABNT NBR NM 67 (1998); air content by the pressure method of ABNT NBR 47 (2002); bulk density according to ABNT NBR 9833 (2008); water/dry material ratio by analogy with ABNT NBR 9605 (1992); and compactability of compacted and non-compacted concretes, by adaptation of BS EN 12350-4 (2008). In order to study the properties of hardened concrete, the specimens were cylindrical, measuring $10 \mathrm{~cm}$ in diameter and $20 \mathrm{~cm}$ in height, and were matured by using two methods adapted from Type A of ASTM C 684 (1999). Some properties were also characterized for normal curing conditions according to ABNT NBR 5738 (2003). The properties studied in hardened concrete were: compressive strength according to ABNT NBR 5739 (2007); splitting tensile strength as per ABNT NBR 7222 (1994); capillary water absorption according to ABNT NBR 9779 (1995); water absorption by immersion and void ratio following ABNT NBR 9778 (2005); carbonation resistance in $\mathrm{CO}_{2}$ chamber $\left(5 \% ; 65 \pm 10 \% \mathrm{RH} ; 23 \pm 3{ }^{\circ} \mathrm{C}\right)$; and chloride and $\mathrm{CO}_{2}$ penetration resistance, using three one-day wet and 27-day dry cycles, between seven and 91 days. As a complement, specific steel and concrete specimens were molded to measure open circuit potential, aiming at the continuity of researches on accelerated ageing._Most properties were measured twice and the individual results are presented in appendices. Preliminary analysis of results from the three batches was descriptive and summarized in tables the mean value, standard deviation, maximum value, minimum value, amplitude and coefficient of variation for each batch. The properties of each batch were also compared using analysis of variance and, at the end, were correlated as a whole, regardless of the batch of origin. In this case, the best correlations among properties were highlighted, regardless of the materials used in each concrete. Among the properties of fresh concrete, the following are noteworthy: a) the slump test presented strong and inverse correlation $\left(r^{2}=-0.802\right.$, for batches 1 and 2) with 
compressive strength after one day of accelerated curing at moderate temperature, using a method similar to Type A of ASTM C 684 (1999); b) air content in the pressure method presented reasonable to strong correlations with compressive strength at 28 days $\left(r^{2}=-0.698\right.$, for batches 1 and 2), with splitting tensile strength with accelerated curing at seven days $\left(r^{2}=-\right.$ 0.818 , for batches 1 and 2), with carbonation depth in $\mathrm{CO}_{2}$ chamber $\left(r^{2}=0.699\right.$, for batches 1 and 2) and with chloride penetration depth after three immersion-drying cycles $\left(r^{2}=0.625\right.$, for batches 1 and 2); c) compactability measurements of compacted concrete, despite being taken in field conditions, presented several moderate correlations with other properties of fresh and hardened concrete. In hardened concrete, the following correlations should be highlighted: a) $r^{2}$ was -0.75 for compressive strength at one day of the concretes from batches 1 and 2, with 0/24hour accelerated curing at moderate temperature, and carbonation depth in $\mathrm{CO}_{2}$ chamber $(5 \%)$ and chloride penetration depth after three immersion-drying cycles, both analyzed at 91 days, after the specimens underwent 24/48-hour initial accelerated curing at moderate temperature, followed by normal immersion for up to seven days; b) $r^{2}$ was -0.682 between splitting tensile strength, with 24/48-hour accelerated curing at moderate temperature followed by normal curing for up to seven days, and chloride ion penetration depth, for the three batches submitted to the aforementioned cycles; c) $r^{2}$ values between 0.521 and -0.561 for the correlations between capillary water absorption, in specimens submitted to initial accelerated curing at moderate temperature for $24 / 48 \mathrm{~h}$ and at normal temperature for up to seven days, and carbonation resistance for the batches submitted to the aforementioned cycles. Therefore, this research concludes and proposes that, besides air content in fresh concrete, compressive strength and splitting tensile strength between one and seven days, using accelerated curing of Type $A$ of ASTM C 684 (1999) or for a duration adapted from that norm, are properties that should be evaluated in concrete, with the purpose of improving and controlling resistance to aggressive agents. In this research, the microstructure of the early ages of concrete proved to be more determinant of the pore structure connection and of the transport of aggressive agents than the microstructure at later ages of hydration; and future studies should confirm this interpretation. It is expected that these results will encourage new practices for the qualification of concrete in mixture proportion studies or when ready mixed concrete is received at construction sites, especially in environments that are more aggressive to reinforcements, with a view to developing future procedures of ABNT NBR 12655 (2006).

Keywords: Concrete, field quality control, chloride, carbonation, durability, corrosion, reinforcements. 


\section{Contribuição ao controle tecnológico de concretos estruturais de cimento Portland em ambientes marítimos}

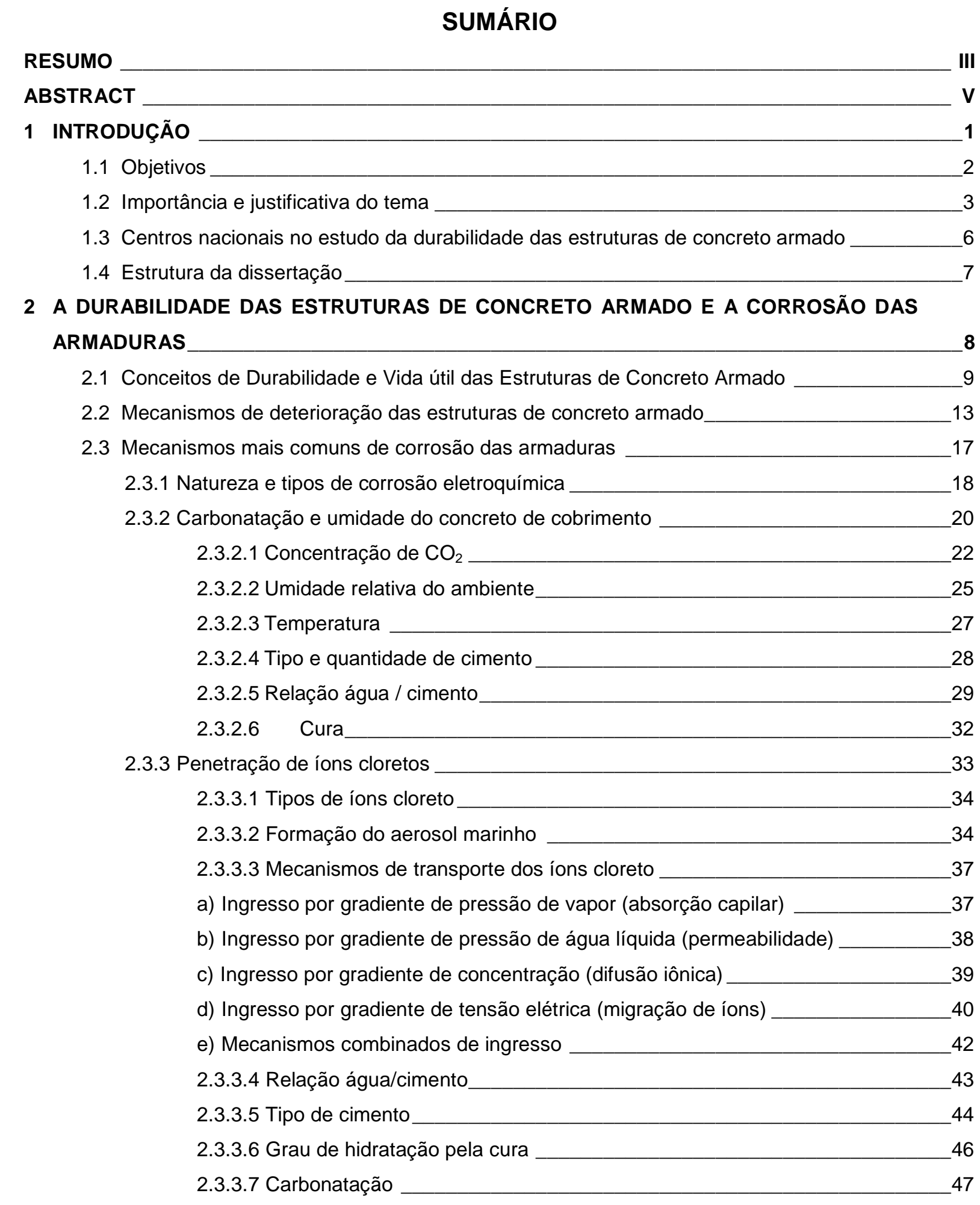


2.3.3.8 Temperatura 48

2.3.3.9 Grau de saturação dos poros 49

2.3.3.10 Tipos de cátions combinados com os íons cloreto 50

2.3.3.11 Fissuras 51

\section{REQUISITOS E CRITÉRIOS PARA A DURABILIDADE DAS ARMADURAS DO CONCRETO} ESTRUTURAL 52

3.1 Classificação da agressividade ambiental quanto ao macroclima 53

3.2 A importância da caracterização dos microclimas no projeto, para a prevenção da corrosão de armaduras 55

3.3 Critérios de projeto quanto ao cobrimento das armaduras 56

3.4 Requisitos e critérios de projeto quanto à especificação do concreto 58

3.4.1 Resistência à compressão axial 58

3.4.2 Relação água/cimento e consumo de cimento 61

3.5 Outras propriedades e critérios de qualidade do concreto para proteção de armaduras 62

3.5.1 Módulo de elasticidade 62

3.5.2 Limites para contaminantes no concreto 64

3.5.3 Tipo de cimento e teor de adições 65

3.5.4 Dimensão máxima característica dos agregados 66

3.5.5 Trabalhabilidade do concreto fresco 67

3.5.6 Critérios de absorção de água e porosidade 68

3.5.7 Resistência ao ingresso de íons cloreto por carga passante pela ASTM C 1202:1994_69

3.5.8 Proteção às armaduras através do potencial de corrosão pela ASTM C 876 (2009) _ 70

3.6 Etapas e exigências quanto à produção do concreto estrutural 72

3.6.1 Definição das propriedades de controle da trabalhabilidade 73

3.6.1.1 Consistência pelo abatimento do tronco-de-cone___ 74

3.6.1.2 Teor de ar pelo método pressométrico ___ 76

3.6.1.3 Massa específica, rendimento e teor de ar por método gravimétrico __ 77

3.6.1.4 Compactabilidade _ـ 80

3.6.2 Definições quanto à composição e proporcionamento do concreto ___ 82

3.6.3 Elaboração do concreto ___ 83

3.6.4 Transporte__ 84

3.6.5 Lançamento___ 85

3.6.6 Adensamento _ 86

3.6.7 Cura _ 87

3.7 Controle de fissuras no concreto __ 89

3.8 Controle de qualidade do concreto pela ABNT NBR 12655 (2006) _ 92

3.8.1 Abrangência e complexidade do controle de qualidade do concreto ___ 92 
3.8.2 Controle da consistência pelo abatimento 93

3.8.3 Controle da resistência à compressão 93

4 PROGRAMA EXPERIMENTAL PARA PROSPECÇÃO DE CONTROLE TECNOLÓGICO DO CONCRETO AMPLIADO À PROTEÇÃO DE ARMADURAS _

4.1 Objetivos do programa experimental __ 96

4.2 Metodologia para a definição dos concretos ___ 96

4.2.1 Definições da classe de resistência, cidade e centrais dosadoras dos concretos ___ 97

4.2.2 Seleção das centrais dosadoras ___ 98

4.2.3 Seleção e visita preliminar às obras __ 98

4.2.4 Plano básico de amostragem dos lotes em estudo ___ 99

4.2.5 Caracterização dos materiais constituintes e dosagem dos concretos __ 100

4.3 Amostragem e caracterização do concreto de cada lote __ 102

4.3.1 Amostragem e ensaios no concreto fresco _ 103

4.3.2 Moldagem de corpos-de-prova e ensaios no concreto endurecido __ 106

4.3.3 Procedimentos de cura dos corpos-de-prova

4.3.4 Ensaios de compressão simples e diametral __ 111

4.3.5 Ensaios indicadores de porosidade __ 113

4.3.6 Ensaios acelerados quanto à penetração de cloretos e $\mathrm{CO}_{2}$

4.3.7 Potencial de corrosão de armaduras em cura normal do concreto

5 APRESENTAÇÃO E DISCUSSÃo dOS RESULTADOS 123

5.1 Análise descritiva das propriedades de cada lote __ 123

5.1.1 Concreto fresco __ 123

5.1.1.1 Informes das notas fiscais de fornecimento ___ 123

5.1.1.2 Abatimento do tronco-de-cone ("slump") _ _ 125

5.1.1.3 Massa específica aparente ___ 126

5.1.1.4 Compactabilidade do concreto adensado___ 127

5.1.1.5 Compactabilidade do concreto não-adensado __ 128

5.1.1.6 Teor de ar pelo método pressométrico __ 129

5.1.1.7 Umidade do concreto fresco __ 131

5.1.2 Concreto endurecido ___ 132

5.1.2.1 Resistência à compressão simples ___ 132

a) Resistências à compressão medidas a 1 dia $\left(f_{c 1}\right.$ e $\left.f_{c 1 a c e l}\right)$

b) Resistências à compressão medidas a 7 dias $\left(f_{c 7}\right.$ e $\left.f_{c 7 a c e l}\right) ـ 134$

c) Resistência à compressão a 28 dias $\left(f_{c 28}\right)$ por cura normal __ 136

d) Resistência à compressão a 63 dias $\left(f_{c 63}\right)$ por cura normal ___ 137

e) Resistência à compressão a 91 dias $\left(f_{c 91}\right)$ por normal ___ 138

f) Análise conjunta das idades por lote___ 139 
g) Análise da evolução da resistência relativa à cura

a 28 dias 145

h) Cálculo da resistência característica estimada à

compressão 148

5.1.2.2 Resistência à tração por compressão diametral 151

a) Resistência à tração acelerada a 7 dias $\left(\mathfrak{f}_{\mathrm{ct}, S P}\right.$ 7acel $)$ por cura térmica 24/48 horas e imersão normal até 7 dias 151

b) Resistência à tração a 28 dias $\left(f_{c t, S P} 28\right)$ por cura normal 152

c) Análise conjunta das idades por lote 153

5.1.2.3 Absorção de água por capilaridade 159

5.1.2.4 Absorção de água total 162

5.1.2.5 Índice de vazios 164

5.1.2.6 Profundidade de carbonatação em corpos-de-prova submetidos à câmara de $\mathrm{CO}_{2}$ sob pressão aos $92 \pm 8$ dias 165

5.1.2.7 Resistência à carbonatação e cloretos por ciclos de imersão e secagem 170

5.1.2.8 Sugestões de cálculos das resistências ao ingresso de $\mathrm{CO}_{2}$ e íons cloreto pelos estimadores da NBR 12655:2006 177

5.1.2.9 Potencial de corrosão das armaduras de aço-carbono 179

5.2 Consideração da normalidade das medidas em geral e verificações para as resistências ao ingresso de $\mathrm{CO}_{2} \mathrm{e}$ íons cloreto 180

5.3 Análise da igualdade de médias entre os lotes 181

5.3.1 Concreto fresco 181

5.3.2 Concreto endurecido 181

5.4 Correlações entre as propriedades 182

5.4.1 Abatimento pelo tronco de cone 183

5.4.2 Massa específica aparente do concreto fresco 183

5.4.3 Compactabilidade do concreto adensado 184

5.4.4 Compactabilidade do concreto não-adensado 186

5.4.5 Teor de ar pelo método pressométrico 186

5.4.6 Umidade do concreto fresco 187

5.4.7 Absorção de água capilaridade 188

5.4.8 Absorção de água total e índice de vazios 189

5.4.9 Resistência à compressão 191

5.4.10 Resistência à tração por compressão diametral 194

5.4.11 Profundidade de carbonatação e penetração de cloretos em corpos-de-prova ciclados por imersão e secagem 197 
5.4.12 Profundidade de carbonatação em corpos-de-prova submetidos

à câmara de $\mathrm{CO}_{2}$ 198

6 CONSIDERAÇÕES FINAIS 200

6.1 Conclusões quanto ao programa experimental 201

6.1.1 Propriedades no estado fresco 202

6.1.2 Propriedades no estado endurecido 204

6.1.2.1 Quanto à aceleração da hidratação por métodos baseados no Tipo A-ASTM C 684 (1999) 204

6.1.2.2 Quanto aos ensaios de envelhecimento acelerado e resistência à penetração de íons agressivos a armaduras em ambientes marítimos 205

6.1.2.3 Proteção das armaduras de aço-carbono pelos concretos 206

6.2 Dificuldades superadas para o desenvolvimento da pesquisa e restrições a extrapolação dos resultados 207

6.3 Sugestões para futuras pesquisas 209

6.4 Transferência para o meio técnico 210

7 REFERÊNCIAS BIBLIOGRÁFICAS 211

APÊNDICE A - Caracterização dos materiais coletados nas centrais dosadoras de concreto 223

APÊNDICE B - Tabelas de controle dos tanques de cura acelerada e de ciclagem de corpos-deprova do estudo 226

APÊNCIDE C - Resultados da caracterização dos lotes 230

APÊNDICE D - Registro fotografico das seções dos corpos-de-prova e medidas quanto à penetração de cloretos e profundidade de carbonatação 272

APÊNDICE E - Relatório CEA 298

ANEXO A - Caracterização das obras que participaram do estudo 330 


\section{LISTA DE FIGURAS}

Figura 1 - Incidência de manifestações patológicas mais freqüentes em edifícios com média de 7,1 anos e $\mathrm{f}_{\mathrm{ck}} 15 \mathrm{MPa}$, na cidade de João Pessoa/PB (SILVA et al. 2003)

Figura 2 - Modelo de vida útil de TUUTTI (1982) 10

Figura 3 - Ampliação do conceito de vida útil das estruturas de concreto, tomando-se por referência o fenômeno da corrosão das armaduras e a realização de reparos de manutenção corretiva (HELENE, 1993) 12

Figura 4 - Lei de evolução de custos (SITTER, 1984 apud HELENE, 1993) 17

Figura 5 - Tipos de corrosão e fatores que as provocam (CAMPOS, 2006) 19

Figura 6 - Esquema do avanço do processo de carbonatação (CEB, 1984 citado por Figueiredo, 2005) 21

Figura 7 - Variação da profundidade de carbonatação com a umidade (ANDRADE, 1992) 25

Figura 8 - Profundidade média de carbonatação a 10, 100, 200 e 500 metros do mar:

(a) $\mathrm{a} / \mathrm{c}=0,50 ;$ (b) $\mathrm{a} / \mathrm{c}=0,57$; (c) $\mathrm{a} / \mathrm{c}=0,65$ (MEIRA et al., 2006) 27

Figura 9 - Profundidade de carbonatação acelerada a 10\% aos 91 dias (COSTA Jr. et al. 2006) 29

Figura 10 - llustração da influência secundária do $\mathrm{GS}_{\text {médio }}$ em comparação à relação água/cimento, na profundidade de carbonatação de concretos, em quatro distancias do mar $(10,100,200$ e $500 \mathrm{~m})$ para os mesmos dados ilustrados na Figura 8: (a) $a / c=0,50$; (b) $a / c=0,57$; (c) $a / c=0,65$ para concretos expostos em João Pessoa-PB (MEIRA et al., 2006)

Figura 11 - Faixa de valores do Grau de saturação em função do distanciamento do mar (MEIRA, 2004). 31

Figura 12 - Representação esquemática das zonas de agressividade do aerosol marinho em cidades litorâneas. (MEIRA, 2004) 35

Figura 13 - Carga passante $x$ relação água/cimento para uma mesma consistência (MEDEIROS; HELENE, 2003)

Figura 14 - Migração de íons cloreto x relação água/cimento (CPI S, CPIII e CPIV) (REGATTIERI, 1998) 42

Figura 15 - Atuação de diversos mecanismos de transporte em uma estrutura marítima (PERRATON et al. ,1992, citado por PEREIRA, 2001) 42

Figura 16 - Efeito da relação água/cimento na penetração de cloretos (JAERGEMAN, 1990, citado por MEIRA, 2004) 44 
Figura 17 - Penetração de íons cloreto versus o tempo de cura em concretos (1, 7 e 28 dias) (PLANTE; BILOUDEAU, 1989 citado por PEREIRA, 2001) 46

Figura 18 - Efeitos isolados da idade e do tipo de cimento de concretos sobre 0 coeficiente efetivo de difusão (PEREIRA, 2001)

Figura 19 - Comportamento do coeficiente de difusão com a variação do grau de saturação do concreto (MEIRA, 2004)

Figura 20 - Variação da profundidade de carbonatação em vigas e pilares de garagem em prédio com 30 anos e comparação com os valores calculados pelo modelo de HELENE (CARMONA, 2005) 56

Figura 21 - Carga passante (C) de cloretos versus porosidade de concretos estruturais (MEDEIROS; HELENE, 2003) 68

Figura 22 - Sequência de passos para a realização do ensaio de abatimento do tronco de cone para concretos de consistência plástica (MEHTA; MONTEIRO, 2008) 75

Figura 23 - Equipamento de medição do teor de ar. llustração do Departamento de Engenheiro de Construção Civil da Escola Politécnica da USP. 77

Figura 25 - Ensaio de massa específica pelo método gravimétrico. llustração do Departamento de Engenharia de Construção Civil da Escola Politécnica da USP 78

Figura 26 - Aparelho de Glanville para medida de fator de compactação do concreto fresco, pela norma extinta, BS 1881-103:1993 - Testing Concrete Method for Determination of Compactability Factor (MEHTA e MONTEIRO, 2008) 81

Figura 27 - Descrição geral da amostragem dos lotes analisados 100

Figura 28 - Fluxograma dos materiais utilizados nos concretos amostrados da obra 1 101

Figura 29 - Fluxograma dos materiais utilizados nos concretos amostrados da obra 2 101

Figura 30 - Fluxograma da amostragem dos ensaios no concreto fresco de cada caminhão-betoneira integrante dos lotes estudados. 103

Figura 31 - Amostragem do concreto fresco 104

Figura 32 - Equipe de técnicos que participaram das concretagens 104

Figura 33 - Moldagem dos corpos-de-prova cilíndricos, de $10 \mathrm{~cm} \times 20 \mathrm{~cm}$, segundo a ABNT NBR 5738 (2003) 107

Figura 34 - Fluxograma de resumo dos ensaios no concreto endurecido 108

Figura 35 - Cura convencional da ABNT NBR 5738 (2003), por imersão em tanque com água saturada de cal, em pátio do laboratório de realização do estudo, em João Pessoa/PB. 
Figura 36- Detalhes da cura térmica em tanques similares ao de cura convencional, mas com aquecimento de água por resistência elétrica a $(35 \pm 3)^{\mathrm{C}} \mathrm{C}$, em analogia ao método A da ASTM C 684:99. 110

Figura 37 - Etapa de imersão total em solução de 3,5\% de $\mathrm{NaCl}$ por 24 horas 115

Figura 38 - Caixa térmica de secagem dos corpos-de-prova, nos períodos diurno e noturno 116

Figura 39 - Imersão das seções dos corpos-de-prova em solução de fenolftaleína e nitrato de prata. 117

Figura 40 - Metade de corpos-de-prova seccionados em terços superior e inferior para nova aspersão de solução nitrato de prata 118

Figura 41 - Câmara de $\mathrm{CO}_{2}$ semi-automática da Bass utilizada na pesquisa no laboratório 119

Figura 42 - Detalhes das barras utilizadas e armação dos corpos-de-prova para medida de potencial de corrosão das armaduras. 120

Figura 43 - Fluxograma dos corpos-de-prova dos lotes treinamento e 1, para medidas de potencial de corrosão, conforme a ASTM C 876 (2009).

Figura 44 - Fluxograma dos corpos-de-prova do lote 2, para medidas de potencial de corrosão, conforme a ASTM C 876 (2009).

Figura 45 - Corpos-de-prova armados após moldagem e cura, na bancada do laboratório da USP e imersos em solução de cal. 122

Figura 46 - Variações do abatimento médio dos concretos analisados nos três lotes. ABNT NBR NM 67 (1998) 126

Figura 47 - Variações da massa específica aparente média dos concretos amostrados nos três lotes. ABNT NBR 9833 (2008) 127

Figura 48 - Variações da compactabilidade adensada média de cada caminhão entre os concretos amostrados nos três lotes (BS EN 12350-4, 2008). 128

Figura 49 - Variações da compactabilidade média do concreto fresco não-adensado, nos lotes 1 e 2. Adaptado da BS EN 12350-4 (2008) 129

Figura 50 - Variações do teor de ar médio por método pressométrico, entre os concretos amostrados nos três lotes. ABNT NBR 47 (2002).

Figura 51 - Variações do teor de umidade médio do concreto fresco entre os concretos amostrados de cada lote 132

Figura 52 - Variação da resistência à compressão média a 1 dia por cura normal nos concretos amostrados em dois lotes. ABNT NBR 5739 (2007). 133

Figura 53 - Variação da resistência à compressão média a 1 por cura acelerada nos concretos amostrados em dois lotes. ABNT NBR 5739 (2007). 134

Figura 54 - Variação da resistência à compressão a 7 dias, por cura normal, nos concretos dos dois lotes amostrados. ABNT NBR 5739 (2007). 135 
Figura 55 - Variação da resistência à compressão a 7 dias, por cura acelerada 24/48 horas mais imersão até 7 dias, nos concretos dos três lotes analisados. ABNT NBR 5739 (2007). 136

Figura 56 - Variação da resistência à compressão média a 28 dias por cura normal, amostrados em três lotes analisados. ABNT NBR 5739 (2007).

Figura 57 - Variação da resistência à compressão média a 63 dias por cura normal, amostrados em dois lotes analisados (ABNT NBR 5739, 2007). 138

Figura 58 - Variação da resistência à compressão média a 91 dias por cura normal, amostrados em dois lotes analisados. ABNT NBR 5739 (2007). 139

Figura 59 - Variação das resistências médias à compressão a 7 dias por cura acelerada e a 28 dias por cura normal, dos concretos amostrados dos seis caminhões do lote treinamento. ABNT NBR 5739 (2007).

Figura 60 - Variação das resistências médias à compressão dos concretos amostrados dos seis caminhões do lote 1. ABNT NBR 5739 (2007).

Figura 61 - Variação das resistências médias à compressão dos concretos amostrados dos cinco caminhões do lote 2. ABNT NBR 5739 (2007). 145

Figura 62 - Variação da resistência à tração por compressão diametral média aos 7 dias de dois corpos-de-prova por caminhão, submetidos à cura acelerada 24/48 h e imersão em água, amostrados em três lotes analisados. ABNT NBR 7222 (1994). 152

Figura 63 - Resistência à tração por compressão diametral média aos 28 dias de dois corpos-de-prova por caminhão, submetidos à cura normal, amostrados em três lotes analisados. ABNT NBR 7222 (1994).

Figura 64 - Variação da absorção de água por capilaridade média nos concretos amostrados, submetidos à cura normal nos três lotes analisados. 160

Figura 65 - Variações da absorção de água por capilaridade média nos concretos amostrados, submetidos à cura acelerada 24/48 horas, nos dois lotes analisados. 161

Figura 66 - Variação da absorção de água total média por imersão total de dois corpos-deprova de concreto por caminhão, submetidos à cura normal até 28 dias nos três lotes amostrados.

Figura 67 - Variação da absorção de água total média por imersão total de dois corposde-prova de concreto por caminhão, submetidos à cura acelerada nos três lotes amostrados. 163

Figura 68 - Variação do índice de vazios médio de dois corpos-de-prova de concreto, por caminhão, submetidos à cura normal até 28 dias, amostrados nos três lotes. 
Figura 69 - Variação do índice de vazios médio de dois corpos-de-prova de concreto com cura acelerada 24/48 horas mais imersão em água até 7 dias, amostrados nos três lotes.

Figura 70 - Variação da profundidade de carbonatação média em câmara de $\mathrm{CO}_{2}$ (5\%;

7 dias), por fenolftaleína, das metades seccionadas de dois corpos-de-prova de concreto, por caminhão, submetidos à cura acelerada 24/48 h mais imersão em água até 7 dias.

Figura 71 - Profundidade de carbonatação média em câmara de $\mathrm{CO}_{2}$ ( $5 \% ; 7$ dias), por timolftaleína, das metades seccionadas de dois corpos-de-prova de concreto, por caminhão, submetidos à cura acelerada 24/48 h mais imersão em água até 7 dias. 167

Figura 72 - Variação do grau de saturação entre os 3 ciclos de imersão e secagem nos corpos-de-prova do lote 1. Cada etapa do ciclo foi constituída de 1 dia de imersão em solução de 3,5\% de $\mathrm{NaCl}$ e 27 dias de secagem em caixa térmica ventilada a $45 \pm 5{ }^{\circ} \mathrm{C}$.

Figura 73- Variação do grau de saturação entre os 3 ciclos de imersão e secagem nos corpos-de-prova do lote 2. Cada etapa do ciclo foi constituída de 1 dia de imersão em solução de $3,5 \%$ de $\mathrm{NaCl}$ e 27 dias de secagem em caixa térmica ventilada a $45 \pm 5{ }^{\circ} \mathrm{C}$. 173

Figura 74 - Variação da profundidade de carbonatação média por três ciclos de imersão e secagem em metades seccionadas de dois corpos-de-prova de concreto, por caminhão, submetidos à cura acelerada $24 / 48$ horas mais imersão em água até 7 dias, amostrados nos três lotes.

Figura 75 - Profundidade de penetração de cloretos média, por três ciclos de imersão e secagem, na direção diametral de dois corpos-de-prova de concreto, por caminhão, submetidos à cura acelerada $24 / 48$ horas mais imersão em água até 7 dias.

Figura 76 - Profundidade de penetração de cloretos média, por três ciclos de imersão e secagem, em dois terços médios de metade de corpos-de-prova de concreto, por caminhão, submetidos à cura acelerada $24 / 48$ horas mais imersão em água até 7 dias.

Figura 77 - Acompanhamento de massa dos corpos-de-prova, expostos a três ciclos de imersão e secagem, amostrados do lote 1.

Figura 78 - Acompanhamento de massa dos corpos-de-prova, expostos a três ciclos de imersão e secagem, amostrados do lote 2 .

Figura 79 - Acompanhamento de massa dos corpos-de-prova, expostos a três ciclos de imersão e secagem, amostrados do lote treinamento. 266 
Figura 80 - Seções de medida da penetração de cloretos nos corpos-de-prova 441 e 442 do lote 1 , após cura acelerada $(24 / 48$ h) e três ciclos de imersão e secagem, entre 7 e 91 dias.

Figura 81 - Seções de medida da penetração de cloretos nos corpos-de-prova $443 \mathrm{e}$ 444 , com cura acelerada $24 / 48$ h, do lote 1 , após três ciclos de imersão e secagem entre 7 e 91 dias.

Figura 82 - Seções de medida da penetração de cloretos nos corpos-de-prova 445 e 446 do lote 1 , após cura acelerada $(24 / 48$ h) e três ciclos de imersão e secagem, entre 7 e 91 dias.

Figura 83 - Seções de medida da penetração de cloretos nos corpos-de-prova 447 e 448 do lote 1 , após cura acelerada $(24 / 48$ h) e três ciclos de imersão e secagem entre 7 e 91 dias.

Figura 84 - Seções de medida da penetração de cloretos nos corpos-de-prova 449 e 450 do lote 1 , após cura acelerada $(24 / 48$ h) e três ciclos de imersão e secagem entre 7 e 91 dias.

Figura 85 - Seções de medida da penetração de cloretos nos corpos-de-prova 451 e 452 do lote 1 , após cura acelerada $(24 / 48$ h) e três ciclos de imersão e secagem entre 7 e 91 dias.

Figura 86 - Seções de medida da profundidade de carbonatação nos corpos-deprova 441, 442, 443 e 444 dos caminhões 1 e 2 do lote 1, após cura acelerada (24/48 h) e três ciclos de imersão e secagem entre 7 e 91 dias.

Figura 87 - Seções de medida da profundidade de carbonatação nos corpos-de-prova 445, 446, 447 e 448 dos caminhões 3 e 4, do lote 1, após cura acelerada (24/48 h) e três ciclos de imersão e secagem entre 7 e 91 dias. 276

Figura 88 - Seções de medida da profundidade de carbonatação nos corpos-deprova 449, 450, 451 e 452 dos caminhões 5 e 6, do lote 1, após cura acelerada (24/48 h) e três ciclos de imersão e secagem entre 7 e 91 dias. 277

Figura 89 - Seções de medida da profundidade de carbonatação nos corpos-de-prova 429, 430, 431 e 432, após secagem prolongada em estufa ventilada e sete dia em câmara com $\mathrm{CO}_{2}$ a $5 \%$. 278

Figura 90 - Seções de medida da profundidade de carbonatação nos corpos-de-prova 433, 434, 435 e 436, após secagem prolongada em estufa ventilada e sete dias em câmara com $\mathrm{CO}_{2}$ a $5 \%$. 279

Figura 91 - Seções de medida da profundidade de carbonatação nos corpos-de-prova 437, 438, 439 e 440, após secagem prolongada em estufa ventilada e sete dias em câmara com $\mathrm{CO}_{2}$ a $5 \%$. 
Figura 92 - Seções de medida da penetração de cloretos nos corpos-de-prova 227 e 228 do lote 2 , após cura acelerada ( $24 / 48$ h) e três ciclos de imersão e secagem entre 7 e 91 dias. 280

Figura 93 - Seções de medida da penetração de cloretos nos corpos-de-prova 229 e 230 do lote 2 , após cura acelerada ( $24 / 48$ h) e três ciclos de imersão e secagem entre 7 e 91 dias. 281

Figura 94 - Seções de medida da penetração de cloretos nos corpos-de-prova 231 e 232 do lote 2 , após cura acelerada ( $24 / 48$ h) e três ciclos de imersão e secagem entre 7 e 91 dias.

Figura 95 - Seções de medida da penetração de cloretos nos corpos-de-prova 233 e 234 do lote 2 , após cura acelerada ( $24 / 48$ h) e três ciclos de imersão e secagem entre 7 e 91 dias. 282

Figura 96 - Seções de medida da penetração de cloretos nos corpos-de-prova 235 e 236 do lote 2 , após cura acelerada (24/48 h) e três ciclos de imersão e secagem entre 7 e 91 dias. 282

Figura 97 - Seções de medida da profundidade de carbonatação nos corpos-de-prova 227, 228, 229 e 230 dos caminhões 1 e 2, do lote 1, após cura acelerada (24/48 h) e três ciclos de imersão e secagem entre 7 e 91 dias. 283

Figura 98 - Seções de medida da profundidade de carbonatação nos corpos-de-prova 231, 232, 233 e 234 dos caminhões 3 e 4, do lote 1, após cura acelerada (24/48 h) e três ciclos de imersão e secagem entre 7 e 91 dias. 284

Figura 99 - Seções de medida da profundidade de carbonatação nos corpos-de-prova 235 e 236 do caminhão 5 , do lote 1 , após cura acelerada $(24 / 48$ h) e três ciclos de imersão e secagem entre 7 e 91 dias. 284

Figura 100 - Seções de medida da profundidade de carbonatação nos corpos-de-prova $217,218,219$ e 220 , do lote 2 , após secagem prolongada em estufa ventilada e sete dias em câmara com $\mathrm{CO}_{2}$ a $5 \%$. 285

Figura 101 - Seções de medida da profundidade de carbonatação nos corpos-de-prova $221,222,223,224$ e 225 , do lote 2, após secagem prolongada em estufa ventilada e sete dias em câmara com $\mathrm{CO}_{2}$ a $5 \%$. 286

Figura 102 - Seções de medida da penetração de cloretos nos corpos-de-prova 109 e 111 do lote treinamento, após cura acelerada (24/48 h) e três ciclos de imersão e secagem, entre 7 e 91 dias. 287

Figura 103 - Seções de medida da penetração de cloretos nos corpos-de-prova 113 e 114 do lote treinamento, após cura acelerada $(24 / 48$ h) e três ciclos de imersão e secagem, entre 7 e 91 dias. 288 
Figura 104 - Seções de medida da penetração de cloretos nos corpos-de-prova 117 e

119 do lote treinamento, após cura acelerada $(24 / 48$ h) e três ciclos de imersão e secagem, entre 7 e 91 dias.

Figura 105 - Seções de medida da profundidade de carbonatação nos corpos-de-prova

109, 110, 111 e 112 dos caminhões 1 e 2, do lote treinamento, após cura acelerada (24/48 h) e três ciclos de imersão e secagem entre 7 e 91 dias. 290

Figura 106 - Seções de medida da profundidade de carbonatação nos corpos-de-prova

113 e 115 dos caminhões 3 e 5, do lote treinamento, após cura acelerada

(24/48 h) e três ciclos de imersão e secagem entre 7 e 91 dias.

Figura 107 - Seções de medida da profundidade de carbonatação nos corpos-de-prova

117, 118, 119 e 120 dos caminhões 5 e 6, do lote treinamento, após cura

acelerada (24/48 h) e três ciclos de imersão e secagem entre 7 e 91 dias.

Figura 108 - Seções de medida da profundidade de carbonatação nos corpos-de-prova

99, 100, 101 e 102 do lote treinamento, após secagem prolongada e sete dias

em câmara com $5 \%$ de $\mathrm{CO}_{2}$. 293

Figura 109 - Seções de medida da profundidade de carbonatação nos corpos-de-prova

103, 104, 105, 106, 107 e 108 do lote treinamento, após secagem prolongada

e sete dias em câmara com $5 \%$ de $\mathrm{CO}_{2}$.

Figura 110 - (a) Corte esquemático da obra 1; (b) Planta baixa do pavimento-tipo da obra 1 331

Figura 111 - (a) Corte esquemático da obra 2; (b) Planta Baixa do pavimento tipo da obra 2 334 


\section{LISTA DE TABELAS}

Tabela 1 - Termos e conceitos relativos à durabilidade dos edifícios e suas partes, pela BS 7543 (1992), em paralelo aos termos propostos por Helene (1993), para descrever a durabilidade das estruturas de concreto armado, sujeitas à deterioração preponderante por corrosão das armaduras

Tabela 2 - Resumo das principais origens e mecanismos da deterioração do concreto armado.

Adaptado de Andrade (2005) 15

Tabela 3 - Ensaios acelerados de carbonatação empregados por diversos autores adaptado de Cafange (2009) 22

Tabela 4 - Coeficiente de difusão de cloretos, a $25^{\circ} \mathrm{C}$ em pastas de cimento com relação água/cimento igual a 0,5 (Page et.al., citado por MEIRA, 2004) 40

Tabela 5 - Coeficiente de difusão efetivo em função da temperatura e relação água/cimento (PAGE et al., 1991 citados por MEIRA, 2004) 48

Tabela 6 - Classe de agressividade ambiental quanto ao macroclima (ABNT NBR 6118, 2003) 54

Tabela 7 - Correspondência entre a classe de agressividade ambiental e o cobrimento (ABNT NBR 6118, 2003) 57

Tabela 8 - Influência das operações de ensaio (HELENE; TERZIAN, 1993)

Tabela 9 - Especificações prescritivas do concreto estrutural pela classe de agressividade ambiental (ABNT NBR 6118, 2003 e ABNT NBR 12655, 2006) 62

Tabela 10 - Teor máximo de íons cloretos para proteção das armaduras do concreto (ABNT NBR 12655, 2006) 64

Tabela 11 - Requisitos para concreto exposto a solução contendo sulfatos (ABNT NBR 12655, 65

Tabela 12 - Classificação dos concretos frente ao risco de mecanismos que levam à corrosão das armaduras por carbonatação, cloretos, lixiviação, formação de compostos expansivos (HELENE, 1998).

Tabela 13 - Classificação dos concretos em função da porosidade e absorção de água (HELENE, 1993)

Tabela 14 - Critérios de avaliação do concreto em função da absorção de água - CEB, 1989 (CASCUDO, 1991) 69

Tabela 15 - Qualidade dos concretos com base na carga passante (ASTM C - 1202, 1994) 69

Tabela 16 - Dados dos concretos estudados relativos à resistência à penetração de cloreto de acordo com a ASTM C-1202 (1994) (MEDEIROS; HELENE, 2003) 70

Tabela 17 - Critérios de avaliação do risco de corrosão da ASTM C 876 (1999). Mantidos na ASTM C 876 (2009). Traduções e cálculos transcritos de Araújo (2004) 71 
Tabela 18 - Classificação dos concretos quanto ao abatimento (HELENE;TERZIAN, 1993) 75

Tabela 19 - Medidas dos recipientes (ABNT NBR 9833, 2008) 78

Tabela 20 - Principais propriedades a serem controlados nos materiais do concreto armado.

Adaptada de ANDRADE; SILVA (2005) 84

Tabela 21- Tipos e procedimentos da cura acelerada (ASTM C 684, 1999) 88

Tabela 22 - Diferentes tipos de fissuras que podem surgir no concreto (MONTOYA et al. Citado por SILVA (2007) 91

Tabela 23 - Valores para formação de lotes de concreto (ABNT NBR 12655, 2006) 93

Tabela 24 - Valores de $\psi_{6}$ (ABNT NBR 12655, 2006) 94

Tabela 25 - Resumo de ensaios no concreto fresco por caminhão amostrado em cada lote. 105

Tabela 26 - Ensaios mecânicos nos três lotes amostrados 112

Tabela 27 - Ensaios físicos nos três lotes amostrados 113

Tabela 28 - Ensaios acelerados nos três lotes amostrados 114

Tabela 29 - Etapas do ensaio cíclico repetido por três vezes entre 7 e 91 dias de idade dos concretos com maturação acelerada.

Tabela 30 - Dados das notas fiscais referente aos concretos dos caminhões amostrados do lote 1

Tabela 31 - Dados das notas fiscais referente aos concretos dos caminhões amostrados do lote 2

Tabela 32 - Resultados do ensaio de abatimento do concreto fresco nos três lotes analisados. ABNT NBR NM 67 (1998).

Tabela 33 - Resultados do ensaio de massa específica aparente do concreto fresco nos três lotes analisados ABNT NBR 9833 (2008).

Tabela 34 - Resultados no concreto fresco do ensaio de compactabilidade do concreto adensado nos três lotes analisados (BS EN 12350-4, 2008).

Tabela 35 - Resultados do ensaio no concreto fresco da compactabilidade do concreto nãoadensado, nos três lotes analisados. Adaptado da BS EN 12350-4 (2008). 129

Tabela 36 - Resultados do ensaio de teor de ar no concreto fresco nos três lotes analisados. ABNT NBR 47 (2002). 130

Tabela 37 - Resultados do ensaio de umidade do concreto fresco nos três lotes analisados 131

Tabela 38 - Resultados do ensaio de resistência à compressão, a 1 dia, nos concretos dos três lotes analisados. ABNT NBR 5739 (2007).

Tabela 39 - Resultados do ensaio de resistência à compressão a 7 dias, por cura normal, nos concretos dos dois lotes analisados. ABNT NBR 5739 (2007). 135

Tabela 40 - Resultados do ensaio de resistência à compressão a 28 dias por cura normal, nos concretos dos três lotes analisados. ABNT NBR 5739 (2007). 136 
Tabela 41 - Resultados do ensaio de resistência à compressão a 63 dias por cura normal, nos concretos dos dois lotes analisados. ABNT NBR 5739 (2007).

Tabela 42 - Resultados do ensaio de resistência à compressão, com cura normal a 91 dias por cura normal nos concretos dos dois lotes analisados. ABNT NBR 5739 (2007). 138

Tabela 43 - Resultados do ensaio de resistência à compressão nos concretos amostrados do lote treinamento. ABNT NBR 5739 (2007) 140

Tabela 44 - Resultados do ensaio de resistência à compressão nos concretos amostrados do lote 1. ABNT NBR 5739 (2007).

Tabela 45 - Resultados do ensaio de resistência à compressão nos concretos amostrados do lote 2. ABNT NBR 5739 (2007).

Tabela 46 - Evolução da resistência relativa a cura normal a 28 dias nos corpos-de-prova amostrados do lote treinamento.

Tabela 47 - Evolução da resistência a 28 dias por cura normal dos corpos-de-prova amostrados do lote1.

Tabela 48 - Evolução da resistência a 28 dias por cura normal dos corpos-de-prova amostrados do lote2.

Tabela 49 - Resistência característica por amostragem parcial dos concretos do lote treinamento. ABNT NBR 12655 (2006).

Tabela 50 - Resistência característica por amostragem parcial dos concretos do lote 1. ABNT NBR 12655 (2006).

Tabela 51 - Simulação da resistência característica por amostragem total dos concretos dos lote treinamento e 1. ABNT NBR 12655 (2006). 150

Tabela 52 - Resistência característica dos concretos amostrados do lote 2. ABNT NBR 12655 (2006)

Tabela 53 - Resultados do ensaio de resistência à tração por compressão diametral, cura acelerada 24/48 horas e imersão em água até 7 dias nos concretos dos três lotes analisados. ABNT NBR 7222 (1994).

Tabela 54 - Resultados do ensaio de resistência à tração por compressão diametral com cura normal até 28 dias nos concretos dos três lotes analisados. ABNT NBR 7222 (1994).

Tabela 55 - Resultados do ensaio de resistência à tração por compressão diametral nos concretos amostrados do lote treinamento e evolução da resistência em função da resistência à tração a 28 dias. ABNT NBR 7222 (1994).

Tabela 56 - Resultados do ensaio de resistência à tração por compressão diametral nos concretos amostrados do lote 1. ABNT NBR 7222 (1994).

Tabela 57 - Resultados do ensaio de resistência à tração por compressão diametral nos concretos amostrados do lote 2. ABNT NBR 7222 (1994). 
Tabela 58 - Relação entre resistência à tração por compressão diametral e a resistência à compressão a 28 dias do concreto do lote treinamento. 157

Tabela 59 - Relação entre resistência à tração por compressão diametral e a resistência à compressão a 28 dias dos concretos do lote 1 . 158

Tabela 60 - Relação entre resistência à tração por compressão diametral e a resistência à compressão a 28 dias dos concretos do lote 2 .

Tabela 61 - Resultados médios da absorção de água por capilaridade, ao final de 72 horas, nos concretos por cura normal até 28 dias e acelerada 24/48 horas mais imersão em água até 7 dias nos lotes analisados. ABNT NBR 9779 (1995). 160

Tabela 62 - Coeficiente de absorção de água por capilaridade nas idades de 15 min e 72 horas (4320 $\mathrm{min}$ ) de ensaio, nos três lotes analisados. 162

Tabela 63 - Resultados do ensaio de absorção de água total nos concretos com cura acelerada $24 / 48$ horas e com imersão em água até 7 dias nos três lotes analisados 162

Tabela 64 - Resultados do ensaio de índice de vazios nos concretos com cura acelerada 24/48 horas e imersão em água até 7 dias dos três lotes analisados. 164

Tabela 65 - Resultados do ensaio de resistência à carbonatação por câmara de $\mathrm{CO}_{2}$ (5\%; 7 dias) de corpos-de-prova submetidos à cura acelerada 24/48 horas mais imersão em água até 7 dias, nos concretos dos três lotes analisados, por fenolftaleína e timolftaleína.

Tabela 66 - Comparação entre as profundidades de carbonatação obtida neste trabalho com as calculadas pelo modelo apresentado por Atis (2003) citado por Silva (2007) 168

Tabela 67 - Comparação entre as profundidades de carbonatação obtida neste trabalho com as calculadas pelo segundo modelo apresentado por Atis (2003) citado por Silva (2007) 169

Tabela 68 - Resultados do ensaio de resistência à carbonatação por três ciclos de imersão e secagem em corpos-de-prova submetidos a cura acelerada 24/48 h mais imersão em água até 7 dias nos concretos dos três lotes analisados. 174

Tabela 69 - Resultados do ensaio de resistência à penetração de cloretos, por três ciclos de imersão e secagem, das metades seccionadas diametralmente e nos terços médios, submetidos a cura acelerada 24/48 horas mais imersão em água até 7 dias nos concretos dos três lotes analisados.

Tabela 70 - Profundidade mínima e máxima característica de carbonatação por câmara de $\mathrm{CO}_{2}$ e por ciclagem nos corpos-de-prova dos três lotes 178

Tabela 71 - Profundidade mínima e máxima característica da penetração de cloretos por ciclagem nos corpos-de-prova dos três lotes 
Tabela 72 - Resultados do ensaio de potencial de corrosão nos corpos-de-prova com 2,5 cm de cobrimento, amostrados dos três lotes analisados 179

Tabela 73 - Correlações entre o abatimento do tronco de cone e propriedades dos três lotes 183

Tabela 74 - Correlações entre a massa específica do concreto fresco aparente e propriedades dos três lotes 184

Tabela 75 - Correlações entre a compactabilidade do concreto adensado e 185

Tabela 76 - Correlações entre a compactabilidade do concreto não-adensado e propriedades de dois lotes de diferentes centrais (Lote 1 e 2 ) 186

Tabela 77 - Correlações entre o teor de ar pelo método pressométrico e propriedades de dois lotes de diferentes centrais (Lote 1 e 2 )

Tabela 78 - Correlações entre a umidade do concreto fresco e propriedades de dois lotes de diferentes centrais (Lotes 1 e 2)

Tabela 79 - Correlações entre a absorção de água por capilaridade e propriedades de dois lotes de diferentes centrais (Lotes 1 e 2 ) 189

Tabela 80 - Correlações entre a absorção de água total e as propriedades dos três lotes 190

Tabela 81 - Correlações entre o índice de vazios entre propriedades dos três lotes 190

Tabela 82 - Correlações entre resistência à compressão a 1 dia entre propriedades de dois lotes de diferentes centrais (Lotes 1 e 2) 191

Tabela 83 - Correlações entre resistência à compressão a 7 dias por cura acelerada entre propriedades de dois lotes de diferentes centrais (Lotes 1 e 2 ) 192

Tabela 84 - Correlações entre resistência à compressão a 28 dias por cura normal entre propriedades dos três lotes 192

Tabela 85 - Correlações entre resistência à compressão a 63 dias por cura normal entre propriedades de dois lotes de diferentes centrais (Lotes 1 e 2) 193

Tabela 86 - Correlações entre resistência à compressão a 91 dias por cura normal entre propriedades de dois lotes de diferentes centrais (Lotes 1 e 2) 194

Tabela 87 - Correlações entre resistência à tração por compressão diametral a 7 dias por cura acelerada $24 / 48$ horas com demais propriedades dos dois lotes analisados 195

Tabela 88 - Correlações entre a profundidade de carbonatação e penetração de cloretos em corpos-de-prova ciclados por imersão e secagem dos três lotes analisados

Tabela 89 - Correlações entre a profundidade de carbonatação por câmara de $\mathrm{CO}_{2} \mathrm{em}$ corpos-de-prova dos três lotes analisados 198

Tabela 90 - Propriedades químicas, físicas e mecânicas do CP V ARI RS do concreto da obra 1 mês de Agosto/08 222

Tabela 91 - Propriedades químicas, físicas e mecânicas do CP IIF 32 do concreto da obra 2 224 
Tabela 92 - Controle de temperatura e umidade da caixa térmica 1 225

Tabela 93 - Controle de temperatura e umidade da caixa térmica 2 226

Tabela 94 - Controle de temperatura do tanque de cura no lote treinamento 227

Tabela 95 - Controle de temperatura do tanque de cura no lote 1

Tabela 96 - Controle de temperatura do tanque de cura no lote 2 228

Tabela 97 - Tempo de descarga dos caminhões e resultados dos ensaios de abatimento do tronco de cone nos concretos do lote 1

Tabela 98 - Resultados dos ensaios de densidade específica do concreto fresco amostrado do lote 1 229

Tabela 99 - Resultados dos ensaios de compactabilidade do concreto fresco adensado e não adensado dos concretos amostrados do lote 1 230

Tabela 100 - Resultados dos ensaios de teor de ar pelo método pressométrico e umidade do concreto fresco nos concretos amostrados do lote 1

Tabela 101 - Resultados dos ensaios de absorção de água total nos corpos-de-prova do lote 1 232

Tabela 102 - Resultados dos ensaios de absorção de água por capilaridade nos corposde-prova do lote 1

Tabela 103 - Resultados dos ensaios mecânicos nos corpos-de-prova amostrados dos caminhões do lote 1

Tabela 104 - Resultados dos ensaios de carbonatação por câmara de $\mathrm{CO}_{2}$ (5\%; 7 dias) nos corpos-de-prova por fenolftaleína, submetidos a cura acelerada 24/48 horas mais imersão em água até 7 dias, do lote 1

Tabela 105 - Resultados dos ensaios de carbonatação por câmara de $\mathrm{CO}_{2}$ (5\%; 7 dias) nos corpos-de-prova por timolftaleína, submetidos a cura acelerada 24/48 horas mais imersão em água até 7 dias, do lote 1

Tabela 106 - Acompanhamento de massa dos corpos-de-prova submetidos a três ciclos de imersão e secagem, amostrados do lote 1

Tabela 107 - Resultados do ensaio de profundidade de carbonatação em corpos-deprova, submetidos a três ciclos de molhagem e secagem, dos caminhões amostrados do lote 1

Tabela 108 - Resultados do ensaio de penetração de cloretos em corpos-de-prova rompidos na diametral, submetidos a ciclos de molhagem e secagem, dos caminhões amostrados do lote 1

Tabela 109 - Resultados do ensaio de penetração de cloretos em corpos-de-prova rompidos nos terços médios, submetidos a ciclos de molhagem e secagem, dos caminhões amostrados do lote 2

Tabela 110 - Valores do potencia de corrosão no potenciostato modelo 273 (mV,ECS), nos corpos-de-prova com cobrimento de $2,5 \mathrm{~cm}$ do lote 1 
Tabela 111 - Valores do potencia de corrosão no potenciostato modelo 273 (mV,ECS), nos corpos-de-prova com cobrimento de 3,5 e $1,5 \mathrm{~cm}$ do lote 1 242

Tabela 112 - Tempo de descarga de cada caminhão e os resultados dos ensaios de abatimento do tronco de cone dos concretos amostrados do lote 2 243

Tabela 113 - Resultados dos ensaios de densidade de massa específica do concreto fresco amostrado dos caminhões do lote 2

Tabela 114 - Resultados dos ensaios de compactabilidade do concreto fresco adensado e não adensado amostrado dos caminhões do lote 2 244

Tabela 115 - Resultados dos ensaios de teor de ar pelo método pressométrico e umidade do concreto fresco dos concretos de cada caminhão amostrados do lote 2 244

Tabela 116 - Resultados do ensaio de absorção de água total nos corpos-de-prova do lote 2 246

Tabela 117 - Resultados dos ensaios de absorção de água por capilaridade nos corpos-de-prova do lote 2

Tabela 118 - Resultados dos ensaios mecânicos dos concretos da obra 2 248

Tabela 119 - Resultados dos ensaios de resistência â tração por compressão diametral do lote 2 249

Tabela 120 - Resultados dos ensaios de carbonatação por câmara de $\mathrm{CO}_{2}$ (5\%; 7 dias) nos corpos-de-prova por fenolftaleína, submetidos a cura acelerada 24/48 horas mais imersão em água até 7 dias, do lote 2 250

Tabela 121 - Resultados dos ensaios de carbonatação por câmara de $\mathrm{CO}_{2}$ (5\%; 7 dias) nos corpos-de-prova por timolftaleína, submetidos a cura acelerada 24/48 horas mais imersão em água até 7 dias, do lote 2 251

Tabela 122 - Acompanhamento de massa dos corpos-de-prova submetidos a três ciclos de imersão e secagem, amostrados do lote 2 253

Tabela 123 - Resultados das medidas dos ensaios de carbonatação em corpos-deprova, submetidos a 3 ciclos de imersão e secagem, por cura acelerada 24/48 horas mais imersão em água até 7 dias, amostrados do lote 2 . 254

Tabela 124 - Resultados do ensaio de penetração de cloretos em corpos-de-prova rompidos na diametral, submetidos a ciclos de molhagem e secagem, dos caminhões amostrados do lote 2

Tabela 125 - Resultados do ensaio de penetração de cloretos em corpos-de-prova rompidos nos terços médios, submetidos a ciclos de molhagem e secagem, dos caminhões amostrados do lote 2 255

Tabela 126 - Valores do potencia de corrosão no potenciostato modelo 273 (mV,ECS), nos corpos-de-prova com cobrimento de $2,5 \mathrm{~cm}$ do lote 2 
Tabela 127 - Valores do potencia de corrosão no potenciostato modelo 273 (mV,ECS), nos corpos-de-prova com cobrimento de 3,5 e $1,5 \mathrm{~cm}$ do lote 2 257

Tabela 128 - Resultados do ensaio de abatimento do tronco de cone do lote treinamento 258

Tabela 129 - Resultados dos ensaios de massa especifica do concreto fresco do lote treinamento 258

Tabela 130 - Resultados do ensaio de compactabilidade com adensamento prévio do concreto amostrado do lote treinamento 259

Tabela 131 - Resultados dos ensaios de teor de ar e umidade do lote treinamento 259

Tabela 132 - Resultados dos ensaios de absorção de água total do lote treinamento 260

Tabela 133 - Resultados dos ensaios de absorção de água por capilaridade do lote treinamento 262

Tabela 134 - Resultados dos ensaios mecânicos e acelerados do lote treinamento 263

Tabela 135 - Resultados dos ensaios de carbonatação por câmara de $\mathrm{CO}_{2}$ (5\%; 7 dias) nos corpos-de-prova por fenolftaleína, submetidos a cura acelerada 24/48 horas mais imersão em água até 7 dias, do treinamento 264

Tabela 136 - Resultados dos ensaios de profundidade de carbonatação em câmara de $\mathrm{CO}_{2}$ (5\%; 7 dias), por timolftaleina nos corpos-de-prova do lote treinamento 265

Tabela 137 - Resultados dos ensaios de carbonatação nos corpos-de-prova submetidos a três ciclos de imersão em solução de $3,5 \%$ de $\mathrm{NaCl}$ e secagem em caixa térmica ventilada, do lote treinamento

Tabela 138 - Resultados do ensaio de penetração de cloretos em corpos-de-prova rompidos na diametral, submetidos a ciclos de molhagem e secagem, dos caminhões amostrados do lote treinamento 267

Tabela 139 - Resultados dos ensaios da penetração de cloretos nos terços médios dos corpos-de-prova do lote treinamento 268

Tabela 140 - Valores do potencia de corrosão no potenciostato modelo 273 (mV,ECS), nos corpos-de-prova com cobrimento de $2,5 \mathrm{~cm}$ do lote treinamento 269

Tabela 141 - Valores do potencia de corrosão no potenciostato modelo 273 (mV,ECS), nos corpos-de-prova com cobrimento de $3,5 \mathrm{~cm}$ e $1,5 \mathrm{~cm}$ do lote treinamento 270 


\section{LISTA DE ABREVIATURAS}

\begin{tabular}{ll} 
ABECE & Associação Brasileira de Engenharia e Consultoria Estrutural \\
ABNT & Associação Brasileira de Normas Técnicas \\
ACI & American Concrete Institute \\
ASTM & American Society for Testing and Materials \\
BS & British Standard \\
CEA & Centro de Estatística Aplicada do IME-USP \\
CEB & Comitê Euro-International Du Beton \\
CEFET & Centro Federal de Educação Tecnológica \\
CP I - S & Cimento Portland comum \\
CP II - F & Cimento Portland composto com filer \\
CP II - Z & Cimento Portland composto com pozolana \\
CP III & Cimento Portland de alto forno \\
CP IV & Cimento Portland pozolanico \\
CP V ARI & Cimento Portland de alta resistência inicial \\
C10,...,C80 & Classe de resistência à compressão \\
EPUSP & Escola Politécnica da Universidade de São Paulo \\
IBRACON & Instituto Brasileiro do Concreto \\
IME & Instituto de Matemática e Estatística da Universidade de São Paulo \\
INT & Instituto Nacional de Tecnologia \\
IPT & Instituto de Pesquisas Tecnológicas do Estado de São Paulo \\
ITA & Instituto da Aeronáutica \\
PUC & Pontifica Universidade Católica \\
UFG & Universidade Federal de Goiás \\
UFPB & Universidade Federal da Paraíba \\
UFSC & Universidade Federal de Santa Catarina \\
UFSM & Universidade Federal de Santa Maria \\
UFRGS & Universidade Federal do Rio Grande do Sul \\
UNICAMP & Universidade de Campinas \\
UR & Umidade Relativa \\
USP & Universidade de São Paulo \\
\hline
\end{tabular}




\section{LISTA DE SÍMBOLOS}

A

$A_{b}$

$A_{b s c}$

$A_{b s t}$

$A_{b 1 / 2 c p}$

$A_{r}$

a/c

C

$\mathrm{Ca}(\mathrm{OH})_{2}$

$\mathrm{C}_{\text {。 }}$

$\mathrm{C}_{3} \mathrm{~A}$

$\mathrm{C}_{4} \mathrm{AF}$

$\mathrm{Cl}-\mathrm{CO}_{2}$

$\mathrm{Cl}^{-}$

$\mathrm{CO}_{291 \mathrm{~d}}$

D

D (t)

$f_{c}$

$f_{\mathrm{ck}}$

$\mathbf{f}_{\mathrm{cj}}$

$f_{\text {ci,acel }}$

$\mathbf{f}_{\mathrm{ck}, \mathrm{est}}$

$f_{\mathrm{ct}, \mathrm{SP}}$

$\mathrm{G}_{\mathrm{s}}$

H

$\mathrm{H}_{2} \mathrm{~S}$

h

$\mathrm{l}_{\mathrm{a}}$

Iv
Teor de ar do concreto fresco

Abatimento do tronco de cone

Absorção de água por capilaridade

Absorção de água total

Absorção de água de meio corpo-de-prova

Teor de ar pelo método pressométrico

Relação água/cimento

Consumo de cimento

Hidróxido de cálcio

Compactabilidade

Aluminato tri-cálcico

Ferro Aluminato tetra-cálcico

Resistência à carbonatação e cloretos simultâneos em corpos-de-prova submetidos a 3 ciclos de molhagem e secagem Íons Cloreto

Resistência à carbonatação em câmara com $5 \%$ de $\mathrm{CO}_{2}$

Coeficiente efetivo de difusão

Coeficiente de difusão em função da temperatura

Resistência à compressão

Resistência característica do concreto à compressão

Resistência à compressão do concreto por ensaio na idade de j dias

Resistência à compressão do concreto por ensaio acelerado na idade de j dias

Resistência característica à compressão estimada

Resistência à tração por compressão diametral

Grau de saturação

Umidade do concreto fresco

Gás Sulfídrico

Altura ou penetração da água no capilar

Índice de ar presente na mistura

Índice de vazios 


\begin{tabular}{|c|c|}
\hline $\mathbf{J}$ & Fluxo \\
\hline$M_{\text {periodo-ciclo }}$ & Massa referente ao período de ciclagem \\
\hline$M_{\text {sat }}$ & Massa teórica saturada \\
\hline$M_{100}{ }^{\circ}$ cpinteiro & Massa seca a $100^{\circ} \mathrm{C}$ do corpo-de-prova inteiro \\
\hline m & Massa do recipiente com concreto \\
\hline $\mathbf{m}_{\mathrm{r}}$ & Massa do recipiente vazio \\
\hline $\mathbf{m}_{\mathrm{c}}$ & Massa de cimento da betonada \\
\hline$m_{f}$ & $\begin{array}{l}\text { Massa total de agregado miúdo da betonada na condição de umidade em } \\
\text { que foi utilizado para o preparo do concreto }\end{array}$ \\
\hline $\mathbf{m}_{\mathrm{g}}$ & $\begin{array}{l}\text { Massa total de agregado graúdo da betonada na condição de umidade em } \\
\text { que foi utilizado para o preparo do concreto }\end{array}$ \\
\hline $\mathbf{m}_{\mathbf{a}}$ & Massa de água adicionada na betonada \\
\hline $\mathrm{NaOH}$ & Hidróxido de sódio \\
\hline $\mathrm{pH}$ & Potencial hidrogênionico \\
\hline $\mathbf{k}$ & Coeficiente de carbonatação \\
\hline $\mathbf{k}_{\mathrm{p}}$ & Coeficiente de permeabilidade do material \\
\hline $\mathrm{KOH}$ & Hidróxido de potássio \\
\hline $\mathbf{R}$ & Constante dos gases \\
\hline $\mathbf{R}_{\mathbf{e}}$ & Rendimento do traço \\
\hline $\mathbf{r}$ & Raio capilar \\
\hline $\mathrm{SO}_{2}$ & Dióxido de Enxofre \\
\hline $\mathbf{S}_{\mathbf{d}}$ & Desvio padrão de dosagem do concreto \\
\hline $\mathbf{T}$ & Temperatura \\
\hline $\mathbf{t}$ & Tempo \\
\hline $\mathbf{V}_{\text {água }}$ & Volume de água \\
\hline$V_{t}$ & Volume total dos componentes da betonada \\
\hline $\mathbf{v}$ & Tensão superficial da água \\
\hline $\mathbf{v}_{\mathbf{r}}$ & Volume do recipiente \\
\hline $\mathbf{x}$ & Profundidade de carbonatação \\
\hline $\mathbf{w}_{\mathbf{k}}$ & Abertura máxima de fissuras \\
\hline$\gamma_{c f}$ & Massa específica aparente do concreto fresco \\
\hline$\gamma_{c}$ & Massa específica do cimento \\
\hline$\gamma_{f}$ & Massa específica do agregado miúdo \\
\hline$\gamma_{g}$ & Massa específica do agregado graúdo \\
\hline
\end{tabular}




$\begin{array}{ll}\boldsymbol{\gamma}_{\mathrm{a}} & \text { Massa específica da água } \\ \boldsymbol{\eta} & \text { Viscosidade da água } \\ \boldsymbol{\delta}_{\boldsymbol{p}} / \boldsymbol{\delta}_{\mathbf{x}} & \text { Gradiente de pressão } \\ \boldsymbol{\varphi} & \text { Diâmetro de poros } \\ \boldsymbol{\mu} & \text { Média } \\ \boldsymbol{\sigma} & \text { Desvio Padrão }\end{array}$




\section{CAPÍTULO 1}

\section{INTRODUÇÃO}

O momento atual da Engenharia Civil, no Brasil e no mundo, tem se caracterizado por uma grande preocupação com a qualidade e a durabilidade das edificações e obras em geral, com vistas ao desenvolvimento sustentável das cidades.

A durabilidade dos edifícios em concreto armado só pode ser alcançada, se atendido um conjunto de requisitos nas etapas de projeto, execução e manutenção. Em cada uma, há propriedades específicas a serem exigidas e atendidas pelos concretos de cimento Portland, enquanto material estrutural envolvente e de proteção das armaduras de aço carbono. Proteção esta que é exclusiva do concreto e do sistema de pintura, em estruturas de concreto aparente, ou conjunta com um sistema de revestimento de argamassa e pintura, que é o caso mais comum. Em qualquer desses casos, a responsabilidade da proteção das armaduras é atribuída apenas ao concreto, enquanto material estrutural.

Parte da área técnica, de projetistas e empresas construtoras a órgãos públicos, tem consciência de que a qualidade das obras é rentável a médio e a longo prazo, e este consenso precisa ser cada vez mais pactuado e respeitado, por todos da cadeia da Construção Civil. Os avanços conseguidos no Brasil, na qualidade das estruturas de concreto armado, aconteceram em função da discussão permanente e da implementação de novas normas técnicas de projeto e execução, e de outros documentos de idoneidade técnica, como são as dissertações e teses acadêmicas.

Como se sabe, as normas de estruturas de concreto armado até a revisão da ABNT NBR 6118 (2003) - Norma Brasileira de Projeto de Estruturas de Concreto - Procedimentos, sempre valorizaram o binômio "esforços solicitantes versus capacidade resistente", dando pouca ênfase nos diferentes níveis de exposição dos elementos estruturais ao meio ambiente, às necessidades diferenciadas de cobrimento das armaduras e vários outros aspectos importantes da produção do concreto.

A partir da ABNT NBR 6118 (2003) e da ABNT NBR 14931 (2003) - Execução de Estruturas de Concreto - Procedimento, a questão da durabilidade das estruturas passou a ser tratada de maneira sistêmica, como necessário, e foram enfatizadas as características do concreto que possam contribuir para longevidade das estruturas em serviço e frente aos mecanismos de deterioração mais comuns. Esta nova visão foi também incorporada na revisão 
da ABNT NBR 12655 (2006) - Concreto de Cimento Portland - Preparo, Controle e Recebimento - Procedimento, mas ainda de forma prescritiva e por limites de relação água/cimento e de consumo de cimento, sem haver evolução no campo de métodos para a pré-seleção ou o controle de qualidade de concretos dosados por esses critérios e que são, usualmente, citados como "critérios de durabilidade".

Mas a etapa de projeto é sabidamente o primeiro e um dos mais importantes passos para se obter estruturas duráveis, e o conhecimento de outras diretrizes que visam à durabilidade como, por exemplo, o de se adotar corretamente a classe ambiental do meio em que a estrutura será executada e ainda conhecer o micro-clima peculiar de cada elemento estrutural e as exigências de espessura de cobrimento das armaduras, além das características do concreto, são todos requisitos de fundamental importância, que precisam agora evoluir pela evolução correspondente no campo da produção do concreto e execução das estruturas.

Os itens que seguem nesta introdução detalham as justificativas e os objetivos desta dissertação; por fim, as instituições que são referência no tema desta pesquisa e a estrutura deste trabalho.

\subsection{Objetivos}

Esta pesquisa teve por objetivo geral contribuir para a evolução de procedimentos para o controle tecnológico e recebimento de concreto estrutural em atmosferas marítimas e urbanas de clima tropical, com vistas à proteção de armaduras e durabilidade dessas estruturas.

O programa experimental objetivou amostrar e caracterizar, em campo, três lotes de concretos estruturais pré-misturados de mesmo abatimento e resistência característica à compressão a 28 dias, com vistas a comparar e correlacionar as suas propriedades desde o estado fresco, quanto à capacidade de proteção de armaduras para estruturas em ambiente urbano do litoral brasileiro. Em especial, no estado fresco, foram visadas propriedades relacionadas ao teor de ar no concreto fresco e algumas propriedades físicas e mecânicas de fácil caracterização no estado endurecido.

As seguintes premissas e objetivos complementares orientaram a definição das propriedades estudadas e dos procedimentos adotados na metodologia:

- Antecipar a idade de qualificação de concretos, através do emprego de cura acelerada em temperatura moderada, segundo procedimento baseado no tipo $\mathrm{A}$ da ASTM C 684 (1999); 
- Adotar recursos laboratoriais acessíveis a empresas de controle tecnológico do mercado brasileiro, para estimular novas práticas em estudo de dosagem, seleção ou recebimento de concretos estruturais.

\subsection{Importância e justificativa do tema}

O início da tecnologia do concreto no Brasil remonta ao final do séc. XIX, com a instalação, pela Escola Politécnica da Universidade de São Paulo, do Gabinete da Resistência dos Materiais, em 1899. Em 1905, foi publicado, pelo Grêmio Politécnico, o Manual de Resistência dos Materiais resultante das atividades laboratoriais empreendidas pelos Engs. Willhem Fischer e Hyppolyto Gustavo Pujol, no qual constavam resultados de ensaios em cimentos e cales, além de metais e madeiras (HELENE; TERZIAN, 1993).

A inexistência de um consenso nacional sobre os procedimentos e parâmetros de dosagem levou vários pesquisadores a proporem o seu método de dosagem, como o método de dosagem do Instituto de Pesquisas Tecnológicas (IPT), proposto por Ary Torres em 1927; o método de dosagem do Instituto Nacional de Tecnologia (INT), proposto por Lobo Carneiro; o método do Instituto Tecnológico do Estado do Rio Grande do Sul, proposto por Eládio Petrucci; o método dos engenheiros Ary Torres e Carlos Eduardo Rosman, baseado nos trabalhos anteriormente publicados, cujos princípios foram posteriormente incorporados às recomendações do projeto de revisão da NB-1 em 1958, entre outros. Várias publicações acadêmicas e livros editados nas décadas seguintes contribuíram para a disseminação de estudos de dosagem de concretos para estruturas, por exemplo, o de Helene; Terzian (1993). Esta evolução culminou recentemente no fato de que vários especialistas endossaram a simplificação e a uniformização dos procedimentos de dosagem do concreto pelo recémbatizado Método de Dosagem IBRACON, divulgado em ISAIA (2005).

Já nas últimas décadas, diversos trabalhos acadêmicos procuraram contribuir para o entendimento de que as variáveis de dosagem, expressas por natureza e teor dos componentes do concreto, bem como a espessura de cobrimento das armaduras, afetam a carbonatação e o ingresso de íons cloreto no concreto, por exemplo: HELENE (1993), CASCUDO (1996, 2001), BAUER (1995); DIAZ (1997) REGATTIERI (1998); TULA (2000); CUNHA (2001); GOMES (2006); SILVA (2007) e MEIRA (2004).

Assim, as normas brasileiras de projeto e execução de estruturas de concreto armado já incorporaram grande parte da evolução tecnológica no campo da durabilidade, nas últimas décadas, a partir da ABNT NBR 6118 (2003). Mas ainda falta a evolução correspondente para 
os procedimentos de controle tecnológico pela ABNT NBR 12655 (2006), pois os concretos passaram a ser dosados por critérios de relação água/cimento máxima além da resistência à compressão, enquanto o controle de recebimento continua sendo feito, na prática, apenas por critérios de abatimento e de atendimento à $\mathrm{f}_{\mathrm{ck} \text {,est }}-$ resistência característica à compressão.

Especialistas americanos e canadenses, como Hooton et al. (2006) vão além e enfatizam ser necessário incorporar melhores métodos e critérios de desempenho e controle às especificações e à produção do concreto estrutural, com vistas à durabilidade das estruturas, e consideram insuficientes os limites prescritivos de relação água/cimento.

Mehta; Monteiro (2008) são de opinião semelhante, pois enfatizam que: "O porte das estruturas de concreto projetadas e construídas atualmente e a velocidade da construção moderna exigem que a tomada de decisão para aceitar ou rejeitar a qualidade do concreto não seja deixada para o ensaio de compressão aos 28 dias, que continua a ser a base na maioria das especificações dos projetos de estruturas".

BAUER et al. (2006), estudando os concretos produzidos no Distrito Federal, também atestam a necessidade de evolução nos procedimentos de controle tecnológico:

A definição e especificação e comercialização da maioria dos concretos utilizados nas obras do Distrito Federal é feita em cima de parâmetros como resistência característica ( $f_{c k}$ ) e abatimento (slump). Na maioria das vezes os clientes (empresas construtoras), tendo por referência somente os parâmetros estruturais, não se atêm a outros aspectos, fundamentais na definição da durabilidade das estruturas de concreto. Assim pode-se mencionar como fundamentais: relação água/cimento; consumo de cimento; teor e natureza de adições (BAUER et al. 2006).

Esta visão também é compartilhada pela ABECE - Associação Brasileira de Engenharia e Consultoria Estrutural, que no ano de 2008 formou um Comitê com especialistas, entre os quais, projetistas de estruturas, representantes de centrais dosadoras e consultores com o objetivo de discutir a qualidade dos concretos estruturais fornecidos em função da conformidade da resistência do concreto estrutural, pois essa qualidade interfere na segurança e durabilidade das estruturas (ABECE, 2008).

Assim, há perspectivas para novos trabalhos, através da retomada do tema, por eventos e publicações mais recentes, como a de Fusco (2008) e documento da ABECE (2008).

Destaca-se, por fim, que o problema da corrosão de armaduras do concreto armado tem sido objeto de grande número de levantamentos e estudos sobre. A seguir, encontra-se descrito um breve cenário sobre a ocorrência desse problema na cidade onde se realizou o programa experimental deste trabalho. 
Em João Pessoa-PB, Silva et al. (2003) fizeram uma breve análise da incidência das manifestações patológicas mais freqüentes ocorridas em 14 edifícios residenciais de múltiplos andares, com idade média de 7,1 anos e resistência característica de $15 \mathrm{MPa}$, localizados em bairros litorâneos daquela cidade. Foi verificado que a corrosão das armaduras chegou a $78 \%$ das manifestações patológicas presentes nas edificações estudadas, conforme a Figura 1. A sua incidência está relacionada ao uso de concretos permeáveis e/ou à falta de cobrimento, permitindo a entrada dos agentes agressivos no concreto. Dois aspectos importantes foram observados no citado levantamento:

a) Em alguns casos, foi observada a presença de umidade constante ao redor do concreto, nos pontos onde se manifestou a corrosão;

b) Os edifícios analisados não dispunham de certificados de recebimento do concreto, nem de projetos estruturais e complementares.

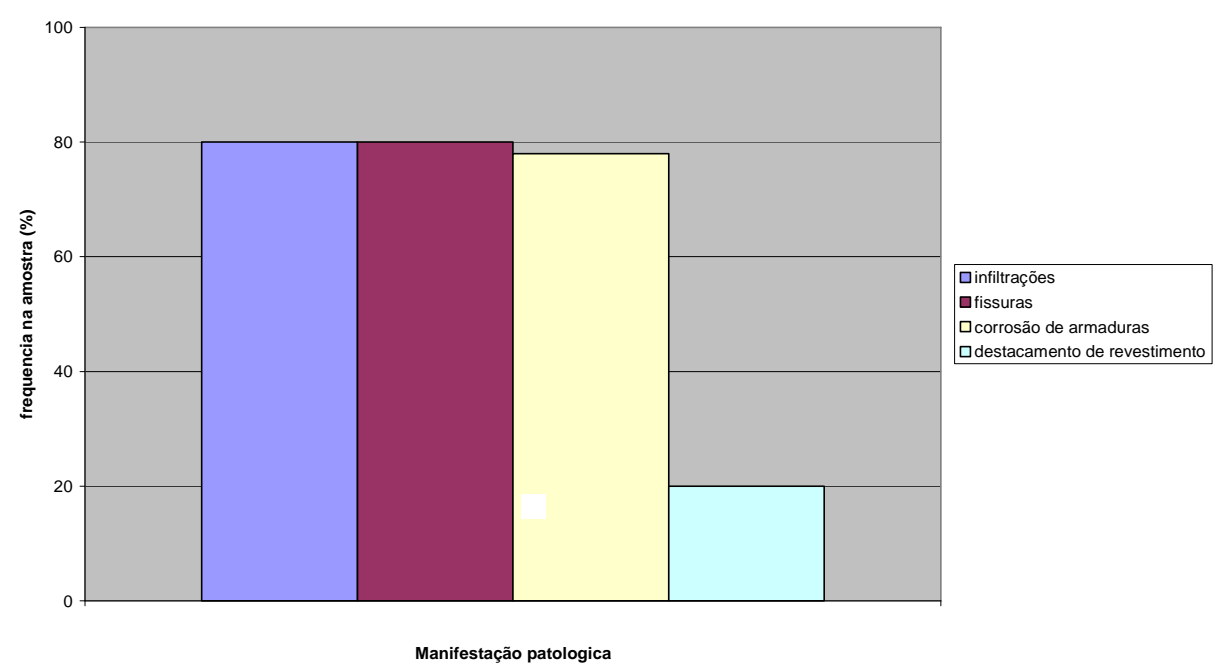

Figura 1 - Incidência de manifestações patológicas mais freqüentes em edifícios com média de 7,1 anos e $f_{c k} 15 \mathrm{MPa}$, na cidade de João Pessoa/PB (SILVA et al. 2003)

Em Pernambuco, Andrade (1997) realizou pesquisa em estruturas de concreto armado, verificando que a maioria das edificações estudadas localizava-se sob a ação da névoa salina, e que $64 \%$ das manifestações patológicas eram corrosão das armaduras.

No Rio Grande do Sul, com análise principal dos dados em obras de Porto Alegre, Dal Molin (1988) observou que a corrosão de armaduras chegou a 40\% das ocorrências então levantadas. 
Nince (1996) pesquisou a incidência de manifestações patológicas em estruturas de concreto na região Centro-Oeste de Brasília-DF, encontrando que 30,1\% de incidência das anomalias eram de corrosão das armaduras. No caso de cidades urbanas e não marítimas, o mecanismo preponderante que desencadeia a corrosão de armaduras é a carbonatação do concreto em presença de umidade.

\subsection{Centros nacionais no estudo da durabilidade das estruturas de concreto armado}

No Brasil, foi pioneiro o grupo da Escola Politécnica da Universidade de São Paulo (EPUSP) liderado pelo Prof. Dr. Paulo Helene, e onde também trabalham a orientadora deste trabalho, a Prof ${ }^{\underline{a}}$ Dr $^{\mathrm{a}}$. Silvia Selmo, e vários outros especialistas em durabilidade do concreto como: a Prof ${ }^{\mathrm{a}}$ Dra . Maria Alba Cincotto, o Prof. Dr. Gaspar Djanikian, o Prof. Dr. Antonio Figueiredo, o Prof. Dr. Vahan Agopyam, o Prof. Dr. Vanderley M. John entre outros.

O Instituto de Pesquisas Tecnológicas (IPT) do Estado de São Paulo tem ainda vários outros especialistas como o Prof. Dr. Ercio Thomaz, o Prof. Dr. Valdecir Quarcione e a Prof ${ }^{a}$ Dra Zehbour Panossian.

O Instituto Tecnológico da Aeronáutica (ITA) ainda no Estado de São Paulo é bem representado pela Prof ${ }^{a}$. Maryangela G. de Lima.

$\mathrm{Na}$ região centro-oeste, pode-se destacar o grupo de pesquisa da Universidade Federal de Goiás (UFG), liderado pelos Prof. Dr. Enio Pazini Figueiredo e Prof. Dr. Osvaldo Cascudo. O grupo de pesquisa da Universidade de Brasília (UnB) é representado pelos Prof. Dr. Alberto Nepomuceno e Prof. Dr. Elton Bauer.

Na região sul, destaca-se o grupo de pesquisa da Universidade Federal do Rio Grande do Sul (UFRGS) liderado pela Prof ${ }^{\mathrm{a}}$. Drª Denise Dal Molin e ainda há os professores de várias outras universidades gaúchas, tais como: o Prof. Dr. Geraldo Isaia da Universidade Federal de Santa Maria (UFSM); o Prof. Dr. André Guimarães da Fundação Universidade do Rio Grande (FURG); o Prof. Dr. Jairo José de Andrade da Pontifícia Universidade Católica do Rio Grande do sul (PUC-RS), Prof. Dr. Wellington Repette, Prof. Dr. Luis Prudêncio Junior e Prof. Dr. Ivo José Padaratz, da Universidade Federal de Santa Catarina (UFSC).

$\mathrm{Na}$ região nordeste, a Prof $\stackrel{a}{\text {. Dra }}$. Eliana Monteiro da Universidade Católica de Pernambuco (UNICAP) e o Prof. Dr. Gibson Rocha Meira, do Centro Federal de Educação Tecnológica da Paraíba (CEFET-PB), trabalham em pesquisas sobre classificação da agressividade ambiental para estruturas de concreto armado. 
Muitos desses professores contribuíram para a elaboração e tradução de livros que disseminaram a tecnologia do concreto no Brasil, tanto por editoras técnicas nacionas, quanto pelo Instituto Brasileiro do Concreto (IBRACON).

\subsection{Estrutura da dissertação}

A apresentação da pesquisa foi estruturada em sete capítulos, conforme descrito a seguir.

O Capítulo um contém a introdução, a importância e justificativas pela escolha do tema, os centros de excelência, os objetivos da pesquisa, bem como explica a estrutura dos capítulos desta dissertação.

O Capitulo dois apresenta os conceitos de interesse ao escopo da dissertação quanto à vida útil e durabilidade das estruturas, mecanismos de deterioração do concreto armado, impactos da deterioração das estruturas por corrosão de armaduras e modelos de previsão da vida útil dessas estruturas.

O Capítulo três aborda os requisitos e critérios das normas brasileiras quanto ao projeto e à execução das estruturas de concreto armado, abordando de forma mais detalhada as exigências pertinentes aos concretos para proteção de armaduras.

No Capítulo quatro é descrito o programa experimental e estão apresentados os objetivos, a escolha das obras, procedimentos de amostragem do concreto de cada lote e a descrição dos ensaios realizados, e a metodologia de ensaios de carbonatação e penetração de cloretos.

No Capitulo cinco estão apresentados os resultados e discussões dos ensaios realizados, em que contou-se com especial contribuição do Centro de Estatística Aplicada do IME-USP, através da Professora Júlia Maria Pavan Soler e dos graduandos Márcio Eduardo Maciel e Karina Paula Santos Silva.

No Capítulo seis são resumidas as principais conclusões e considerações finais, bem como sugestões para estudos futuros.

O Capítulo sete apresenta as referências bibliográficas.

Os Apêndices e Anexo tem o conteúdo descrito pelos seus títulos respectivos, conforme o sumário. 


\section{CAPÍTULO 2}

\section{A DURABILIDADE DAS ESTRUTURAS DE CONCRETO ARMADO E A CORROSÃO DAS ARMADURAS}

No Brasil, o conceito tecnológico de durabilidade dos edifícios foi possivelmente difundido por especialistas do Instituto de Pesquisas Tecnológicas (IPT), nas décadas de 70 e 80, para a previsão de desempenho de novos sistemas construtivos. Portanto, no que tange ao desempenho, a durabilidade é interpretada para o edifício como um todo, e não apenas à deterioração dos materiais. Logo, é uma propriedade complexa e que resulta de um amplo atendimento de condicionantes críticas do projeto, da execução e da manutenção dos edifícios, além das propriedades dos materiais empregados.

Do ponto de vista da Engenharia de Materiais aplicada ao projeto estrutural dos edifícios, a interação das armaduras de aço-carbono com o meio ambiente ocorre em função das características físicas do cobrimento do concreto, como: porosidade, permeabilidade, absorção e características químicas que dependem principalmente da composição do cimento, adições e dosagem dos materiais no concreto. Estas características permitem uma maior ou menor capacidade de interação com os agentes agressivos que podem permear o concreto a partir do meio ambiente e comprometer a durabilidade das armaduras.

Segundo Helene (1993), os problemas quanto à durabilidade dos edifícios geralmente apresentam manifestações patológicas características, a partir das quais se podem deduzir ou estimar a natureza, a origem e os mecanismos dos fenômenos envolvidos. Em geral a maior parte desses mecanismos resulta por também causar a corrosão de armaduras.

"A degradação de estruturas de concreto frente ao problema da corrosão é algo que afeta a construção civil em todo mundo, com repercussão em função do volume de casos registrados, da precocidade com que ocorrem, bem como do montante de recursos envolvidos" (MEIRA, 2004).

Uma importância ainda mais ampla da durabilidade das estruturas de concreto, e bastante atual, está em favorecer o desenvolvimento sustentável, pois à medida que se prolonga o ciclo de vida das edificações, há economia de recursos naturais e redução do impacto ambiental.

A indústria da construção civil vem aprimorando suas técnicas construtivas, e caminhando para o avanço tecnológico. Mas essa mesma indústria, que cresce e se aprimora, 
está às voltas com alguns problemas tão grandes, quanto o seu crescimento. Uma dos questionamentos é o futuro da Construção Civil com a minimização da oferta de recursos naturais, antes tidos como inesgotáveis e renováveis (VIEIRA, 2003).

Segundo John (2000), a cadeia produtiva da construção civil é responsável por grandes impactos ambientais, em todas as etapas do seu processo, que é da extração, produção de materiais, construção, uso, até a demolição.

Ainda mais, Mehta; Monteiro (2008) alertam quanto à necessidade de se diminuir o consumo energético na produção do concreto estrutural, sem prejuízo da durabilidade das estruturas.

Assim, há que se registrar e controlar melhor a qualidade do concreto atualmente empregado na construção de edifícios, para se poder evoluir em tecnologias de projeto, produção e uso dessas estruturas.

\subsection{Conceitos de Durabilidade e Vida útil das Estruturas de Concreto Armado}

Helene (1998) entende que a durabilidade das estruturas de concreto armado é o resultado da sua interação com o ambiente e as condições de uso, operação e manutenção. Portanto, não é uma propriedade inerente ou intrínseca à estrutura. Uma mesma estrutura pode ter diferentes comportamentos quanto à durabilidade.

A ABNT NBR 6118 (2003), conceitua durabilidade como "a capacidade da estrutura resistir às influências ambientais previstas e definidas em conjunto pelo autor do projeto estrutural e o contratante, no início dos trabalhos de elaboração dos projetos", e cita que "as estruturas de concreto devem ser projetadas e construídas de modo que sob as condições ambientais previstas na época do projeto e quando utilizadas conforme preconizado em projeto conservem sua segurança, estabilidade e aptidão em serviço, durante o período correspondente à sua vida útil".

Sobre vida útil de projeto a ABNT NBR 6118 (2003) diz que, "entende-se por vida útil de projeto o período de tempo durante o qual se mantêm as características das estruturas de concreto, desde que atendidos os requisitos de uso e manutenção prescritos pelo projetista e pelo construtor, bem como de execução dos reparos necessários decorrentes de acidentes. $O$ conceito de vida útil aplica-se à estrutura como um todo ou às suas partes. Dessa forma, determinadas partes das estruturas podem merecer consideração especial com valor de vida útil diferente do todo".

Verifica-se acima que os conceito de durabilidade e de vida útil de projeto da ABNT NBR 6118 (2003) não estão adequadamente diferenciados. 
A diferenciação dos conceitos de vida útil de projeto e de durabilidade dos edifícios e de suas partes está bem estabelecida em norma estrangeira, como a BSI 7543 (2003), com origem em documentos ingleses da década de 50. Cabe salientar que Tuutti (1982) e Helene (1993) usaram conceitos similares ao deste documento inglês, para interpretar a durabilidade das estruturas com mecanismo de deterioração por corrosão das armaduras.

Como a BS 7543 (1992) é muito mais precisa ao diferenciar dois conceitos de durabilidade e vida útil, esta norma está resumida na Tabela 1. Observar que o conceito de vida útil de projeto deveria envolver o desenvolvimento de modelagem dos mecanismos preponderantes de deterioração do edifício, além dos esforços mecânicos previstos no projeto estrutural, para a correta interpretação do comportamento do aço, do concreto e demais materiais.

Portanto, há necessidade de evolução nos procedimentos de controle tecnológico dos materiais de construção estruturais, em especial do concreto e do aço, para que seja possível a evolução e efetiva aplicação de conceitos no campo da durabilidade e vida útil das estruturas, como os resumidos na Tabela 1.

Tuutti (1982) deu uma grande contribuição para o estudo da corrosão, quando introduziu o modelo teórico de previsão de vida útil para as estruturas de concreto armado, considerando a degradação por corrosão das armaduras. No modelo a vida útil é dividida em duas fases: período de iniciação e o período de propagação, conforme a Figura 2.

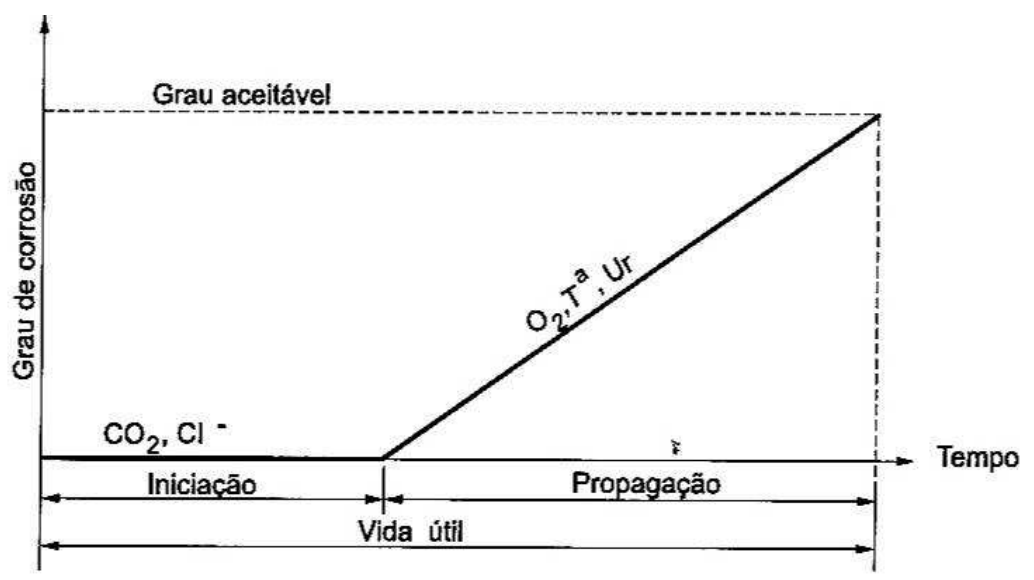

Figura 2 - Modelo de vida útil de TUUTTI (1982) 
Tabela 1 - Termos e conceitos relativos à durabilidade dos edifícios e suas partes, pela BS 7543 (1992), em paralelo aos termos propostos por Helene (1993), para descrever a durabilidade das estruturas de concreto armado, sujeitas à deterioração preponderante por corrosão das armaduras

\begin{tabular}{|c|c|c|c|c|}
\hline $\begin{array}{c}\text { Tipo de } \\
\text { durabiliade }\end{array}$ & $\begin{array}{l}\text { Termos } \\
\text { aplicados }\end{array}$ & $\begin{array}{l}\text { Termo } \\
\text { original }\end{array}$ & $\begin{array}{c}\text { Descrição BS } 7543 \text { (1992) para } \\
\text { edifícios }\end{array}$ & $\begin{array}{c}\text { Proposição de Helene (1993) } \\
\text { para as estruturas de concreto }\end{array}$ \\
\hline \multirow[t]{3}{*}{$\begin{array}{l}\text { Efetiva ou real (de } \\
\text { senviço) }\end{array}$} & Durabilidade & "Durability" & $\begin{array}{l}\text { Habilidade da construção e suas } \\
\text { partes em desempenhar suas funções, } \\
\text { ao longo de um período de tempo, sob } \\
\text { a influência de agentes de exposição. }\end{array}$ & - \\
\hline & $\begin{array}{c}\text { Limite de } \\
\text { durabilidade }\end{array}$ & $\begin{array}{l}\text { "Durability } \\
\text { limit" }\end{array}$ & $\begin{array}{l}\text { Ponto no qual a perda de desempenho } \\
\text { leva ao fim da vida útil de serviço. }\end{array}$ & - \\
\hline & $\begin{array}{l}\text { Vida útil ou } \\
\text { vida útil de } \\
\text { serviço }\end{array}$ & "Service life" & $\begin{array}{l}\text { Período real de tempo durante o qual } \\
\text { não há gastos excessivos para uso, } \\
\text { manutenção ou reparo de um } \\
\text { componente construtivo ou da } \\
\text { construção. É o registro efetivo da } \\
\text { durabilidade, pela retroalimentação de } \\
\text { informação da edificação em uso. }\end{array}$ & $\begin{array}{l}\text { Período de tempo equivalente ao } \\
\text { período de despassivação das } \\
\text { armaduras mais o período de } \\
\text { propagação da corrosão em níveis } \\
\text { aceitáveis. }\end{array}$ \\
\hline \multirow[t]{5}{*}{$\begin{array}{l}\text { Teórica (de } \\
\text { projeto) }\end{array}$} & $\begin{array}{l}\text { Vida útil } \\
\text { requerida }\end{array}$ & $\begin{array}{l}\text { "Required } \\
\text { service life" }\end{array}$ & $\begin{array}{l}\text { Vida útil a ser especificada para } \\
\text { atender às exigências dos usuários. É } \\
\text { definida pelo proprietário da obra, } \\
\text { obedecendo a critérios da norma ou } \\
\text { estabelecidas pelo projetista. }\end{array}$ & - \\
\hline & $\begin{array}{l}\text { Vida útil } \\
\text { prevista }\end{array}$ & $\begin{array}{l}\text { "Predicted } \\
\text { service life" }\end{array}$ & $\begin{array}{l}\text { Declaração do fabricante de um } \\
\text { produto ou processo acerca da sua } \\
\text { durabilidade estimada, por ensaios } \\
\text { acelerados ou registros de } \\
\text { desempenho em serviço. }\end{array}$ & $\begin{array}{c}\text { Iterpretado pelo tempo que } \\
\text { agentes agressivos ingressam } \\
\text { pelo cobrimento até as armaduras }\end{array}$ \\
\hline & $\begin{array}{l}\text { Vida útil de } \\
\text { projeto }\end{array}$ & "Design life" & $\begin{array}{l}\text { Proposta do projetista para o } \\
\text { proprietário da obra. }\end{array}$ & $\begin{array}{l}\text { Período de tempo que vai até a } \\
\text { despassivação da armadura }\end{array}$ \\
\hline & $\begin{array}{l}\text { Vida útil } \\
\text { residual }\end{array}$ & - & - & $\begin{array}{c}\text { Corresponde ao período de tempo } \\
\text { que a estrutura ainda será capaz } \\
\text { de desempenhar suas funções, } \\
\text { contando a partir da data de uma } \\
\text { vistoria }\end{array}$ \\
\hline & $\begin{array}{l}\text { Vida útil total } \\
\text { ou estrutural }\end{array}$ & - & - & $\begin{array}{l}\text { Período de tempo desde a } \\
\text { produção até o colapso parcial ou } \\
\text { total da estrutura, pela corrosão }\end{array}$ \\
\hline
\end{tabular}

O período de iniciação da corrosão, quando a armadura passa de um estado passivo para um estado ativo, é determinado pelo período de tempo no qual os agentes agressivos penetram no concreto de cobrimento e alcançam a armadura, podendo atingir concentrações que provocam o rompimento da película de passivação.

O modelo de HELENE (1993) introduz o conceito teórico de vida útil residual, que corresponde ao período de tempo estimado em que a estrutura ainda será capaz de desempenhar suas funções, conforme ilustra a Figura 3. 


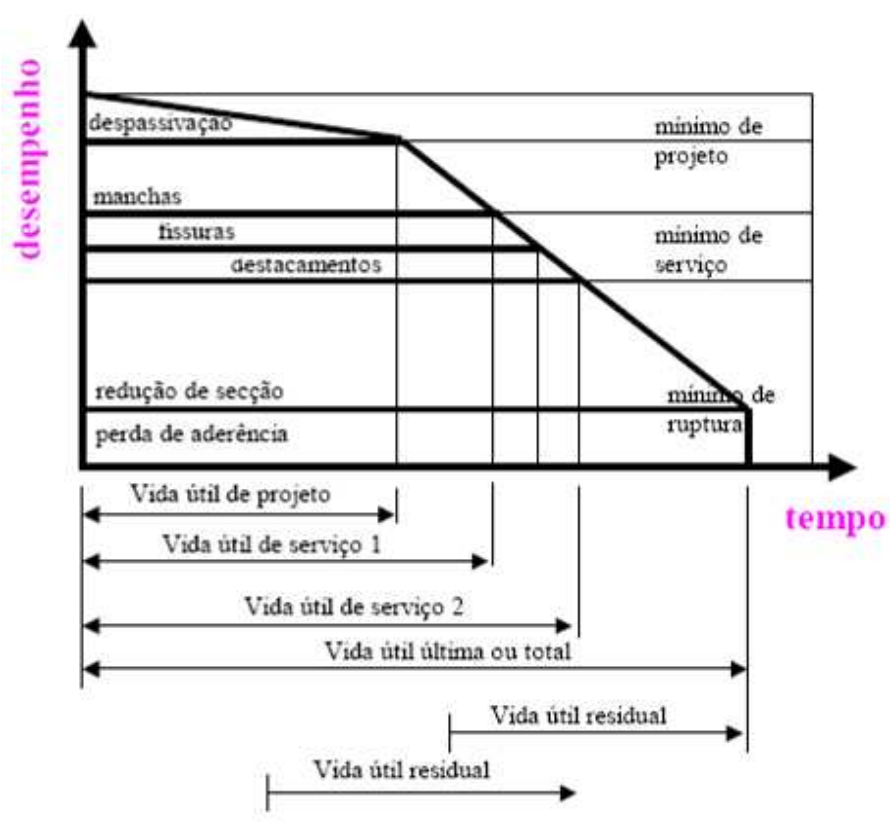

Figura 3 - Ampliação do conceito de vida útil das estruturas de concreto, tomando-se por referência o fenômeno da corrosão das armaduras e a realização de reparos de manutenção corretiva (HELENE, 1993)

Assim HELENE (1993) ampliou e diferenciou os conceitos de vida útil, como segue:

$\checkmark \quad$ Vida útil de serviço: Período de tempo equivalente ao período de despassivação das armaduras mais o período de propagação da corrosão em níveis aceitáveis;

$\checkmark \quad$ Vida útil de projeto: Período de tempo que vai até a despassivação da armadura;

$\checkmark \quad$ Vida útil residual: Corresponde ao período de tempo o qual a estrutura ainda será capaz de desempenhar suas funções, contado-se a partir da data de uma vistoria;

$\checkmark \quad$ Vida útil total: Período de tempo desde a produção até o colapso parcial ou total da estrutura, pela corrosão.

A análise de vida útil para o projeto de estruturas de concreto pode ser efetuada através de requisitos e critérios, que podem ser específicos de cada projeto e não generalizados, quando se pensa em evoluir de especificações prescritivas para especificações de desempenho, e estabelecidas com base em: experiência anterior de campo acumulada por especialistas (em geral, assume caráter prescritivo); previsão por ensaios acelerados; enfoque determinista ou enfoque probabilista.

Todavia, as informações para modelagem de vida útil de projeto, de serviço ou vida útil residual de armaduras de concreto requerem dados e modelos muito mais precisos sobre as características do concreto de produção das estruturas. Isto, portanto, requer a melhoria e a 
evolução permanente de normas de projeto e do controle de qualidade da execução, incluído aqui o controle de qualidade do concreto, foco principal deste trabalho.

Para o caso de edifícios com sistemas construtivos em concreto armado parte dos critérios da ABNT NBR 6118 (2003) para equacionar a vida útil de projeto das estruturas está baseada na proteção das armaduras, pelo cobrimento e a qualidade do concreto estrutural, e são critérios empíricos estabelecidos por ensaios laboratoriais e pela experiência de especialistas, como evidenciam os requisitos e critérios tratados no Capítulo 3.

Em se tratando de obras com caráter repetitivo quanto aos aspectos construtivos, é possível antever que apenas a progressão conjunta do controle tecnológico do concreto e da memória técnica de projeto e construção das estruturas em concreto armado é que podem, fundamentalmente, contribuir para a evolução da modelagem dos seus processos de deterioração e de previsão de desempenho, em novas formulações de concretos ou de sistemas construtivos.

Em qualquer dos enfoques devem ser levados em conta a geometria da estrutura, os materiais utilizados na construção, o ambiente no qual a estrutura está localizada, variabilidade dos fatores, mecanismos de deterioração, qualidade da mão de obra de execução do concreto e inspeção da estrutura.

\subsection{Mecanismos de deterioração das estruturas de concreto armado}

Para toda causa de deterioração do concreto armado, existe um ou mais agentes atuantes que interagem com o concreto e o aço, reduzindo o seu desempenho estrutural (ANDRADE, 2005). A seguir a Tabela 2, adaptada do autor citado, resume as principais origens, mecanismos e sintomas da deterioração do concreto armado nas estruturas.

A velocidade em que ocorrerá a perda de desempenho das estruturas, por um ou mais dos mecanismos informados, dependerá dos cuidados adotados no projeto, na execução, no controle de qualidade dessas etapas e na manutenção frente às ações e agentes atuantes, durante a etapa de serviço da obra.

Para Nepomuceno (1992) o principal fator de deterioração das estruturas de concreto armado é a interação do meio ambiente com o concreto. O que determina a penetração dos agentes agressivos nas estruturas de concreto é o tipo, tamanho e distribuição dos poros, a presença de água e fissuras (NEVILLE, 1997).

Segundo Mehta; Monteiro (2008), vazios capilares maiores do que $50 \mathrm{~nm}$, chamados de macroporos na literatura moderna, tem, provavelmente, mais influência na resistência mecânica e no transporte de agentes agressivos, do que os poros abaixo desse valor, cuja 
importância é relevante em outras propriedades, como a retração por secagem e a fluência. Já os vazios de ar aprisionados ou incorporado ao concreto fresco tem em geral dimensões acima de $50 \mu \mathrm{m}$ e reduzem tanto a resistência mecânica, quanto a permeabilidade, em especial para concretos com consumo de cimento mais elevado e acima de 250 a $300 \mathrm{~kg} / \mathrm{m}^{3}$. Além disso, Mehta; Monteiro (2008) bem destacam que as microfissuras presentes na zona de transição, entre pasta de argamassa e agregados graúdos no concreto, podem se constituir no ponto mais vulnerável do concreto à ação de água ou de agentes agressivos e, inclusive, aumentar a taxa de corrosão do aço. 
Tabela 2 - Resumo das principais origens e mecanismos da deterioração do concreto armado. Adaptado de Andrade (2005)

\begin{tabular}{|c|c|c|c|c|}
\hline $\begin{array}{c}\text { Origem da } \\
\text { deterioração inicial }\end{array}$ & \multicolumn{3}{|c|}{ Mecanismos de deterioração } & Sintomas \\
\hline \multirow{4}{*}{ Mecânica } & \multicolumn{3}{|c|}{ Sobrecarga } & \multirow{4}{*}{ Fissuração } \\
\hline & \multicolumn{3}{|c|}{ Impacto } & \\
\hline & \multicolumn{3}{|c|}{ Carga cíclica } & \\
\hline & \multicolumn{3}{|c|}{$\begin{array}{l}\text { Restrição à variação de volumes sob } \\
\text { gradientes normais de temperatura e } \\
\text { umidade }\end{array}$} & \\
\hline \multirow{11}{*}{ Física } & \multirow{3}{*}{ Desgaste superficial } & & Abrasão & \multirow{3}{*}{$\begin{array}{l}\text { Desgaste } \\
\text { superficial }\end{array}$} \\
\hline & & Atrito & Erosão & \\
\hline & & \multicolumn{2}{|c|}{ Cavitação } & \\
\hline & \multirow{2}{*}{\multicolumn{3}{|c|}{ Cristalização de sais }} & Fissuração \\
\hline & & & & Escamamento \\
\hline & \multirow{3}{*}{\multicolumn{3}{|c|}{ Congelamento e degelo }} & Expansão \\
\hline & & & & Fissuração \\
\hline & & & & Escamamento \\
\hline & \multirow{3}{*}{\multicolumn{3}{|c|}{ Fogo }} & Fissuração \\
\hline & & & & Expansão \\
\hline & & & & $\begin{array}{c}\text { Desidratação da } \\
\text { pasta }\end{array}$ \\
\hline \multirow{10}{*}{ Química } & \multicolumn{3}{|c|}{ Lixiviação } & Dissolução \\
\hline & \multirow{2}{*}{ Troca iônica } & \multicolumn{2}{|c|}{ Ação de sais } & decomposição \\
\hline & & \multicolumn{2}{|c|}{ Ação de ácidos } & química \\
\hline & \multirow{5}{*}{$\begin{array}{l}\text { Formação de } \\
\text { compostos } \\
\text { expansivos }\end{array}$} & \multirow{3}{*}{\multicolumn{2}{|c|}{$\begin{array}{l}\text { Sulfato de sódio, } \\
\text { potássio, cálcio e } \\
\text { magnésio }\end{array}$}} & Expansão \\
\hline & & & & Fissuração \\
\hline & & & & $\begin{array}{c}\text { Decomposição } \\
\text { química }\end{array}$ \\
\hline & & \multicolumn{2}{|c|}{$\begin{array}{l}\text { Reação álcalis } \\
\text { agregado }\end{array}$} & \multirow{2}{*}{$\begin{array}{l}\text { Expansão; } \\
\text { Fissuração }\end{array}$} \\
\hline & & \multicolumn{2}{|c|}{$\begin{array}{c}\text { Hidratação do } \mathrm{MgO} \text { e } \\
\mathrm{CaO}\end{array}$} & \\
\hline & \multicolumn{3}{|c|}{ Corrosão de armaduras } & $\begin{array}{l}\text { Expansão; } \\
\text { Fissuração }\end{array}$ \\
\hline & \multicolumn{3}{|c|}{ Biólogica } & $\begin{array}{l}\text { Dissolução } \\
\text { decomposição } \\
\text { química }\end{array}$ \\
\hline
\end{tabular}


É interessante observar que a grande maioria dos mecanismos de deterioração listados na Tabela 2, também tem conseqüências sobre a deterioração do cobrimento de proteção das armaduras, de modo que o controle tecnológico do concreto precisa evoluir com vistas a prevenir mecanismos de agressão potencial às armaduras, pois estará então atuando de forma efetiva com vistas à durabilidade das estruturas em serviço.

As estruturas de concreto armado quando sujeitas à corrosão das armaduras, perdem durabilidade, ocasionando perdas na estabilidade, funcionabilidade e estética da estrutura, diminuindo a sua vida útil. A corrosão das armaduras do concreto provoca vários danos à estrutura, que se manifestam na forma de expansão, fissuração, desplacamento do concreto, perda de aderência e redução da seção da armadura.

$\mathrm{Na}$ fase em que se trata da recuperação das estruturas de concreto, deterioradas por corrosão ou qualquer outro mecanismo, não se pode deixar de comentar os impactos econômicos bem descritos pela "lei dos cinco" elaborada por SITTER (1983)1, citado por HELENE (1993). Essa lei comenta a importância de se dar atenção à qualidade, nas etapas de projeto e de construção, e ainda à manutenção preventiva, no período de iniciação da corrosão, em relação às manutenções corretivas tomadas no período de propagação. A importância da "lei dos cinco", conforme a Figura 4, está na conscientização de que o foco da atenção, na cadeia produtiva, deve ser concentrado na fase de projeto e construção e na manutenção preventiva, para obtenção da durabilidade das estruturas de concreto (ANDRADE; SILVA, 2005). A manutenção preventiva, na maioria das vezes, não está relacionada diretamente com a estrutura, mas com os subsistemas que interagem com a estrutura, como: instalações prediais, impermeabilização, fachadas e outros. O programa experimental desta pesquisa no Capítulo 4 visa justamente, estimular evoluções no controle tecnológico do concreto estrutural, pois justamente falta melhorar a aquisição de dados na fase de execução, para o gradativo refinamento das especificações de projeto e de manutenção das estruturas.

1 SITTER, W. R. Costs for service life optimization the "Law of Fives". Comite Euro International du Beton CEB. Boletim Técnico. Copenhagen, Denmark, n. 152, p. 131 - 134, 1983. 


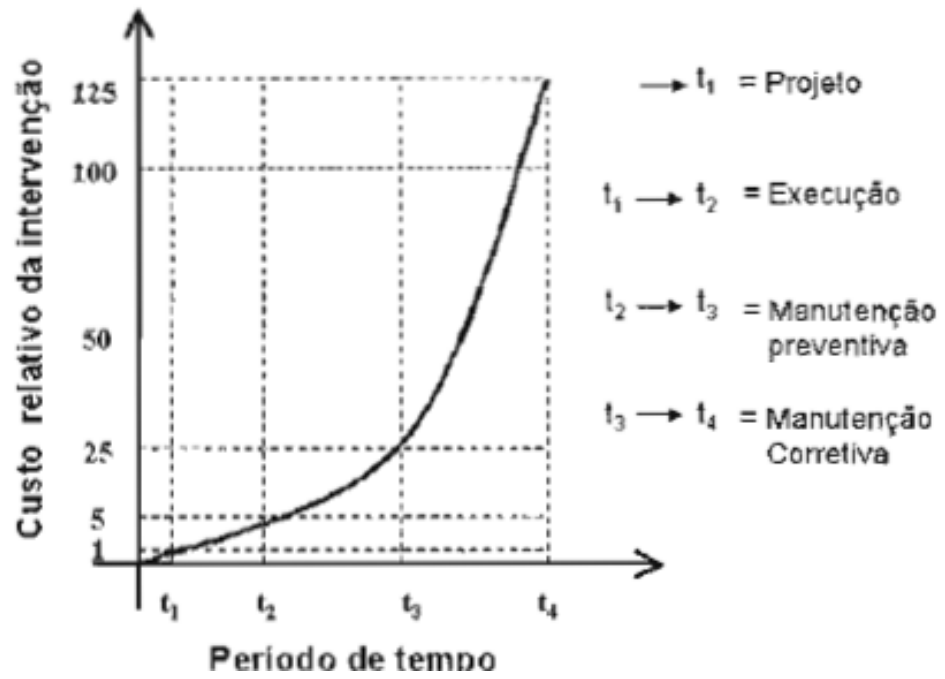

Figura 4 - Lei de evolução de custos (SITTER, 1984 apud HELENE, 1993)

De acordo com Gomes (2006), manutenção de uma estrutura "é o conjunto de atividades necessárias à garantia de seu desempenho satisfatório ao longo do tempo, ou o conjunto de rotinas que tenha por finalidade o prolongamento de sua vida útil, a um custo compensador. Intervenções preventivas e avaliações programadas de manutenção possibilitam que sejam minimizadas as necessidades de reparos e/ou reforços".

Apesar do avanço tecnológico no campo das técnicas e dos materiais de construção, tem-se observado um grande número de edificações apresentando manifestações patológicas, após pouco tempo de serviço. O uso inadequado de materiais aliado à falta de cuidados na execução e à falta de manutenção tem criado despesas extras aos condomínios, tendo que consumir recursos financeiros em reparações que poderiam ser evitados (SILVA et al. 2003), além de causar a geração de resíduos.

\subsection{Mecanismos mais comuns de corrosão das armaduras}

A passivação do aço deve ser gerada por película de óxidos estáveis, na interface do metal com a pasta de cimento Portland, e ser uma barreira química efetiva para reduzir a sua taxa de corrosão a valores muito baixos ou desprezíveis, segundo consenso internacional que passou a ser discutido no Brasil a partir de Helene (1986).

Em resumo, o concreto oferece ao aço uma dupla proteção: uma proteção física, separando-o do contato com o meio externo, e a outra é uma proteção química, dada pela película passivadora que promove ao metal. A elevada alcalinidade do meio, com pH entre 12 e 13,5, é obtida a partir de álcalis liberados no meio aquoso durante a hidratação do cimento. 
Quando essa passivação é destruída, poderá haver a corrosão, pela conjunção simultânea dos agentes atuantes nesse processo.

A corrosão em armaduras de aço-carbono do concreto armado é de natureza eletroquímica, propriamente dita. Ocorre na presença de água, isto é, em ambiente úmido, pela redução da alcalinidade da solução aquosa dos poros do concreto e a alteração da película de óxidos passivantes, ou pelo ingresso de certos íons agressivos, que podem romper essa película mesmo em elevado $\mathrm{pH}$.

Para que ocorra a formação da célula de corrosão na armadura do concreto, é necessária a configuração física de quatro componentes. Um ânodo, onde ocorre a reação de oxidação ou dissolução; um cátodo onde ocorre a reação de redução; um condutor metálico, no caso, a armadura, que permite o fluxo de elétrons interior ao metal e um eletrólito que é a fase aquosa do concreto e viabiliza o elo de fechamento da pilha entre regiões anódicas e catódicas. As áreas anódicas e catódicas surgem como resultado de diferenças de potencial elétrico das regiões das armaduras (ANDRADE, 1992). A corrosão só ocorre quando existir um eletrólito, uma diferença de potencial e oxigênio. A água presente nos poros do concreto constitui o eletrólito. A diferença de potencial pode ocorrer por variações de umidade, aeração ou de tensões no concreto e no aço.

\subsubsection{Natureza e tipos de corrosão eletroquímica}

No período de propagação, a corrosão da armadura começa a se desenvolver com a aceleração da pilha eletroquímica, até que se alcance um grau de deterioração inaceitável.

Segundo a morfologia, a corrosão das armaduras pode ser classificada em três tipos, segundo CASCUDO (1997):

$\checkmark \quad$ Corrosão generalizada;

$\checkmark \quad$ Corrosão por pite;

$\checkmark \quad$ Corrosão sob tensão.

A corrosão generalizada é uniforme e ocorre em toda a superfície do metal, podendo ser causada pela carbonatação do concreto associado à presença de umidade.

A corrosão por pites ou puntiforme é um tipo de corrosão localizada, no qual ocorre perda pontual de massa na superfície metálica, podendo causar a ruptura da barra, como na corrosão causada por cloretos.

A corrosão sob tensão é um tipo de corrosão localizada, que se dá por meio de uma tensão de tração na armadura, podendo dar origem à propagação de fissuras no aço, conforme a Figura 5. 


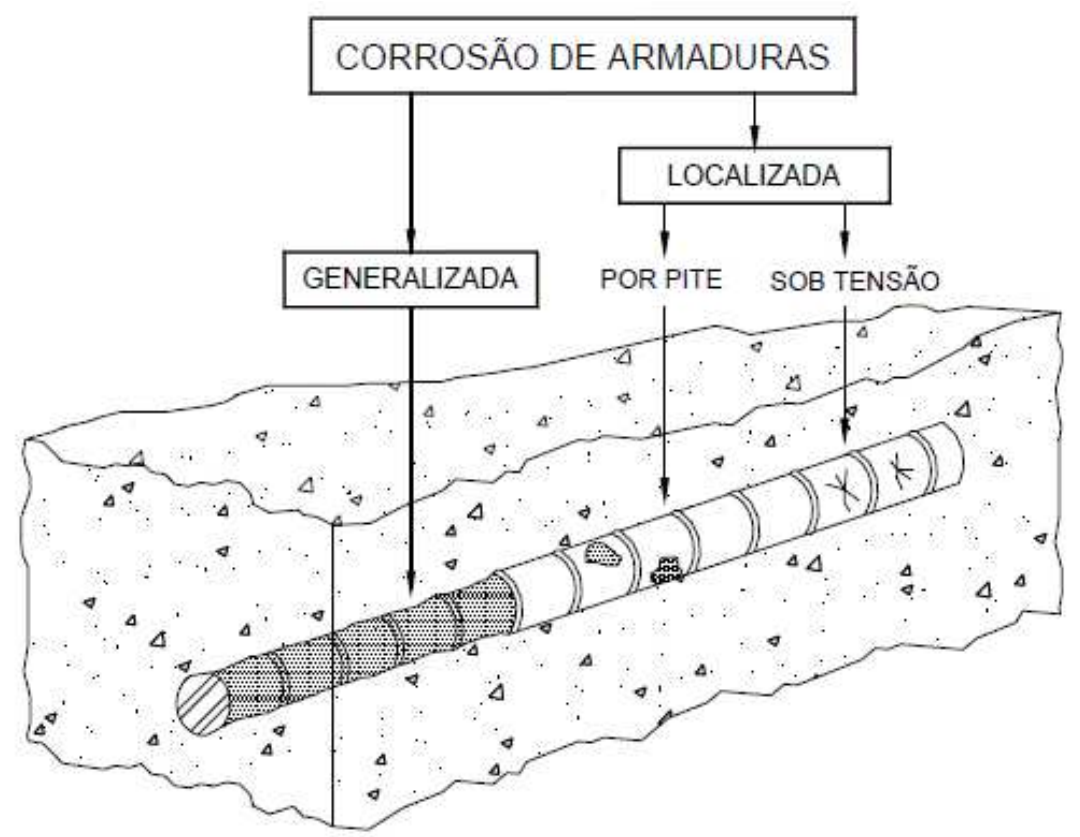

Figura 5 - Tipos de corrosão e fatores que as provocam (CAMPOS, 2006)

As estruturas de concreto armado sujeitas à corrosão de armaduras diminuem a durabilidade e conseqüentemente, a sua vida útil. As mesmas ficam sujeitas aos agentes agressivos presentes no meio ambiente, que são os causadores da despassivação da armadura. A despassivação pode ocorrer devido ao ingresso de $\mathrm{CO}_{2}$, cloretos, dentre outros agentes.

Em resumo, são duas as principais causas que podem destruir a película passivante de óxidos do aço carbono e ocasionar a sua corrosão:

$\checkmark \quad$ Presença de um teor suficiente de cloretos livres ou de outro íon despassivante do metal;

A diminuição da alcalinidade da solução dos poros do concreto por carbonatação, ou pela reação da pasta com íons de solução provenientes do meio externo envolvente da estrutura.

Assim, a contribuição do concreto para a durabilidade das estruturas, deve ser alcançada através do controle das quatro principais variáveis, que definem as características da camada física que separa o aço do meio externo, usualmente citados como a "regra dos 4C", e detalhadas no Capítulo 3, a saber:

1. Cobrimento das armaduras, relativo à espessura de concreto sobre barras e fios;

2. Composição do concreto;

3. Compactação ou adensamento do concreto; 
4. Cura efetiva do concreto na estrutura.

\subsubsection{Carbonatação e umidade do concreto de cobrimento}

Todas as estruturas de concreto armado expostas ao ar estão sujeitas ao fenômeno da carbonatação. Algumas carbonatam com maior velocidade e outras com menor velocidade. $\mathrm{O}$ concreto propicia uma boa proteção às armaduras devido à sua natureza alcalina. A armadura, em contato com o concreto fresco, forma um filme de óxidos passivantes pela hidratação do cimento Portland, que mantém o aço carbono protegido. A Figura 6 ilustra esse mecanismo.

A formação e a estabilidade desse filme na superfície do aço é dependente do $\mathrm{pH}$ na solução dos poros do concreto que circunda o aço. Para pH acima de 11,5 na solução dos poros, a estabilidade dessa película é mantida, e a corrosão não se instala.

Os principais agentes atmosféricos causadores da redução do $\mathrm{pH}$ do concreto são (HELENE, 1993):

$$
\begin{array}{ll}
\checkmark & \mathrm{CO}_{2}-\text { Gás Carbônico; } \\
\checkmark & \mathrm{SO}_{2}-\text { Dióxido de Enxofre; } \\
\checkmark & \mathrm{H}_{2} \mathrm{~S}-\text { Gás Sulfídrico; }
\end{array}
$$

Ao penetrar no concreto, o gás carbônico reage com os compostos hidratados da pasta de cimento, alterando a microestrutura, a composição e o pH da solução intersticial do concreto de cobrimento.

Assim, a carbonatação é um processo físicoquímico de neutralização da fase líquida intersticial do concreto, quando saturado de hidróxido de cálcio e de outros compostos alcalinos hidratados. O gás carbônico penetra nos poros do concreto de cobrimento, por difusão, reagindo com o hidróxido de cálcio, $\mathrm{Ca}(\mathrm{OH})_{2}$, e de outros compostos alcalinos hidratados da pasta de cimento, como $\mathrm{NaOH}, \mathrm{KOH}$ e, a longo tempo, também os silicatos e aluminatos. Isto altera a microestrutura, a composição e o pH da solução intersticial do concreto de cobrimento. Essa mudança no pH provoca a despassivação da armadura e uma possível ocorrência de corrosão da mesma, se houver a presença simultânea dos demais fatores que desencadeiam a corrosão, isto é, oxigênio, água e diferença de potencial elétrico entre pontos distintos do metal. 


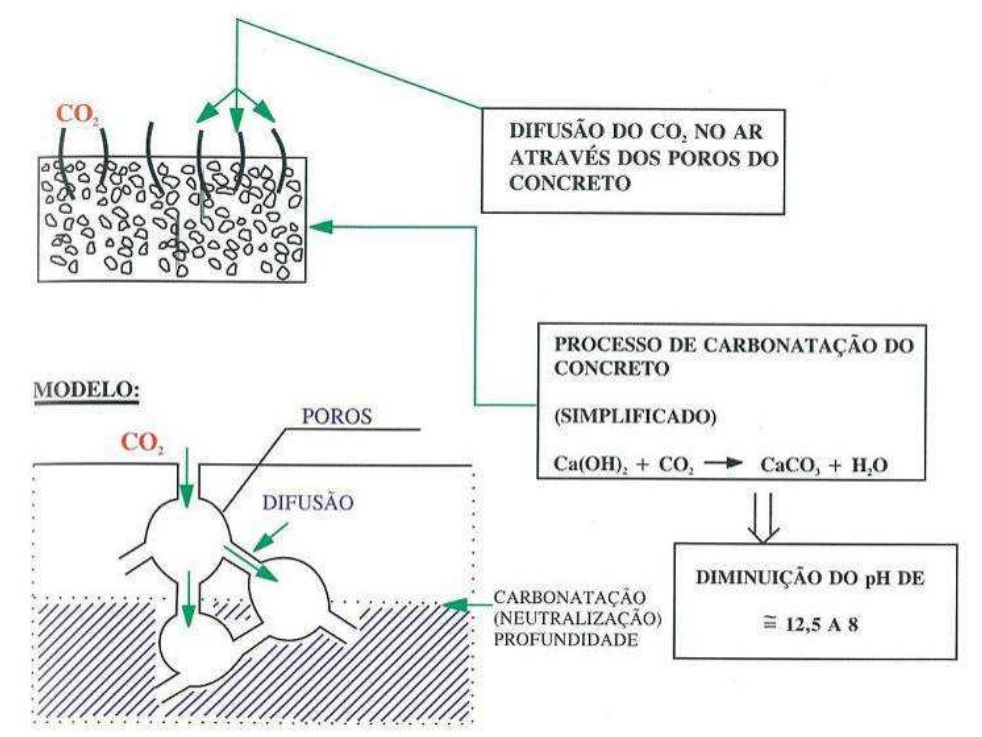

Figura 6 - Esquema do avanço do processo de carbonatação (Figueiredo, 2005)

Para que possa ter a reação química do $\mathrm{CO}_{2}$ com os elementos alcalinos, primeiramente tem que ocorrer a difusão gasosa do $\mathrm{CO}_{2}$, que se encontra na atmosfera, na fase aquosa. Para que a carbonatação se desenvolva, é necessário que primeiro ocorra a solubilização do dióxido de carbono. As reações presentes no processo de carbonatação são apresentadas a seguir, de modo simplificado (FIGUEIREDO, 2005):

$$
\begin{array}{ll}
\checkmark & \mathrm{Ca}(\mathrm{OH})_{2} \rightarrow \mathrm{Ca}^{2+}+2 \mathrm{OH}^{-} \text {(fase aquosa dos poros) } \\
\checkmark & \mathrm{CO}_{2}+2 \mathrm{OH}^{-} \rightarrow \mathrm{CO}^{2-}{ }_{3}+\mathrm{H}_{2} \mathrm{O} \text { (solubilização do } \mathrm{CO}_{2} \text { ) } \\
\checkmark & \mathrm{CO}_{2}+\mathrm{Ca}(\mathrm{OH})_{2} \rightarrow \mathrm{CaCO}_{3}+\mathrm{H}_{2} \mathrm{O} \\
\checkmark & \mathrm{CO}_{2}+2 \mathrm{NaOH} \rightarrow \mathrm{Na}_{2} \mathrm{CO}_{3}+\mathrm{H}_{2} \mathrm{O} \\
\checkmark & \mathrm{CO}_{2}+\mathrm{KOH} \rightarrow \mathrm{K}_{2} \mathrm{CO}_{3}+\mathrm{H}_{2} \mathrm{O}
\end{array}
$$

A durabilidade depende da espessura e da estanqueidade que o concreto de cobrimento deve proporcionar ao longo do tempo às armaduras, bem como da reserva alcalina responsável pela passivação das armaduras (HELENE, 1993).

A velocidade e a profundidade de carbonatação dependem de fatores relacionados com o meio ambiente e com as características do concreto, conforme resumem os itens, 2.3.2.1 a 2.3.2.6, que seguem.

A medida mais utilizada para estimativa da profundidade de carbonatação de concretos é através do indicador de $\mathrm{pH}$ à base de fenolftaleína ou timolftaleína, embora hoje questionada por alguns autores, como Chang (2004). 
Outras pesquisas para aprimorar as medidas de espessura da frente de carbonatação de concretos vêm também sendo feitas, como as de Silva; Helene (2007) e Cafange (2009).

Existem vários modelos em discussão na literatura internacional, mas os de destaque e mais difundidos até hoje no Brasil são: o modelo da raiz quadrada do tempo, TUUTTI (1982) e HELENE (1993).

O modelo da raiz quadrada do tempo representa a penetração do $\mathrm{CO}_{2}$ através da rede de poros do concreto, através da Equação 1.

onde:

$$
\mathbf{x}=\mathbf{k} \sqrt{\mathbf{t}} \quad \text { (Equação 1) }
$$

$\mathrm{X}=$ profundidade de carbonatação $(\mathrm{mm})$;

$\mathrm{k}=$ coeficiente de carbonatação ( $\mathrm{mm} / \mathrm{ano})$;

$\mathrm{t}=$ tempo (anos).

\subsubsection{Concentração de $\mathrm{CO}_{2}$}

A quantidade de $\mathrm{CO}_{2}$ influencia bastante a velocidade de carbonatação, pois aumenta quando o ambiente possui uma maior concentração de $\mathrm{CO}_{2}$, principalmente para concretos de elevada relação água/cimento.

Mas, os ensaios acelerados de carbonatação em presença de teores de $\mathrm{CO}_{2}$ muito acima do comum na maioria dos ambientes, são utilizados com o objetivo de diminuir o tempo de resposta desse fenômeno nos concretos estruturais. Mas não existem normas internacionais de consenso que regulamentem os ensaios de carbonatação, e cada pesquisador acaba adotando um método específico. No levantamento bibliográfico realizado por Cafange (2009), pode ser verificada a falta de padronização dos ensaios, apresentando percentuais de exposição de $\mathrm{CO}_{2}$ variando de natural até $100 \%$, conforme a Tabela 3 . Isto já vem sendo apontado por levantamentos precedentes, como o de Medeiros (2002).

A utilização de elevados teores de $\mathrm{CO}_{2}$ em ensaios acelerados, pode resultar em alterações na microestrutura da pasta carbonatada (FIGUEIREDO, 2005). Mehta; Monteiro (1994) alertam ainda que, quando a velocidade de carbonatação é alta, devido à elevada taxa de $\mathrm{CO}_{2}$, a reação entre o hidróxido de cálcio e dióxido de carbono, poderá tornar-se instável, pela geração de ácido carbônico e a conseqüente transformação do carbonato de cálcio (insolúvel) em bicarbonato de cálcio (solúvel).

Isaia, et. al. (2005) realizaram estudo comparativo de concretos com substituição de cimentos por misturas de cinza volante, cinzas de casca de arroz e sílica ativa com teores entre 
10 e $50 \%$ em massa. Foram feitos ensaios acelerados com $10 \%$ de exposição de $\mathrm{CO}_{2}$ com leituras após 4, 8, 12 e 16 semanas e exposição natural após 0,5, 1 e 2 anos de exposição em ambiente de laboratório. Os ensaios mostraram que a relação entre os coeficientes de carbonatação calculados a partir do ensaio acelerado e natural tem uma boa correlação para concretos com relação água/cimento inferiores a 0,45. 
Tabela 3 - Ensaios acelerados de carbonatação empregados por diversos autores adaptado de Cafange (2009)

\begin{tabular}{|c|c|c|c|c|c|c|}
\hline Referência & Documento & $\mathrm{CO}_{2}(\%)$ & UR (\%) & $\begin{array}{c}\text { Duração do } \\
\text { ensaio }\end{array}$ & Cura/Condicionamento & $\begin{array}{c}\text { Temperatura } \\
\left.\text { ( }{ }^{\circ} \mathrm{C}\right)\end{array}$ \\
\hline $\begin{array}{c}\text { Ying- Yu e } \\
\text { Qui-Dong, } \\
1987 \\
\end{array}$ & Artigo & 9 & 52 & - & - & 20 \\
\hline Nunes, 1998 & Dissertação & 15 & 65 & 12 semanas & $\begin{array}{l}\text { Cura úmida por } 7 \text { dias }+ \\
\text { pré condicionamento de } \\
21 \text { dias a } 70 \% \text { e UR }\end{array}$ & $24 \pm 2$ \\
\hline Tula, 2000 & Tese & 5 & 59 & 7 dias & - & - \\
\hline \begin{tabular}{|c|} 
Nepomuceno, \\
1992 \\
\end{tabular} & Tese & 100 & 50 a 70 & - & - & - \\
\hline Bauer, 1995 & Tese & 50 & 65 a 70 & - & $\begin{array}{l}\text { Cura em camara úmida } \\
\text { até } 63 \text { dias/secagem em } \\
\text { estufa ventilad } 50^{\circ} \mathrm{C} \text { por } \\
14 \text { dias após câmara } \\
\text { seca }\end{array}$ & 50 \\
\hline $\begin{array}{c}\text { Papadakis, } \\
2000\end{array}$ & Artigo & 3 & 61 & - & - & 20 \\
\hline Cunha, 2001 & Dissertação & 100 & 65 a 70 & 28 a 55 dias & $\begin{array}{c}\text { Cura por } 28 \text { dias em } \\
\text { camara úmida e } 15 \text { dias } \\
\text { em ambiente de } \\
\text { laboratorio }\end{array}$ & - \\
\hline $\begin{array}{l}\text { Monteiro, } \\
2002\end{array}$ & Tese & 100 & 70 & - & - & - \\
\hline $\begin{array}{l}\text { Isaia et al. } \\
2005\end{array}$ & Artigo & 10 & - & 4 a 16 semanas & Ambiente de laboratório & \\
\hline $\begin{array}{l}\text { Costa Jr.; } \\
\text { Silva; } \\
\text { Zandonade; } \\
\text { Morimoto; } \\
2005 \\
\end{array}$ & Artigo & 10 & 60 & 77 e 91 dias & cura úmida ate 15 dias & $26 \pm 2$ \\
\hline $\begin{array}{l}\text { Pauletti; Dal } \\
\text { Molin; } \\
\text { Kazmierczak, } \\
2005\end{array}$ & Artigo & 6 e 100 & $70 \pm 5$ & $7,14,28$ e 63 dias & $\begin{array}{c}\text { Cura úmida com } \\
\text { superficie protegida (UR } \\
100 \% \text { ) por } 24 \mathrm{hs} \text {, após } \\
\text { cura submersa por } 28 \\
\text { dias. }\end{array}$ & $20 \pm 1$ \\
\hline $\begin{array}{c}\text { Cavalcanti; } \\
\text { Monteiro; } \\
\text { Helene, 2005 }\end{array}$ & Artigo & natural & 70 & 28 dias & cura por 28 dias ao ar livre & 22 \\
\hline $\begin{array}{c}\text { Bourguignon; } \\
\text { Silva, Costa } \\
\text { Jr.; } \\
\text { Zandonade; } \\
\text { Morimoto, } \\
2006\end{array}$ & Artigo & $\begin{array}{c}\text { natural e } \\
\text { acelerada } \\
\text { com } 10\end{array}$ & $\begin{array}{c}\text { natural: } \\
50 \text { e } \\
\text { acelerada } \\
: 65 \pm 5\end{array}$ & $\begin{array}{l}\text { natural: } 365 \text { dias; } \\
\text { acelrada: } 91 \text { dias }\end{array}$ & $\begin{array}{l}\text { Cura úmida ate } 15 \text { e } 28 \\
\text { dias, após camara seca }\end{array}$ & 26 \\
\hline \begin{tabular}{|c|} 
Meira et.al., \\
2006 \\
\end{tabular} & Artigo & natural & 65 & 4 anos & Cura úmida de 7 dias & - \\
\hline Gomes, 2006 & Dissertação & natural & 65 & - & Natural & - \\
\hline $\begin{array}{l}\text { Nakao; } \\
\text { Bertocini; } \\
\text { Almeida } \\
\text { Neto, } 2006\end{array}$ & Artigo & natural & - & - & - & - \\
\hline
\end{tabular}


Pauletti, et al. (2005) estudaram a influência do percentual de dióxido de carbono na profundidade de carbonatação de argamassas submetidas a ensaios acelerados. Utilizaram cimento CPI 32, três relações água/cimento: 0,40, 0,55 e 0,70 e cura submersa por 28 dias. Os ensaios de carbonatação acelerada foram realizados em câmaras com temperatura de $20 \pm$ $1^{\circ} \mathrm{C}$ e umidade relativa de $70 \pm 5 \%$. Uma das câmaras utilizou $6 \%$ de exposição de $\mathrm{CO}_{2}$ e a outra foi saturada de $\mathrm{CO}_{2}$, sendo as medidas realizadas após 7, 14, 28 e 63 dias. Concluíram que a frente de carbonatação na menor concentração de $6 \%$, se mostrou mais definida para visualização e maiores profundidades, concordando com opinião de Saetta e Vitaliani (2004), que supõem que se a reação é rápida, a massa de $\mathrm{CaCO}_{3}$ produzida, em um dado intervalo, coincide com a liberação de uma quantidade de água maior que aquela que a porosidade da matriz é capaz de expelir, no mesmo intervalo de tempo, e logo são alcançadas condições de equilíbrio, baixando a velocidade de propagação da frente de carbonatação.

\subsubsection{Umidade relativa do ambiente}

Os maiores graus de carbonatação ocorrem quando a umidade relativa situa-se entre 50 e 75\%, segundo proposição clássica de Andrade (1992), na Figura 7. Em umidades relativas inferiores a $20 \%$ e superiores a $95 \%$, a carbonatação ocorre lentamente ou mesmo não ocorre. Esta opinião é compartilhada por vários autores, entre eles: ANDRADE (1992), HELENE (1993), NEVILLE (1997), NEPOMUCENO (1992), BAUER (1995), NUNES (1998), MONTEIRO (2002), PAULETTI et al. (2005) e MEIRA et al. (2006), entre outros.

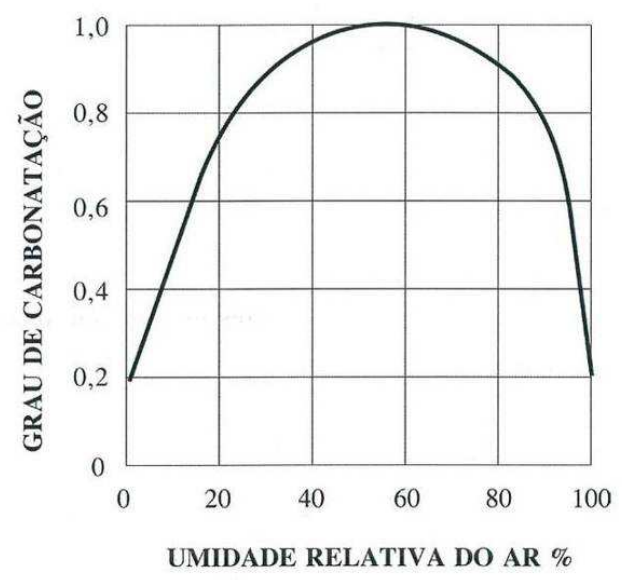

Figura 7 - Variação da profundidade de carbonatação com a umidade (ANDRADE, 1992)

Mas muito pouco se discutiu até agora sobre a carbonatação do concreto em condições de umidade e temperatura mais variáveis e similares às do clima brasileiro. Aliás, a exposição de concretos a efeitos alternados de molhagem e secagem já é considerada em normas 
européias como um nível diferenciado de agressividade, segundo levantamento de Cafange (2009).

A umidade relativa pode exercer grande influência na água e no $\mathrm{CO}_{2}$ contidos em certa faixa de poros do concreto. Quando os poros estão secos, o $\mathrm{CO}_{2}$ pode difundir até as regiões internas mais permeáveis do concreto, mas devido à falta de água, a reação não ocorre. Quando os poros estão saturados de água, a velocidade de penetração e reação do $\mathrm{CO}_{2}$ é diminuída, devido à dificuldade de difusão desse gás na água.

Meira et al. (2006) expuseram vários pilaretes de concreto, com relação água/cimento de 0,$5 ; 0,57$ e 0,65 , à agressividade do ambiente de João Pessoa-PB, com distanciamento do mar controlado em 10 m, 100 m, 200 m e 500 m, e mediram a profundidade de carbonatação em 6 , 10, 14, 18 e 46 meses. Os concretos possuíam abatimento plástico na faixa de $8 \pm 1 \mathrm{~cm}$, e consumo de cimento, respectivamente, igual a $320 \mathrm{~kg} / \mathrm{m}^{3}, 356 \mathrm{~kg} / \mathrm{m}^{3}$ e $406 \mathrm{~kg} / \mathrm{m}^{3}$.

Os resultados naquela região mostram alguma tendência à redução da profundidade de carbonatação com a proximidade do mar, de acordo com a Figura 8. Todavia, o efeito da relação água/cimento na profundidade de carbonatação informada parece ter um peso mais importante para definir a evolução da frente de $\mathrm{CO}_{2}$, inclusive, por ser uma variável determinante do nível de saturação dos poros em efeito conjunto com o ambiente de exposição. Esta opinião está corroborada para esses mesmos dados ilustrados, segundo a relação água/cimento e o grau de saturação, no subitem 2.3.2.5.

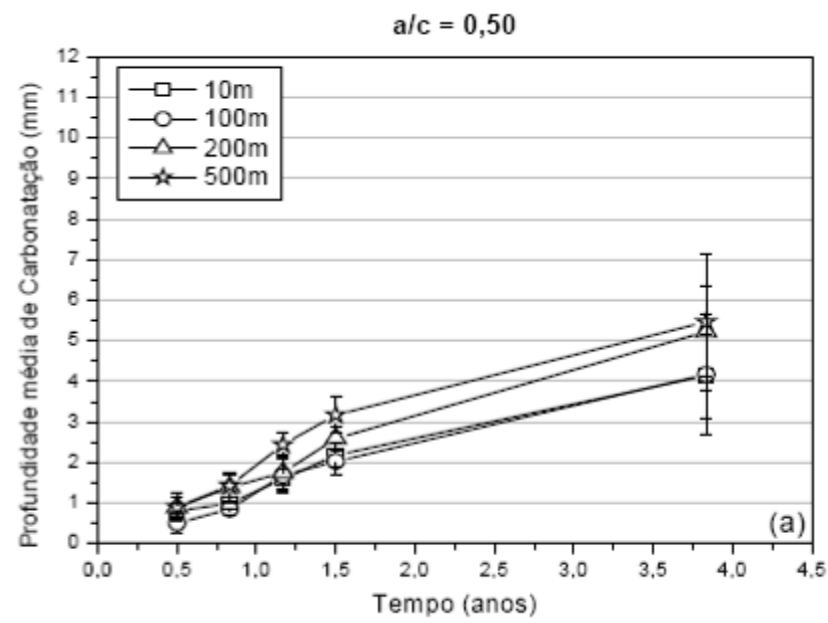



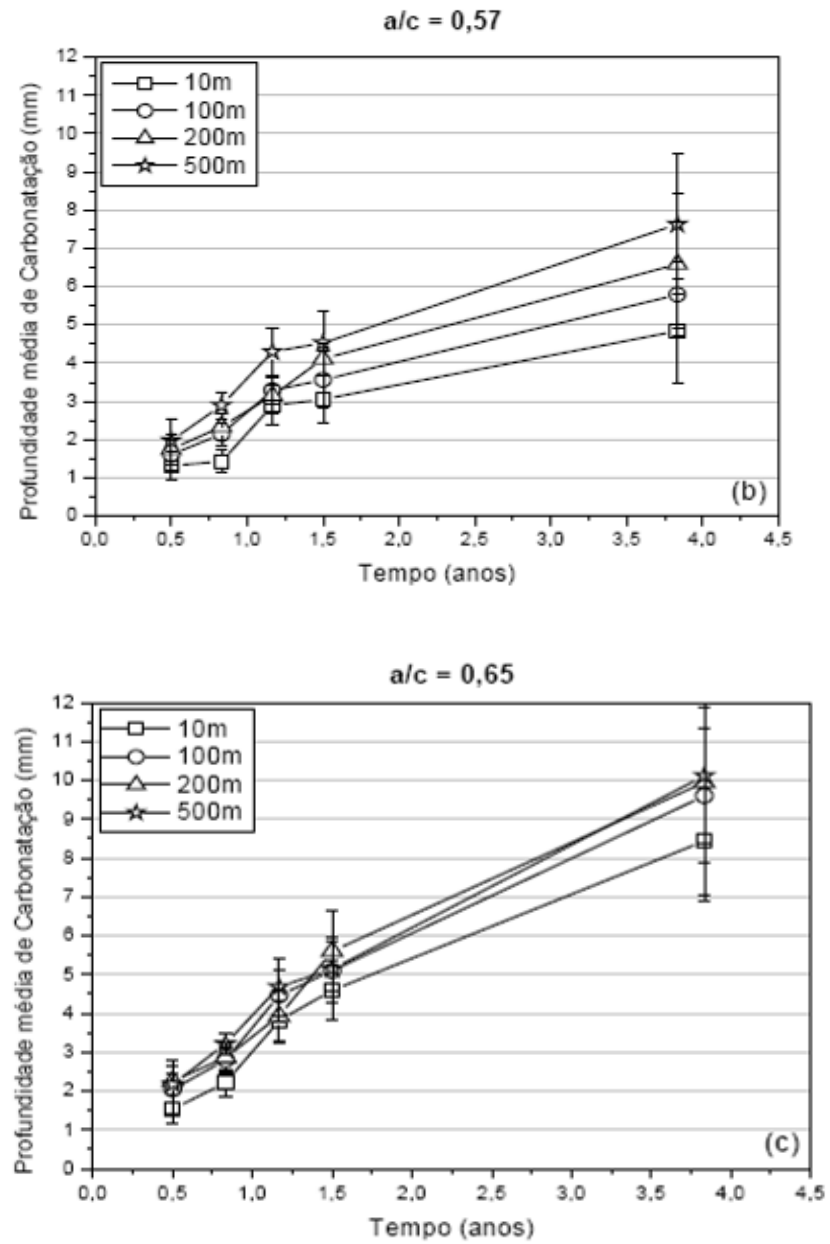

Figura 8 - Profundidade média de carbonatação a 10, 100, 200 e 500 metros do mar: (a) a/c = 0,50; (b) $a / c=0,57 ;$ (c) $a / c=0,65$ (MEIRA et al., 2006)

\subsubsection{Temperatura}

O aumento da temperatura funciona como acelerador das reações químicas, portanto, climas equatoriais e tropicais são piores que os temperados para a carbonatação do concreto (HELENE, 1993).

Mas, conforme o tipo de ensaio acelerado para carbonatação, o fenômeno de transporte dominante é a difusão do $\mathrm{CO}_{2}$, cuja velocidade é pouco influenciada por variações de temperatura, na opinião de Figueiredo (2005). Mesmo exercendo pouca influência essa variável não deve ser desprezada, pois atua na corrosão.

Do ponto de vista do mapeamento climático disponível em bases de dados especializados, muito pouco ainda se usa para inferir sobre a vida útil de projeto de novos edifícios ou mesmo para realizar diagnóstico de estruturas com manifestações patológicas de 
corrosão de armaduras. Possivelmente, o distanciamento das condições usuais de ensaios acelerados, com pressão elevada de $\mathrm{CO}_{2}$, em relação aos mecanismos reais de carbonatação, contribuem para essa situação.

\subsubsection{Tipo e quantidade de cimento}

O tipo de cimento é uma das variáveis que mais influem na velocidade de carbonatação, já que a reserva alcalina é função da composição do cimento. Com o aumento do $\mathrm{Ca}(\mathrm{OH})_{2}$ na solução intersticial, o $\mathrm{CO}_{2}$ não penetra com a mesma velocidade, pois precisa primeiro baixar o $\mathrm{pH}$ e depois reagir com o $\mathrm{Ca}(\mathrm{OH})_{2}$ para então seguir penetrando e precipitando $\mathrm{CaCO}_{3}$.

Helene (1993) explica que as adições reduzem a porosidade, a permeabilidade e aumentam a resistência à compressão, porém aumentam a profundidade de carbonatação, devido à menor reserva alcalina.

Muitos pesquisadores como: HELENE (1993), BAUER (1995), ISAIA (1995), MONTEIRO (1996), BARBOSA et al. (2005), COSTA Jr. et al. (2006), FIGUEIREDO (2005) e BOURGUIGNON et al. (2006), encontraram que o emprego de adições resulta em maiores taxas de carbonatação, já que a sílica das adições reage com o $\mathrm{Ca}(\mathrm{OH})_{2}$, diminuindo a reserva alcalina do concreto.

Segundo Figueiredo (2005), a constatação que o aumento do teor de escória leva à diminuição do teor de $\mathrm{Ca}(\mathrm{OH})_{2}$ é consensual entre os pesquisadores. A velocidade de carbonatação passa a ser maior para uma mesma relação água/cimento, pois a reserva alcalina é menor. Quanto mais fina for a escória, maior será a frente de carbonatação, uma vez que a finura representa um fator positivo na reatividade da escória. Reagindo mais intensamente, diminui a quantidade de hidróxido de cálcio disponível, ocorrendo redução da reserva alcalina.

Costa Jr. et al. (2006) estudaram a carbonatação em concretos, classes C20; C30; C35; C40, com altos teores de escória, utilizando teores da ordem de $30 \%, 66 \%$ e $83 \%$ da massa do cimento. Foi utilizado o CP II E 32, o CP III 32 RS e o material cimentício CP III 32 RS com mais escória. Os corpos-de-prova foram expostos a $10 \%$ de $\mathrm{CO}_{2}$. As medidas de carbonatação foram realizadas nas idades de 63, 77 e 91 dias, e os resultados são apresentados na Figura 9.

Os autores verificaram que as maiores profundidades encontradas foram para os concretos com maiores teores de escória, isto é, para o material cimentício CP III 32 RS + Escória, o que está de acordo com a opinião dos vários autores já citados. 


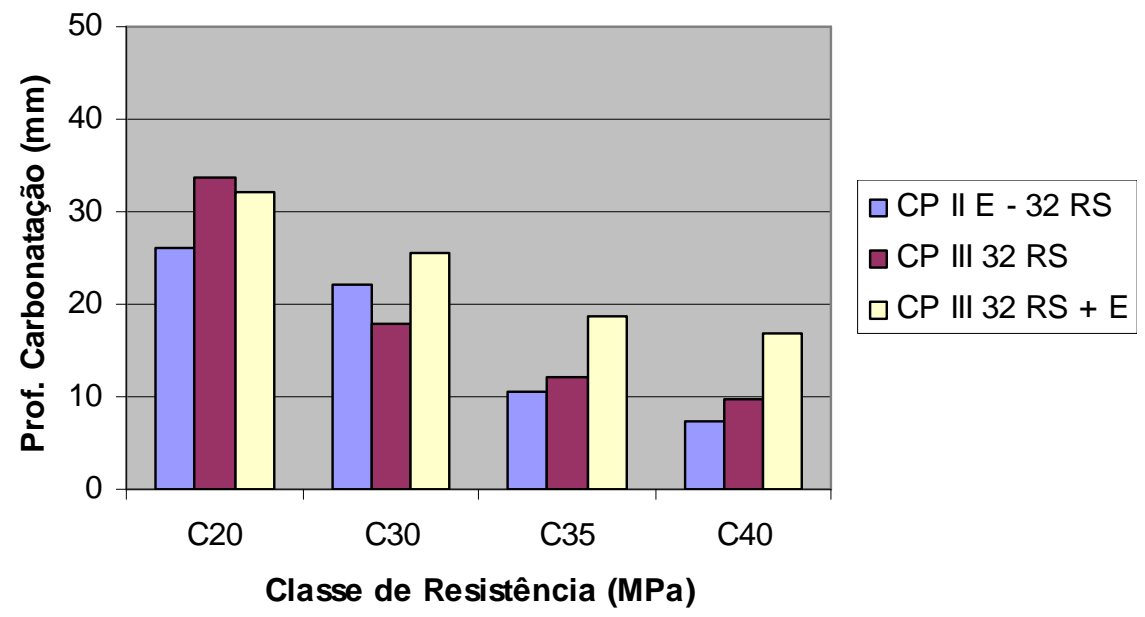

Figura 9 - Profundidade de carbonatação acelerada a 10\% aos 91 dias (COSTA Jr. et al. 2006)

A profundidade de carbonatação diminui com o aumento da quantidade de cimento por metro cúbico de concreto (FIGUEIREDO, 2005).

Monção Jr. et al (2006) estudaram a carbonatação natural do concreto para várias dosagens, encontrando a maior profundidade de carbonatação para a dosagem de menor consumo.

Todavia, a quantidade de cimento por metro cúbico do concreto é uma variável dependente da natureza e dosagem dos materiais e que não informa necessariamente sobre a porosidade do sistema, sendo a relação a/c e o tipo de cimento as variáveis mais determinantes desta propriedade, por afetarem diretamente a zona de transição entre a pasta e os agregados do concreto.

\subsubsection{Relação água / cimento}

A relação água/cimento está diretamente ligada à quantidade e ao tamanho dos poros no concreto no estado endurecido e a sua capacidade de reter ou perder água, em função da umidade relativa ambiente. Quanto maior a relação água/cimento, maior será a porosidade e a permeabilidade do concreto, logo maior será a sua velocidade de secagem e a de penetração do $\mathrm{CO}_{2}$. Reduzir a relação água/cimento, significa reduzir as dimensões dos poros, a velocidade de perda de água pelo sistema e a de carbonatação do concreto.

Uma vez estabelecida a relação a/c no concreto, o grau de saturação dos poros por água, a partir do endurecimento, passa a regular a possibilidade de evolução da microestrutura pela hidratação progressiva do cimento em função do tempo.

O grau de saturação (GS) é o percentual do teor de umidade da massa de concreto em relação à máxima que pode ser absorvida por imersão e fervura. É uma propriedade física 
clássica de caracterização de materiais porosos e foi recentemente interpretada em estudos nacionais por GUIMARÃES (2000) e MEIRA (2004).

Para o estudo já relatado no item 2.3.2.2, de Meira et al. (2006), em que expuseram pilaretes de concreto, com relação água/cimento de 0,5; 0,57 e 0,65, em ambiente urbano na cidade de João Pessoa/PB e mediram a profundidade de carbonatação entre 6 e 46 meses, os resultados comprovaram que a menor relação água/cimento sempre resultou em menores profundidades de carbonatação, como ilustra a Figura 10, evidenciando ter regulado o grau de saturação dos poros de modo mais importante que a umidade relativa do ar, pelo distanciamento ou proximidade da costa. Observar que os concretos mais porosos, de relação água/cimento 0,57 e 0,65 foram os que mais rapidamente atingiram grau de saturação abaixo de $70 \%$ e que carbonataram com maior velocidade. 

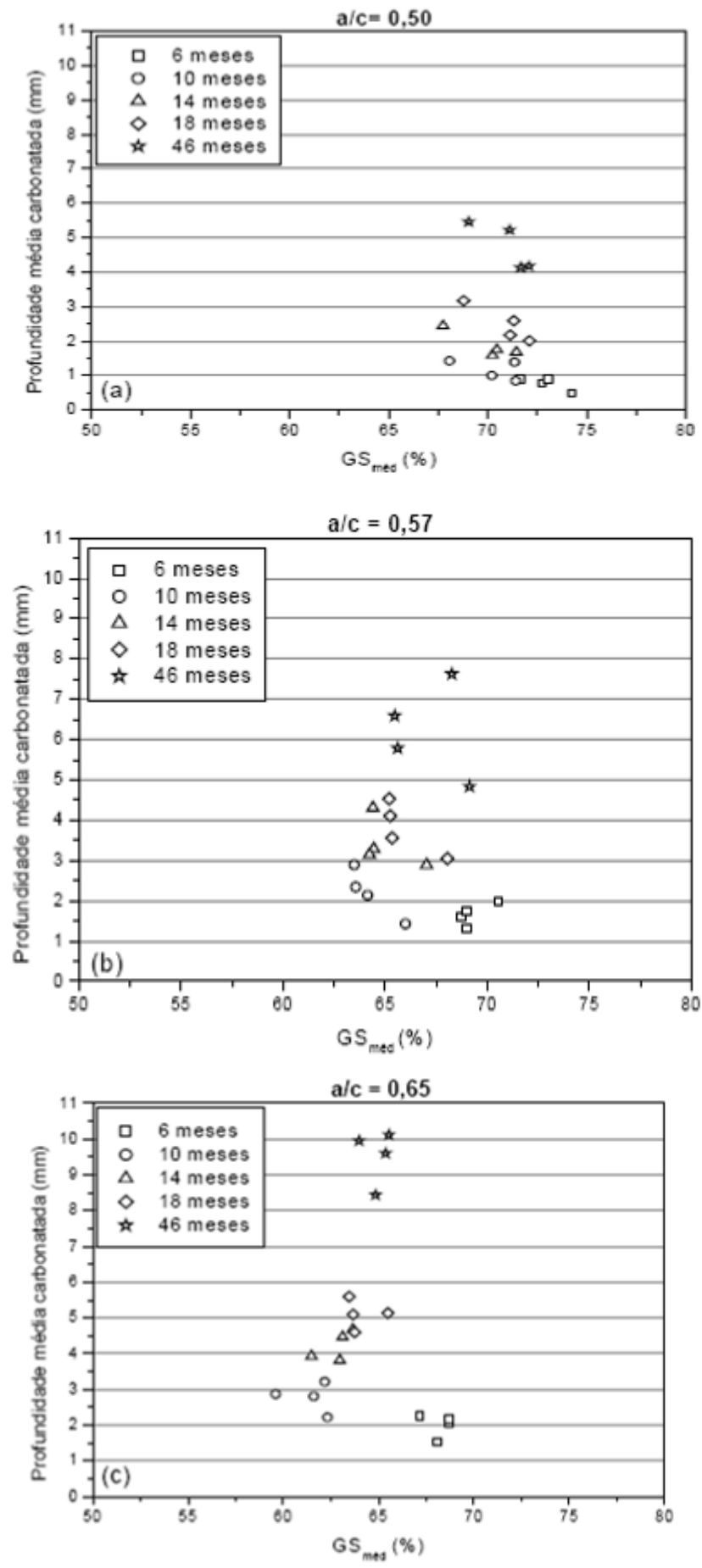

Figura 10 - llustração da influência secundária do GS $_{\text {médio }}$ em comparação à relação água/cimento, na profundidade de carbonatação de concretos, em quatro distâncias do mar (10, 100, 200 e $500 \mathrm{~m}$ ) para os mesmos dados ilustrados na Figura 8: (a) $a / c=0,50$; (b) a/c $=0,57$; (c) $\mathrm{a} / \mathrm{c}=0,65$ para concretos expostos em João Pessoa-PB (MEIRA et al., 2006). 
A Figura 11 apresenta a faixa de valores do Grau de saturação em função do distanciamento do mar (MEIRA, 2004).

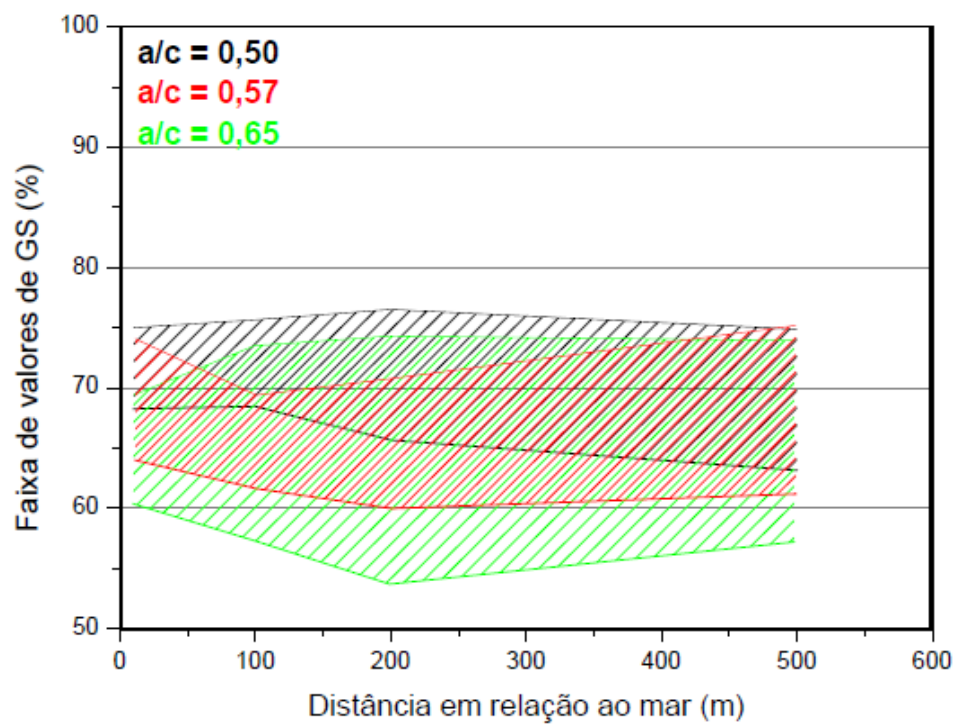

Figura 11 - Faixa de valores do Grau de saturação em função do distanciamento do mar (MEIRA, 2004).

\subsubsection{Cura}

A cura nas primeiras idades do concreto é o principal mecanismo responsável pela continuidade da hidratação do cimento e uso do seu potencial aglomerante, pois a permeabilidade do concreto pode diminuir com o aumento do grau de hidratação do cimento. Com a diminuição das dimensões capilares e da sua permeabilidade, pode-se ter uma menor velocidade de carbonatação.

O grau de saturação é o percentual do teor de umidade da massa de concreto em relação à máxima que pode ser absorvida por imersão e fervura. É uma propriedade física clássica de caracterização de materiais porosos e foi recentemente interpretada em estudos nacionais por GUIMARÃES (2000) e MEIRA (2004).

Barbosa et al. (2005) estudaram o efeito da carbonatação natural em concretos produzidos com cimento CP V ARI e CP III com e sem sílica ativa, submetidos a diferentes tipos de cura: cura térmica, cura imersa até 7 dias e cura ambiente. A cura térmica foi realizada nas temperaturas de $60^{\circ} \mathrm{C}$ e $80^{\circ} \mathrm{C}$ e as idades de ensaio foram $28,90,180$ e 365 dias. Foi observado que o tipo de cura influenciou na carbonatação. Em ambos os concretos com e sem sílica ativa, a cura ambiente, foi a que apresentou maiores profundidades de carbonatação. Concretos submetidos à cura imersa apresentaram melhores resistências à carbonatação. Concretos submetidos à cura térmica apresentaram desempenho intermediários em relação às 
curas imersas e ao ar, comprovando que o tipo de cura interfere na profundidade de carbonatação.

\subsubsection{Penetração de íons cloretos}

A preocupação com este mecanismo ocorre em regiões litorâneas (atmosfera marinha, ação direta de água do mar, lençol freático), pois a proximidade do mar faz com que a atmosfera contenha íons cloretos. As partículas de água do mar contendo sais dissolvidos, quando em suspensão na atmosfera, são arrastadas pelo vento e podem depositar-se nas estruturas, podendo os íons cloreto ingressar no concreto por absorção capilar da água, em que se encontram dissolvidos. Ainda há outras situações de projeto ou obras em que pode haver o ingresso ou a contaminação do concreto, respectivamente, água ou solo contaminados e sais de degelo, e agregados ou aditivos contendo sais de cloreto.

Os íons cloreto são um dos agentes mais problemáticos para a corrosão de armaduras, pois são capazes de despassivar o aço mesmo em pH extremamente elevado. Os cloretos penetram nos poros do concreto por meio de difusão ou pela absorção capilar de águas, que diluem a deposição do aerosol marinho a partir da sua superfície, contendo o íon na forma dissolvida e ao superarem, na solução dos poros, um certo limite em relação à concentração de hidroxilas, despassivam a superfície do aço e dão início ao processo corrosivo.

O mecanismo de penetração dos íons cloreto através do concreto depende de uma série de fatores inter-relacionados, no que diz respeito ao concreto, por exemplo, as características do macroclima, tipo de exposição do concreto, o tipo de cátion associado ao cloreto, à presença de ânions como o sulfato, o tipo de cimento empregado na produção do concreto, à relação água/cimento, o consumo de cimento, as formas de produção e cura das peças estruturais, a velocidade de carbonatação do concreto, entre outros fatores.

Outras fontes de cloretos no concreto e argamassa podem ser os agregados, a água ou solo contaminado, o aditivo acelerador de pega à base de cloretos, os sais de degelo, a atmosfera marinha ou a ação direta de água do mar, sendo que a maior incidência ocorre em regiões litorâneas, atmosfera marinha. 


\subsubsection{Tipos de íons cloreto}

Os íons cloreto podem estar presentes na matriz da pasta de cimento Portland, em uma ou mais dos três diferentes estados físicos, a saber:

$\checkmark$ Quimicamente combinados na forma de sal de Frields (C-A-H), por reação com o $\mathrm{C}_{3} \mathrm{~A}$ do cimento Portland ou com o $\mathrm{C}_{4} \mathrm{AF}$, formando os cloroferratos;

$\checkmark$ Fisicamente adsorvidos ao C-S-H;

$\checkmark$ Livres na solução aquosa dos poros.

O somatório de cloretos livres e cloretos combinados é denominado cloretos totais. É consenso que apenas os cloretos livres são os agentes nocivos à armadura. Entretanto, os cloretos combinados podem se tornar livres através das reações de carbonatação e da elevação de temperatura do concreto. Daí a importância de ensaios cíclicos de umedecimento e secagem em estudos de durabilidade ou com controle de qualidade do concreto nesses ambientes.

As pesquisas sobre o ingresso de cloretos por ciclos de umedecimento e secagem são pontuais e, em geral, realizadas com vistas apenas a contaminar o concreto e não propriamente para discutir a resistência a este mecanismo de transporte, como se pretende medir nesta dissertação.

A avaliação do teor de contaminação ou de ingresso de cloretos em um dado concreto pode ser feita por métodos químicos normalizados, como da ASTM C 1152 (1999) - Standard test method for acid-soluble chloride in mortar and concrete, entre outros.

Há ainda métodos colorimétricos para determinar a profundidade de penetração de cloretos livres, na rede capilar de concretos e argamassas, e que é o método de aspersão de solução de nitrato de prata, já bem testado para cimentos nacionais, por Jucá (2002), tendo a facilidade de também ser aplicado em inspeção de estruturas.

\subsubsection{Formação do aerosol marinho}

"A formação do aerosol marinho e o seu transporte na direção do continente representam o início de todo o processo agressivo frente às estruturas de concreto armado no que se refere à ação dos cloretos na região da costa" (MEIRA, 2004). 
Swammy et al. (1994)² citado por MEIRA (2004), segmentaram o ambiente marinho em cinco zonas: zona submersa, zona de flutuação de maré, zona de respingo, zona de interface solo/respingo e zona de solo, descrito abaixo e visto na Figura 12.

$\checkmark$ Zona submersa: o concreto está localizado sempre abaixo do nível mínimo de água;

$\checkmark$ Zona de flutuação de maré: em certos momentos o concreto está submerso; em outros está exposto ao ar, simulando ciclos de molhagem e secagem;

$\checkmark$ Zona de respingo: o concreto está localizado um pouco acima do nível máximo da água, fazendo com que os respingos entrem em contato com o mesmo;

$\checkmark$ Zona de interface solo/respingo (zona de "spray"): o concreto está localizado entre a zona de solo e a zona de respingo. Na presença de ventos fortes, o concreto está sujeito aos respingos da maré e na presença de ventos fracos, o concreto não sofre a ação dos respingos da maré;

Zona de solo: o concreto está localizado a uma distância de 10 - 20 metros do mar, fazendo com que o mesmo receba a ação do aerosol marinho.

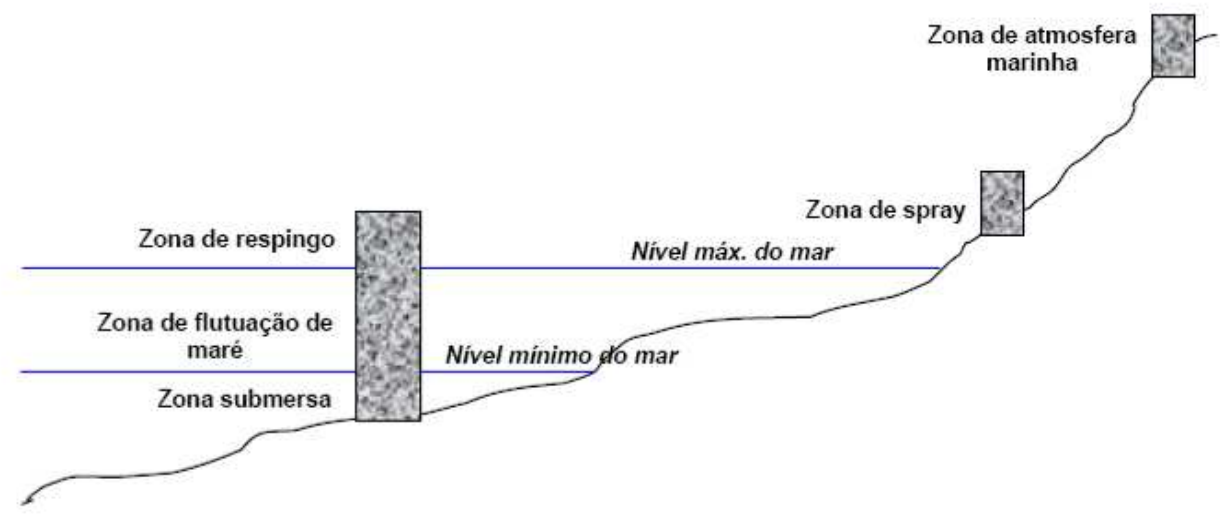

Figura 12 - Representação esquemática das zonas de agressividade do aerosol marinho em cidades litorâneas. (MEIRA, 2004)

\footnotetext{
2 SWAMY, R.N.; HAMADA, H.; LAIW, J.C. A critical evaluation of chloride penetration into concrete in marine environment. In: PROCEEDINGS OF INTERNAL CONFERENCE ON CORROSION AND CORROSION PROTECTION OF STEEL IN CONCRETE (Edited by Swamy, 1994, Sheffield - UK) Proceedings...Shefield Academic Press, 1994. P.404 - 419.
} 
De acordo com Fitzgerald (1991)3; O'dowd et al. (1997) 4 citados por MEIRA (2004), a produção do aerosol marinho tem origem na agitação da superfície do mar pelo vento. Esse efeito gera bolhas de ar que, em seguida, explodem produzindo gotículas em forma de espuma. Essas bolhas são mais numerosas na zona de quebra das ondas, onde são formadas pelo aprisionamento do ar na superfície da água com o movimento de quebra das ondas. $\mathrm{O}$ aerosol também é formado a partir do atrito entre o vento e a superfície do mar, fazendo com que as áreas de mar aberto também contribuam para a produção do aerosol.

Após a geração das gotículas, estas entram em equilíbrio com o ambiente e, dependendo das condições de temperatura e de umidade relativa, assumem a forma de partículas salinas, ou soluções salinas de diferentes concentrações. A intensidade dos ventos aumenta a quantidade de partículas salinas no aerosol e facilita a geração de partículas de maior tamanho e massa. A intensidade dos ventos também influi no maior alcance que as partículas possam atingir na direção da costa (MEIRA, 2004).

No trabalho de Morcillo et al. (2000) ${ }^{5}$ citado por MEIRA (2004), os resultados indicaram que a partir de $3,0 \mathrm{~m} / \mathrm{s}(10,8 \mathrm{~km} / \mathrm{h})$, o efeito do vento assume um valor de relevância na geração e transporte do aerosol, valor também assumido por Fitzgerald (1991) citado por Meira (2004).

Gustafsson e Franzen (1996) ${ }^{6}$, citados por MEIRA (2004), relatam que:

A influência do vento na concentração salina diminui à medida que se avança na direção do continente, isto é explicado, pelo fato de que nas primeiras faixas de terra há uma forte ação do efeito gravitacional e as partículas maiores logo se depositam. Com o aumento da velocidade do vento, estas partículas podem chegar um pouco mais longe. Contudo, o efeito gravimétrico ainda é importante e se sobrepõe ao efeito do vento. Desta forma, a relação não é linear, mas sofre atenuação com o afastamento em relação à costa. Aliado a esse comportamento, o efeito de fricção com obstáculos pode assumir uma importante parcela de contribuição na redução da concentração salina com a distância.

\footnotetext{
${ }^{3}$ FITZGERALD, J. W. Marine aerosol: a review. Atmospheric Environment, v. 25A, n. 3/4, p. 533-545, 1991.

4 O`DOWD, C. D.; SMITH, M. H.; CONSTERDINE, I. A.; LOWE, J. A. Marine aerosol sea-salt, and the marine sulphur cycle: a short review. Atmospheric Environment, v. 31, n.1, p. 73-80, 1997.

5 MORCILlO, M.; CHICO, B.; MARIACA, L.; OTERO, E. Salinity in marine atmospheric corrosion: its dependence on the wind regime existing in the site. Corrosion Science, v. 42, p. 91-104, 2000.

6 GUSTAFSSON, M. E. R.; FRANZÉN, L. G. Dry deposition and concentration of marine aerosol in a coastal area, sw sweden. Atmospheric Envirnonment, v. 30, n. 6, p. 997-989, 1996.
} 
Em sua tese, Meira (2004) aplicou metodologia para caracterizar a deposição de sais em ambientes marinhos e, inclusive, propôs uma classificação de agressividade do aerosol marinho às estruturas de concreto da orla marítima de João Pessoa-PB. Por monitoramento de corpos-de-prova em campo, nessa cidade, Meira (2004) constatou que a faixa entre 10 e 100 metros da orla é bastante crítica para a exposição do concreto ao aerosol marinho.

\subsubsection{Mecanismos de transporte dos íons cloreto}

Os mecanismos de transporte dependem ainda das características físicas e químicas e da concentração superficial das substâncias que penetram no material, das condições ambientais, do grau de umidificação do concreto e da temperatura.

$O$ ingresso de fluidos e íons agressivos no concreto ocorre através da gravidade (infiltração) ou permeabilidade (penetração sob pressão externa), difusão (gradiente de concentração), absorção (pressão interna) e da migração (efeito de um campo elétrico).

\section{a) Ingresso por gradiente de pressão de vapor (absorção capilar)}

É o fenômeno que se dá através do contato entre o concreto e a água líquida, que adentra através de poros sujeitos a tensões capilares. As características do líquido que influem na absorção capilar são: viscosidade, densidade e tensão superficial.

De acordo com HELENE (1993), a absorção capilar pode ser modelada pela lei de Jurin que relaciona a altura de ascensão ao raio capilar (Equação 2) e pode ser ainda descrita em função do tempo de contato com a água, no regime estacionário e na ausência de evaporação, conforme a Equação 3.

Onde:

$$
\begin{aligned}
& h=2 v / r \text { y (Equação 2) } \\
& h=1 / 2 \sqrt{ } \text { v r t } / \eta \text { (Equação 3) }
\end{aligned}
$$

$\mathrm{h}$ - altura ou penetração da água no capilar (m);

$\mathrm{u}$ - tensão superficial da água, $\mathrm{kg} / \mathrm{m}\left(\approx 75 \times 10^{-4}\right)$;

$\mathrm{Y}$ - massa específica da água $\mathrm{em} \mathrm{kg} / \mathrm{m}^{3}$;

$r$ - raio do capilar $(m)$;

$\eta$ - viscosidade da água $\left(\mathrm{kgs} / \mathrm{m}^{2}\right)\left(\approx 13 \times 10^{-5}\right)$;

$\mathrm{t}$ - período de tempo para atingir a penetração $\mathrm{h},(\mathrm{s})$. 
Após penetrar por capilaridade até certa propriedade limitada ao máximo fornecido pela lei de Jurin, a água só poderá continuar penetrando por difusão e não mais por absorção capilar.

Helene (1993) conclui por afirmar que concretos de baixa relação água / cimento apresentam capilares de menor diâmetro e menos intercomunicáveis, resultando menores alturas de sucção e menores volumes absorvidos.

Aqui cabe ainda lembrar que a rede capilar interconectada à zona de transição ou a vazios de ar pode ser o caminho preferencial e mais importante para o ingresso de água em concretos com média a alta relação água/cimento

A absorção capilar se manifesta, na maioria dos casos, em concretos aparentes ou sem revestimento, expostos ao intemperismo, semi-enterrados ou sem-submersos, isto é, sujeitos a alternância ou ciclos de molhagem e secagem. Não há absorção capilar em concretos saturados, pois o concreto deve estar com os poros secos ou parcialmente secos para que seja possível a absorção de água por capilaridade.

A absorção capilar é o principal mecanismo para a penetração de cloretos em estruturas em atmosfera marinha, pois os cloretos ficam impregnados na superfície da peça e quando dissolvidos em contato com a água penetram por absorção capilar. Em concretos saturados de forma permanente, o principal mecanismo de ingresso de cloretos passa a ser por difusão, associado ou não a gradiente de pressão.

\section{b) Ingresso por gradiente de pressão de água líquida (permeabilidade)}

Mehta; Monteiro (2008) definem permeabilidade como a facilidade com que um fluido pode escoar através de um sólido, sob um gradiente de pressão externa. O mecanismo de penetração de água sob pressão se caracteriza pela existência de um gradiente hidráulico que força a entrada de água no concreto, estando diretamente ainda ligado com a porosidade do material. Esta situação ocorre em estruturas submersas ou parcialmente submersas e pode acelerar a penetração de agentes agressivos no concreto e corrosão de armaduras.

Marchand; Gerard (1995) ${ }^{7}$ citados por MEIRA (2004) definem que "a permeabilidade de um fluido pode ser descrita através da lei de Darcy, considerando que há um fluxo laminar, em regime estacionário, desconsiderando-se a ação da gravidade nas partículas". Nilsson; Tang

\footnotetext{
7 MARCHAND, J.; GÉRADRD, B. New developments inthe modeling of mass transport process in cement-based composites - a review. In: ADVANCES IN CONCRETE THECNOLOGY, $2^{\mathrm{TH}}$ ACI/CANMET INTERNATIONAL SYMPOSIUM. (1995: Las Vegas). Proceedings...Las Vegas: ACI, 1995.
} 
(1996) abordam outra forma de determinação da permeabilidade, através da equação geral de transporte de massa, Equação 4.

Onde:

$$
\mathrm{J}=-\left(\mathrm{K}_{\mathrm{p}} / \eta\right)\left(\delta_{\mathrm{p}} / \delta_{\mathrm{x}}\right) \quad(\text { Equação } 4)
$$

$\mathrm{J}-$ fluxo $\left(\mathrm{m}^{3} / \mathrm{s}\right)$;

$\eta$ - viscosidade do fluxo $\left(\mathrm{kgs} / \mathrm{m}^{2}\right)$;

$\delta_{p} / \delta_{x}-$ gradiente de pressão;

$\mathrm{K}_{\mathrm{p}}$ - coeficiente de permeabilidade do material.

\section{c) Ingresso por gradiente de concentração (difusão iônica)}

Consiste no movimento de íons provocado pela diferença de concentração, buscando um equilíbrio entre meios contínuos. No caso do concreto esse fenômeno ocorre devido ao contato da solução dos poros com o ambiente.

Este fenômeno de transporte ocorre tanto para substâncias em estado líquido como para aquelas em estado gasoso. Os dois principais agentes agressivos, que comprometem as armaduras de aço, íons cloreto e $\mathrm{CO}_{2}$, têm sua penetração no concreto controlada principalmente por este fenômeno.

A difusão dos íons cloreto será tanto mais intensa quanto maior a sua concentração na solução externa. Os mecanismos de transporte dos cloretos, em sua maioria, ocorrem por absorção capilar e por difusão iônica. A absorção capilar se dá na camada mais externa do concreto, onde ocorre o umedecimento e a secagem do cobrimento; no interior do concreto, onde a presença do eletrólito é mais intensa, tem-se basicamente a difusão.

As expressões matemáticas que indicam esse fenômeno de transporte são dadas pelas leis de Fick da difusão. $O$ coeficiente de difusão $D$, das substâncias que penetram no concreto, é calculado através das seguintes expressões.

1ำ lei - Difusão em estado estacionário - fluxo constante:

Onde:

$$
\mathrm{J}=-\mathrm{D}(\delta \mathrm{C} / \delta \mathrm{X})=\text { cte } \quad(\text { Equação } 5)
$$

$\mathrm{J}$ - fluxo de íons $\left(\mathrm{mol} / \mathrm{cm}^{2} \mathrm{~s}\right)$;

$D$ - Coeficiente efetivo de difusão $\left(\mathrm{cm}^{2} / \mathrm{s}\right)$;

$\delta \mathrm{C} / \delta \mathrm{X}$ - Gradiente de concentração $\left(\mathrm{cm}^{2} / \mathrm{s}\right)$;

$X$ - Profundidade considerada ( $\mathrm{mm})$.

2a lei - Difusão em fluxo variável - fluxo variável em relação ao tempo.

$$
\delta \mathrm{C} / \delta \mathrm{T}=-\mathrm{D}\left(\delta^{2} \mathrm{C} / \delta \mathrm{X}^{2}\right) \quad \text { (Equação 6) }
$$


Para que ocorra a difusão iônica no concreto é necessário certo teor mínimo de umidade, que permita a movimentação dos íons. A difusão iônica é mais efetiva quando os poros da pasta de cimento hidratado estão saturados, mas também ocorre em concretos parcialmente saturados (NEVILLE, 1997).

Page et al. (1981) 8 estudaram o comportamento da difusão de cloretos em pastas de cimento elaboradas com cimento Portland comum, cimento resistente a sulfato (baixo teor de $\mathrm{C}_{3} \mathrm{~A}$ ), cimento com adição de $65 \%$ de escória de alto forno e cimento com $30 \%$ de adição de cinza volante. Os resultados mostram que a presença de adições reduz a difusão de cloretos, o que é explicado pelo refinamento da estrutura porosa, como pode ser visto na Tabela 4.

Tabela 4 - Coeficiente de difusão de cloretos, a 25 C em pastas de cimento com relação
água/cimento igual a 0,5 (Page et.al., citado por MEIRA, 2004)
\begin{tabular}{|c|c|}
\hline Tipo de cimento & Coeficiente de difusão $\times \mathbf{1 0}^{-19} \mathbf{( \mathbf { c m } ^ { 2 } / \mathbf { s } )}$ \\
\hline $\begin{array}{c}\text { Cimento Portland } \\
\text { comum }\end{array}$ & 44,7 \\
\hline $\begin{array}{c}\text { Cimento com } 30 \% \text { de } \\
\text { cinza volante }\end{array}$ & 14,7 \\
\hline $\begin{array}{c}\text { Cimento com } 65 \% \text { de } \\
\text { escória }\end{array}$ & 4,1 \\
\hline $\begin{array}{c}\text { Cimento resistente a } \\
\text { sulfetos }\end{array}$ & 100 \\
\hline
\end{tabular}

Conforme Helene (1993), as adições aumentam a resistência do concreto à penetração de cloretos. A difusividade está relacionada com as características do cimento, devido ao fato de parte dos cloretos reagirem com compostos da hidratação do cimento. O coeficiente de difusão varia com a idade, pois o sistema de poros do concreto varia com o tempo, especialmente com a evolução da hidratação do cimento.

\section{d) Ingresso por gradiente de tensão elétrica (migração de íons)}

Consiste na movimentação dos íons provocada por uma diferença de potencial elétrico, de forma que os íons positivos são atraídos pelo pólo negativo; e os íons negativos pelo pólo positivo. No concreto, geralmente, o campo elétrico é gerado pela corrente elétrica do processo eletroquímico ou de uma diferença de potencial gerada por uma fonte externa. Durante este

\footnotetext{
8 PAGE, C. L.; SHORT, N. R.; EL TARRAS, A. Diffusion of chloride ions in hardened cement pastes. Cement and concrete research, v.11, p. 395-406, 1991.
} 
processo, os íons cloreto se movem no sentido da armadura, desde que a mesma esteja polarizada positivamente.

Medeiros; Helene (2003) estudaram a influência dos parâmetros de dosagem, tais como consistência, relação água/cimento e consumo de cimento, na propriedade de migração de cloretos através do concreto. O estudo foi realizado variando a relação água/cimento; deixando constante a consistência e variando a consistência e deixando constante a relação água/cimento. Os resultados indicam que a quantidade e a qualidade da pasta são fatores de extrema importância na penetração de cloretos no concreto, concluindo que a migração de cloretos é função direta do consumo de cimento, quando se mantém a relação água/cimento constante, e também é função inversa do consumo de cimento, quando se varia a relação água/cimento e se mantém constante a consistência. Pode-se concluir que a relação água/cimento é o principal agente controlador da resistência à penetração de cloretos no concreto, como mostra a Figura 13.

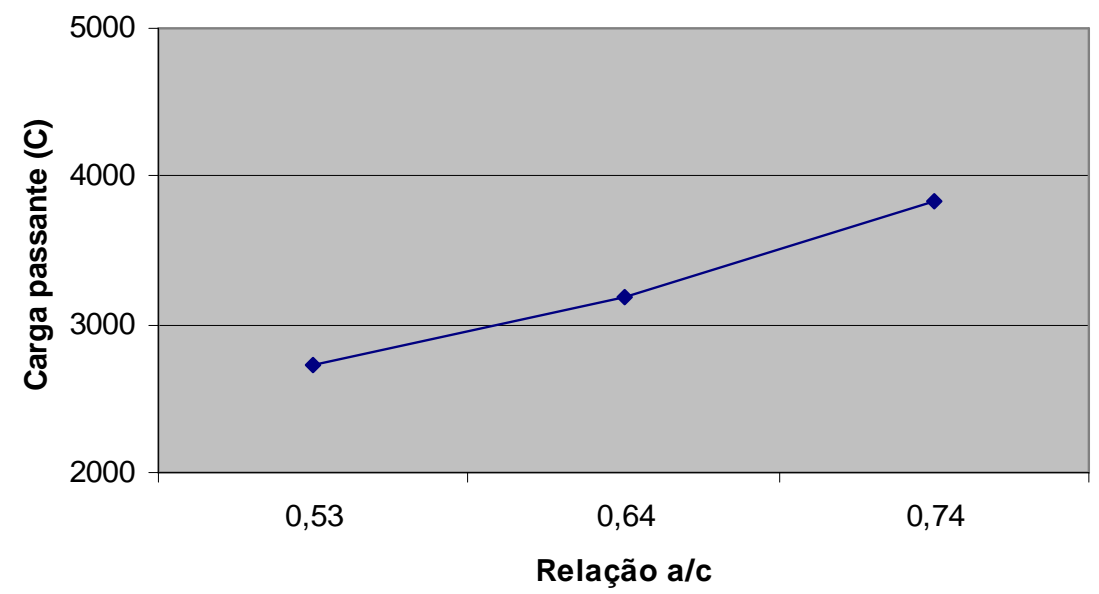

Figura 13 - Carga passante x relação água/cimento para uma mesma consistência (MEDEIROS; HELENE, 2003)

Regattieri (1998) também estudou a migração de cloretos, variando a relação água/cimento e o tipo de cimento; os resultados podem ser vistos na Figura 14. Os resultados encontrados concordam com a conclusão de Medeiros; Helene (2003) e por estes resultados é possível diferenciar como os concretos com adições de escória e de cinza volante são menos afetados pela relação água/cimento do que aqueles com cimento CP I S. 


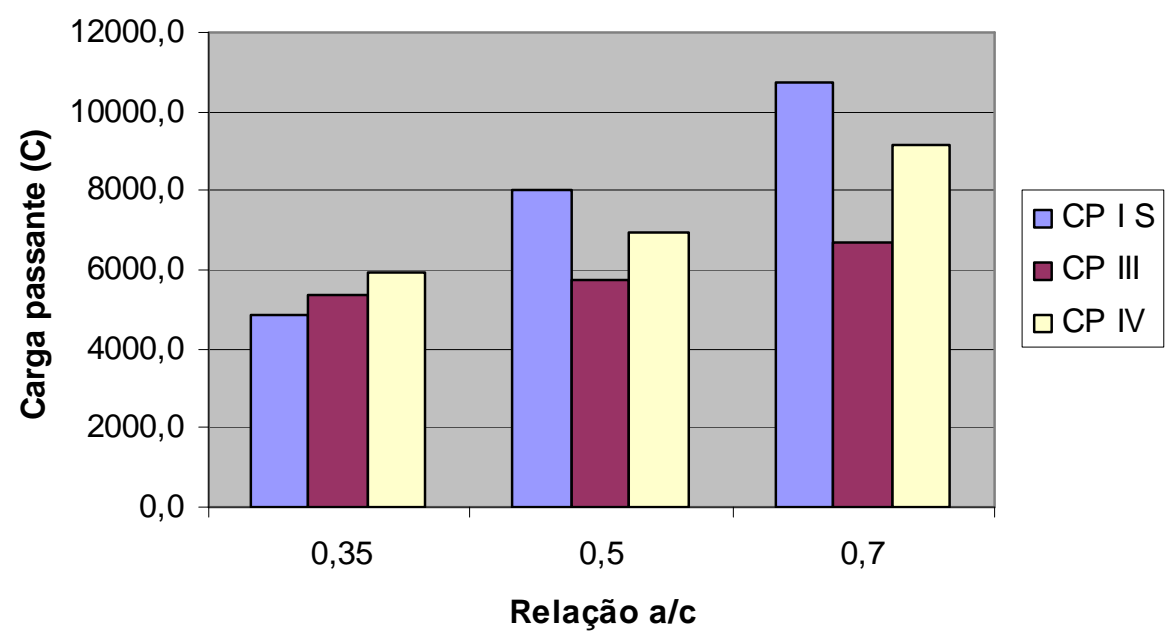

Figura 14 - Migração de íons cloreto x relação água/cimento (CPI S, CPIII e CPIV) (REGATTIERI, 1998)

\section{e) Mecanismos combinados de ingresso}

De acordo com Helene (1993), as maiores penetrações de cloretos são observadas onde os mecanismos de penetração de cloretos podem atuar juntos. A Figura 15 mostra como uma peça estrutural pode estar exposta a vários mecanismos de transporte.

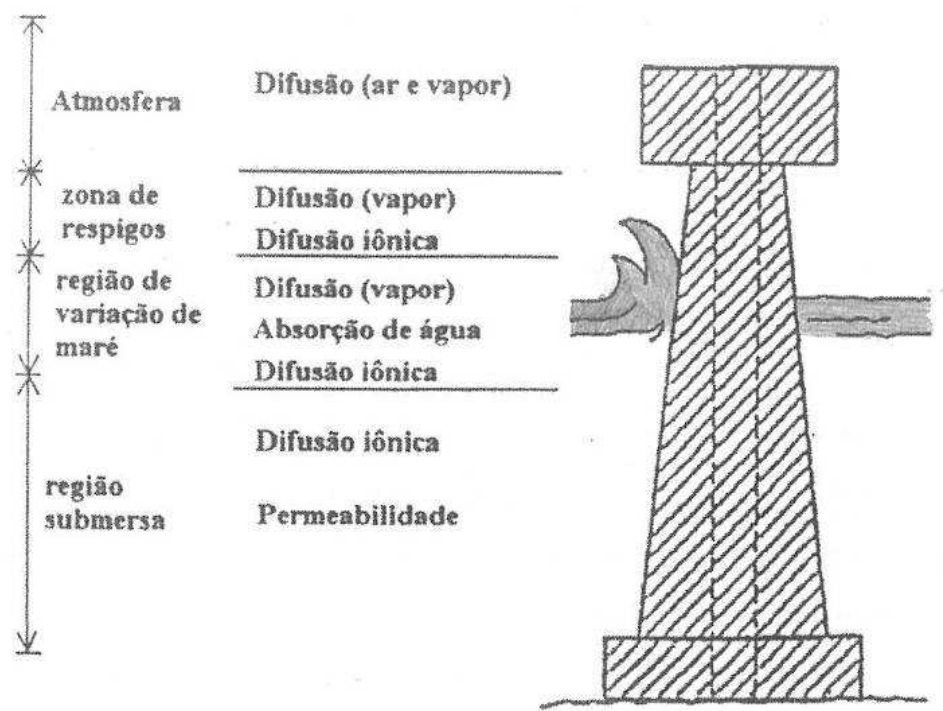

Figura 15 - Atuação de diversos mecanismos de transporte em uma estrutura marítima (PERRATON et al. ,1992, citado por PEREIRA, 2001) 
No caso de exposição das estruturas de concreto em ambientes marítimos, os mecanismos de transporte de cloretos e $\mathrm{CO}_{2}$ são mistos e atuam com elevado grau de complexidade, dado o fato de que a microestrutura do concreto é também evolutiva com o tempo. Obviamente, fissuras no concreto sempre são o caminho preferencial para o ingresso de agentes agressivo, e isto dificulta ainda mais os trabalhos de modelagem deste fenômeno. Mas é consenso de que a porosidade total do concreto governa e controla o ingresso de agentes agressivos no concreto. Helene (1993) propôs classificação importante para este critério, discutido no próximo Capítulo.

\subsubsection{Relação água/cimento}

A relação água/cimento é a responsável pela porosidade e permeabilidade do concreto, sendo assim, controla a penetração dos cloretos. Quanto maior a relação água/cimento, maior será a porosidade e a permeabilidade do concreto e, maior será a penetração de cloretos.

Monteiro (1996), estudando três tipos de cimento produzidos no Brasil, verificou que a redução da relação água/cimento melhorou o desempenho de todos os cimentos, em relação à corrosão das armaduras por cloretos.

Pereira (2001) avaliou a difusão de íons cloretos em concretos confeccionados com dois tipos diferentes de cimentos (CP \| F e CP IV), distintas relações água/cimento, cinco temperaturas de cura e cinco idades diferentes. Concluiu que os coeficientes de difusão diminuem com o uso de cimento CP IV e com a redução da relação água/cimento. Confirmou que a relação água/cimento exerce grande influência no coeficiente de difusão de cloretos, como observado por vários outros autores como TUUTTI (1982), MONTEIRO (1996), MEDEIROS e HELENE (2003), MEIRA (2004); dentre outros, e aqui ilustrado pela Figura 16. 


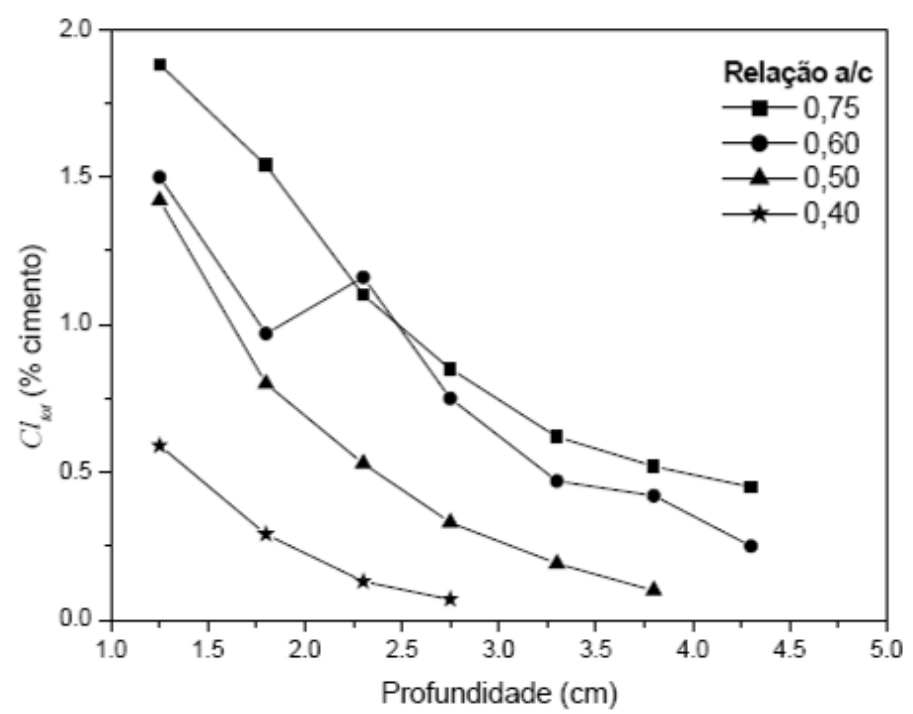

Figura 16 - Efeito da relação água/cimento na penetração de cloretos (JAERGEMAN, 1990, citado por MEIRA, 2004)

\subsubsection{Tipo de cimento}

A composição química do cimento tem influência na penetração de cloretos. Já que a capacidade de fixação dos íons cloreto é determinada pelo teor de $C_{3} A$ e $C_{4} A F$. Esta fixação ocorre pela reação dos íons cloreto com os aluminatos, formando cloroaluminatos de cálcio e diminuindo a quantidade de cloretos livres nas soluções dos poros do concreto.

Cimentos com adições, quando submetidos a cloretos, apresentam comportamento contrário de quando submetidos ao $\mathrm{CO}_{2}$. $\mathrm{Na}$ carbonatação, as adições aparentam influir de forma negativa na capacidade de retardar as reações de carbonatação; na resistência à penetração de cloretos as adições agem de forma a frear a penetração desses íons (FIGUEIREDO, 2005). De qualquer forma, os fatores determinantes da corrosão decorrem da presença simultânea de água, oxigênio e diferença de potencial na barra, juntamente com um ou mais desses agentes.

O uso de cimento com adições, tais como: cinza volante, escória de alto forno, microssílica, entre outras, aumenta a resistividade elétrica do concreto e diminui o tamanho dos poros. A utilização de escória granulada de alto-forno, substituindo parte do cimento, pode melhorar a estrutura dos poros do concreto, ocorrendo uma diminuição do coeficiente de difusão de cloretos (REGATTIERI, 1998).

Bauer (1995) constatou que a adição de escória ao cimento tem um efeito benéfico da capacidade de fixação de cloretos para relação água/cimento abaixo de 0,5. 
Nos experimentos realizados por Zhang; Gjoro (1991), citados por FIGUEIREDO (2005), a introdução de sílica ativa em pastas de cimento reduziu a difusividade dos íons cloreto; os mesmos associaram este desempenho à diminuição da porosidade total e à distribuição dos poros.

Costa Jr et al. (2006) avaliaram a difusão de íons cloreto em concretos confeccionados com três tipos de cimento (CP II E-32, CP III - 32 RS e CP III - 32 RS + Escória), com classes de resistência de 20,30, 35 e $40 \mathrm{MPa}$ e utilizando teores de escória granulada de alto-forno iguais a 30, 66 e $83 \%$, em massa de cimento. Os autores encontraram nos concretos com maiores teores de escória as maiores resistências à penetração de íons cloreto, concordando com a opinião dos demais pesquisadores.

Vários autores, entre eles, HELENE (1993), BAUER (1995) e FIGUEIREDO (2005) afirmam que a escória de alto-forno, empregada como adição mineral, reduz significativamente o coeficiente de difusão dos cloretos, quer seja pelo efeito da adição ou pela maior capacidade de fixação de cloretos.

Monteiro (1996) estudou o comportamento de alguns cimentos (CPII - F 32, CPIII 32 e CP V - ARI - RS - MS) em relação à proteção contra a corrosão das armaduras, com diferentes relações água/cimento $(0,4$ e 0,7$)$ e cura. Foram feitos dois tipos de ensaios onde, no primeiro, os corpos-de-prova foram submetidos a ensaios de carbonatação acelerada e posteriormente à penetração de cloretos com ciclos de umedecimento e secagem; e no segundo, os corpos-de-prova foram submetidos a ensaios de penetração de cloretos com ciclos de umedecimento e secagem e posteriormente à carbonatação acelerada. A carbonatação acelerada foi realizada em câmara com $100 \%$ de exposição de $\mathrm{CO}_{2}$ e umidade relativa de $60 \%$. Nos ensaios com cloretos, foram utilizados semi-ciclos de imersão parcial em solução de $5 \%$ de $\mathrm{NaCl}$ por dois dias e secagem em estufa a $50^{\circ} \mathrm{C}$ por cinco dias. Em todos os casos, os cimentos CP III 32 e CP V ARI-RS-MS apresentam um pior desempenho em relação à carbonatação; e um melhor comportamento em relação à corrosão decorrente do ingresso de cloretos. O desempenho dos três tipos de cimento, em medidas de taxas de corrosão por cloretos foi significativamente melhor quando as argamassas não estavam carbonatadas; em outras palavras, os corpos-de-prova não-carbonatados, apresentaram intensidade de corrosão bastante inferior em relação aos corpos-de-prova carbonatados, quando submetidos às mesmas condições de ciclos em uma solução de cloretos com mesma concentração, estando de acordo com DHIR et al. (1993). Ressalvas devem ser feitas, que medidas de corrosão por ação de cloretos precisam ser feitas ou comparadas com muita cautela, pois o efeito de cloretos se dá inicialmente por pites, em concretos passivados e não-carbonatados. 
Todavia é mais difícil a previsão de comportamento pela exposição a ciclos de imersão e secagem do concreto, em que a carbonatação pode ocorrer de modo simultâneo ao ingresso de cloretos, pela razão que se destaca no item 2.3.3.7.

\subsubsection{Grau de hidratação pela cura}

As condições de cura úmida do concreto nas primeiras idades fazem a hidratação do cimento progredir e modificam a estrutura dos poros da pasta e, por conseqüência, alteram a porosidade final. Um concreto com período de cura mais curto apresentará uma maior penetração de cloretos que um concreto com período de cura mais prolongado (FIGUEIREDO, 2005).

Plante; Bilodeau (1989) ${ }^{9}$ citados por PEREIRA (2001), mostraram a diminuição da penetração de cloretos com o aumento do tempo de cura (1, 7 e 28 dias), em concretos confeccionados com diferentes relações água/cimento, a saber: 0,22; 0,65;0,50 e 0,71, devido à redução da porosidade com o decorrer do tempo de cura, conforme apresentado na Figura 17.

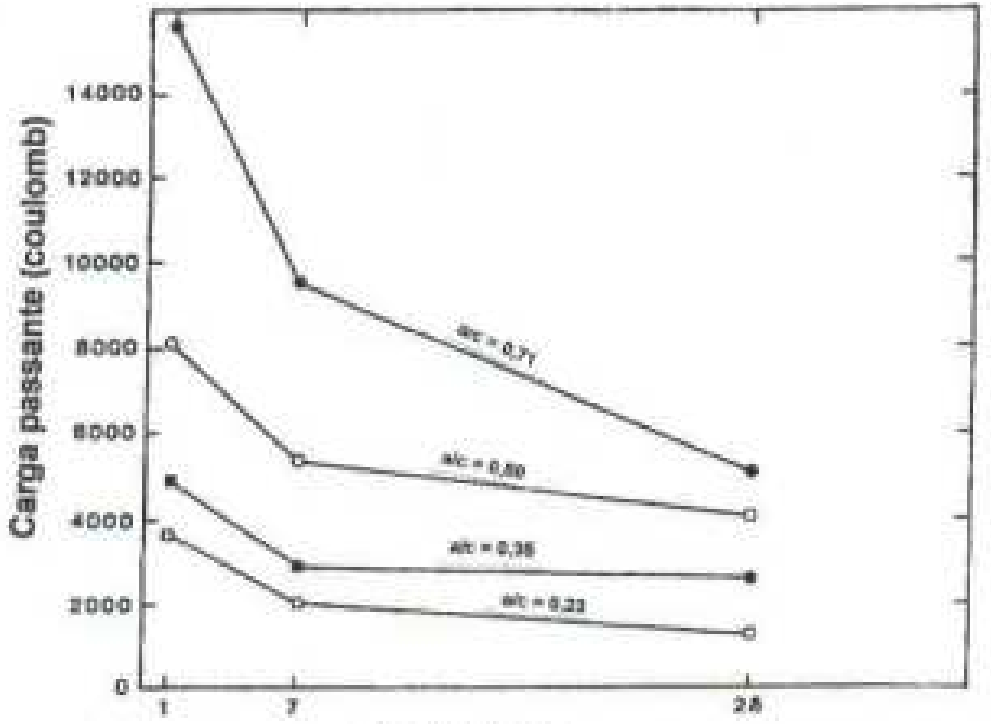

Figura 17 - Penetração de íons cloreto versus o tempo de cura em concretos (1, 7 e 28 dias) (PLANTE; BILODEAU, 1989 citado por PEREIRA, 2001)

\footnotetext{
9 PLANTE, P.; BILODEAU, A. Rapid chloride íon permeability test: data on concretes incorporating supplementary cementing materials: In: INTERNATIONAL CONFERENCE FLY ASH, SILICA FUME, SLAG AND NATURAL POZZOLANS IN CONCRETE, 3., 1989, Trodheim. Proceedings...Trodheim, 1989. v.1, p. 654644.
} 
Pereira (2001), avaliando a difusão de íons cloretos em concretos confeccionados com dois tipos diferentes de cimentos (CP II F e CP IV) e cinco idades diferentes de cura $(7,14,28$, 63 e 91 dias) obteve os resultados apresentados na Figura 18. A partir dos resultados apresentados, observa-se que, quanto maior é a idade, menor é o coeficiente efetivo de difusão de cloretos, para os dois tipos de cimento. Essa redução ocorreu devido ao prosseguimento da hidratação do cimento com o decorrer do tempo.

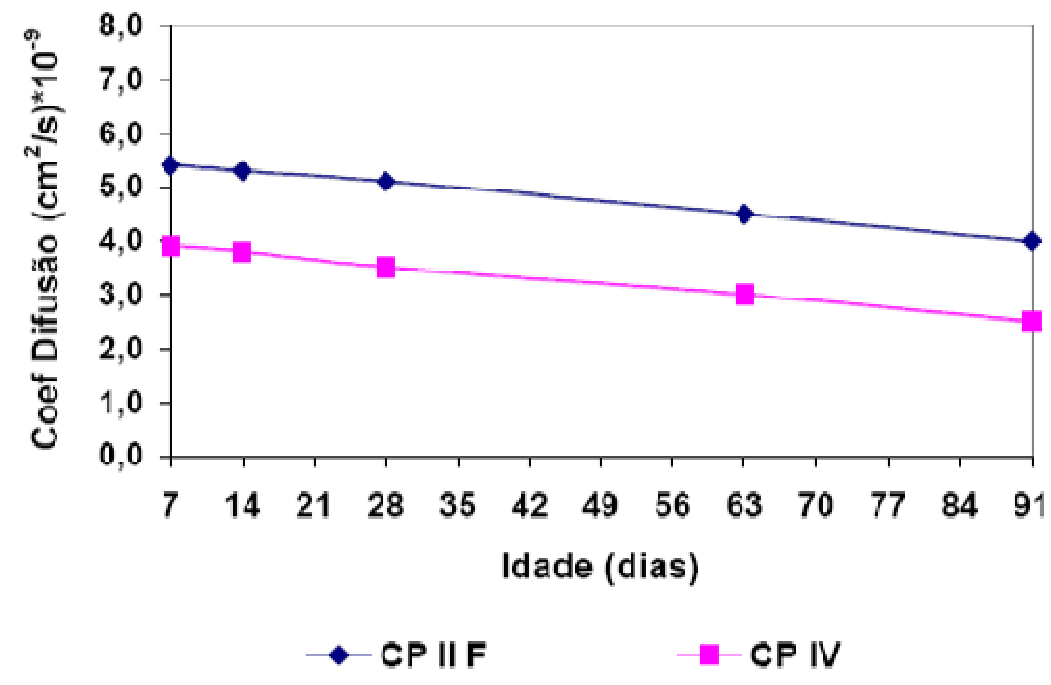

Figura 18 - Efeitos isolados da idade e do tipo de cimento de concretos sobre o coeficiente efetivo de difusão (PEREIRA, 2001)

\subsubsection{Carbonatação}

Um concreto carbonatado não possui a mesma capacidade de fixar cloretos no gel cimento de que um concreto não carbonatado. Quando o concreto começa a carbonatar parte dos cloretos que estiverem combinados passam à condição de livres, podendo atingir o limite crítico. De acordo com HELENE (1993), a capacidade de fixação dos cloretos pelo $C_{3} A$ é reduzida quando há ocorrência de carbonatação, pois os cloroaluminatos não são estáveis em valores baixos de $\mathrm{pH}$.

Jones et al. (1991) ${ }^{10}$ citados por PEREIRA (2001) estudaram o tempo de iniciação da corrosão através do ingresso de cloretos, e observaram que esse tempo é reduzido quando os corpos-de-prova já estão parcialmente carbonatados.

10 JONES, M. R.; DHIR, R. K.; GILL, J. P. Concrete surface treatment: effect of exposure temperature on chloride diffusion resistance. Cement Concrete Research, v. 25, n. 1, p. 197-208, 1991. 


\subsubsection{Temperatura}

A elevação da temperatura pode reduzir a vida útil de serviço das estruturas de concreto armado, como conseqüência do aumento da velocidade de penetração dos cloretos, uma vez que esses íons têm mais mobilidade em temperaturas mais elevadas.

Também as reações de corrosão são mais rápidas a temperaturas mais elevadas, e há um estimulo à mobilidade das moléculas, portanto o efeito acelerador da temperatura explica por que existem muitos mais concretos deteriorados em regiões litorâneas quentes do que em regiões temperadas (NEVILLE, 1997).

A relação temperatura e difusão de íons pode ser representada pela equação de Arrehnius, segundo o qual o crescimento do coeficiente de difusão é função do aumento da temperatura, conforme Equação 7.

Onde:

$$
D(t)=D_{0} e^{-U / R T} \quad(\text { Equação } 7)
$$

$D(t)$ - coeficiente de difusão da temperatura $T\left(\mathrm{~cm}^{2} / \mathrm{s}\right)$;

$\mathrm{D}_{0}, \mathrm{U}$ - constantes características de cada sistema;

$\mathrm{R}$ - constante dos gases;

$T$ - temperatura $\left({ }^{\circ} \mathrm{C}\right)$.

Page et al. (1981), citados por MEIRA (2004), estudando pastas de cimento a diversas temperaturas, calcularam o aumento do coeficiente de difusão para uma variação de 7 a 44ํㅡ, como consta na Tabela 5. Analisando esta tabela, pode-se inferir que o aumento da relação água/cimento é tão nocivo quanto o aumento da temperatura, podendo esta segunda variável ser ainda mais prejudicial, nas faixas de variação consideradas. Obviamente, estes resultados podem ser questionados e cabem ser confirmados para outros concretos.

Tabela 5 - Coeficiente de difusão efetivo em função da temperatura e relação água/cimento (PAGE et al., 1991 citados por MEIRA, 2004)

\begin{tabular}{|c|c|c|c|}
\hline \multirow{2}{*}{$\begin{array}{c}\text { Temperatura } \\
(\mathrm{C})\end{array}$} & $\mathbf{a} / \mathbf{C}=\mathbf{0 , 4}$ & $\mathbf{a} / \mathbf{c}=\mathbf{0 , 5}$ & $\mathbf{a} / \mathbf{c}=\mathbf{0 , 6}$ \\
\cline { 2 - 4 } & $\begin{array}{c}\mathbf{D}_{\mathrm{e}} \times \mathbf{1 0}^{-19} \\
\mathbf{c m}^{2} / \mathbf{s}\end{array}$ & $\begin{array}{c}\mathbf{D}_{\mathrm{e}} \times \mathbf{1 0}^{-19} \\
\mathbf{c m}^{2} / \mathbf{s}\end{array}$ & $\begin{array}{c}\mathbf{D}_{\mathrm{e}} \times \mathbf{1 0}^{-19} \\
\mathbf{c m}^{2} / \mathbf{s}\end{array}$ \\
\hline 7 & 11,03 & 20,7 & 51,9 \\
\hline 14,5 & 12,7 & 23,6 & 84,6 \\
\hline 25 & 26 & 44,7 & 123,5 \\
\hline 35 & 44,7 & 94,8 & 165,2 \\
\hline 44 & 84 & 183,6 & 318,2 \\
\hline
\end{tabular}


Em estudo realizado por Jones et al. (1991), citados por PEREIRA (2001), em concretos curados em água a $20^{\circ} \mathrm{C}$, por um período de 28 dias, o coeficiente de difusão de cloretos aumentou com a elevação da temperatura de ensaio $\left(-10,10,20,35,45^{\circ} \mathrm{C}\right)$. Os autores justificam este comportamento devido à maior mobilidade dos íons cloretos a elevadas temperaturas.

\subsubsection{Grau de saturação dos poros}

O transporte dos íons cloreto somente ocorre em presença de água. Nas situações em que a água que contém os cloretos encontra-se estagnada, a penetração no interior do concreto ocorre através de mecanismos de difusão (FIGUEIREDO, 2005). Em condições de saturação, os íons vão se difundir pelos poros cheios de água. Quando a quantidade de água diminui, o processo é dificultado pelo decréscimo da quantidade de poros que mantém uma continuidade da solução no seu interior.

Almenar (2000) ${ }^{11}$, citado por MEIRA (2004), em estudo sobre a difusividade em meios não saturados, apresentou uma redução no coeficiente de difusão de $9,92 \times 10^{-12} \mathrm{~m}^{2} / \mathrm{s}$ em concretos com grau de saturação ao redor de $70 \%$, para $0,21 \times 10^{-12} \mathrm{~m}^{2} / \mathrm{s}$ em concretos com grau de saturação de 33\%, conforme a Figura 19. Em Nielsen; Geiker (2003) ${ }^{12}$ citado por MEIRA (2004), o coeficiente de difusão decresceu de $12 \times 10^{-12} \mathrm{~m}^{2} / \mathrm{s}$ para $2,7 \times 10^{-12} \mathrm{~m}^{2} / \mathrm{s}$, variando a condição ambiental de saturado para 66\%, conforme a Figura 19.

Portanto, conclui-se que a mobilidade de cloretos por difusão é acelerada pela saturação dos poros do concreto, enquanto a penetração de $\mathrm{CO}_{2}$ se propaga de forma inversa. Por outro lado, em condições de molhagem e secagem das estruturas, os fenômenos de absorção capilar de água podem ser preponderantes para o ingresso de agentes agressivos no concreto

\footnotetext{
11 ALMENAR, G.V. Ingreso de cloruros em hormigon: métodos de analisis, deteccion no destructiva y modelizacion del transporte tras um aporte inicial limitado. Alicante: Universidad de Alicante, 2000 (Tesis Doctoral).

12 NIELSEN, E.P.; GEIKER, M. R. Chloride diffusion in partially saturated commentitious material. Cement and Concrete Research, v.33, p. 133-138, 2003.
} 


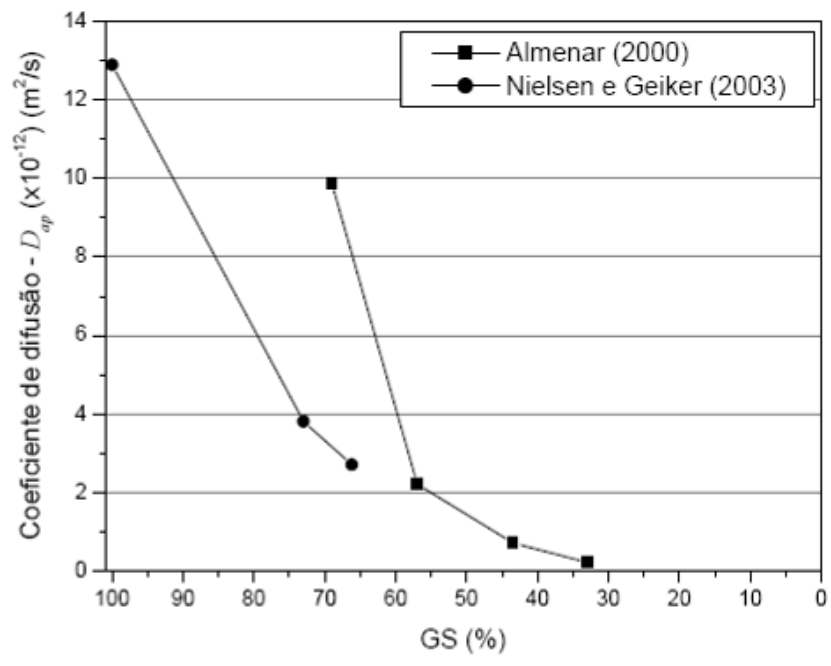

Figura 19 - Comportamento do coeficiente de difusão com a variação do grau de saturação do concreto (MEIRA, 2004)

\subsubsection{Tipos de cátions combinados com os íons cloreto}

A taxa de penetração de cloretos depende da quantidade de cloretos que são fixados depende do tipo de sal que contêm os cloretos (FIGUEIREDO, 2005).

"Analisando o efeito do tipo de sal na capacidade de fixação dos cloretos, Byfors (1990) ${ }^{13}$ observou que há um incremento da quantidade de cloretos combinados na presença de $\mathrm{KCl}$, $\mathrm{CaCl}_{2}, \mathrm{MgCl}_{2}$, respectivamente, em comparação com a presença de $\mathrm{NaCl}$ (MEIRA, 2004). Tritthart (1989) ${ }^{14}$, citado por MEIRA (2004), afirma que este comportamento se deve à influência do tipo de cátion em formar hidróxidos relativamente menos solúveis, como $\left(\mathrm{Ca}(\mathrm{OH})_{2}\right.$ e $\mathrm{Mg}(\mathrm{OH})_{2}$ ), pois reduzem a concentração de $\mathrm{OH}^{-}$na solução dos poros. Assim, o tipo de cátion influencia a concentração de $\mathrm{OH}^{-}$, que, por sua vez, influencia a fixação de cloretos.

13 BYFORS, K. Chloride - initiated reinforcement corrosion: chloride binding. Stockholm: CBI (report 1:90), $1990.121 \mathrm{p}$.

14 TRITTHART, J. Chloride binding in cement - in the influence of hydroxide concentration in the pore solution of hardened cement paste on chloride binding. Cement and Concrete research, v. 19, p. 683-691, 1989. 


\subsubsection{Fissuras}

Como bem resume FIGUEIREDO (2005), quando uma estrutura de concreto está exposta à água, vapor ou solo que contenham íons cloretos, o ingresso preferencial se dá nas regiões fissuradas, do cobrimento e é por elas que se inicia a corrosão, ao atingirem teores críticos deste contaminante.

Por conseguinte, além dos efeitos do meio ambiente, uma considerável parcela da resistência ao ingresso de cloretos nas estruturas de concreto depende da compacidade e da durabilidade física do cobrimento.

A limitação de abertura de fissuras, em função da agressividade ambiental, é proposta pela NBR 6118 (2003) e sempre que possível deve ser minimizada, para as estruturas sujeitas à ação de cloretos ou outros íons agressivos. 


\section{CAPÍTULO 3}

\section{REQUISITOS E CRITÉRIOS PARA A DURABILIDADE DAS ARMADURAS DO CONCRETO ESTRUTURAL}

Todo projeto estrutural deve ter por objetivo conseguir uma estrutura de mínimo custo que atenda com segurança às solicitações de uso. Para isso, é necessário conhecer o comportamento das estruturas semelhantes já construídas e a influência das principais as variáveis que entram no dimensionamento da nova estrutura. Toda estrutura de concreto armado, depois de acabada, possui uma série de características próprias que a diferenciam daquela que foi especificada no projeto estrutural. $O$ aço e o concreto não possuem exatamente a resistência característica especificada, as armaduras não estão perfeitamente nas posições desenhadas, as formas não têm as dimensões com as quais se efetuou o dimensionamento do componente estrutural, os pilares não guardam o prumo absoluto, entre outros (HELENE, 1981). O projeto estrutural não pode assegurar que durante a execução da estrutura sejam empregados os materiais e os métodos construtivos por ele especificados.

A etapa de execução da obra está sempre sujeita às variações aleatórias, de tal modo que não é possível prever com certeza qual o resultado final. O grau de concordância dessas características finais com aquelas que foram anteriormente especificadas pode ser medido e informa sobre a qualidade da execução. Essa qualidade será tanto mais alta quanto maior a conformidade do executado com o que foi projetado (HELENE, 1981).

Há requisitos qualitativos e alguns critérios quantitativos muito importantes e relacionados à durabilidade das estruturas de concreto e que devem ser atendidos pelo projeto estrutural, pelo projeto arquitetônico e durante a execução da obra. Entre estes se incluem a qualidade e a espessura de cobrimento do concreto sobre as armaduras, bem como a limitação de fissuras pela ação de esforços sobre os elementos estruturais.

Inicialmente, cabe destacar a seguinte e importante recomendação da ABNT NBR 6118 (2003) no seu item 5.2 - Requisitos de Qualidade de Projeto:

"A qualidade da solução adotada deve ainda considerar as condições arquitetônicas, funcionais, construtivas, estruturais, de integração com os demais projetos (elétricos, hidráulicos, e outros), explicitadas pelos responsáveis técnicos de cada especialidade com a anuência do contratante". 
Devem ser utilizadas formas arquitetônicas e estruturais apropriadas, de modo a evitar disposições espaciais ou construtivas que reduzam a durabilidade da estrutura, isto é, sem prejudicar os aspectos estéticos e a inspiração artística da arquitetura.

É conveniente prever acesso adequado para a inspeção e a manutenção de partes da estrutura com vida útil inferior ao todo.

Assim, muitos outros requisitos de projeto caberiam listados aqui, mas podem ser resumidos pelos seguintes procedimentos:

1 - Evitar formas arquitetônicas e estruturais inexeqüíveis;

2 - Prever drenagens eficientes;

3 - Controlar fissuração das peças;

4 - Prever revestimento protetor em exposição ambiental muita agressiva;

5 - Detalhar adequadamente as armaduras;

6 - Garantir cobrimento de concretos apropriado para proteção às armaduras;

7 - Garantir concreto com qualidade apropriada, ao macroclima local e particularmente nas regiões superficiais dos elementos estruturais;

Os itens 3.1 a 3.8, que seguem analisam em especial os requisitos e critérios para definição do concreto, segundo normas brasileiras pertinentes à essa lista de verificações.

\subsection{Classificação da agressividade ambiental quanto ao macroclima}

A agressividade do meio ambiente está relacionada às ações físicas e químicas que atuam sobre as estruturas de concreto, além das ações mecânicas, das variações volumétricas de origem térmica, da hidratação e outras, conforme resumo pela Tabela 1, no item 2.1.

A classificação da agressividade do meio ambiente deve ser feita com base nas condições de exposição da estrutura ou suas partes, e ainda deve levar em conta o microclima atuante em suas diferentes partes.

Lima (2005) enfatiza que:

As variações térmicas do ambiente exercem influência nos processos físicos e químicos de degradação das estruturas de concreto. O clima brasileiro apresenta consideráveis amplitudes térmicas médias e elevadas temperaturas médias anuais, fatos que exercem grande influência nos processos de degradação das obras de concreto (LIMA, 2005). 
A ABNT NBR 6118 (2003) determina que, nos projetos das estruturas correntes, a agressividade ambiental da região geográfica onde se situa a obra seja classificada de acordo com a Tabela 6, cabendo inclusive a análise de sua atividade econômica.

Assim, neste trabalho, as características geográficas e econômica do local de implantação da obra estão sendo denominadas de macroclima.

Tabela 6 - Classe de agressividade ambiental quanto ao macroclima (ABNT NBR 6118, 2003)

\begin{tabular}{|c|c|c|c|}
\hline $\begin{array}{c}\text { Classe de } \\
\text { agressividade } \\
\text { ambiental }\end{array}$ & Agressividade & $\begin{array}{l}\text { Classificação geral do } \\
\text { tipo de ambiente para } \\
\text { efeito de projeto }\end{array}$ & $\begin{array}{c}\text { Risco de } \\
\text { deterioração } \\
\text { da estrutura }\end{array}$ \\
\hline \multirow{2}{*}{ I } & \multirow{2}{*}{ Fraca } & Rural & \multirow{2}{*}{ Insignificante } \\
\hline & & Submersa & \\
\hline II & Moderada & Urbana $^{1,2}$ & Pequeno \\
\hline \multirow{2}{*}{ III } & \multirow{2}{*}{ Forte } & Marinha $^{1}$ & \multirow{2}{*}{ Grande } \\
\hline & & Industrial $^{2}$ & \\
\hline \multirow{2}{*}{ IV } & \multirow{2}{*}{ Muito Forte } & Industrial $^{3}$ & \multirow{2}{*}{ Elevado } \\
\hline & & Respingo de maré & \\
\hline \multicolumn{4}{|c|}{$\begin{array}{l}\text { 1- Pode-se admitir um microclima com uma classe de agressividade mais branda (um nível } \\
\text { acima) para ambientes secos (salas, dormitórios, banheiros, cozinha e áreas de serviço de } \\
\text { apartamentos residenciais e conjuntos comerciais ou ambientes com concreto revestido } \\
\text { com argamassa e pintura). } \\
2 \text { - Pode-se admitir uma classe de agressividade mais branda (um nivel acima) em obras em } \\
\text { regiões de clima seco, com umidade relativa do ar menor ou igual a } 65 \% \text { partes da estrutura } \\
\text { protegida de chuvas em ambientes predominantemente secos, ou regiões onde chove } \\
\text { raramente. } \\
3 \text { - Ambientes químicamente agressivos, tanques industriais, galvanoplastia, } \\
\text { branqueamento em indústrias de celulose e papel, armazém de fertilizantes, indústrias } \\
\text { químicas. }\end{array}$} \\
\hline
\end{tabular}

Vilasboas; Machado (2005) em pesquisa sobre a durabilidade das estruturas de concreto armado na cidade de Salvador-BA, observaram que $88,2 \%$ dos profissionais entrevistados tinham dificuldades para escolha da classe de agressividade moderada ou forte da Tabela 6.1 da ABNT NBR 6118 (2003), aqui apresentada na Tabela 6, em projetos de estruturas localizados na zona urbana de uma cidade marítima. Dificuldade esta também apontada por projetistas de outras cidades litorâneas brasileiras, com quem este autor mantém contato.

Em princípio pode ser entendido que o ambiente rural é uma região, à grande distância de fontes poluidoras do ar, com baixos teores de poluentes e baixos riscos de corrosão.

O ambiente submerso em água também apresenta menor risco de deterioração por corrosão por ser uma região sem a presença de oxigênio.

Já o meio ambiente urbano pode apresentar teores muito variados de poluentes que afetam a alcalinidade do concreto. No caso, a ocorrência de chuvas ácidas, a deposição de 
partículas sólidas e lançamento de dióxido de carbono na atmosfera, responsável pela carbonatação dos concretos e por uma possível corrosão das armaduras (LIMA, 2005).

O ambiente industrial também apresenta um elevado risco de deterioração das estruturas, já que contem tipicamente produtos químicos que podem acelerar de 60 a 80 vezes o processo de corrosão de armaduras, quando comparado a taxas de corrosão em atmosferas rurais (HELENE, 1993).

No meio ambiente marinho são encontrados vários agentes que atuam para a degradação das estruturas de concreto armado, reduzindo seu desempenho e que podem ser agrupados em agentes químicos, agentes físicos e biológicos.

Como ilustrado na Figura 12, item 2.3.3.2, a zona de variação da maré é muito agressiva, já que a estrutura fica exposta, a ciclos alternados de molhagem e secagem e a impactos da água do mar com teor elevado de íons cloretos e outros sais nocivos ao aço-carbono das armaduras.

Em João Pessoa/PB, a comunidade técnica local já realiza pesquisas para a detecção de limites da ação de cloretos, além da orla marítima, segundo publicação internacional de Meira et al. (2004) e conforme alguns de seus resultados analisados nos itens 2.3.2.2 e 2.3.2.5. Por aqueles resultados, e na interpretação deste autor, a zona a ser considerada mais agressiva, por manter maior umidade no concreto, está localizada a até $200 \mathrm{~m}$ da orla marítima.

\subsection{A importância da caracterização dos microclimas no projeto, para a prevenção da corrosão de armaduras}

Deve-se ter cuidado nos projetos em verificar os microclimas formados pelos diversos elementos construtivos internos e externos ao edifício, já que podem ser mais agressivos às armaduras do que o macroclima geográfico e econômico de localização da estrutura. Alguns exemplos estão listados nas notas de observação da Tabela 8 e outros podem se dados como: fundações, subsolos confinados e reservatórios de água, entre outros. Nesses elementos, deve-se ter mais atenção com o $f_{c k}$ especificado, com o cobrimento das armaduras e com a relação água/cimento. Muitos projetistas quando se deparam com um microclima muito agressivo, já especificam um aumento do cobrimento das armaduras, uma relação água/cimento mais baixa e um $\mathrm{f}_{\mathrm{ck}}$ maior.

Na maioria de projetos em edifícios de múltiplos andares é muito comum a construção de subsolos confinados, destinados ao uso de garagens. Esses subsolos apresentam pouca circulação de ar e maiores concentrações de $\mathrm{CO}_{2}$ proveniente dos veículos. Isso caracteriza um ambiente favorável à corrosão das armaduras das fundações e dos pilares. 
Carmona (2005) estudou a profundidade de carbonatação nas garagens de um edifício residencial. O edifício selecionado para o estudo, com aproximadamente 30 anos de idade, encontra-se na zona central da cidade de São Paulo-SP. A garagem do edifício estudado estava situada a aproximadamente 2 metros abaixo do nível da rua e apresentava pouca ventilação. A estrutura era em concreto armado e pintada com caiação, com o piso apoiado diretamente sobre o solo. Foi encontrada uma elevada incidência de carbonatação no meio dos pilares e nos vãos das vigas. Na base dos pilares, a menor carbonatação pode ter sido pela maior absorção capilar da água do concreto junto ao solo e à presença de água de lavagem do piso. Já na região central das vigas, a maior profundidade de carbonatação foi atribuída a maior fissuração nessa região, em relação aos apoios, conforme a Figura 20.

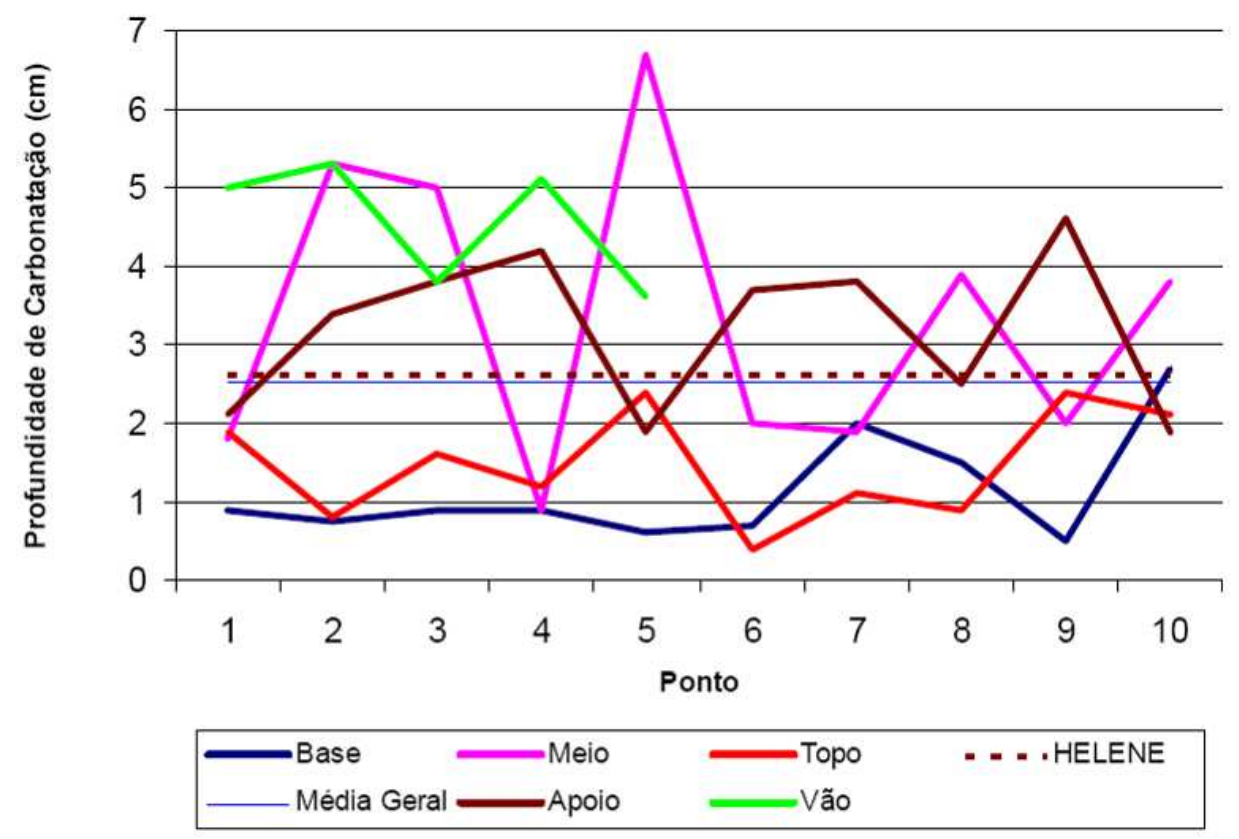

Figura 20 - Variação da profundidade de carbonatação em vigas e pilares de garagem em prédio com 30 anos e comparação com os valores calculados pelo modelo de HELENE (CARMONA, 2005)

Assim, é consenso no meio técnico, que a agressividade específica do microclima em certos elementos estruturais e ambientes do edifício pode contribuir, de modo diferenciado, pra a incidência de corrosão das armaduras, nos mais diversos tipos de projeto.

\subsection{Critérios de projeto quanto ao cobrimento das armaduras}

Uma das grandes vantagens do concreto armado em relação a outros materiais de construção é que ele pode, por natureza, e desde que bem executado, proteger o aço-carbono 
das armaduras contra a corrosão. Essa proteção baseia-se no impedimento do progresso da corrosão através de uma barreira física e de uma proteção de natureza química (HELENE, 1993).

O cobrimento das armaduras deve ter alta compacidade, teor de argamassa adequado e homogêneo, que possa gerar proteção à armadura. $\mathrm{O}$ pH da solução dos poros do concreto de cobrimento deve estar acima de 12 e sem íons cloretos, para que se possa dizer que a armadura encontra-se passivada, cumprido o papel de barreira química (MEHTA; MONTEIRO, 1994).

Vilasboas; Machado (2005) em estudo realizado na cidade de Salvador-BA avaliaram 48 obras com problemas de corrosão. Dentre essas, 27 obras ou 56,25\% apresentavam cobrimento inadequado, devido ao projeto ou à execução. Este fato indica a necessidade de cuidados com o cobrimento das armaduras e com a qualidade do concreto,

A respeito do cobrimento das armaduras, a ABNT NBR 6118 (2003) diz que, atendidas as demais condições estabelecidas, a durabilidade das estruturas é altamente dependente da espessura do concreto de cobrimento da armadura, e prescreve o indicado na Tabela 7, para os elementos estruturais, nas suas condições de projeto, definidas pelo macroclima geral e microclima específicos.

Tabela 7 - Correspondência entre a classe de agressividade ambiental e o cobrimento (ABNT NBR $6118,2003)$

\begin{tabular}{|c|c|c|c|c|c|}
\hline \multirow{3}{*}{ Tipos de Estrutura } & \multirow{3}{*}{$\begin{array}{l}\text { Componentes ou } \\
\text { elemento }\end{array}$} & \multicolumn{4}{|c|}{ Classe de agressividade ambiental } \\
\hline & & I & II & III & $\mathrm{IV}^{3}$ \\
\hline & & \multicolumn{4}{|c|}{ Cobrimento nominal ( $\mathrm{mm})$} \\
\hline \multirow{2}{*}{ Concreto Armado } & Laje $^{2}$ & 20 & 25 & 35 & 45 \\
\hline & Viga/Pilar & 25 & 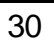 & 40 & 50 \\
\hline Concreto Protendido & Todos & 30 & 35 & 45 & 55 \\
\hline \multicolumn{6}{|c|}{$\begin{array}{l}1 \text { - Cobrimento nominal da armadura passiva que envolve a bainha ou os fios, cabos e cordoalhas, } \\
\text { sempre superior ao especificado para o elemento de concreto armado, devido aos riscos de corrosão } \\
\text { fragilizante sob tensão. } \\
2 \text { - Para a face superior de lajes e vigas que serão revestidas com argamassa de contra-piso, com } \\
\text { revestimentos finais secos tipo carpete e madeira, com argamassa de revestimento e acabamento tais } \\
\text { como pisos de elevado desempenho, pisos cerâmicos, pisos asfálticos e outros tantos, as exigências } \\
\text { desta tabela podem ser substituidas pot } 7.4 .7 .5 \text {, respeitado um cobrimento nominal } \geq 15 \mathrm{~mm} \text {. } \\
3 \text { - Nas faces inferiores de lajes e vigas de reservatórios, estações de tratamento de água e esgoto, } \\
\text { canaletas de efluentes e outras obras em ambiente químico e intensamente agressivos, a armadura } \\
\text { dever ter cobrimento nominal } \geq 45 \mathrm{~mm} \text {. }\end{array}$} \\
\hline
\end{tabular}

Fusco (2008) reforça que: "É preciso lembrar que os códigos normalizadores especificam espessuras de cobrimento com valores absolutos. Quaisquer falhas de arranjo das armaduras, 
no projeto ou na construção, podem levar a espessuras reais menores que esses mínimos absolutos, tornando-se causas eficientes de corrosão das armaduras. Por esse motivo, é prudente admitir-se que no projeto sejam especificados cobrimentos nominais com um acréscimo de 0,5 a 1,0 centímetro acima dos mínimos absolutos regulamentares".

\subsection{Requisitos e critérios de projeto quanto à especificação do concreto}

Este item, inicialmente, apresenta os critérios para especificação do concreto vigentes na ABNT NBR 6118 (2003) e que devem ser complementados por outros da ABNT NBR 12655 (2006). Ao final, estão analisados ainda certos critérios empíricos ou de normas estrangeiras, para determinadas propriedades do concreto, que poderiam ser mais empregados e testados por empresas de controle tecnológico, em serviços de dosagem ou na fase de execução das estruturas, inclusive, pois iria permitir o seu refinamento progressivo.

Segundo a ABNT NBR 6118 (2003), cabe ao profissional responsável pelo projeto estrutural:

- o registro da resistência característica do concreto, $f_{c k}$ em todos os desenhos e memórias que descrevem o projeto tecnicamente;

- a especificação, quando necessário, dos valores de $f_{c k}$ para as etapas construtivas e outros procedimentos, tais como: retirada do cimbramento, aplicação de protensão, etc.;

- a especificação dos requisitos e critérios correspondentes para a durabilidade da estrutura e propriedades específicas do concreto, tais como: consumo mínimo do cimento, relação água/cimento, módulo de deformação estático mínimo na idade da desforma e outras propriedades necessárias à estabilidade e durabilidade da estrutura, durante a fase construtiva e a sua vida útil.

Assim, os critérios de especificação do concreto para a durabilidade das estruturas devem levar em consideração aspectos como os materiais constituintes e o seu proporcionamento (agregados, cimento, relação água/cimento, aditivos e adições) e na execução, a concretagem dos elementos estruturais, pelo transporte, lançamento, adensamento e cura adequada do concreto em um dado sistema de formas, que também influi na qualidade da estrutura, entre outros itens do processo construtivo da estrutura.

\subsubsection{Resistência à compressão axial}

A resistência à compressão simples do concreto é um dos requisitos sempre especificados no projeto de estruturas de concreto armado, por razões tecnológicas diversas. 
A experiência tem demonstrado que quando o concreto é fabricado sob condições usuais e constantes, a distribuição de resultados dessa propriedade pode ser considerada normal, isto é, com distribuição de Gauss e ser descrita por dois parâmetros: a média $(\mu)$ e o desvio padrão $(\sigma)$ em torno de uma população com $n \rightarrow \infty$ valores. (HELENE; TERZIAN, 1993).

Desde 1978, por proposição da então vigente Norma Brasileira de Cálculo e Execução das Estruturas de Concreto Armado - NB 1, a resistência à compressão do concreto no projeto das estruturas deixou de ser tratada como um valor médio e determinístico $\left(\mathrm{f}_{\mathrm{cmj}}\right)$, em tese no quantil de $50 \%$ de probabilidade de ocorrência, e passou a ser indicada para um valor característico $\left(f_{c k j}\right)$, no quantil de $5 \%$ da curva de distribuição de Gauss. Portanto, um valor de resistência à compressão a ser atendido e ultrapassado por $95 \%$, do volume de concreto a ser empregado na execução da estrutura, em idade de ensaio de controle a "i" dias, em geral 28 dias.

Em Helene (1981) e Fusco (2008), podem ser encontradas as considerações estatísticas e do estado da arte que embasaram esta mudança de critério para especificação da resistência à compressão do concreto. Em Fusco (2008), por exemplo, há duas justificativas resumidas e cabe serem destacas:

- A resistência característica inferior "é quase sempre o valor que interessa à segurança das estruturas, pois o risco de danos estruturais está quase sempre associado à diminuição da resistência dos materiais";

- "O emprego do valor característico inferior, como valor de referência para a especificação das resistências dos materiais, decorre do fato de que a dispersão dos valores no entorno da média é muito maior do que no entorno do quantil de $5 \%$ ".

O valor da resistência característica do concreto $\left(f_{c k}\right)$ dá atualmente nome correspondente à sua classe de resistência, pelas siglas C15, C20, C25, C30, C35, C40, C45, C50, segundo a ABNT NBR 8953 (1992).

Assim, construtores e engenheiros, de uma maneira geral, apenas relacionam a classe de concreto para fins de segurança no projeto estrutural e muitas vezes não entendem que o $f_{c k}$ utilizado no dimensionamento da estrutura também deve ser escolhido e adotado para atender a requisitos de durabilidade das armaduras, segundo os demais itens analisados neste capítulo, além dos outros pertinentes ao dimensionamento geométrico e ao controle de fissuração das peças, que fogem ao escopo desse trabalho analisar.

Portanto, é necessário sempre lembrar que um $\mathrm{f}_{\mathrm{ck}}$ mais alto pode significar, também, uma estrutura menos deformável, menos permeável e, conseqüentemente mais durável e econômica. 
Por outro lado, não há hoje consenso no meio técnico, quanto à diferenciação da qualidade de concretos produzidos por diferentes empresas, quando equiparados por $f_{c k}$ ou no que diz respeito a outros requisitos de produção da estruturas, vistos no item 3.6, e que podem também interferir na sua qualidade potencial para a proteção de armaduras, com o que está dissertação visa colaborar.

O certo é que a composição e formulação dos concretos é cada vez mais diversificada, e a sua especificação tão somente pela resistência característica à compressão e demais requisitos empíricos da ABNT NBR 6118 (2003), a seguir analisados, pode não ser suficiente para garantir a proteção de armaduras de aço-carbono, em ambientes de exposição mais agressivos.

De fato, na execução, o controle da resistência à compressão do concreto é necessário para a comprovação daquilo que está sendo executado frente ao que foi adotado no projeto da estrutura. Não deve ser confundido com o controle tecnológico das estruturas de concreto. (HELENE; TERZIAN, 1993).

Do ponto de vista da determinação da resistência à compressão do concreto, as normas ABNT NBR 5739 (2007) determina os procedimentos de ensaio. Cabe salientar que embora seja um dos ensaios de mais fácil realização e amplamente adotado, trata-se de uma propriedade de Engenharia bastante complexa, tanto pela distribuição interna de tensões no interior do corpo-de-prova não resultar uniforme, quanto por estar ainda sujeita a considerável influência dos procedimentos de produção do concreto (qualidade e dosagem dos materiais, equipamentos de pesagem e mistura, prazo e volume de amostragem, entre outros) e dos procedimentos de ensaio (qualidade das formas, método de compactação, cura, capeamento, tolerâncias de idade, prensa de ensaio e carregamento propriamente ditos). A Tabela 8 quantifica essa influência e critérios para a sua qualificação. Em geral, a maioria dos procedimentos de ensaio, diminuem a resistência à compressão do concreto. Por esta razão, em geral, sempre a resistência à compressão para uma certa composição ou idade de ensaio é sempre determinada para um exemplar constituído de pelo menos dois corpos-de-prova, adotando-se o valor mais alto de resistência ou o médio, segundo a finalidade do ensaio. 
Tabela 8 - Influência das operações de ensaio (HELENE; TERZIAN, 1993)

\begin{tabular}{|c|c|c|c|}
\hline $\begin{array}{c}\text { Coeficiente de variação } \\
\text { real do processo de } \\
\text { produção do concreto } \\
\mathbf{v}_{\mathrm{c}, \text { real }}(\%)\end{array}$ & \multicolumn{2}{|c|}{$\begin{array}{c}\text { Coeficiente de } \\
\text { variação dos } \\
\text { procedimentos de } \\
\text { ensaio e controle } \\
v_{\mathrm{e}}(\%)\end{array}$} & \multirow[t]{2}{*}{$\begin{array}{c}\begin{array}{c}\text { Coeficiente de variação } \\
\text { total do processo de } \\
\text { produção e ensaio do } \\
\text { concreto } \mathbf{v}_{\mathrm{c}}(\%) \\
\text { Resistência }\end{array} \\
9,5\end{array}$} \\
\hline \multirow{3}{*}{$\begin{array}{l}9 \% \text { usual em usinas } \\
\text { gravimétricas }\end{array}$} & muito bom & 3,0 & \\
\hline & razoável & 5,5 & 10,5 \\
\hline & deficiente & 7,0 & 11,4 \\
\hline \multirow{3}{*}{$\begin{array}{c}12 \% \text { usual em canteiros de } \\
\text { obras bem administrados }\end{array}$} & muito bom & 3,0 & 12,4 \\
\hline & razoável & 5,5 & 13,2 \\
\hline & deficiente & 7,0 & 13,9 \\
\hline \multirow{3}{*}{$\begin{array}{l}16 \% \text { usual em canteiro de } \\
\text { obras mal administrados }\end{array}$} & muito bom & 3,0 & 16,3 \\
\hline & razoável & 5,5 & 16,9 \\
\hline & deficiente & 7,0 & 17,5 \\
\hline
\end{tabular}

\subsubsection{Relação água/cimento e consumo de cimento}

Segundo a ABNT NBR 12655 (2006) a relação água/cimento é a "relação em massa entre o conteúdo efetivo de água e o conteúdo de cimento Portland". Admite esta norma que o consumo efetivo de água é o que resulta da "diferença entre a água total presente no concreto fresco e a água absorvida pelos agregados", sendo esta uma premissa relativamente simplificada e que desconsidera as interações na interface pasta/agregados.

A relação água/cimento total de um concreto pode ser também considerada a variável mais influente na porosidade da matriz e da zona de transição, e conseqüentemente na resistência do concreto. Em geral, esta relação controla a microestrutura e propriedades do concreto endurecido. Quanto maior a relação água /cimento total de um concreto, maior será a sua porosidade e permeabilidade

Parte da água de amassamento tem como finalidade transmitir à mistura fresca uma consistência adequada para o lançamento e adensamento do concreto. Após a aplicação, parte dessa água irá se evaporar, devendo esta evaporação ser bem controlada, de forma que não ocorra com muita velocidade, causando tensões internas e, consequentemente, o surgimento de fissuras no concreto. Parte da água de amassamento deverá permanecer no concreto, com a finalidade de promover a hidratação do cimento, reação responsável pela resistência mecânica e durabilidade do concreto endurecido (NEVILLE, 1997).

Estudos de dosagem do concreto devem ponderar a durabilidade da estrutura frente ao tipo e nível de agressividade previsto em projeto, e sempre que possível confirmar os critérios 
mínimos a serem atendidos pelo concreto. Na falta destes estudos, e devido à existência de uma forte correspondência entre a relação água/cimento, a resistência à compressão do concreto e à capacidade de proteção das armaduras, permite-se adotar os critérios na Tabela 9, da ABNT NBR 6118 (2003) e da ABNT NBR 12655 (2006). Exigências complementares para ambientes de exposição específicos contendo sulfatos constam ainda na Tabela 11.

Observar que o consumo mínimo de cimento por metro cúbico de concreto é uma variável interdependente tanto da relação água/cimento quanto da resistência característica à compressão e que é determinada a partir de controle da determinação da densidade aparente do concreto fresco, segundo o item 3.6.1.4

\begin{tabular}{|c|c|c|c|c|c|}
\hline \multirow{2}{*}{ Concreto } & \multirow{2}{*}{ Tipo } & \multicolumn{4}{|c|}{ Classe de agressividade do ambiente } \\
\hline & & I & II & III & IV \\
\hline \multirow{2}{*}{$\begin{array}{c}\text { Relação água/cimento } \\
\text { em massa }\end{array}$} & $\mathrm{CA}$ & $\leq 0,65$ & $\leq 0,60$ & $\leq 0,55$ & $\leq 0,45$ \\
\hline & $\mathrm{CP}$ & $\leq 0,60$ & $\leq 0,55$ & $\leq 0,50$ & $\leq 0,45$ \\
\hline \multirow{2}{*}{$\begin{array}{c}\text { Classe do concreto } \\
\text { (ABNT) }\end{array}$} & $\mathrm{CA}$ & $\geq \mathrm{C} 20$ & $\geq \mathrm{C} 25$ & $\geq$ C30 & $\geq \mathrm{C} 40$ \\
\hline & $\mathrm{CP}$ & $\geq \mathrm{C} 25$ & $\geq \mathrm{C} 30$ & $\geq$ C35 & $\geq$ C40 \\
\hline \multirow{2}{*}{$\begin{array}{l}\text { Consumo de cimento } \\
\text { por metro cúbico de } \\
\text { concreto } \mathrm{kg} / \mathrm{m}^{3}\end{array}$} & CA & \multirow{2}{*}{$\geq 260$} & \multirow{2}{*}{$\geq 280$} & \multirow{2}{*}{$\geq 320$} & \multirow{2}{*}{$\geq 360$} \\
\hline & $\mathrm{CP}$ & & & & \\
\hline \multicolumn{6}{|c|}{ CA - Componentes e elementos estruturais de concreto armado } \\
\hline & 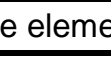 & - & on & $p$ & ido \\
\hline
\end{tabular}

\subsection{Outras propriedades e critérios de qualidade do concreto para proteção de armaduras}

Em condições desfavoráveis de macroclima e de microclima atuantes sobre elementos estruturais em um dado projeto, é recomendável a especificação de requisitos e critérios complementares para o concreto, com vistas à proteção de armaduras, conforme itens $3.5 .1 \mathrm{a}$ 3.5.8, sendo que o primeiro a seguir discutido vem sendo bastante empregado em obras especiais, com vistas ao controle da fissuração das estruturas.

\subsubsection{Módulo de elasticidade}

Para que um cálculo estrutural se aproxime da maneira mais realista do comportamento do material é de grande importância o conhecimento das propriedades da deformação do material a ser utilizado, não só a resistência à compressão, tem-se que conhecer com precisão 
o módulo de elasticidade, retração, a fluência, e outros parâmetros que expressem as condições dos estados limites de serviço (MELO NETO, 2002).

O módulo de elasticidade pode ser definido como sendo a relação entre a tensão aplicada e deformação instantânea dentro de um limite proporcional adotado (MEHTA; MONTEIRO, 2004).

"De forma simplificada, o ensaio de determinação do módulo estático de deformação do concreto se dá através da construção de uma curva "tensão-deformação especifica" com um mínimo de dois pontos. A relação das diferenças de tensão e deformação nesses dois pontos fornece o módulo de deformação" (MONTIJA, 2007). A mediação das deformações, em laboratórios brasileiros, se dá preferencialmente no terço médio central longitudinal do corpode-prova cilíndrico com altura igual ao dobro do diâmetro e por esta região ser praticamente isenta de esforços externos transversais. A leitura das deformações se dá através de medidores com sensibilidade mínima de milésimo de milímetro, fixados na citada região do corpo-de-prova. As tensões atingidas são obtidas ou calculadas a partir de plano de carga em porcentagem da tensão estimada de ruptura, aplicado pela da máquina de ensaio" (MONTIJA, 2007)

A ABNT NBR 6118 (2003) destaca que o módulo de elasticidade deve ser obtido segundo a ABNT NBR 8522 (2008), sendo considerado o módulo de deformação tangencial inicial cordal a $30 \% \mathrm{f}_{\mathrm{c}}$ ou outra tensão especificada em projeto. Quando não forem feitos os ensaios e não existiram dados mais precisos sobre o concreto usado na idade de 28 dias, pode-se estimar o valor do módulo de elasticidade usando a seguinte Equação (8):

$$
E_{c t}=5600 f_{c k}^{1 / 2} \text { (Equação 8) }
$$

Onde:

$\mathrm{E}_{\mathrm{ct}}=$ Módulo de elasticidade, em MPa;

$\mathrm{f}_{\mathrm{ck}}=$ Resistência à compressão, em MPa;

A retirada das fôrmas e do escoramento só pode ser feita quando o concreto estiver suficientemente endurecido para resistir às ações e tensões que atuarem sobre ele, sem resultarem em deformações que possam fissurar peças de modo precoce, o que pode prejudicar também a durabilidade de armaduras. Enfim, com vistas à prevenção de fissuras no concreto e exposição precoce de armaduras, se tornam importantes tanto o módulo de elasticidade quanto a evolução das resistências à tração e à compressão do concreto, nas primeiras idades, além das características do projeto de forma e plano reescoramento. 
A ABNT NBR 12655 (2006) recomenda que o profissional responsável pelo projeto estrutural especifique o módulo de deformação mínimo na idade da desforma, movimentação de elementos pré-moldados e protensão.

\subsubsection{Limites para contaminantes no concreto}

A ABNT NBR 12655 (2006) estabelece o valor máximo da concentração de íons cloreto total no concreto endurecido, considerando a contribuição de todos os seus componentes, conforme a Tabela 10.

Cabe salientar que não é permitido o uso de aditivos contendo cloretos em concretos armados, nem protendidos, pelas razões analisadas no Capítulo 2, item 2.3.3.

Tabela 10 - Teor máximo de íons cloretos para proteção das armaduras do concreto (ABNT NBR 12655, 2006)

\begin{tabular}{|c|c|}
\hline Tipo de estrutura & $\begin{array}{c}\text { Teor máximo de íons } \\
\text { cloretos no concreto \% } \\
\text { sobre a massa do cimento }\end{array}$ \\
\hline Concreto Protendido & 0,05 \\
\hline $\begin{array}{c}\text { Concreto armado exposto a } \\
\text { cloretos nas condições de } \\
\text { serviço da esrtutura }\end{array}$ & 0,15 \\
\hline $\begin{array}{c}\text { Concreto armado em } \\
\text { condições de exposiçao } \\
\text { não severa (seco ou } \\
\text { protegido de umidade nas } \\
\text { condições de serviço da } \\
\text { estrutura) }\end{array}$ & 0,40 \\
\hline $\begin{array}{c}\text { Outros tipos de construção } \\
\text { em concreto armado }\end{array}$ & 0,30 \\
\hline
\end{tabular}

A ABNT NBR 12655 (2006) também apresenta critérios orientativos para a especificação de sulfatos em água de amassamento do concreto, ou para o concreto de estruturas expostas a ambientes contendo esse íon, quais sejam basicamente a água do mar ou águas e solos contaminados, conforme a Tabela 11. Observar que na condição de exposição classificada como severa, é obrigatória também a especificação de cimento resistente a sulfatos. A ABNT NBR 12655 (2006) também apresenta os limites para sulfatos para concretos exposto a soluções contendo esse íon. 
Tabela 11 - Requisitos para concreto exposto a solução contendo sulfatos (ABNT NBR 12655, 2006)

\begin{tabular}{|c|c|c|c|c|}
\hline $\begin{array}{l}\text { Condições de } \\
\text { exposição em } \\
\text { função da } \\
\text { agressividade }\end{array}$ & $\begin{array}{c}\text { Sultafos } \\
\text { solúveis em } \\
\text { água }\left(\mathrm{SO}_{4}\right) \\
\text { presente no } \\
\text { solo \% em } \\
\text { massa }\end{array}$ & $\begin{array}{c}\text { Sultafos } \\
\text { solúvel }\left(\mathrm{SO}_{4}\right) \\
\text { presente na } \\
\text { água ppm }\end{array}$ & $\begin{array}{c}\text { Máxima relação } \\
\text { água/cimento, em } \\
\text { massa, para } \\
\text { concreto com } \\
\text { agregado normal* }\end{array}$ & $\begin{array}{c}\text { Mínimo } \mathbf{f}_{\mathrm{ck}} \\
\text { (para } \\
\text { concreto com } \\
\text { agregado } \\
\text { normal ou } \\
\text { leve) MPa }\end{array}$ \\
\hline Fraca & 0,00 a 0,10 & & - & - \\
\hline Moderada** & 0,10 a 0,20 & 150 a 1500 & 0,50 & 3 \\
\hline Severa*** & Acima de 0,20 & Acima de 1500 & 0,45 & 40 \\
\hline \multicolumn{5}{|c|}{$\begin{array}{l}\text { * Baixa relação água/cimento ou elevada resistência podem ser necessárias para } \\
\text { obtenção de baixa permeabilidade do concreto ou proteção contra a corrosão de } \\
\text { armadura ou proteção a processos de congelamento e degelo; } \\
\qquad * * \text { Água do mar; } \\
\text { *** Para condições de agressividade, devem ser obrigatoriamente usados cimentos } \\
\text { resistentes a sulfatos. }\end{array}$} \\
\hline
\end{tabular}

\subsubsection{Tipo de cimento e teor de adições}

A escolha do tipo de cimento a ser aplicado para a produção do concreto deve levar em consideração o ambiente onde será construída esta estrutura. Mas, a ABNT NBR 6118 (2003) não traz em seus itens sobre durabilidade das estruturas, nenhuma recomendação ou critérios referentes ao tipo de cimento a ser utilizado nas construções, em função da agressividade ambiental. Entretanto, segundo prescrições de Helene (1998), na Tabela 12, deveria haver orientação para o tipo e a quantidade de adições, e estas sempre cabe serem confirmadas em estudos específicos de dosagem. 
Tabela 12 - Classificação dos concretos frente ao risco de mecanismos que levam à corrosão das armaduras por carbonatação, cloretos, lixiviação, formação de compostos expansivos (HELENE, 1998).

\begin{tabular}{|c|c|c|c|c|c|c|c|}
\hline \multirow{2}{*}{$\begin{array}{l}\text { Classe do } \\
\text { concreto }\end{array}$} & \multirow{2}{*}{$\begin{array}{l}\text { Classe de } \\
\text { resistência }\end{array}$} & \multirow{2}{*}{$\begin{array}{l}\text { Máxima } \\
\text { relação a/c } \\
(\mathbf{k g} / \mathbf{k g})\end{array}$} & \multicolumn{2}{|c|}{$\begin{array}{c}\text { Teor de adições (deterioração } \\
\text { preponderante) }\end{array}$} & \multirow{2}{*}{$\frac{\mid \begin{array}{c}\text { Teor de } \mathrm{C}_{3} \mathrm{~A} \text { no } \\
\text { cimento anidro }\end{array}}{\text { Expansão po }}$} & \multirow{2}{*}{$\begin{array}{l}\text { Teor de } \\
\text { adições }\end{array}$} & \multirow{2}{*}{$\begin{array}{c}\begin{array}{c}\text { Teor de } \\
\text { adições }\end{array} \\
\text { Lixiviação }\end{array}$} \\
\hline & & & Carbonatação & Cloretos & & & \\
\hline Durável & $\geq$ C50 & $\leq 0,38$ & $\begin{array}{c}\quad \leq 10 \% \text { de } \\
\text { pozolana, sílica } \\
\text { ativa ou escória } \\
\text { de alto forno }\end{array}$ & $\begin{array}{c}\geq 20 \% \text { de } \\
\text { pozolana ou } \\
\text { sílica ativa; } \\
\geq 65 \% \text { de } \\
\text { escória }\end{array}$ & $\leq 5 \%$ & \begin{tabular}{c|}
$\geq 20 \%$ de \\
pozolana ou \\
sílica ativa; \\
$\geq 65 \%$ de \\
escória
\end{tabular} & $\begin{array}{c}\geq 20 \% \text { de } \\
\text { pozolana ou } \\
\text { sílica ativa; } \\
\geq 65 \% \text { de } \\
\text { escória }\end{array}$ \\
\hline \multirow{3}{*}{ Resistente } & C35 & \multirow{3}{*}{$\leq 0,50$} & \multirow{3}{*}{$\begin{array}{c}\leq 10 \% \text { de } \\
\text { pozolana, sílica } \\
\text { ativa } ; \\
\leq 15 \% \text { de escória }\end{array}$} & \multirow{3}{*}{$\begin{array}{c}\geq 10 \% \text { de } \\
\text { pozolana ou } \\
\text { sílica ativa; } \\
\geq 35 \% \text { de } \\
\text { escória }\end{array}$} & \multirow{3}{*}{$\leq 5 \%$} & \multirow{3}{*}{$\begin{array}{c}\leq 10 \% \text { de } \\
\text { pozolana, } \\
\text { sílica ativa; } \\
\leq 15 \% \text { de } \\
\text { escória }\end{array}$} & \multirow{3}{*}{$\begin{array}{c}\geq 10 \% \text { de } \\
\text { pozolana ou } \\
\text { sílica ativa; } \\
\geq 35 \% \text { de } \\
\text { escória de alto } \\
\text { forno }\end{array}$} \\
\hline & $\mathrm{C} 40$ & & & & & & \\
\hline & C45 & & & & & & \\
\hline \multirow{2}{*}{ Normal } & $\mathrm{C} 25$ & \multirow{2}{*}{$\leq 0,62$} & \multirow{2}{*}{ qualquer } & \multirow{2}{*}{ qualquer } & \multirow{2}{*}{$\leq 8 \%$} & \multirow{2}{*}{ qualquer } & \multirow{2}{*}{ qualquer } \\
\hline & C30 & & & & & & \\
\hline Efêmero & $\mathrm{C} 10$ & qualquer & qualquer & qualquer & qualquer & qualquer & qualquer \\
\hline
\end{tabular}

\subsubsection{Dimensão máxima característica dos agregados}

Os agregados do concreto podem ser divididos em graúdos e miúdos, conforme sua composição granulométrica. A composição granulométrica é feita por métodos normalizados e informa sobre a distribuição do tamanho de partículas de um agregado, podendo ser resumida por curvas em função das peneiras usadas no ensaio, ou por propriedades calculadas a partir dessa análise, tais como a dimensão máxima característica e o módulo de finura.

A dimensão máxima característica de um agregado é representada pela abertura de peneira onde fica retida acumulada uma porcentagem em massa de agregado igual ou imediatamente inferior a $5 \%$.

"É preciso salientar que, para se obter um concreto mais resistente, a compacidade da mistura deve ser aumentada. Para isso, é preciso aumentar a quantidade de diâmetros menores. No caso particular de altíssima resistência, é necessário empregar praticamente apenas a brita 0" (FUSCO, 2008). O diâmetro característico do agregado graúdo condiciona o espaçamento das barras da armadura e é condicionado pelas espessuras das peças estruturais a serem construídas.

Por outro lado, o espaçamento das barras de armaduras e as espessuras das peças estruturais no projeto condicionam a dimensão máxima característica do agregado graúdo no concreto. De acordo com a ABNT NBR 6118 (2003), nas vigas, o espaço livre entre as barras 
da armadura, nas camadas horizontais, deve ser maior que 1,2 vezes a dimensão máxima característica do agregado e, no plano vertical, maior que 0,5 vezes aquele valor.

\subsubsection{Trabalhabilidade do concreto fresco}

Todas as pesquisas na área de durabilidade das estruturas de concreto armado são enfáticas na importância da espessura e compacidade do concreto de cobrimento das armaduras de aço-carbono.

Mas, a compacidade do concreto de cobrimento de armaduras é apenas indiretamente controlada pelos requisitos e critérios empíricos adotados na fase de projeto, discutidos no item 3.4, dado que o mecanismo de transporte de água, de oxigênio e outros agentes agressivos à durabilidade das armaduras é controlado pela interconexão efetiva de poros e microfissuras no concreto a partir do seu estado fresco, e ainda por fissuras com origem na fase de execução ou de serviço das estruturas.

Por outro lado, é muito grande o avanço na caracterização do concreto no estado fresco, em especial no seu comportamento reológico e de outras propriedades relacionadas, usualmente reunidas pelo termo trabalhabilidade e que tem importância fundamental na compacidade e resistência do concreto estrutural.

Portanto, é na caracterização do concreto fresco que reside um dos principais paradigmas do controle tecnológico atual do concreto, tanto porque continua sem informar sobre o cumprimento dos requisitos e critérios que passaram a ser adotados em projetos como importantes para a durabilidade das armaduras, como o atendimento à relação água/cimento e consumo de cimento, e sem controle mais efetivo sobre a compacidade do concreto de cobrimento das armaduras, que poderia ser controlada pela compactabilidade e manutenção de trabalhabilidade do concreto fresco.

No item 3.6.1, são descritos os ensaios de caracterização do concreto fresco que podem auxiliar na evolução dos serviços de controle de produção ou de recebimento deste material em obras, vários dos quais foram testados no âmbito do programa experimental desta pesquisa. 


\subsubsection{Critérios de absorção de água e porosidade}

Helene (1993) propôs uma classificação dos concretos em função da absorção de água e porosidade, de acordo com a Tabela 13, complementada por relações empíricas com $\mathrm{f}_{\mathrm{ck}}$.

Tabela 13 - Classificação dos concretos em função da porosidade e absorção de água (HELENE, 1993)

\begin{tabular}{|c|c|c|c|}
\hline $\begin{array}{c}\text { Concreto } \\
\text { Armado }\end{array}$ & Porosidade & $\begin{array}{c}\text { Absorção de água por } \\
\text { imersão }\end{array}$ & $\begin{array}{c}\text { Resistência } \\
\text { Característica }\end{array}$ \\
\hline Durável & $\leq 10 \%$ & $<4,2 \%$ & $\mathrm{f}_{\mathrm{ck}}>35 \mathrm{MPa}$ \\
\hline Normal & entre 10 e $15 \%$ & entre 4,2 e $6,3 \%$ & $20 \leq \mathrm{f}_{\mathrm{ck}}<35 \mathrm{MPa}$ \\
\hline Deficiente & $\geq 15 \%$ & $>6,3 \%$ & $\mathrm{fck}<20 \mathrm{MPa}$ \\
\hline
\end{tabular}

As classificações físicas propostas por HELENE (1993) foram ignoradas pela ABNT NBR 6118 (2003) e ABNT NBR 12655 (2006) como critérios de durabilidade, especificação e aceitação de concretos estruturais, o que pode ser uma omissão, já que a porosidade e a absorção de água são propriedades de grande importância para a durabilidade das estruturas, pois podem regular melhor as características do concreto que interferem no ingresso de agentes agressivos, do que propriamente a resistência característica à compressão $\left(f_{c k}\right)$.

Isto pode ser demonstrado por Medeiros; Helene (2003) que estudaram a penetração de cloretos em concretos avaliando os parâmetros de dosagem e concluíram uma influência direta da porosidade na penetração de cloretos, conforme a Figura 21 Meira et al.(2007) chegaram a conclusões semelhantes.

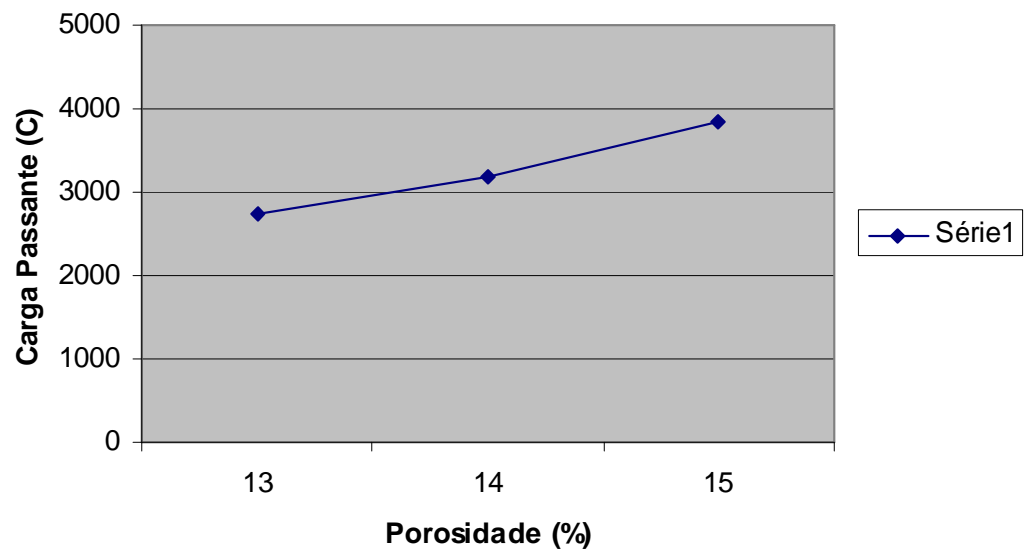

Figura 21 - Carga passante (C) de cloretos versus porosidade de concretos estruturais (MEDEIROS; HELENE, 2003) 
Cabe destacar que o CEB - Commite Euro-Internacional du Beton, em documento de 1989 segundo CASCUDO (1991), também propôs classificar a qualidade de concretos em função da absorção de água, conforme a Tabela 14, mas por critérios mais rigorosos do que Helene (1993), sendo interessante pesquisar se tiveram definição ou não a partir das condições climáticas do clima europeu.

Tabela 14 - Critérios de avaliação do concreto em função da absorção de água - CEB, 1989 (CASCUDO, 1991)

\begin{tabular}{|c|c|c|}
\hline $\begin{array}{c}\text { Absorção de } \\
\text { água (\%) }\end{array}$ & $\begin{array}{c}\text { Classe de } \\
\text { absorção de } \\
\text { água }\end{array}$ & $\begin{array}{c}\text { Qualidade } \\
\text { do concreto }\end{array}$ \\
\hline$<3,0$ & baixa & boa \\
\hline $3,0-5,0$ & média & média \\
\hline$>5,0$ & alta & pobre \\
\hline
\end{tabular}

\subsubsection{Resistência ao ingresso de íons cloreto por carga passante pela ASTM C 1202:1994}

A Tabela 15 apresenta os critérios para a classificação dos concretos com base na resistência a íons cloretos, por carga passante em ensaio de migração da norma ASTM C 1202 (1994), atualmente já disponível em versão mais recente, do ano de 2008.

Tabela 15 - Qualidade dos concretos com base na carga passante (ASTM C - 1202, 1994)

\begin{tabular}{|c|c|}
\hline Carga Passante (C) & Risco de Penetração dos íons cloretos \\
\hline$>4000$ & Alto \\
\hline $2000-4000$ & Moderado \\
\hline $1000-2000$ & Baixo \\
\hline $100-1000$ & Muito Baixo \\
\hline$<100$ & Desprezível \\
\hline
\end{tabular}

Medeiros; Helene (2003) encontraram que essa classificação da ASTM C 1202 (1994) não se mostrou adequada para diferenciar os concretos estudados, pois as faixas de classificação desta norma são muito amplas, atribuindo a mesma classificação para concretos com relação água/cimento muito distintas, como pode ser visto na Tabela 16 e no item 2.3.3.3. 
Tabela 16 - Dados dos concretos estudados relativos à resistência à penetração de cloreto de acordo com a ASTM C-1202 (1994) (MEDEIROS; HELENE, 2003)

\begin{tabular}{|c|c|c|c|c|}
\hline \multicolumn{3}{|c|}{ Concreto } & Carga passante & $\begin{array}{c}\text { Risco de penetração de íons } \\
\text { (Cloretos }\end{array}$ \\
\hline $\mathbf{1 : m}$ & Relação a/c & Abatimento & Moderada \\
\hline $1: 4.0$ & 0,53 & $90 \pm 10 \mathrm{~mm}$ & 2732 & Moderada \\
\hline $1: 5.0$ & 0,64 & $90 \pm 10 \mathrm{~mm}$ & 3188 & Moderada \\
\hline $1: 6.0$ & 0,74 & $90 \pm 10 \mathrm{~mm}$ & 3828 & Moderada \\
\hline $1: 4.0$ & 0,64 & $220 \mathrm{~mm}$ & 3438 & Moderada \\
\hline $1: 6.0$ & 0,64 & $60 \mathrm{~mm}$ & 2870 & \\
\hline
\end{tabular}

Existem vários métodos que podem indicar a resistência física do concreto em relação ao ingresso de íons cloreto. Por exemplo, o ensaio de migração de cloretos, que é um ensaio de penetração acelerada de cloretos, normalizado pela ASTM C 1202 (2008). Muitos pesquisadores têm estudado e difundido o uso desse método no Brasil, como PEREIRA (2001). Pesquisas recentes de evolução na metodologia do ensaio estão sendo discutidas em MEDEIROS (2007).

\subsubsection{Proteção às armaduras através do potencial de corrosão pela ASTM C 876 (2009)}

As medidas eletroquímicas constituem uma das ferramentas utilizadas para estudar a corrosão de metais, sendo muito adotada para acompanhar a evolução da corrosão de armaduras de aço durante ensaios de desempenho de concreto (ARAÚJO, 2004).

O potencial de corrosão das armaduras imersas no concreto é uma medida estabelecida com base na Eletroquímica e que pode ser usada para informar sobre a situação de corrosão ou passivação do aço-carbono no concreto, a partir de leituras comparativas a um eletrodo de referência.

O eletrodo de referência pode ser de prata/cloreto de prata (EPCP), cobre/sulfato de cobre (ECSC) ou calomelano saturado (ECS), o eletrodo de cobre/sulfato de cobre não deve ser usado para concreto, o de calomelano deve ser preferido. Devido o eletrodo de cobre/sulfato de cobre conter uma solução ácida que pode penetrar nos poros do concreto, estimulando o processo corrosivo. Entretanto, o de cobre é o eletrodo descrito e recomendado pela ASTM C 876 (2009) e é o mais utilizado desde Cascudo (1997). A seguir são apresentadas as fórmulas de conversão.

$$
\begin{aligned}
& \mathrm{E}_{\text {cal }}=\mathrm{E}_{\mathrm{H}}-241 \\
& \mathrm{E}_{\text {cal }}=\mathrm{E}_{\text {cobre }}+59
\end{aligned}
$$




$$
\begin{aligned}
& E_{\text {cobre }}=E_{H}-300 \\
& E_{\text {cobre }}=E_{c a l}-59 \\
& E_{H}=E_{c a l}+241 \\
& E_{H}=E_{\text {cobre }}+300
\end{aligned}
$$

A Tabela 17 apresenta a faixa de potencial que indica os riscos de corrosão de acordo com a ASTM C 876 (2009) - Standard Test Method for Corrosion Potencial of Uncoated Reinforcing Steel in Concrete.

Tabela 17 - Critérios de avaliação do risco de corrosão da ASTM C 876 (1999). Mantidos na ASTM C 876 (2009). Traduções e cálculos transcritos de Araújo (2004)

\begin{tabular}{|c|c|c|}
\hline $\begin{array}{c}\text { Valores de potenciais em } \\
\text { relação ao eletrodo } \\
\text { calomelano saturado }\end{array}$ & $\begin{array}{c}\text { Valores de potenciais em } \\
\text { relação ao eletrodo } \\
\text { cobre/sulfato de cobre }\end{array}$ & $\begin{array}{c}\text { Risco de ocorrência da } \\
\text { corrosão de armadura }\end{array}$ \\
\hline Valores positivos & Valores positivos & $\begin{array}{c}\text { Falta de umidificação ou a } \\
\text { resistência elétrica é muito } \\
\text { elevada. Desprezar tais valores }\end{array}$ \\
\hline Entre 0 e -114 mV & Entre 0 e -200 mV & $\begin{array}{c}90 \% \text { de probabilidade de não } \\
\text { estar ocorrendo corrosão de } \\
\text { armaduras }\end{array}$ \\
\hline Entre -141 mV e -291 mV & Entre -200 mV e -350 mV & $\begin{array}{c}\text { A ocorrência de corrosão é } \\
\text { incerta }\end{array}$ \\
\hline Mais negativos que -291 mV & Mais negativos que -350 mV & $\begin{array}{c}90 \% \text { de probabilidade de estar } \\
\text { ocorrendo corrosão de } \\
\text { armaduras }\end{array}$ \\
\hline
\end{tabular}

A utilização de aditivos inibidores de corrosão vem crescendo gradativamente, principalmente após década de 90 , onde houve uma intensificação do uso de adições e aditivos no preparo do concreto com a finalidade de aumentar a durabilidade das estruturas (BOLINA et.al., 2009). Essas substâncias podem ser aditivadas ao concreto, aplicados sobre as armaduras durante o processo de construção ou impregnados sobre a superfície do concreto.

Os aditivos inibidores de corrosão são muito empregados como método preventivo, pois não exigem mão-de-obra especializada e possuem baixo custo em relação a outras soluções. O inibidor de corrosão é adicionado à água de amassamento, controlando-se a sua homogeneidade da mistura e a dosagem segundo ARAUJO (2004).

A norma ASTM G 109 (2007) normaliza um procedimento de ensaio para determinação dos efeitos dos aditivos inibidores de corrosão. Este procedimento de ensaio fornece um meio 
confiável e comparativo para prever as propriedades dos inibidores de corrosão para ser usado no concreto. Todavia a técnica se baseia em medidas de diferencial de potencial de corrosão entre armaduras do concreto e muito pouco se sabe ainda quanto à real confiabilidade dessas medidas de potencial de corrosão em condições de campo, sendo isto tema de teses recentes, como a de BASTOS (2005).

Como se vê, é importante a continuação de pesquisas para avaliar a estabilidade eletroquímica de armaduras, tanto em laboratório quanto em condições mais próximas as que se verificam em obras, e o potencial de corrosão ainda é uma das mais empregadas.

Por conseguinte, é importante a continuidade de pesquisas para avaliar a estabilidade de medidas de potencial de corrosão potencial de corrosão de armaduras do concreto, seja em condições de campo ou de laboratório, pois poucos trabalhos se dedicaram às medidas de variabilidade desta propriedade, após Cascudo (1991).

\subsection{Etapas e exigências quanto à produção do concreto estrutural}

A produção do concreto é um dos itens para a execução da estrutura e envolve as seguintes etapas: preparo, transporte, lançamento, adensamento e cura.

Para o concreto destinado às estruturas são previstas na ABNT NBR 12655 (2006), duas modalidades diferentes de preparo:

- Concreto preparado pelo executante da obra;

- Concreto preparado por empresa de serviço de concretagem.

Ao profissional responsável pela execução da obra de concreto cabem as seguintes responsabilidades, segundo a ABNT NBR 12655 (2006):

- escolha da modalidade de preparo do concreto;

- escolha do tipo de concreto a ser empregado e sua consistência, dimensão máxima do agregado e demais propriedades, de acordo com o projeto e com as condições de aplicação;

- atendimento a todos os requisitos de projeto, inclusive quanto à escolha dos materiais a serem empregados;

- aceitação do concreto;

- cuidados requeridos pelo processo construtivo e pela retirada do escoramento, levando em consideração as peculiaridades dos materiais (em particular do cimento) e as condições de temperatura do ambiente;

- verificação do atendimento a todos os requisitos desta Norma. 
Para concretos produzidos em centrais dosadoras, o atendimento às recomendações relativas à caracterização dos materiais e dosagem do concreto, aqui apresentadas no item 3.6.2, são da empresa fornecedora desse serviço. Na prática, essas empresas também escolhem os materiais constituintes do concreto, salvo especificações expressas.

As principais normas que regem a produção de concretos estruturais são a ABNT NBR 12655 (2006) - Concreto de cimento Portland - Preparo, controle e recebimento Procedimentos, ABNT NBR 12654 (1992) - Controle Tecnológico de Materiais Componentes do Concreto e a ABNT NBR 14931 (2003) - Execução de Estruturas de Concreto Procedimento e ABNT NBR 7212 (1984) - Execução de concreto dosado em central.

"O programa de controle de tecnologia deve ser elaborado em função do grau de responsabilidade da estrutura, das condições agressivas existentes no local da obra, do conhecimento prévio das características dos materiais disponíveis para a execução das obras e outras condições estabelecidas pelos responsáveis por este controle" (ABNT NBR 12654, 1992).

\subsubsection{Definição das propriedades de controle da trabalhabilidade}

A ASTM C 125 (2009) - Standard Terminology Relating to Concrete and Concete Aggregate define trabalhabilidade como a energia necessária para manipular o concreto fresco sem perda considerável da homogeneidade.

Já o ACl 116R (1990) - Cement and Concrete Terminology; descreve trabalhabilidade como a facilidade e homogeneidade com que o concreto fresco pode ser manipulado desde a mistura até o acabamento.

$\mathrm{O}$ conceito do $\mathrm{ACl}$ parece mais abrangente e adequado ao complexo de operações efetivas na concretagem de uma estrutura, pois envolve a importante variável do tempo transcorrido desde a mistura até o acabamento da peças, em que deve ser mantida inclusive a compactabilidade do concreto fresco.

Assim, a trabalhabilidade do concreto deve ser estabelecida em função da geometria da peça estrutural, do tipo de forma, da taxa de armadura, dos equipamentos de mistura, de transporte, de lançamento e de adensamento. O concreto deve apresentar tixotropia e coesão durante a execução das peças estruturais. A tixotropia é a facilidade de mobilidade por ação dos equipamentos de lançamento e adensamento e a coesão é a resistência à exsudação e à segregação.

As variáveis que alteram a trabalhabilidade do concreto fresco são a priori aquelas que causam mudanças na sua consistências, plasticidade, coesão, compactabilidade e tixotropia, 
várias estudadas pelo seu comportamento reológico. São elas: qualidade e proporcionamento do cimento, dos agregados, aditivos e adições; relação água/cimento, relação água/materiais secos, entre outras. Sãos variáveis de dosagem que só podem ser controladas por pesagem em massa dos materiais.

Já outras propriedades do concreto fresco, como teor de ar, massa específica e exsudação, são decorrentes das variáveis de dosagem citadas e usualmente avaliadas apenas em estudos de dosagem. Mas, em tese deveriam passar a ser propriedades medidas de forma rotineira em controle tecnológico de produção ou de recebimento de concretos, inclusive, por terem relação direta com variações no consumo de cimento e compacidade do cobrimento de armaduras.

\subsubsection{Consistência pelo abatimento do tronco-de-cone}

O ensaio mais usado para controle tecnológico da trabalhabilidade do concreto é o de abatimento de tronco de cone e a ABNT NM NBR 67 (1998) normaliza esse ensaio no Brasil.

No centro de uma base metálica, posiciona-se um molde também metálico de um tronco de cone proposto por Abrams, com 300 mm de altura, base com 200 mm de diâmetro e topo com $100 \mathrm{~mm}$ de diâmetro. Mantém-se o molde firme à base metálica, colocando-se os pés sobre as alças fixas junto à base do tronco de cone, para ser preenchido com três camadas de concreto, adensando cada camada 25 vezes com uma barra de aço carbono com $16 \mathrm{~mm}$ de diâmetro. Após o adensamento, remove-se o excesso de concreto. Mantem-se firme o molde sobre a base, pela colocação das mãos sobre as alças fixas, enquanto os pés são retirados das alças inferiores. A seguir o molde é erguido, em prazo de $10 \mathrm{~s}$, deixando o concreto fresco sob a ação da sua coesão e consistência interna e que podem ser suficiente para:

a) manter a forma original do molde (consistência seca ou elevada), ou

b) abater o concreto fresco de modo uniforme (consistência plástica ou fluida) ou

c) desagregar o concreto de modo heterogêneo, por falta de coesão, consistência e plasticidade.

Após ser retirado, o molde é colocado como o topo apoiado na base metálica ao lado do concreto e, com o auxílio de uma régua de aço e de outra escala posicionada diretamente sobre o concreto, mede-se o abatimento do tronco de cone no seu centro, como pode ser visto na Figura 22. 

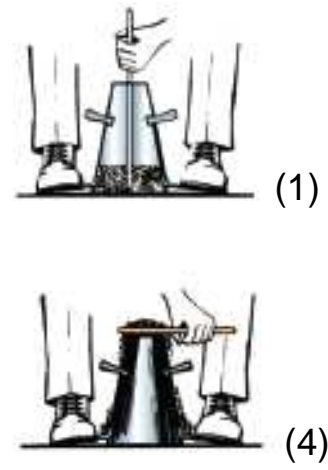

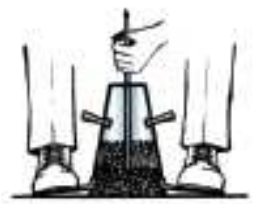

$(2)$

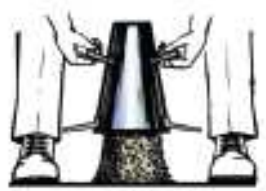

(5)

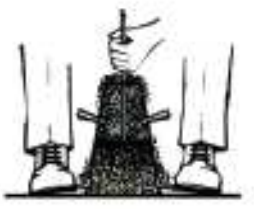

(3)

Figura 22 - Sequência de passos para a realização do ensaio de abatimento do tronco de cone para concretos de consistência plástica (MEHTA; MONTEIRO, 2008)

A Tabela 18 apresentada por HELENE; TERZIAN (1993) apresenta a classificação dos abatimentos em função da consistência e as tolerâncias dos abatimentos.

Tabela 18 - Classificação dos concretos quanto ao abatimento (HELENE;TERZIAN, 1993)

\begin{tabular}{|c|c|c|}
\hline Consistência & Abatimento $(\mathbf{m m})$ & Tolerâncias $(\mathbf{m m})$ \\
\hline seca & 0 a 20 & \pm 5 \\
\hline mediamente plástica & 30 a 50 & \pm 10 \\
\hline plástica & 60 a 90 & \pm 10 \\
\hline fluida & 100 a 150 & \pm 20 \\
\hline líquida & $\geq 160$ & \pm 30 \\
\hline
\end{tabular}

A ABNT NBR NM 67 (1998) faz apenas um comentário sobre a tolerância do abatimento em função da consistência, pelo seguinte: "O método é aplicado aos concretos plásticos e coesivos que apresentem um assentamento igual ou superior a $10 \mathrm{~mm}$, como resultado do ensaio realizado de acordo com esta norma. O método não se aplica a concretos cujo agregado graúdo apresente dimensão nominal máxima superior a 37,7 mm".

Importante avaliação complementar com respeito ao abatimento é verificar o tempo de manutenção dessa propriedade em função do prazo de mistura do concreto.

Todavia, o abatimento do tronco-de-cone não é uma medida apropriada para controlar a consistência de concretos nas faixas extremas da Tabela 18, ou seja, para consistências seca ou fluida. Para essas faixas de consistência existem vários ensaios normalizados e recomendase obter detalhes em Mehta; Monteiro (2008), entre outros livros clássicos. 


\subsubsection{Teor de ar pelo método pressométrico}

De acordo com Metha; Monteiro (2008) pode-se encontrar ar dentro do concreto fresco, por duas formas de ocorrência: através de vazios de ar aprisionado por efeito da formulação e mistura do concreto e ar incorporado intencionalmente pelo uso de aditivos para este fim ou por efeito colateral de certos aditivos. As bolhas de ar incorporado possuem dimensões entre 50 $\mu \mathrm{m}$ e $200 \mu \mathrm{m}$ e devem ser estáveis, enquanto os vazios de ar aprisionado são maiores, em geral podendo chegar a $3 \mathrm{~mm}$.

O controle do teor de ar do concreto fresco deveria ser tido como rotineiro ao controle da qualidade desse material, pois poderia auxiliar em informações sobre as variações das suas demais propriedades físicas e mecânicas. Além do mais, o ar no concreto fresco representa em geral a maior fração de sua porosidade total, dadas as suas dimensões em comparação aos demais tipos de poros presentes na pasta de cimento ou mesmo na zona de transição pasta/agregado.

Mas, no levantamento do estado da arte para esta dissertação, observou-se que não há experimentos em condições reais de campo com foco em medidas do teor de ar do concreto fresco, que justifiquem ou motivem as empresas produtoras de concreto ou as prestadoras de controle tecnológico de concreto, adotá-lo como ensaio de rotina.

No Brasil a ABNT NBR NM 47 (2002) é o ensaio mais utilizado em laboratórios para a obtenção do teor de ar incorporado e/ou aprisionado no concreto, em estudos de dosagem ou pela qualificação e ajustes de aditivos.

$\mathrm{Na}$ Figura 23 apresenta-se o principal equipamento preconizado por essa norma da medida de teor de ar no concreto, o qual consiste de um recipiente cilíndrico, que é preenchido com concreto em três camadas, aplicando 30 golpes em cada uma com haste lisa com $16 \mathrm{~mm}$ de diâmetro e maior ou igual a $400 \mathrm{~mm}$, com extremidades semiesféricas de diâmetro igual ao da haste. Após cada camada a ser adensada, emprega-se um martelo de borracha, para bater a parede externa do recipiente, 10 a 15 vezes, fechando os vazios deixados pela haste e eliminando as bolhas de ar. Ao finalizar o adensamento, a superfície do concreto é uniformizada pelos golpes do martelo e então rasada pelo deslizando uma régua rígida, larga e com no mínimo $3 \mathrm{~mm}$ de espessura, apoiada sobre a borda do recipiente de medida, com movimentos de vai-e-vem, até que o recipiente fique cheio exatamente nesse nível. Após esta operação, a face externa do recipiente é limpa cuidadosamente com um pano úmido, para que uma tampa superior possa ser acoplada e fechar o equipamento de modo hermético. $\mathrm{Na}$ tampa, é então fechada uma válvula de ar principal e são abertas outras duas que se encontram conectadas ao recipiente com o concreto. Usando-se uma seringa, é injetada água 
através de uma dessas duas válvulas, até que o recipiente fique completo em seu volume com a água e esta saia através da outra válvula oposta. Sacudir o equipamento suavemente até que todo o ar acima da superfície da amostra de concreto seja expulso através da chave. Fechar a válvula de sangramento de ar e bombear ar para a câmara superior principal da tampa, até que o manômetro esteja na linha de pressão inicial. Fechar as válvulas por onde foi completado o volume do recipiente com água, que se encontra na tampa e abrir a válvula de ar principal. Bater ligeiramente no manômetro para estabilizar a perda de pressão e ler a porcentagem de ar equivalente na escala.

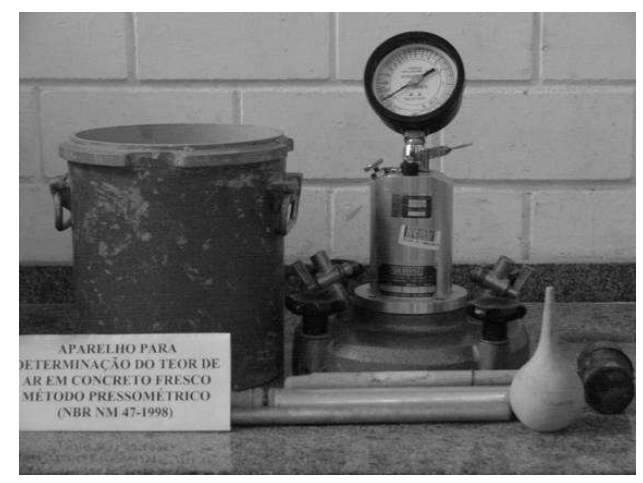

Figura 23 - Equipamento de medição do teor de ar. Ilustração do Departamento de Engenharia da Construção Civil da Escola Politécnica da USP.

\subsubsection{Massa específica, rendimento e teor de ar por método gravimétrico}

Estas propriedades são medidas pela ABNT NBR 9833 (2008). Para realização do ensaio é necessário um recipiente cilíndrico, dimensões conforme a Tabela 19, balança calibrada, concha metálica, martelo de borracha, haste de socamento de aço carbono, lisa, com diâmetro de $16 \mathrm{~mm}$ e comprimento entre 600 e $800 \mathrm{~mm}$ e régua metálica com espessura de $5 \mathrm{~mm}$, com bordas retas, largura de $50 \mathrm{~mm}$ e comprimento de pelo menos $100 \mathrm{~mm}$ maior que o diâmetro do recipiente. 
Tabela 19 - Medidas dos recipientes (ABNT NBR 9833, 2008)

\begin{tabular}{|c|c|c|c|}
\hline $\begin{array}{c}\text { Dimensão } \\
\text { máxima } \\
\text { característica do } \\
\text { agregado "d" } \\
(\mathbf{m m})\end{array}$ & $\begin{array}{c}\text { Capacidade } \\
\text { mínima dos } \\
\text { recipientes } \\
\left(\mathbf{d m}^{\mathbf{3}}\right)\end{array}$ & $\begin{array}{c}\text { Diâmetro } \\
\text { interno dos } \\
\text { recipientes } \\
(\mathbf{m m})\end{array}$ & $\begin{array}{c}\text { Altura } \\
\text { interna dos } \\
\text { recipientes } \\
(\mathbf{m m})\end{array}$ \\
\hline $\mathrm{d} \leq 38$ & 7,5 & 200 & 240 \\
\hline $38<\mathrm{d} \leq 50$ & 15 & 260 & 283 \\
\hline $50<\mathrm{d} \leq 75$ & 30 & 360 & 295 \\
\hline $75<\mathrm{d} \leq 152$ & 90 & 450 & 566 \\
\hline
\end{tabular}

O concreto deve ser colocado no recipiente em camadas, 3 camadas iguais, aplicando 25 golpes em cada uma, com a haste de aço carbono, tal que a haste não penetre mais do que 25 $\mathrm{mm}$ na camada anteriormente adensada. Golpear suavemente com o martelo de borracha várias vezes as paredes externas do recipiente, na altura correspondente a cada camada adensada, até que não observem, na superfície do concreto, marcas deixadas pela haste de adensamento. Após adensamento, rasar a superfície com a régua metálica em movimentos de vai-e-vem. Terminado o rasamento, limpar a superfície externa do recipiente e determinar a sua massa, com precisão de $50 \mathrm{~g}$ (ABNT NBR 9833, 2008).

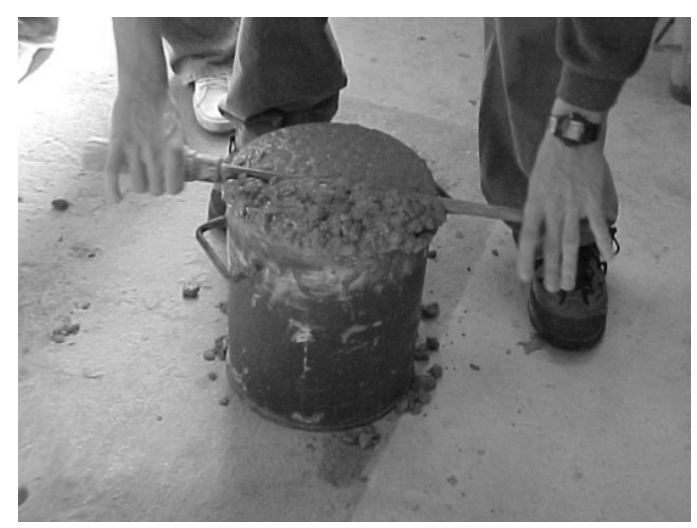

Figura 24 - Ensaio de massa específica pelo método gravimétrico. llustração do Departamento de Engenharia de Construção Civil da Escola Politécnica da USP

A massa específica ou densidade aparente do concreto fresco é obtida a partir da Equação (9) abaixo.

Onde:

$$
Y_{c f}=\left(m-m_{r} / v_{r}\right) \quad(\text { Equação } 9)
$$

$Y_{c f}=$ massa específica aparente do concreto fresco, em $\mathrm{kg} / \mathrm{m}^{3}$; 
$\mathrm{m}$ = massa do recipiente com o concreto, $\mathrm{kg}$;

$\mathrm{m}_{\mathrm{r}}=$ massa do recipiente vazio, em $\mathrm{kg}$;

$v_{r}=$ volume do recipiente, em $\mathrm{dm}^{3}$;

Além da densidade de massa específica, por este ensaio, pode-se obter o rendimento, o consumo de cimento, volume total dos componentes da betonada, índice de ar e teor de ar.

O rendimento do concreto no traço é calculado pela Equação (10).

Onde:

$$
R_{e}=\left(m_{c}+m_{f}+m_{a}\right) / Y_{c f} \quad(\text { Equação 10) }
$$

$R=$ rendimento, expresso em metros cúbico $\left(\mathrm{m}^{3}\right)$;

$\mathrm{m}_{\mathrm{c}}=$ é a massa do cimento da betonada $(\mathrm{kg})$;

$\mathrm{m}_{\mathrm{f}}=$ é a massa total de agregado miúdo da betonada, na condição de umidade em que foi utilizados para o preparo do concreto $(\mathrm{kg})$;

$\mathrm{m}_{\mathrm{g}}=$ é a massa total de agregado graúdo da betonada, na condição de umidade em que foi utilizado para o preparo do concreto $(\mathrm{kg})$;

$\mathrm{m}_{\mathrm{a}}=$ é a massa de água adicionada na betonada $(\mathrm{kg})$.

O consumo de cimento do traço pelo método gravimétrico é obtido pela Equação (11).

$$
\mathrm{C}=\mathrm{m}_{\mathrm{c}} / \mathrm{R} \quad \text { (Equação 11) }
$$

Onde:

$C$ = é o consumo de cimento do concreto $\left(\mathrm{kg} / \mathrm{m}^{3}\right)$;

$\mathrm{m}_{\mathrm{c}}=$ é a massa de cimento da betonada $(\mathrm{kg})$;

$\mathrm{R}=$ rendimento do concreto $\left(\mathrm{m}^{3}\right)$;

O volume teórico total dos componentes da betonada é obtido pela Equação (12).

$$
V_{t}=m_{c} / p_{c}+m_{f} / p_{f}+m_{g} / p_{g}+m_{a} / p_{a} \text { (Equação 12) }
$$

Onde:

$V_{t}=$ volume total dos componentes da betonada $\left(\mathrm{m}^{3}\right)$;

$p_{c}=$ é a massa específica do cimento $\left(\mathrm{kg} / \mathrm{m}^{3}\right)$;

$D_{\mathrm{f}}=$ é a massa específica do agregado miúdo $\left(\mathrm{kg} / \mathrm{m}^{3}\right)$;

$p_{g}=$ é a massa específica do agregado graúdo $\left(\mathrm{kg} / \mathrm{m}^{3}\right)$;

$\mathrm{P}_{\mathrm{a}}=$ é a massa específica da água, que deve ser adotada como sendo igual a 1000 $\mathrm{kg} / \mathrm{m}^{3}$;

$\mathrm{m}_{\mathrm{c}}, \mathrm{m}_{\mathrm{f}}, \mathrm{m}_{\mathrm{g}}, \mathrm{m}_{\mathrm{a}}=$ as massas dos componentes do concreto $(\mathrm{kg})$. 
O índice de ar é calculado pela Equação (13).

Onde:

$$
I_{a}=R / V_{t} \text { (Equação 13) }
$$

$\mathrm{I}_{\mathrm{a}}=$ é o índice de ar presente na mistura (\%);

$V_{t}=$ é o volume total dos componentes da betonada $\left(\mathrm{m}^{3}\right)$;

$R=$ é p rendimento $\left(\mathrm{m}^{3}\right)$.

O teor de ar pelo método gravimétrico é calculado pela Equação (14).

Onde:

$$
A=(1-1 / l a)^{\star} 100 \quad \text { (Equação 14) }
$$

$A=$ é o teor de ar do concreto fresco (\%);

$\mathrm{I}_{\mathrm{a}}=$ é $\mathrm{o}$ índice de ar presente na mistura.

\subsubsection{Compactabilidade}

A compactabilidade mede o grau de compactação alcançado por uma mistura de concreto fresco quando é submetida a um esforço padrão de vibração ou deslocamento.

Em caso de concretos auto-adensáveis, a compactabilidade é uma propriedade que deve ser alcançada sem vibração, mediante deslocamento controlado em diversos tipos de equipamento, como tem sido amplamente divulgado pela literatura especializada.

No caso de concretos com consistência medianamente plástica até fluida, um dos métodos para avaliar essa propriedade em laboratório foi proposto e desenvolvido por meio do aparelho de Glanville (apresentado na Figura 25), e que consiste em dois reservatórios troncocônicos com portinholas na base e colocados um sobre o outro e uma fôrma cilíndrica de 150 por $300 \mathrm{~mm}$ colocada abaixo desses reservatórios. O reservatório superior, que é maior do que o inferior, é preenchido com o concreto e nivelado sem compactação. Ao abrir a portinhola na parte inferior do reservatório, o concreto cai por gravidade no reservatório inferior que, por sua vez, transborda. Fazendo com que uma parte de concreto seja obtida em estado padrão de adensamento, sem influência do fator humano. A portinhola do reservatório inferior é aberta, e o concreto cai no cilindro. O excesso de material é removido, e a massa do concreto, no cilindro de volume conhecido, é determinada, a partir desses valores. O grau de compacidade, denominado fator de compactação, é medido pelo fator de massa específica, isto é, a relação entre massa especifica determinada no ensaio e a massa específica do mesmo concreto em condições ideais de adensamento total (MEHTA; MONTEIRO, 2008). Este método foi 
originalmente normalizado em alguns países, como na Inglaterra, pela BS 1881-103 (1993) Testing Concrete Method for determination of Compactability Factor, mas atualmente foi cancelad0.

$\mathrm{Na}$ pesquisa bibliográfica para este trabalho constatou-se que a citada norma foi substituída pela BS-EN 12350-4:2008 - Testing fresh concrete - Part 4: Degree of Compactability. Por se tratar de método de determinação mais fácil em campo, foi então testado de forma inédita, no programa experimental desta pesquisa, conforme Capítulos 4 e 5.

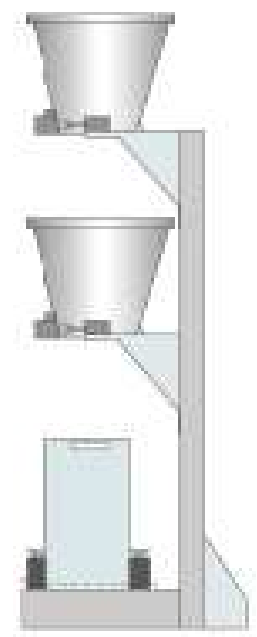

Figura 25 - Aparelho de Glanville para medida de fator de compactação do concreto fresco, pela norma extinta, BS 1881-103:1993 - Testing Concrete Method for Determination of Compactability Factor (MEHTA e MONTEIRO, 2008)

A norma inglesa BS-EN 12350-4 (2008) - Testing fresh concrete - Part 4: Degree of Compactability, normalizou outra forma de ensaio para medir a compactabilidade do concreto fresco, que pode ser usada em campo e foi testada nesta pesquisa, em caráter inédito, pois se trata de método novo e ainda pouco discutido em artigos técnicos.

Este método não pode ser aplicado em concretos com agregados de dimensão máxima superior a $63 \mathrm{~mm}$. O ensaio consiste num recipiente prismático de metal, com base quadrada de lado igual a $200 \mathrm{~mm} \pm 2 \mathrm{~mm}$ e altura de aproximadamente $400 \mathrm{~mm} \pm 2 \mathrm{~mm}$. Deve-se encher o recipiente por meio de colher apropriada, inclinando-a dentro do recipiente, em camadas iguais espalhando o concreto por todos os quatro lados do recipiente, sem adensá-lo. Após o enchimento do recipiente deve ser feito o rasamento das bordas superiores com régua metálica de comprimento maior do que $200 \mathrm{~mm}$, em movimentos de vai-e-vem. Após o rasamento, realiza-se a limpeza das bordas superiores e se introduz o vibrador de imersão $(120 \mathrm{~Hz})$ ou 
coloca o recipiente sobre mesa vibratória $(40 \mathrm{~Hz})$, tomando cuidado para evitar perda de concreto através de espirros ou na vibração com imersão, em caso de ar incorporado. Quando a superfície do concreto ficar brilhosa e/ou cristalina (aproximadamente 2 min) retira-se o vibrador ou desliga-se a mesa vibratória e mede-se a profundidade que o concreto compactou quatro pontos centrais de cada face do recipiente, ou seja, mede-se o quanto a sua superfície desceu, em relação à borda original do recipiente. O índice de compactabilidade é calculado em função da altura do recipiente e da altura de compactação, de acordo com a Equação 15.

$$
\text { I.C = h / (h-s) (Equação 15) }
$$

I.C = Índice de compactabilidade;

$\mathrm{h}=$ altura do recipiente $(\mathrm{cm})$;

$\mathrm{s}=$ altura compactada $(\mathrm{cm})$.

Se o índice de compactabilidade for inferior a 1,04 ou superior a 1,46, o concreto tem uma consistência inapropriada.

\subsubsection{Definições quanto à composição e proporcionamento do concreto}

As etapas da produção do concreto estrutural precedentes à sua elaboração, propriamente, devem dizer respeito às definições da sua composição e proporcionamento, podendo ser assim resumidas:

a) escolha e caracterização dos materiais constituintes;

b) estudo de dosagem, para qual todos os requisitos e critérios analisados nos itens precedentes devem ser definidos, medidos e confirmados;

c) ajustes e comprovações do traço de concreto, nas condições de produção. $O$ cálculo de dosagem do concreto deve ser refeito cada vez que for previsto uma mudança de marca, tipo ou classe de cimento, na procedência ou qualidade dos agregados e demais materiais.

O cálculo da resistência de dosagem do concreto pode ser resumido pelas seguintes instruções da ABNT NBR 12655 (2006).

O cálculo da resistência à compressão de dosagem do concreto segue a Equação (16) e que prevê a distribuição normal desta propriedade, segundo o modelo clássico da curva de 
Gauss, expressa pelo valor característico no quantil de $5 \%\left(f_{c k}\right)$, acrescido da variável normal reduzida, em unidades de desvio padrão, na segunda parcela da Equação:

$$
f_{c j}=f_{c k}+1,65 s_{d} \quad \text { (Equação 16) }
$$

$\mathrm{f}_{\mathrm{cj}}=$ resistência do concreto à compressão na idade de $\mathrm{j}$ dias (MPa), obtida por moldagem e ensaio de corpos-de-prova segundo a ABNT NBR 5739 (2007), tomando-se em geral o maior valor entre dois resultados, assumida como resistência média;

$\mathrm{f}_{\mathrm{ck}}=$ resistência característica à compressão do concreto $(\mathrm{MPa})$;

$\mathrm{s}_{\mathrm{d}}=$ desvio-padrão de dosagem (MPa).

A ABNT NBR 12655 (2006), recomenda que o concreto seja considerado com desviopadrão, $s_{d}$, conhecido com no mínimo 20 resultados de ensaios consecutivos obtidos no intervalo de 30 dias, em período imediatamente anterior a uma nova etapa de produção, com os mesmo materiais, mediante equipamentos similares e sob condições equivalentes. Em nenhum caso o valor de $s_{d}$ adotado pode ser menor que 2,0 MPa.

Para concreto com desvio padrão $s_{d}$ desconhecido no início da obra, deve-se adotar para calculo da resistência de dosagem o valor de acordo com a condição de preparo do concreto, a saber:

a) Classe C10 até C80: cimento e agregados são medidos em massa; água de amassamento é medida em volume e corrigida em função da umidade dos agregados. Utilizar $\mathrm{s}_{\mathrm{d}}=4,0 \mathrm{MPa}$;

b) C10 até C25: cimento medido em massa, a água de amassamento é medida em volume e os agregados medidos em massa. Utilizar $\mathrm{s}_{d}=5,5 \mathrm{MPa}$;

c) C10 e C15: cimento medido em massa; agregados medidos em volume; a água de amassamento é medida em volume e a sua quantidade é corrigida em função da estimativa da umidade dos agregados e da determinação da consistência do concreto. Utilizar $\mathrm{s}_{d}=7,0 \mathrm{MPa}$.

\subsubsection{Elaboração do concreto}

A elaboração do concreto abrange desde o recebimento e o armazenamento dos materiais, sua medida e mistura, bem como a verificação das quantidades utilizadas desses materiais. Esta verificação deve ser feita uma vez ao dia, ou quando houver alteração na dosagem.

A ABNT NBR 12654 (1992) recomenda que antes de ser iniciado o preparo, devem ser realizados ensaios de qualificação do cimento Portland, agregados, água, adições e dos 
aditivos em função dos requisitos e da localização da construção. Na Tabela 20, são apresentados os itens a controlar.

Tabela 20 - Principais propriedades a serem controlados nos materiais do concreto armado.
\begin{tabular}{|c|c|}
\hline Adaptada de ANDRADE; SILVA (2005) \\
\hline Material & O quê controlar? \\
\hline $\begin{array}{c}\text { Cimento } \\
\text { Portland }\end{array}$ & $\begin{array}{c}\text { Propriedades físicas e mecânicas: resistência à compressão, } \\
\text { finura, início e fim de pega, expansibilidade, calor de hidratação, } \\
\text { etc. } \\
\text { Propriedades químicas: composição, percentual de adição, perda } \\
\text { ao fogo, resíduo insolúvel, teores de } \mathrm{C}_{3} \mathrm{~A} \text { e de álcalis }\left(\mathrm{Na}_{2} \mathrm{O} \text { e }\right. \\
\left.\mathrm{K}_{2} \mathrm{O}\right)\end{array}$ \\
\hline Agregados & $\begin{array}{c}\text { Propriedades físicas: distribuição granulométrica, formato dos } \\
\text { grãos, materiais pulverulentos. }\end{array}$ \\
\hline Água & Propriedades químicas: análise petrografica, reatividade potencial \\
\hline Aditivos & Teor de cloretos, sulfatos, álcalis, pH \\
\hline Armadura & $\begin{array}{r}\text { Patamar de escoamento, limite de resistência, alongamento } \\
\text { mínimo, desbitolamento e dobramento }\end{array}$ \\
\hline
\end{tabular}

A mistura do concreto deve visar a homogeneização dos materiais constituintes e pode ser realizada em betoneiras estacionárias ou móveis, em caminhões, ou em central dosadora. A seqüência de colocação dos materiais, o tempo de mistura e os erros nas quantidades dos materiais podem comprometer a consistência, a resistência mecânica e a durabilidade do concreto.

\subsubsection{Transporte}

O transporte de concreto compreende o processo de se levar o material desde o seu local de mistura até as formas. O concreto deve ser transportado do local do amassamento ou da boca de descarga do caminhão-betoneira até o local da concretagem num tempo compatível com as condições de lançamento. O meio utilizado para o transporte não deve acarretar desagregação dos componentes do concreto ou perda sensível de água, pasta ou argamassa por vazamento ou evaporação. O sistema de transporte deve, sempre que possível, permitir o lançamento direto do concreto nas formas, evitando estocagens intermediárias; quando estas forem necessárias, devem ser tomadas todas as precauções para evitar a segregação do concreto, que consiste na separação dos materiais componentes e podem ocasionar o 
aparecimento de "ninhos", isto é, vazios no concreto, que o adensamento não conseguirá eliminar.

Durante o transporte realizado por meio de caminhão-betoneira, cuidados especiais devem ser tomados quanto ao estado de conservação das pás misturadoras, que pode comprometer a homogeneidade da mistura. Outro ponto importante é o tempo de saída do caminhão da central até a descarga e lançamento do concreto nas fôrmas. Esse tempo deve ser compatível com as características do concreto e as condições de temperatura, para minimizar perda de abatimento ou início das reações de hidratação do cimento.

Ensaios prévios de controle de perda de abatimento de concreto devem sempre ser realizados por fornecedores de concreto ou por laboratórios, em rotinas de comparação e seleção de materiais, em especial, de aditivos.

\subsubsection{Lançamento}

É a operação de colocação do concreto nas formas. Nesta etapa, deve-se também tomar cuidado com a segregação do concreto. Deve ser feito de forma a preencher todo o volume das formas, mesmo nos locais de difícil acesso, visando eliminar ao máximo o ar aprisionado nos processos de mistura, transporte e lançamento.

A operação de lançamento deve ser continua, de maneira que, uma vez iniciada, não sofra nenhuma interrupção, até que todo o volume previsto no plano de concretagem tenha sido completado.

A ABNT NBR 14931 (2003) - Execução de Estruturas de Concreto - Procedimento, faz as seguintes recomendações:

$\checkmark \quad$ "O concreto deve ser lançado e adensado de modo que toda a armadura, além dos componentes embutidos previstos no projeto, sejam adequadamente envolvidos na massa do concreto";

$\checkmark \quad$ "Em nenhuma hipótese deve ser realizado o lançamento do concreto após o início da pega. Concreto contaminado com solo ou com outros materiais não deve ser lançado na estrutura. O concreto deve ser lançado o mais próximo possível de sua posição definitiva, evitando-se a incrustação de argamassa nas paredes das fôrmas e nas armaduras";

$\checkmark \quad$ "O concreto deve ser lançado com técnica que elimine ou reduza a segregação entre seus componentes, observando-se maiores cuidados quanto maiores forem a altura de lançamento e a densidade das armaduras. Estes cuidados devem ser majorados quando a altura de queda livre ultrapassar dois metros de altura, no caso de peças estreitas e altas, de 
modo a evitar a segregação e a falta de argamassa (como nos pés de pilares e na juntas de concretagem de paredes)".

\subsubsection{Adensamento}

O adensamento do concreto é a operação para a retirada do ar presente na massa do concreto, com o objetivo de se reduzir a porosidade ao máximo e o perfeito preenchimento das formas. Como benefício adicional obtém-se a melhoria da resistência mecânica, dificultando a entrada de agentes agressivos.

"O adensamento pode ser feito por qualquer processo que seja eficiente: réguas ou placas vibratórias, vibrador de bancada, vibrador incorporado à forma etc. $\mathrm{Na}$ execução de lajes e estruturas reticuladas, o adensamento usual é executado com vibrador de imersão, composto por um motor, um mangote e uma ponta vibratória" (THOMAZ, 2005).

Para os casos correntes de adensamento por vibração mecânica ou manual, a norma ABNT NBR 14931 (2003) recomenda os seguintes procedimentos em seu item 9.6.1:

$\checkmark \quad$ Evitar a vibração da armadura para não prejudicar a aderência com o concreto;

$\checkmark \quad$ No adensamento mecânico com vibradores de imersão, a altura das camadas não deve ultrapassar $3 / 4$ do comprimento da agulha;

$\checkmark \quad$ O vibrador deve ser aplicado na posição vertical;

$\checkmark \quad$ Fazer a vibração em um maior número possível de pontos da peça concretada;

$\checkmark \quad$ A retirada do vibrador deve ser lenta, mantendo-o sempre ligado;

$\checkmark \quad$ Não permitir que o vibrador entre em contato com as formas para evitar 0 aparecimento de bolhas de ar;

$\checkmark \quad$ Para um bom adensamento é necessário estabelecer um plano de lançamento adequado às necessidades da peça concretada.

Pelo discutido nos itens 3.6.1 até 3.6.4 pode-se concluir que o preparo, transporte, lançamento e adensamento são operações fundamentais que interferem muito na durabilidade das estruturas.

Em razão disto, as exigências de trabalhabilidade e compactabilidade do concreto fresco precisam ser observadas de forma mais precisa do que hoje ocorre, principalmente porque são propriedades muito sensíveis à natureza e o teor de aditivos redutores de água cada vez mais usados. 


\subsubsection{Cura}

O cimento Portland é constituído de vários compostos anidros, e só adquire propriedades de aglomerante hidráulico a partir da sua mistura à água. Isto acontece porque as reações químicas do cimento com a água, chamadas de hidratação, geram produtos que possuem características de pega e endurecimento. Quando um cimento é hidratado, seus compostos reagem com a água para atingir estados estáveis de menor energia, pela liberação de calor. Assim, as reações de hidratação dos compostos do cimento Portland são exotérmicas e decorrem do processo de fabricação do cimento, que no estado anidro é quimicamente instável e acumula energia latente.

"Os processos de cura úmida visam garantir as reações de hidratação e retardar a retração dos concretos, de forma que o concreto possa desenvolver resistência razoável antes que se manifestem as tensões de tração nas superfícies das peças" (THOMAZ, 1999). A importância da cura é cada vez maior na medida em que se utiliza cimentos mais finos e com diversificadas adições minerais. A cura deve ser iniciada ao final da pega e enrijecimento do concreto, em duas a três horas após o seu lançamento, e quando não houver mais possibilidade da pasta do concreto ser misturada à água de cura.

Não há um tempo predeterminado para a realização da cura, sabe-se que quanto maior for a duração da cura melhores serão as condições de formação dos cristais, mais refinada será a estrutura interna, com maior resistência e maior durabilidade (THOMAZ, 1999).

Os métodos de cura em temperatura ambiente mais usuais são: o borrifamento de água, revestimentos saturados, areia molhada e películas químicas.

Há processos especiais de cura térmica com temperatura acima da ambiente, seja para pré-fabricados, seja para previsão de resistência do concreto, em controle tecnológico. $\mathrm{O}$ tempo para conhecimento da resistência à compressão do concreto aos 28 dias, não é compatível com a velocidade nas execuções das estruturas de concreto armado, por isso, justifica-se o emprego de cura com temperaturas acima da ambiente.

O tempo para medida da resistência à compressão do concreto aos 28 dias, embora seja a idade de referência para a maior parte dos projetos, não é compatível com a atual velocidade de execução de muitas das estruturas de concreto armado. Assim, para efeitos de controle de produção do concreto ou de recebimento em certas condições, justifica-se o emprego de cura acelerada, com temperaturas acima da ambiente.

A ASTM C 684 (1999) classifica em quatro os métodos de cura do concreto, conforme a Tabela 21, sendo que três utilizam temperatura alta ou procedimentos complexos de execução e apenas o tipo A de fácil execução, pois faz uso de temperatura amena, o de menor custo 
operacional e ainda é aprovado por Mehta; Monteiro (2008), que afirmam tratar-se de método testado e confiável para o controle rotineiro da qualidade de concretos estruturais.

$\mathrm{Na}$ cura acelerada pelo Método A da ASTM, os corpos-de-prova são imersos em água aquecida à temperatura de $35{ }^{\circ} \mathrm{C} \pm 3{ }^{\circ} \mathrm{C}$ durante $23,5 \mathrm{~h} \pm 0,5 \mathrm{~h}$, período este iniciado logo após a moldagem dos corpos-de-prova. Assim, após moldados, os mesmos devem ser acomodados em banho térmico com espaçamento de $100 \mathrm{~mm}$ entre si e $100 \mathrm{~mm}$ de cobertura de água. $\mathrm{O}$ programa experimental aplicou método similar ao método tipo $A$.

Tabela 21- Tipos e procedimentos da cura acelerada (ASTM C 684, 1999)

\begin{tabular}{|c|c|c|c|c|c|c|c|}
\hline \multicolumn{2}{|c|}{ Procedimento } & \multirow{2}{*}{\begin{tabular}{|c|} 
Moldes \\
Reutilizáveis \\
ou \\
descartável \\
\end{tabular}} & \multirow{2}{*}{$\begin{array}{c}\begin{array}{c}\text { Origem da } \\
\text { aceleração da } \\
\text { resistência }\end{array} \\
\begin{array}{c}\text { Calor de } \\
\text { hidratação }\end{array}\end{array}$} & \multirow{2}{*}{$\begin{array}{c}\begin{array}{c}\text { Temperatura de cura } \\
\text { acelerada }{ }^{\circ} \mathrm{C}\left({ }^{\circ} \mathrm{F}\right)\end{array} \\
35(95)\end{array}$} & \multirow{2}{*}{$\begin{array}{l}\begin{array}{l}\text { Idade para inicio } \\
\text { da cura acelerada }\end{array} \\
\begin{array}{l}\text { Imediatamente } \\
\text { após moldagem }\end{array}\end{array}$} & \multirow{2}{*}{\begin{tabular}{|c|}
$\begin{array}{c}\text { Duração da } \\
\text { cura acelerada }\end{array}$ \\
$23,5 \mathrm{~h} \pm 30 \mathrm{~min}$
\end{tabular}} & \multirow{2}{*}{$\begin{array}{c}\begin{array}{c}\text { Idade de } \\
\text { ensaio }\end{array} \\
24 \mathrm{~h} \pm 15 \mathrm{~min}\end{array}$} \\
\hline A & Água quente & & & & & & \\
\hline B & Água fervente & $\begin{array}{c}\text { Reutilizáveis } \\
\text { ou } \\
\text { descartável }\end{array}$ & Água fervente & Ebulição & $\begin{array}{c}23 \mathrm{~h} \pm 30 \mathrm{~min} \\
\text { após moldagem }\end{array}$ & $3,5 \mathrm{~h} \pm 5 \mathrm{~min}$ & $28,5 \mathrm{~h} \pm 15 \mathrm{~min}$ \\
\hline C & Autógena & Uso único & $\begin{array}{c}\text { Calor de } \\
\text { hidratação }\end{array}$ & $\begin{array}{l}\text { A temperatura inicial do } \\
\text { concreto é aumentada } \\
\text { pelo calor de hidratação }\end{array}$ & $\begin{array}{l}\text { Imediatamente } \\
\text { após moldagem }\end{array}$ & $48 \mathrm{~h} \pm 15 \mathrm{~min}$ & $49 \mathrm{~h} \pm 15 \mathrm{~min}$ \\
\hline D & $\begin{array}{c}\text { Alta } \\
\text { temperatura e } \\
\text { pressão }\end{array}$ & Reutilizáveis & $\begin{array}{l}\text { Calor e pressão } \\
\text { externos }\end{array}$ & $150(300)$ & $\begin{array}{l}\text { Imediatamente } \\
\text { após moldagem }\end{array}$ & $5 \mathrm{~h} \pm 5 \mathrm{~min}$ & $5,25 \mathrm{~h} \pm 5 \mathrm{~min}$ \\
\hline
\end{tabular}

"A cura térmica, limitando-se a temperatura do concreto no máximo a $70^{\circ} \mathrm{C}$, implicará que o cimento se hidrate com cristais mais graúdos, com menor interpenetração, o que resultará em resistência potencialmente menor do concreto nas idades avançadas (comparativamente com a resistência esperada, se a cura fosse realizada com temperaturas entre $20^{\circ} \mathrm{C}$ e $30^{\circ} \mathrm{C}$ )" (THOMAZ, 1999).

BARBOSA (2005) concluiu que o tipo de cura interfere na profundidade de carbonatação e na resistência dos concretos. Nos concretos estudados (CPV ARI e CPIII) com e sem utilização de sílica ativa, aqueles submetidos à cura térmica apresentaram desempenho intermediários de resistência mecânica e profundidade de carbonatação, em relação aos concretos curados ao ar e em cura imersa, mas apresentaram os melhores resultados nas primeiras idades.

A ABNT NBR 14931 (2004) diz em seu texto, apenas que: "Elementos estruturais de superfície devem ser curados até que atinjam resistência característica à compressão $\left(f_{c k}\right)$, de acordo com a ABNT NBR12655 (2006), igual ou maior que 15 MPa". Ou seja, peças com 
grande superfície em relação ao seu volume, tais como placas, cascas e lajes precisam receber ainda maior atenção quanto ao prazo de cura, por possuírem maior área para interagir com o ambiente, sendo mais suscetíveis à perda precoce de água do concreto pela ação do sol e vento.

Para garantir a eficiência de certos requisitos e critérios da durabilidade de armaduras, seria conveniente definir em projeto executivo, o tipo e a duração da cura do concreto, em especial para as regiões da estrutura com condições mais críticas de exposição ambiental.

\subsection{Controle de fissuras no concreto}

O concreto armado é dimensionado para que atinja fissuração sem entrar em colapso, sendo isto compatível com as teorias de dimensionamento. É o caso típico de elementos estruturais fletidos em que as fissuras se formam quando a resistência à tração do concreto é atingida, lembrando que uma mesma seção transversal fica sujeita a simultaneamente a deformações de compressão e de tração.

Elementos estruturais em concreto submetidos à ação de momento fletor e força cortante apresentam, nas seções transversais em que atuam, deformações e tensões de tração. Quando a intensidade de tensão ficar próxima da resistência à tração, há uma grande probabilidade de ser iniciar o processo de abertura de fissuras (JACINTHO; GIONGO, 2005). A fissuração dos elementos estruturais de concreto armado é inevitável, uma vez que o concreto possui baixa resistência à tração. Segundo Leonhardt (1997), as peças de concreto armado fissuram mesmo quando submetidas a pequenas intensidades de tensões de tração.

A determinação da resistência característica à tração segue a mesma determinação da resistência à compressão do concreto. Tradicionalmente, as Normas Brasileiras admitem relações fixas entre as resistências do concreto à tração e à compressão. A ABNT NBR 6118 (2003) adota os seguintes valores:

$$
\begin{gathered}
f_{c t, m}=0,3 f_{c k}^{2 / 3} \text { (Equação 17) } \\
f_{c t k, \text { inf }}=0,7 f_{c t, m} \text { (Equação 18) } \\
f_{c t k, s u p}=1,3 f_{c t, m} \text { (Equação 19) }
\end{gathered}
$$

Por outro lado, a resistência à tração do concreto é, geralmente, controlada por métodos indiretos como são os ensaios de determinação da resistência à tração por compressão diametral ou por flexão simples, havendo em JACINTHO; GIONGO (2005) ou em MEHTA; MONTEIRO (2008) sobre os procedimentos e correlações entre essas propriedades, inclusive com a resistência à compressão simples do concreto. 
Silva (2007) estudando vigas de concreto armado, com cobrimento de $3,0 \mathrm{~cm}$, sujeitas a esforços de tração e compressão com cura a 7 e 56 dias e exposição em câmara climatizada com $50 \%$ de $\mathrm{CO}_{2}$ por 28 dias, encontrou que a fissura é um caminho preferencial para difusão do dióxido de carbono, pois este ultrapassa o cobrimento e facilmente atinge a armadura. $A$ determinação da carbonatação nas regiões com fissuras demonstrou que maiores aberturas de fissuras proporcionam o aumento na profundidade de carbonatação. Concordando com a opinião de HELENE (1998) que diz: "É mais importante conhecer a profundidade da fissura, ou seja, se esta alcança ou não a armadura".

De acordo com a ABNT NBR 6118 (2003), nas armaduras passivas, a abertura máxima de fissuras $\left(w_{k}\right)$ é $0,4 \mathrm{~mm}$ para concreto armado exposto a uma classe de agressividade ambiental fraca; 0,3 $\mathrm{mm}$, quando essa classe for de moderada a forte, e 0,2 $\mathrm{mm}$, quando for muito forte.

O controle de fissuras nas estruturas de concreto inicia pela fase de projeto, mas é fundamental que seja verificado para as condições de execução da obra, pois pode interferir de forma bastante complexa na durabilidade de armaduras e no desempenho em geral, das estruturas de concreto.

Após o concreto fresco ser lançado, ocorre um assentamento volumétrico do concreto a partir da superfície. Este fenômeno, que é devido à redução de volume do concreto fresco pelo seu assentamento, é conhecido como retração plástica e pode causar fissuras precoces.

Nas lajes, a secagem rápida do concreto fresco provoca retração plástica, quando a taxa de perda de água da superfície, por evaporação, excede a taxa disponível de água de exsudação. As fissuras típicas de retração plástica são paralelas entre si e afastadas uma das outras de 0,30 a 1,0 m e com 25 a 30 mm de profundidade (MEHTA; MONTEIRO, 1994).

Almusallan (2001) ${ }^{15}$ citado por LIMA (2005), afirma que a temperatura do ar, umidade relativa e velocidade do vento, afetam as propriedades tanto do concreto fresco quanto do concreto endurecido. Temperatura elevada e baixa umidade relativa aceleram a retração plástica do concreto. Devido ao fenômeno de retração, as fissuras que surgem podem acelerar a carbonatação do concreto e a corrosão de armaduras, principalmente por permitirem a penetração de ar e umidade no material.

Para que um concreto tenha um risco mínimo de fissuração, deve sofrer pouca retração e ter módulo de deformação inicial, fluência e resistência à tração, compatíveis entre si.

15 ALMUSALLAM, A. A. Effect of environmental condition on the properties of fresh and hardened concrete. Cement and Concrete Composites, v. 23, p. 353 - 361, 2001. 
Montoya et al. (2000) ${ }^{16}$ aborda muitas causas de fissuras em concretos, e a Tabela 22 , apresenta as fissuras relacionadas ao concreto fresco.

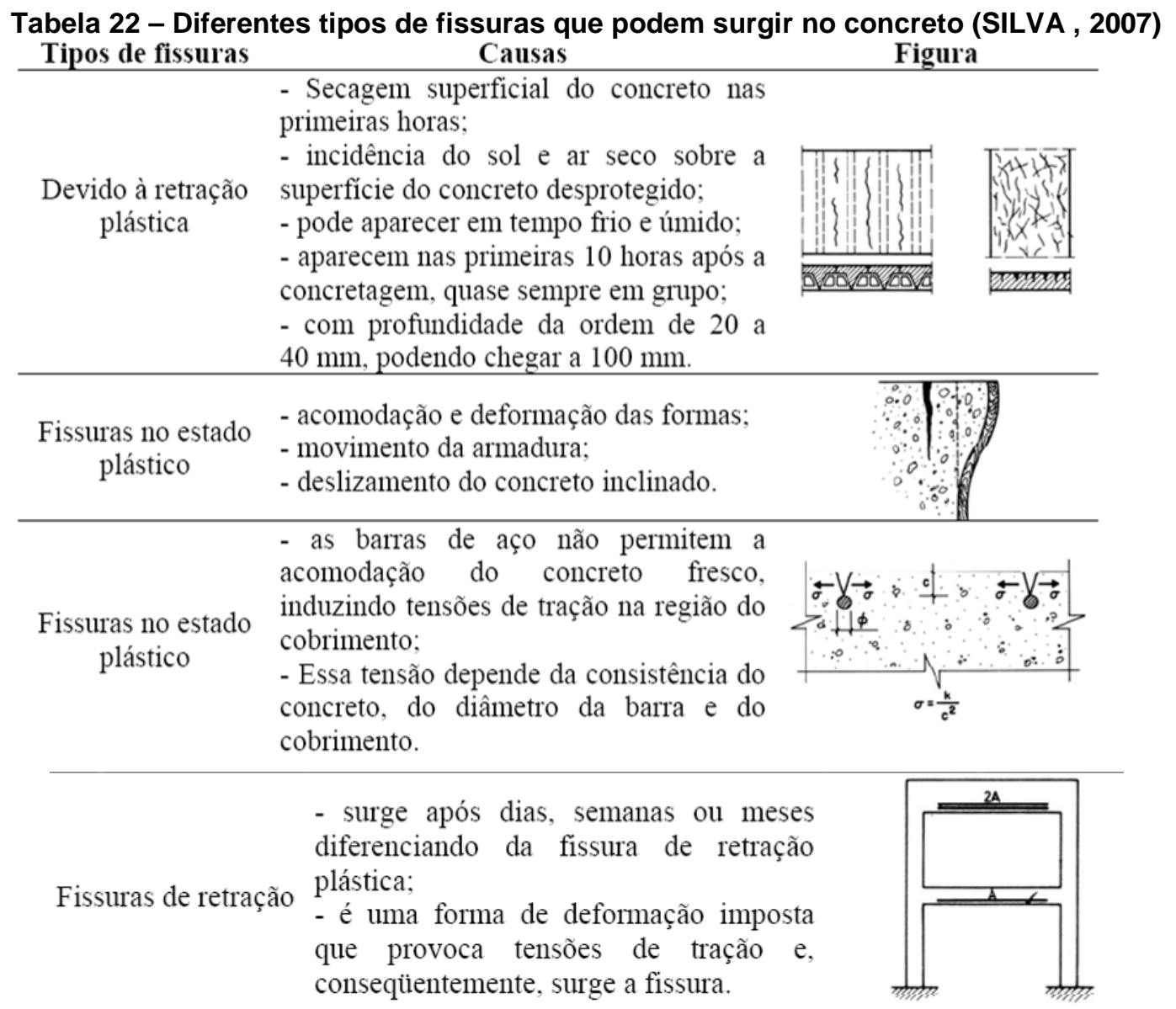

O Engenheiro Egydio Hervé Neto (informação verbal) ${ }^{17}$ destaca a importância do acompanhamento de um engenheiro especialista em controle tecnológico de concreto auxiliando a equipe responsável pelo projeto estrutural:

...Estando o calculista no comando de um processo tecnologicamente multidisciplinar, deve se inteirar melhor da tecnologia do concreto, hoje parte fundamental do projeto tendo em vista as exigências da nova NBR $6118 / 03$ e seu foco em durabilidade. Por isto entendo que o tecnologista faça parte da equipe de projeto fornecendo o escopo que o calculista não tem. Não cabe ao construtor tomar decisões por conta própria a respeito da movimentação de escoramentos e outras ações executivas

\footnotetext{
16 MONTOYA, P. J.; MESEGUER, A. G.; CABRÉ, F. M. Hormigón armado. Barcelona,Editora Gustavo Gili.

17 Informação fornecida pela comunidade calculistas-ba@ yahoogrupos.com.br, em 2008.
} 
que geram tensões na estrutura, especialmente na fase construtiva, com idades anteriores a 28 dias. Cabe ao calculista, como rezam as normas, fornecer $\circ \mathrm{f}_{\mathrm{cj}}$ e $\circ \mathrm{E}_{\mathrm{c}}$ necessários nessas idades para estas ações. Um projeto não está completo sem esta informação e quem pode fornecê-la, mesmo antes da obra iniciada, é um tecnologista de concreto...

\subsection{Controle de qualidade do concreto pela ABNT NBR 12655 (2006)}

\subsubsection{Abrangência e complexidade do controle de qualidade do concreto}

"A organização e a implementação do controle da qualidade da construção civil devem envolver um mecanismo duplo de ação: o controle de produção e o controle de recebimento. controle de produção é exercido por quem gera produtos em uma das etapas do processo, tratando-se de um controle interno. O controle de recebimento é exercido por quem fiscaliza e aceita os produtos e os serviços executados nas várias etapas do processo" (HELENE; TERZIAN, 1993).

O controle de qualidade para a produção do concreto deve ser entendido como um conjunto de procedimentos que tem por objetivo fornecer esse material com uma qualidade especificada, ao mínimo custo possível, com metodologia organizada através de conceitos da Engenharia e da Estatística.

"Um bom controle da qualidade tem por objetivo garantir um nível preestabelecido de qualidade de um determinado produto. Não pode ser confundido com qualidade, como se estivesse implícito que ao fazer um controle de qualidade obrigatoriamente obter-se-ia produtos de alta qualidade. Não é objetivo do controle da qualidade elevar ou abaixar a qualidade, e sim, manter uma qualidade" (HELENE, 1981).

No controle de recebimento do concreto, as exigências mínimas são a avaliação das condições da nota fiscal; análise da trabalhabilidade e da quantidade de água através do ensaio de abatimento e a avaliação da resistência à compressão a 28 dias de idade.

Embora, Helene (1993) tenha apontado para critérios de qualificação dos concretos e para a proteção de armaduras, baseados em propriedades físicas como o índice de vazios e a absorção de água, não houve até hoje a interpretação ou confirmação suficiente para esses critérios, nos trabalhos consultados e nem nas normas em foco nesta pesquisa.

Logo, persiste o paradigma da especificação do concreto estrutural tão somente por critérios empíricos de durabilidade, através da dosagem por limite de relação a/c e pelo $f_{c k}$. Cabe reconhecer que esses critérios até podem ser razoavelmente eficientes para o controle 
empírico da porosidade do concreto, mas podem não ser suficientes para a comparação, a diferenciação técnica ou o controle de recebimento do concreto estrutural.

\subsubsection{Controle da consistência pelo abatimento}

A ABNT NBR 12655 (2006) recomenda a realização de ensaios de consistência pelo abatimento de tronco-de-cone ou pelo espalhamento do tronco-de-cone, já descritos anteriormente.

Para o concreto preparado pelo executante da obra, devem ser realizados ensaios de consistência sempre que ocorrerem alterações na umidade dos agregados; na primeira amassada do dia; ao reiniciar o preparo após uma interrupção da concretagem de pelo menos 2 horas; na troca dos operários e a cada vez que forem moldados corpos-de-prova.

Para concretos preparados por empresas de serviço de concretagens a norma recomenda a realização de ensaio de consistência a cada caminhão-betoneira entregue à obra.

\subsubsection{Controle da resistência à compressão}

O controle de resistência à compressão do concreto mais freqüente é apenas um ensaio de recebimento e visa à comprovação daquilo que está sendo executado frente ao que foi especificado no projeto de estrutura.

A amostragem do concreto para ensaios de resistência à compressão, deve ser feito dividindo-se a estrutura em lotes, volume este homogêneo de concreto e que se analisa de uma só vez, como mostra a Tabela 23. De cada lote deve ser retirada uma amostra, conjunto de " $n$ " exemplares, que se admitem como representativos do lote, sendo cada exemplar formado por dois corpos-de-prova moldados de uma mesma porção de fornecimento (volume preparado em betoneira estacionária ou em caminhão-betoneira).

Tabela 23 - Valores para formação de lotes de concreto (ABNT NBR 12655, 2006)

\begin{tabular}{|c|c|c|}
\hline \multirow[b]{2}{*}{ Limites superiores } & \multicolumn{2}{|c|}{ Solicitação principal dos elementos da estrutura } \\
\hline & $\begin{array}{l}\text { Compressão ou } \\
\text { Compressão e flexão }\end{array}$ & Flexão simples \\
\hline Volume de concreto & $50 \mathrm{~m}^{3}$ & $100 \mathrm{~m}^{3}$ \\
\hline Número de andares & 1 & 1 \\
\hline $\begin{array}{c}\text { Tempo de } \\
\text { concretagem }\end{array}$ & \multicolumn{2}{|c|}{3 dias de concretagem } \\
\hline
\end{tabular}


A ABNT NBR 12655 (2006) prescreve para determinação do $f_{c k e s t ~}$ (resistência característica estimada à compressão) por amostragem parcial, para lotes com número de exemplares entre 6 e 20, a Equação 20 a seguir:

Onde,

$$
f_{\text {ckest }}=2\left[\left(f_{1}+f_{2}+\ldots+f_{m-1}\right) /(m-1)\right]-f_{m} \text { (Equação 20) }
$$

$\mathrm{n}=$ número de exemplares;

$\mathrm{m}=\mathrm{n} / 2$. Despreza-se o valor mais alto de $\mathrm{n}$, se for ímpar;

$f_{1}, f_{2}, \ldots f_{m}=$ valores das resistências dos exemplares, em ordem crescente.

Segundo esta fórmula não se deve tomar para $\mathrm{f}_{\text {ckest }}$ valor menor que " $\psi_{6} . \mathrm{f}_{1}$ " adotando-se para $\psi_{6}$ um valor tabelado pela norma em questão, em função das condições de preparo do concreto e número de exemplares do lote, conforme a Tabela 24.

Tabela 24 - Valores de $\psi_{6}$ (ABNT NBR 12655, 2006)

\begin{tabular}{|c|c|c|c|c|c|c|c|c|c|c|c|}
\hline Condição de & \multicolumn{10}{c|}{ Número de exemplares (n) } \\
\cline { 2 - 13 } preparo & $\mathbf{2}$ & $\mathbf{3}$ & $\mathbf{4}$ & $\mathbf{5}$ & $\mathbf{6}$ & $\mathbf{7}$ & $\mathbf{8}$ & $\mathbf{1 0}$ & $\mathbf{1 2}$ & $\mathbf{1 4}$ & $\geq \mathbf{1 6}$ \\
\hline A & 0,82 & 0,86 & 0,89 & 0,91 & 0,92 & 0,94 & 0,95 & 0,97 & 0,99 & 1,00 & 1,02 \\
\hline B ou C & 0,75 & 0,80 & 0,84 & 0,87 & 0,89 & 0,91 & 0,93 & 0,96 & 0,98 & 1,00 & 1,02 \\
\hline
\end{tabular}

Para amostragem total (100\%), prescreve a determinação do $f_{\text {ckest }}$, pela Equação (21) e Equação (22):

$$
\begin{array}{ll}
\text { Para } n \leq 20, f_{\text {ckest }}=f_{1} ; & (\text { Equação 21) } \\
\text { Para } n>20, f_{\text {ckest }}=f_{i 1} ; & (\text { Equação 22) }
\end{array}
$$

Onde,

$\mathrm{n}=$ número de exemplares;

$\mathrm{i}=0,05 \mathrm{n}$. Quando o valor de i for fracionário, adota-se o número inteiro imediatamente superior; $f_{1}, f_{2}, \ldots, f_{m}=$ valor das resistências dos exemplares, em ordem crescente.

Os lotes de concreto devem ser aceitos, quando o valor estimado da resistência característica, calculado conforme Equações 20, 21 ou 22, satisfazer a relação:

$$
f_{\text {ckest }} \geq f_{\text {ck }}
$$

Recomenda-se fazer o rastreamento do concreto juntamente com a amostragem total, pois, é possível reduzir custos de ações corretivas em eventuais não conformidades, recuperando apenas os lotes com problema. 
A ABNT NBR 6118 (2003) recomenda algumas ações corretivas no caso de nãoconformidade do concreto, ou seja se a resistência estimada à compressão resultar inferior ao valor do $f_{\text {ck. }}$.

No caso de existência de não-conformidades, devem ser adotadas as seguintes ações corretivas:

a) "revisão do projeto para determinar se a estrutura, no todo ou em partes, pode ser considerada aceita, considerando os valores obtidos nos ensaios;"

b) "no caso negativo devem ser extraídos e ensaiados testemunhos conforme disposto na ABNT NBR 7680, se houver também deficiência na resistência do concreto cujos resultados devem ser avaliados de acordo com a ABNT NBR 12655, procedendo-se a seguir a nova verificação da estrutura visando a sua aceitação;"

c) "constatada a não-conformidade final de parte ou do todo da estrutura, deve ser escolhida uma das seguintes alternativas: determinar as restrições de uso da estrutura, providenciar projeto de reforço, decidir pela demolição parcial ou total".

Pelo menos é necessário assegurar que o concreto empregado atenda às especificações de projeto, que possam ser mais importantes para a durabilidade das armaduras, nas classes mais agressivas de exposição, já que a resistência à compressão não pode responder diretamente pelas propriedades de transporte dos agentes e processos mais comuns envolvidos na corrosão de armaduras, vistos no Capítulo 2. 


\section{CAPÍTULO 4}

\section{PROGRAMA EXPERIMENTAL PARA PROSPECĈ̃O DE CONTROLE TECNOLÓGICO DO CONCRETO AMPLIADO À PROTEÇÃO DE ARMADURAS}

Este capítulo apresenta o programa experimental realizado em campo e laboratório, com o objetivo de contribuir para o progressivo aperfeiçoamento do controle tecnológico de concretos, em ambientes marítimos, com vistas à proteção de armaduras de aço carbono.

\subsection{Objetivos do programa experimental}

O programa experimental objetivou amostrar e caracterizar, em campo, três lotes de concretos estruturais pré-misturados de mesmo abatimento e resistência característica à compressão a 28 dias, com vistas a comparar e correlacionar as suas propriedades desde o estado fresco, quanto à capacidade de proteção de armaduras para estruturas em ambiente urbano do litoral brasileiro. Em especial, no estado fresco, foram visadas propriedades relacionadas ao teor de ar no concreto fresco e algumas propriedades físicas e mecânicas de fácil caracterização no estado endurecido.

As seguintes premissas e objetivos complementares orientaram a definição das propriedades estudadas e dos procedimentos adotados na metodologia:

- Antecipar a idade de qualificação de concretos, através do emprego de cura acelerada em temperatura moderada, segundo procedimento baseado no tipo $A$ da ASTM C 684 (1999);

- Adotar recursos laboratoriais acessíveis a empresas de controle tecnológico do mercado brasileiro, para estimular novas práticas em estudo de dosagem, seleção ou recebimento de concretos estruturais.

\subsection{Metodologia para a definição dos concretos}

Como até a presente década a pesquisa acadêmica experimental, sobre o comportamento do concreto estrutural, se encontra majoritariamente concentrada em estudos laboratoriais focados na variação do proporcionamento e na natureza dos constituintes do concreto, este programa empregou o método indutivo para desenvolvimento desta metodologia (VARGAS, 1985), e métodos estatísticos para a avaliação dos resultados. Portanto, a fixação dos concretos e das obras para a realização do programa experimental foram definidos 
aleatoriamente, após a qualificação de algumas premissas técnicas e operacionais, a seguir explicadas.

\subsubsection{Definições da classe de resistência, cidade e centrais dosadoras dos concretos}

Três lotes de concretos estruturais de $\mathrm{f}_{\mathrm{ck}} 30 \mathrm{MPa}$, produzidos em duas centrais dosadoras de concretos diferentes, na cidade de João Pessoa-PB, foram o objeto da caracterização pelo programa experimental.

A escolha dessa resistência característica se deu por atender a três das quatro classes de agressividade da ABNT NBR 6118 (2003), segundo a Tabela 9 no item 3.4.2;

A cidade de João Pessoa/PB foi escolhida para sediar o estudo, de forma estratégica, pelos seguintes motivos:

a) por ser uma cidade tipicamente marítima, representativa de macroclimas com alta agressividade ambiental e para a deterioração das estruturas de concreto armado, por corrosão de armaduras;

b) por haver subsídios de infra-estrutura adequada à pesquisa, pela empresa onde trabalha este autor, a TECNCON - Tecnologia do Concreto e Engenharia Ltda., que dispõe de escritório de cálculo estrutural e laboratório de concreto muito bem estabelecidos naquela cidade;

C) por haver publicações sobre estudos avançados de envelhecimento natural de concretos em João Pessoa/PB, pelos estudos de MEIRA; PADARATZ; BORBA (2006);

d) porque a cidade apresenta grande expansão imobiliária, principalmente de edifícios altos com estrutura de concreto armado.

Assim, foram escolhidas duas obras (1 e 2), cada uma abastecida por uma central dosadora de concreto diferente. A especificação do concreto estrutural nessas obras era semelhante, em termos de abatimento $(10 \mathrm{~cm} \pm 2 \mathrm{~cm})$ e de resistência característica a 28 dias $\left(f_{c k} 30 \mathrm{MPa}\right)$. Foram definidas e analisadas certas propriedades do estado fresco e endurecido com maturação natural e acelerada para ensaios a 7, 28 e 91 dias, segundo procedimento nos itens 4.3.1 e 4.3.2.

Os valores da relação a/c máxima e do consumo de cimento embora pudessem ser também preestabelecidos, através da ABNT NBR 6118 (2003), não foram fixados pelo programa, pois poderiam interferir na produção de rotina das centrais produtoras com vistas às obras escolhidas. 


\subsubsection{Seleção das centrais dosadoras}

Devido à existência de apenas três centrais dosadoras de concreto na cidade de João Pessoa/PB, no ano de 2008, a seleção de duas foi feita a partir da produção mensal de concreto de cada uma e da disponibilidade de estar fornecendo concreto de $f_{c k} 30 \mathrm{MPa}$, em obra de edifício de múltiplos andares.

Por ocasião do levantamento, as duas centrais definidas para este estudo, tinham capacidade de produção instalada de $8000 \mathrm{~m}^{3}$ por mês e forneciam a maior parte do volume mensal de concreto que abastecia as obras em João Pessoa/PB.

\subsubsection{Seleção e visita preliminar às obras}

Nesta etapa foram feitos contatos de interesse, para a identificação de empresas construtoras com obras em andamento e atendidas pelas duas centrais dosadoras preestabelecidas

Então, foi realizado o reconhecimento preliminar de algumas obras, para confirmar a disponibilidade das empresas construtoras em participar do projeto, principalmente fornecendo previsões e dados sobre as concretagens, bem como o espaço físico no canteiro, para a realização da caracterização dos concretos.

Foram solicitadas as propriedades especificadas para o concreto (abatimento, aditivos, relação a/c e outras eventuais que pudessem ter sido especificadas pelo projeto), e ainda informações sobre a produção da estrutura (cobrimento das armaduras, resultados de controle do concreto em lotes anteriores, volume de lotes, plano de concretagem). Dados de interesse quanto às estruturas das duas obras constam no Anexo $A$.

Para concluir o desenvolvimento desta etapa, foi realizada uma visita técnica específica e adicional, em cada obra selecionada, para acompanhar previamente uma concretagem e preparar as instalações físicas na obra, para apoio à caracterização do concreto, nos respectivos lotes objeto deste estudo. Também foi elaborado o cronograma físico detalhado das etapas seguintes deste programa, de modo a não haver superposição de atividades na caracterização dos três lotes.

Para treinar a equipe foi realizada uma amostragem e caracterização de um lote na obra 1, o qual foi aqui identificado como "lote treinamento". 


\subsubsection{Plano básico de amostragem dos lotes em estudo}

Como visto no item 3.8.3, a ABNT NBR 12655 (2006) faculta a amostragem de lotes de concreto pelos dois seguintes procedimentos:

a) Amostragem parcial com coleta e caracterização de pelo menos seis caminhõesbetoneira constituintes de um dado lote;

b) Amostragem total com coleta e caracterização de todos os caminhões-betoneira constituintes do lote.

Em principio, definiu-se que todos os lotes do programa experimental seriam representados pelo concreto de seis caminhões-betoneira, produzidos para uma dada concretagem, no transcorrer da única data e com volume e elementos estruturais típicos de um lote homogêneo, segundo a Tabela 23 do item 3.8.3. Todavia, por questões de cronograma, isto só pode ser atendido para dois lotes de uma das obras e como a seguir informado.

$\mathrm{Na}$ obra 1, foram caracterizados dois lotes da mesma central dosadora e com amostragem de seis caminhões-betoneira por lote, assim identificados: Lote treinamento em 7/11/2008 e Lote 1 em 14/01/2009.

O lote treinamento foi de concretagem de $71 \mathrm{~m}^{3}$ de concreto (10 caminhões-betoneira e mais um complemento) e foi caracterizado por amostragem parcial de seis caminhões.

O lote1 também foi de concretagem de $71 \mathrm{~m}^{3}$ de concreto (10 caminhões-betoneira e mais um complemento) e foi da mesma forma caracterizado por amostragem parcial.

$\mathrm{Na}$ obra 2, foi amostrado apenas um lote de outra central dosadora (Lote $2-27 / 11 / 08$ ). 0 lote estudado foi de $40 \mathrm{~m}^{3}$ de concreto (5 caminhões-betoneira) e foi caracterizado por amostragem total da ABNT NBR 12655 (2006), já que a concretagem foi de volume menor.

Em cada uma das obras, foi realizado um conjunto de ensaios no concreto fresco, conforme descrito no item 4.3.1; sendo que, cada ensaio foi realizado com uma repetição. 
O fluxograma da Figura 26 apresenta o plano de amostragem.
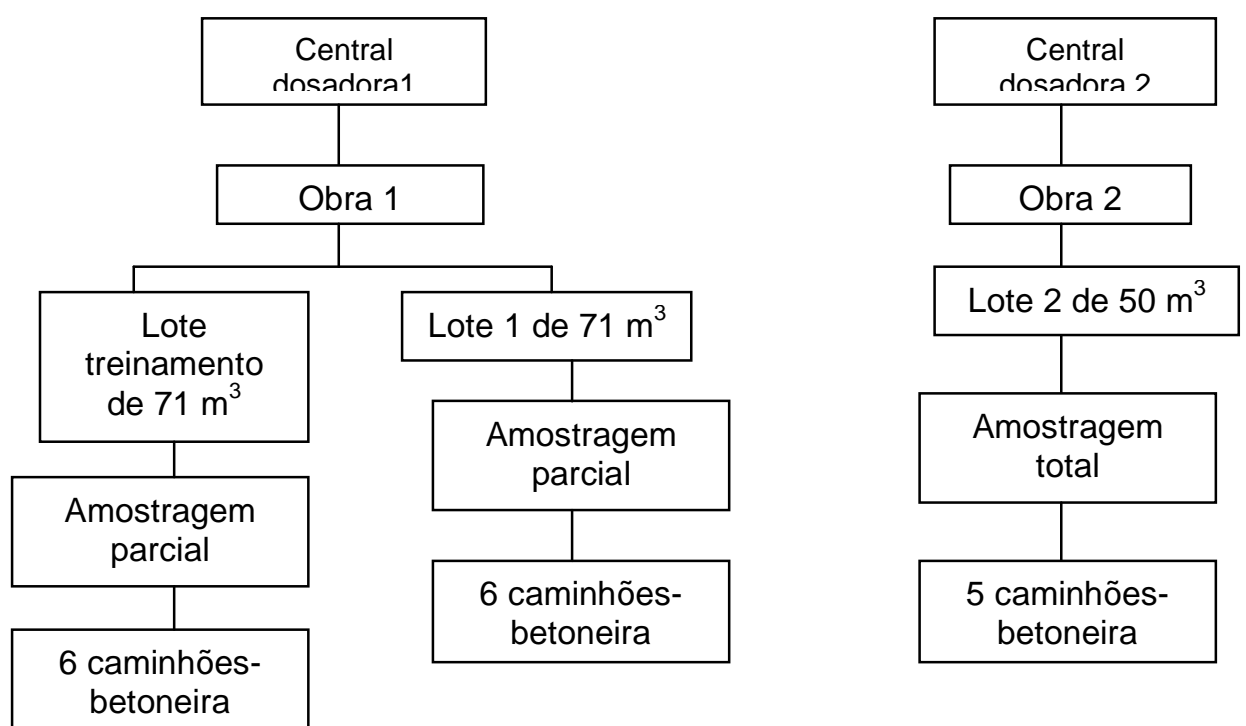

Figura 26 - Descrição geral da amostragem dos lotes analisados

\subsubsection{Caracterização dos materiais constituintes e dosagem dos concretos}

Os materiais constituintes e respectivas dosagens dos concretos deste estudo foram integralmente definidos pelas respectivas centrais produtoras, sem qualquer envolvimento prévio deste autor e de seu orientador, limitando-se este programa experimental a analisar a variação e a relação entre as propriedades dos concretos fresco e endurecido, como descrito nos itens 4.3.1 e 4.3.2.

As características dos materiais de cada lote foram solicitadas em visita preliminar à respectiva concreteira produtora, com base na ABNT NBR 12654 (1992), através de certificados próprios ou de terceiros e foram confirmadas apenas para propriedades de interesse da pesquisa.

Para tanto, em mês precedente ao estudo de campo, foram coletados e caracterizados os agregados, nas duas concreteiras, com dados principais resumidos na Figura 27 e 28 . Os resultados das análises estão apresentados no Apêndice A. Como é possível verificar, pelos dados resumidos nessas figuras, tanto o cimento quanto os agregados eram de diferentes fabricantes e fornecedores. A central dosadora 2 trabalhava com agregados graúdo e miúdo um pouco mais finos do que a central dosadora 1. 


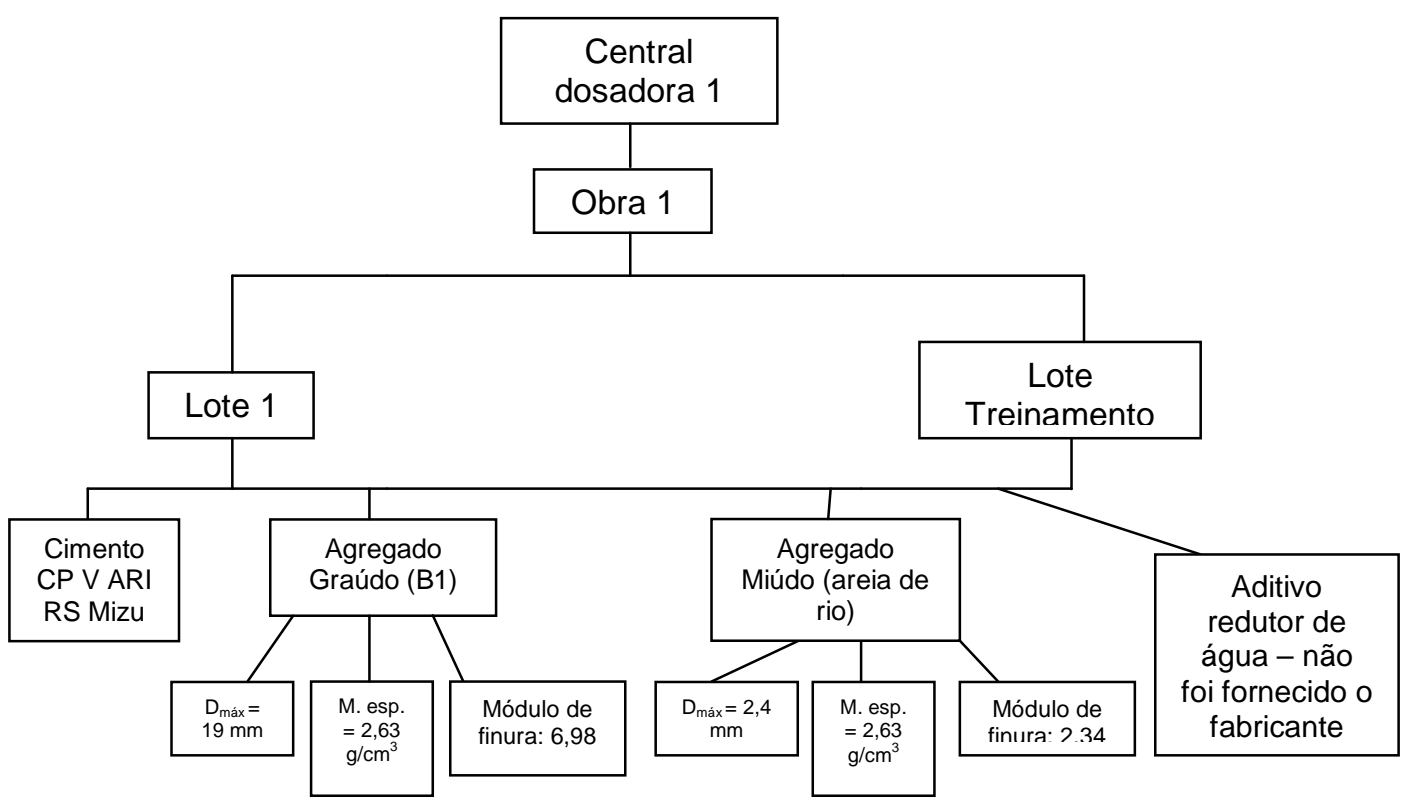

Figura 27 - Resumo das características dos materiais utilizados nos concretos amostrados da obra 1, produtora dos lotes 1 e treinamento.

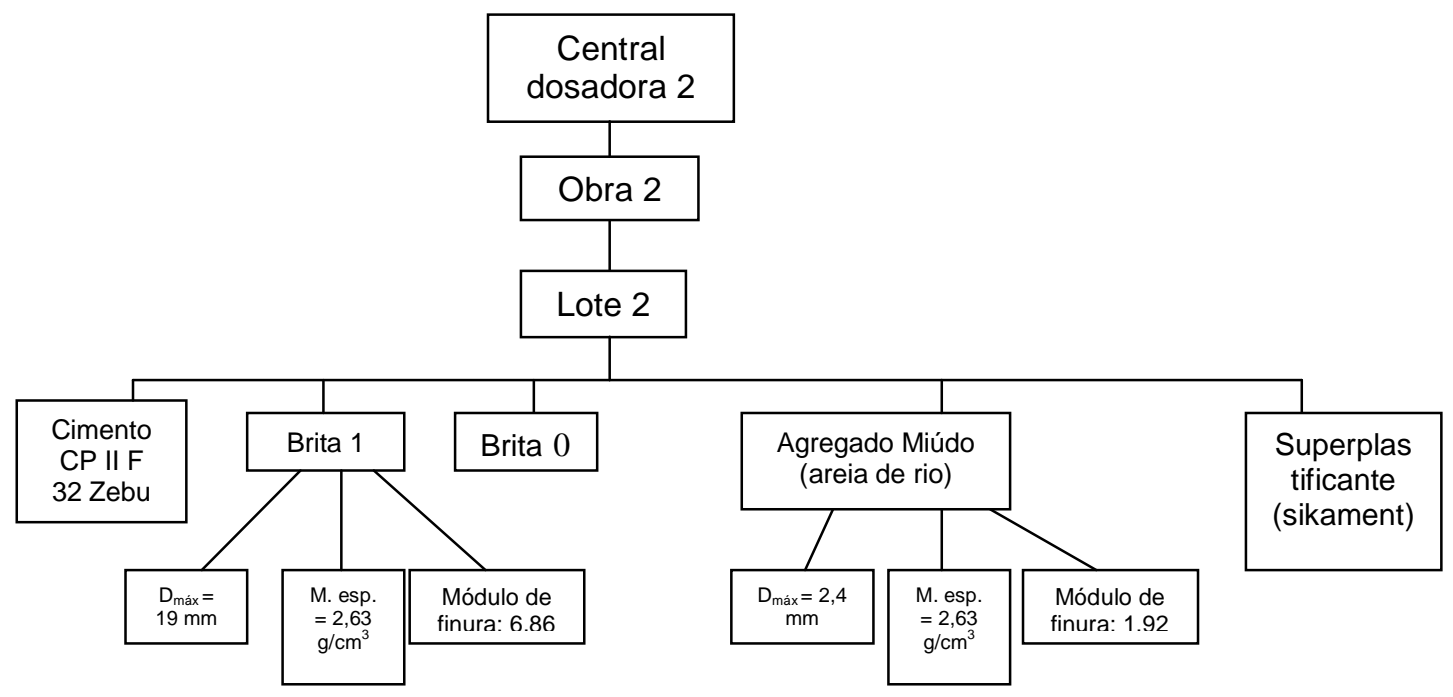

Figura 28 - Resumo das características materiais utilizados nos concretos amostrados da obra 2, produtora do lote 2. 
De forma ideal, a amostragem e caracterização deveria ter sido repetida também nas datas de produção dos lotes em estudo, mas isto foi realizado apenas em parte, como informado a seguir.

As amostras coletadas na central de concreto na data de cada concretagem foram as seguintes:

a) Amostra do cimento, com cerca de $10 \mathrm{~kg}$, para ensaio de massa específica, feito por picnometria a hélio, no Laboratório de Microestrutura do Departamento de Engenharia de Construção Civil da EP USP;

b) Amostras dos agregados graúdos e miúdos com cerca de $10 \mathrm{~kg}$ cada uma, para o mesmo ensaio massa específica citado na alínea anterior. Por motivo de limitação operacional da equipe, não pode ser determinada a umidade dos agregados, em cada concretagem

\subsection{Amostragem e caracterização do concreto de cada lote}

A mesma equipe de técnicos realizou a caracterização integral dos três lotes previstos, realizando o treinamento antecipado dos ensaios e demais atividades, pela caracterização do lote treinamento, na obra 1.

As propriedades de caracterização básica de cada lote foram as normalizadas para concretos estruturais, pela ABNT NBR 6118 (2003) e ABNT NBR 12655 (2006), quais sejam:

a) Abatimento do tronco de cone segundo a ABNT NBR NM 67 (1998);

b) Resistência à compressão a 28 dias segundo a ABNT NBR 5739 (2007).

Outras propriedades no estado fresco de interesse para a previsão da capacidade potencial de proteção das armaduras, e que dizem respeito à massa específica, ao teor de ar, teor de umidade do concreto fresco e grau de compactabilidade dos concretos, foram medidas por este trabalho, conforme item 4.3.1. É uma contribuição importante desta pesquisa, pois não há publicações que discutam as conseqüências da variação destas propriedades em controle tecnológico real de obras.

No estado endurecido, foi testado um método inédito em obras brasileiras de cura acelerada em temperatura moderada e que pode ser praticado por empresas de controle tecnológico ou por centrais dosadoras.

Assim, além da resistência à compressão, outras propriedades indicadoras de qualidade do concreto para a proteção de armaduras, como a resistência à tração, absorção capilar, absorção de água total e índice de vazios foram previstas para caracterização por cura acelerada comparada à cura normal. A qualidade de proteção potencial do aço pelos concretos 
foi ainda analisada por medidas de resistência à carbonatação e ao ingresso de íons cloreto, em procedimentos acelerados, e também por medidas de potencial de corrosão em barras de aço nos concretos em cura normal, como detalhado nos itens 4.3.6 e 4.3.7.

\subsubsection{Amostragem e ensaios no concreto fresco}

O procedimento geral de amostragem de cada caminhão seguiu a ABNT NBR 12655 (2006). Dois carrinhos de 90L foram amostrados por caminhão, o primeiro após aproximadamente os $15 \%$ iniciais da descarga do caminhão e o segundo, antes dos $15 \%$ finais de descarga do caminhão.

Assim, a amostragem e a caracterização dos concretos de cada caminhão-betoneira seguiram o fluxograma, conforme a Figura 29.

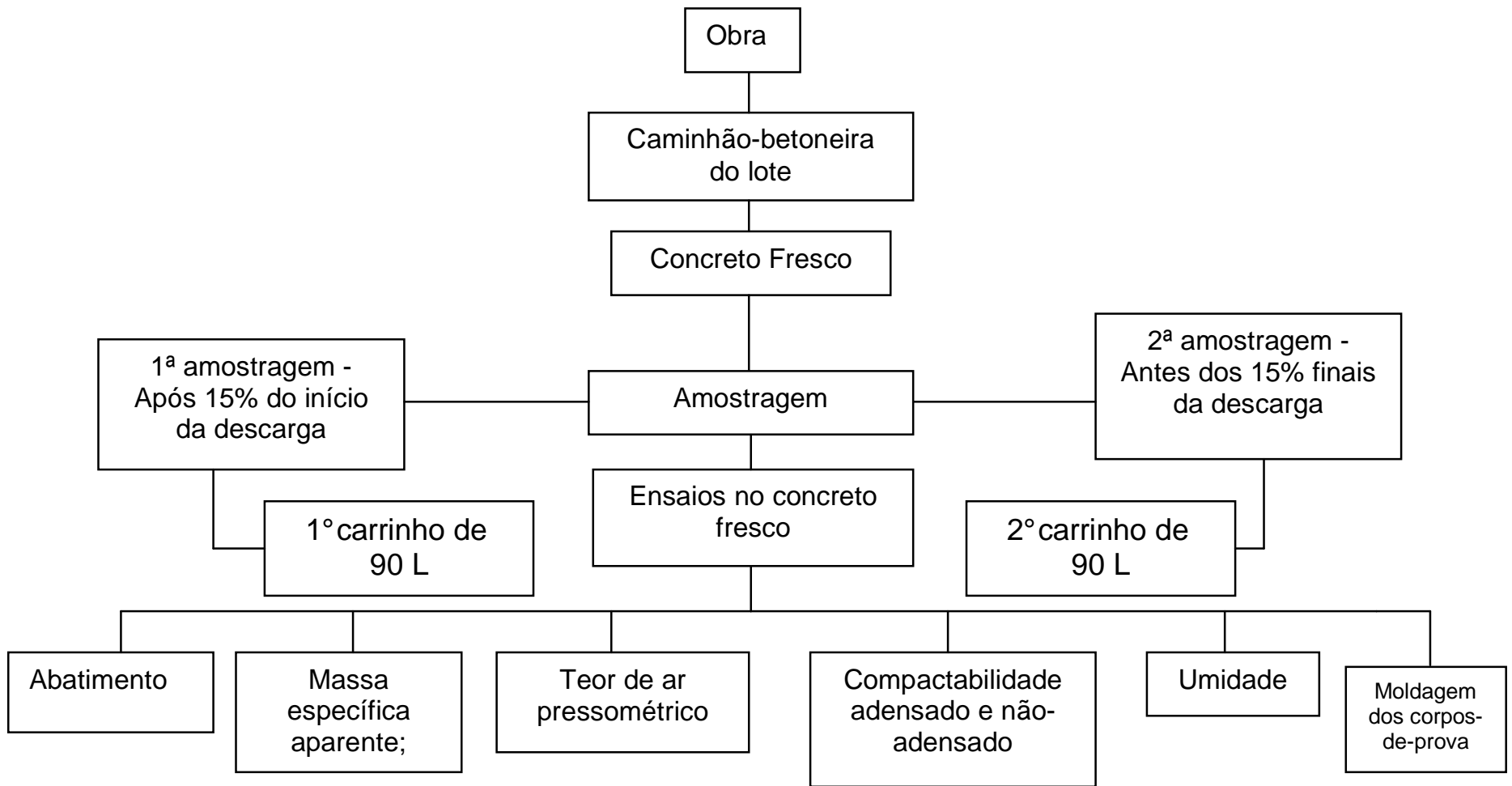

Figura 29 - Fluxograma da amostragem e dos ensaios no concreto fresco de cada caminhãobetoneira integrante da amostra constituída para representar cada lote desta pesquisa. 
A Figura 30 ilustra o momento da amostragem em uma das obras.
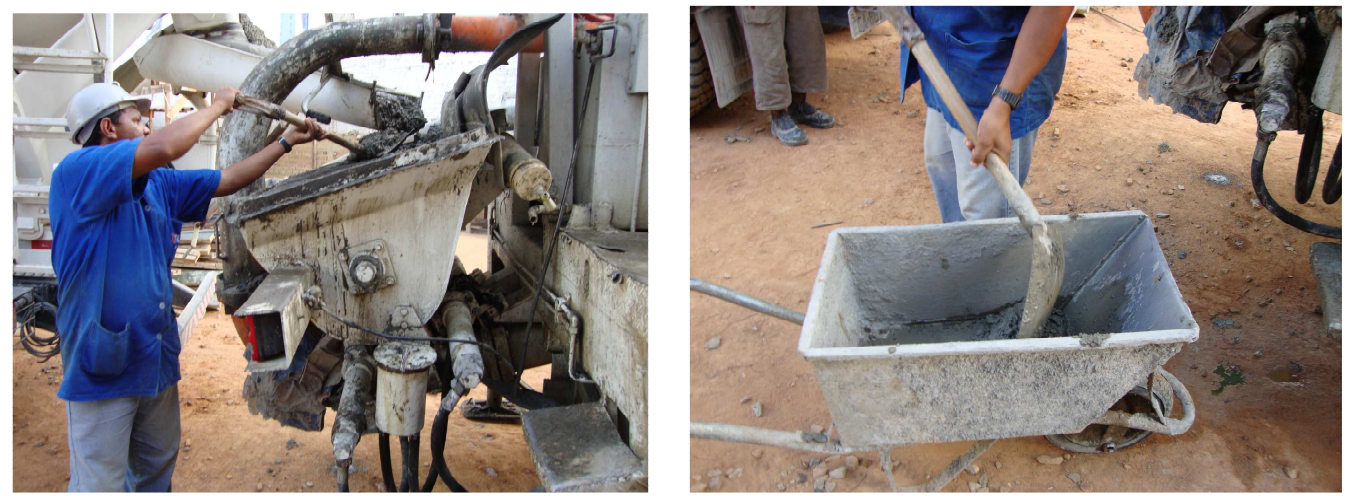

Figura 30 - Amostragem do concreto fresco na descarga do caminhão-betoneira na grelha de bombeamento e transferência para carrinho de $90 \mathrm{~L}$.

Os técnicos participantes do programa experimental possuíam quatro anos de experiência em laboratório tecnológico de concreto, em atividades de rotina de laboratório, e estão reunidos na Figura 31, como forma de reconhecimento do trabalho que realizaram.

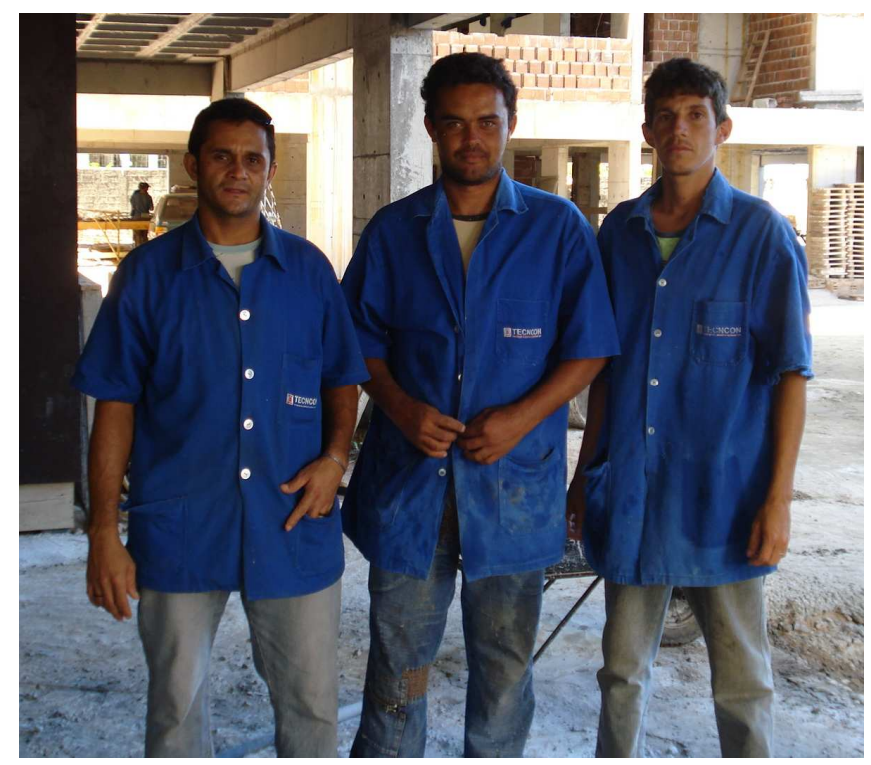

Figura 31 - Equipe de técnicos que participaram das concretagens

Nas concretagens, o primeiro técnico ficou responsável pela coleta do concreto na descarga, moldagem dos corpos-de-prova armados e auxílio aos demais membros da equipe; o segundo técnico da equipe foi o responsável pela moldagem de todos os corpos-de-prova cilíndricos com $10 \times 20 \mathrm{~cm}$, e o terceiro técnico e este pesquisador executaram os ensaios no 
concreto fresco e anotações respectivas. Este pesquisador foi o responsável direto pelo ensaio de teor de ar pelo método pressométrico. A Figura 32 apresenta os três técnicos participantes das concretagens.

As propriedades de caracterização básica do concreto fresco foram as seguintes: abatimento, massa específica aparente, teor de ar pressométrico e gravimétrico, compactabilidade, relação água/materiais seco (umidade), conforme apresentados na Tabela 25. Também foi prevista a caracterização do teor de finos total abaixo de $75 \mu \mathrm{m}$ do concreto fresco como forma de estimar o consumo de aglomerantes, mas não foi possível a realização por motivos operacionais.

Tabela 25 - Resumo de ensaios no concreto fresco por caminhão amostrado em cada lote.

\begin{tabular}{|c|c|c|c|c|}
\hline $\begin{array}{l}\text { Propriedade } \\
\text { analisada }\end{array}$ & $\begin{array}{c}\text { Método de } \\
\text { ensaio }\end{array}$ & $\begin{array}{l}\frac{\pi}{3} \\
\frac{\pi}{\pi} \\
\frac{\pi}{2} \\
\frac{0}{0}\end{array}$ & $\begin{array}{l}\frac{0}{0} \\
\frac{\pi}{0} \\
\frac{0}{5}\end{array}$ & $\begin{array}{l}\text { Número de } \\
\text { ensaios por } \\
\text { caminhão }\end{array}$ \\
\hline $\begin{array}{l}\text { Abatimento do } \\
\text { tronco de cone } \\
\text { "slump" }\end{array}$ & $\begin{array}{c}\text { ABNT NBR } \\
\text { NM } 67 \text { (1998) }\end{array}$ & $A_{b}$ & $\mathrm{~cm}$ & 2 \\
\hline $\begin{array}{c}\text { Massa específica } \\
\text { aparente }\end{array}$ & $\begin{array}{l}\text { ABNT NBR } \\
9833(2008)\end{array}$ & $D_{e n}$ & $\mathrm{~kg} / \mathrm{m}^{3}$ & 2 \\
\hline $\begin{array}{l}\text { Teor de ar pelo } \\
\text { método } \\
\text { pressométrico }\end{array}$ & $\begin{array}{c}\text { ABNT NBR } \\
47(2002)\end{array}$ & $A_{r}$ & $\%$ & 2 \\
\hline $\begin{array}{l}\text { Compactabiliadde } \\
\text { adensado e não } \\
\text { adensado }\end{array}$ & $\begin{array}{c}\text { BS-EN 12350- } \\
4(2008)\end{array}$ & C & $\mathrm{cm}$ & 2 \\
\hline $\begin{array}{c}\text { Umidade do } \\
\text { concreto fresco }\end{array}$ & $\begin{array}{l}\text { ABNT NBR } \\
\text { 9605(1992) }\end{array}$ & $\mathrm{H}$ & $\%$ & 2 \\
\hline
\end{tabular}

Dois ensaios de compactabilidade do concreto fresco foram adaptados a partir da BS EN 12350-4:2009. Neste trabalho adotou-se um recipiente cilíndrico de $15 \mathrm{~L}$ e altura de $250 \mathrm{~mm}$, pois é o mesmo normalizado para a massa específica pela ABNT NBR 9833 (3008), e o concreto foi colocado de duas formas:

a) Adensado: em 3 camadas iguais, aplicando-se em cada camada 30 golpes uniformes, tal que a haste de aço carbono da ABNT NBR 9833 (2008) não penetrasse na camada anteriormente adensada uma profundidade maior do que $25 \mathrm{~mm}$. Após o adensamento foi feito o rasamento das bordas superiores com régua metálica em movimentos de vai-e-vem, realizou-se a limpeza das bordas superiores e se adensou o concreto com vibrador de imersão. Quando a superfície do concreto ficou brilhosa 
ou cristalina (após, aproximadamente, $2 \mathrm{~min}$ ) retirou-se o vibrador e mediu-se a profundidade que o concreto compactou em quatro pontos, ou seja, mediu-se o quanto a sua superfície desceu, em relação à borda original do recipiente e calculouse o valor médio com precisão de milímetro.

b) Não-adensado: a medida da compactabilidade não-adensada teve uma modificação principal em relação ao ensaio anterior e mais próxima às instruções da BS EN 12350-9: 2009 e, que foi o não-adensamento do concreto ao ser lançado no recipiente, tendo o enchimento ocorrido de forma contínua. O resultado foi calculado da mesma forma.

O método de ensaio para determinação da umidade do concreto fresco foi adaptada da ABNT NBR 9605 (1992): Concreto - Reconstituição do concreto do traço de concreto fresco. O ensaio consistiu na coleta e pesagem do concreto fresco no momento da amostragem em recipientes de alumínio previamente adicionados com $100 \mathrm{ml}$ de água e $10 \mathrm{~g}$ de açúcar, com o objetivo de retardar a pega até a realização do ensaio no laboratório. Após coleta e transporte, o concreto foi exposto ao fogo em frigideira por 1 hora, após isso, foi colocado em estufa a $1^{100} \mathrm{C}$ por 24 horas. Após esse período o concreto se co foi pesado e conhecido a sua massa seca.

À exceção do abatimento, os demais ensaios da Tabela 25, visaram verificar se seria possível relacionar a resistência potencial à carbonatação e à penetração de cloretos nos concretos às medidas de massa específica e teor de ar no estado fresco, por analogia a constatações experimentais de SELMO, BUONOPANE et al. (2007), que no caso ocorreram para argamassas de reparo industrializadas com diferentes procedências e formulações.

\subsubsection{Moldagem de corpos-de-prova e ensaios no concreto endurecido}

No ato da amostragem de cada caminhão, também foram moldados corpos-de-prova para ensaios no concreto endurecido, sendo realizado cada ensaio sempre com uma repetição, conforme a Figura 32.

Para avaliação do concreto endurecido, foram moldados corpos-de-prova, conforme a ABNT NBR 5738 (2003), segundo ilustra a Figura 33, e realizados os seguintes ensaios:

a) Ensaios com dois procedimentos de cura acelerada comparada à cura normal: compressão simples, tração por compressão diametral, absorção de água por capilaridade e total, índice de vazios;

b) Ensaios com cura acelerada apenas: $\mathrm{CO}_{2}, \mathrm{Cl}$;

c) Ensaios com cura normal apenas: $\mathrm{E}_{\text {corr }}$. 
O item 4.3.3 informa detalhes e procedimentos dos três tipos de cura.
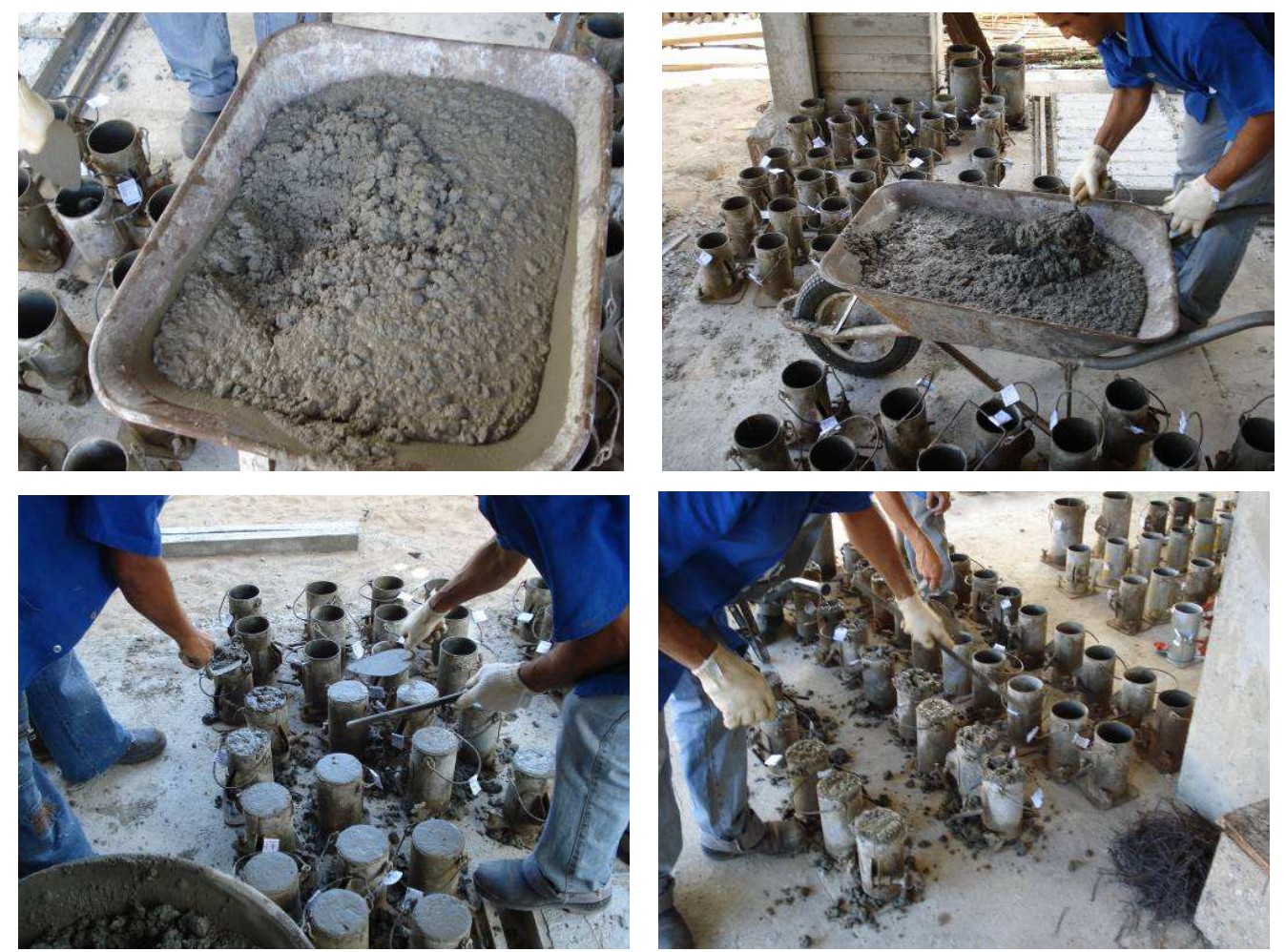

Figura 32 - Moldagem dos corpos-de-prova cilíndricos, de $10 \mathrm{~cm} \times 20 \mathrm{~cm}$, segundo a ABNT NBR $5738(2003)$

O fluxograma da Figura 34 apresenta um resumo desses ensaios. As propriedades de caracterização dos concretos podem ser agrupadas pelas idades de análise e respectivas condições de cura. 


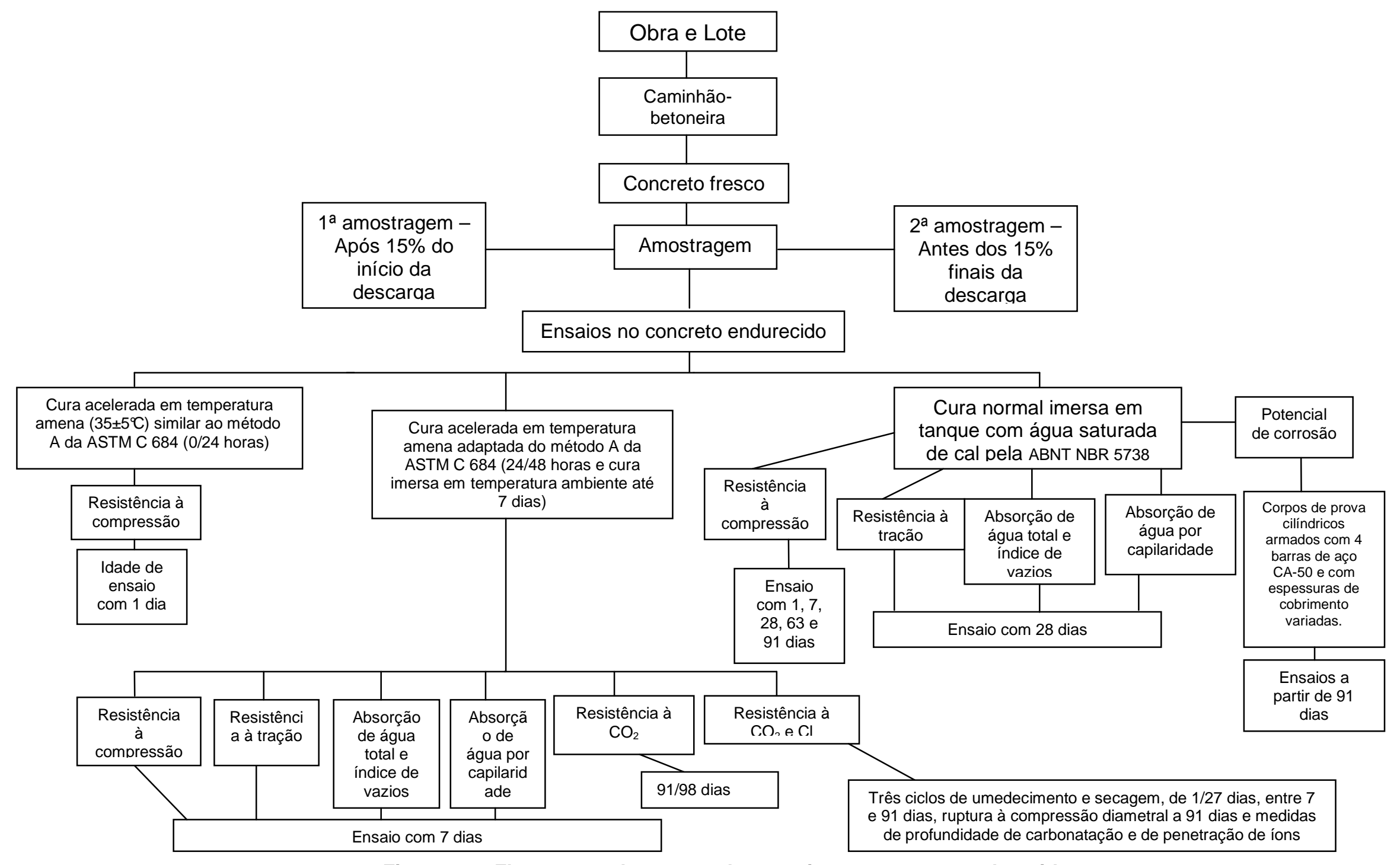

Figura 33 - Fluxograma de resumo dos ensaios no concreto endurecido 
Cada propriedade e idade no estado endurecido analisada foi caracterizada por dois corpos-de-prova irmãos de cada caminhão-betoneira constituinte do lote, conforme itens 4.3.4, 4.3.5 e 4.3.6.

Os resultados obtidos serviram para avaliar as propriedades do concreto no estado endurecido e para correlacionar os resultados dos ensaios físicos e mecânicos com as propriedades do concreto no estado fresco.

\subsubsection{Procedimentos de cura dos corpos-de-prova}

Como resumido na Figura 33, foram testados dois tipos de cura por maturação acelerada, em temperatura amena e a partir do Método A da ASTM C 684 (1999) Standard Test Method Curing and Testing Concrete Compression Test Specimens. O terceiro procedimento foi o de cura convencional da ABNT NBR 5738 (2003), adotado na empresa que apoiou este trabalho.

A cura convencional dos corpos-de-prova, pela ABNT NBR 5738 (2003) foi por total imersão em tanque de água saturada de cal após $24 \mathrm{~h}$ de moldados até idades de 7, 28, 63 e 91 dias, conforme a Figura 34, quando foram então ensaiados.

A escolha pelo Método A da ASTM C 684 (1999) foi devida à temperatura amena de aquecimento da água, que não agride a estrutura interna do concreto, além de ser operacional e economicamente mais viável para utilização por empresas de controle tecnológico.

Nas curas aceleradas, a água foi aquecida por meio de uma resistência elétrica, conforme a Figura 35. O controle de temperatura foi executado manualmente, e o registro dessa variável foi através de um termômetro imerso entre os corpos-de-prova. 

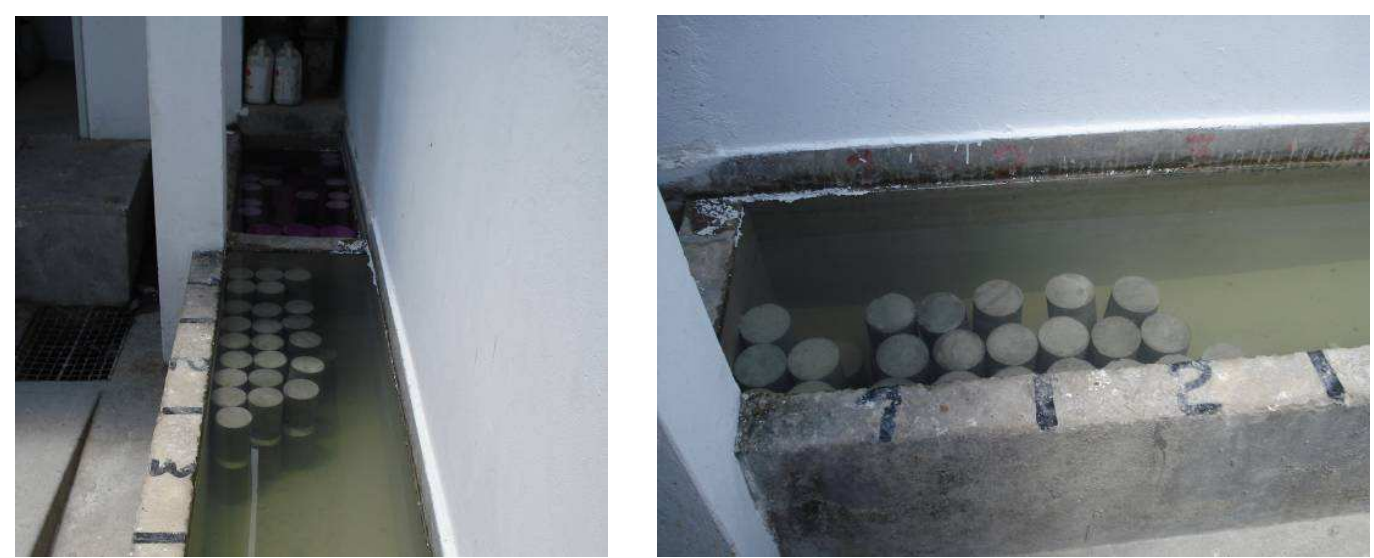

Figura 34 - Cura convencional da ABNT NBR 5738 (2003), por imersão em tanque com água saturada de cal, em pátio do laboratório de realização do estudo, em João Pessoa/PB.

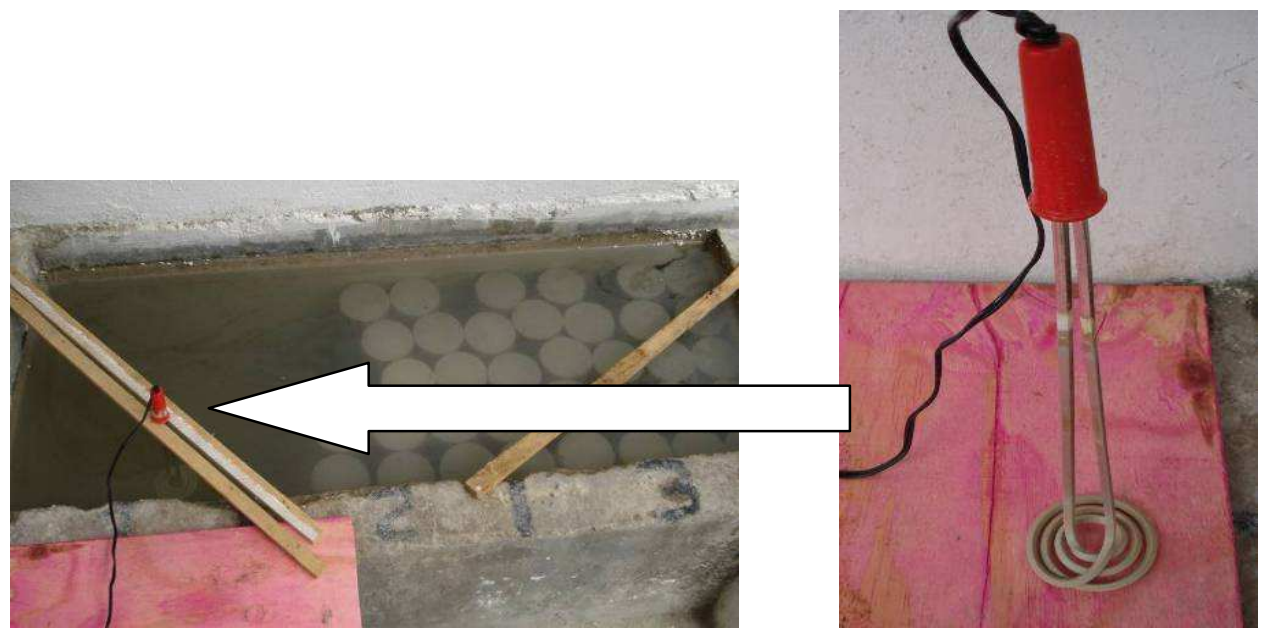

Figura 35- Detalhes da cura térmica em tanques similares ao de cura convencional, mas com aquecimento de água por resistência elétrica a $(35 \pm 3)^{\complement} \mathrm{C}$, em analogia ao método A da ASTM C 684:99.

O primeiro procedimento de cura acelerada foi o executado de forma mais comparativa ao método A da ASTM C 684 (1999), mas apenas testado para ensaios de compressão simples a 1 dia, pois assim determina este método. Para isto, os corpos-de-prova que foram colocados em cura acelerada logo após moldagem (0/24 horas), como recomenda a citada norma. Assim, neste grupo, optou-se pelo transporte dos corpos-de-prova devidamente acomodados em caixas de madeira, no final da concretagem para o laboratório de controle tecnológico, sendo isto feito cerca de 2 horas após a moldagem. A opção de transportá-los ao laboratório foi devida à falta de condições de instalação do tanque térmico na obra. 
O segundo procedimento de cura térmica aqui testado foi propositadamente defasado em relação ao período de cura do Método A da ASTM C 684 (1999) e realizado por limitações operacionais em se construir um tanque com aquecimento de água no campo. Então a cura acelerada foi postergada para o período de 24 horas a 48 horas (24/48 horas) após a moldagem, sendo que nas primeiras 24 horas os corpos-de-prova foram mantidos nas fôrmas em campo, e o transporte para o laboratório foi realizado em idade superior a $16 \mathrm{~h}$ das concretagens.

Em resumo, em ambos os procedimentos de cura acelerada adaptados do método $\mathrm{A}$ da ASTM C 684 (1999), os corpos-de-prova foram imersos em água aquecida a temperatura nominal de $(35 \pm 3)^{\circ} \mathrm{C}$ durante 24 horas, sendo o do primeiro tipo no prazo nominal de 0/24 horas de idade, com os ensaios dos corpos-de-prova à compressão simples a 1 dia. No segundo procedimento acelerado, os corpos-de-prova após o período de cura térmica entre 24 e 48 horas, permaneceram ainda em água a temperatura ambiente até 7 dias de idade. A razão de se estender o prazo de cura até 7 dias se deu como uma forma de compensar o retardo de 24 horas no início da cura térmica. Cabe observar que se considerou este estudo exploratório quanto à aceleração da maturidade do concreto e pesquisas a respeito devem prosseguir em outros trabalhos, como o de Cafange (2009).

\subsubsection{Ensaios de compressão simples e diametral}

As propriedades mecânicas estudadas foram à resistência à compressão axial e tração por compressão diametral por cura acelerada 24/48 horas mais imersão em água até 7 dias, resistência à compressão axial por cura acelerada 0/24 horas e por cura imersa em água saturada de cal por 1,7, 28, 63 e 91 dias, conforme a Figura 33 e a Tabela 26 a seguir.

O ensaio de módulo de elasticidade, embora inicialmente previsto, não pode ser realizado por falta de infra-estrutura adequada naquela ocasião, tanto no laboratório da Tecncon, quanto na UFPB e USP. Os corpos-de-prova chegaram a ser transportado para São Paulo, mas houve problemas com o equipamento de torneamento mecânico, que danificaram o paralelismo das bases dos corpos-de-prova destinados a este ensaio. Então optou-se por destinar os mesmos a ensaio acelerados em câmara de carbonatação, em idade mais avançada e que permitisse a sua pré-secagem. 
Tabela 26 - Ensaios mecânicos nos três lotes amostrados

\begin{tabular}{|c|c|c|c|c|c|c|c|}
\hline$\stackrel{9}{\stackrel{9}{0}}$ & 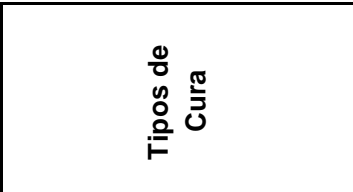 & $\begin{array}{l}\text { Idade de } \\
\text { ensaio }\end{array}$ & $\begin{array}{l}\text { Propriedades } \\
\text { analisadas nos lotes }\end{array}$ & 晃 & $\begin{array}{l}\frac{0}{2} \\
\frac{\pi}{0} \\
\text { 음 }\end{array}$ & $\begin{array}{c}\mathrm{N}^{\circ} \mathrm{de} \\
\text { corpos-de } \\
\text { prova por } \\
\text { idade e } \\
\text { cura }\end{array}$ & $\begin{array}{l}\text { Nototal de } \\
\text { corpos-de- } \\
\text { prova por } \\
\text { caminhão }\end{array}$ \\
\hline \multirow{2}{*}{$\begin{array}{c}\text { Lote } \\
\text { treinamento }\end{array}$} & $\begin{array}{c}\text { Cura acelerada ( } 24 / 48 \\
\text { horas) adaptada do método } \\
\text { A da ASTM C } 684: 99 \text { mais } \\
\text { imersão em água até } 7 \text { dias }\end{array}$ & \multirow{2}{*}{$\begin{array}{l}7 \text { e } 28 \\
\text { dias }\end{array}$} & \multirow{2}{*}{$\begin{array}{c}\text { Resistência à } \\
\text { compressão (ABN NBR } \\
\text { 5739:2007); } \\
\text { Resistência à tração por } \\
\text { compressão diametral } \\
\text { (ABNT NBR 7222:1994) }\end{array}$} & $f_{c}$ & \multirow{2}{*}{$\mathrm{MPa}$} & 2 & 4 \\
\hline & $\begin{array}{c}\text { Cura normal imersa em } \\
\text { tanque com água saturada } \\
\text { de cal }\end{array}$ & & & $f_{c t, s p}$ & & 2 & 4 \\
\hline \multirow{3}{*}{ Lote 1} & $\begin{array}{l}\text { Cura acelerada 0/24 horas, } \\
\text { mais similar ao método A da } \\
\text { ASTM C } 684: 99\end{array}$ & $1 \mathrm{dia}$ & \multirow{3}{*}{$\begin{array}{c}\text { Resistência à } \\
\text { compressão (ABN NBR } \\
\text { 5739:2007); } \\
\text { Resistência à tração por } \\
\text { compressão diametral } \\
\text { (ABNT NBR 7222:1994) }\end{array}$} & $f_{c}$ & \multirow[b]{2}{*}{$\mathrm{MPa}$} & 2 & 2 \\
\hline & $\begin{array}{l}\text { Cura acelerada ( } 24 / 48 \\
\text { horas) adaptada do método } \\
\text { A da ASTM C } 684: 99 \text { mais } \\
\text { imersão em água até } 7 \text { dias }\end{array}$ & 7 dias & & $\mathrm{f}_{\mathrm{c} ;} ; \mathrm{f}_{\mathrm{ct}, \mathrm{sp}}$ & & 2 & 4 \\
\hline & $\begin{array}{c}\text { Cura normal imersa em } \\
\text { tanque com água saturada } \\
\text { de cal }\end{array}$ & $\begin{array}{l}1,7,28,63 \\
\text { e } 91 \text { dias }\end{array}$ & & $\mathrm{f}_{\mathrm{c} ;} ; \mathrm{f}_{\mathrm{ct}, \mathrm{sp}}$ & $\mathrm{MPa}$ & 2 & 12 \\
\hline \multirow{3}{*}{ Lote 2} & $\begin{array}{l}\text { Cura acelerada 0/24 horas, } \\
\text { mais similar ao método A da } \\
\text { ASTM C } 684: 99\end{array}$ & $1 \mathrm{dia}$ & \multirow{3}{*}{$\begin{array}{c}\text { Resistência à } \\
\text { compressão (ABN NBR } \\
\text { 5739:2007); } \\
\text { Resistência à tração por } \\
\text { compressão diametral } \\
\text { (ABNT NBR 7222:1994) }\end{array}$} & $f_{c}$ & \multirow[b]{2}{*}{$\mathrm{MPa}$} & 2 & 2 \\
\hline & $\begin{array}{c}\text { Cura acelerada ( } 24 / 48 \\
\text { horas) adaptada do método } \\
\text { A da ASTM C } 684: 99 \text { mais } \\
\text { imersão em água até } 7 \text { dias }\end{array}$ & 7 dias & & $\mathrm{f}_{\mathrm{c}} ; \mathrm{f}_{\mathrm{ct}, \mathrm{sp}}$ & & 2 & 4 \\
\hline & $\begin{array}{c}\text { Cura normal imersa em } \\
\text { tanque com água saturada } \\
\text { de cal }\end{array}$ & $\begin{array}{l}1,7,28,63 \\
\text { e } 91 \text { dias }\end{array}$ & & $\mathrm{f}_{\mathrm{c} ;} \mathrm{f}_{\mathrm{ct}, \mathrm{sp}}$ & $\mathrm{MPa}$ & 2 & 12 \\
\hline
\end{tabular}




\subsubsection{Ensaios indicadores de porosidade}

As propriedades físicas estudadas foram absorção de água por capilaridade, absorção total e índice de vazios, com cura acelerada e imersão em água até 7 dias e cura normal por imersão em água saturada de cal, conforme a Tabela 27 a seguir.

Tabela 27 - Ensaios físicos nos três lotes amostrados

\begin{tabular}{|c|c|c|c|c|c|c|c|c|}
\hline Lotes & 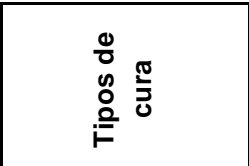 & $\begin{array}{c}\text { Idade de } \\
\text { ensaio }\end{array}$ & $\begin{array}{l}\text { Propriedades } \\
\text { analisadas nos } \\
\text { lotes }\end{array}$ & $\begin{array}{r}\text { Método } \\
\text { de ensaio }\end{array}$ & 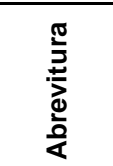 & $\begin{array}{l}\frac{0}{8} \\
\frac{\pi}{0} \\
\frac{0}{5} \\
\frac{5}{5}\end{array}$ & \begin{tabular}{|c} 
Node \\
corpos- \\
de-prova \\
por idade
\end{tabular} & $\begin{array}{l}\text { Nototal de } \\
\text { corpos-de- } \\
\text { prova por } \\
\text { cam inhão }\end{array}$ \\
\hline \multirow{2}{*}{$\begin{array}{l}\text { Lote } \\
\text { treinamento }\end{array}$} & $\begin{array}{c}\text { Cura acelerada } \\
24 / 48 \text { horas e mais } \\
\text { imersão em água } \\
\text { até } 7 \text { dias }\end{array}$ & \multirow{2}{*}{$\begin{array}{l}7 \text { e } 28 \\
\text { dias }\end{array}$} & $\begin{array}{c}\text { Absorção de água } \\
\text { por capilaridade }\end{array}$ & $\begin{array}{c}\text { NBR } \\
9779: 1995\end{array}$ & $A b_{c}$ & $\mathrm{~g} / \mathrm{cm}^{2}$ & 2 & 4 \\
\hline & $\begin{array}{l}\text { Cura normal imersa } \\
\text { em tanque com } \\
\text { água saturada de } \\
\text { cal }\end{array}$ & & $\begin{array}{c}\text { Absorção de água } \\
\text { total e índice de } \\
\text { vazios }\end{array}$ & $\begin{array}{c}\text { NBR } \\
9778: 2005\end{array}$ & $A b_{t} ; I_{v}$ & $\%$ & 2 & 4 \\
\hline \multirow{2}{*}{ Lote 1} & $\begin{array}{c}\text { Cura acelerada } \\
24 / 48 \text { horas e mais } \\
\text { imersão em água } \\
\text { até } 7 \text { dias }\end{array}$ & \multirow{2}{*}{$\begin{array}{l}7 \text { e } 28 \\
\text { dias }\end{array}$} & $\begin{array}{l}\text { Absorção de água } \\
\text { por capilaridade }\end{array}$ & $\begin{array}{c}\text { NBR } \\
9779: 1995\end{array}$ & $A b_{c}$ & $\mathrm{~g} / \mathrm{cm}^{2}$ & 2 & 4 \\
\hline & $\begin{array}{c}\text { Cura normal imersa } \\
\text { em tanque com } \\
\text { água saturada de } \\
\text { cal }\end{array}$ & & $\begin{array}{c}\text { Absorção de água } \\
\text { total e índice de } \\
\text { vazios }\end{array}$ & $\begin{array}{c}\text { NBR } \\
9778: 2005\end{array}$ & $A b_{t} ; I_{v}$ & $\%$ & 2 & 4 \\
\hline \multirow{2}{*}{ Lote 2} & $\begin{array}{c}\text { Cura acelerada } \\
\text { 24/48 horas e mais } \\
\text { imersão em água } \\
\text { até } 7 \text { dias }\end{array}$ & \multirow{2}{*}{$\begin{array}{l}7 \text { e } 28 \\
\text { dias }\end{array}$} & $\begin{array}{l}\text { Absorção de água } \\
\text { por capilaridade }\end{array}$ & $\begin{array}{c}\text { NBR } \\
9779: 1995\end{array}$ & $A b_{c}$ & $\mathrm{~g} / \mathrm{cm}^{2}$ & 2 & 4 \\
\hline & $\begin{array}{c}\text { Cura normal imersa } \\
\text { em tanque com } \\
\text { água saturada de } \\
\text { cal }\end{array}$ & & $\begin{array}{c}\text { Absorção de água } \\
\text { total e índice de } \\
\text { vazios }\end{array}$ & $\begin{array}{c}\text { NBR } \\
9778: 2005\end{array}$ & $A b_{t} ; l$ & $\%$ & 2 & 4 \\
\hline
\end{tabular}

\subsubsection{Ensaios acelerados quanto à penetração de cloretos e $\mathrm{CO}_{2}$}

A avaliação da resistência à carbonatação e cloretos foi realizada entre 7 a 91 dias de idade dos concretos maturados pelo segundo procedimento de cura acelerada e por dois tipos de exposição, a saber:

a) A ação simultânea de cloretos e $\mathrm{CO}_{2}$ por ciclagem de corpos-de-prova submetidos a três ciclos de umedecimento em solução de 3,5\% de $\mathrm{NaCl}$ seguido de secagem em temperatura amena, no período entre 7 e 91 dias; 
b) A ação de $\mathrm{CO}_{2}$ sob pressão por 7 dias, em câmara regulada para pressão de $5 \% \mathrm{e}$ umidade relativa de $65 \pm 10 \%$, em idade dos concretos após 91 dias e com présecagem adiante informada.

Tabela 28 - Ensaios acelerados nos três lotes amostrados

\begin{tabular}{|c|c|c|c|c|c|c|c|}
\hline Lotes & $\begin{array}{l}\stackrel{0}{0} \text { 뜐 } \\
\text { 을 인 }\end{array}$ & $\begin{array}{l}\text { Idade de } \\
\text { ensaio }\end{array}$ & Propriedade analisada & 这 & $\begin{array}{l}\frac{0}{0} \\
\frac{\pi}{0} \\
\frac{0}{c}\end{array}$ & $\begin{array}{c}N^{\circ} \text { de } \\
\text { corpos-de- } \\
\text { prova por } \\
\text { idade }\end{array}$ & $\begin{array}{c}N^{\circ} \text { total de } \\
\text { corpos-de-prova } \\
\text { por cam inhão }\end{array}$ \\
\hline \multirow[t]{2}{*}{$\begin{array}{c}\text { Lote } \\
\text { treinamento }\end{array}$} & \multirow{2}{*}{$\begin{array}{l}\text { Cura acelerada } \\
24 / 48 \text { horas e } \\
\text { mais imersão } \\
\text { em água até } 7 \\
\text { dias }\end{array}$} & $\begin{array}{l}\text { Entre } 7 \text { e } 91 \\
\quad \text { dias }\end{array}$ & $\begin{array}{c}\text { Resistência à carbonatação } \\
\text { e cloretos simultânea em } \\
\text { corpos-de-prova } \\
\text { submetidos a } 3 \text { ciclos de } \\
\text { molhagem e secagem }\end{array}$ & $\mathrm{Cl}-\mathrm{CO}_{2}$ & $\mathrm{~mm}$ & 2 & 2 \\
\hline & & $\begin{array}{l}\text { Entre } 91 \text { e } 98 \\
\text { dias }\end{array}$ & $\begin{array}{l}\text { Resistência à carbonatação } \\
\text { em câmara com } 5 \% \text { de } \mathrm{CO}_{2}\end{array}$ & $\mathrm{CO}_{2-91 \mathrm{~d}}$ & $\mathrm{~mm}$ & 2 & 2 \\
\hline \multirow[t]{2}{*}{ Lote 1} & \multirow{2}{*}{$\begin{array}{l}\text { Cura acelerada } \\
24 / 48 \text { horas e } \\
\text { mais imersão } \\
\text { em água até } 7 \\
\text { dias }\end{array}$} & $\begin{array}{l}\text { Entre } 7 \text { e } 91 \\
\quad \text { dias }\end{array}$ & $\begin{array}{c}\text { Resistência à carbonatação } \\
\text { e cloretos simultânea em } \\
\text { corpos-de-prova } \\
\text { submetidos a } 3 \text { ciclos de } \\
\text { molhagem e secagem }\end{array}$ & $\mathrm{Cl}-\mathrm{CO}_{2}$ & $\mathrm{~mm}$ & 2 & 2 \\
\hline & & $\begin{array}{c}\text { Entre } 91 \text { e } 98 \\
\text { dias } \\
\end{array}$ & $\begin{array}{l}\text { Resistência à carbonatação } \\
\text { em câmara com } 5 \% \text { de } \mathrm{CO}_{2}\end{array}$ & $\mathrm{CO}_{2-91 \mathrm{~d}}$ & $\mathrm{~mm}$ & 2 & 2 \\
\hline \multirow[t]{2}{*}{ Lote 2} & \multirow[t]{2}{*}{$\begin{array}{l}\text { Cura acelerada } \\
24 / 48 \text { horas e } \\
\text { mais imersão } \\
\text { em água até } 7 \\
\text { dias }\end{array}$} & $\begin{array}{l}\text { Entre } 7 \text { e } 91 \\
\quad \text { dias }\end{array}$ & $\begin{array}{c}\text { Resistência à carbonatação } \\
\text { e cloretos simultânea em } \\
\text { corpos-de-prova } \\
\text { submetidos a } 3 \text { ciclos de } \\
\text { molhagem e secagem }\end{array}$ & $\mathrm{Cl}-\mathrm{CO}_{2}$ & $\mathrm{~mm}$ & 2 & 2 \\
\hline & & $\begin{array}{l}\text { Entre } 91 \text { e } 98 \\
\text { dias }\end{array}$ & $\begin{array}{l}\text { Resistência à carbonatação } \\
\text { em câmara com } 5 \% \text { de } \mathrm{CO}_{2}\end{array}$ & $\mathrm{CO}_{2-91 \mathrm{~d}}$ & $\mathrm{~mm}$ & 2 & 2 \\
\hline
\end{tabular}

Os subitens que seguem ilustram e descrevem os procedimentos específicos dos dois tipos de exposição dos corpos-de-prova respectivos de cada lote e informados na Tabela 28.

\section{a) Ensaio acelerado de resistência à carbonatação e cloretos por ciclagem}

A exposição acelerada a $\mathrm{CO}_{2}$ e íons cloreto, foi realizada entre 7 a 91 dias de idade dos concretos, maturados por cura acelerada entre $24 / 48$ horas e cura normal até 7 dias, conforme a Figura 34, mediante três ciclos de umedecimento e secagem resumidos na Tabela 29. 
Tabela 29 - Etapas do ensaio cíclico repetido por três vezes entre 7 e 91 dias de idade dos concretos com maturação acelerada.

\begin{tabular}{|c|c|c|}
\hline Etapa & Duração & Condicionamento \\
\hline Umedecimento & 1 dia & $\begin{array}{c}\text { Imersão total em água com } \\
3,5 \% \text { de NaCl }\end{array}$ \\
\hline Secagem & 27 dias & $\begin{array}{c}\text { Caixa térmica ventilada } \\
\text { parcialmente controlada para } \\
45 \pm 5 \mathrm{C}\end{array}$ \\
\hline
\end{tabular}

A condição de umedecimento consistiu em submeter os corpos-de-prova à imersão total em solução de água destilada com 3,5\% de $\mathrm{NaCl}$ por 24 horas. Esta imersão foi realizada em duas etapas, sendo a primeira de uma hora de duração e feita até a metade da altura do corpode-prova, e outra após uma hora até cobrir o corpo-de-prova, conforme a Figura 36.

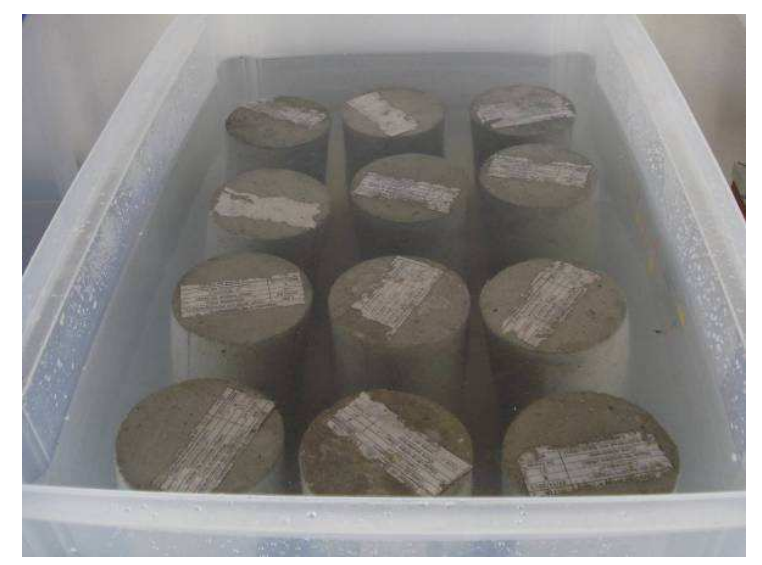

Figura 36 - Etapa de imersão total em solução de 3,5\% de $\mathrm{NaCl}$ por 24 horas

Por restrições de infra-estrutura para realizar esta pesquisa, a secagem acelerada dos corpos-de-prova foi realizada em uma caixa de secagem, construída em alvenaria e forrada por folhas de isopor e papel alumínio, aquecida por radiação solar no período diurno e por lâmpadas de $100 \mathrm{~W}$ fixadas na sua tampa superior móvel no período noturno, conforme a Figura 37.

A condição de secagem consistiu em dispor os corpos-de-prova na citada caixa térmica ventilada em ambiente externo e manter a sua temperatura em $45^{\circ} \mathrm{C} \pm 5^{\circ} \mathrm{C}$ por 27 dias, controlando a sua massa semanalmente. 

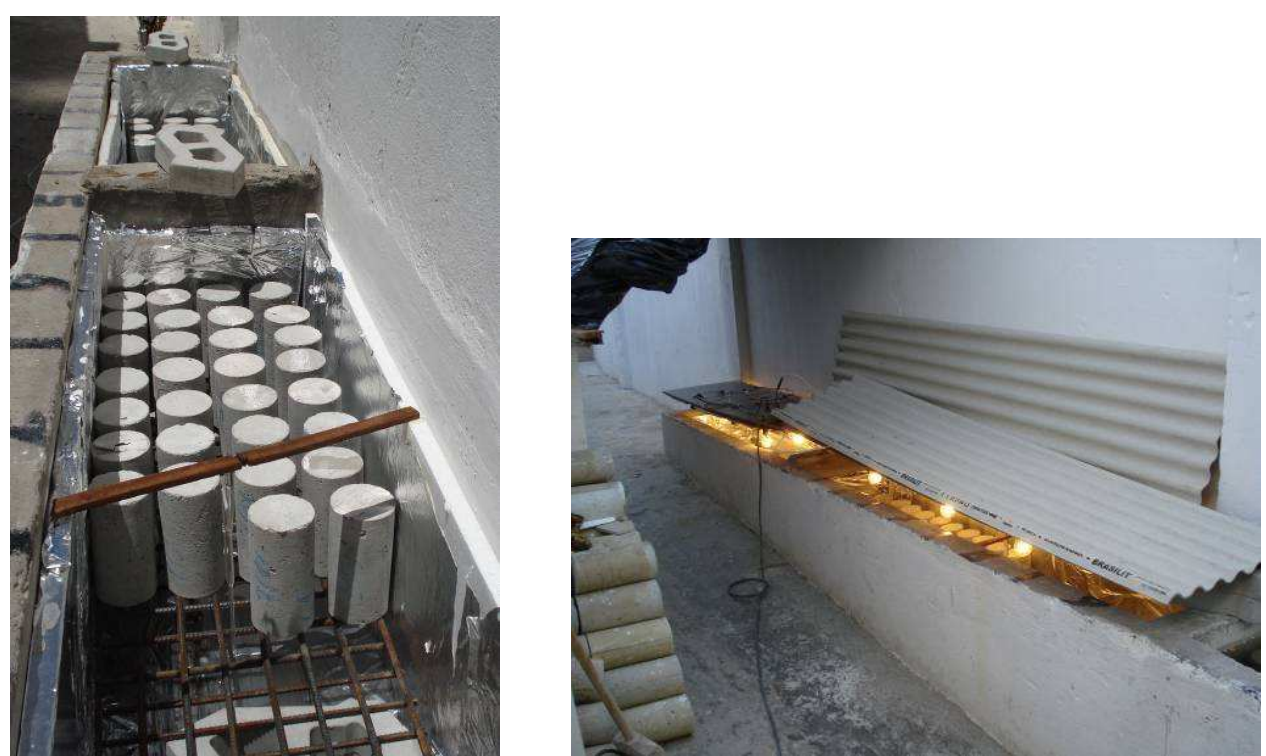

Figura 37 - Caixa térmica de secagem dos corpos-de-prova, nos períodos diurno e noturno

O ciclo descrito na Tabela 29 foi repetido por três vezes e na idade de 91 dias, os corposde-prova foram rompidos diametralmente e avaliada as suas profundidades de carbonatação e de penetração de cloretos. De cada corpo-de-prova com dimensões de $10 \mathrm{~cm} \times 20 \mathrm{~cm}$, uma metade foi destinada à medida de cloretos, e a outra à medida de carbonatação.

A profundidade de carbonatação foi obtida pelo método tradicional de indicador de $\mathrm{pH}$, a fenolftaleína. A solução foi assim preparada:

$\checkmark \quad 1 \%$ de fenolftaleína em $70 \%$ de álcool etílico e $29 \%$ de água destilada.

A profundidade de penetração de cloretos foi medida pelo método colorimétrico com solução de $0,1 \mathrm{M}$ de nitrato de prata, por ser um método rápido e barato, já testado no Brasil desde JUCÁ (2002). Entre outros o método de aspersão de nitrato de prata é qualitativo e indica a presença ou não de cloretos livres em amostras de concreto ou argamassa, sendo também usado em inspeção de estruturas. Quando a solução de nitrato de prata é aspergida na superfície ocorre uma reação fotoquímica. Esta reação somente ocorre em presença de luz ou é catalisada pela mesma. Onde há presença de cloretos livres, ocorre a formação de um precipitado branco, denominado cloreto de prata e onde não há cloretos ou os cloretos encontram-se na forma combinada, ocorre à formação de um precipitado marrom, o óxido de prata (JUCÁ, 2002). 
Assim, os respectivos corpos-de-prova de cada lote foram ensaiados à tração por compressão diametral, e uma metade de cada destinada à medida de penetração de cloretos e a outra à medida de carbonatação, pelos ensaios colorimétricos descritos.

Tanto para a medida de frente de carbonatação quanto para frente de cloretos, as seções de análise foram imersas por $1 \mathrm{~min}$, em respectivos recipientes e como ilustra a Figura 38.

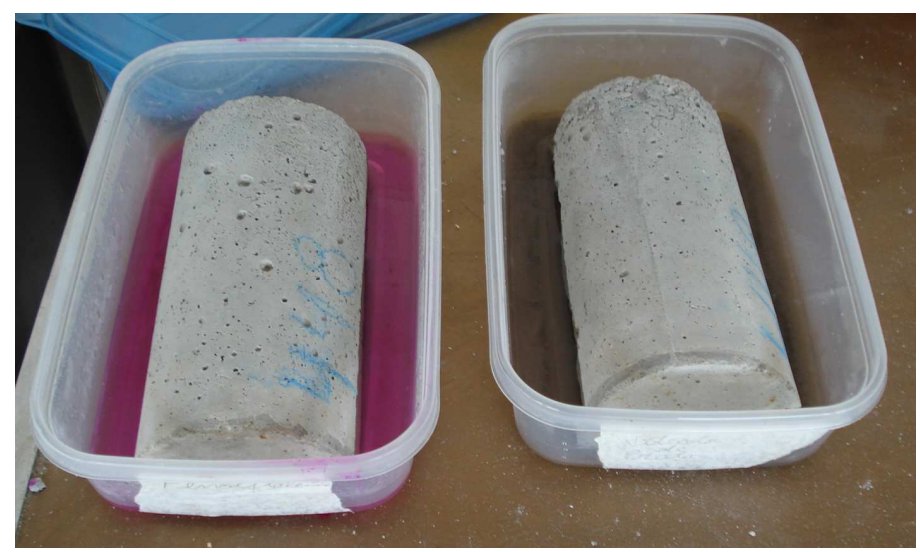

Figura 38 - Imersão das seções dos corpos-de-prova em solução de fenolftaleína e nitrato de prata.

Com vistas a tirar dúvidas sobre a contaminação da solução de nitrato de prata por cloretos livres na superfície externa de imersão dos corpos-de-prova, pelo procedimento da Figura 38, já que algum teor de cloreto livre poderia estar presente na superfície externa de cada corpo-de-prova, foi decidido repetir as medidas de penetração de cloretos pela fratura de outras duas seções, nos terços médios de uma mesma metade, formando duas novas seções (TS - Terço superior e TI - Terço inferior) e então efetuando-se nova aspersão da solução de nitrato de prata com borrifador, em cada uma. A Figura 39 ilustra o corte feito em cada metade utilizada, o corte TS representa o terço superior e o corte TI representa o terço inferior. 


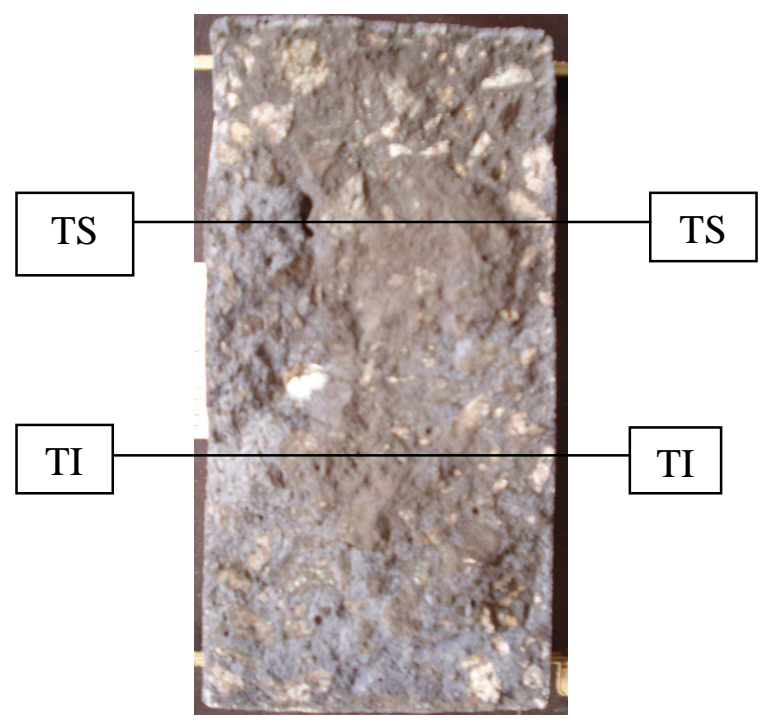

Figura 39 - llustração de como a metade dos corpos-de-prova foi seccionada em terços superior e inferior, para aspersão de solução nitrato de prata

\section{b) Ensaio acelerado de resistência à carbonatação em câmara de $\mathrm{CO}_{2}$}

$\mathrm{O}$ ensaio de resistência à carbonatação por exposição $\mathrm{CO}_{2}$ sob pressão, foi realizado com duração de 7 dias em câmara semi-automática da Bass, conforme a Figura 40, para as seguintes condições de operação:

a) Pressão nominal a $5 \%$ de $\mathrm{CO}_{2}$;

b) Umidade relativa de $65 \pm 10 \%$, com limites registrados durante os ensaios;

c) Temperatura de $23 \pm 3^{\circ} \mathrm{C}$, com limites registrados durante os ensaios.

A profundidade de carbonatação foi obtida pelos métodos tradicionais de indicadores de $\mathrm{pH}$, fenolftaleína e timolftaleína. As soluções foram assim preparadas, segundo indicações de Figueiredo (2005):

a) Solução de fenolftaleína: $1 \%$ de fenolftaleína em $70 \%$ de álcool etílico e $29 \%$ de água destilada;

b) Solução de timolftaleína: $0,4 \mathrm{~g}$ de timolftaleína dissolvida em $600 \mathrm{~cm}^{3}$ de etanol, e após diluída com água até $1000 \mathrm{~cm}^{3}$. 

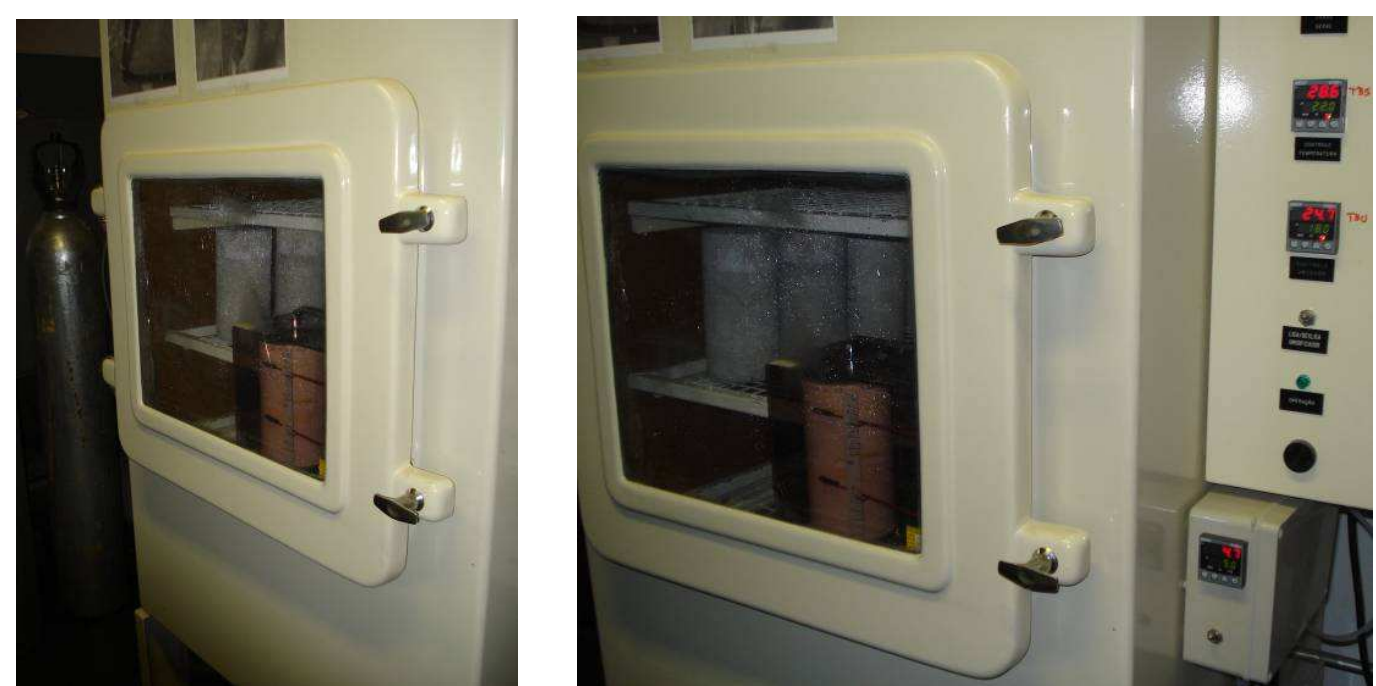

Figura 40 - Câmara de $\mathrm{CO}_{2}$ semi-automática da Bass utilizada na pesquisa no laboratório da USP

Por questões de transporte de João Pessoa/PB para o laboratório da USP e ainda por problemas iniciais para regularizar a umidade relativa da câmara de carbonatação, a présecagem dos corpos-de-prova de cada lote, antes da exposição ao $\mathrm{CO}_{2}$ sob pressão, diferiu um pouco, e pode ser assim resumida:

a) Equipamento da pré-secagem: estufa ventilada da marca Fanem, regulada para $40 \pm 5{ }^{\circ}$;

b) Idade de início da pré-secagem dos concretos: $35 \pm 8$ dias, sendo 42 dias (Lote treinamento); 33 dias (Lote 1) e 27 dias (Lote 2);

c) Duração da pré-secagem: $49 \pm 8$ dias, sendo 49 dias (Lote treinamento); 52 dias (Lote 1) e 57 dias (Lote 2);

$\mathrm{A}$ idade de exposição dos concretos à câmara de $\mathrm{CO}_{2}$ nas condições já informadas neste item, então ocorreu a $91 \pm 8$ dias de idade dos concretos, a saber:

a) Lote treinamento: exposição de 99 a 106 dias de idade;

b) Lote 1: exposição de 85 a 92 dias de idade;

c) Lote 2: exposição de 84 a 91 dias de idade. 


\subsubsection{Potencial de corrosão de armaduras em cura normal do concreto}

A medida de potencial foi feita em corpos-de-prova cilíndricos armados com quatro barras de aço-carbono CA 50, com diâmetro nominal de $10 \mathrm{~mm}$. O aço foi adquirido em única compra no mesmo estabelecimento comercial onde as construtoras participantes do estudo abasteciam as suas obras.

Para moldagem, as barras foram cortadas com $15 \mathrm{~cm}$ de comprimento e envoltas por fita adesiva flexível, em dois pontos, por onde passaram duas linhas de estribo, este foi feito com arame recozido de $18 \mathrm{~mm}$, conforme a Figura 41.

Para tornar o trabalho o mais próximo à realidade de obra e ainda por questões de manuseio das formas no campo, as barras não sofreram nenhum tipo de limpeza prévia. $A$ área de exposição ao concreto foi limitada por fita isolante com área nominal de aproximadamente 3 $\mathrm{cm}^{2}$.

Os corpos-de-prova ficaram com comprimentos de $10 \pm 5 \mathrm{~cm}$ e cobrimentos variáveis, com espessuras de $1,5 \mathrm{~cm}, 2,5 \mathrm{~cm}$ e $3,5 \mathrm{~cm}$, conforme fluxogramas das Figuras 43 e 44 . Após confecção das armaduras de aço carbono, elas foram introduzidas com um suporte de isopor dentro de formas cilíndricas metálicas de $15 \times 30 \mathrm{~cm}$.
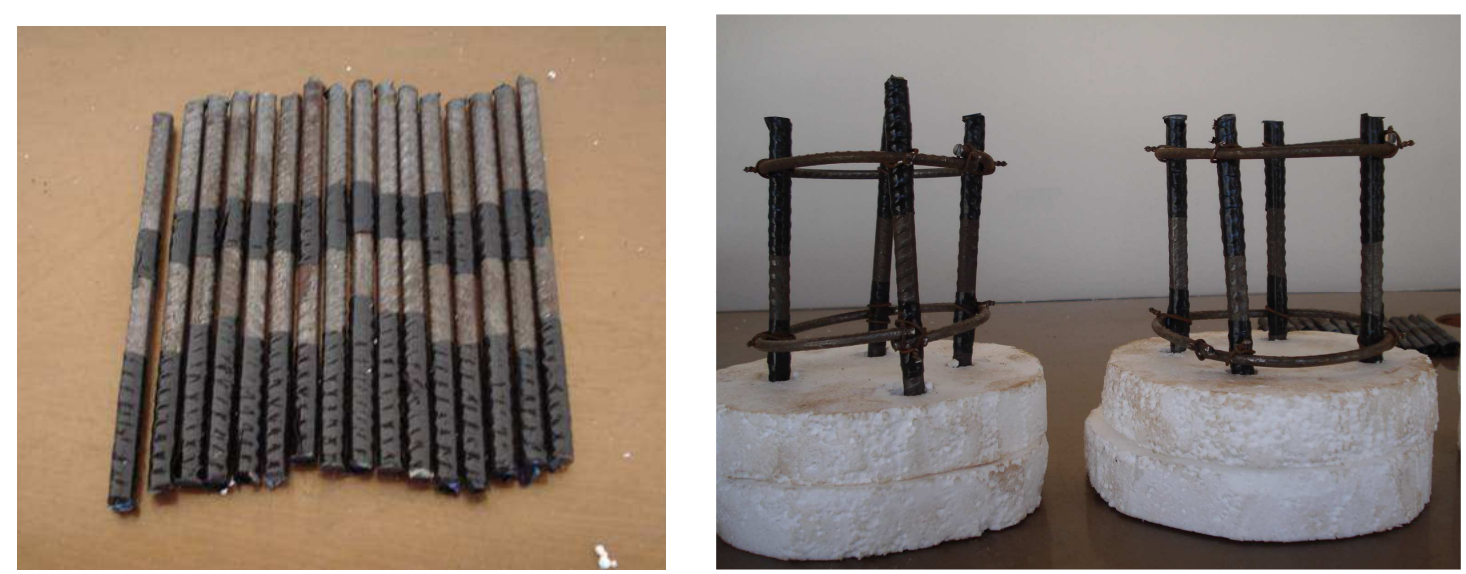

Figura 41 - Detalhes das barras utilizadas e armação dos corpos-de-prova para medida de potencial de corrosão das armaduras.

Essa forma de fixação ainda precisa ser aperfeiçoada para um suporte mais resistente, pois o método usado apresentou deformações e resultou que algumas barras ficaram fora da posição original, também é necessário o desenvolvimento de um limitador do volume de 
concreto em cada corpo-de-prova, para que os corpos-de-prova não tenham volumes variado. Enfim, cabe melhorar a forma de produção de corpos-de-prova em campo para medidas de potencial de corrosão.

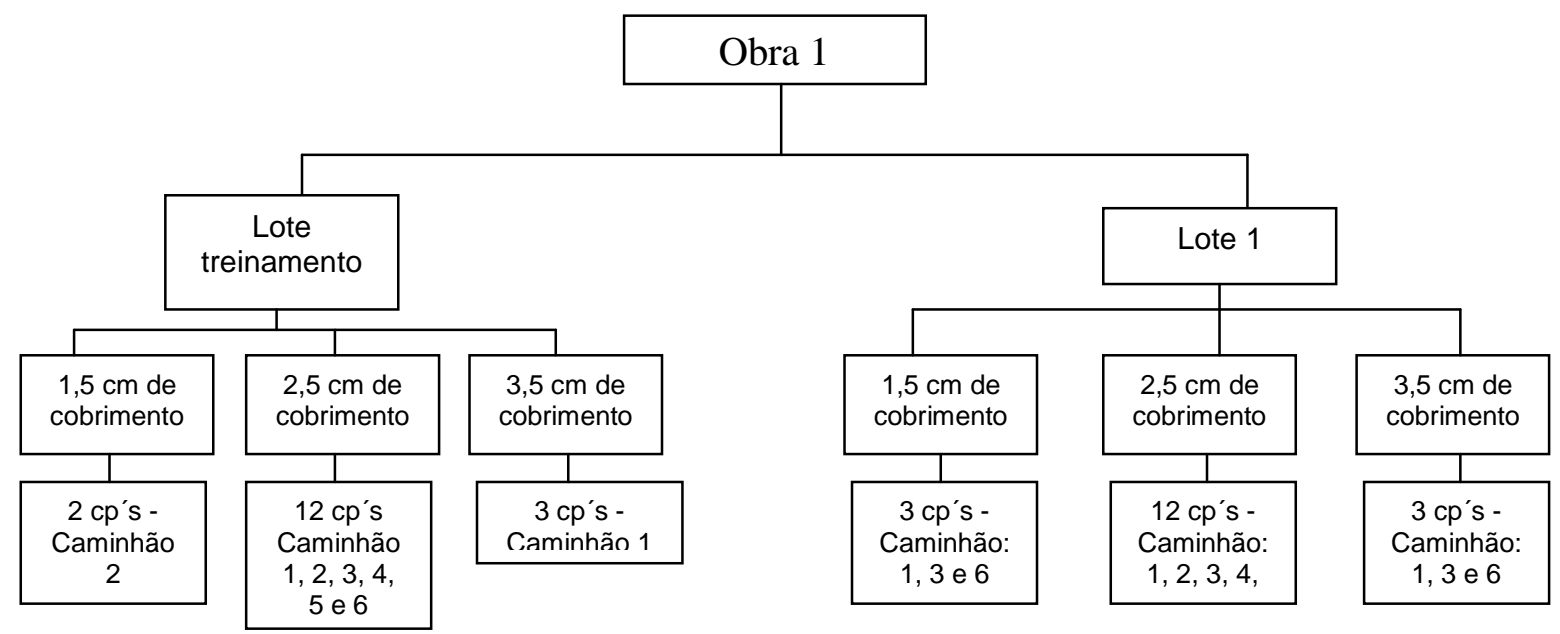

Figura 42 - Resumo dos corpos-de-prova dos lotes treinamento e 1, para medidas de potencial de corrosão, conforme a ASTM C 876 (2009).

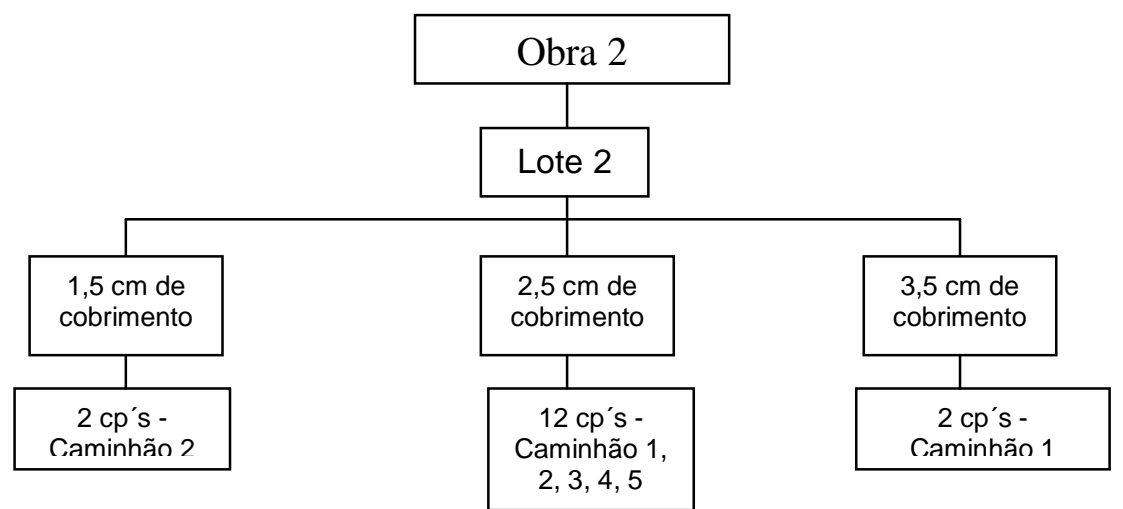

Figura 43 - Resumo dos corpos-de-prova do lote 2, para medidas de potencial de corrosão, conforme a ASTM C 876 (2009).

O adensamento dos corpos-de-prova foi realizado utilizando vibrador de agulha (imersão), em movimentos verticais, os suportes de isopor impediram o concreto cobrir toda a barra, ficando cerca de $5 \mathrm{~cm}$ de cada de barra sem concreto, conforme a Figura 44.

Após a moldagem os corpos-de-prova foram curados nos próprios moldes durante as primeiras 24 horas, quando então foram desmoldados e colocados em imersão inicial de água 
saturada de cal até 28 dias e então foram transportados para a USP, onde prosseguiram em cura até 91 dias, conforme a Figura 44.
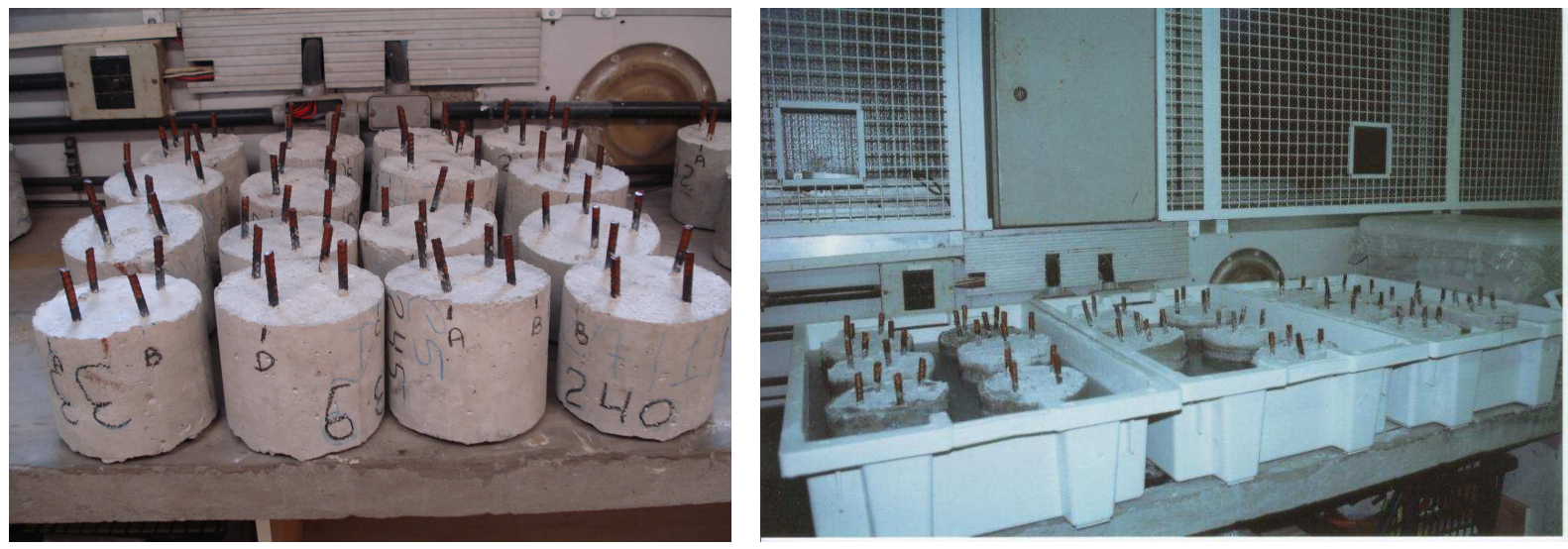

Figura 44 - Corpos-de-prova armados e mantidos saturados até 91 dias, em solução saturada de cal, e removidos para secagem após medida de potencial de corrosão, no LabCorr na USP.

As idades de monitoração do potencial de corrosão foram:
a) Lote treinamento: De 91 a 98 dias;
b) Lote 1: De 91 a 94 dias;
c) Lote 2: De 91 a 97 dias.

As medidas de potencial de corrosão foram feitas em potenciostato modelo 273 da PAR, para os corpos-de-prova em condição de imersão, na solução saturada de cal, sendo referência o eletrodo de calomelano saturado (ECS) protegido por ponta de vidro com haste condutora. $O$ $E_{\text {corr }}$ de cada barra foi a leitura tomada a 600 s de medição contínua, pelo software de operação do equipamento. 


\section{CAPÍTULO 5}

\section{APRESENTAÇÃO E DISCUSSÃO DOS RESULTADOS}

Neste capítulo são apresentados os resultados e as discussões relativas à comparação dos lotes empregados no programa experimental, e às correlações entre as suas propriedades.

Os resultados completos dos três lotes constam no Apêndice $C$ e estão resumidos nos itens seguintes, através de média, desvio padrão, coeficiente de variação, valores máximo e mínimo e amplitude de cada uma das propriedades objeto de estudo, conforme as Figuras 30 e 34.

Ao final deste capítulo são apresentadas as comparações entre os lotes e as correlações entre as vinte e cinco propriedades analisadas, do estado fresco ao estado endurecido, calculadas por assessoria estatística do CEA/IME-USP.

\subsection{Análise descritiva das propriedades de cada lote}

Neste item é apresentada uma análise descritiva das propriedades estudadas, para os três lotes de concreto, inicialmente caracterizados em campo junto a duas obras na cidade de João Pessoa/PB e com análise de propriedades no estado endurecido realizadas em laboratórios.

Os Apêndicas B,C e D contem os resultados dos ensaios de modo detalhado.

\subsubsection{Concreto fresco}

\subsubsection{Informes das notas fiscais de fornecimento}

Na Tabela 30 são apresentados os dados das notas fiscais referentes ao concreto fresco do lote 1.

As notas fiscais do concreto referente ao lote treinamento não foram fornecidas. 
Tabela 30 - Dados das notas fiscais referentes ao concreto dos caminhões amostrados do lote 1

\begin{tabular}{|c|c|c|c|c|c|c|c|c|c|c|c|c|c|}
\hline \multirow{3}{*}{ 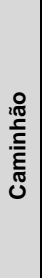 } & \multirow{3}{*}{$\begin{array}{l}N^{\circ} \text { da } \\
\text { nota } \\
\text { fiscal }\end{array}$} & \multirow{3}{*}{ 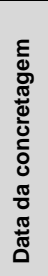 } & \multirow{3}{*}{ 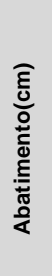 } & \multirow{3}{*}{$\sum_{-=}^{\bar{\delta}}$} & \multirow{3}{*}{$\begin{array}{c}\text { Volume } \\
\text { de } \\
\text { concreto } \\
\text { em cada } \\
\text { cam inhão } \\
\left(m^{3}\right)\end{array}$} & \multicolumn{3}{|c|}{ Cimento } & \multicolumn{2}{|c|}{ Aditivo } & \multirow{3}{*}{$\begin{array}{l}\text { Quantidade } \\
\text { de água } \\
\text { utilizada } \\
\text { em cada } \\
\text { cam inhão } \\
\text { (kg) }\end{array}$} & \multirow{3}{*}{$\begin{array}{c}\text { Quantidad } \\
\text { e de areia } \\
\text { em cada } \\
\text { cam inhão } \\
\text { (kg) }\end{array}$} & \multirow{2}{*}{$\begin{array}{c}\text { Quantidade } \\
\text { de brita em } \\
\text { cada } \\
\text { caminhão } \\
(\mathrm{kg})\end{array}$} \\
\hline & & & & & & & & Con & & & & & \\
\hline & & & & & & Tipo & $\begin{array}{l}\text { Quantidade } \\
\text { (kg) }\end{array}$ & $\begin{array}{c}\text { de } \\
\text { cimento } \\
\left(\mathrm{kg} / \mathrm{m}^{3}\right)\end{array}$ & Tipo & $\begin{array}{c}\text { Quantidade } \\
\text { (L) }\end{array}$ & & & 1 \\
\hline 1 & 26422 & \multirow{6}{*}{ 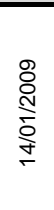 } & \multirow{6}{*}{$10 \pm 2$} & \multirow{6}{*}{30,0} & \multirow{6}{*}{7,0} & \multirow{6}{*}{$\begin{array}{l}\text { CPV - } \\
\text { Mizu }\end{array}$} & \multirow{6}{*}{2240,0} & \multirow{6}{*}{320,0} & \multirow{6}{*}{$\begin{array}{c}\text { Super - } \\
\text { plastificante }\end{array}$} & \multirow{6}{*}{9,10} & \multirow{6}{*}{1362} & \multirow{6}{*}{5190} & \multirow{6}{*}{6300} \\
\hline 2 & 26424 & & & & & & & & & & & & \\
\hline 3 & 26426 & & & & & & & & & & & & \\
\hline 4 & 26427 & & & & & & & & & & & & \\
\hline 5 & 26428 & & & & & & & & & & & & \\
\hline 6 & 26430 & & & & & & & & & & & & \\
\hline
\end{tabular}

O valor teórico da relação água/cimento encontrado pelos dados da nota fiscal dos concretos do lote 1 foi de 0,60, não estando de acordo com a especificação do projeto e da ABNT NBR 6118 (2003), para a classe de agressividade em que se enquadra a obra.

$\mathrm{Na}$ Tabela 31 são apresentados os dados das notas ficais referentes ao concreto fresco do lote 2. Observar que a empresa não declarou o consumo de cimento por metro cúbico de concreto nas notas fiscais, mas o valor estimado pelos dados informados seria de $356 \mathrm{~kg} / \mathrm{m}^{3}$.

Tabela 31 - Dados das notas fiscais referente ao concreto dos caminhões amostrados do lote 2

\begin{tabular}{|c|c|c|c|c|c|c|c|c|c|c|c|c|c|}
\hline \multirow{3}{*}{ 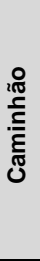 } & \multirow{3}{*}{$\begin{array}{l}\text { Noda } \\
\text { nota } \\
\text { fiscal }\end{array}$} & \multirow{3}{*}{ 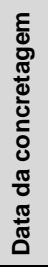 } & \multirow{3}{*}{$\begin{array}{c}\text { Slump } \\
\text { (cm) }\end{array}$} & \multirow{3}{*}{$\begin{array}{c}\mathbf{f}_{\mathrm{ck}} \\
(\mathrm{MPa})\end{array}$} & \multirow{3}{*}{$\begin{array}{c}\text { Volume } \\
\text { de } \\
\text { concreto } \\
\text { em cada } \\
\text { cam inhão } \\
\left(m^{3}\right)\end{array}$} & \multicolumn{2}{|c|}{ Cimento } & \multicolumn{2}{|c|}{ Aditivo } & \multirow{3}{*}{$\begin{array}{l}\text { Quantidade } \\
\text { de água } \\
\text { utilizada em } \\
\text { cada } \\
\text { cam inhão } \\
\text { (L) }\end{array}$} & \multirow{3}{*}{$\begin{array}{c}\text { Quantidad } \\
\text { e de areia } \\
\text { em cada } \\
\text { cam inhão } \\
\text { (kg) }\end{array}$} & \multirow{2}{*}{\multicolumn{2}{|c|}{$\begin{array}{l}\text { Quantidade de } \\
\text { brita em cada } \\
\text { cam inhão (kg) }\end{array}$}} \\
\hline & & & & & & & & & & & & & \\
\hline & & & & & & 1100 & (kg) & 1100 & (L) & & & 0 & 1 \\
\hline 1 & 9853 & \multirow{5}{*}{ 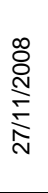 } & \multirow{5}{*}{$10 \pm 2$} & \multirow{5}{*}{30} & \multirow{5}{*}{8} & \multirow{5}{*}{$\mathrm{CP} \| \mathrm{F}$} & \multirow{5}{*}{2848} & \multirow{5}{*}{$\begin{array}{c}\text { Superplasti } \\
\text { ficante - } \\
\text { Sikament } \\
171 \mathrm{R}\end{array}$} & \multirow{5}{*}{14,26} & \multirow{5}{*}{1560} & \multirow{5}{*}{6592} & \multirow{5}{*}{3096} & \multirow{5}{*}{4656} \\
\hline 2 & 9854 & & & & & & & & & & & & \\
\hline 3 & 9859 & & & & & & & & & & & & \\
\hline 4 & 9860 & & & & & & & & & & & & \\
\hline 5 & 9863 & & & & & & & & & & & & \\
\hline
\end{tabular}

O valor teórico da relação água/cimento encontrado pelos dados da nota fiscal foi de 0,55 , estando de acordo com a especificação de projeto e da ABNT NBR 6118 (2003), para classe de agressividade em que se enquadra a obra. 


\subsubsection{Abatimento do tronco-de-cone ("slump")}

A Tabela 32 apresenta as médias, os desvios padrão, os valores máximo e mínimo, as amplitudes e os coeficientes de variação dos três lotes. Percebe-se que as médias dos três lotes se enquadram no previsto de $(10 \pm 2 \mathrm{~cm})$, mas as variações do abatimento no lote 1 expressam possíveis problemas no treinamento operacional da central de produção, naquela data.

Tabela 32 - Resultados do ensaio de abatimento do concreto fresco nos três lotes analisados. ABNT NBR NM 67 (1998).

\begin{tabular}{|c|c|c|c|c|c|c|}
\hline Lote & $\begin{array}{c}\text { Média } \\
(\mathbf{c m})\end{array}$ & $\begin{array}{c}\text { Desvio } \\
\text { padrão } \\
(\mathbf{c m})\end{array}$ & $\begin{array}{c}\text { Valor } \\
\text { máximo } \\
\mathbf{( c m})\end{array}$ & $\begin{array}{c}\text { Valor } \\
\text { mínimo } \\
\mathbf{( c m})\end{array}$ & $\begin{array}{c}\text { Amplitude } \\
\mathbf{( c m})\end{array}$ & $\begin{array}{c}\text { Coeficiente } \\
\text { de variação } \\
(\%)\end{array}$ \\
\hline Treinamento & 10 & 1,3 & 12 & 8 & 4 & 13 \\
\hline 1 & 12 & 2,7 & 16 & 9 & 7 & 23 \\
\hline 2 & 10 & 1,1 & 11 & 8 & 3 & 12 \\
\hline
\end{tabular}

A Figura 45 ilustra os resultados de abatimento do tronco-de-cone do concreto de cada caminhão dos três lotes analisados. Observa-se que, o lote 1 teve a maior dispersão entre os três lotes, e que o lote 1 e o treinamento apresentaram resultados diferentes, sendo que os dois lotes são da mesma concreteira, com mesmo $f_{c k}$ e materiais de mesma procedência em princípio.

Caba ressaltar que todos os abatimentos foram feitos pelo mesmo técnico de laboratório, cedido pela empresa que apoiou o estudo. 


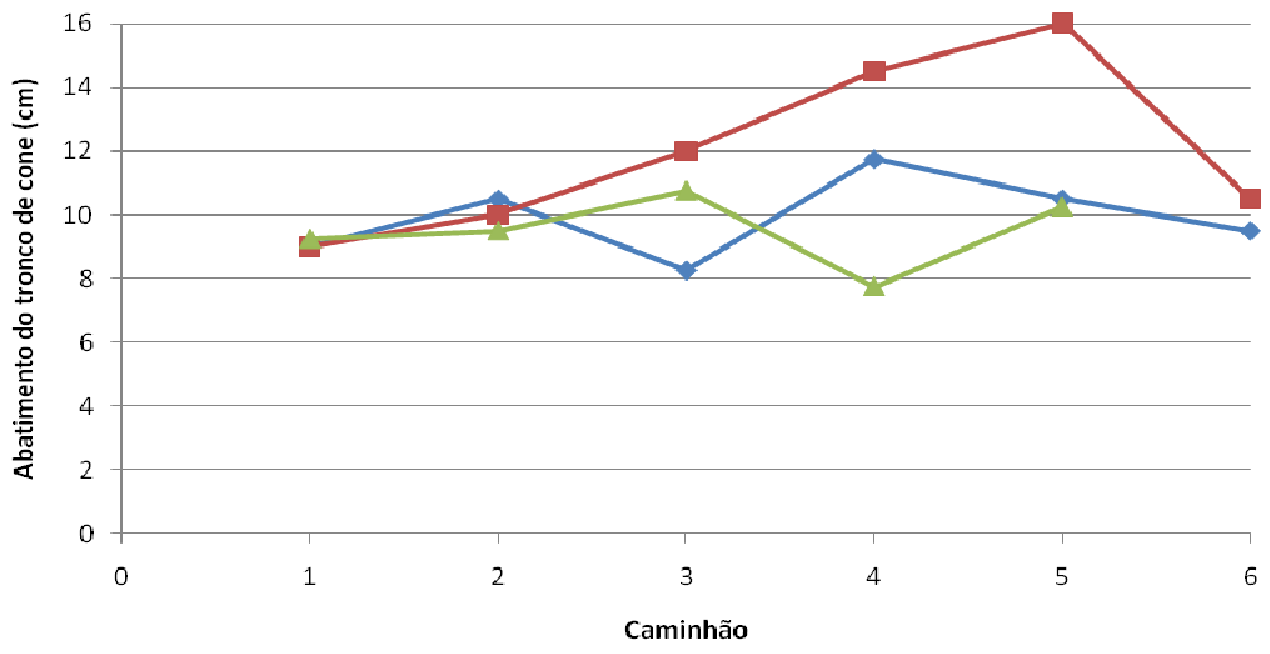

Figura 45 - Variações do abatimento médio dos concretos analisados nos três lotes. ABNT NBR NM 67 (1998)

\subsubsection{Massa específica aparente}

A Tabela 33 apresenta as médias, os desvios padrão, os valores máximo e mínimo, as amplitudes e os coeficientes de variação dos três lotes. Constata-se que foram pequenas a moderadas as variações nos três lotes, o que pode ser visto também na Figura 47 . Todas as medidas foram realizadas pelo mesmo técnico de laboratório.

Tabela 33 - Resultados do ensaio de massa específica aparente do concreto fresco nos três lotes analisados ABNT NBR 9833 (2008).

\begin{tabular}{|c|c|c|c|c|c|c|}
\hline Lote & $\begin{array}{c}\text { Média } \\
\left(\mathbf{k g} / \mathbf{m}^{3}\right)\end{array}$ & $\begin{array}{c}\text { Desvio } \\
\text { padrão } \\
\left(\mathbf{k g} / \mathbf{m}^{3}\right)\end{array}$ & $\begin{array}{c}\text { Valor } \\
\text { máximo } \\
\left(\mathbf{k g} / \mathbf{m}^{3}\right)\end{array}$ & $\begin{array}{c}\text { Valor } \\
\mathbf{m i ́ n i m o} \\
\left(\mathbf{k g} / \mathbf{m}^{3}\right)\end{array}$ & $\begin{array}{c}\text { Amplitude } \\
\left(\mathbf{k g} / \mathbf{m}^{3}\right)\end{array}$ & $\begin{array}{c}\text { Coeficiente } \\
\text { de } \\
\text { variação } \\
(\%)\end{array}$ \\
\hline Treinamento & 2314 & 18,3 & 2325 & 2277 & 48 & 0,8 \\
\hline 1 & 2348 & 26,6 & 2385 & 2310 & 75 & 1,0 \\
\hline 2 & 2380 & 33,2 & 2430 & 2340 & 90 & 1,0 \\
\hline
\end{tabular}

Pela Figura 46, vê-se que o concreto do caminhão 2 do lote 2 apresentou valor atípico em relação aos demais, o que pode ser justificado por alguma alteração na dosagem, na amostragem ou nos procedimentos de ensaio, propriamente; sendo esta última a causa menos provável pela experiência do técnico envolvido e bem evidenciada pelos resultados do lote treinamento que foram os melhores. 


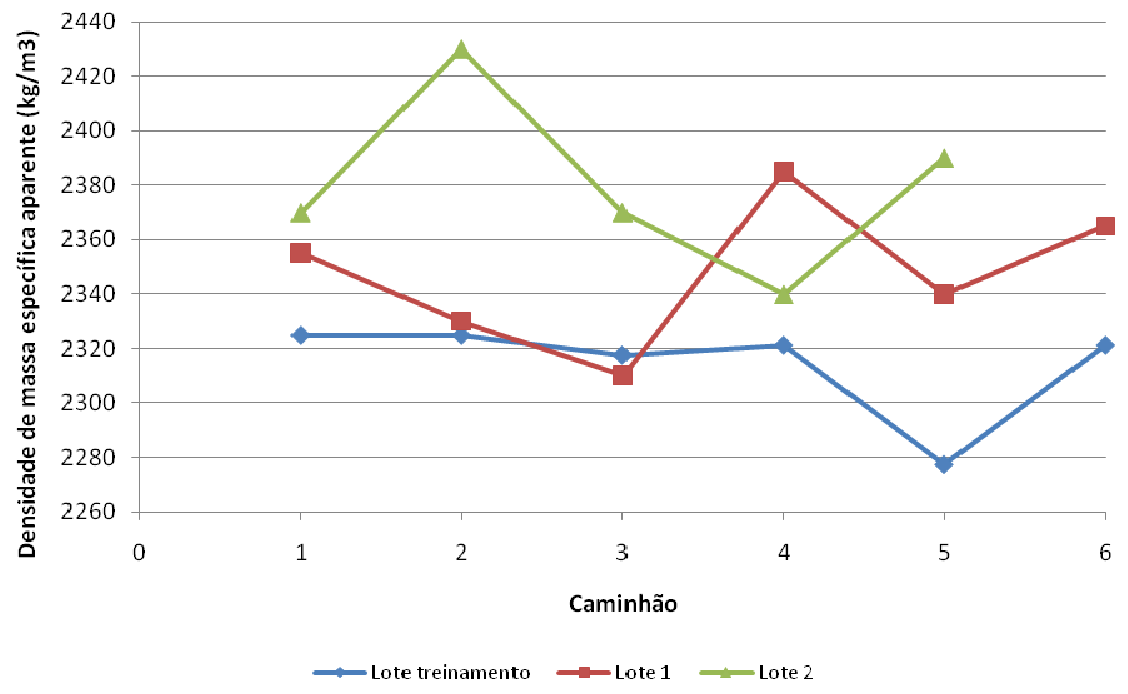

Figura 46 - Variações da massa específica aparente média dos concretos amostrados nos três lotes. ABNT NBR 9833 (2008)

\subsubsection{Compactabilidade do concreto adensado}

A Tabela 34 apresenta as médias, os desvios padrão, os valores máximo e mínimo, as amplitudes, os coeficientes de variação e os teores de ar equivalentes dos três lotes, quando submetidos a adensamento prévio. Pode-se ver que o maior valor médio foi encontrado no lote 1, o que está coerente com o resultado de abatimento médio desse lote que foi o maior também.

Tabela 34 - Resultados no concreto fresco do ensaio de compactabilidade do concreto adensado nos três lotes analisados (BS EN 12350-4, 2008).

\begin{tabular}{|c|c|c|c|c|c|c|c|}
\hline \multirow[b]{2}{*}{ Lote } & \multicolumn{6}{|c|}{ Espessura compactada } & \multirow[b]{2}{*}{$\begin{array}{c}\text { Teor de ar } \\
\text { equivalente } \\
\text { (\%) }\end{array}$} \\
\hline & $\begin{array}{l}\text { Média } \\
\text { (cm) }\end{array}$ & $\begin{array}{l}\text { Desvio } \\
\text { padrão } \\
(\mathrm{cm})\end{array}$ & $\begin{array}{c}\text { Valor } \\
\text { máximo } \\
(\mathrm{cm})\end{array}$ & $\begin{array}{l}\text { Valor } \\
\text { mínimo } \\
(\mathrm{cm})\end{array}$ & $\begin{array}{l}\text { Amplitude } \\
\text { (cm) }\end{array}$ & $\begin{array}{c}\text { Coeficiente } \\
\text { de variação } \\
(\%)\end{array}$ & \\
\hline Treinamento & 0,36 & 0,10 & 0,50 & 0,25 & 0,25 & 28 & $1,3 \%$ \\
\hline 1 & 0,66 & 0,17 & 0,95 & 0,50 & 0,45 & 26 & $2,3 \%$ \\
\hline 2 & 0,42 & 0,06 & 0,50 & 0,35 & 0,15 & 14 & $1,5 \%$ \\
\hline
\end{tabular}

A Figura 47 ilustra os resultados do ensaio de compactabilidade do concreto adensado dos três lotes.

Apenas o lote de concreto da segunda central dosadora (lote 2) mostrou menor coeficiente de variação nesta propriedade, o que provavelmente é indicativo da necessidade de 
melhor padronização da forma de adensamento ou de redução do volume de concreto a ser compactado. Ainda assim considera-se que o ensaio foi sensível a mudanças de reologia e de abatimento do concreto entre caminhões de mesmo lote, pelo que se comenta a seguir.

Por comparação com a Figura 45, observa-se que os concretos do lote $1 \mathrm{com}$ maior abatimento (caminhões 3, 4 e 5), tornaram-se também mais compactáveis, ou seja com menor espessura compactada após serem novamente adensados, em relação aos demais do respectivo lote, ainda que o concreto já estivesse previamente adensado.

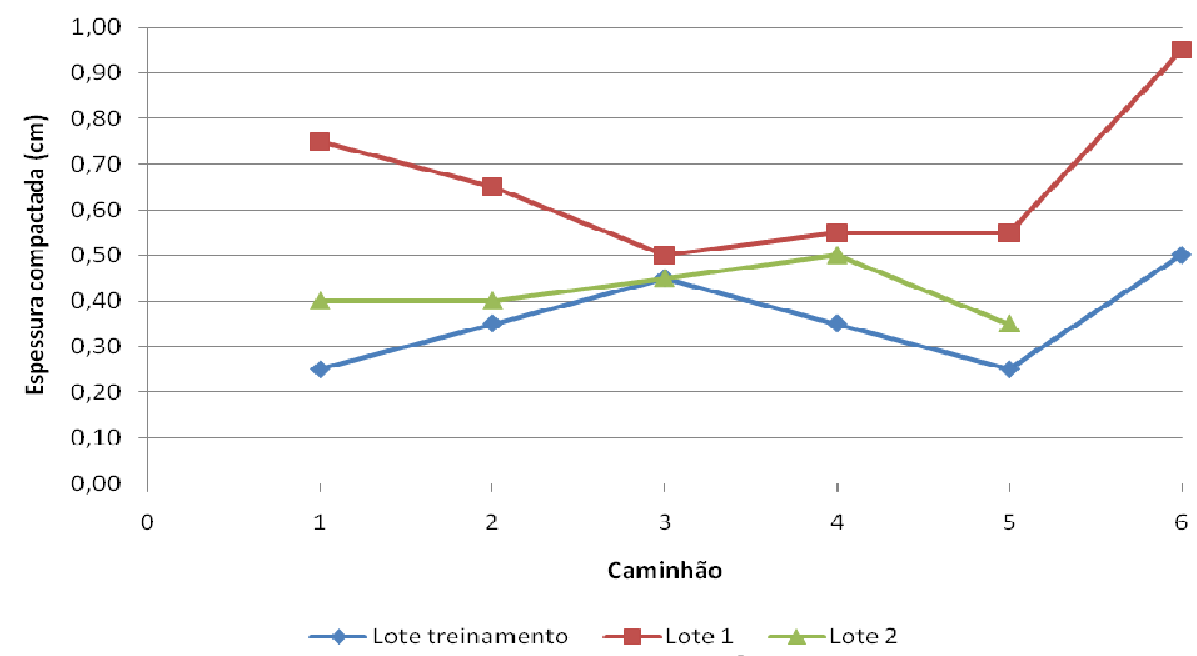

Figura 47 - Variações da compactabilidade adensada média dos concretos amostrados nos três lotes (BS EN 12350-4, 2008).

\subsubsection{Compactabilidade do concreto não-adensado}

A Tabela 35 apresenta as médias, os desvios padrão, os valores máximos e mínimos, as amplitudes, os coeficientes de variação e os teores de ar equivalente dos três lotes analisados. Pela Tabela 35 e Figura 48 percebe-se uma semelhança entre os dois lotes analisados.

Observar que a análise desta propriedade pode ser um indicativo do rendimento volumétrico real de concretos com diferentes formulações e auxiliar no controle das perdas de concretagem. O lote 1 mais uma vez mostra resultados coerentes entre 0 abatimento e compactabilidade do concreto com e sem adensamento. 
Tabela 35 - Resultados do ensaio no concreto fresco da compactabilidade do concreto nãoadensado, nos três lotes analisados. Adaptado da BS EN 12350-4 (2008).

\begin{tabular}{|c|c|c|c|c|c|c|c|}
\hline \multirow[b]{2}{*}{ Lote } & \multicolumn{6}{|c|}{ Espessura compactada } & \multirow[b]{2}{*}{$\begin{array}{c}\text { Teor de ar } \\
\text { equivalente } \\
\text { (\%) }\end{array}$} \\
\hline & $\begin{array}{l}\text { Média } \\
\text { (cm) }\end{array}$ & $\begin{array}{l}\text { Desvio } \\
\text { padrão } \\
\text { (cm) }\end{array}$ & $\begin{array}{l}\text { Valor } \\
\text { máximo } \\
\text { (cm) }\end{array}$ & $\begin{array}{l}\text { Valor } \\
\text { mínimo } \\
\text { (cm) }\end{array}$ & $\begin{array}{c}\text { Amplitude } \\
\text { (cm) }\end{array}$ & $\begin{array}{c}\text { Coeficiente } \\
\text { de variação } \\
(\%)\end{array}$ & \\
\hline Treinamento & - & - & - & - & - & - & - \\
\hline 1 & 0,74 & 0,10 & 0,9 & 0,60 & 0,3 & 14 & $2,6 \%$ \\
\hline 2 & 0,66 & 0,07 & 0,7 & 0,55 & 0,15 & 10 & $2,4 \%$ \\
\hline
\end{tabular}

$\mathrm{Na}$ Figura 48, observa-se que os concretos dos caminhões 3,5 e 6 do lote 1 apresentaram um valor mais elevado em comparação com os demais, do mesmo lote. Todas as medidas foram realizadas pelo mesmo técnico de laboratório.

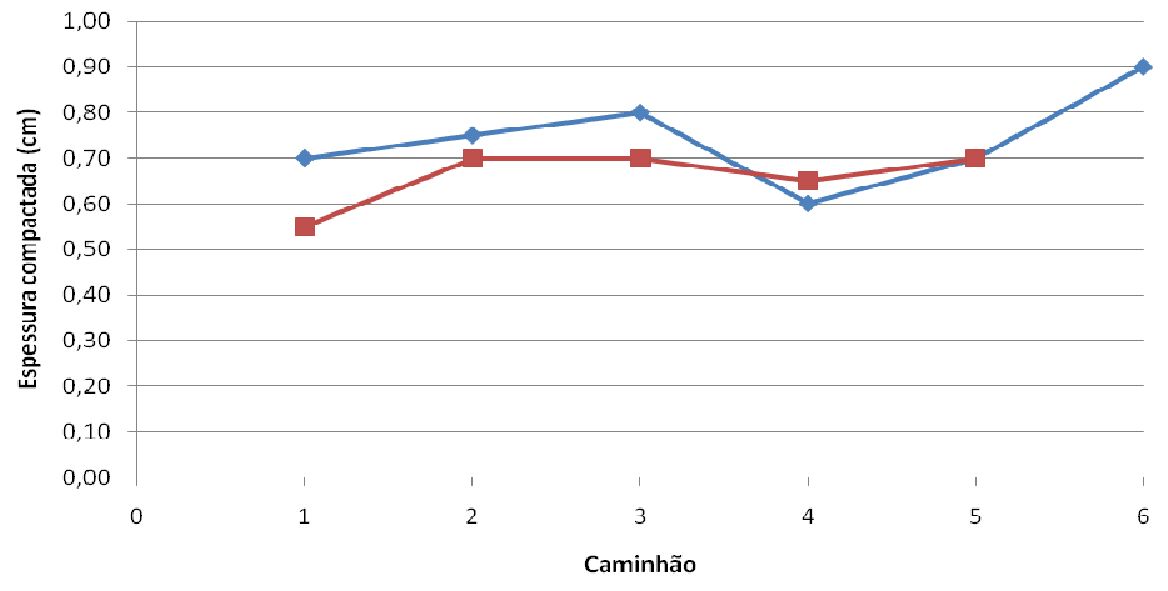

Figura 48 - Variações da compactabilidade média do concreto fresco não-adensado, nos lotes 1 e 2. Adaptado da BS EN 12350-4 (2008)

A comparação dos resultados médios de compactabilidade adensada está coerente em relação aos valores médios para os concretos não-adensados, sendo esta segunda medida sempre maior.

\subsubsection{Teor de ar pelo método pressométrico}

A Tabela 36 apresenta as médias, os desvios padrão, os valores máximos e mínimos, as amplitudes, os coeficientes de variação e os teores de ar equivalente dos três lotes analisados.

Os coeficientes de variação mostram valores bem aceitáveis por se tratar de medidas em campo. 
Tabela 36 - Resultados do ensaio de teor de ar no concreto fresco nos três lotes analisados. ABNT NBR 47 (2002).

\begin{tabular}{|c|c|c|c|c|c|c|}
\hline Lote & $\begin{array}{c}\text { Média } \\
(\%)\end{array}$ & $\begin{array}{c}\text { Desvio } \\
\text { padrão } \\
(\%)\end{array}$ & $\begin{array}{c}\text { Valor } \\
\text { máximo } \\
(\%)\end{array}$ & $\begin{array}{c}\text { Valor } \\
\text { mínimo } \\
(\%)\end{array}$ & $\begin{array}{c}\text { Amplitude } \\
(\%)\end{array}$ & $\begin{array}{c}\text { Coeficiente } \\
\text { de variação } \\
(\%)\end{array}$ \\
\hline Treinamento & 2,8 & 0,2 & 3,0 & 2,5 & 0,5 & 8 \\
\hline 1 & 3,3 & 0,2 & 3,6 & 3,0 & 0,6 & 6 \\
\hline 2 & 2,8 & 0,4 & 3,6 & 2,5 & 1,1 & 15 \\
\hline
\end{tabular}

No lote treinamento, foi realizada apenas uma medida por caminhão, do número 1 ao número 4, por problemas operacionais.

A Figura 49 ilustra os resultados do ensaio de teor de ar pressométrico dos três lotes analisados. Por problemas operacionais no dia da concretagem, no lote treinamento o ensaio só foi realizado nos quatro primeiros caminhões.

Pode-se observar que os lotes tiveram resultados dentro de variações de $\pm 0,5 \%$, apenas o concreto do caminhão 2 do lote 2 apresentou um resultado ligeiramente superior em relação aos demais caminhões do mesmo lote. O lote 1 apresentou resultado médio e individual ligeiramente superior aos dois outros lotes à exceção do amostrado no citado caminhão do lote 2. O teor de ar médio ligeiramente superior no lote 1 está coerente com o seu abatimento e com as medidas de compactabilidade nas Figura 45 e Figura 46, onde apresentou resultados também maiores de espessura compactada.

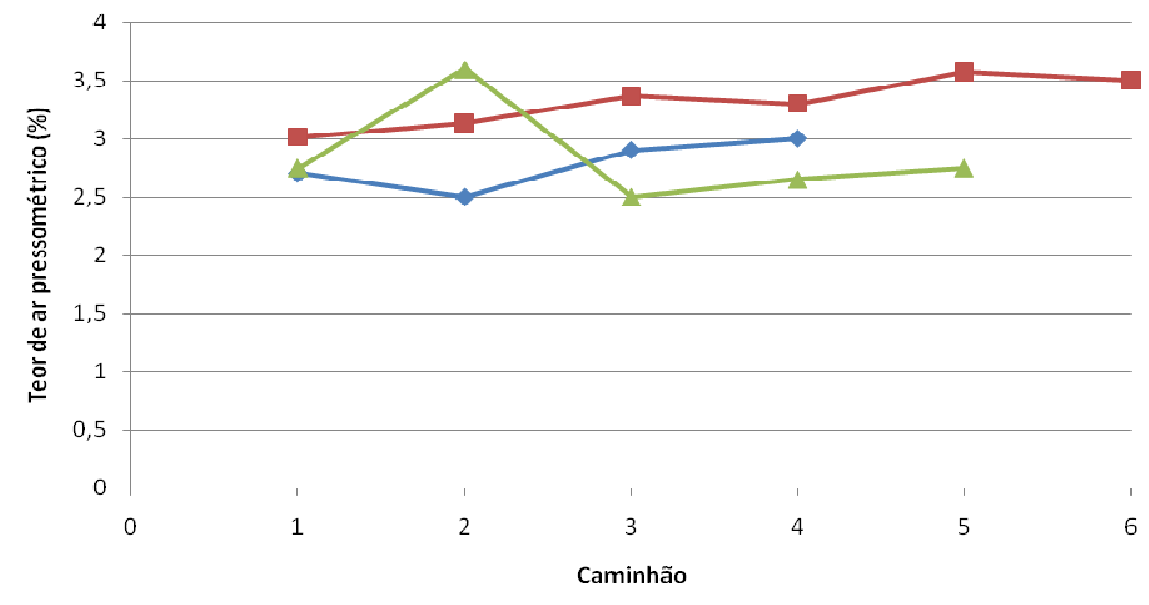

Figura 49 - Variações do teor de ar médio por método pressométrico, entre os concretos amostrados nos três lotes. ABNT NBR 47 (2002). 


\subsubsection{Umidade do concreto fresco}

A Tabela 37 apresenta as médias, os desvios padrão, os valores máximos e mínimos, as amplitudes e os coeficientes de variação dos resultados do ensaio de umidade do concreto fresco dos três lotes estudados. Por problemas operacionais, no dia da concretagem, no lote treinamento o ensaio só foi realizado nos três últimos caminhões.

Observar que embora os valores médios de umidade determinados sejam valores possíveis, o coeficiente de variação apenas resultou aceitável para o lote treinamento, sendo isto indicativo de problemas operacionais do procedimento ou dos equipamentos de ensaio, como comentado mais adiante.

Tabela 37 - Resultados do ensaio de umidade do concreto fresco nos três lotes analisados

\begin{tabular}{|c|c|c|c|c|c|c|c|}
\hline Lote & $\begin{array}{c}\text { Média } \\
(\%)\end{array}$ & $\begin{array}{c}\text { Desvio } \\
\text { padrão } \\
(\%)\end{array}$ & $\begin{array}{c}\text { Valor } \\
\text { máximo } \\
(\%)\end{array}$ & $\begin{array}{c}\text { Valor } \\
\text { mínimo } \\
(\%)\end{array}$ & $\begin{array}{c}\text { Amplitude } \\
(\%)\end{array}$ & $\begin{array}{c}\text { Coeficiente } \\
\text { de variação } \\
(\%)\end{array}$ & $\begin{array}{c}\text { No de } \\
\text { ensaios }\end{array}$ \\
\hline Treinamento & 11 & 0,60 & 11 & 10 & 1 & 6 & 6 \\
\hline 1 & 5 & 1,90 & 8 & 3 & 5 & 42 & 12 \\
\hline 2 & 10 & 6,10 & 21 & 6 & 15 & 63 & 10 \\
\hline
\end{tabular}

No lote treinamento, a média é relativa a apenas uma determinação no concreto amostrado dos caminhões 4, 5 e 6, por problemas operacionais.

Pela Figura 50, percebe-se que o concreto caminhão 2 do lote 2 apresentou um resultado anômalo comparado com os demais do mesmo lote, o que seria plausível e esperado do concreto estrutural em questão. Em princípio, este resultado poderia ser explicado por alguma falha na execução do ensaio do concreto desse caminhão, mas os resultados das duas amostras foram parelhos. Por outro lado, observar que o concreto do caminhão 2 também apresentou valores médios de massa específica e de teor de ar acima dos demais. Então é possível que o concreto do caminhão 2 tenha sido fornecido com alguma alteração de dosagem que esteja relacionada a um maior teor de argamassa, pelo menos nas amostras em que se caracterizou a umidade, isto poderia ser uma explicação plausível. Também seria possível admitir que se tratasse de um valor médio afetado por alguma determinação espúria, mas isto não foi considerado, pois as duas medidas da amostra deste caminhão foram parelhas, segundo os dados no Apêndice $C$. 


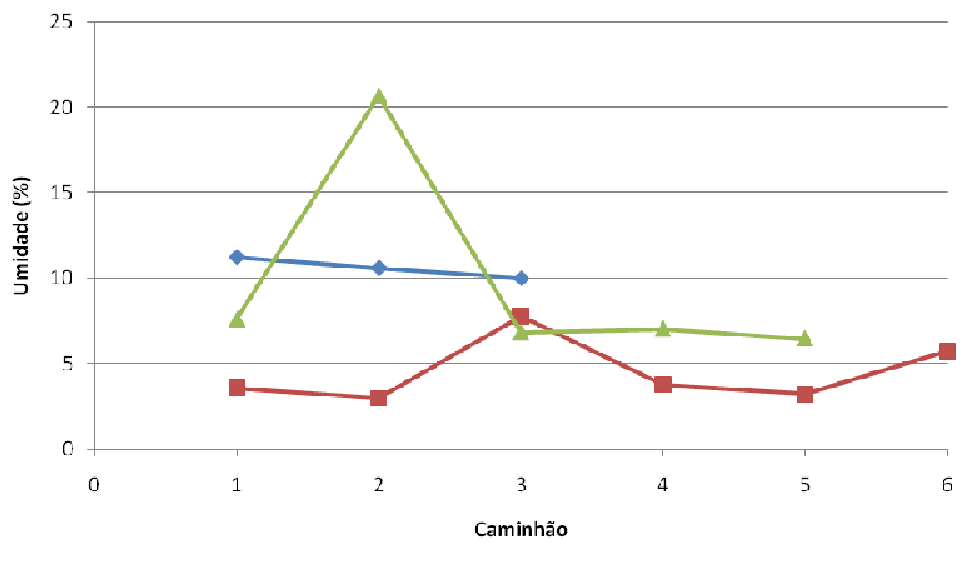

Figura 50 - Variações do teor de umidade médio do concreto fresco entre os concretos amostrados de cada lote

O método de ensaio testado para medir a umidade do concreto fresco em menor quantidade de massa do que a preconizada pela ABNT NBR 9605 (1992) se mostrou de fácil execução e possível de realização por laboratórios de controle tecnológico, mas precisaria ter havido disponibilidade de estufa ventilada no laboratório, para melhorar a eficiência de secagem dos concretos, pois se observou maior variação dos resultado, quando mais amostras foram usadas simultaneamente.

\subsubsection{Concreto endurecido}

\subsubsection{Resistência à compressão simples}

\section{a) Resistências à compressão medidas a 1 dia ( $\mathbf{f}_{\mathrm{c} 1}$ e $\left.\mathbf{f}_{\mathrm{c} 1 \mathrm{acel}}\right)$}

A Tabela 38 apresenta as médias, os desvios padrão, os valores máximos e mínimos, as amplitudes e os coeficientes de variação dos resultados da resistência à compressão com 1 dia de idade, com cura normal e acelerada 0/24 horas.

O lote 1 apresentou coeficientes de variação próximos nos ensaios com cura normal e maior com a cura acelerada (0/24 horas). Como esperado, as resistências obtidas por curas aceleradas foram superiores às de cura normal e a sua eficiência está discutira no item 6.1. 
Tabela 38 - Resultados do ensaio de resistência à compressão a 1 dia, nos concretos dos lotes 1 e 2. ABNT NBR 5739 (2007).

\begin{tabular}{|c|c|c|c|c|c|c|c|}
\hline Lote & Cura & $\begin{array}{l}\text { Média } \\
(\mathrm{MPa})\end{array}$ & $\begin{array}{l}\text { Desvio } \\
\text { padrão } \\
\text { (MPa) }\end{array}$ & $\begin{array}{c}\text { Valor } \\
\text { máximo } \\
(\mathrm{MPa})\end{array}$ & $\begin{array}{c}\text { Valor } \\
\text { mínimo } \\
(\mathrm{MPa})\end{array}$ & $\begin{array}{c}\text { Amplitude } \\
\text { (MPa) }\end{array}$ & $\begin{array}{l}\text { Coeficiente } \\
\text { de variação } \\
(\%)\end{array}$ \\
\hline Treinamento & \multirow{3}{*}{ Normal } & - & - & - & - & - & - \\
\hline 1 & & 17,7 & 2,0 & 19,6 & 14,8 & 4,8 & 10 \\
\hline 2 & & 12,1 & 5,2 & 15,4 & 2,9 & 1,5 & 43 \\
\hline Treinamento & \multirow{3}{*}{$\begin{array}{l}\text { Acelerada - } \\
0 / 24 \text { horas }\end{array}$} & - & - & - & - & - & - \\
\hline 1 & & 26,3 & 3,3 & 30,9 & 22,0 & 8,9 & 13 \\
\hline 2 & & 30,8 & 5,2 & 32,5 & 29,7 & 2,8 & 4 \\
\hline
\end{tabular}

A Figura 51 ilustra os resultados médios de dois corpos-de-prova por caminhão dos dois lotes analisados. Observar que o concreto do caminhão 3 do lote 2 apresentou o resultado mais baixo entre todos, possivelmente devido a um retardo na sua hidratação. Esse retardo é provável, pois a resistência mecânica na maioria das demais idades do concreto deste caminhão não foi prejudicada e até se destacou, como ligeiramente superior em relação aos demais concretos amostrados do lote 2, conforme a Figura 51.

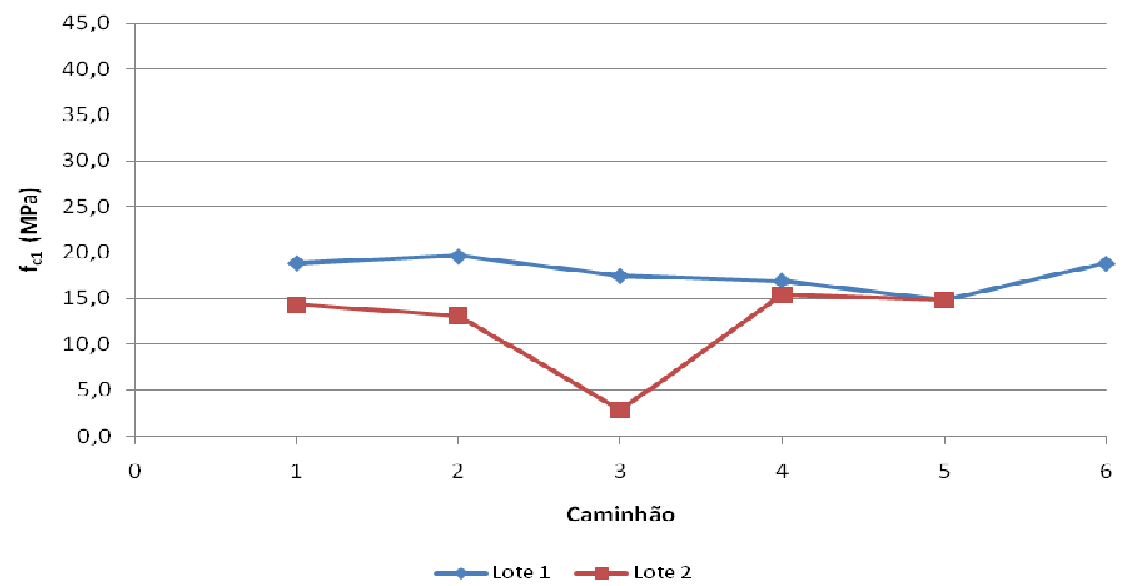

Figura 51 - Variação da resistência à compressão média a 1 dia por cura normal nos concretos amostrados em dois lotes. ABNT NBR 5739 (2007).

A Figura 52 apresenta os resultados da resistência à compressão a 1 dia com cura acelerada (0/24 horas), o lote 2 apresentou as maiores resistências à compressão.

Observar na Figura 52 que o comportamento da resistência acelerada a 1 dia entre os concretos dos caminhões do lote 1 mostra evidente relação com as medidas de abatimento do mesmo lote, na Figura 45, onde por exemplo o concreto do caminhão 5 apresentou o maior abatimento $(16 \mathrm{~cm})$ e a menor resistência por cura acelerada 0/24 h, na Figura 53. 


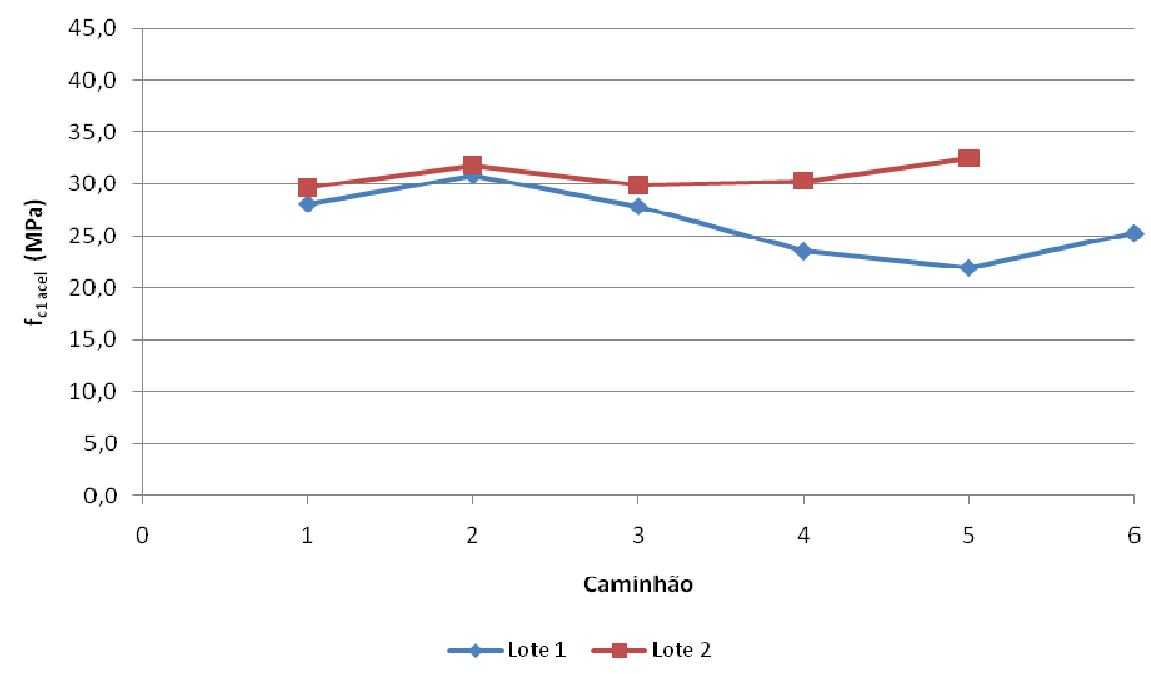

Figura 52 - Variação da resistência à compressão média a 1 por cura acelerada nos concretos amostrados em dois lotes. ABNT NBR 5739 (2007).

\section{b) Resistências à compressão medidas a 7 dias $\left(f_{c 7}\right.$ e $\left.f_{c 7 a c e l}\right)$}

A Tabela 39 apresentam as médias, os desvios padrão, os valores máximos e mínimos, as amplitudes e os coeficientes de variação dos resultados do ensaio de resistência à compressão a 7 dias com cura normal e acelerada 24/48 horas mais imersão em água até 7 dias nos concretos analisados.

Pelos resultados apresentados na Tabela 39, constata-se a igualdade de resistência e coeficiente de variação na idade de 7 dias com cura normal entre os dois lotes que pode ser comparados.

Nas resistências com cura acelerada, os três lotes amostrados já apresentaram resultados superiores à resistência característica $\left(f_{c k} 30 \mathrm{MPa}\right)$ e com baixo coeficientes de variação, atestando a eficiência da cura acelerada testada neste trabalho, sendo isto também evidenciado por análise do $f_{c k, e s t}$ no sub-item $h$.

Observar que todos os coeficientes de variação obtidos nesta idade resultaram dentro da faixa de controle muito bom para usinas gravimétricas, segundo Helene; Terzian (1993), na Tabela 8. 
Tabela 39 - Resultados do ensaio de resistência à compressão a 7 dias, por cura normal, nos concretos dos dois lotes analisados. ABNT NBR 5739 (2007).

\begin{tabular}{|c|c|c|c|c|c|c|c|}
\hline Lote & Cura & $\begin{array}{l}\text { Média } \\
(\mathrm{MPa})\end{array}$ & $\begin{array}{c}\text { Desvio } \\
\text { padrão } \\
\text { (MPa) } \\
\end{array}$ & $\begin{array}{c}\text { Valor } \\
\text { máximo } \\
\text { (MPa) }\end{array}$ & $\begin{array}{c}\text { Valor } \\
\text { mínimo } \\
\text { (MPa) }\end{array}$ & $\begin{array}{c}\text { Amplitude } \\
\text { (MPa) }\end{array}$ & $\begin{array}{c}\text { Coeficiente } \\
\text { de variação } \\
(\%)\end{array}$ \\
\hline Treinamento & \multirow{3}{*}{ Normal } & - & - & - & - & - & - \\
\hline 1 & & 26,3 & 2,2 & 28,6 & 23,7 & 4,9 & 8 \\
\hline 2 & & 26,3 & 2,1 & 28,9 & 23,5 & 5,4 & 8 \\
\hline Treinamento & \multirow{3}{*}{$\begin{array}{c}\text { Acelerada } 24 / 48 \\
\text { horas mais imersão } \\
\text { em água até } 7 \text { dias }\end{array}$} & 31,8 & 2,1 & 34,7 & 28,8 & 5,9 & 7 \\
\hline 1 & & 30,3 & 1,9 & 34,2 & 29,2 & 5 & 6 \\
\hline 2 & & 31,6 & 1,4 & 33,3 & 30,2 & 3,1 & 5 \\
\hline
\end{tabular}

A Figura 53 ilustra os resultados médios de dois corpos-de-prova por caminhão dos lotes 1 e 2. Observar que as resistências médias foram bastante similares, entre os caminhões desses lotes.

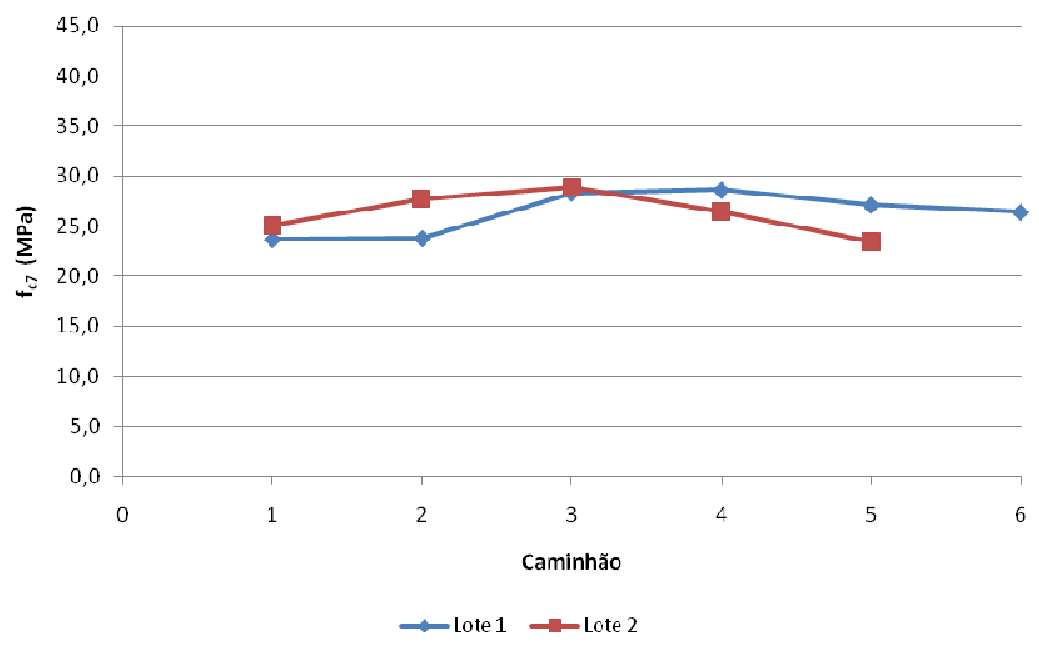

Figura 53 - Variação da resistência à compressão média a 7 dias, por cura normal, nos concretos dos dois lotes amostrados. ABNT NBR 5739 (2007).

Pela Figura 54 vê-se que há pequenas variações nas resistências médias entre os concretos dos três lotes analisados, e o lote 1 foi o que apresentou as menores resistências, coerentes com medidas ligeiramente maiores de teor de ar pressométrico e de compactabilidade adensado, que este lote apresentou. 


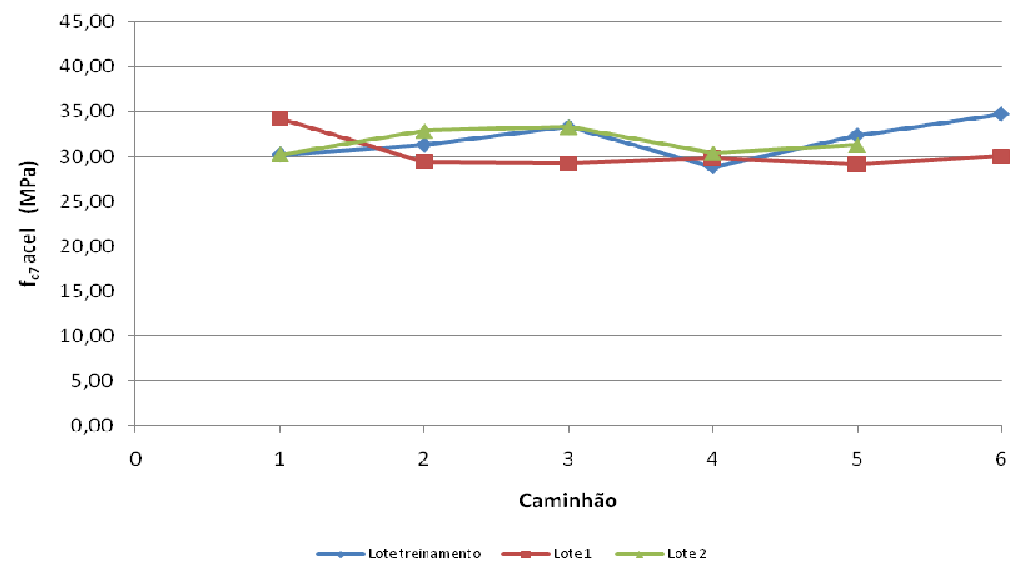

Figura 54 - Variação da resistência à compressão média a 7 dias, por cura acelerada 24/48 horas mais imersão até 7 dias, nos concretos dos três lotes analisados. ABNT NBR 5739 (2007).

\section{c) Resistência à compressão a 28 dias $\left(f_{c 28}\right)$ por cura normal}

A Tabela 40 apresenta as médias, os desvios padrão, os valores máximos e mínimos, as amplitudes e os coeficientes de variação dos resultados do ensaio de resistência à compressão aos 28 dias com cura imersa em água saturada de cal. Percebe-se que todos os três lotes apresentaram variações nos seus resultados, que tanto podem estar associadas às condições de produção quanto às variações de ensaio. Pelos critérios de Terzian; Helene (1993), estes coeficientes de variação se enquadram entre muito bom e razoável.

Tabela 40 - Resultados do ensaio de resistência à compressão a 28 dias por cura normal, nos concretos dos três lotes analisados. ABNT NBR 5739 (2007).

\begin{tabular}{|c|c|c|c|c|c|c|}
\hline Lote & $\begin{array}{c}\text { Média } \\
(\mathbf{M P a})\end{array}$ & $\begin{array}{c}\text { Desvio } \\
\text { padrão } \\
(\mathbf{M P a})\end{array}$ & $\begin{array}{c}\text { Valor } \\
\text { máximo } \\
(\mathbf{M P a})\end{array}$ & $\begin{array}{c}\text { Valor } \\
\text { mínimo } \\
(\mathbf{M P a})\end{array}$ & $\begin{array}{c}\text { Amplitude } \\
\mathbf{( M P a})\end{array}$ & $\begin{array}{c}\text { Coeficiente } \\
\text { de variação } \\
(\%)\end{array}$ \\
\hline Treinamento & 35,5 & 3,7 & 39,4 & 30,1 & 9,3 & 10 \\
\hline 1 & 31,8 & 2,5 & 36,4 & 29,6 & 6,8 & 8 \\
\hline 2 & 34,6 & 3,5 & 38,7 & 31,4 & 7,3 & 10 \\
\hline
\end{tabular}

A Figura 55 ilustra os resultados médios de dois corpos-de-prova por caminhão dos três lotes analisados, na idade de 28 dias com cura normal. Observar que o concreto do caminhão 3 apresentou o maior resultado entre os demais do lote 2, o que é coerente com eventual retardo inicial na sua hidratação, cogitada pela resistência inicial bem mais baixa (Figura 51).

Como seria esperado, a resistência média dos concretos de todos os caminhões foi superior ao $f_{c k}$ da obra (30 MPa), e no sub-item $h$, é analisado o valor do $f_{c k, e s t}$. 


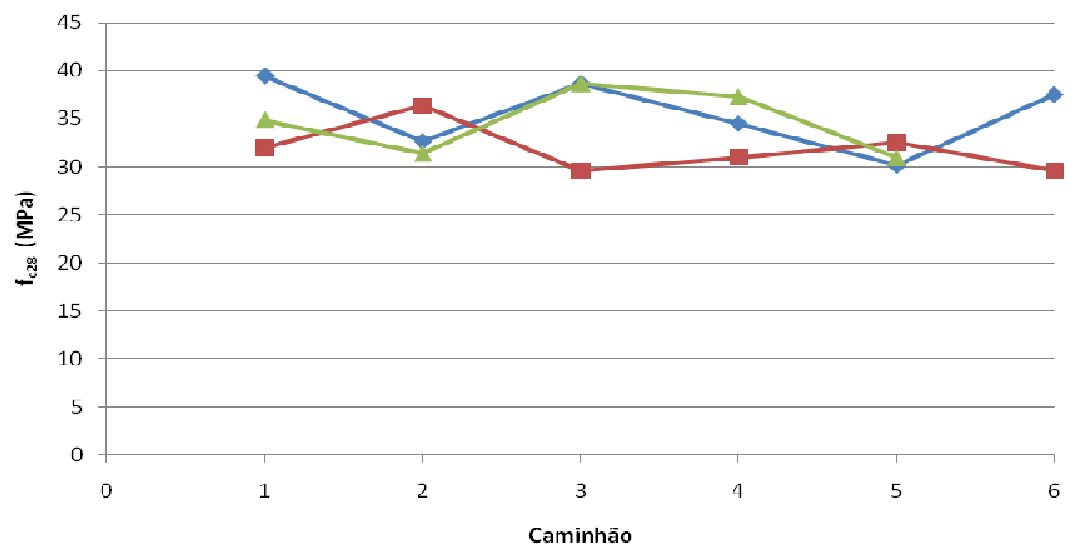

Figura 55 - Variação da resistência à compressão média a 28 dias por cura normal, nos três lotes analisados. ABNT NBR 5739 (2007).

\section{d) Resistência à compressão a 63 dias $\left(f_{c 63}\right)$ por cura normal}

A Tabela 41 apresenta as médias, os desvios padrão, os valores máximos e mínimos, as amplitudes e os coeficientes de variação dos resultados do ensaio de resistência à compressão aos 63 dias com cura imersa em água saturada de cal. No lote treinamento, o ensaio não foi realizado. Os coeficientes de variação foram ainda menores do que a 28 dias.

Tabela 41 - Resultados do ensaio de resistência à compressão a 63 dias por cura normal, nos concretos dos dois lotes analisados. ABNT NBR 5739 (2007).

\begin{tabular}{|c|c|c|c|c|c|c|}
\hline Lote & $\begin{array}{c}\text { Média } \\
(\mathbf{M P a})\end{array}$ & $\begin{array}{c}\text { Desvio } \\
\text { padrão } \\
(\mathbf{M P a})\end{array}$ & $\begin{array}{c}\text { Valor } \\
\text { máximo } \\
(\mathbf{M P a})\end{array}$ & $\begin{array}{c}\text { Valor } \\
\text { mínimo } \\
(\mathbf{M P a})\end{array}$ & $\begin{array}{c}\text { Amplitude } \\
(\mathbf{M P a})\end{array}$ & $\begin{array}{c}\text { Coeficiente } \\
\text { de variação } \\
(\%)\end{array}$ \\
\hline Treinamento & - & - & - & - & - & - \\
\hline 1 & 38,7 & 3,6 & 42,3 & 32,8 & 9,5 & 9 \\
\hline 2 & 38,4 & 0,9 & 39,4 & 37,5 & 1,9 & 2 \\
\hline
\end{tabular}

A Figura 56 ilustra os resultados médios de dois corpos-de-prova por caminhão dos dois lotes analisados. O concreto do caminhão 3 do lote 2 continuou apresentando o maior resultado médio. No lote 1, o concreto o caminhão 6 teve a maior resistência à compressão nessa idade. 


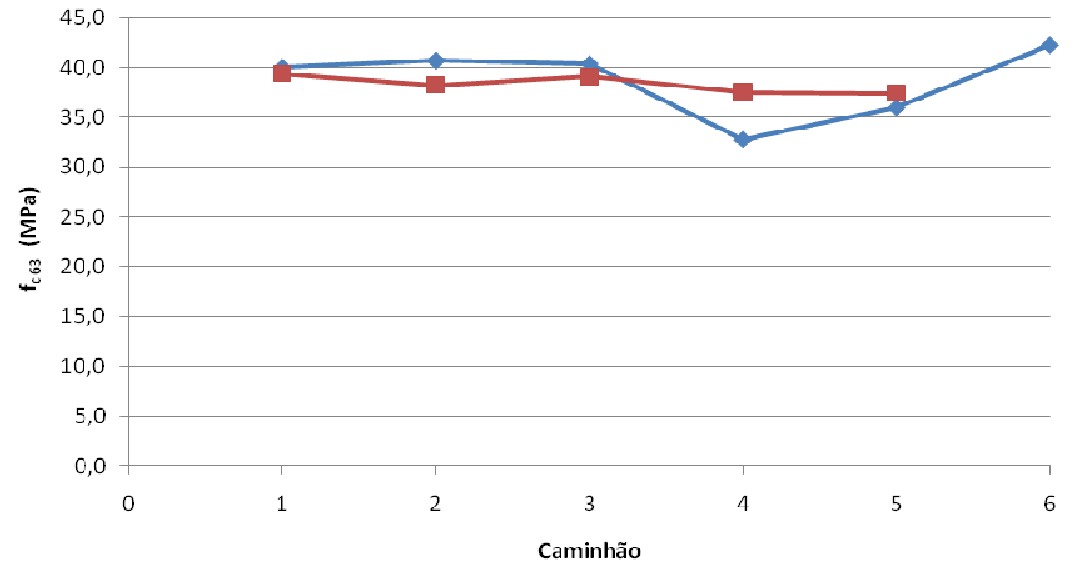

Figura 56 - Variação da resistência à compressão média a 63 dias por cura normal, em dois dos lotes analisados (ABNT NBR 5739, 2007).

\section{e) Resistência à compressão a 91 dias $\left(f_{c 91}\right)$ por normal}

A Tabela 42 apresenta as médias, os desvios padrão, os valores máximos e mínimos, as amplitudes e os coeficientes de variação dos resultados do ensaio de resistência à compressão aos 91 dias com cura imersa em água. No lote treinamento, o ensaio não foi realizado. Os coeficientes de variação foram ainda menores do que a 28 e a 63 dias.

Os resultados obtidos foram muito semelhantes entre os dois lotes.

Tabela 42 - Resultados do ensaio de resistência à compressão, com cura normal a 91 dias por cura normal nos concretos dos dois lotes analisados. ABNT NBR 5739 (2007).

\begin{tabular}{|c|c|c|c|c|c|c|}
\hline Lote & $\begin{array}{c}\text { Média } \\
(\mathbf{M P a})\end{array}$ & $\begin{array}{c}\text { Desvio } \\
\text { padrão } \\
(\mathbf{M P a})\end{array}$ & $\begin{array}{c}\text { Valor } \\
\text { máximo } \\
(\mathbf{M P a})\end{array}$ & $\begin{array}{c}\text { Valor } \\
\text { mínimo } \\
(\mathbf{M P a})\end{array}$ & $\begin{array}{c}\text { Amplitude } \\
(\mathbf{M P a})\end{array}$ & $\begin{array}{c}\text { Coeficiente } \\
\text { de variação } \\
(\%)\end{array}$ \\
\hline Treinamento & - & - & - & - & - & - \\
\hline 1 & 39,7 & 2,3 & 43,1 & 36,5 & 6,6 & 6 \\
\hline 2 & 39,0 & 1,5 & 41,1 & 37,2 & 3,9 & 4 \\
\hline
\end{tabular}

O concreto do caminhão 3 continuou apresentando o maior resultado médio entre todos do lote 2 , e no lote 1 foi o concreto do caminhão 6, conforme a Figura 57. 


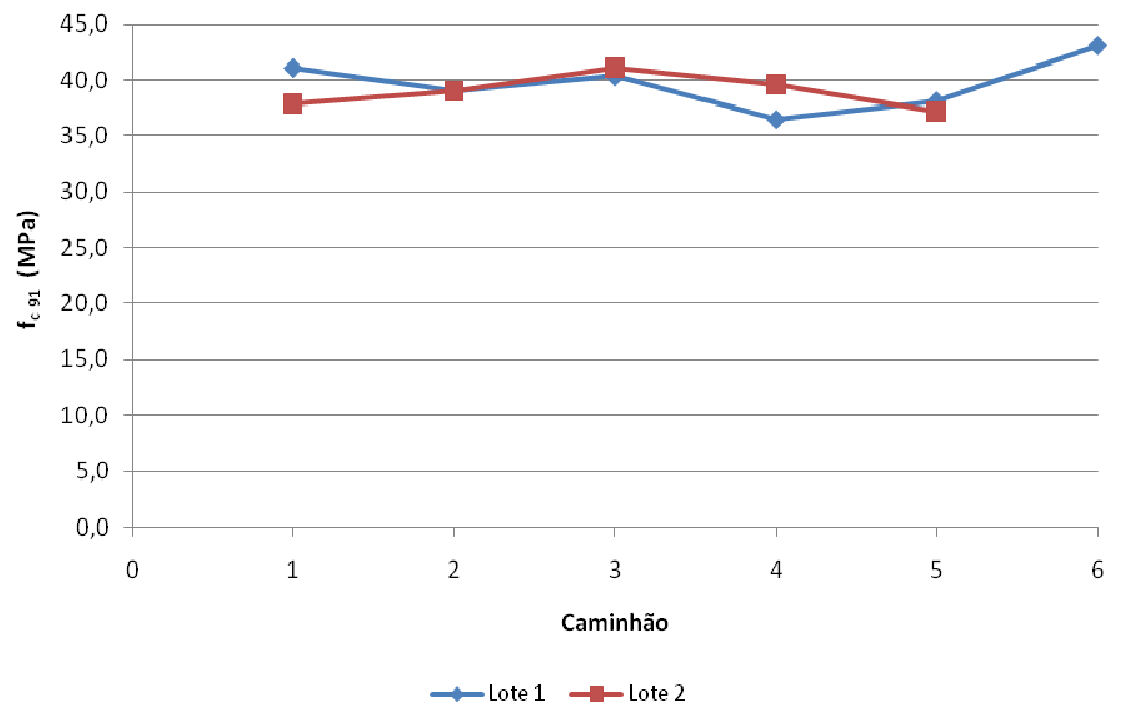

Figura 57 - Variação da resistência à compressão média a 91 dias por cura normal, em dois dos lotes analisados. ABNT NBR 5739 (2007).

\section{f) Análise conjunta das idades por lote}

A Tabela 43 apresenta os resultados das resistências à compressão nas idades analisadas, com os dois tipos de cura estudados no lote treinamento e que devem ser

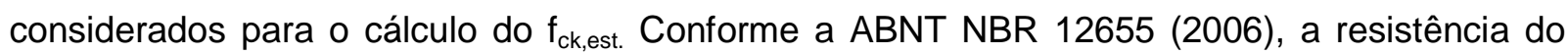
exemplar é o maior valor entre os dois valores obtidos, e na Tabela 43 esses valores são apresentados de forma sublinhada. 
Tabela 43 - Resultados do ensaio de resistência à compressão nos concretos amostrados do lote treinamento. ABNT NBR 5739 (2007)

\begin{tabular}{|c|c|c|c|}
\hline Caminhão & $\begin{array}{l}\text { Corpo-de- } \\
\text { prova }\end{array}$ & $f_{c 7 \text { acel }}$ & $\mathbf{f}_{\mathrm{c} 28}$ \\
\hline \multirow{2}{*}{1} & 1 & 30,3 & 36,6 \\
\hline & 2 & $\overline{30,1}$ & $\underline{42,3}$ \\
\hline \multirow{2}{*}{2} & 3 & 31,4 & $\overline{29,9}$ \\
\hline & 4 & $\overline{31,2}$ & 35,4 \\
\hline \multirow{2}{*}{3} & 5 & 33,6 & $\overline{39,4}$ \\
\hline & 6 & $\overline{33,0}$ & $\overline{37,9}$ \\
\hline \multirow{2}{*}{4} & 7 & 28,9 & 31,8 \\
\hline & 8 & $\overline{28,8}$ & 37,2 \\
\hline \multirow{2}{*}{5} & 9 & 33,0 & $\overline{31,9}$ \\
\hline & 10 & $\overline{31,7}$ & $\overline{28,4}$ \\
\hline \multirow{2}{*}{6} & 11 & 34,9 & 36,8 \\
\hline & 12 & $\overline{34,6}$ & 38,2 \\
\hline \multicolumn{2}{|c|}{$\begin{array}{c}\text { Média entre os maiores } \\
\text { valores (MPa) }\end{array}$} & 32,0 & 37,4 \\
\hline \multicolumn{2}{|c|}{ Valor máximo (MPa) } & 34,9 & 42,3 \\
\hline \multicolumn{2}{|c|}{ Valor mínimo (MPa) } & 28,9 & 31,9 \\
\hline \multicolumn{2}{|c|}{$\begin{array}{l}\text { Desvio padrão para os } \\
\text { maiores valores (MPa) }\end{array}$} & 2,2 & 3,5 \\
\hline \multicolumn{2}{|c|}{$\begin{array}{c}\text { Coeficiente de variação para } \\
\text { os maiores valores (MPa) }\end{array}$} & $7 \%$ & $9 \%$ \\
\hline
\end{tabular}

A Figura 58 ilustra as resistências médias de dois corpos-de-prova dos concretos dos seis caminhões amostrados do lote treinamento, em todas as idades e tipos de cura analisadas. Esses resultados mostram que foi eficiente o procedimento de cura testado neste trabalho, se considerada a forma simples do procedimento operacional para a sua aplicação e que pode ser ainda aperfeiçoada, para efeito de controle de produção ou de recebimento. 


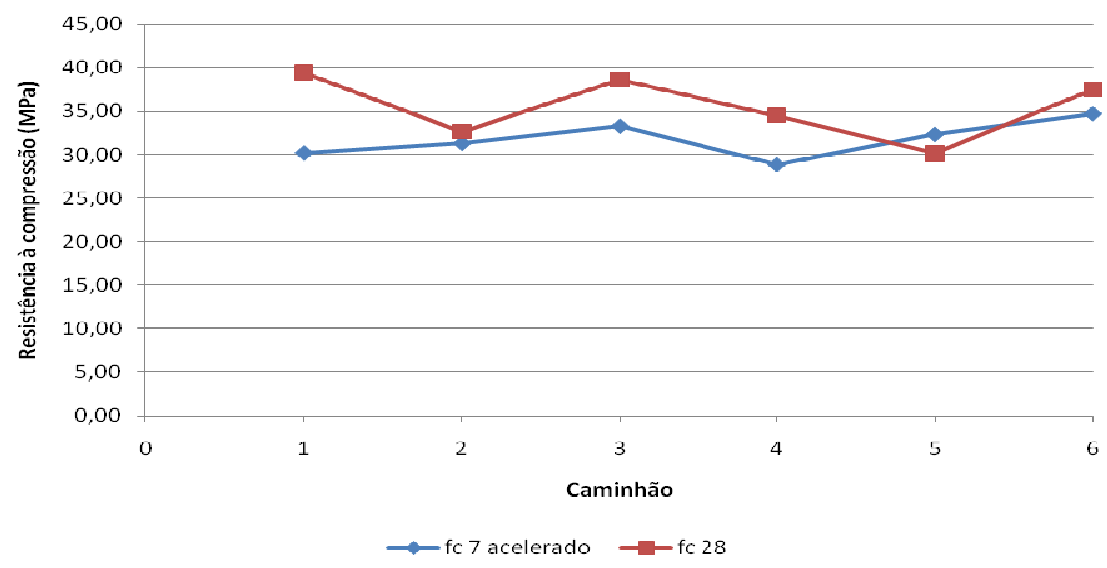

Figura 58 - Variação das resistências médias à compressão a 7 dias por cura acelerada e a 28 dias por cura normal, dos concretos amostrados dos seis caminhões do lote treinamento. ABNT NBR 5739 (2007).

A Tabela 44 apresenta os resultados das resistências à compressão nas idades analisadas e com os três tipos de cura testados no lote 1, que devem ser considerados para o

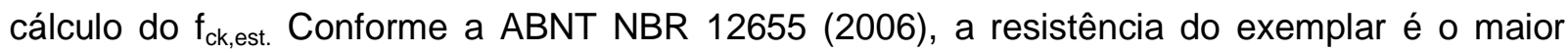
valor entre os dois valores obtidos, e na Tabela 44 esses valores são apresentados de forma sublinhada. A média, os valores máximo e mínimo, o desvio padrão e o coeficiente de variação foram calculados em função do maior valor entre os corpos-de-prova irmãos. Observar que a resistência por cura acelerada térmica de $24 / 48$ h seguida de imersão até 7 dias resultou com o menor coeficiente de variação entre as idades com cura normal comparada até 91 dias 
Tabela 44 - Resultados do ensaio de resistência à compressão nos concretos amostrados do lote 1. ABNT NBR 5739 (2007).

\begin{tabular}{|c|c|c|c|c|c|c|c|c|}
\hline 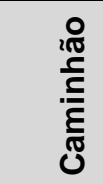 & $\begin{array}{c}\text { Corpo-de } \\
\text { prova }\end{array}$ & $\mathrm{f}_{\mathrm{c1}}(\mathrm{MPa})$ & $\begin{array}{l}f_{\text {clacel }} \\
(\mathrm{MPa})\end{array}$ & $\mathrm{f}_{\mathrm{c7}}(\mathrm{MPa})$ & $\begin{array}{r}f_{\text {c7acel }} \\
(\mathrm{MPa})\end{array}$ & $\mathrm{f}_{\mathrm{c} 28}(\mathrm{MPa})$ & $\mathrm{f}_{\mathrm{c} 63}(\mathrm{MPa})$ & $\mathrm{f}_{\mathrm{c} 91}(\mathrm{MPa})$ \\
\hline \multirow{2}{*}{1} & 1 & 18,4 & 27,7 & 23,6 & 34,1 & 31,6 & 39,9 & 42,7 \\
\hline & 2 & 19,3 & 28,5 & 23,7 & 34,3 & 32,4 & 40,2 & 39,5 \\
\hline \multirow{2}{*}{2} & 3 & 20,0 & 31,2 & 23,1 & 30,3 & 35,6 & 40,9 & 37,4 \\
\hline & 4 & 19,2 & 30,5 & 24,4 & 28,5 & 37,1 & 40,5 & 40,7 \\
\hline \multirow{2}{*}{3} & 5 & 18,5 & 28,2 & 27,0 & 29,9 & 32,4 & 39,0 & 40,0 \\
\hline & 6 & 16,4 & 27,5 & 29,7 & 28,5 & 26,7 & 41,8 & 40,7 \\
\hline \multirow{2}{*}{4} & 7 & 16,6 & 23,1 & 30,9 & 28,7 & 30,2 & 27,0 & 37,0 \\
\hline & 8 & 17,2 & 24,0 & 26,3 & 31,0 & 31,8 & 38,6 & 36,0 \\
\hline \multirow{2}{*}{5} & 9 & 14,4 & 23,4 & 27,4 & 28,3 & 29,7 & 35,4 & 37,5 \\
\hline & 10 & 15,1 & 20,5 & 26,8 & 30,0 & 35,4 & 36,6 & 38,8 \\
\hline \multirow{2}{*}{6} & 11 & 18,6 & $\underline{25,7}$ & $\underline{\underline{26,5}}$ & 30,2 & $\overline{\underline{31,0}}$ & $\overline{41,3}$ & $\underline{\underline{43,7}}$ \\
\hline & 12 & $\underline{19,0}$ & 24,8 & $\overline{26,3}$ & 29,8 & $\overline{28,1}$ & $\underline{43,2}$ & $\overline{42,5}$ \\
\hline \multicolumn{2}{|c|}{$\begin{array}{l}\text { Média entre os } \\
\text { maiores valores } \\
(\mathrm{MPa})\end{array}$} & 18,2 & 26,8 & 27,1 & 31,0 & 33,4 & 40,2 & 40,6 \\
\hline \multicolumn{2}{|c|}{ Valor máximo $(\mathrm{MPa})$} & 20,0 & 31,2 & 30,9 & 34,3 & 37,1 & 43,2 & 43,7 \\
\hline \multicolumn{2}{|c|}{ Valor mínimo (MPa) } & 15,1 & 23,4 & 23,7 & 29,9 & 31,0 & 36,6 & 37,0 \\
\hline \multicolumn{2}{|c|}{$\begin{array}{c}\text { Desvio padrão para } \\
\text { os maiores valores } \\
\text { (MPa) }\end{array}$} & 1,8 & 3,0 & 2,8 & 1,7 & 2,4 & 2,3 & 2,5 \\
\hline \multicolumn{2}{|c|}{$\begin{array}{c}\text { Coeficiente de } \\
\text { variação para os } \\
\text { maiores valores (\%) }\end{array}$} & $10 \%$ & $11 \%$ & $11 \%$ & $5 \%$ & $7 \%$ & $6 \%$ & $6 \%$ \\
\hline
\end{tabular}

A Figura 59 ilustra as resistências médias de dois corpos-de-prova dos concretos dos seis caminhões amostrados do lote 1, em todas as idades e tipos de cura analisadas. Esses resultados também evidenciam a predição eficiente do procedimento de cura acelerada alternativo empregado neste trabalho, mas ao mesmo tempo indicam que a maturidade do concreto poderia ter sido otimizada, caso a duração da cura em temperatura moderada tivesse sido estendida por um prazo maior entre 24 h e 7 dias. É interessante também observar que mesmo o concreto com cura normal apresentou razoável evolução de resistência entre 28 e 63 dias, para o tipo de cimento empregado (CP V) e talvez isto possa ter relação com efeitos secundários do aditivo empregado. 


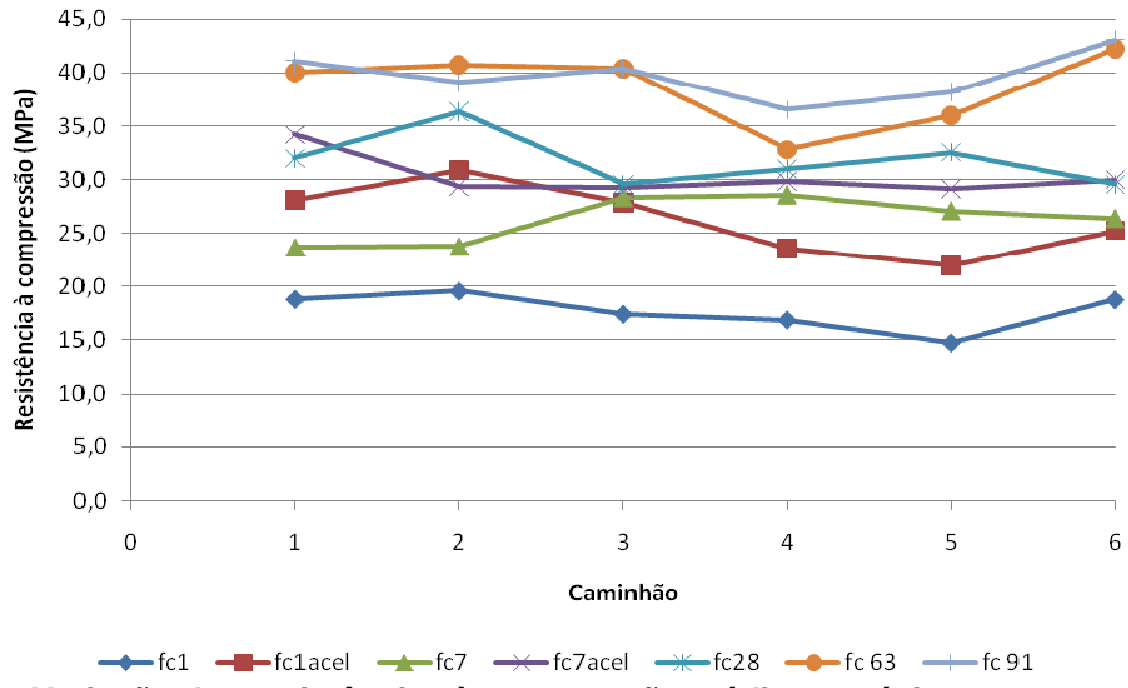

Figura 59 - Variação das resistências à compressão médias e máximas por exemplar, dos concretos amostrados dos seis caminhões do lote 1. ABNT NBR 5739 (2007).

A Tabela 45 apresenta os resultados das resistências à compressão nas idades analisadas e com os três tipos de cura testados no lote 2, que devem ser considerados para

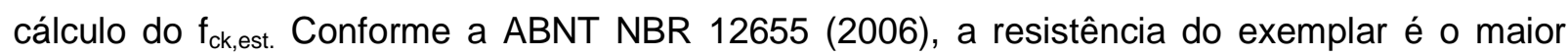
entre os dois valores obtidos, e na Tabela 45 esses valores são apresentados de forma sublinhada. As médias, os valores máximo e mínimo, os desvios padrão e os coeficientes de variação foram calculados em função do maior valor entre os corpos-de-prova irmãos. 
Tabela 45 - Resultados do ensaio de resistência à compressão nos concretos amostrados do lote 2. ABNT NBR 5739 (2007).

\begin{tabular}{|c|c|c|c|c|c|c|c|c|}
\hline 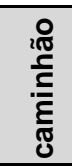 & $\begin{array}{l}\text { Corpo-de- } \\
\text { prova }\end{array}$ & $\mathrm{f}_{\mathrm{c} 1}(\mathrm{MPa})$ & $\begin{array}{l}\mathbf{f}_{\text {c1acel }} \\
(\mathrm{MPa})\end{array}$ & $\mathrm{f}_{\mathrm{c} 7}(\mathrm{MPa})$ & $\begin{array}{l}\mathbf{f}_{\mathrm{c} 7 \mathrm{acel}} \\
(\mathrm{MPa})\end{array}$ & $\mathrm{f}_{\mathrm{c} 28}(\mathrm{MPa})$ & $\mathrm{f}_{\mathrm{c} 63}(\mathrm{MPa})$ & $\mathrm{f}_{\mathrm{c} 91}(\mathrm{MPa})$ \\
\hline \multirow{2}{*}{1} & 1 & 14,3 & $\underline{30,3}$ & 24,1 & $\underline{30,3}$ & $\underline{38,6}$ & $\underline{40,2}$ & $\underline{40,7}$ \\
\hline & 2 & 14,3 & 29,1 & $\underline{26,0}$ & 30,1 & 31,1 & 38,6 & 35,1 \\
\hline \multirow{2}{*}{2} & 3 & $\underline{14,0}$ & 31,8 & $\underline{28,3}$ & $\underline{33,2}$ & 30,2 & $\underline{38,5}$ & 38,6 \\
\hline & 4 & 12,1 & 31,8 & 27,2 & 32,5 & 32,5 & 38,0 & 39,4 \\
\hline \multirow{2}{*}{3} & 5 & 2,8 & $\underline{32,8}$ & 28,9 & 33,6 & 36,5 & $\underline{40,0}$ & $\underline{42,4}$ \\
\hline & 6 & 2,9 & 27,0 & 28,8 & 33,0 & 40,8 & 38,2 & 39,8 \\
\hline \multirow{2}{*}{4} & 7 & $\underline{15,5}$ & 29,2 & 24,6 & 29,0 & 34,2 & 38,7 & 39,7 \\
\hline & 8 & 15,2 & $\underline{31,4}$ & $\underline{28,3}$ & $\underline{31,7}$ & $\underline{40,3}$ & 36,4 & 39,5 \\
\hline \multirow{2}{*}{5} & 9 & 13,9 & $\underline{33,9}$ & $\underline{23,6}$ & 32,1 & 29,4 & 35,8 & $\overline{36,4}$ \\
\hline & 10 & 15,7 & 31,1 & 23,3 & 30,4 & 32,4 & 39,1 & 38,0 \\
\hline \multicolumn{2}{|c|}{\begin{tabular}{|c|} 
Média entre os \\
maiores valores (MPa)
\end{tabular}} & 12,5 & 32,0 & 27,0 & 32,2 & 36,9 & 39,3 & 40,0 \\
\hline \multicolumn{2}{|c|}{ Valor máximo (MPa) } & 15,7 & 33,9 & 28,9 & 33,6 & 40,8 & 40,2 & 42,4 \\
\hline \multicolumn{2}{|c|}{ Valor mínimo (MPa) } & 2,9 & 30,3 & 23,6 & 30,3 & 29,4 & 38,5 & 38,0 \\
\hline \multicolumn{2}{|c|}{$\begin{array}{l}\text { Desvio padrão para os } \\
\text { maiores valores(MPa) }\end{array}$} & 5,4 & 1,4 & 2,2 & 1,3 & 4,2 & 0,8 & 1,6 \\
\hline \multicolumn{2}{|c|}{$\begin{array}{c}\text { Coeficiente de variação } \\
\text { para os maiores } \\
\text { valores (\%) }\end{array}$} & $43 \%$ & $4 \%$ & $8 \%$ & $4 \%$ & $11 \%$ & $2 \%$ & $4 \%$ \\
\hline
\end{tabular}

A Figura 60 ilustra as resistências dos concretos dos cinco caminhões amostrados do lote 2, em todas as idades analisadas e tipos de cura. Observa-se o resultado eficiente do segundo procedimento de cura acelerada empregado neste trabalho. Mas, também indicam que a maturidade do concreto poderia ter sido otimizada, caso a duração da cura em temperatura moderada tivesse sido estendida por um prazo maior entre 24 h e 7 dias. 


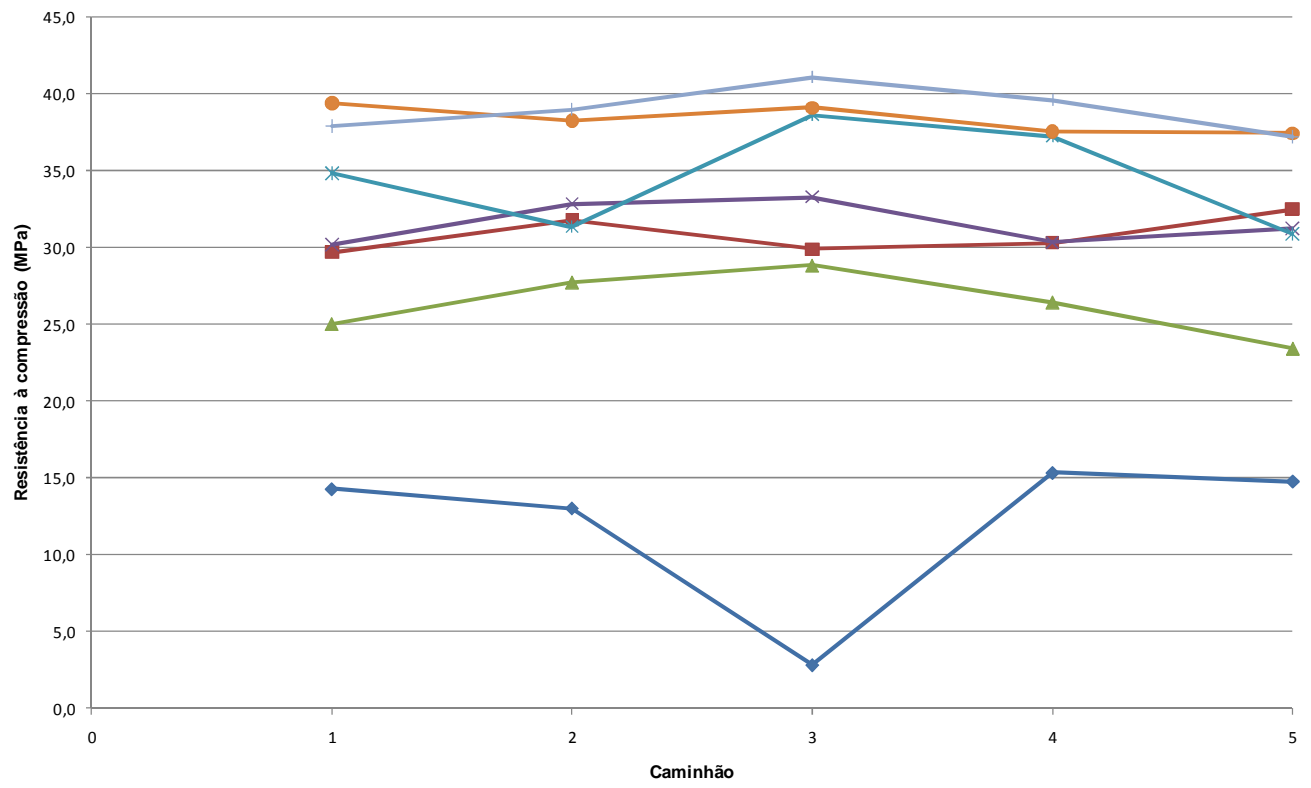

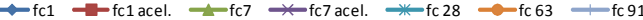

Figura 60 - Variação das resistências médias à compressão dos concretos amostrados dos cinco caminhões do lote 2. ABNT NBR 5739 (2007).

\section{g) Análise da evolução da resistência relativa à cura a 28 dias}

A Tabela 46 apresenta os índices relativos de resistência em função da obtida a 28 dias por cura normal nos corpos-de-prova amostrados do lote treinamento. Esse índice foi calculado para os maiores valores entre os corpos-de-prova irmãos. 
Tabela 46 - Evolução da resistência relativa a cura normal a 28 dias nos corpos-de-prova amostrados do lote treinamento.

\begin{tabular}{|c|c|c|}
\hline Caminhão & Corpo-de-prova & $\mathbf{f}_{\text {c7acel }} / \mathbf{f}_{\mathrm{c} 28}$ \\
\hline \multirow{2}{*}{1} & 1 & 0,72 \\
\cline { 2 - 3 } & 2 & - \\
\hline \multirow{2}{*}{2} & 3 & 0,89 \\
\cline { 2 - 3 } & 4 & - \\
\cline { 2 - 3 } 3 & 5 & 0,85 \\
\hline \multirow{2}{*}{4} & 6 & - \\
\cline { 2 - 3 } & 7 & 0,78 \\
\hline \multirow{2}{*}{5} & 9 & - \\
\cline { 2 - 3 } & 10 & - \\
\hline \multirow{2}{*}{6} & 11 & 0,91 \\
\cline { 2 - 3 } & 12 & - \\
\hline \hline \multirow{2}{*}{ Índice de crescimento médio } & 0,86 \\
\hline \multicolumn{2}{|c|}{ Desvio Padrão (\%) } & 0,11 \\
\hline \multicolumn{2}{|c|}{ Coeficiente de Variaçao (\%) } & $12,9 \%$ \\
\hline
\end{tabular}

Os resultados da Tabela 47 apresentam os índices de crescimento das resistências à compressão em função da obtida a 28 dias por cura normal nos corpos-de-prova amostrados do lote 1, levando em conta apenas os maiores valores entre corpos-de-prova irmãos. 
Tabela 47 - Evolução da resistência a 28 dias por cura normal dos corpos-de-prova amostrados do lote1.

\begin{tabular}{|c|c|c|c|c|c|c|c|}
\hline \multirow{2}{*}{ 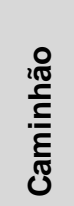 } & \multirow{2}{*}{$\begin{array}{l}\text { Corpo- } \\
\text { de-prova }\end{array}$} & \multicolumn{6}{|c|}{ Relativo à resistência a 28 dias por normal ( $\left.f_{c 28}\right)$} \\
\hline & & $f_{c 1} / f_{c 28}$ & $f_{\text {c1acel }} / f_{c 28}$ & $f_{c 7} / f_{c 28}$ & $f_{c 7 a c e l} / f_{c 28}$ & $f_{c 63} / f_{c 28}$ & $\mathbf{f}_{\mathrm{c} 91} / \mathbf{f}_{\mathrm{c} 28}$ \\
\hline \multirow{2}{*}{1} & 1 & 0,60 & 0,88 & 0,73 & 1,06 & 1,24 & 1,32 \\
\hline & 2 & - & - & - & - & - & - \\
\hline \multirow{2}{*}{2} & 3 & 0,54 & 0,84 & 0,66 & 0,82 & 1,10 & 1,10 \\
\hline & 4 & - & - & - & - & - & - \\
\hline \multirow{2}{*}{3} & 5 & 0,57 & $\overline{0,87}$ & 0,92 & 0,92 & 1,29 & 1,26 \\
\hline & 6 & - & - & - & - & - & - \\
\hline \multirow{2}{*}{4} & 7 & 0,54 & 0,75 & 0,97 & 0,97 & 1,21 & 1,16 \\
\hline & 8 & - & - & - & - & - & - \\
\hline \multirow{2}{*}{5} & 9 & 0,43 & 0,66 & 0,77 & 0,85 & 1,03 & 1,10 \\
\hline & 10 & - & - & - & - & - & - \\
\hline \multirow{2}{*}{6} & 11 & 0,61 & 0,83 & 0,85 & 0,97 & 1,39 & 1,41 \\
\hline & 12 & - & - & - & - & & \\
\hline \multicolumn{2}{|c|}{$\begin{array}{l}\text { Indice de } \\
\text { crescimento } \\
\text { médio }\end{array}$} & 0,55 & 0,81 & 0,82 & 0,93 & 1,21 & 1,22 \\
\hline \multicolumn{2}{|c|}{ Desvio padrão } & 0,07 & 0,09 & 0,12 & 0,09 & 0,13 & 0,13 \\
\hline \multicolumn{2}{|c|}{$\begin{array}{l}\text { Coeficiente de } \\
\text { Variação }\end{array}$} & $12 \%$ & $11 \%$ & $14 \%$ & $10 \%$ & $11 \%$ & $10 \%$ \\
\hline
\end{tabular}

Os resultados da Tabela 48 apresentam os índices relativos das resistências à compressão em função da obtida a 28 dias por cura normal nos corpos-de-prova amostrados do lote 2, levando em conta apenas o maior valor entre corpos-de-prova irmãos. 
Tabela 48 - Evolução da resistência a 28 dias por cura normal dos corpos-de-prova amostrados do lote2.

\begin{tabular}{|c|c|c|c|c|c|c|c|}
\hline \multirow{2}{*}{ 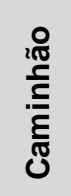 } & \multirow{2}{*}{$\begin{array}{c}\text { Corpo- } \\
\text { de- } \\
\text { prova }\end{array}$} & \multicolumn{6}{|c|}{ Relativo à resistência a 28 dias por cura normal ( $f_{c 28}$ ) } \\
\hline & & $\mathbf{f}_{\mathrm{c} 1} / \mathbf{f}_{\mathrm{c} 28}$ & $f_{c 1 a c e l} / f_{c 28}$ & $f_{c 7} / f_{c 28}$ & $\mathbf{f}_{\mathrm{c} 7 \mathrm{acel}} / \mathbf{f}_{\mathrm{c} 28}$ & $f_{c 63} / f_{c 28}$ & $f_{c 91} / f_{c 28}$ \\
\hline \multirow{2}{*}{1} & $\overline{1}$ & 0,37 & 0,78 & $\overline{0,67}$ & 0,78 & 1,04 & 1,05 \\
\hline & 2 & - & - & - & 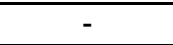 & 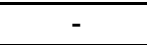 & - \\
\hline \multirow{2}{*}{2} & 3 & 0,43 & 0,98 & 0,87 & 1,02 & 1,18 & 1,21 \\
\hline & 4 & - & - & - & - & - & - \\
\hline \multirow{2}{*}{3} & 5 & 0,07 & 0,80 & 0,71 & 0,82 & 0,98 & 1,04 \\
\hline & 6 & - & - & - & - & - & - \\
\hline \multirow{2}{*}{4} & 7 & 0,38 & 0,78 & 0,70 & 0,79 & 0,96 & 0,99 \\
\hline & 8 & - & - & - & - & - & - \\
\hline \multirow{2}{*}{5} & $\overline{9}$ & 0,48 & 1,05 & 0,73 & 0,99 & 1,21 & 1,17 \\
\hline & 10 & - & - & - & - & - & - \\
\hline \multicolumn{2}{|c|}{$\begin{array}{l}\text { Índice de } \\
\text { crescimento } \\
\text { médio }\end{array}$} & 0,42 & 0,88 & 0,74 & 0,88 & 1,07 & 1,09 \\
\hline \multicolumn{2}{|c|}{ Desvio Padrão } & 0,05 & 0,12 & 0,08 & 0,12 & 0,11 & 0,10 \\
\hline \multicolumn{2}{|c|}{$\begin{array}{l}\text { Coefieciente de } \\
\text { Variação }\end{array}$} & $12 \%$ & $14 \%$ & $11 \%$ & $13 \%$ & $11 \%$ & $9 \%$ \\
\hline
\end{tabular}

\section{h) Cálculo da resistência característica estimada à compressão}

Como já mencionado no item 4.2.3 do Capítulo 4, o volume dos lotes treinamento e lote 1 foi de $71 \mathrm{~m}^{3}$ e foi caracterizado por amostragem parcial da ABNT NBR 12655 (2006).

Os valores calculados da resistência característica estimada à compressão para os lotes treinamento e 1, podem ser vistos nas Tabelas 49 e 50, respectivamente.

No lote treinamento as resistências características entre os dois tipos de cura apresentaram resultados um pouco mais distantes. A resistência característica estimada à compressão a 28 dias foi superior à resistência especificada, logo de acordo com a ABNT NBR 12655 (2006), o lote seria aceito. Já a resistência característica estimada à compressão a 7 dias por cura acelerada apresentou valor inferior ao de projeto, e de acordo com ABNT NBR 12655 (2008), o lote poderia ser rejeitado. 
Tabela 49 - Resistência característica por amostragem parcial dos concretos do lote treinamento. ABNT NBR 12655 (2006).

\begin{tabular}{|c|c|c|}
\hline Amostragem & $\begin{array}{c}\text { Resistência à } \\
\text { compressão }\end{array}$ & $\begin{array}{c}\text { Resistência característica à } \\
\text { compressão estimada - } \\
\mathbf{f}_{\text {ckest }} \text { (MPa) }\end{array}$ \\
\hline \multirow{2}{*}{ Parcial } & $\mathrm{f}_{\mathrm{c} 7 \text { acel }}$ & 27,8 \\
\cline { 2 - 3 } & $\mathrm{f}_{\mathrm{c} 28}$ & 30,1 \\
\hline
\end{tabular}

Para o lote 1, pela Tabela 50 tem-se que $f_{c k \text {,est 7acel }}$ e $f_{c k, e s t ~ 28} \geq f_{c k \text {,esp }}$ são maiores do que 0 valor especificado pelo projeto $(29,7$ e $30,4 \mathrm{MPa} \geq 30 \mathrm{MPa})$ e de acordo com a ABNT NBR 12655 (2006), o lote poderia ser aceito desde o ensaio acelerado a 7 dias.

Tabela 50 - Resistência característica por amostragem parcial dos concretos do lote 1. ABNT NBR 12655 (2006).

\begin{tabular}{|c|c|c|}
\hline Amostragem & $\begin{array}{c}\text { Resistência à } \\
\text { compressão }\end{array}$ & $\begin{array}{c}\text { Resistência } \\
\text { característica à } \\
\text { compressão } \\
\text { estimada - } f_{\text {ckest }}\end{array}$ \\
\hline \multirow{7}{*}{ Parcial } & $\mathrm{f}_{\mathrm{c} 1}$ & 13,8 \\
\cline { 2 - 3 } & $\mathrm{f}_{\mathrm{c} 1 \text { acel }}$ & 21,7 \\
\cline { 2 - 3 } & $\mathrm{f}_{\mathrm{c} 7}$ & 21,6 \\
\cline { 2 - 3 } & $\mathrm{f}_{\mathrm{c} 7 \text { acel }}$ & 29,7 \\
\cline { 2 - 3 } & $\mathrm{f}_{\mathrm{c} 28}$ & 30,4 \\
\cline { 2 - 3 } & $\mathrm{f}_{\mathrm{c} 63}$ & 35,0 \\
\cline { 2 - 3 } & $\mathrm{f}_{\mathrm{c} 91}$ & 35,1 \\
\hline
\end{tabular}

A Tabela 51 apresenta uma simulação da resistência característica estimada à compressão, caso a amostragem fosse total para os lotes treinamento e 1, pelos critérios da ABNT NBR 12655 (2006) e segundo o item 3.8.3 do Capitulo 3.

Pela simulação realizada, percebe-se que as resistências característica estimada à compressão entre os dois critérios de amostragem apresentaram resultados próximos nos dois lotes testados, sendo que a resistência característica estimada à compressão por amostragem total resultou ligeiramente superior em todas as idades já que melhora a confiança matemática do estimador em se amostrando todos os caminhões de um lote, o que sempre é recomendável em concretagem de pilares.

Como na amostragem total, pelos critérios da ABNT NBR 12655 (2006), os concretos com cura acelerada $24 / 48$ horas e normal até 28 dias do lote 1 , seriam considerados aceitos. 
Tabela 51 - Simulação da resistência característica por amostragem total dos concretos dos lotes treinamento e 1. ABNT NBR 12655 (2006).

\begin{tabular}{|c|c|c|}
\hline \multirow{2}{*}{ Amostragem } & $\begin{array}{c}\text { Resistência à } \\
\text { compressão }\end{array}$ & $\begin{array}{c}\text { Resistência característica à } \\
\text { compressão estimada - } \\
\mathbf{f}_{\text {ckest }}(\mathrm{MPa})\end{array}$ \\
\hline \multirow{3}{*}{ Total } & \multicolumn{2}{|c|}{ Lote treinamento } \\
\cline { 2 - 3 } & $\mathrm{f}_{\mathrm{c} 7 \text { acel }}$ & 28,9 \\
\hline \multirow{5}{*}{ Total } & $\mathrm{f}_{\mathrm{c} 28}$ & 31,9 \\
\hline & \multicolumn{2}{|c|}{ Lote 1 } \\
\cline { 2 - 3 } & $\mathrm{f}_{\mathrm{c} 1}$ & 15,1 \\
\cline { 2 - 3 } & $\mathrm{f}_{\mathrm{c} 1 \text { acel }}$ & 23,4 \\
\cline { 2 - 3 } & $\mathrm{f}_{\mathrm{c} 7}$ & 23,7 \\
\cline { 2 - 3 } & $\mathrm{f}_{\mathrm{c} 7 \text { acel }}$ & 29,9 \\
\cline { 2 - 3 } & $\mathrm{f}_{\mathrm{c} 28}$ & 31,0 \\
\cline { 2 - 3 } & $\mathrm{f}_{\mathrm{c} 63}$ & 36,6 \\
\cline { 2 - 3 } & $\mathrm{f}_{\mathrm{c} 91}$ & 37,0 \\
\hline
\end{tabular}

Como já mencionado no item 4.2.4 do Capítulo 4, o volume de concreto estudado no lote 2 foi de $40 \mathrm{~m}^{3}$ e foi caracterizado por amostragem total da ABNT NBR 12655 (2006).

O valor estimado da resistência característica à compressão em cada idade analisada é apresentado na Tabela 52.

Pela Tabela 52 tem-se que $f_{c k \text {,est } 7 a c e l}$ e $f_{c k \text {,est } 28} \geq f_{c k \text {,esp }}$ são maiores do que o valor especificado pelo projeto $(30,3$ e $32,4 \mathrm{MPa} \geq 30 \mathrm{MPa})$, de acordo com a ABNT NBR 12655 (2006), concreto do lote 2 poderia ser considerado aceito desde o ensaio acelerado a um ou sete dias. 
Tabela 52 - Resistência característica dos concretos amostrados do lote 2. ABNT NBR 12655 (2006)

\begin{tabular}{|c|c|c|}
\hline Amostragem & $\begin{array}{c}\text { Resistência } \\
\text { à } \\
\text { compressão }\end{array}$ & $\begin{array}{c}\text { Resistência } \\
\text { característica à } \\
\text { compressão } \\
\text { estimada - } f_{\text {ckest }} \\
\text { (MPa) }\end{array}$ \\
\hline \multirow{5}{*}{ Total } & $\mathrm{f}_{\mathrm{c} 1}$ & 2,9 \\
\cline { 2 - 3 } & $\mathrm{f}_{\mathrm{c} 1 \text { acel }}$ & 30,3 \\
\cline { 2 - 3 } & $\mathrm{f}_{\mathrm{c} 7}$ & 23,6 \\
\cline { 2 - 3 } & $\mathrm{f}_{\mathrm{c} 7 \text { acel }}$ & 30,3 \\
\cline { 2 - 3 } & $\mathrm{f}_{\mathrm{c} 28}$ & 32,4 \\
\cline { 2 - 3 } & $\mathrm{f}_{\mathrm{c} 63}$ & 38,5 \\
\cline { 2 - 3 } & $\mathrm{f}_{\mathrm{c} 91}$ & 38,0 \\
\hline
\end{tabular}

\subsubsection{Resistência à tração por compressão diametral}

\section{a) Resistência à tração acelerada a 7 dias $\left(f_{c t, S P ~ 7 a c e l}\right)$ por cura térmica $24 / 48$ horas e imersão normal até 7 dias}

A Tabela 53 apresenta as médias, os desvios padrão, os valores máximos e mínimos, as amplitudes e os coeficientes de variação dos resultados do ensaio de resistência à tração por compressão diametral a 7 dias por cura acelerada.

Tabela 53 - Resultados do ensaio de resistência à tração por compressão diametral, cura acelerada 24/48 horas e imersão em água até 7 dias nos concretos dos três lotes analisados.

ABNT NBR 7222 (1994).

\begin{tabular}{|c|c|c|c|c|c|c|}
\hline Lote & $\begin{array}{c}\text { Média } \\
(\mathbf{M P a})\end{array}$ & $\begin{array}{c}\text { Desvio } \\
\text { padrão } \\
(\mathrm{MPa})\end{array}$ & $\begin{array}{c}\text { Valor } \\
\text { máximo } \\
(\mathbf{M P a})\end{array}$ & $\begin{array}{c}\text { Valor } \\
\text { mínimo } \\
(\mathrm{MPa})\end{array}$ & $\begin{array}{c}\text { Amplitude } \\
(\mathrm{MPa})\end{array}$ & $\begin{array}{c}\text { Coeficiente } \\
\text { de variação } \\
(\%)\end{array}$ \\
\hline Treinamento & 3,6 & 0,1 & 3,85 & 3,46 & 0,39 & 4 \\
\hline 1 & 2,8 & 0,1 & 2,88 & 2,64 & 0,24 & 4 \\
\hline 2 & 3,7 & 0,4 & 4,19 & 3,05 & 1,14 & 12 \\
\hline
\end{tabular}

Os lotes 1 e treinamento apresentaram os menores coeficientes de variação, como pode ser visto na Figura 61, e os resultados do lote 1 são inferiores para o concreto dos seis caminhões, em boa concordância com as medidas de teor de ar deste lote, que foram $0,5 \%$ superiores às do lote treinamento e lote 2. 


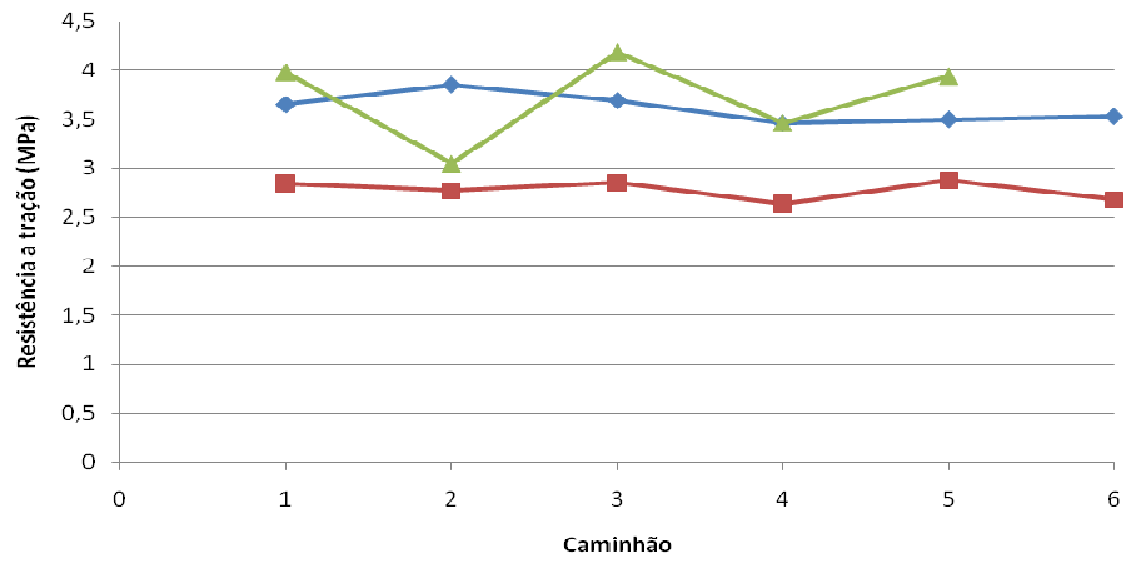

Figura 61 - Variação da resistência à tração por compressão diametral média aos 7 dias de dois corpos-de-prova por caminhão, submetidos à cura acelerada 24/48 h e imersão em água, amostrados em três lotes analisados. ABNT NBR 7222 (1994).

\section{b) Resistência à tração a 28 dias $\left(\mathbf{f}_{\mathrm{ct}, \mathrm{SP} 28}\right)$ por cura normal}

A Tabela 54 apresenta as médias, os desvios padrão, os valores máximos e mínimos, as amplitudes e os coeficientes de variação dos resultados do ensaio de resistência à tração por compressão diametral a 28 dias com cura imersa em água.

Tabela 54 - Resultados do ensaio de resistência à tração por compressão diametral com cura normal até 28 dias nos concretos dos três lotes analisados. ABNT NBR 7222 (1994).

\begin{tabular}{|c|c|c|c|c|c|c|}
\hline Lote & $\begin{array}{c}\text { Média } \\
(\mathbf{M P a})\end{array}$ & $\begin{array}{c}\text { Desvio } \\
\text { padrão } \\
(\mathbf{M P a})\end{array}$ & $\begin{array}{c}\text { Valor } \\
\text { máximo } \\
(\mathrm{MPa})\end{array}$ & $\begin{array}{c}\text { Valor } \\
\text { mínimo } \\
(\mathbf{M P a})\end{array}$ & $\begin{array}{c}\text { Amplitude } \\
(\mathrm{MPa})\end{array}$ & $\begin{array}{c}\text { Coeficiente } \\
\text { de variação } \\
(\%)\end{array}$ \\
\hline Treinamento & 3,4 & 0,4 & 3,85 & 2,99 & 0,86 & 10 \\
\hline 1 & 3,2 & 0,2 & 3,41 & 3,08 & 0,33 & 5 \\
\hline 2 & 3,0 & 0,3 & 3,53 & 2,74 & 0,79 & 11 \\
\hline
\end{tabular}

A Figura 62 apresenta o resultado dos concretos amostrados nos caminhões dos três lotes, mas nesta idade houve uma variação mais aleatória nos resultados entre os caminhões, sem distinção dos lotes, como ocorreu na idade de 7 dias com cura acelerada. 


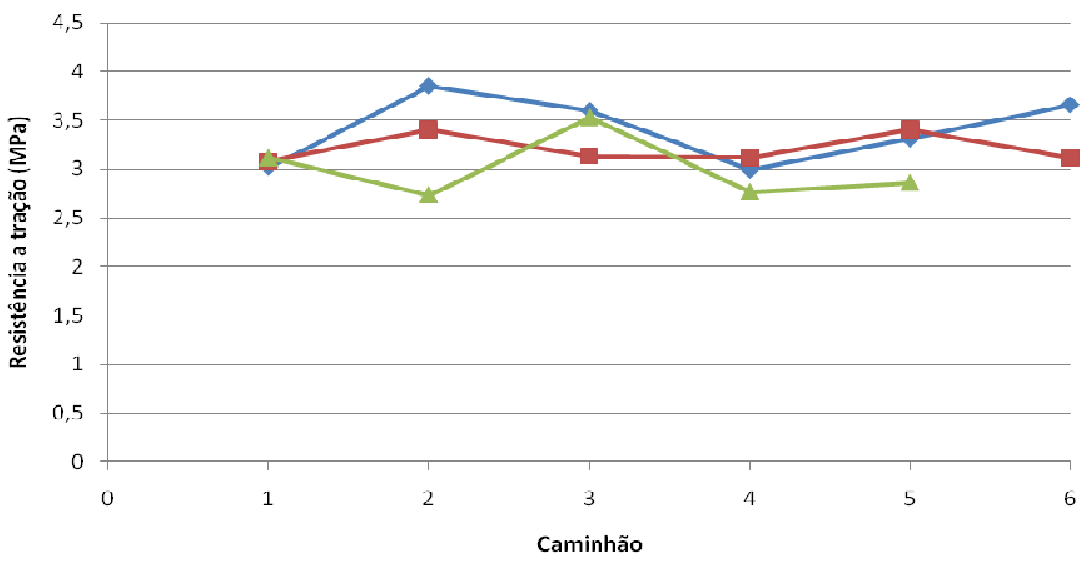

Figura 62 - Resistência à tração por compressão diametral média aos 28 dias de dois corpos-deprova por caminhão, submetidos à cura normal, amostrados em três lotes analisados. ABNT NBR 7222 (1994).

Também foram realizados ensaios de tração por compressão diametral com 91 dias, nos corpos-de-prova dos três lotes analisados, que foram destinados ao ensaios de ciclagem, mas os resultados encontram-se apenas relacionados no Anexo C, pois não foram interpretados inicialmente pelo CEA, devendo somente serem discutidos em futuros trabalhos de divulgação desta pesquisa.

\section{c) Análise conjunta das idades por lote}

A Tabela 55 apresenta os valores das resistências à tração por compressão diametral nos corpos-de-prova amostrados do lote treinamento e o índice relativo de resistência em função da obtida a 28 dias. As médias, os valores máximo e mínimo, os desvios padrão e os coeficientes de variação foram calculados em função do maior entre os corpos-de-prova irmãos. Conforme a ABNT NBR 12655 (2006), a resistência do exemplar de cada caminhão amostrado é o maior valor entre os dois obtidos nos ensaios, e na Tabela 55 esses valores são apresentados de forma sublinhada.

A resistência média a 7 dias por cura acelerada $24 / 48$ horas apresentou resultado maior do que a resistência à 28 dias por cura normal. Esses resultados justificam a utilização desse método de cura no controle tecnológico de concretos estruturais, já que consegue antecipar a resistência a 28 dias. 
Tabela 55 - Resultados do ensaio de resistência à tração por compressão diametral nos concretos amostrados do lote treinamento e evolução da resistência em função da resistência à tração a 28 dias. ABNT NBR 7222 (1994).

\begin{tabular}{|c|c|c|c|c|}
\hline Ů & Corpo-de-prova & $\begin{array}{c}\mathbf{f}_{\mathrm{ct}, \mathrm{sp} 7}- \\
\text { acelerado } \\
(\mathrm{MPa})\end{array}$ & $\begin{array}{l}\mathbf{f}_{\mathrm{ct}, \mathrm{sp} 28} \\
(\mathrm{MPa})\end{array}$ & $f_{c t, s p 7 a c e l} / f_{c t, s p 28}$ \\
\hline \multirow{2}{*}{1} & 1 & 3,56 & 2,48 & 1,05 \\
\hline & 2 & 3,75 & 3,56 & - \\
\hline \multirow{2}{*}{2} & 3 & $\overline{3,50}$ & $\overline{3,88}$ & 1,08 \\
\hline & 4 & 4,20 & $\overline{3,82}$ & - \\
\hline \multirow{2}{*}{3} & 5 & $\overline{3,56}$ & 3,50 & 1,04 \\
\hline & 6 & 3,82 & 3,69 & - \\
\hline \multirow{2}{*}{4} & $\overline{7}$ & $\overline{4,07}$ & $\overline{2,99}$ & 1,36 \\
\hline & 8 & $\overline{2,86}$ & 3,00 & - \\
\hline \multirow{2}{*}{5} & 0 & 3,37 & $\overline{3,70}$ & 0,98 \\
\hline & 10 & 3,63 & $\overline{2,92}$ & - \\
\hline \multirow{2}{*}{6} & 11 & $\overline{4,20}$ & 3,12 & 1,00 \\
\hline & 12 & $\overline{2,86}$ & 4,20 & - \\
\hline \multicolumn{2}{|c|}{$\begin{array}{l}\text { Média entre os maiores } \\
\text { valores }\end{array}$} & 3,9 & 3,7 & - \\
\hline \multicolumn{2}{|c|}{ Valor máximo } & 4,2 & 4,2 & 1,36 \\
\hline \multicolumn{2}{|c|}{ Valor mínimo } & 3,6 & 3,0 & 0,98 \\
\hline \multicolumn{2}{|c|}{$\begin{array}{l}\text { Índice de crescimento } \\
\text { médio }\end{array}$} & - & - & 1,08 \\
\hline \multicolumn{2}{|c|}{\begin{tabular}{|l|} 
Desvio padrão para os \\
maiores valores
\end{tabular}} & 0,2 & 0,4 & 0,14 \\
\hline \multicolumn{2}{|c|}{$\begin{array}{l}\text { Coeficiente de variação } \\
\text { para os maiores valores }\end{array}$} & $6 \%$ & $11 \%$ & $13 \%$ \\
\hline
\end{tabular}

A resistência média a 7 dias por cura acelerada $24 / 48$ horas apresentou resultado maior do que a resistência a 28 dias por cura normal, com índices relativos variando entre 1,0 e 1,4. Esses resultados justificam o prosseguimento de estudos para o aperfeiçoamento desse tipo de cura, inclusive para ensaios de tração, já que consegue efetivamente antecipar resultados com custos operacionais baixos.

A Tabela 56 apresenta os valores das resistências à tração por compressão diametral nos corpos-de-prova amostrados do lote 1. Conforme a ABNT NBR 12655 (2006), a resistência do exemplar é o maior valor entre os dois valores obtidos, e na Tabela 56 esses valores são apresentados de forma sublinhada.

De modo análogo ao lote treinamento, a resistência à tração média a 7 dias por cura acelerada $24 / 48$ horas dos concretos do lote 1 , também apresentou resultado próximo a resistência a 28 dias por cura normal, mas com índices um pouco menores e variando entre 0,8 e 1,0 . 
Tabela 56 - Resultados do ensaio de resistência à tração por compressão diametral nos concretos amostrados do lote 1. ABNT NBR 7222 (1994).

\begin{tabular}{|c|c|c|c|c|}
\hline 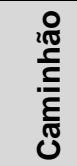 & Corpo-de-prova & $\begin{array}{c}\mathbf{f}_{\mathrm{ct}, \mathrm{SP} 7 \mathrm{acel}} \\
(\mathrm{MPa})\end{array}$ & $\begin{array}{l}f_{c t, S P} 28 \\
(\mathrm{MPa})\end{array}$ & $\mathbf{f}_{\mathrm{ct}, \mathrm{SP7acel}} / \mathbf{f}_{\mathrm{ct}, \mathrm{SP} 28}$ \\
\hline \multirow{2}{*}{1} & 1 & $\underline{2,9}$ & 3,2 & 0,89 \\
\hline & 2 & 2,8 & 2,9 & - \\
\hline \multirow{2}{*}{2} & 3 & 2,6 & 3,3 & 0,84 \\
\hline & 4 & 2,9 & 3,5 & - \\
\hline \multirow{2}{*}{3} & 5 & 2,6 & 2,4 & 0,82 \\
\hline & 6 & 3,2 & 3,9 & - \\
\hline \multirow{2}{*}{4} & 7 & 2,2 & $\underline{3,2}$ & 0,98 \\
\hline & 8 & 3,1 & 3,1 & - \\
\hline \multirow{2}{*}{5} & 9 & 3,2 & 3,2 & 0,88 \\
\hline & 10 & 2,5 & 3,6 & - \\
\hline \multirow{2}{*}{6} & 11 & $\underline{2,9}$ & $\overline{3,4}$ & 0,85 \\
\hline & 12 & 2,5 & 2,9 & \\
\hline \multicolumn{2}{|c|}{$\begin{array}{l}\text { Média entre os maiores } \\
\text { valores }\end{array}$} & 3,03 & 3,46 & - \\
\hline \multicolumn{2}{|c|}{ Valor máximo } & 3,20 & 3,31 & 0,98 \\
\hline \multicolumn{2}{|c|}{ Valor mínimo } & 2,90 & 3,18 & 0,82 \\
\hline \multicolumn{2}{|c|}{$\begin{array}{l}\text { Indice de crescimento } \\
\text { médio }\end{array}$} & - & - & 0,88 \\
\hline \multicolumn{2}{|c|}{$\begin{array}{l}\text { Desvio padrão para os } \\
\text { maiores valores }\end{array}$} & 0,15 & 0,25 & 0,06 \\
\hline \multicolumn{2}{|c|}{$\begin{array}{l}\text { Coeficiente de variação } \\
\text { para os maiores valores } \\
(\%)\end{array}$} & $5 \%$ & $7 \%$ & $7 \%$ \\
\hline
\end{tabular}

A Tabela 57 apresenta os valores das resistências à tração por compressão diametral nos corpos-de-prova amostrados do lote 2. Conforme a ABNT NBR 12655 (2006), a resistência do exemplar é o maior valor entre os dois valores obtidos, e na Tabela 57 esses valores são apresentados de forma sublinhada.

Como no lote treinamento, a resistência média a 7 dias por cura acelerada 24/48 horas dos concretos do lote 2, apresentou resultado médio superior ao da resistência a 28 dias por cura normal. De modo análogo ao lote treinamento, a resistência à tração média a 7 dias por cura acelerada $24 / 48$ horas dos concretos do lote 2, também apresentou resultado próximo a resistência a 28 dias por cura normal, com índices variando entre 1,1 e 1,4 e com média de 1,22 
Tabela 57 - Resultados do ensaio de resistência à tração por compressão diametral nos concretos amostrados do lote 2. ABNT NBR 7222 (1994).

\begin{tabular}{|c|c|c|c|c|}
\hline 选 & $\begin{array}{l}\text { Corpo-de- } \\
\text { prova }\end{array}$ & $\begin{array}{l}\mathbf{f}_{\mathrm{ct}, \mathrm{SP} 7 \mathrm{acel}} \\
(\mathrm{MPa})\end{array}$ & $\begin{array}{l}\mathbf{f}_{\mathrm{ct}, \mathrm{SP} 28} \\
(\mathrm{MPa})\end{array}$ & 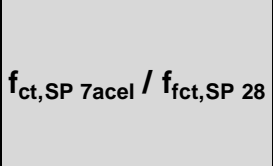 \\
\hline \multirow{2}{*}{1} & 1 & 3,8 & 3,31 & 1,25 \\
\hline & 2 & 4,1 & $\overline{2,92}$ & - \\
\hline \multirow{2}{*}{2} & 3 & $\overline{3,0}$ & 2,86 & 1,08 \\
\hline & 4 & 3,1 & $\overline{2,61}$ & - \\
\hline \multirow{2}{*}{3} & 5 & $\overline{4,5}$ & 3,18 & 1,15 \\
\hline & 6 & $\overline{3,9}$ & 3,88 & - \\
\hline \multirow{2}{*}{4} & 7 & 3,6 & 2,92 & 1,22 \\
\hline & 8 & $\overline{3,4}$ & $\overline{2,61}$ & - \\
\hline \multirow{2}{*}{5} & 9 & 3,4 & 3,18 & 1,40 \\
\hline & 10 & 4,5 & $\overline{2,54}$ & - \\
\hline \multicolumn{2}{|c|}{\begin{tabular}{|l|} 
Média entre os \\
maiores valores
\end{tabular}} & 3,9 & 3,2 & - \\
\hline \multicolumn{2}{|c|}{ Valor máximo } & 4,5 & 3,9 & 1,40 \\
\hline \multicolumn{2}{|c|}{ Valor mínimo } & 3,1 & 2,9 & 1,08 \\
\hline \multicolumn{2}{|c|}{$\begin{array}{l}\text { Índice de crescimento } \\
\text { médio }\end{array}$} & - & - & 1,22 \\
\hline \multicolumn{2}{|c|}{$\begin{array}{l}\text { Desvio padrão para os } \\
\text { maiores valores }\end{array}$} & 0,59 & 0,48 & 0,12 \\
\hline \multicolumn{2}{|c|}{$\begin{array}{l}\text { Coeficiente de } \\
\text { variação para os } \\
\text { maiores valores (\%) }\end{array}$} & $15 \%$ & $15 \%$ & \#VALOR! \\
\hline
\end{tabular}


As Tabelas 58 a 60 apresentam a relação entre as resistências à tração por compressão diametral e a resistências à compressão a 28 dias nos três lotes analisados.

Pela Tabela 58 percebe-se que a resistência à tração por compressão diametral por cura acelerada foi em média $10 \%$ do valor da resistência à compressão simples por cura normal a 28 dias dos concretos, dentro do esperado e já bem discutido, por exemplo, em Mehta; Monteiro (2008), entre outros livros clássicos da tecnologia do concreto.

Tabela 58 - Relação entre resistência à tração por compressão diametral e a resistência à compressão a 28 dias do concreto do lote treinamento.

\begin{tabular}{|c|c|c|c|c|c|}
\hline 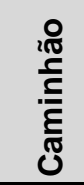 & 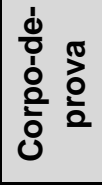 & $\begin{array}{c}\mathrm{f}_{\mathrm{ct}, \mathrm{SP} 7 \text { acel }} \\
(\mathrm{MPa})\end{array}$ & $\begin{array}{c}\mathbf{f c}_{\mathrm{ct}, \mathrm{SP}} 28 \\
(\mathrm{MPa})\end{array}$ & $\begin{array}{c}\mathbf{f}_{\mathrm{ct}, \mathrm{SP}} 7 \text { acel } \\
\left(\mathbf{f}_{\mathrm{c} 28}\right. \\
(\mathrm{MPa})\end{array}$ & $\begin{array}{c}\mathbf{f}_{\mathrm{ct}, \mathrm{SP} 28} / \mathbf{f}_{\mathrm{c} 28} \\
(\mathrm{MPa})\end{array}$ \\
\hline \multirow{2}{*}{1} & $\overline{1}$ & 3,56 & 2,48 & 0,12 & 0,08 \\
\hline & 2 & 3,75 & 3,56 & - & - \\
\hline \multirow{2}{*}{2} & 3 & $\overline{3,50}$ & 3,88 & 0,13 & 0,11 \\
\hline & 4 & 4,20 & $\overline{3,82}$ & - & - \\
\hline \multirow{2}{*}{3} & 5 & $\overline{3,56}$ & 3,50 & 0,11 & 0,09 \\
\hline & 6 & 3,82 & 3,69 & - & - \\
\hline \multirow{2}{*}{4} & 7 & 4,07 & 2,99 & 0,14 & 0,08 \\
\hline & 8 & $\overline{2,86}$ & 3,00 & - & - \\
\hline \multirow{2}{*}{5} & 9 & 3,37 & 3,70 & 0,11 & 0,12 \\
\hline & 10 & 3,63 & $\overline{2,92}$ & - & - \\
\hline \multirow{2}{*}{6} & 11 & 4,20 & 3,12 & 0,12 & 0,11 \\
\hline & 12 & $\overline{2,86}$ & 4,20 & - & - \\
\hline \multicolumn{4}{|c|}{ Média } & 0,12 & 0,10 \\
\hline \multicolumn{4}{|c|}{ Desvio Padrão } & 0,01 & 0,01 \\
\hline \multicolumn{4}{|c|}{ Coeficiente de Variação (\%) } & $10 \%$ & $15 \%$ \\
\hline
\end{tabular}

Pela Tabela 59 percebe-se que no lote 1, a resistência à tração por compressão diametral por cura acelerada foi em média $10 \%$ do valor da resistência à compressão simples por cura normal a 28 dias dos concretos, dentro do esperado. 
Tabela 59 - Relação entre resistência à tração por compressão diametral e a resistência à compressão a 28 dias dos concretos do lote 1.

\begin{tabular}{|c|c|c|c|c|c|}
\hline & 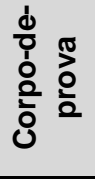 & $\begin{array}{c}f_{c t, S P} 7 \text { acel } \\
(\mathrm{MPa})\end{array}$ & $\begin{array}{c}\mathrm{fc}_{\mathrm{ct}, \mathrm{SP} 28} \\
(\mathrm{MPa})\end{array}$ & $\begin{array}{c}f_{\text {ct, SP } 7 \text { acel }} / f_{c 2} 28 \\
(\mathrm{MPa})\end{array}$ & $\begin{array}{c}\mathbf{f}_{\mathrm{ct}, \mathrm{SP} 28} / \mathbf{f}_{\mathrm{c} 28} \\
(\mathrm{MPa})\end{array}$ \\
\hline \multirow{2}{*}{1} & 1 & 2,89 & 3,24 & 0,09 & 0,10 \\
\hline & 2 & 2,80 & 2,92 & - & - \\
\hline \multirow{2}{*}{2} & 3 & 2,61 & 3,31 & 0,08 & 0,09 \\
\hline & 4 & 2,93 & 3,5 & - & - \\
\hline \multirow{2}{*}{3} & 5 & 2,55 & 2,42 & 0,10 & 0,12 \\
\hline & 6 & 3,15 & 3,85 & - & - \\
\hline \multirow{2}{*}{4} & 7 & 2,16 & 3,18 & 0,10 & 0,10 \\
\hline & 8 & 3,12 & 3,05 & - & - \\
\hline \multirow{2}{*}{5} & 9 & 3,21 & 3,18 & 0,09 & 0,10 \\
\hline & 10 & 2,54 & 3,63 & - & - \\
\hline \multirow{2}{*}{6} & 11 & 2,86 & 3,37 & 0,09 & 0,11 \\
\hline & 12 & 2,50 & 2,86 & - & - \\
\hline \multicolumn{4}{|l|}{ Média } & 0,09 & 0,10 \\
\hline \multicolumn{4}{|c|}{ Desvio Padrão } & 0,01 & 0,01 \\
\hline \multicolumn{4}{|c|}{ Coeficiente de Variação } & $8 \%$ & $8 \%$ \\
\hline
\end{tabular}

Pela Tabela 60 percebe-se que no lote 2, a resistência à tração por compressão diametral por cura acelerada também foi em média $9,0 \%$ do valor da resistência à compressão simples por cura normal a 28 dias dos concretos, dentro do esperado. 
Tabela 60 - Relação entre resistência à tração por compressão diametral e a resistência à compressão a 28 dias dos concretos do lote 2.

\begin{tabular}{|c|c|c|c|c|c|}
\hline 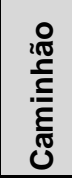 & 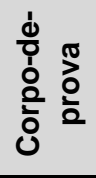 & $\begin{array}{c}\mathbf{f}_{\mathrm{ct}, \mathrm{SP} 7 \text { acel }} \\
(\mathrm{MPa})\end{array}$ & $\begin{array}{c}\mathbf{f c}_{\mathrm{ct}, \mathrm{SP}} 28 \\
(\mathrm{MPa})\end{array}$ & $\begin{array}{c}\mathbf{f}_{\mathrm{ct}, \mathrm{SP} 7 \mathrm{acel}} / \mathbf{f}_{\mathrm{c} 28} \\
(\mathrm{MPa})\end{array}$ & $\begin{array}{c}\mathbf{f}_{\mathrm{ct}, \mathrm{SP} 28} / \mathbf{f}_{\mathrm{c} 28} \\
(\mathrm{MPa})\end{array}$ \\
\hline \multirow{2}{*}{1} & 1 & 3,8 & 3,31 & 0,11 & 0,09 \\
\hline & 2 & 4,1 & 2,92 & - & - \\
\hline \multirow{2}{*}{2} & 3 & 3,0 & $\underline{2,86}$ & 0,10 & 0,09 \\
\hline & 4 & 3,1 & $\overline{2,61}$ & - & - \\
\hline \multirow{2}{*}{3} & 5 & 4,5 & 3,18 & 0,11 & 0,10 \\
\hline & 6 & 3,9 & $\underline{3,88}$ & - & - \\
\hline \multirow{2}{*}{4} & 7 & 3,6 & 2,92 & 0,09 & 0,07 \\
\hline & 8 & $\overline{3,4}$ & $\overline{2,61}$ & - & - \\
\hline \multirow{2}{*}{5} & 9 & 3,4 & 3,18 & 0,14 & 0,10 \\
\hline & 10 & $\underline{4,5}$ & 2,54 & - & - \\
\hline \multicolumn{4}{|c|}{ Média } & 0,11 & 0,09 \\
\hline \multicolumn{4}{|c|}{ Desvio Padrão } & 0,02 & 0,01 \\
\hline \multicolumn{4}{|c|}{ Coeficiente de Variação } & $17 \%$ & $12 \%$ \\
\hline
\end{tabular}

\subsubsection{Absorção de água por capilaridade}

A Tabela 61 apresenta os resultados das médias, os desvios padrão, valores máximo e mínimo, as amplitudes e os coeficientes de variação do ensaio de absorção de água por capilaridade por cura normal até 28 dias e cura acelerada 24/48 horas seguidos de imersão em temperatura normal até 7 , dias nos lotes analisados. No lote treinamento o ensaio com cura acelerada não foi realizado.

Pela Tabela 61 pode-se ver que os lotes apresentaram pequenos desvios padrão e coeficientes de variação. As médias de cada lote, nas duas condições de cura foram bem próximas para os lotes 1 e 2, mas caberia ainda serem analisadas por análise de variância. 
Tabela 61 - Resultados médios da absorção de água por capilaridade, ao final de 72 horas, nos concretos por cura normal até 28 dias e acelerada $24 / 48$ horas mais imersão em água até 7 dias nos lotes analisados. ABNT NBR 9779 (1995).

\begin{tabular}{|c|c|c|c|c|c|c|c|}
\hline Lote & Cura & $\begin{array}{c}\text { Média } \\
\left(\mathrm{g} / \mathrm{cm}^{2}\right)\end{array}$ & $\begin{array}{l}\text { Desvio } \\
\text { padrão } \\
\left(\mathrm{g} / \mathrm{cm}^{2}\right) \\
\end{array}$ & $\begin{array}{c}\text { Valor } \\
\text { máximo } \\
\left(\mathrm{g} / \mathrm{cm}^{2}\right)\end{array}$ & $\begin{array}{c}\text { Valor } \\
\text { mínimo } \\
\left(\mathrm{g} / \mathrm{cm}^{2}\right) \\
\end{array}$ & $\begin{array}{c}\text { Amplitude } \\
\left(\mathrm{g} / \mathrm{cm}^{2}\right)\end{array}$ & $\begin{array}{c}\text { Coeficiente } \\
\text { de variação } \\
(\%)\end{array}$ \\
\hline Treinamento & \multirow{3}{*}{ Normal } & 0,75 & 0,06 & 0,8 & 0,66 & 0,14 & 7 \\
\hline 1 & & 0,60 & 0,07 & 0,70 & 0,51 & 0,19 & 11 \\
\hline 2 & & 0,63 & 0,02 & 0,68 & 0,57 & 0,11 & 4 \\
\hline Treinamento & \multirow{3}{*}{$\begin{array}{l}\text { Acelerada } \\
24 / 48 \text { horas }\end{array}$} & - & 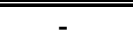 & - & - & 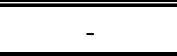 & - \\
\hline 1 & & 0,56 & 0,04 & 0,61 & 0,49 & 0,12 & 7 \\
\hline 2 & & 0,62 & 0,04 & 0,68 & 0,57 & 0,11 & 7 \\
\hline
\end{tabular}

Pela Figura 63 percebe-se que os lotes 1 e 2 apresentaram valores próximos, com os caminhões 5 e 2 apresentando os maiores valores nos lotes 1 e 2 respectivamente. $O$ lote treinamento apresentou valores médios superiores para cinco das seis betonadas que foram caracterizadas. É interessante destacar que o perfil dos resultados para o lote 1 tem variações similares às ocorridas para o ensaio de abatimento (Figura 45) do mesmo lote.

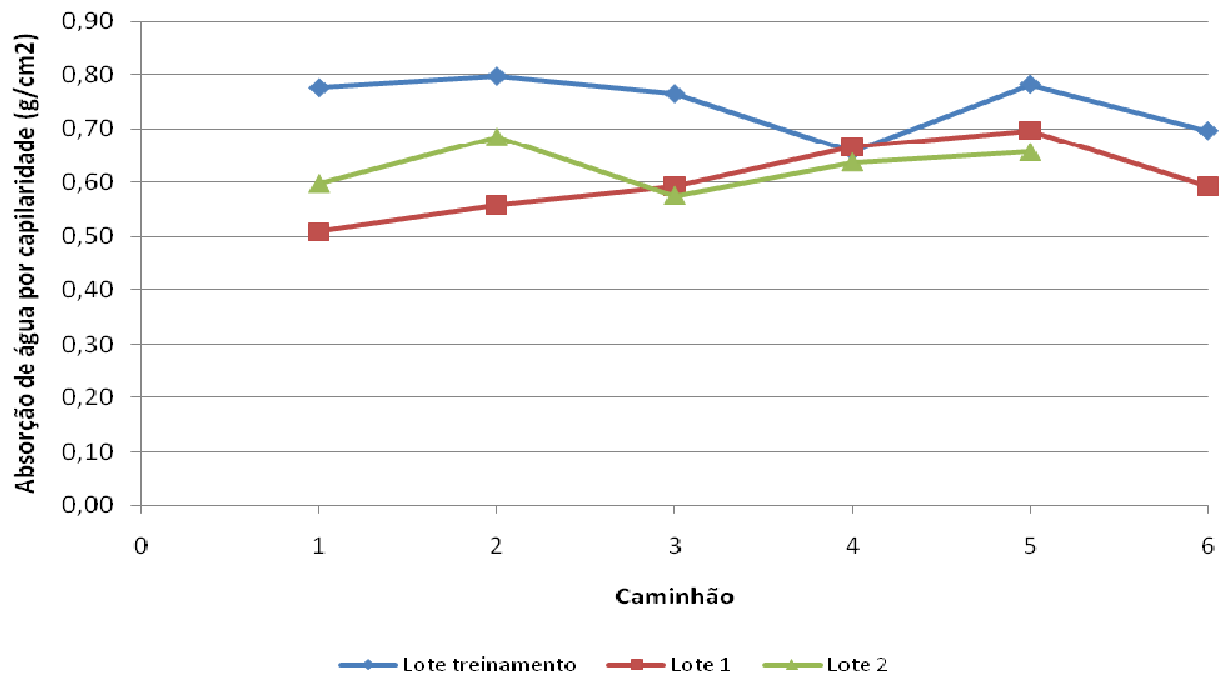

Figura 64 - Variação da absorção de água por capilaridade média a 28 dias dos concretos amostrados, submetidos à cura normal nos três lotes analisados.

A Figura 64 ilustra os resultados médios da absorção de água por capilaridade a 7 dias por cura térmica de 24/48 horas seguida de cura em temperatura normal até ensaio. Os resultados foram semelhantes, com exceção do concreto do caminhão 2 do lote 1 , que apresentou a menor absorção, como mostra a Figura 64. 


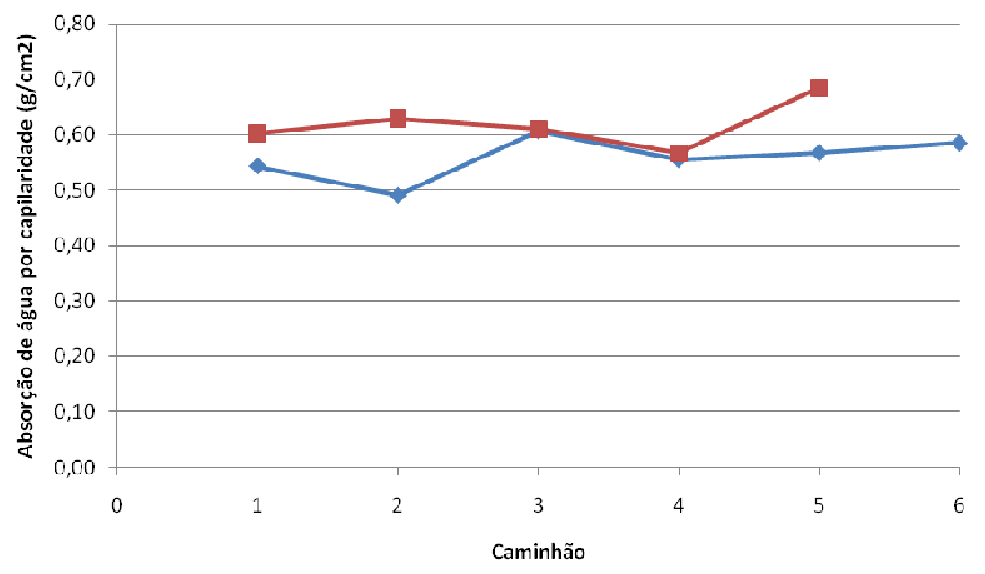

Figura 64 - Variações da absorção de água por capilaridade média a 7 dias nos concretos amostrados, submetidos à cura térmica $24 / 48$ horas seguidos de imersão normal, nos dois lotes analisados.

Pelos resultados obtidos a cura térmica acelerada não influenciou as características físicas de absorção de água dos concretos amostrados submetido a esse ensaio. Comparando a absorção capilar com cura acelerada à cura normal, vê-se que a cura acelerada apresentou resultados menores de absorção e menores variações em seus resultados. Isto indica a eficácia e utilização da cura acelerada também para ensaios de absorção de água por capilaridade.

A Tabela 62 apresenta a média dos coeficientes de absorção de água por capilaridade em função de tempos iniciais e finais do ensaio. As Tabelas completas com os coeficientes de absorção de água por capilaridade estão apresentadas no Apêndice $C$. Observar que a análise desta propriedade em função do tempo torna os concretos aparentemente muito similares, especialmente a $72 \mathrm{~h}$. Em razão disto, o valor da absorção capilar de água a $72 \mathrm{~h}, \mathrm{em} \mathrm{g} / \mathrm{cm}^{2}$, foi a propriedade considerada para análises finais de comparação entre lotes ao invés do coeficiente de absorção capilar. 
Tabela 62 - Coeficiente de absorção de água por capilaridade nas idades de 15 min e 72 horas (4320 min) de ensaio para os dois tipos de cura, nos três lotes analisados.

\begin{tabular}{|c|c|c|c|}
\hline \multirow{2}{*}{ Lote } & \multirow{2}{*}{ Cura } & \multicolumn{2}{|c|}{$\begin{array}{l}\text { Coeficiente de absorção de água por } \\
\text { capilaridade nas idades de } 15 \mathrm{~min} \text { e } \\
\qquad 72 \text { horas }\left(\mathrm{g} / \mathrm{cm}^{2} \cdot \mathrm{min}^{-1 / 2}\right)\end{array}$} \\
\hline & & $\begin{array}{l}\text { Média } \\
\text { observada com } \\
15 \mathrm{~min}\end{array}$ & $\begin{array}{l}\text { Média observada } \\
\text { com } 72 \text { horas }(4320 \\
\text { min) }\end{array}$ \\
\hline Treinamento & \multirow{3}{*}{ Normal } & 0,06 & 0,02 \\
\hline 1 & & 0,02 & 0,02 \\
\hline 2 & & 0,06 & 0,02 \\
\hline Treinamento & \multirow{3}{*}{$\begin{array}{c}\text { Acelerada } \\
\text { 24/48 horas } \\
\text { mais imersão } \\
\text { em água até } 7 \\
\text { dias }\end{array}$} & 0,09 & 0,02 \\
\hline 1 & & 0,03 & 0,02 \\
\hline 2 & & 0,03 & 0,02 \\
\hline
\end{tabular}

\subsubsection{Absorção de água total}

A Tabela 63 apresenta os resultados das médias, os desvios padrão, os valores máximos e mínimos, as amplitudes e os coeficientes de variação do ensaio de absorção de água total nos concretos com cura normal até 28 dias e acelerada 24/48 horas mais imersão em temperatura normal até 7 dias, nos três lotes analisados.

Pela Tabela 63, percebe-se semelhança de resultados entre os lotes nos valores médios e pequena diferença nos coeficientes de variação entre os lotes, com destaque para o lote treinamento que apresentou os menores coeficientes de variação.

Tabela 63 - Resultados do ensaio de absorção de água total nos concretos com cura acelerada 24/48 horas seguida de imersão normal até 7 dias nos três lotes analisados

\begin{tabular}{|c|c|c|c|c|c|c|c|}
\hline Lote & Cura & $\begin{array}{c}\text { Média } \\
(\%)\end{array}$ & $\begin{array}{c}\text { Desvio } \\
\text { padrão } \\
(\%)\end{array}$ & $\begin{array}{c}\text { Valor } \\
\text { máximo } \\
(\%)\end{array}$ & $\begin{array}{c}\text { Valor } \\
\text { mínimo } \\
(\%)\end{array}$ & $\begin{array}{c}\text { Amplitude } \\
(\%)\end{array}$ & $\begin{array}{c}\text { Coeficiente } \\
\text { de variação } \\
(\%)\end{array}$ \\
\hline Treinamento & \multirow{3}{*}{ Normal } & 5,1 & 0,2 & 5,4 & 4,8 & 0,36 & 4 \\
\hline 1 & & 5,8 & 0,4 & 6,3 & 5,4 & 0,8 & 6 \\
\hline 2 & & 5,8 & 0,4 & 6,1 & 5,3 & 0,8 & 6 \\
\hline Treinamento & \multirow{3}{*}{$\begin{array}{c}\text { Acelerada } \\
24 / 48 \text { horas }\end{array}$} & 5,2 & 0,1 & 5,4 & 5,0 & 0,36 & 2 \\
\hline 1 & & 5,7 & 0,3 & 6,2 & 5,4 & 0,8 & 6 \\
\hline 2 & & 5,6 & 0,4 & 6,0 & 5,2 & 0,8 & 7 \\
\hline
\end{tabular}


A Figura 65 ilustra os resultados médios do ensaio de absorção de água total dos concretos submetidos a cura normal por 28 dias, nos três lotes analisados. Destaca-se a pequena variação entre os três lotes.

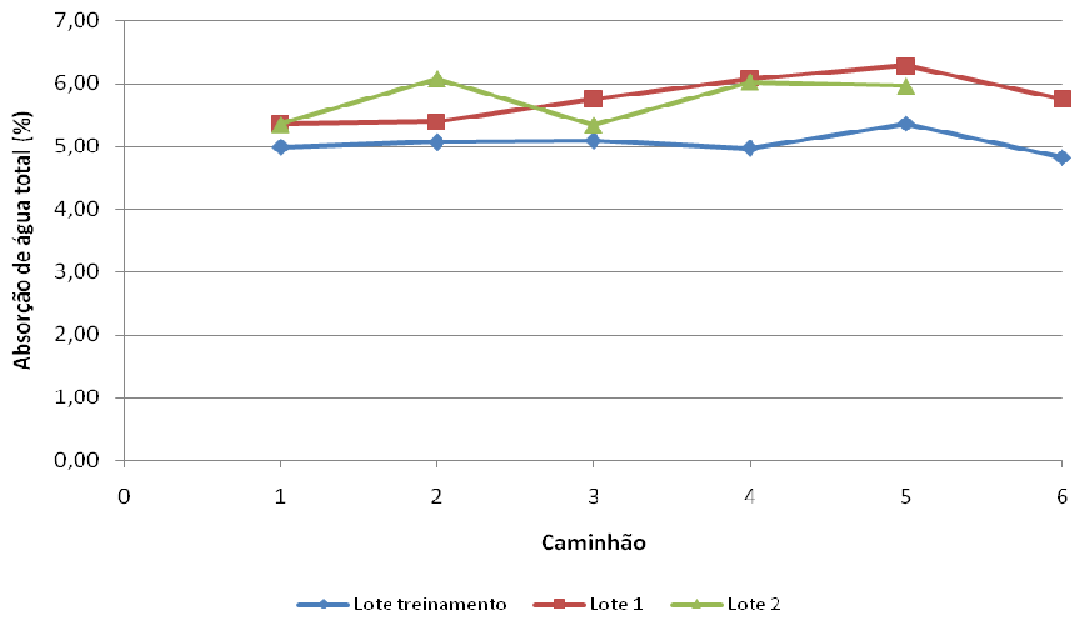

Figura 65 - Variação da absorção de água total média por imersão total de dois corpos-de-prova de concreto por caminhão, submetidos à cura normal até 28 dias nos três lotes amostrados.

A Figura 66 ilustra os resultados médios do ensaio de absorção de água total nos concretos submetidos a cura acelerada $24 / 48$ horas mais imersão em água até 7 dias, nos três lotes analisados. Pode-se observar que não existiram grandes variações entre os resultados, como seria esperado.

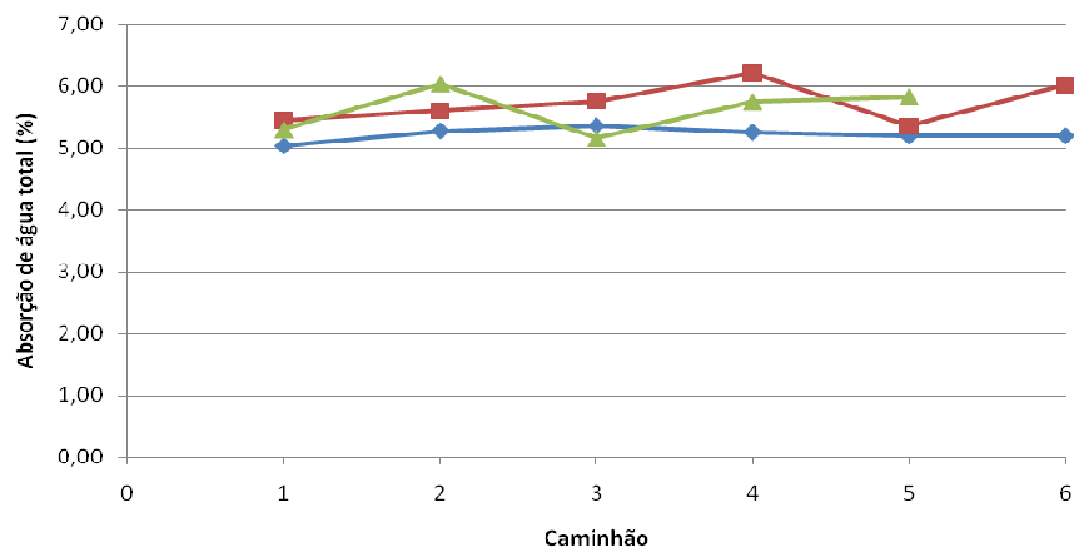

Figura 66 - Variação da absorção de água total média por imersão total de dois corpos-de-prova de concreto por caminhão, submetidos à cura acelerada de $24 / 48$ horas seguida de imersão normal até 7 dias, nos três lotes amostrados. 


\subsubsection{5 Índice de vazios}

A Tabela 64 apresenta as médias, os desvios padrão, os valores máximos e mínimos, as amplitudes e os coeficientes de variação dos resultados do ensaio de índice de vazios nos concretos submetidos a cura normal até 28 dias e cura acelerada 24/48 horas mais imersão em água até 7 dias, dos três lotes analisados.

O lote treinamento foi o que apresentou os menores coeficientes de variação e o lote $1 \mathrm{e}$ 2 apresentaram resultados iguais.

Tabela 64 - Resultados do ensaio de índice de vazios nos concretos com normal a 28 dias e acelerada 24/48 horas seguida de imersão normal até 7 dias, nos três lotes analisados.

\begin{tabular}{|c|c|c|c|c|c|c|c|}
\hline Lote & Cura & $\begin{array}{l}\text { Média } \\
\text { (\%) }\end{array}$ & $\begin{array}{c}\text { Desvio } \\
\text { padrão } \\
(\%)\end{array}$ & $\begin{array}{c}\text { Valor } \\
\text { máximo } \\
(\%)\end{array}$ & $\begin{array}{c}\text { Valor } \\
\text { mínimo } \\
(\%)\end{array}$ & $\begin{array}{c}\text { Amplitude } \\
\text { (\%) }\end{array}$ & $\begin{array}{c}\text { Coeficiente } \\
\text { de variação } \\
(\%)\end{array}$ \\
\hline Treinamento & \multirow{3}{*}{ Normal } & 11,4 & 0,4 & 12 & 11,0 & 1 & 3 \\
\hline 1 & & 13,0 & 0,7 & 14 & 12,2 & 1,8 & 6 \\
\hline 2 & & 12,9 & 0,8 & 14 & 12,1 & 1,5 & 6 \\
\hline Treinamento & \multirow{3}{*}{$\begin{array}{c}\text { Acelerada } \\
24 / 48 \text { horas }\end{array}$} & 11,7 & 0,2 & 12,0 & 11,4 & 0,6 & 2 \\
\hline 1 & & 12,9 & 0,6 & 13,8 & 12,2 & 1,6 & 5 \\
\hline 2 & & 12,7 & 0,7 & 13,5 & 11,7 & 1,8 & 6 \\
\hline
\end{tabular}

A Figura 67 ilustra os resultados médios do ensaio de índice de vazios nos concretos dos caminhões submetidos a cura normal por 28 dias.

Pode-se observar que não existiram grandes variações nos resultados.

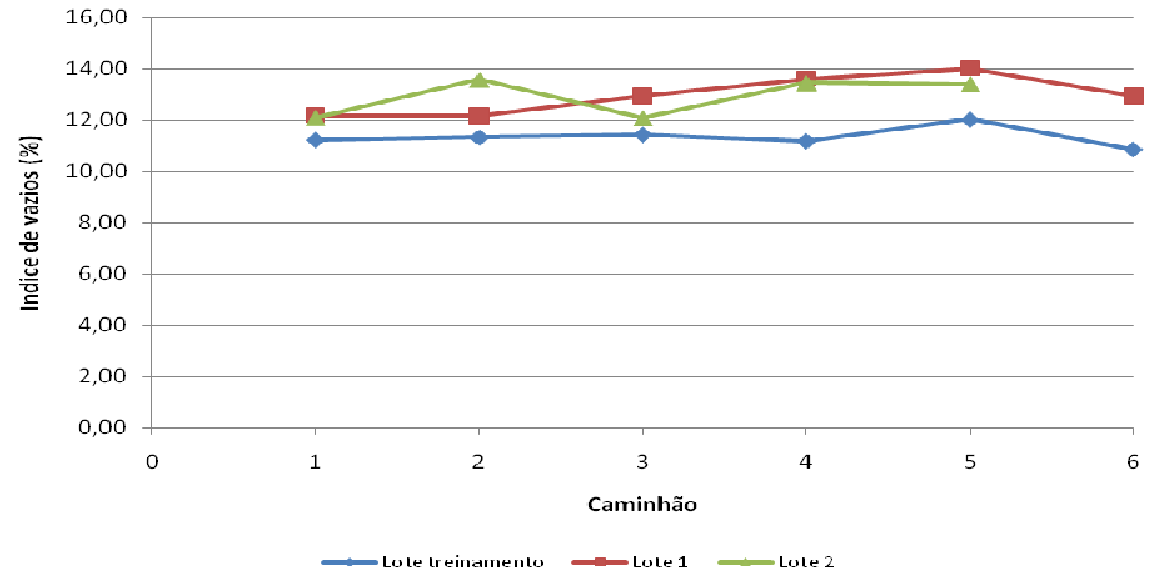

Figura 67 - Variação do índice de vazios médio de dois corpos-de-prova de concreto, por caminhão, submetidos à cura normal até 28 dias, amostrados nos três lotes. 
A Figura 68 ilustra os resultados médios do ensaio de índice de vazios nos concretos dos caminhões submetidos a cura acelerada $24 / 48$ horas seguida de imersão em temperatura normal até 7 dias.

Pode-se observar que não existiram grandes variações nos resultados.

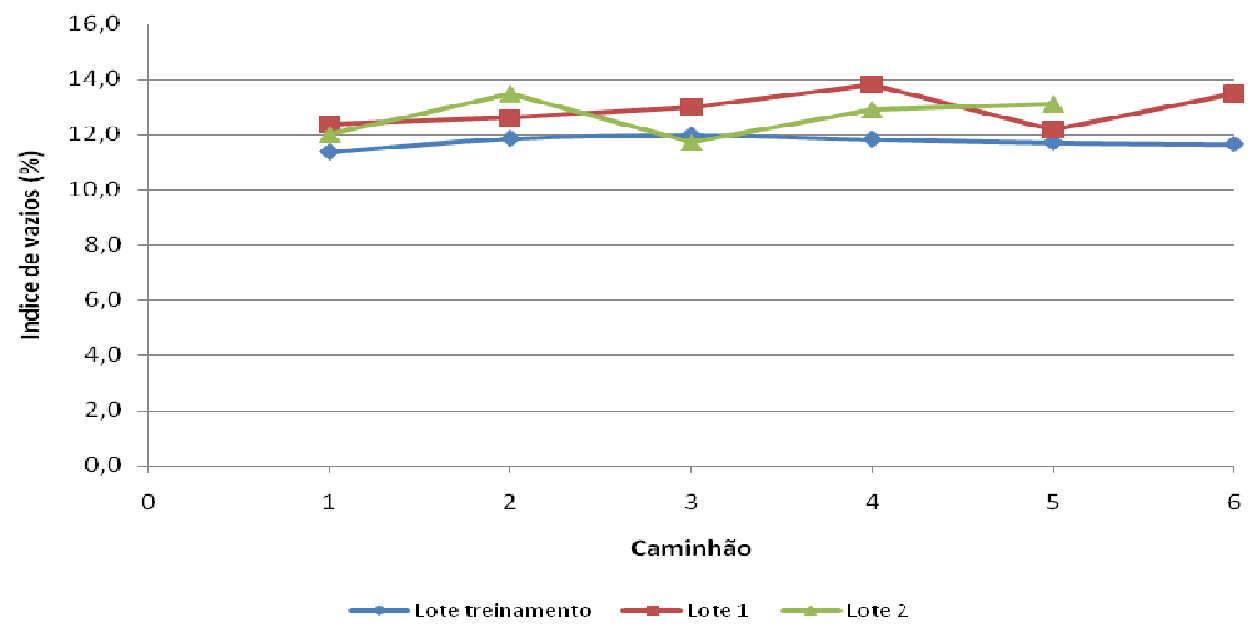

Figura 68 - Variação do índice de vazios médio de dois corpos-de-prova de concreto com cura acelerada $24 / 48$ horas seguida de imersão normal até 7 dias, nos três lotes.

\subsubsection{Profundidade de carbonatação em corpos-de-prova submetidos à câmara de $\mathrm{CO}_{2}$ sob pressão aos $92 \pm 8$ dias}

A Tabela 65 apresenta as médias, desvios padrão, valores máximos e mínimos, as amplitudes, os coeficientes de variação e o coeficiente de carbonatação, a partir da profundidade de carbonatação, em corpos-de-prova de $10 \times 20 \mathrm{~cm}$, por fenolftaleína e timolftaleína nos três lotes amostrados. A tabela completa com todas as medidas realizadas consta no Apêndice C. Como esperado, pela timolftaleína, obteve-se as maiores profundidades de carbonatação, devido à sua faixa de $\mathrm{pH}$ ser mais elevada.

O lote 1 apresentou as maiores profundidades média e os menores coeficiente e variação entre os lotes, para os dois tipos de indicadores usados. Analisando as fotos dos corpos-deprova ensaiados por fenolftaleína, Apêndice $\mathrm{D}$, e pelas tabelas das medidas individuais e médias realizadas, conforme o Apêndice $\mathrm{C}$, percebe-se que o lote treinamento apresentou as maiores amplitudes e valores de profundidade de carbonatação ligeiramente superiores ao lote 1, com exceção ao respectivo ao caminhão 6 que não apresentou profundidade de carbonatação, conforme a Figura 70, justificando o coeficiente de variação bem maior do que o apresentado pelo lote 1, na Tabela 65. 
Tabela 65 - Resultados do ensaio de resistência à carbonatação por câmara de $\mathrm{CO}_{2}$ ( $5 \%$; 7 dias) de corpos-de-prova submetidos à cura acelerada $24 / 48$ horas seguida de imersão em normal até 7 dias, nos concretos dos três lotes analisados, por fenolftaleína e timolftaleína.

\begin{tabular}{|c|c|c|c|c|c|c|c|c|}
\hline Lote & $\begin{array}{c}\text { Solução } \\
\text { indicadora }\end{array}$ & $\begin{array}{c}\text { Média } \\
\text { observada } \\
(\mathrm{mm})\end{array}$ & $\begin{array}{l}\text { Desvio } \\
\text { padrão } \\
(\mathrm{mm})\end{array}$ & $\begin{array}{l}\text { Valor } \\
\text { máximo } \\
(\mathrm{mm})\end{array}$ & $\begin{array}{l}\text { Valor } \\
\text { mínimo } \\
(\mathrm{mm})\end{array}$ & $\begin{array}{c}\text { Amplitude } \\
(\mathrm{mm})\end{array}$ & $\begin{array}{c}\text { Coeficiente } \\
\text { de variação } \\
(\%)\end{array}$ & $\begin{array}{c}\text { Velocidade de } \\
\text { penetração do } \mathrm{CO}_{2} \\
(\mathrm{x}=\mathrm{k} \mathrm{vt}) \mathrm{mm} / \mathrm{ano}^{-1 / 2}\end{array}$ \\
\hline Treinamento & \multirow{3}{*}{ Fenolftaleína } & 8,1 & 4,5 & 11,4 & 0,0 & 11,4 & 55 & 59 \\
\hline 1 & & 9,0 & 1,5 & 10,4 & 6,8 & 3,6 & 17 & 65 \\
\hline 2 & & 4,7 & 3,2 & 7,3 & 0,0 & 7,3 & 68 & 34 \\
\hline Treinamento & \multirow{3}{*}{ Timolftaleína } & 9,0 & 4,4 & 13,0 & 1,2 & 11,8 & 48 & 65 \\
\hline 1 & & 14,3 & 2,8 & 19,2 & 11,8 & 7,4 & 19 & 104 \\
\hline 2 & & 6,0 & 3,6 & 8,5 & 0,0 & 8,5 & 62 & 44 \\
\hline
\end{tabular}

A Figura 69 apresenta os resultados da profundidade de carbonatação por fenolftaleína. Todos os lotes apresentaram variações nas medidas entre corpos-de-prova de diferentes caminhões e uma variação ainda considerável entre corpos-de-prova do mesmo caminhão, o que pode ter alguma relação com a distribuição irregular do $\mathrm{CO}_{2}$ no interior da câmara utilizada, ou com os períodos de secagem, que se seguiram após a cura acelerada de 24/48 h seguida de imersão normal até 7 dias, pois então ocorreu o transporte dos mesmos para o laboratório da USP, em São Paulo.

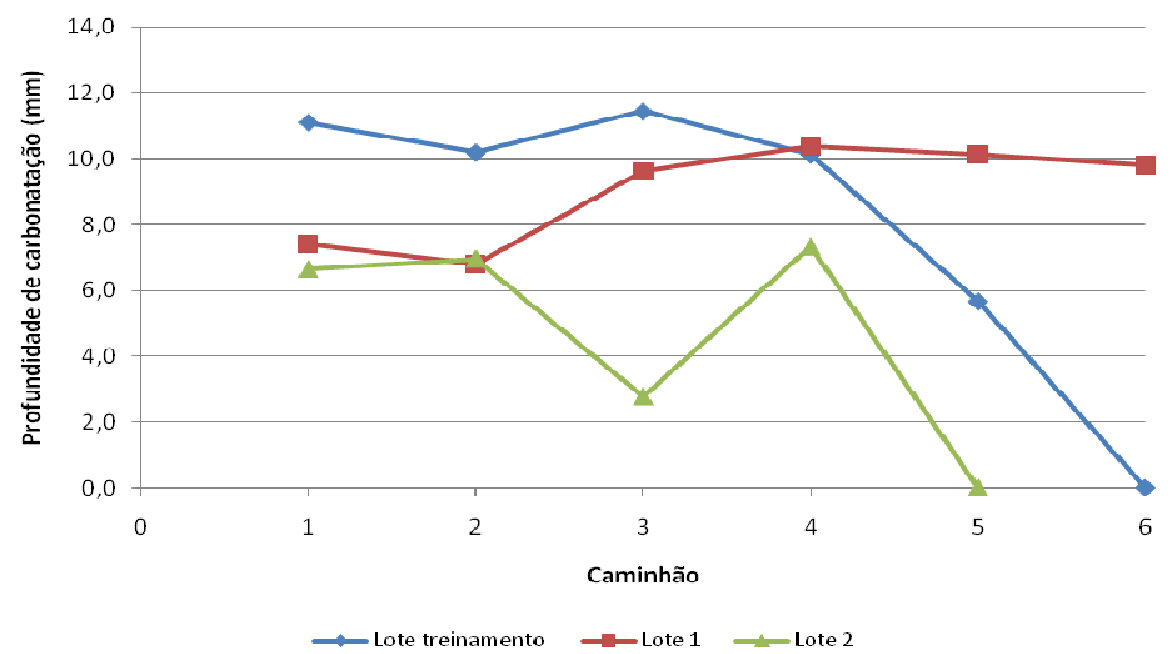

Figura 69 - Variação da profundidade de carbonatação média em câmara de $\mathrm{CO}_{2}$ ( $5 \%$; 7 dias), por fenolftaleína, das metades seccionadas de dois corpos-de-prova de concreto, por caminhão, submetidos à cura acelerada $24 / 48$ h seguida de imersão normal até 7 dias e depois de secagem acelerada até $92 \pm 2$ dias. 
A Figura 70 apresenta os resultados da profundidade de carbonatação por timolftaleína e observa-se que o lote 1 apresentou os resultados médios maiores para todos os seis concretos amostrados, de modo coerente com os seus valores ligeiramente mais elevados de teor de ar no estado fresco.

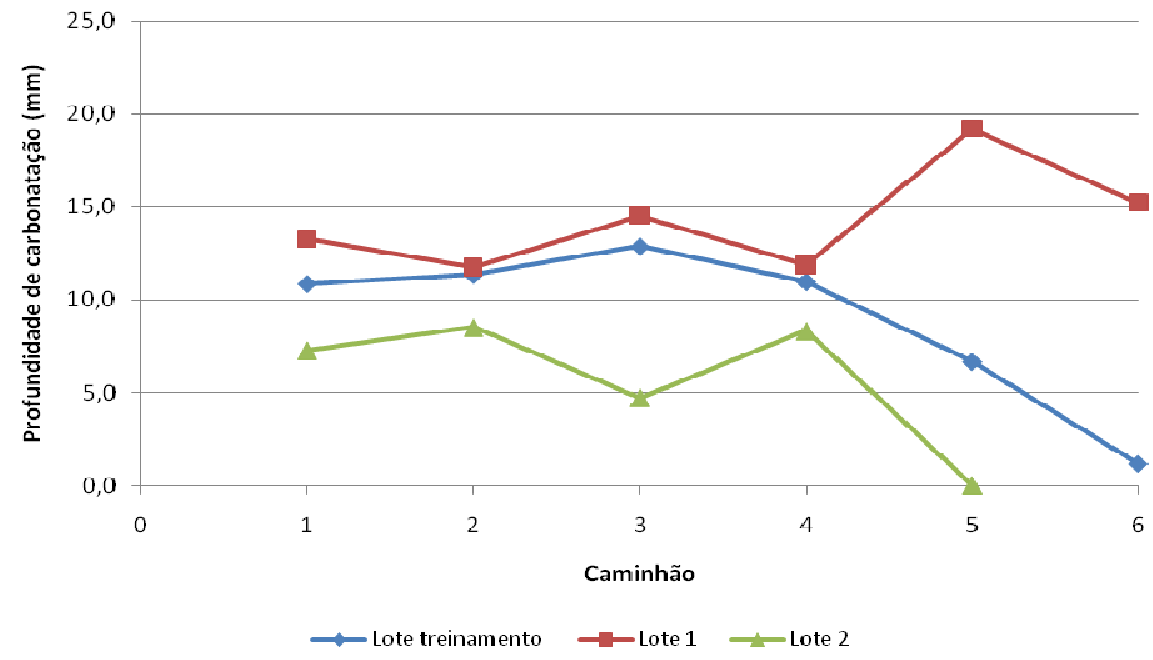

Figura 70 - Profundidade de carbonatação média em câmara de $\mathrm{CO}_{2}(5 \% ; 7$ dias), por timolftaleína, das metades seccionadas de dois corpos-de-prova de concreto, por caminhão, submetidos à cura acelerada 24/48 h mais imersão em água até 7 dias.

A seguir, a título de simples exercício, são apresentadas duas simulações de modelos de previsão da profundidade de carbonatação, adaptadas para a realidade deste estudo.

O primeiro modelo testado foi o de ATIS (2003) ${ }^{18}$ citado por SILVA (2007), que relacionou a espessura de carbonatação, em concretos confeccionados com e sem adição de cinza volante, com a sua resistência à compressão axial e obteve a Equação $17 \mathrm{com} \mathrm{r}^{2}=0,90$ no trabalho original.

$$
x=-0,18 f_{c}+16,18 \text { (Equação 23) }
$$

Onde:

$\mathrm{x}=$ profundidade de carbonatação $(\mathrm{mm})$;

$\mathrm{f}_{\mathrm{c}}=$ resistência à compressão axial $(\mathrm{MPa})$;

Concentração de $\mathrm{CO}_{2}=5 \%$.

18 ATIS, C. D. Carbonation - Porosity - Strength model for fly ash concrete. Journal of Material in Civil Engineering, p. 91-94. 
A Tabela 66 apresenta os resultados encontrados em função da resistência à compressão a 7 dias por cura acelerada 24/48 horas mais imersão em água até 7 dias e a 28 dias por cura normal, de cada lote calculado e também a profundidade de carbonatação real encontrada.

Percebe-se que as profundidades calculadas pelo modelo foram superiores as reais encontradas neste trabalho e ficaram ainda mais próximas entre os lotes, na medida em que apenas associadas à resistência à compressão simples.

Tabela 66 - Comparação entre as profundidades de carbonatação obtida neste trabalho com as calculadas pelo modelo apresentado por Atis (2003) citado por Silva (2007)

\begin{tabular}{|c|c|c|c|c|c|}
\hline Lote & Cura & $\begin{array}{c}\text { Média da } \\
\text { resistência à } \\
\text { compressão } \\
(\mathrm{MPa})\end{array}$ & $\begin{array}{c}\text { Solução } \\
\text { indicadora }\end{array}$ & $\begin{array}{c}\text { Média observada } \\
\text { da profundidade de } \\
\text { carbonatação }(\mathrm{mm})\end{array}$ & $\begin{array}{c}\text { Profundidade } \\
\text { pelo modelo } \\
\text { de Atis (2003) } \\
(\mathrm{mm})\end{array}$ \\
\hline Treinamento & \multirow{3}{*}{$\begin{array}{c}\text { Acelerada } 24 / 48 \\
\text { horas mais imersão } \\
\text { em água até } 7 \text { dias }\end{array}$} & 31,8 & \multirow{6}{*}{ Fenolftaleína } & 8,1 & 10,5 \\
\hline 1 & & 30,3 & & 9,0 & 10,7 \\
\hline 2 & & 31,6 & & 4,7 & 10,5 \\
\hline Treinamento & \multirow{3}{*}{ Normal por 28 dias } & 35,5 & & 8,1 & 9,8 \\
\hline 1 & & 31,8 & & 9,0 & 10,5 \\
\hline 2 & & 34,6 & & 4,7 & 10,0 \\
\hline
\end{tabular}

Valores adotados dos corpos-de-prova com cura acelerada 
O segundo modelo testado foi em função da resistência à compressão e da porosidade do concreto, também proposto por ATIS (2003) citado por SILVA (2007), pela Equação 24 apresentou $r^{2}=0,96$.

$$
x=5,32-0,112 f_{c}+0,822 p \text { (Equação 24) }
$$

Onde:

$\mathrm{x}=$ profundidade de carbonatação $(\mathrm{mm})$;

$\mathrm{f}_{\mathrm{c}}=$ resistência à compressão axial $(\mathrm{MPa})$;

$\mathrm{p}=$ porosidade em porcentagem;

Concentração de $\mathrm{CO}_{2}=5 \%$.

Nesta simulação, foi usado o índice de vazios para estimar a porosidade, na Equação 24. A Tabela 67 apresenta os resultados encontrados em função da resistência à compressão a 7 dias por cura acelerada 24/48 horas seguida de imersão normal até 7 dias e a 28 dias por cura normal e os respectivos valores de índice de vazios de cada lote calculado, comparados à profundidade de carbonatação real medida. Percebe-se que as profundidades calculadas pelo modelo se afastaram ainda mais das reais encontradas neste trabalho, sem conseguir diferenciar os resultados para o lote 2 .

Tabela 67 - Comparação entre as profundidades de carbonatação obtida neste trabalho com as calculadas pelo segundo modelo apresentado por Atis (2003) citado por Silva (2007)

\begin{tabular}{|c|c|c|c|c|c|c|}
\hline Lote & Cura & $\begin{array}{l}\text { Média da } \\
\text { resistência à } \\
\text { compressão } \\
\text { (MPa) }\end{array}$ & $\begin{array}{c}\text { Média dos } \\
\text { índices de } \\
\text { vazio (\%) }\end{array}$ & $\begin{array}{c}\text { Solução } \\
\text { indicadora }\end{array}$ & $\begin{array}{c}\text { Média } \\
\text { observada da } \\
\text { profundidade de } \\
\text { carbonatação } \\
(\mathrm{mm})\end{array}$ & $\begin{array}{c}\text { Profundidade } \\
\text { pelo modelo } \\
\text { de Atis (2003) } \\
(\mathrm{mm})\end{array}$ \\
\hline Treinamento & $\begin{array}{c}\text { Acelerada } 24 / 48 \\
\text { horas mais } \\
\text { imersão em água }\end{array}$ & 31,8 & 11,7 & \multirow{4}{*}{ Fenolftaleína } & 8,1 & 11,4 \\
\hline Treinamento & \multirow{3}{*}{$\begin{array}{c}\text { Normal por } 28 \\
\text { dias }\end{array}$} & 35,5 & 11,4 & & 8,1 & 10,7 \\
\hline 1 & & 31,8 & 13,0 & & 9,0 & 12,4 \\
\hline 2 & & 34,6 & 12,9 & & 4,7 & 12,0 \\
\hline
\end{tabular}

Valores adotados dos corpos-de-prova com cura acelerada

Por fim, lembrando que os lotes estudados foram oriundos de diferentes centrais, cabe salientar que este trabalho não objetivou gerar modelos de predição da resistência à carbonatação dos concretos, em função das suas propriedades físicas ou mecânicas, mas tão somente discutir as correlações, conforme os itens finais deste capítulo. 


\subsubsection{Resistência à carbonatação e cloretos por ciclos de imersão e secagem}

\section{a) Controle de massa e estimativa do grau de saturação}

As variações de massa nas etapas da ciclagem são apresentadas no Apêndice C.

$\mathrm{Na}$ Figura 71, o controle de massa está apresentado em função do grau de saturação estimado para os corpos-de-prova de concreto dos lotes 1 e 2. Para o cálculo do grau de saturação dos lotes 1 e 2 , foram levadas em conta as medidas de absorção de água total de respectivos $1 / 2$ corpos-de-prova ao final da ciclagem. A massa teórica saturada do corpo-deprova inteiro, foi estimada pela Equação (25) a seguir:

$$
M_{\text {sat }}=M_{100 \text { cp inteiro }} \times\left(1+A_{b 1 / 2 c p} / 100\right) \text { (Equação 25) }
$$

Onde:

$\mathrm{M}_{\text {sat }}=$ Massa teórica saturada $(\mathrm{g})$;

$\mathrm{M}_{100 \mathrm{C} \text { cp inteiro }}=$ Massa seca a $100^{\circ} \mathrm{C}$ do corpo-de-prova inteiro (g) ;

$A_{b 1 / 2 c p}=$ Absorção de água de meio corpo-de-prova (\%).

Após o cálculo da massa teórica saturada de cada corpo-de-prova, foi calculado o volume de água pela fórmula a seguir, sendo levada em conta a massa dos corpos-de-prova nos respectivos períodos dos ciclos e a massa seca a $100{ }^{\circ} \mathrm{C}$ ao final da ciclagem, pela Equação (26).

$$
V_{\text {água }}=M_{\text {período-ciclo }}-M_{100^{\circ}} \text { (Equação 26) }
$$

Onde:

$\mathrm{V}_{\text {água }}=$ Volume de água $\left(\mathrm{cm}^{3}\right)$;

$\mathrm{M}_{\text {período-ciclo }}=$ Massa do corpo-de-prova no período da ciclagem (g);

$M_{100^{\circ}}=$ Massa do corpo-de-prova seco a $100{ }^{\circ} \mathrm{C}(\mathrm{g})$ 
Logo, o grau de saturação foi obtido a partir da seguinte da equação 27:

$$
G_{s}=V_{\text {água }} /\left(M_{\text {sat }}-M_{100 c}\right) \quad \text { (Equação 27) }
$$

Onde:

$\mathrm{G}_{\mathrm{s}}=\mathrm{Grau}$ de saturação dos corpos-de-prova;

$\mathrm{V}_{\text {água }}=$ Volume de água $\left(\mathrm{cm}^{3}\right)$;

$\mathrm{M}_{\text {sat }}=$ Massa teórica saturada $(\mathrm{g})$;

$\mathrm{M}_{100 \mathrm{C}}=$ Massa seca a $100{ }^{\circ} \mathrm{C}(\mathrm{g})$;

Por falta de dados da secagem a $100^{\circ} \mathrm{C}$ no final da ciclagem, o grau de saturação nos corpos-de-prova do lote treinamento não foi estimado.

A Figura 71 apresenta a variação do grau de saturação nas etapas da ciclagem nos corpos-de-prova amostrados do lote 1 . Como já comentado no Capítulo 4, as etapas foram formadas por 1 dia de imersão em solução de 3,5\% de $\mathrm{NaCl}$ e 27 dias de secagem em caixa térmica ventilada a $45 \pm 5^{\circ} \mathrm{C}$.

Percebe-se com o decorrer da ciclagem, que os corpos-de-prova apresentaram uma maior secagem, com os corpos-de-prova 441 e 451 apresentando duas pesagens diferentes, o que pode ter relação com o erro de pesagem, de anotação ou com a sua posição na caixa de secagem (Figura 37). 


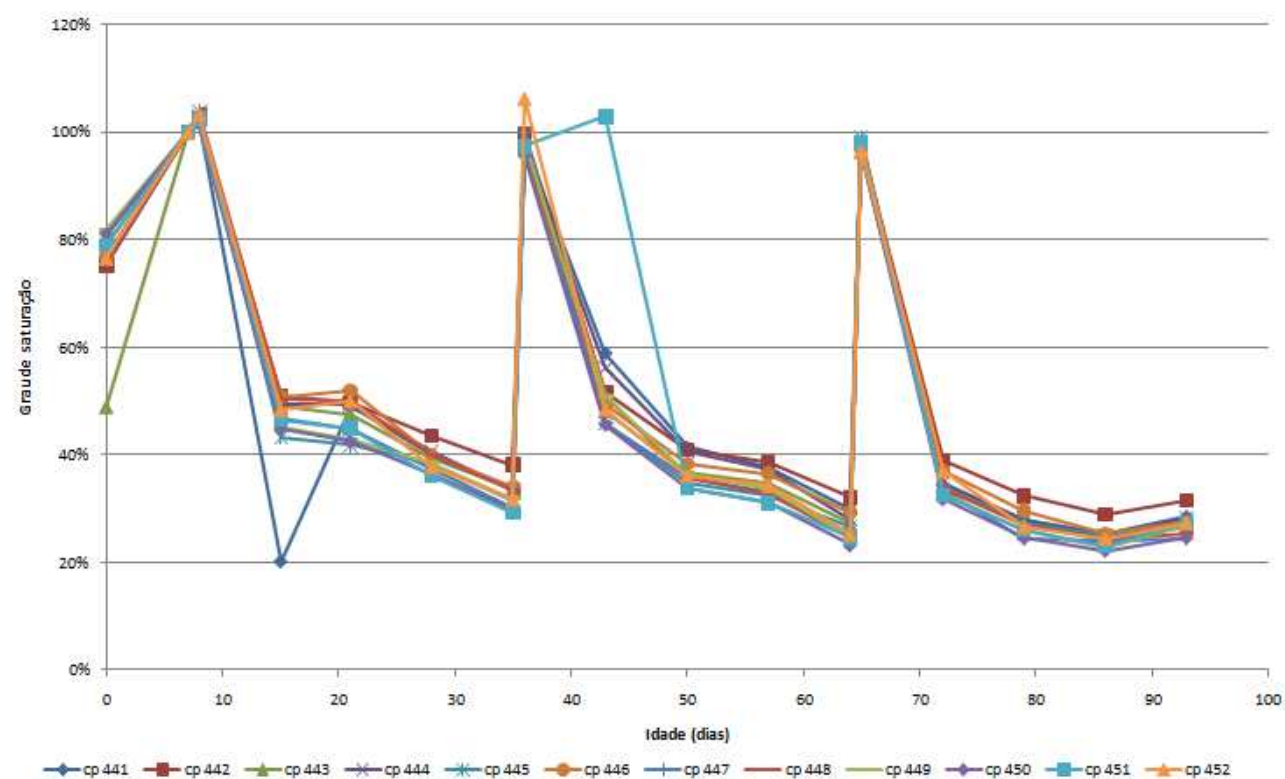

Figura 71 - Variação do grau de saturação entre os 3 ciclos de imersão e secagem nos corpos-deprova do lote 1. Cada etapa do ciclo foi constituída de 1 dia de imersão em solução de $3,5 \%$ de $\mathrm{NaCl}$ e 27 dias de secagem em caixa térmica ventilada a $45 \pm 5{ }^{\circ} \mathrm{C}$.

A Figura 72 apresenta a variação do grau de saturação nas etapas da ciclagem nos corpos-de-prova amostrados do lote 2.

Percebe-se com o decorrer da ciclagem, que os corpos-de-prova do lote 1 apresentaram uma maior saturação e menor secagem. Por outro lado, os valores de grau de saturação até 1,2 são indicativos de que a secagem final destes corpos-de-prova pode ter sido insuficiente. Mas, de qualquer forma, a manutenção de um patamar de umidade residual maior, nesses corposde-prova na fase de secagem, está coerente com os resultados que apresentaram em relação ao lote 2, apresentados na alínea b).

Os corpos-de-prova 229, 233 e 236 apresentaram pelo menos uma pesagem anômala, em diferentes etapas da ciclagem, mas isto não invalidou o seu comportamento e massa ao final dos três ciclos. 


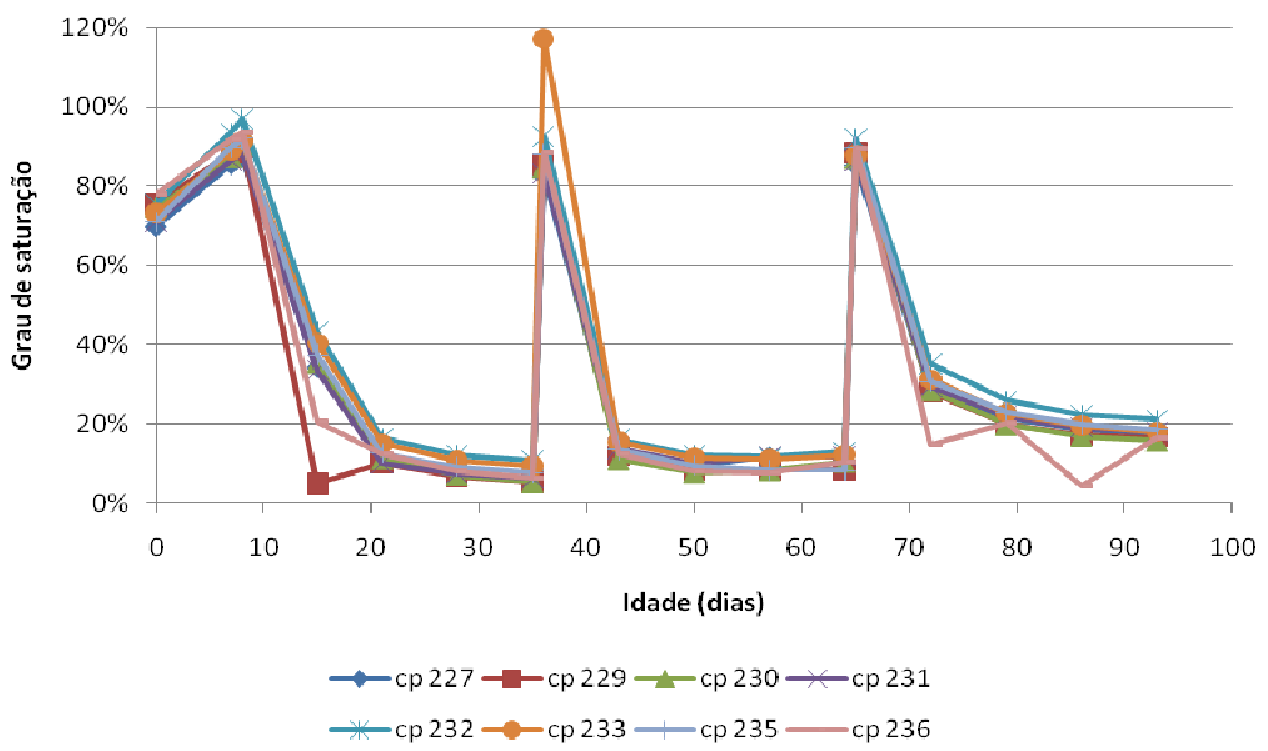

Figura 72 - Variação do grau de saturação entre os 3 ciclos de imersão e secagem nos corpos-deprova do lote 2. Cada etapa do ciclo foi constituída de 1 dia de imersão em solução de $3,5 \%$ de $\mathrm{NaCl}$ e 27 dias de secagem em caixa térmica ventilada a $45 \pm 5^{\circ} \mathrm{C}$.

\section{b) Profundidade de carbonatação por ciclagem}

A Tabela 68 apresenta as médias, os desvios padrão, os valores máximos e mínimos, as amplitudes, os coeficientes de variação e os coeficientes de carbonatação, a partir dos resultados do ensaio de profundidade de carbonatação por ciclagem. As medidas feitas no ensaio constam no Apêndice $C$.

O lote treinamento apresentou a maior profundidade de carbonatação, e o lote 1, a menor profundidade, mas com o maior coeficiente de variação. Isto é, são resultados ao contrario do que aconteceu com os corpos-de-prova do lote 1 , submetidos à câmara com pressão de $\mathrm{CO}_{2}$, que apresentaram as maiores profundidades e os menores coeficientes de variação. Em parte, se os corpos-de-prova do lote 1 tinham propriedade de reter mais umidade nos seus poros, isto pode ter contribuído para uma maior carbonatação $\operatorname{com} \mathrm{CO}_{2}$ sob pressão, mas não em atmosfera normal, como feito na ciclagem e, portanto, o seu comportamento estaria justificado. 
Tabela 68 - Resultados do ensaio de resistência à carbonatação a 91 dias por três ciclos de imersão e secagem em corpos-de-prova cilíndricos de $10 \times 20 \mathrm{~cm}$ submetidos a cura acelerada 24/48 $\mathrm{h}$ seguida de imersão normal até 7 dias nos concretos dos três lotes analisados.

\begin{tabular}{|c|c|c|c|c|c|c|c|}
\hline \multirow{2}{*}{ Lote } & \multicolumn{6}{|c|}{ Profundidade de carbonatação } & Coeficiente de \\
\cline { 2 - 8 } & $\begin{array}{c}\text { Média } \\
(\mathbf{m m})\end{array}$ & $\begin{array}{c}\text { Desvio } \\
\text { padrão } \\
(\mathbf{m m})\end{array}$ & $\begin{array}{c}\text { Valor } \\
\text { máximo } \\
(\mathbf{m m})\end{array}$ & $\begin{array}{c}\text { Valor } \\
\text { mínimo } \\
(\mathbf{m m})\end{array}$ & $\begin{array}{c}\text { Amplitude } \\
(\mathbf{m m})\end{array}$ & $\begin{array}{c}\text { Coeficiente de } \\
\text { Variação (\%) }\end{array}$ & $\begin{array}{c}\text { canatação } \\
\text { (x= k vt) } \\
\mathbf{m m} / \text { ano }^{-1 / 2}\end{array}$ \\
\hline Treinamento & 3,7 & 0,7 & 4,2 & 2,4 & 6,6 & 20 & 7 \\
\hline 1 & 1,6 & 1,1 & 3,4 & 0,0 & 3,4 & 70 & 3 \\
\hline 2 & 2,3 & 0,5 & 2,9 & 1,7 & 1,2 & 22 & 5 \\
\hline
\end{tabular}

A Figura 73 ilustra que as variações entre betonadas de um mesmo lote por ciclagem não se assemelham ao ocorrido no respectivo ensaio em câmara de $\mathrm{CO}_{2}$ sob pressão, para nenhum dos três lotes. Isto sugere que os procedimentos operacionais são importantes em ambos os tipos de ensaio, e talvez a carbonatação por ciclagem possa resultar mais reprodutível do que a carbonatação em câmara sob pressão. Observar que as amplitudes das medidas foram bem menores para dois dos três lotes (treinamento e lote 2) e iguais para o lote 1. É necessário reconhecer que não foi possível manter controle sobre o uso de desmoldante nas formas dos corpos-de-prova e que isto pode ter contribuído para aumentar a amplitude das medidas, ainda que a cura inicial em banho térmico e depois até 7 dias em água alcalina possam ter sido favoráveis à limpeza e remoção superficial do desmoldante.

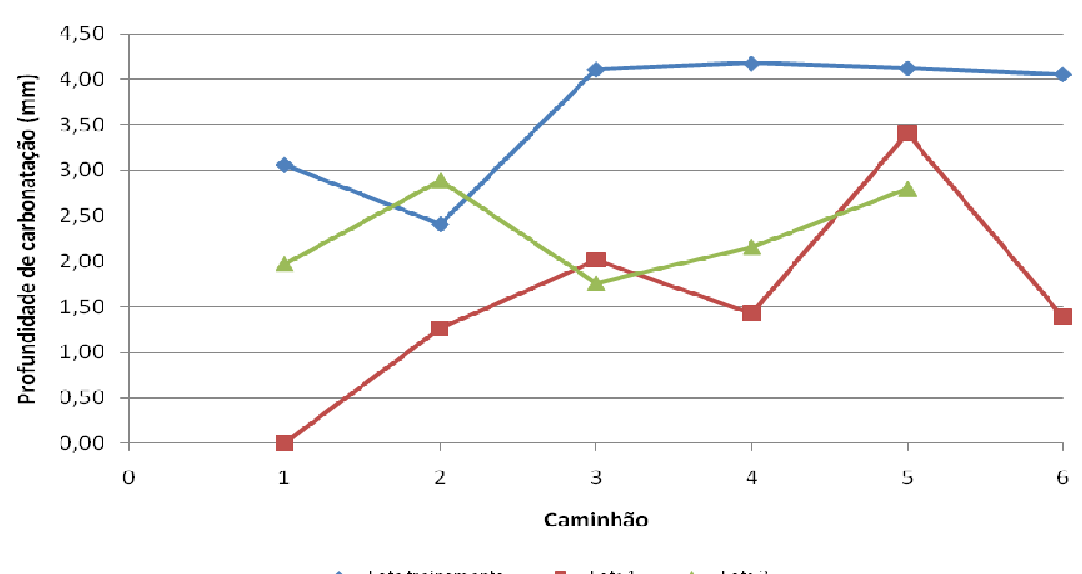

Figura 73 - Variação da profundidade de carbonatação média por três ciclos de imersão e secagem até 91 dias, em dois corpos-de-prova de concreto por caminhão, submetidos à cura acelerada 24/48 horas seguida de imersão normal até 7 dias, nos três lotes. Valores médios de metades diametralmente seccionadas de cada corpo-de-prova cilíndrico de $10 \times 20 \mathrm{~cm}$. 


\section{c) Profundidade de penetração de cloretos em corpos-de-prova ciclados por imersão e secagem}

A Tabela 69 apresenta as médias, os desvios padrão, os valores máximos e mínimos, as amplitudes e os coeficientes de variação dos resultados do ensaio de profundidade de penetração de cloretos, após o primeiro e segundo rompimento na direção diametral e nos terços médios, respectivamente, segundo procedimentos descritos no item 4.3.6 do Capítulo 4.

Os resultados dos ensaios das metades $10 \times 20 \mathrm{~cm}$ e dos terços médios dos corpos-deprova, resultaram em diferentes interpretações do lote 1, sendo os resultados da direção diametral mais coerente com os resultados de carbonatação por ciclagem. Mas o coeficiente de variação das profundidades nos primeiros ensaios foram maiores nos três lotes. Esse comportamento pode ser explicado pela maior superfície de penetração dos cloretos, no primeiro caso.

O lote 1 apresentou a maior profundidade de penetração de cloretos, sendo que este resultado também é coerente com a menor profundidade de carbonatação pela ciclagem, já que o sal é higroscópico, e com o resultado mais desfavorável da profundidade de carbonatação em câmara de $\mathrm{CO}_{2}$, já que é indicativo de uma rede de poros mais aberta e interconectada.

Tabela 69 - Resultados do ensaio de resistência à penetração de cloretos, por três ciclos de imersão e secagem a 91 dias, de corpos-de-prova cilíndricos de $10 \times 20 \mathrm{~cm}$, submetidos a cura acelerada 24/48 horas seguida de imersão normal até 7 dias, nos concretos dos três lotes analisados. Valores medidos para as metades seccionadas diametralmente e nos terços médios.

\begin{tabular}{|c|c|c|c|c|c|c|c|}
\hline Lote & Rompimento & $\begin{array}{r}\text { Média } \\
(\mathrm{mm})\end{array}$ & $\begin{array}{c}\text { Desvio } \\
\text { padrão } \\
(\mathrm{mm}) \\
\end{array}$ & $\begin{array}{c}\text { Valor } \\
\text { máximo } \\
(\mathrm{mm})\end{array}$ & $\begin{array}{c}\text { Valor } \\
\text { mínimo } \\
(\mathrm{mm})\end{array}$ & $\begin{array}{l}\text { Amplitude } \\
\text { (mm) }\end{array}$ & $\begin{array}{c}\text { Coeficiente } \\
\text { de variação } \\
\text { (\%) }\end{array}$ \\
\hline Treinamento & \multirow{3}{*}{ Diametral } & 3,8 & 1,9 & 6,5 & 1,6 & 4,9 & 51 \\
\hline$\overline{1}$ & & 7,1 & 1,2 & 8,5 & 5,0 & 3,5 & 18 \\
\hline 2 & & 4,0 & 0,6 & 4,8 & 3,3 & 1,5 & 16 \\
\hline Treinamento & \multirow{3}{*}{ Terços médios } & 3,4 & 0,4 & 4,0 & 2,7 & 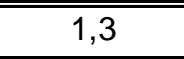 & 12 \\
\hline 1 & & 4,5 & 0,5 & 5,2 & 3,6 & 1,6 & 10 \\
\hline 2 & & 4,4 & 0,1 & 5,0 & 3,8 & $\overline{1,2}$ & 3 \\
\hline
\end{tabular}

A Figura 74 apresenta os resultados das profundidades médias de dois corpos-de-prova por caminhão e percebe-se que os três lotes analisados apresentaram variação em suas medidas, sendo o lote treinamento o que apresentou a maior variação. Todas as medidas médias do lote 1 foram superiores aos demais lotes, o que é coerente com o seu maior teor de ar no estado fresco. 
Os corpos-de-prova do lote 1 apresentaram tanto maior grau de saturação na fase de umedecimento quanto de secagem, explicando a maior penetração de cloretos e a menor profundidade de carbonatação por ciclagem. Observar que o resultado para o ensaio na câmara de $\mathrm{CO}_{2}$ não deixou de ser indicativo de uma maior permeabilidade desse lote, mas não pode informar sobre o menor efeito de carbonatação em presença de cloretos e umidade.

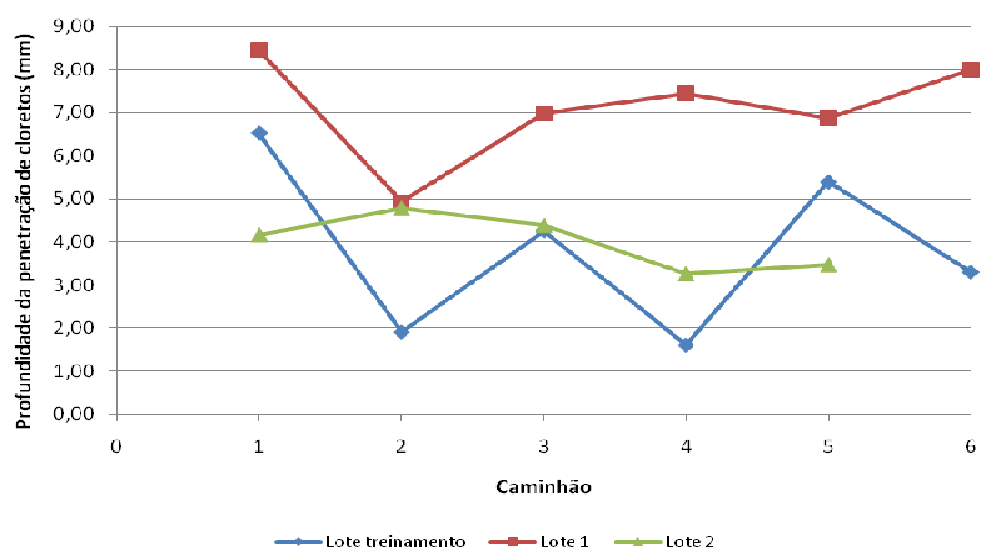

Figura 74 - Profundidade de penetração de cloretos média, por três ciclos de imersão e secagem até 91 dias, em dois corpos-de-prova de concreto por caminhão, submetidos à cura acelerada 24/48 horas seguida de imersão normal até 7 dias. Valores medidos em metades diametralmente seccionadas em cada corpo-de-prova cilíndrico de $10 \times 20 \mathrm{~cm}$.

A Figura 75 apresenta a profundidade de penetração de cloretos média das duas seções em terços médios de metade de corpos-de-prova respectivos, com menor variação das medidas nos três lotes analisados, o que é coerente com a menor área analisada. O lote 1 apresentou a maior variação entre as suas medidas, com o lote 2 apresentando a menor variação. 


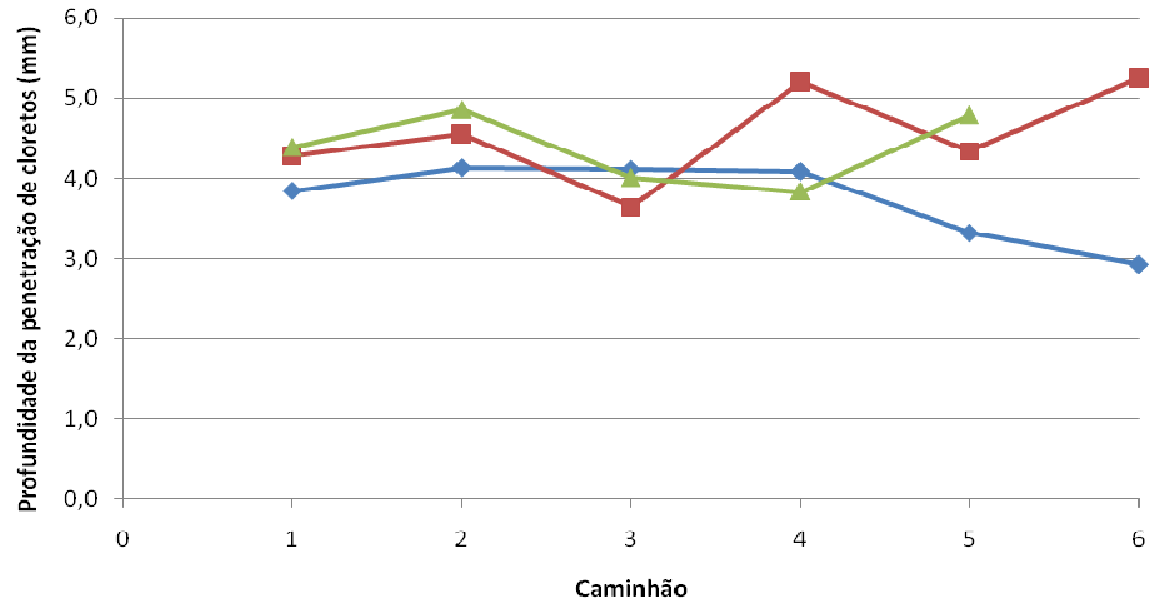

Figura 75 - Profundidade de penetração média de cloretos, por três ciclos de imersão e secagem até 91 dias, em dois terços médios de metade de corpos-de-prova de concreto, por caminhão, submetidos à cura acelerada $24 / 48$ horas seguida de imersão normal até 7 dias. Valores medidos em dois terços médios de metades diametralmente seccionadas em cada corpo-de-prova cilíndrico de $10 \times 20 \mathrm{~cm}$.

\subsubsection{Sugestões de cálculos das resistências ao ingresso de $\mathrm{CO}_{2}$ e íons cloreto pelos} estimadores da NBR 12655:2006

Neste item está apresentada uma breve simulação de valores característicos da profundidade de carbonatação e de penetração de cloretos, com os mesmos estimadores da ABNT NBR 12655 (2006), dados os testes de normalidade conforme o item 5.2. Para o lote treinamento e lote 1 foi utilizado o estimador da amostragem parcial e para o lote 2 o estimador referente à amostragem parcial. Levou-se em conta os maiores valores entre corpos-de-prova irmãos para cálculo do valor máximo característico estimado, e os menores valores entre corpos-de-prova irmãos para cálculo do valor mínimo característico estimado. 


\section{a) Profundidades características estimadas de carbonatação}

A Tabela 70 apresenta as profundidades máxima e mínima características estimada calculados para os três lotes.

Tabela 70 - Profundidade mínima e máxima característica estimada de carbonatação por câmara de $\mathrm{CO}_{2}$ e por ciclagem nos corpos-de-prova dos três lotes

\begin{tabular}{|c|c|c|c|}
\hline Lote & Ensaio & $\begin{array}{l}\text { Profundidade mínima } \\
\text { característica estimada } \\
\text { de carbonatação }(\mathrm{mm})\end{array}$ & $\begin{array}{l}\text { Profundidade máxima } \\
\text { característica estimada } \\
\text { de carbonatação }(\mathrm{mm})\end{array}$ \\
\hline Treinamento & \multirow{3}{*}{$\begin{array}{l}\text { Carbonatação } \\
\text { por câmara de } \\
\mathrm{CO}_{2}\end{array}$} & 0,0 & 12,0 \\
\hline 1 & & 4,1 & 14,2 \\
\hline 2 & & 0,0 & 6,8 \\
\hline Treinamento & \multirow{3}{*}{$\begin{array}{l}\text { Carbonatação } \\
\text { por câmara por } \\
\text { ciclagem }\end{array}$} & 3,5 & 6,1 \\
\hline 1 & & 0,0 & 4,1 \\
\hline 2 & & 2,1 & 3,1 \\
\hline
\end{tabular}

\section{b) Profundidades características estimadas da penetração de cloretos}

A Tabela 71 apresenta as profundidades máxima e mínima características calculados para os três lotes.

Tabela 71 - Profundidades características estimadas, mínima e máxima estimada da penetração de cloretos por ciclagem nos corpos-de-prova dos três lotes

\begin{tabular}{|c|c|c|c|}
\hline \multirow{2}{*}{ Lote } & Ensaio & $\begin{array}{c}\text { Profundidade mínima } \\
\text { característica estimada da } \\
\text { profundidade de penetração } \\
\text { de cloretos }(\mathbf{m m})\end{array}$ & $\begin{array}{c}\text { Profundidade máxima } \\
\text { característica estimada da } \\
\text { profundidade de penetração } \\
\text { de cloretos (mm) }\end{array}$ \\
\cline { 1 - 1 } Treinamento & \multirow{2}{*}{\begin{tabular}{c} 
Profundidade da \\
penetração de \\
\cline { 1 - 1 }
\end{tabular}} & 1,7 & 13,2 \\
\hline 1 & cloretos por ciclagem & 4,2 & 11,1 \\
\cline { 1 - 1 } & & 3,5 & 4,2 \\
\hline
\end{tabular}




\subsubsection{Potencial de corrosão das armaduras de aço-carbono}

A Tabela 72 apresenta as médias, os desvios padrão, os valores máximos e mínimos, as amplitudes, os coeficientes de variação do potencial de corrosão de barras de aço-carbono, a 91 dias de cura úmida e normal dos concretos dos três lotes analisados, e a probabilidade de corrosão pela ASTM C 876 (1999, 2009), conforme critérios na Tabela 17, no Capítulo 3.

O eletrodo de referência utilizado foi o de calomelano saturado (ECS), mas devido aos critérios da ASTM C 876 (1999), serem em cobre/sulfato de cobre (ECSC), os resultados foram recalculados conforme consta no item 3.5.8. Observa-se que os coeficientes de variação calculados para o ECSC tornam-se menores do que os obtidos para o ECS.

O lote treinamento apresentou o pior resultado, de acordo com a ASTM C 876 (2009), com $90 \%$ de probabilidade de estar ocorrendo corrosão nas armaduras, de acordo com a Tabela 72.

Apenas o lote 2 apresentou valores de potencial de corrosão seguramente compatíveis para o aço passivado em concreto com cura úmida prolongada e sem exposição a meio agressivo, como no caso dos corpos-de-prova em análise.

As razões para estes comportamentos estão provavelmente associadas à composição dos respectivos concretos, mas que não é objetivo aprofundar nesta dissertação.

Tabela 72 - Resultados do ensaio de potencial de corrosão nos corpos-de-prova com $2,5 \mathrm{~cm}$ de cobrimento, amostrados dos três lotes analisados

\begin{tabular}{|c|c|c|c|c|c|c|c|}
\hline Lote & $\begin{array}{l}\text { Média } \\
(\mathrm{mV}, \\
\text { ECSC) }\end{array}$ & $\begin{array}{c}\text { Desvio } \\
\text { padrão } \\
(\mathrm{mV}, \text { ECSC })\end{array}$ & $\begin{array}{l}\text { Valor } \\
\text { máximo } \\
(\mathrm{mV}, \\
\text { ECSC) }\end{array}$ & $\begin{array}{l}\text { Valor } \\
\text { mínimo } \\
(\mathrm{mV}, \\
\text { ECSC) } \\
\end{array}$ & $\begin{array}{c}\text { Amplitude } \\
\text { (mV, ECSC) }\end{array}$ & $\begin{array}{l}\text { Coeficiente } \\
\text { de variação } \\
\text { (\%) }\end{array}$ & $\begin{array}{c}\text { Avaliação da ASTM C } 876 \\
\text { (1999) }\end{array}$ \\
\hline Treinamento & -480 & 39 & -564 & -371 & 193 & -8 & $\begin{array}{c}90 \% \text { de probabilidade de } \\
\text { estar ocorrendo corrosão } \\
\text { nas armaduras }\end{array}$ \\
\hline 1 & -240 & 72 & -373 & -153 & 220 & -30 & $\begin{array}{c}\text { A ocorrência de corrosão é } \\
\text { incerta }\end{array}$ \\
\hline 2 & -110 & 45 & -217 & -1 & 216 & -41 & $\begin{array}{l}\text { 90\% de probabilidade de } \\
\text { não estar ocorrendo } \\
\text { corrosão de armaduras }\end{array}$ \\
\hline
\end{tabular}




\subsection{Consideração da normalidade das medidas em geral e verificações para as resistências ao ingresso de $\mathrm{CO}_{2}$ e íons cloreto}

Conforme já comentado, os resultados do programa experimental apresentados no item 5.1 foram submetidos à análise pelo Centro de Estatística Aplicada - CEA, do Instituto de Matemática e Estatística da Universidade de São Paulo - IME - USP, conforme relatório técnico que consta no Apêndice $\mathrm{E}$.

Como as variáveis de interesse são de caráter físico e mecânico, foi assumido que as observações seguem uma distribuição normal de probabilidade.

Para as medidas de profundidade de carbonatação e de penetração de cloretos foram realizados testes de normalidade específicos, conforme os gráficos A.27-A.32, do Apêndice $E$, e os valores de Anderson-Darling para os respectivos testes de normalidade, permitem concluir que:

- Ao nível de 5\%, não há evidências para se rejeitar a suposição de normalidade para a variável profundidade de carbonatação por ciclagem quando se avaliam os valores independentemente do lote. Entretanto, quando os valores são analisados dentro de cada lote, os dados aparentam não apresentar normalidade no lote treinamento;

- Para a variável profundidade de carbonatação em câmara de $\mathrm{CO}_{2}$, a suposição de normalidade parece se satisfazer, ao nível de $5 \%$, para os lotes 1 e 2 . Para o lote treinamento, o nível descritivo do teste foi de 0,049, bem próximo ao nível de significância estabelecido, de forma que não haveria grande problema em aceitar a suposição de normalidade também para este lote. No entanto, quando não se consideram os lotes e realiza-se o teste para todas as observações do estudo, a hipótese de normalidade é rejeitada. Os valores médios de cada lote são também indicativos de que os dados não vêm de uma única distribuição;

- Considerando-se a estratificação por lote, a suposição de normalidade não é rejeitada, ao nível de $5 \%$, para a variável profundidade da penetração de cloretos. 0 mesmo ocorre quando se analisam os dados conjuntamente. 


\subsection{Análise da igualdade de médias entre os lotes}

Sob a premissa de variação normal das propriedades, foram realizados testes $t$ para verificar a igualdade de médias entre as variáveis dos lotes 1 e 2 e dos lotes 1 e treinamento. Dado o número restrito de observações em cada amostra, é pouco razoável assumir igualdade entre as variâncias populacionais, de forma que os testes efetuados consideraram diferenças entre as mesmas.

Apenas os resultados de potencial de corrosão foram excluídos da análise pelo CEA, por necessidades de limitação do escopo daquele relatório.

\subsubsection{Concreto fresco}

As Tabelas B.1 e B.2, no Apêndice E, apresentam os valores médios e seus respectivos erros padrão (ou intervalos de confiança) para as variáveis do estudo, além dos níveis descritivos dos testes de diferenças de médias entre os lotes.

A um nível de $5 \%$ de significância, apenas não se verificaram diferenças significativas entre lote treinamento e lote 1 , no estado fresco, para as medidas de abatimento do tronco de cone. Isto é, apenas para esta propriedade o lote treinamento e o lote 1, ou seja, apenas no abatimento do tronco de cone, o lote treinamento e o lote 1 apresentaram igualdades no concreto fresco, cabendo lembrar que procederam da mesma central de concreto. É possível que esta igualdade tenha se verificado tão somente pelo maior coeficiente de variação do abatimento para o lote 1, o que aumenta a incerteza na citada comparação.

Já na comparação dos lotes 1 e 2, assumindo-se um nível de significância de 5\%, é possível observar que os valores do lote 1 são, em média, superiores aos do lote 2 apenas na variável índice de compactabilidade adensado, ou seja, nas demais propriedades do concreto fresco os lotes 1 e 2 podem ser considerados iguais.

\subsubsection{Concreto endurecido}

As Tabelas B.1 e B.2, no Apêndice E, apresentam os valores médios e seus respectivos erros padrão (intervalo de confiança) para as variáveis do estudo, além dos níveis descritivos dos testes de diferenças de médias entre os lotes.

Entre o lote treinamento e o lote 1, a um nível de significância de 5\%, não se verificaram diferenças significativas entras as seguintes variáveis: índice de vazios por cura acelerada 
24/48 horas, resistência à compressão a 7 dias por cura acelerada 24/48 horas, resistência à compressão a 28 dias por cura normal, resistência à tração por compressão diametral a 28 dias por cura normal e profundidade de carbonatação por câmara de $\mathrm{CO}_{2}$, cabendo lembrar que procederam da mesma central dosadora.

Entre os lotes 1 e 2, a um nível de significância de 5\%, foi possível observar que os valores do lote 1 foram, em média, superiores aos do lote 2 nas variáveis profundidade de carbonatação em câmara de $\mathrm{CO}_{2}$ e profundidade de penetração de cloretos, e inferiores em absorção de água por capilaridade por cura acelerada, resistência à compressão a 1 dia por cura acelerada 0/24 horas e resistência à tração por compressão diametral a 7 dias por cura acelerada. Para as demais variáveis das propriedades analisadas no item 5.1, a hipótese de igualdade de média não foi rejeitada, ao nível de 5,0\%. Apenas os resultados de potencial de corrosão foram excluídos da análise pelo CEA, além do teor de ar pressométrico no lote treinamento (ponderado apenas na Tabela B.4 do Apêndice E, a pedido deste autor

\subsection{Correlações entre as propriedades}

A partir da teoria de associação entre variáveis quantitativas e fazendo uso do programa Minitab 15, os relatores do CEA (IME-USP) elaboraram duas matrizes de correlações lineares, uma com correlações entre os três lotes de forma conjunta e a outra com correlações entre dois lotes (lote 1 e 2), face à inexistência de algumas medidas para o lote treinamento. As correlações dentro de cada lote não foram apresentadas, pois consideraram que os cálculos se tornariam menos precisos, pelo pouco número de observações em cada lote.

As Tabelas B4 presentes no relatório entregue pelo CEA, no Apêndice $\mathrm{E}$, trazem todos os coeficientes de Pearson para a matriz de correlações lineares testadas e salienta-se que podem ser interpretadas da seguinte forma:

a) correlação forte: coeficiente de Pearson $\left(r^{2}\right)$ maior que 0,75 ;

b) correlação razoável: coeficiente de Pearson $\left(r^{2}\right)$ entre 0,50 e 0,75;

c) correlação fraca: coeficiente de Pearson $\left(r^{2}\right)$ entre 0,25 e 0,50;

d) correlação quase nula; coeficiente de Pearson $\left(r^{2}\right)$ entre 0 e 0,25;

e) o sinal negativo indica que as variáveis são inversamente proporcionais.

Os itens 5.4.1 a 5.4.12 destacam separadamente as melhores correlações obtidas e que poderiam ser classificadas entre razoáveis a fortes. 


\subsubsection{Abatimento pelo tronco de cone}

As correlações de razoáveis a forte, na Tabela 73, tomaram por base os três lotes analisados.

O abatimento pelo tronco de cone do concreto fresco apresentou forte correlação com a resistência à compressão a 1 dia por cura acelerada $\left(r^{2}=-0,802\right)$, mas não com a resistência a 1 dia não acelerada $\left(r^{2}=0,001\right)$. Possivelmente, no primeiro caso foi mínima a perda de água e o tratamento mais homogêneo entre os três lotes, já que os corpos-de-prova foram levados na mesma data da moldagem, para o tanque de cura em temperatura moderada, no laboratório, e depois logo ensaiados.

Tabela 73 - Correlações entre o abatimento do tronco de cone e propriedades dos três lotes

\begin{tabular}{|c|c|c|}
\hline $\begin{array}{c}\text { Propriedade } \\
\text { analisada }\end{array}$ & Propriedade correlacionada & $\mathbf{r}^{2}$ \\
\hline \multirow{2}{*}{$\begin{array}{c}\text { Abatimento pelo } \\
\text { tronco de cone }\end{array}$} & $\begin{array}{c}\text { Tesistência à compressão a 1 } \\
\text { dia por cura acelerada 0/24 } \\
\text { horas }\end{array}$ & $-0,802$ \\
\cline { 2 - 3 } & $\begin{array}{c}\text { Resistência à compressão a 63 } \\
\text { dias por cura normal }\end{array}$ & $-0,556$ \\
\hline
\end{tabular}

\subsubsection{Massa específica aparente do concreto fresco}

As correlações razoáveis apresentadas, na Tabela 74, tomaram por base os três lotes analisados. Observa-se que são correlações com propriedades físicas que respondem diretamente pela capacidade de proteção das armaduras pelo concreto, o que mostra a sua importância para o controle tecnológico.

Nas análises restritas aos lotes 1 e 2, observou-se ainda correlações dessa propriedade com:

- a umidade do concreto fresco $\left(r^{2}=0,615\right) \mathrm{e}$;

- a resistência à tração por compressão diametral, em cura normal e a 91 dias $\left(r^{2}=\right.$ $-0,906)$, mas não com essa resistência a tração por cura acelerada e a 7 dias $\left(r^{2}=\right.$ $-0,419)$. 
Tabela 74 - Correlações entre a massa específica do concreto fresco aparente e propriedades dos três lotes

\begin{tabular}{|c|c|c|}
\hline $\begin{array}{c}\text { Propriedade } \\
\text { analisada }\end{array}$ & Propriedade correlacionada & $\mathbf{r}^{2}$ \\
\hline \multirow{4}{*}{$\begin{array}{c}\text { Massa } \\
\text { específica } \\
\text { aparente do } \\
\text { concreto fresco }\end{array}$} & $\begin{array}{c}\text { Absorção de água total por cura } \\
\text { acelerada 24/48 horas mais } \\
\text { imersão em água até 7 dias }\end{array}$ & 0,613 \\
\cline { 2 - 3 } & $\begin{array}{c}\text { Índice de vazios por cura } \\
\text { acelerada 24/48 horas mais }\end{array}$ & 0,627 \\
\cline { 2 - 3 } & $\begin{array}{c}\text { Absorção de água total por cura até } 7 \text { dias } \\
\text { normal a 28 dias }\end{array}$ & 0,554 \\
\cline { 2 - 4 } & $\begin{array}{c}\text { Indice de vazios por cura normal } \\
\text { a 28 dias }\end{array}$ & 0,569 \\
\hline
\end{tabular}

As relações diretas entre massa específica do concreto fresco e as propriedades físicas da Tabela 74 e ainda com o teor de umidade do concreto fresco não seriam, em princípio esperadas, mas podem ter alguma relação com fenômenos de compactabilidade e de assentamento do concreto plástico. Observar que a relação inversa entre a massa específica do concreto fresco e a resistência à tração a 91 dias, em corpos-de-prova dos cinco caminhões do lote 2, foi muito boa e poderia ser explicada pela mesma razão.

\subsubsection{Compactabilidade do concreto adensado}

As correlações na Tabela 75 tomaram por base os três lotes analisados. Mesmo sendo um ensaio realizado de forma introdutória por esta pesquisa, aplicado em campo e através de procedimento ainda não aperfeiçoado, apresentou correlações razoáveis, o que justifica a continuidade do estudo desse método em futuras pesquisas.

Nas análises restritas aos lotes 1 e 2, observou-se ainda correlações dessa propriedade com:

- a compactabilidade do concreto não-adensado $\left(r^{2}=0,638\right)$;

- a absorção de água por capilaridade, para os corpos-de-prova com cura acelerada e a 7 dias $\left(r^{2}=-0,558\right)$;

- a resistência à compressão a $1 \mathrm{dia}\left(r^{2}=0,526\right)$;

- a resistência à compressão a 91 dias $\left(r^{2}=0,667\right)$. 
Observar ainda que as relações inversas, entre a compactabilidade do concreto fresco adensado e suas propriedades no estado endurecido, como a absorção de água por capilaridade e a resistência à tração, podem ser indicativas de efeitos de sedimentação natural do concreto ainda no estado plástico, seja pelas manipulações de formas logo após a moldagem, seja pelo período de repouso transcorrido até o final de pega.

Quanto à resistência à compressão estar associada de forma direta à compactabilidade do concreto adensado, especialmente em idade inicial (1 dia, cura em campo) e depois somente em idade mais avançada (91 dias), isto pode reforçar a hipótese de que a maior suscetibilidade à compactação do concreto fresco introduz fenômenos de assentamento do concreto plástico, após a moldagem dos corpos-de-prova, enquanto os poros decorrentes desse mecanismo não são percebidos a curto prazo, já que a hidratação pode ser incipiente conforme a ação de aditivos e então os mesmos poros passam a ser consolidados em fase bem mais adiantada da hidratação, no caso 91 dias. Observa-se ainda que uma outra hipótese plausível seria a compactabilidade favorecer a uma melhor qualidade dos corpos-de-prova em si e não propriamente à sedimentação no estado plástico, como aqui analisado, mas para essa hipótese ser mais coerente, as relações diretas de $r^{2}$ precisariam ter ocorrido também para as idades intermediárias, como 7 dias $\left(r^{2}=-0,158\right) ; 28$ dias $\left(r^{2}=-0,254\right)$ e 63 dias $\left(r^{2}=0,447\right)$.

Com isso, recomenda-se que esta propriedade continue a ser objeto de estudo, quanto ao procedimento de determinação, principalmente porque também demonstrou potencial para prever a resistência à tração por compressão diametral acelerada a 7 dias, a profundidade de carbonatação e a penetração de cloretos, em situações de ciclagem, no caso em que foram comparados os três lotes.

Tabela 75 - Correlações entre a compactabilidade do concreto adensado e propriedades dos três lotes

\begin{tabular}{|c|c|c|}
\hline $\begin{array}{c}\text { Propriedade } \\
\text { analisada }\end{array}$ & Propriedade correlacionada & $\mathbf{r}^{\mathbf{2}}$ \\
\hline \multirow{4}{*}{$\begin{array}{c}\text { Compactabilidade } \\
\text { do concreto fresco } \\
\text { adensado }\end{array}$} & $\begin{array}{c}\text { Absorção de água por capilaridade por } \\
\text { cura normal até 28 dias }\end{array}$ & $-0,651$ \\
\cline { 2 - 3 } & $\begin{array}{c}\text { Resistência à tração por compressão } \\
\text { mais imersão em água até 7 dias }\end{array}$ & $-0,667$ \\
\cline { 2 - 3 } & $\begin{array}{c}\text { Profundidade de carbonatação por } \\
\text { ciclagem }\end{array}$ & $-0,596$ \\
\cline { 2 - 3 } & $\begin{array}{c}\text { Profundidade da penetração de cloretos } \\
\text { por ciclagem }\end{array}$ & 0,568 \\
\hline
\end{tabular}




\subsubsection{Compactabilidade do concreto não-adensado}

As correlações feitas tomaram por base dois lotes analisados (lote 1 e 2), o lote treinamento não foi correlacionado por não ter sido realizado esse ensaio, e as melhores correlações constam na Tabela 76. Também para esta propriedade, resultaram boas correlações com resistência à compressão a longas idades, de forma direta, o que se suscita as mesmas razões já apontadas no item anterior.

Da mesma forma que a compactabilidade adensada, cabe ser objeto de estudo para o refinamento e aperfeiçoamento dos procedimentos de ensaio.

Tabela 76 - Correlações entre a compactabilidade do concreto não-adensado e propriedades de dois lotes de diferentes centrais (Lote 1 e 2)

\begin{tabular}{|c|c|c|}
\hline $\begin{array}{c}\text { Propriedade } \\
\text { analisada }\end{array}$ & Propriedade correlacionada & $\mathbf{r}^{\mathbf{2}}$ \\
\hline \multirow{2}{*}{$\begin{array}{c}\text { Compactabilidade } \\
\text { do concreto fresco } \\
\text { não-adensado }\end{array}$} & $\begin{array}{r}\text { Resistência à compressão a 63 dias por } \\
\text { cura normal }\end{array}$ & 0,634 \\
\cline { 2 - 3 } & $\begin{array}{r}\text { Resistência à compressão a 91 dias por } \\
\text { cura normal }\end{array}$ & 0,730 \\
\cline { 2 - 3 } & $\begin{array}{c}\text { Resistência à tração por compressão } \\
\text { diamentral a 91 dias por cura normal }\end{array}$ & $-0,545$ \\
\hline
\end{tabular}

\subsubsection{Teor de ar pelo método pressométrico}

As correlações feitas tomaram por base dois lotes analisados (lote 1 e 2) e constam na Tabela 77. O lote treinamento foi excluído da análise desta propriedade, por não ter sido medido para os seis caminhões.

Pelas correlações na Tabela 77, confirma-se que o teor de ar pelo método pressométrico é um ensaio importante para controle tecnológico de concretos estruturais, pois mostrou correlações fortes com as resistências à compressão e à tração, com a profundidade de carbonatação por câmara de $\mathrm{CO}_{2}$ sob pressão e penetração de cloretos, em ciclagem. 
Tabela 77 - Correlações entre o teor de ar pelo método pressométrico e propriedades de dois lotes de diferentes centrais (Lote 1 e 2 )

\begin{tabular}{|c|c|c|}
\hline $\begin{array}{l}\text { Propriedade } \\
\text { analisada }\end{array}$ & Propriedade correlacionada & $r^{2}$ \\
\hline \multirow{7}{*}{$\begin{array}{l}\text { Teor de ar pelo } \\
\text { método } \\
\text { pressométrico }\end{array}$} & $\begin{array}{c}\text { Índice de vazios por cura acelerada } \\
24 / 48 \text { horas mais imersão em água até } \\
\text { a } 7 \text { dias }\end{array}$ & 0,513 \\
\hline & $\begin{array}{c}\text { Índice de vazios por cura normal até } 28 \\
\text { dias }\end{array}$ & 0,502 \\
\hline & $\begin{array}{l}\text { Resistência à compressão a } 1 \text { dia por } \\
\text { cura acelerada } 0 / 24 \text { horas }\end{array}$ & $-0,537$ \\
\hline & $\begin{array}{c}\text { Resistência à compressão a } 28 \text { dias por } \\
\text { cura normal }\end{array}$ & $-0,698$ \\
\hline & $\begin{array}{c}\text { Resistência à tração por compressão } \\
\text { diametral por cura acelerada } 24 / 48 \text { horas } \\
\text { mais imersão em água até } 7 \text { dias }\end{array}$ & $-0,818$ \\
\hline & $\begin{array}{l}\text { Profundidade de carbonatação por } \\
\text { câmara de } \mathrm{CO}_{2}\end{array}$ & 0,699 \\
\hline & Profundidade da penetração de cloretos & 0,625 \\
\hline
\end{tabular}

\subsubsection{Umidade do concreto fresco}

As correlações feitas tomaram por base dois lotes analisados (lote 1 e 2) e as melhores correlações constam na Tabela 78, o lote treinamento não foi correlacionado por não ter sido realizado esse ensaio.

A correlação forte com a resistência à tração por compressão diametral a 91 dias, evidencia que é importante continuar estudos para caracterização mais precisa da umidade do concreto fresco, já que aqui a experiência e recursos no laboratório eram bastante limitadas e mesmo assim foi possível obter esse valor de correlação. 
Tabela 78 - Correlações entre a umidade do concreto fresco e propriedades de dois lotes de diferentes centrais (Lotes 1 e 2)

\begin{tabular}{|c|c|c|}
\hline $\begin{array}{c}\text { Propriedade } \\
\text { analisada }\end{array}$ & $\begin{array}{c}\text { Propriedade } \\
\text { correlacionada }\end{array}$ & $\mathbf{r}^{2}$ \\
\hline \multirow{4}{*}{$\begin{array}{c}\text { Umidade do } \\
\text { concreto fresco }\end{array}$} & $\begin{array}{c}\text { Absorção de água por } \\
\text { capilaridades por cura } \\
\text { acelerada 24/48 horas } \\
\text { mais imersão em água até }\end{array}$ & 0 \\
\cline { 2 - 3 } & $\begin{array}{c}\text { Resistência à tração por } \\
\text { compressão diametral a } \\
28 \text { dias por cura normal }\end{array}$ & $-0,569$ \\
\cline { 2 - 3 } & $\begin{array}{c}\text { Resistência à tração por } \\
\text { compressão diametral a } \\
91 \text { dias por cura normal }\end{array}$ & $-0,866$ \\
\hline
\end{tabular}

\subsubsection{Absorção de água capilaridade}

As correlações feitas para absorção de água por capilaridade por cura normal até 28 dias e acelerada $24 / 48$ horas estendida a 7 dias, tomaram por base dois dos lotes analisados (lote 1 e 2), e constam na Tabela 79. O lote treinamento não foi correlacionado por não ter sido caracterizado para absorção de água por cura acelerada 24/48 horas mais 7 dias de imersão em água.

A absorção de água por capilaridade a 28 dias e a sua correlação com a profundidade de carbonatação por ciclagem mostra a importância de controle de propriedades físicas do concreto, além das suas propriedades mecânicas, no que diz respeito à proteção de armaduras. 
Tabela 79 - Correlações entre a absorção de água por capilaridade e propriedades de dois lotes de diferentes centrais (Lotes 1 e 2)

\begin{tabular}{|c|c|c|c|}
\hline $\begin{array}{l}\text { Propriedade } \\
\text { analisada }\end{array}$ & Cura & Propriedade correlacionada & $r^{2}$ \\
\hline \multirow{5}{*}{$\begin{array}{l}\text { Absorção de água por } \\
\text { capilaridade }\end{array}$} & \multirow{2}{*}{$\begin{array}{l}\text { Cura acelerada } 24 / 48 \\
\text { horas mais imersão } \\
\text { em água até } 7 \text { dias }\end{array}$} & $\begin{array}{l}\text { Resistência à tração por } \\
\text { compressão diametral por cura } \\
\text { acelerada 24/48 horas mais } \\
\text { imersão em água até } 7 \text { dias }\end{array}$ & 0,582 \\
\hline & & $\begin{array}{l}\text { Profundidade de carbonatação } \\
\text { por câmara de } \mathrm{CO}_{2}\end{array}$ & $-0,561$ \\
\hline & \multirow{3}{*}{$\begin{array}{c}\text { Cura normal até } 28 \\
\text { dias }\end{array}$} & $\begin{array}{l}\text { Profundidade de carbonatação } \\
\text { por ciclagem }\end{array}$ & 0,757 \\
\hline & & $\begin{array}{c}\text { Resistência à compressão a } 63 \\
\text { dias por cura normal }\end{array}$ & $-0,688$ \\
\hline & & $\begin{array}{c}\text { Resistência à compressão a } 91 \\
\text { dias por cura normal }\end{array}$ & $-0,593$ \\
\hline
\end{tabular}

\subsubsection{Absorção de água total e índice de vazios}

As correlações feitas tomaram por base os três lotes analisados, e as melhores correlações constam na Tabela 80 e Tabela 81.

As relações com propriedades mecânicas foram melhores do que as verificadas para a absorção de água por capilaridade, mas em contrapartida não houve boas correlações com as medidas de profundidade de carbonatação e nem com a profundidade de ingresso de cloretos. 
Tabela 80 - Correlações entre a absorção de água total e as propriedades dos três lotes

\begin{tabular}{|c|c|c|c|}
\hline $\begin{array}{l}\text { Propriedade } \\
\text { analisada }\end{array}$ & Cura & Propriedade correlacionada & $r^{2}$ \\
\hline \multirow{10}{*}{$\begin{array}{l}\text { Absorção de } \\
\text { água total }\end{array}$} & \multirow{6}{*}{$\begin{array}{l}\text { Acelerada } 24 / 48 \\
\text { horas mais } \\
\text { imersão em água } \\
\text { até } 7 \text { dias }\end{array}$} & $\begin{array}{c}\text { Índice de vazios por cura acelerada } 24 / 48 \\
\text { horas mais imersão em água até } 7 \text { dias }\end{array}$ & 0,996 \\
\hline & & $\begin{array}{c}\text { Absorção de água total por cura normal } \\
\text { até } 28 \text { dias }\end{array}$ & 0,747 \\
\hline & & $\begin{array}{c}\text { Índice de vazios por cura normal até } 28 \\
\text { dias }\end{array}$ & 0,750 \\
\hline & & $\begin{array}{c}\text { Resistência à compressão a } 28 \text { dias por } \\
\text { cura normal }\end{array}$ & $-0,573$ \\
\hline & & $\begin{array}{c}\text { Resistência à tração por compressão } \\
\text { diametral por cura acelerada } 24 / 48 \text { horas } \\
\text { mais imersão em água até } 7 \text { dias }\end{array}$ & $-0,597$ \\
\hline & & $\begin{array}{l}\text { Resistência à tração por compressão } \\
\text { diametral a } 28 \text { dias por cura normal }\end{array}$ & $-0,519$ \\
\hline & \multirow{4}{*}{$\begin{array}{c}\text { Normal até } 28 \\
\text { dias }\end{array}$} & $\begin{array}{c}\text { Índice de vazios por cura normal até } 28 \\
\text { dias }\end{array}$ & 0,999 \\
\hline & & $\begin{array}{c}\text { Resistência à compressão a } 28 \text { dias por } \\
\text { cura normal }\end{array}$ & $-0,532$ \\
\hline & & $\begin{array}{c}\text { Resistência à compressão a } 63 \text { dias por } \\
\text { cura normal }\end{array}$ & $-0,637$ \\
\hline & & $\begin{array}{l}\text { Resistência à tração por compressão } \\
\text { diametral a } 28 \text { dias por cura normal }\end{array}$ & $-0,512$ \\
\hline
\end{tabular}

Tabela 81 - Correlações entre o índice de vazios entre propriedades dos três lotes

\begin{tabular}{|c|c|c|c|}
\hline $\begin{array}{l}\text { Propriedade } \\
\text { analisada }\end{array}$ & Cura & Propriedade correlacionada & $r^{2}$ \\
\hline \multirow{7}{*}{ Índice de vazios } & \multirow{5}{*}{$\begin{array}{c}\text { Acelerada } \\
24 / 48 \text { horas } \\
\text { mais imersão } \\
\text { em água até } 7 \\
\text { dias }\end{array}$} & $\begin{array}{c}\text { Absorção de água total por cura } \\
\text { normal até } 28 \text { dias }\end{array}$ & 0,782 \\
\hline & & $\begin{array}{c}\text { Índice de vazios por cura normal a } 28 \\
\text { dias }\end{array}$ & 0,788 \\
\hline & & $\begin{array}{l}\text { Resistência à compressão a } 28 \text { dias } \\
\text { por cura normal }\end{array}$ & $-0,589$ \\
\hline & & $\begin{array}{c}\text { Resistência à tração por compressão } \\
\text { diametral a } 7 \text { dias por cura acelerada } \\
24 / 48 \text { horas mais imersão em água } \\
\text { até } 7 \text { dias }\end{array}$ & $-0,606$ \\
\hline & & $\begin{array}{l}\text { Resistência à tração por compressão } \\
\text { diametral a } 28 \text { dias por cura normal }\end{array}$ & $-0,544$ \\
\hline & \multirow{2}{*}{$\begin{array}{c}\text { Normal até } 28 \\
\text { dias }\end{array}$} & $\begin{array}{c}\text { Resistência à compressão a } 28 \text { dias } \\
\text { por cura normal }\end{array}$ & $-0,534$ \\
\hline & & $\begin{array}{c}\text { Resistência à tração por compressão } \\
\text { diametral a } 28 \text { dias por cura normal }\end{array}$ & $-0,522$ \\
\hline
\end{tabular}




\subsubsection{Resistência à compressão}

\section{a) Resistência à compressão medida a 1 dia ( $f_{c 1}$ e $\left.f_{c 1 a c e l}\right)$}

As correlações feitas tomaram por base dois lotes analisados (lote 1 e 2), e as melhores correlações constam na Tabela 82.

A resistência à compressão a 1 dia por cura acelerada apresentou ótimas correlações com a profundidade de carbonatação por câmara de $\mathrm{CO}_{2}$ e penetração de cloretos, sendo isto um forte indício de que a microestrutura do concreto em fases intermediárias da hidratação do cimento pode responder de modo bem satisfatório pela previsão da sua resistência à penetração de agentes agressivos.

Em princípio, isto pode sugerir que os macroporos e defeitos iniciais formados na microestrutura do concreto podem responder de modo bem mais importante, pela sua resistência à penetração de agentes agressivos, do que as alterações da microestrutura pela evolução da hidratação, o que também sugere pela análise de correlações para a resistência à compressão na Tabela 83 e Tabela 84.

Tabela 82 - Correlações entre resistência à compressão a 1 dia entre propriedades de dois lotes de diferentes centrais (Lotes 1 e 2)

\begin{tabular}{|c|c|c|c|}
\hline $\begin{array}{l}\text { Propriedade } \\
\text { analisada }\end{array}$ & Cura & Propriedade correlacionada & $r^{2}$ \\
\hline \multirow{6}{*}{$\begin{array}{l}\text { Resistência à } \\
\text { compressão a } 1 \\
\text { dia }\end{array}$} & \multirow{3}{*}{ Normal } & $\begin{array}{l}\text { Resistência à compressão a } 28 \text { dias } \\
\text { por cura normal }\end{array}$ & $-0,539$ \\
\hline & & $\begin{array}{c}\text { Resistência à tração por compressão } \\
\text { diametral a } 7 \text { dias por cura acelerada } \\
24 / 48 \text { horas mais imersão em água até } \\
7 \text { dias }\end{array}$ & $-0,731$ \\
\hline & & $\begin{array}{l}\text { Profundidade de carbonatação por } \\
\text { câmara de } \mathrm{CO}_{2}\end{array}$ & 0,516 \\
\hline & \multirow{3}{*}{$\begin{array}{c}\text { Acelerada } 0 / 24 \\
\text { horas }\end{array}$} & $\begin{array}{c}\text { Resistência à tração por compressão } \\
\text { diametral a } 7 \text { dias por cura acelerada } \\
24 / 48 \text { horas mais imersão em água até } \\
7 \text { dias }\end{array}$ & 0,567 \\
\hline & & $\begin{array}{l}\text { Profundidade de carbonatação por } \\
\text { câmara de } \mathrm{CO}_{2}\end{array}$ & $-0,750$ \\
\hline & & $\begin{array}{l}\text { Profundidade da penetração de } \\
\text { cloretos }\end{array}$ & $-0,738$ \\
\hline
\end{tabular}


b) Resistência à compressão medida a 7 dias ( $f_{c 7}$ e $\left.f_{c 7 a c e l}\right)$

A resistência à compressão a 7 dias por cura normal não apresentou correlações com nenhuma outra variável analisada. Entretanto, a resistência à compressão a 7 dias por cura acelerada 24/48 horas mais imersão em água até 7 dias apresentou alguma correlação com a profundidade de carbonatação por câmara de $\mathrm{CO}_{2}$ segundo a Tabela 83.

O resultado evidencia ser possível adotar os métodos de cura acelerada, em temperatura amena, para prever a profundidade de carbonatação por câmara de $\mathrm{CO}_{2}$, a partir de ensaios entre 1 a 7 dias.

Tabela 83 - Correlações entre resistência à compressão a 7 dias por cura acelerada entre propriedades de dois lotes de diferentes centrais (Lotes 1 e 2)

\begin{tabular}{|c|c|c|c|}
\hline $\begin{array}{c}\text { Propriedade } \\
\text { analisada }\end{array}$ & Cura & Propriedade correlacionada & $\mathbf{r}^{2}$ \\
\hline Resistência à \\
$\begin{array}{c}\text { compressão a 7 } \\
\text { dias }\end{array}$ & $\begin{array}{c}\text { Acelerada } \\
24 / 48 \text { horas } \\
\text { mais imersão } \\
\text { em água até 7 } \\
\text { dias }\end{array}$ & $\begin{array}{c}\text { Profundidade de carbonatação } \\
\text { por câmara de } \mathrm{CO}_{2}\end{array}$ & $-0,542$ \\
\hline
\end{tabular}

\section{c) Resistência à compressão medida a 28 dias $\left(\mathbf{f}_{\mathrm{c} 28}\right)$}

As correlações encontradas com a resistência à compressão a 28 dias por cura normal são apresentadas na Tabela 84. Pela ausência de correlações com outras propriedades mecânicas, seria recomendável uma revisão dos procedimentos de ensaio adotados.

Tabela 84 - Correlações entre resistência à compressão a 28 dias por cura normal entre propriedades dos três lotes

\begin{tabular}{|c|c|c|}
\hline $\begin{array}{c}\text { Propriedade } \\
\text { analisada }\end{array}$ & Propriedade correlacionada & $\mathbf{r}^{2}$ \\
\hline \multirow{2}{*}{$\begin{array}{c}\text { Resistência à } \\
\text { compressão a 28 } \\
\text { dias por cura normal }\end{array}$} & $\begin{array}{c}\text { Teor de ar do concreto fresco pelo } \\
\text { método pressométrico }\end{array}$ & $-0,698$ \\
\cline { 2 - 3 } & $\begin{array}{c}\text { Absorção de água total por cura } \\
\text { imersão em água até 7 dias }\end{array}$ & $-0,573$ \\
\cline { 2 - 3 } & $\begin{array}{c}\text { Absorção de água total por cura } \\
\text { normal até 28 dias }\end{array}$ & $-0,532$ \\
\cline { 2 - 4 } & $\begin{array}{c}\text { Resistência à compressão a 1 dia } \\
\text { por cura normal }\end{array}$ & $-0,539$ \\
\hline
\end{tabular}




\section{d) Resistência à compressão medida a 63 dias $\left(f_{c 63}\right)$}

As correlações feitas tomaram por base dois lotes analisados (lote 1 e 2), e as melhores correlações constam na Tabela 85.

Tabela 85 - Correlações entre resistência à compressão a 63 dias por cura normal entre propriedades de dois lotes de diferentes centrais (Lotes 1 e 2)

\begin{tabular}{|c|c|c|}
\hline $\begin{array}{c}\text { Propriedade } \\
\text { analisada }\end{array}$ & Propriedade correlacionada & $r^{2}$ \\
\hline \multirow{5}{*}{$\begin{array}{c}\text { Resistência à } \\
\text { compressão a } 63 \text { dias } \\
\text { por cura normal }\end{array}$} & $\begin{array}{l}\text { Abatimento pelo tronco de } \\
\text { cone }\end{array}$ & $-0,556$ \\
\hline & $\begin{array}{l}\text { Compactabilidade do concreto } \\
\text { fresco não-adensado }\end{array}$ & 0,634 \\
\hline & $\begin{array}{c}\text { Absorção de água por } \\
\text { capilaridade por cura acelerada } \\
\text { 24/48 horas mais imersão em } \\
\text { água até } 7 \text { dias }\end{array}$ & $-0,688$ \\
\hline & $\begin{array}{l}\text { Absorção de água total por } \\
\text { cura normal até } 28 \text { dias }\end{array}$ & $-0,637$ \\
\hline & $\begin{array}{l}\text { Resistência à compressão a } \\
91 \text { dias por cura normal }\end{array}$ & 0,778 \\
\hline
\end{tabular}

\section{e) Resistência à compressão aos 91 dias por cura normal}

As correlações encontradas com a resistência à compressão a 91 dias estão apresentadas na Tabela 86.

Chamou a atenção o fato da resistência à compressão em idades mais avançadas não se correlacionar de modo linear e evidente com os resultados de carbonatação e penetração de cloretos. Assim, caberia explorar outras formas de correlação e ainda investigar sobre as particularidades desses ensaios especificamente. 
Tabela 86 - Correlações entre resistência à compressão a 91 dias por cura normal entre propriedades de dois lotes de diferentes centrais (Lotes 1 e 2)

\begin{tabular}{|c|c|c|}
\hline $\begin{array}{c}\text { Propriedade } \\
\text { analisada }\end{array}$ & Propriedade correlacionada & $\mathbf{r}^{2}$ \\
\hline & $\begin{array}{c}\text { Compactabilidade do concreto } \\
\text { fresco não-adensado }\end{array}$ & 0,730 \\
\cline { 2 - 3 } $\begin{array}{c}\text { Resistência à } \\
\text { compressão a 91 dias } \\
\text { por cura normal }\end{array}$ & $\begin{array}{c}\text { Absorção de água por } \\
\text { capilaridade por cura normal até } \\
28 \text { dias }\end{array}$ & $-0,593$ \\
\cline { 2 - 3 } & $\begin{array}{c}\text { Resistência à compressão a 63 } \\
\text { dias por cura normal }\end{array}$ & 0,778 \\
\hline
\end{tabular}

\subsubsection{Resistência à tração por compressão diametral}

As correlações feitas tomaram por base dois lotes analisados (lote 1 e 2), e as melhores resultantes constam na Tabela 87. 
Tabela 87 - Correlações entre resistência à tração por compressão diametral a 7 dias por cura acelerada 24/48 horas com demais propriedades dos dois lotes analisados

\begin{tabular}{|c|c|c|c|}
\hline $\begin{array}{c}\text { Propriedade } \\
\text { analisada } \\
\end{array}$ & Cura & Propriedade correlacionada & $r^{2}$ \\
\hline \multirow{13}{*}{$\begin{array}{l}\text { Resistência à tração } \\
\text { por compressão } \\
\text { diametral }\end{array}$} & \multirow{8}{*}{$\begin{array}{c}\text { Acelerada } 24 / 48 \text { horas } \\
\text { mais imersão em água } \\
\text { até } 7 \text { dias }\end{array}$} & $\begin{array}{l}\text { Compactabilidade do concreto } \\
\text { fresco adensado }\end{array}$ & $-0,667$ \\
\hline & & $\begin{array}{c}\text { Teor de ar do concreto fresco pelo } \\
\text { método pressométrico }\end{array}$ & $-0,818$ \\
\hline & & $\begin{array}{c}\text { Absorção de água por } \\
\text { capilaridade por cura acelerada } \\
24 / 48 \text { horas mais imersão em } \\
\text { água até } 7 \text { dias }\end{array}$ & 0,582 \\
\hline & & $\begin{array}{l}\text { Absorção de água total por cura } \\
\text { acelerada } 24 / 48 \text { horas mais } \\
\text { imersão em água até } 7 \text { dias }\end{array}$ & $-0,597$ \\
\hline & & $\begin{array}{l}\text { Índice de vazios por cura } \\
\text { acelerada } 24 / 48 \text { horas mais } \\
\text { imersão em água até } 7 \text { dias }\end{array}$ & $-0,606$ \\
\hline & & \begin{tabular}{|c|} 
Resistência à compressão a 1 dia \\
por cura normal
\end{tabular} & $-0,731$ \\
\hline & & $\begin{array}{c}\text { Resistência à compressão a } 1 \text { dia } \\
\text { por cura acelerada } 0 / 24 \text { horas }\end{array}$ & $-0,567$ \\
\hline & & $\begin{array}{l}\text { Profundidade da penetração de } \\
\text { cloretos }\end{array}$ & $-0,682$ \\
\hline & \multirow{5}{*}{$\begin{array}{c}\text { Cura normal até } 28 \\
\text { dias }\end{array}$} & Umidade do concreto fresco & $-0,569$ \\
\hline & & $\begin{array}{c}\text { Absorção de água total por cura } \\
\text { acelerada } 24 / 48 \text { horas mais } \\
\text { imersão em água até } 7 \text { dias }\end{array}$ & $-0,519$ \\
\hline & & $\begin{array}{c}\text { Absorção de água total por cura } \\
\text { normal até } 28 \text { dias }\end{array}$ & $-0,512$ \\
\hline & & $\begin{array}{l}\text { Índice de vazios por cura } \\
\text { acelerada } 24 / 48 \text { horas mais } \\
\text { imersão em água até } 7 \text { dias }\end{array}$ & $-0,544$ \\
\hline & & $\begin{array}{c}\text { Índice de vazios por cura normal } \\
\text { até } 28 \text { dias }\end{array}$ & $-0,522$ \\
\hline
\end{tabular}

Após as propriedades do estado fresco relativas à compactabilidade com adensamento e ao teor de ar pelo método pressométrico, a resistência à tração por compressão diametral, pelo ensaio acelerado 24/48h mais imersão em água até 7 dias, foi a propriedade que melhor se correlacionou com as demais, cabendo destacar:

- correlação forte, inversa e coerente com o teor de ar pressométrico $\left(r^{2}=-0,818\right.$ para os lotes 1 e 2 ; e $r^{2}=-0,841$ para os três lotes) e ainda com a resistência à compressão a 1 dia $\left(r^{2}=-0,731\right)$; 
- correlação razoável com várias outras propriedades, inclusive com a profundidade da frente de penetração de cloretos por ciclagem, de modo indireto e coerente $\left(r^{2}\right.$ $=-0,682)$.

Considerando que essas correlações podem ser explicadas, do ponto de vista da microestrutura, pela provável ocorrência de zona de transição na interface com os agregados, o ensaio de resistência à tração por compressão diametral deve ser mais utilizado pelos laboratórios de controle tecnológico, seja para estudos de dosagem, seja para ensaios de recebimento e com vistas a diferenciar concretos quanto à sua resistência a agentes agressivos, e os ensaios aqui conduzidos permitem antever idades entre 1 a 7 dias, para se obter resultados por ensaio acelerado em temperatura moderada.

A forte correlação da resistência à tração por compressão diametral a 91 dias por cura normal tanto com os resultados da densidade de massa do concreto fresco $\left(r^{2}=-0,906\right)$ quanto com os resultados da frente de cloretos por ciclagem $\left(r^{2}=-0,827\right)$ permite realmente confirmar que macroporos e macrodefeitos, entre a pasta e os agregados do concreto endurecido para esta faixa de $f_{c k}$, sejam os mesmos determinantes da percolação de cloretos. 


\subsubsection{Profundidade de carbonatação e penetração de cloretos em corpos-de-prova ciclados por imersão e secagem}

As correlações encontradas com a profundidade de carbonatação e a penetração de cloretos (direção diametral) por três ciclos de imersão e secagem conduzidos para os lotes com cura acelerada $24 / 48$ h e entre 7 e 91 dias, constam na Tabela 88.

Tabela 88 - Correlações entre a profundidade de carbonatação e penetração de cloretos em corpos-de-prova ciclados por imersão e secagem dos três lotes analisados

\begin{tabular}{|c|c|c|}
\hline $\begin{array}{l}\text { Propriedade } \\
\text { analisada }\end{array}$ & Propriedade correlacionada & $r^{2}$ \\
\hline \multirow{2}{*}{$\begin{array}{l}\text { Profundidade de } \\
\text { carbonatação por } \\
\text { imersão e secagem }\end{array}$} & $\begin{array}{l}\text { Compactabilidade do concreto } \\
\text { fresco adensado }\end{array}$ & $-0,596$ \\
\hline & $\begin{array}{c}\text { Absorção de água por } \\
\text { capilaridade por cura normal até } \\
28 \text { dias }\end{array}$ & 0,757 \\
\hline \multirow{4}{*}{$\begin{array}{l}\text { Profundidade da } \\
\text { penetração de cloretos } \\
\text { por imersão e } \\
\text { secagem }\end{array}$} & $\begin{array}{l}\text { Compactabilidade do concreto } \\
\text { fresco adensado }\end{array}$ & 0,568 \\
\hline & $\begin{array}{l}\text { Teor de ar do concreto fresco } \\
\text { pelo método pressométrico }\end{array}$ & 0,625 \\
\hline & $\begin{array}{c}\text { Resistência à compressão a } 1 \\
\text { dia por cura acelerada 0/24 horas }\end{array}$ & $-0,738$ \\
\hline & $\begin{array}{c}\text { Resistência à tração por } \\
\text { compressão diametral por cura } \\
\text { acelerada 24/48 horas mais } \\
\text { imersão em água até } 7 \text { dias }\end{array}$ & $-0,682$ \\
\hline
\end{tabular}

De modo resumido, cabe destacar:

a) a profundidade de carbonatação por ciclagem em relação direta com a absorção de água por capilaridade por cura normal a 28 dias $\left(r^{2}=0,757\right.$ para os três lotes) e em relação inversa com a compactabilidade do concreto fresco adensado, $\left(r^{2}=-0,596\right.$ para os lotes 1 e 2);

b) a profundidade de penetração de cloretos em relação inversa com a resistência à compressão a 1 dia por cura acelerada $0 / 24$ horas $\left(r^{2}=-0,738\right)$, analisada para os lotes 1 e 2, lembrando serem de diferentes centrais de produção e com diferentes materiais. 
Somente a primeira correlação citada em a) pode ser facilmente associada a efeitos do mecanismo de transporte preponderante no tipo de ensaio realizado e que foi de ciclagem por imersão total alternada com secagem, onde é óbvio o efeito da absorção por capilaridade tanto para o ingresso de água na fase de imersão quanto para a secagem em etapa seguinte. Já a maior compactatibilidade do concreto fresco adensado tender a minimizar a carbonatação por efeito de ciclagem, isto é algo a ser melhor interpretado e que pode estar associado também ao assentamento plástico do concreto fresco, como já discutido no item 5.4 .3 , de análise da primeira propriedade e cabe certamente ser confirmado pela evolução dos procedimentos de medida da compactabilidade.

Quanto à correlação inversa entre a resistência à compressão a 1 dia, por cura acelerada 0/24 h e a profundidade de penetração de cloretos, esta é facilmente explicada se ponderado que uma maior resistência equivale a uma maior hidratação do cimento Portland, menos poros na pasta formada nas primeiras idades e ainda uma maior capacidade de fixar cloretos, pelos produtos hidratados das fases de $\mathrm{C}_{3} \mathrm{~A}$ e $\mathrm{C}_{4} \mathrm{AF}$.

\subsubsection{Profundidade de carbonatação em corpos-de-prova submetidos à câmara de $\mathrm{CO}_{2}$}

As correlações encontradas com a profundidade de carbonatação por câmara de $\mathrm{CO}_{2}$ constam na Tabela 89.

Tabela 89 - Correlações entre a profundidade de carbonatação por câmara de $\mathrm{CO}_{2}$ em corpos-deprova dos três lotes analisados

\begin{tabular}{|c|c|c|}
\hline $\begin{array}{c}\text { Propriedade } \\
\text { analisada }\end{array}$ & Propriedade correlacionada & $\mathbf{r}^{2}$ \\
\hline \multirow{4}{*}{$\begin{array}{c}\text { Profundidade de } \\
\text { carbonatação } \\
\text { por câmara de } \\
\mathrm{CO}_{2}\end{array}$} & $\begin{array}{c}\text { Teor de ar do concreto fresco pelo } \\
\text { método pressométrico }\end{array}$ & 0,699 \\
\cline { 2 - 4 } & $\begin{array}{c}\text { Absorção de água por capilaridade por } \\
\text { cura acelerada 24/48 horas mais } \\
\text { imersão em água até 7 dias }\end{array}$ & $-0,561$ \\
\cline { 2 - 4 } & $\begin{array}{c}\text { Resistência à compressão a 1 dia por } \\
\text { cura normal }\end{array}$ & 0,516 \\
\cline { 2 - 4 } & $\begin{array}{c}\text { Resistência à compressão a 1 dia por } \\
\text { cura acelerada 0/24 horas }\end{array}$ & $-0,750$ \\
\cline { 2 - 4 } & $\begin{array}{c}\text { Resistência à compressão a 7 dias por } \\
\text { cura acelerada 24/48 horas mais } \\
\text { imersão em água até 7 dias }\end{array}$ & $-0,542$ \\
\hline
\end{tabular}


De modo resumido, cabe destacar que as correlações acima de valor 0,7 ocorreram para:

a) Teor de ar pelo método pressométrico, com $r^{2}=0,699$, se incluídos apenas os resultados do lotes 1 e 2 na correlação;

b) Resistência à compressão a 1 dia por cura acelerada 0/24 horas, com $r^{2}=-0,750$ também para os lotes 1 e 2 .

As justificativas para tais correlações são coerentes com a influência do volume de ar e de gel cimentício na estruturação e interconexão dos poros da pasta hidratada nas primeiras idades, bem como na resistência mecânica do concreto a curto prazo, pelo menos nesta faixa intermediária de $\mathrm{f}_{\mathrm{ck}}$. 


\section{CAPÍTULO 6}

\section{CONSIDERAÇÕES FINAIS}

As normas brasileiras de projeto e execução de estruturas de concreto armado já incorporaram grande parte da evolução tecnológica no campo da durabilidade, nas últimas décadas, a partir da ABNT NBR 6118 (2003). Mas, ainda falta a evolução correspondente para os procedimentos de controle tecnológico, pela ABNT NBR 12655 (2006). Por esta norma, os concretos passaram a ser especificados por critérios de relação água/cimento máxima e de consumo de cimento mínimo, atendidos por estudos de dosagem experimental, mas o controle de recebimento continua sendo feito, na prática, apenas por critérios de abatimento no estado fresco e de atendimento à resistência característica à compressão de projeto.

Além disso, face às inúmeras variáveis que podem influenciar o desempenho do concreto estrutural em serviço e dada a oferta crescente de novos materiais e de concretos especiais, especialistas americanos e canadenses como Hooton et al. (2006), enfatizam ser necessário incorporar melhores métodos e critérios de desempenho às especificações e ao controle da controle às especificações e à produção do concreto estrutural, com vistas à durabilidade das estruturas, e consideram insuficientes os limites prescritivos como os acima citados.

Por outro lado, os avanços em modelagem de vida útil de projeto, de serviço ou residual das estruturas de concreto armado só podem ocorrer se houver melhoria contínua na aquisição de informações no campo do controle tecnológico das estruturas em projeto e execução, no tempo presente, e por isto enfatiza-se a sua importância através desta dissertação.

Mas, a revisão bibliográfica e os trabalhos consultados evidenciam que o controle tecnológico do concreto estrutural está essencialmente fixado a procedimentos normativos e iniciativas para a sua evolução tem sido poucas, no Brasil. Os principais livros disponíveis remontam a década de 1980, como é a publicação de Helene; Terzian (1993), mas há perspectivas para novos trabalhos, através da retomada do tema, por eventos e publicações mais recentes, como a de Fusco (2008) e documento da ABECE (2009).

Portanto, espera-se que esta dissertação possa contribuir para futuros trabalhos de revisão da ABNT NBR 12655 (2006) ou de normalização de métodos de ensaios relacionados e 
que possam ser úteis à qualificação de concretos, para a proteção e durabilidade de armaduras de aço-carbono, nas estruturas.

Pelos trabalhos consultados pode-se observar que o controle tecnológico das estruturas é apenas praticado em campo com pouca interface na área acadêmica e deve continuar a ser explorado em pesquisas futuras, pois os resultados do programa experimental desta dissertação foram animadores e apontam para esta possibilidade de contínua evolução.

A pesquisa foi realizada em João Pessoa/PB, no período de Outubro de 2008 a Maio de 2009, com o apoio das entidades, empresas e pessoas especialmente citadas nos Agradecimentos desta dissertação.

\subsection{Conclusões quanto ao programa experimental}

O programa experimental caracterizou em campo três lotes distintos de concretos estruturais pré-misturados de mesmo abatimento, $10 \pm 2 \mathrm{~cm}$, e resistência à compressão característica $\left(f_{c k}\right) 30 \mathrm{MPa}$.

Os objetivos principais de comparar as propriedades destes lotes, desde o estado fresco e em especial evidenciar os efeitos do teor de ar em características relacionadas à sua capacidade de proteção de armaduras de aço-carbono para ambientes marítimos, foram alcançados; e foi possível avançar na interpretação da correlação entre propriedades, com apoio de análises realizadas através do Centro de Estatística Aplicada do IME-USP.

Da mesma forma, os seguintes objetivos complementares também foram alcançados, a saber:

- Foi possível antecipar a idade de qualificação de concretos, quanto a propriedade físicas e mecânicas, através do emprego de cura acelerada em temperatura amena, segundo procedimento alternativo baseado no Tipo A da ASTM C 684 (1999);

- Conseguiu-se estudar métodos de análise dos concretos por recursos laboratoriais simples, de baixo custo operacional, e mais acessíveis a empresas de controle tecnológico do mercado brasileiro;

- Os resultados permitem orientar, estimular e justificar novas práticas de controle tecnológico de concretos estruturais, em estudos de dosagem, seleção, produção ou recebimento. 


\subsubsection{Propriedades no estado fresco}

Inicialmente, observou-se que os requisitos e critérios de especificação do concreto, pela atuais normas brasileiras, com vistas à durabilidade de armaduras nas estruturas de concreto, precisam ser garantidos em campo, por controles de recebimento mais ativos e efetivos.

O abatimento do tronco de cone revelou-se uma propriedade de razoável predição da resistência à compressão inicial dos concretos, no campo da consistência plástica estudada, pois apresentou correlação muito satisfatória com resistência a compressão a 1 dia por cura acelerada em temperatura moderada em método similar ao Tipo I da ASTM C 684 (1999), testado nesta pesquisa $\left(r^{2}=-0,802\right)$. Mas não apresentou relação com as resistências à compressão medidas nas demais idades em condições de cura normal (7, 28, 63 e 91 dias).

Quanto às outras propriedades caracterizadas no estado fresco, esta pesquisa conclui que as seguintes citadas devem ser priorizadas e consideradas de modo mais rotineiro, para a especificação, a comparação ou o controle de propriedades de concretos estruturais, seja em estudos de dosagem, produção ou recebimento, com vistas a otimizar a proteção de armaduras do concreto armado:

a) Teor de ar pelo método pressométrico;

b) Compactabilidade no estado adensado;

c) Massa específica ou massa aparente;

Essas propriedades apresentaram correlações de razoáveis a forte com propriedades físicas, mecânicas e indicadoras de durabilidade do concreto, para ambientes marítimos, podendo auxiliar no controle de diferentes dosagens ou aditivos, em especial no campo dos concretos plásticos.

O ensaio de compactabilidade, tanto o adensado quanto o não-adensado, ambos baseados na BS EN 12350-4 (2008), foi aplicado de modo rústico, sem estudos mais aprofundados de refinamento da metodologia, pois usou vibradores de imersão para aplicar compactação ao concreto fresco, e ainda assim apresentou correlações importantes. Portanto, a expectativa é de que vindo a ser mais pesquisado e aperfeiçoado pode resultar num excelente instrumento de previsão de propriedades importantes do concreto estrutural e assim, ser incorporado como ensaio de rotina em seu controle tecnológico ou pelo menos em estudos de dosagem. Também cabe salientar que esse tipo de ensaio pode permitir um cálculo ainda mais preciso de perdas do concreto, por seu assentamento plástico natural em formas da estrutura. 
O teor de ar pelo método pressométrico já é um ensaio conhecido e com norma brasileira de procedimento a ABNT NBR NM 47 (2002), mas é ainda pouco utilizado por laboratórios no controle tecnológico de concretos. Neste programa, apresentou excelentes correlações com propriedades físicas, mecânicas e indicadores de durabilidade, atestando a sua eficiência em prever propriedades no concreto endurecido. Resta, por fim, a pergunta porque essa propriedade não é melhor discutida por livros, ou pelos laboratórios de tecnologia do concreto, seja em estudos de dosagem, seja em campo, seja em pesquisas acadêmicas?

Pois bem, é hora de mudar paradigmas, pois o teor de ar pelo método pressométrico mostrou correlação forte e inversa com propriedade importante relacionada à proteção de armaduras do concreto estrutural, como é a resistência à tração, no caso medida por compressão diametral, e tanto por cura acelerada 24/48 horas mais imersão em água até 7 dias $\left(r^{2}=-0,841\right)$, quanto por cura normal a 91 dias $\left(r^{2}=-0,797\right)$. Também mostrou correlação razoável a forte com a profundidade de carbonatação por câmara de $\mathrm{CO}_{2}\left(r^{2}=0,699\right)$ e com a profundidade de penetração de cloretos $\left(r^{2}=0,625\right)$. Estas correlações confirmam a provável influência da zona de transição entre agregados e a matriz de cimento, na percolação de íons agressivos às armaduras, e os possíveis efeitos do teor de ar na sua formação e interconexão, na faixa de variação estudada, com valores médios entre $2,8 \%$ e 3,3\%.

Observar que livros recentes e muito abrangentes no campo da tecnologia do concreto, como são os de ISAIA (2005) e de MEHTA; MONTEIRO (2008) dão pouca ênfase à influência do teor de ar do concreto fresco nas propriedades relacionadas à durabilidade e vida útil de armaduras. Algumas pesquisas inclusive apontam que pode haver efeitos benéficos de baixos teores de ar, na zona de transição, mas as correlações obtidas neste trabalho foram inversas e indicam, portanto, que essa característica deve ser melhor controlada no concreto fresco.

No que diz respeito a outras propriedades do estado fresco, a massa específica ou densidade de massa aparente do concreto fresco pode ser uma propriedade importante para o controle tecnológico, mas apenas se adotada de modo simultâneo a outros procedimentos simultâneos para o controle da relação água/materiais secos e estimativas de teor de agregados e aglomerantes. Lembrar que aplicadas em conjunto podem permitir a conferência de propriedades relacionadas ao consumo de cimento e à relação água/cimento total dos concretos, mas neste trabalho não houve condições operacionais para se evoluir nessa metodologia. 


\subsubsection{Propriedades no estado endurecido}

\subsubsection{Quanto à aceleração da hidratação por métodos baseados no Tipo A-ASTM C 684} (1999)

Esta pesquisa mostrou que é possível adaptar o método de cura acelerada em temperatura moderada, como a do tipo A da ASTM C 684 (1999), para ser realizada em prazos mais flexíveis e melhor adaptados às condições de campo.

As propriedades físicas e mecânicas caracterizadas entre 1 e 7 dias dos concretos, por cura acelerada em temperatura amena, por método similar e outro adaptado do Método A da ASTM C 684 (1999), se correlacionaram de forma razoável tanto com propriedades do concreto fresco, quanto com outras estudadas em condições de cura normal a 28 dias, a saber: absorção de água e índice de vazios por imersão, resistência à compressão e resistência à tração por compressão diametral.

Além disso, foram observadas correlações com $r^{2}$ na faixa de razoável a forte para a resistência à compressão a 1 dia dos concretos com cura acelerada 0/24 horas, e as profundidades de carbonatação em câmara de $\mathrm{CO}_{2}$ a $5 \%\left(r^{2}=-0,75\right)$ e a de penetração de cloretos por ciclos de imersão e secagem $\left(r^{2}=-0,738\right)$, analisadas a partir de 91 dias, tendo esses corpos-de-prova recebido cura acelerada de 24/48 h seguida de imersão normal até 7 dias, o que confirma a influência importante da microestrutura nas primeiras idades em relação à proteção de armaduras. Confirmou-se, portanto, o potencial dos métodos de cura testados por este trabalho, pois em geral as temperaturas de cura acelerada discutidas em trabalhos nacionais alcançam valores bem mais elevados e que precisam ser adotados com maior cautela, pelo menos em estudos relacionados a indicadores de durabilidade para a proteção de armaduras, pois podem prejudicar a microestrutura e introduzir alguma microfissuração no concreto.

Isto possibilita antever a aplicação desses tipos de cura, para análise mais ágil de outras propriedades físicas, mecânicas e de durabilidade do concreto, seja em estudo de dosagem ou no controle tecnológico de obras.

Assim, é recomendável a continuidade do estudo para avaliar a possibilidade de aplicar a cura térmica em temperatura moderada para transcorrer em prazo de $24 \mathrm{~h}$ a até 7 dias, com vistas à previsão de resistência em idades mais avançadas, como 28, 63 e 91 dias. Para a previsão da resistência a 28 dias, os resultados apontaram que o prazo de cura inicial em temperatura moderada pode ocorrer entre $24 \mathrm{~h}$ a $48 \mathrm{~h}$, cabendo confirmar a importância ou não 
da dilatação deste prazo e ainda do transcurso de cura normal até 7 dias, conforme a composição do concreto.

\subsubsection{Quanto aos ensaios de envelhecimento acelerado e resistência à penetração de íons agressivos a armaduras em ambientes marítimos}

A ciclagem testada nesta pesquisa para análise da suscetibilidade ao ingresso de cloretos dos lotes de concreto em estudo, foi iniciada a 7 dias do concreto com cura acelerada em temperatura moderada e consistiu de três ciclos de imersão por um dia em solução de $3,5 \%$ de $\mathrm{NaCl}$ e secagem em caixa térmica ventilada a $45^{\circ} \mathrm{C} \pm 5^{\circ} \mathrm{C}$ por 27 dias. Esta ciclagem se mostrou um bom instrumento comparativo para a previsão do período de passivação das armaduras, em estruturas de concreto armado em ambientes marítimos, já que com pouco tempo de ciclagem foram obtidos resultados consideráveis de penetração de $\mathrm{CO}_{2}$ e íons cloretos. Observar que as medidas de profundidade de penetração de cloretos nos três ciclos realizados nesta pesquisa indicaram valores médios compreendidos entre 3,8 a 6,9 mm e coeficientes de carbonatação com valores médios entre 3 a $7 \mathrm{~mm} / \mathrm{ano}^{-1 / 2}$, o que não seria um indicador de longa vida útil em elementos diretamente expostos à ação de cloretos e $\mathrm{CO}_{2}$. Este processo é um método alternativo de fácil execução e baixo custo, que pode ser realizado pelos laboratórios de controle tecnológico.

Cabe destacar que estas medidas indicadoras de suscetibilidade ao ingresso de agentes

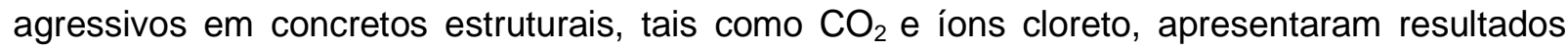
com distribuição normal, mesmo nas condições de moldagem em obra e para cilindros de 10 $\mathrm{cm} \times 20 \mathrm{~cm}$, testados em condições parcialmente controladas, como se reconhece no item 6.2. No procedimento adotado, os cilindros foram abertos por ensaio de compressão segundo a direção diametral. Considerou-se ser isto mais adequado, pois ao mesmo tempo em que forneceu um valor indicador da resistência à tração do concreto, a análise dessa seção diametral plena conduziu a valores bem representativos da superfície de acabamento do concreto, inclusive para análise de fenômenos de sedimentação, que podem tornar a superfície do topo e do fundo dos corpos-de-prova com diferentes compacidades. Nos ensaios a 91 dias para a medida inicial da frente de cloretos, a imersão da metade seccionada do corpo-de-prova na solução com nitrato de prata, também apresentou-se satisfatória.

A resistência à tração por compressão diametral resultou com correlações razoáveis a forte com a profundidade de ingresso de íons cloreto $\left(r^{2}=-0,682\right.$ para diametral e acelerado a 7 dias e $r^{2}=-0,827$ para ensaio diametral a 91 dias com cura normal). 
Já a profundidade de carbonatação por ação dos três ciclos citados mostrou melhor correlação com a absorção de água por capilaridade do concreto em cura normal até 28 dias $\left(r^{2}\right.$ $=0,757)$, do que com a absorção capilar caracterizada para os concretos com cura acelerada 24/48 h seguida de imersão até 7 dias.

Como houve excelente correlação entre a resistência à compressão a 1 dia por cura acelerada dos lotes e as medidas indicadoras de durabilidade, tais como a profundidade de carbonatação por câmara de $\mathrm{CO}_{2}\left(r^{2}=-0,750\right)$ e com a penetração de cloretos $\left(r^{2}=-0,738\right)$, não se tendo observado boas correlações com a resistência à compressão a 28 dias, esta pesquisa por ora conclui e propõe que:

- Além da resistência à tração por compressão diametral, a resistência à compressão a 1 dia por cura acelerada seja uma propriedade que também passe a ser avaliada em concretos, com vistas a melhorar e controlar a sua resistência a agentes agressivos;

- Futuros trabalhos confirmem e justifiquem a falta de correlações constatadas entre as propriedades indicadoras da resistência à penetração de agentes agressivos no concreto e a sua resistência à compressão por cura normal, por estudos e interpretação da sua reologia e microestrutura nas primeiras idades, com e sem aceleração de cura. Houve indicações, por correlações realizadas para os lotes 1 e 2 , em conjunto, de que a compactabilidade dos concretos no estado plástico possa ter conduzido a uma sedimentação excessiva da sua massa em formas cilíndricas, o que precisa ser ainda confirmado.

As expectativas de boas correlações das propriedades indicadoras de resistência a agentes agressivos com as que eram inicialmente pretendidas, como a absorção de água total ou índice de vazios, não ocorreram de forma evidente neste trabalho. Essas propriedades apenas tiveram melhor relação com a resistência à compressão simples a 28 dias, por cura normal.

\subsubsection{Proteção das armaduras de aço-carbono pelos concretos}

As medidas de potencial de corrosão indicaram risco de corrosão alto para os concretos do lote treinamento, risco incerto para os concretos do lote 1 e sem risco de corrosão para os concretos do lote 2, pelos critérios da ASTM C 876 (2009). Os coeficientes de variação foram baixos para o lote treinamento, mas mais elevados nos outros dois. Ainda que possa ter fornecido uma indicação aproximada da estabilidade eletroquímica do aço nesses concretos, com coeficiente de variação bem aceitável para um dos lotes (8\%), o método a ser empregado em moldagens em campo precisa ser aperfeiçoado. Entre outras coisas, é necessário melhor 
padronizar a limpeza prévia de armaduras e o volume de concreto em cada corpo-de-prova. A adequação da medida de potencial de corrosão do aço, como instrumento de controle tecnológico da interface concreto/armadura, principalmente em obras especiais para ambientes marítimos, deve continuar a ser estudada, entre outras razões para se comparar a ação de aditivos inibidores de cloretos e para realizar ensaios específicos sobre a sua eficiência por métodos tais como o da ASTM G 109 (2007). Além disso, este tipo de ensaio, pode diferenciar a passivação do aço por diferentes concretos, em função da sua composição e velocidade de hidratação, se as medidas forem feitas desde idades iniciais. No caso dos lotes medidos por esta pesquisa, observou-se prazo de passivação bem diferenciado para um dos lotes.

Pelo exposto e discutido no Capítulo 5, conclui-se que não é coerente controlar e especificar o concreto estrutural somente por abatimento e resistência à compressão e depois exigir características de durabilidade das obras, no que tange à corrosão de armaduras, pois de acordo com as análises estatísticas, os lotes de concretos com mesmo $\mathrm{f}_{\mathrm{ck}}$ e mesmo abatimento apresentaram diferenças em propriedades no estado fresco e endurecido.

Por ora, espera-se com estes resultados estimular novas práticas de qualificação e recebimento de concretos pré-misturados, por laboratórios especializados com vistas à futura evolução de procedimentos da ABNT NBR 12655 (2006).

\subsection{Dificuldades superadas para o desenvolvimento da pesquisa e restrições a extrapolação dos resultados}

Este projeto enfrentou falta de financiamento, quando submetido a órgão de fomento à pesquisa do Estado de São Paulo. Entre as razões pela assessoria que o analisou, foi considerado com perfil de consultoria tecnológica e não propriamente adequado para uma pesquisa acadêmica de mestrado, já que propunha o desafio de lidar com todas as variáveis inerentes à produção real do concreto pré-misturado em campo e não com variáveis previsíveis e passíveis de controle, em estudos realizados integralmente em laboratório.

Assim, o projeto teve limitações em relação ao planejamento inicial, em especial para:

- a realização dos ensaios no estado fresco, pois houve necessidade de limitar os recursos humanos em campo a três técnicos, além do autor. Assim, alguns testes alternativos para controle mais fácil da relação água/materiais secos não puderam ser aplicados e também não foi possível amostrar os materiais em uso pelas respectivas centrais, nas datas de amostragem dos concretos; 
- dispor de equipamentos automatizados para aperfeiçoar os procedimentos de cura acelerada em temperatura moderada, de modo mais equivalente ao Método A da ASTM C 684 (1999), bem como para realizar secagem de corpos-de-prova em estufas ventiladas e realizar os ciclos de imersão e secagem, de forma ainda melhor padronizada, no envelhecimento acelerado dos três lotes;

- Realizar o ensaio de módulo de elasticidade em laboratório privado, pois inicialmente constava no projeto a sua realização, mas não foi possível devido a dificuldades de realização na cidade de João Pessoa-PB e no laboratório da Escola Politécnica da Universidade de São Paulo - EPUSP, tendo sido retirado do programa experimental.

Pela falta de uma estufa ventilada de grande porte, foi necessária a construção da caixa térmica ventilada, já apresentada no item 4.3.6. Naquela a dificuldade no controle da temperatura e umidade, pode ter contribuído para aumentar a variabilidade da frente de secagem nos corpos-de-prova e isso pode ter interferido na dispersão nas medidas de profundidade de cloretos e carbonatação. Todavia, como houve correlação entre as medidas de profundidade de penetração de cloretos com a resistência à tração por compressão diametral, tanto para o concreto com cura acelerada $24 / 48$ horas e ensaiado a 7 dias $\left(r^{2}=-0,682\right)$, quanto para o concreto com cura normal e ensaiado a $91\left(r^{2}=-0,827\right)$, além de outras propriedades no estado fresco e endurecido, conforme a Tabela 88 , avalia-se que a caixa térmica pode ter gerado apenas problemas localizados e pontuais de secagem, para algumas das semanas de ensaio apenas, como mostraram os gráficos de controle de massa e de grau de saturação estimados para os concretos.

De qualquer forma, as restrições ocorridas com equipamentos e a falta de automação no desenvolvimento da cura e dos três ciclos de umedecimento e secagem limitam os resultados desta pesquisa aos lotes estudados, e permitem prever que correlações ainda melhores podem ser obtidas com instalações físicas melhores. 


\subsection{Sugestões para futuras pesquisas}

Esta dissertação procurou iniciar e incentivar pesquisas que possam contribuir para evolução do controle tecnológico dos concretos estruturais em campo, pois há ainda muito a ser feito e disseminado para melhores práticas, em controles de produção e recebimento.

Do ponto de vista do aperfeiçoamento da metodologia empregada, cabe recomendar o prosseguimento das seguintes pesquisas:

$\checkmark$ Continuar estudos de propriedades do concreto no estado fresco, em especial o teor de ar, massa específica e compactabilidade, do concreto adensado e nãoadensado, tanto em pesquisas de laboratório quanto de campo, para evoluir em limites de especificação e na predição de propriedades mecânicas a baixas idades, como indicadoras de resistência ao ingresso de agentes agressivos;

$\checkmark$ Prosseguir em estudo de metodologia para a caracterização de umidade e teor de finos total em concretos pré-misturados;

$\checkmark$ Prosseguir em estudos de métodos de cura acelerada baseados no tipo A da ASTM C 684 (1999), em temperatura amena entre 1 e até 7 dias, como feito nesta pesquisa e continuados no projeto de Cafange (2009), para a predição de propriedades relacionadas à proteção de armaduras do concreto, em especial a resistência à compressão e à tração por compressão diametral em idades de curto prazo comparadas a ensaios de longa duração e com envelhecimento natural dos concretos;

$\checkmark$ Realizar estudos abrangentes de resistência à compressão de concretos plásticos, em função da hidratação e idade, estudando possíveis interferências de procedimentos para a aplicação de carga, nas idades de curto e longo prazo;

$\checkmark$ Estudar efeitos da consistência inicial do concreto fresco em propriedades mecânicas de médio e longo prazo;

$\checkmark$ Prosseguir na aplicação de conceitos estatísticos, para a interpretação e aplicação de profundidades características de carbonatação e de ingresso de íons cloreto em concretos estruturais;

$\checkmark$ Estudar procedimentos de lubrificação de formas em moldagem de corpos-deprova que possam ter pouca ou nenhuma influência na sua capilaridade superficial; 
$\checkmark$ Ampliar estudos e evoluir em critérios de correlação da absorção de água por capilaridade e a resistência à carbonatação do concreto por efeitos de ciclos de molhagem/secagem.

\subsection{Transferência para o meio técnico}

As seguintes publicações já estão discutindo parte dos resultados desta pesquisa:

1. CAVALCANTI FILHO, Antonio Nereu; CAVALCANTI, Guilherme Augusto; SELMO, Silvia Maria de Souza. Estudo de propriedades mecânicas de concretos estruturais em cura acelerada com temperatura moderada. In: $51^{\circ} \mathrm{CONGRESSO} \mathrm{BRASILEIRO} \mathrm{DO}$ CONCRETO, 2009, Curitiba. 2009. v. único.

2. CAVALCANTI FILHO, Antonio Nereu; CAVALCANTI, Guilherme Augusto; SELMO, Silvia Maria de Souza. Avaliação de concretos estruturais de João Pessoa-PB quanto à resistência à carbonatação e a cloretos por ensaios de ciclagem. In: $52^{\circ}$ CONGRESSO BRASILEIRO DO CONCRETO, 2010, Fortaleza. 2010. v. único. 


\section{CAPÍTULO 7}

\section{REFERÊNCIAS BIBLIOGRÁFICAS}

AMERICAN CONCRETE INSTITUTE. Materials and General Properties of Concrete. Committee 222. Part 1 - 1991. Detroit, Michigan, 1991, 11p.

. Cement and Concrete Terminology, ACI Committee 116R, Detroit, 2000.

AMERICAN SOCIETY FOR TESTING AND MATERIALS - Standard test method for acidsoluble chloride in mortar and concrete. ASTM C 1152: Philadelphia: Annual book of ASTM Standards, 1999.

. Standard test test method for electrical indication of concrete's ability to resist chloride ion penetration. ASTM C 1202: Philadelphia, 1994. Philadelphia: Annual book of ASTM Standards, 1994.

. Standard test test method for electrical indication of concrete's ability to resist chloride ion penetration. ASTM C 1202: Philadelphia, 2008. Philadelphia: Annual book of ASTM Standards, 2008.

Standard test method for making, accelerated curing, and testing concrete compression test specimens. ASTM C 684 : Philadelphia: Annual book of ASTM Standards, 1999.

. Standard terminology relating to concrete and concrete aggregates. ASTM C 125: Philadelphia: Annual book of ASTM Standards, 2009.

Standard test method for corrosion potentials of uncoated reinforcing steel in concrete. ASTM C 876: Philadelphia: Annual book of ASTM Standards, 2009.

Standard test method for determining effects of chemical admixtures on corrosion of embedded steel reinforcement in concrete exposed to chloride environments. ASTM G 109 (2007). Philadelphia, 2007.

ARAUJO, A. Estudo para o estabelecimento de metodologia de seção de vernizes na proteção ao concreto armado contra a penetração de agentes agressivos. Dissertação (Mestrado) - Instituto de Pesquisas Tecnológicas do Estado de São Paulo. São Paulo, 2004. 
ASSOCIAÇÃO BRASILEIRA DE NORMAS TÉCNICAS. NBR NM 47: Concreto fesco Determinação do teor de ar pelo método pressométrico. Rio de Janeiro, 2002.

NBR NM 67: Concreto - Determinação da consistência pelo abatimento do tronco de cone. Rio de Janeiro, 1998.

NBR NM 68: Concreto - Ensaio de abatimento na mesa de Graff. Rio de Janeiro, 1998.

NBR 5738: Concreto - Procedimento para moldagem e cura de corpos de prova. Rio de Janeiro. 2003.

NBR 5739: Concreto - Ensaios de compressão de corpos-de-prova cilíndricos. Rio de Janeiro, 2007.

NBR 6118: Projetos de estruturas de concreto - Procedimento. Rio de Janeiro, 2003.

NBR 7212: Execução de concreto dosado em central. Rio de Janeiro, 1984.

NBR 7217: Agregados - Determinação da composição granulométrica. Rio de Janeiro, 1987.

NBR 7218: Determinação do teor de argila em torrões nos agregados. Rio de Janeiro, 1982.

.NBR 7222: Argamassa e concreto - Determinação da resistência à tração por compressão diametral de corpos-de-prova cilíndricos. Rio de Janeiro, 1994.

NBR 7223: Concreto - Determinação da consistência pelo ensaio do tronco de cone. Rio de Janeiro. 1992.

NBR 7251: Agregado em estado solto - Determinação da massa unitária. Rio de Janeiro, 1982.

NBR 7680: Concreto - Extração e preparo de ensaio de testemunhos de concreto. Rio de Janeiro, 2007.

NBR 7809: Agregado Graúdo - Determinação do índice de forma pelo método do paquímetro. Rio de Janeiro, 1983.

- NBR 8522: Concreto - Determinação do módulo de estático de elasticidade à compressão. Rio de Janeiro, 2008.

NBR 8953: Concreto para fins estruturais - Classificação por grupos de resistência. Rio de Janeiro, 1992. 
NBR 9776: Agregado - Determinação da massa especifica de agregados miúdos por meio do frasco de Chapman. Rio de Janeiro, 1987.

NBR 9778: Argamassa e concreto endurecido - Determinação da absorção de água, índice de vazios e massa específica. Rio de Janeiro, 2005.

NBR 9779: Argamassa e concreto endurecido - Determinação da absorção de água por capilaridade. Rio de Janeiro, 1995.

NBR 9833: Concreto fresco - Determinação da massa específica, do rendimento e do teor de ar pelo método gravimétrico. Rio de Janeiro. 2008.

NBR 12654: Controle tecnológico de materiais componentes do concreto. Rio de Janeiro, 1992.

NBR 12655 - Concreto - Preparo, controle e recebimento. Rio de Janeiro, 2006.

.NBR 14931: Execução de estruturas de concreto - Procedimentos. Rio de Janeiro, 2003.

. NBR 15558: Concreto fresco - Determinação da Exsudação. Rio de Janeiro. 2008

ANDRADE, M.C. Manual para diagnóstico de obras deterioradas por corrosão de armaduras. Trad, Antonio Carmona e Paulo Helene, São Paulo, Pini: 1992.

ANDRADE, J.J.O. Durabilidade das estruturas de concreto armado: análise das manifestações patológicas na estruturas no estado de Pernambuco. 1997. Dissertação (Mestrado) - Universidade Federal do Rio Grande do Sul, Porto Alegre, 1997.

ANDRADE, T.W.O. Tópicos sobre durabilidade do concreto. In: ISAIA, G. C. Concreto Ensino, pesquisa e realizações. São Paulo. IBRACON, 2005.

ANDRADE, T. W.O.; SILVA, A.J.C. Patologia das estruturas. In: ISAIA, G. C. Concreto Ensino, pesquisa e realizações. São Paulo. IBRACON, 2005.

BARBOSA, D.C.; BARDELLA, P.S.; CAMARINI, G. Avaliação da carbonatação natural em concretos produzidos com e sem sílica ativa submetido a diferentes procedimentos de cura. In: CONGRESSO BRASILEIRO DO CONCRETO, 47², 2005, Rio de Janeiro. Anais: IBRACON, 2005.

BASTOS, E. J. O. Propedêutica para o estudo da corrosão de armaduras em estruturas de concreto. 2005. Tese (Doutorado) - Escola Politécnica da Universidade de São Paulo, São Paulo, 2005. 
BAUER, E. Avaliação comparativa da influência da adição de escoria de alto forno na corrosão das armaduras através de técnicas eletroquímicas. 1995. Tese (Doutorado) Escola Politécnica da Universidade de São Paulo, São Paulo, 2005.

BAUER, E.; NEPOMUCENO, A.A; PEREIRA, C.H. Avaliação da carbonatação de concretos produzidos no DF. In: CONGRESSO BRASILEIRO DO CONCRETO, 48, 2006, Rio de Janeiro. Anais: IBRACON, 2006.

BOURGUIGNON, K. M. B. G.; SILVA, M.G.; COSTA JUNIOR, M.P.; PINHEIRO, S.M.M.; SOUZA, F.L.; MORIMOTO, T. Avaliação da carbonatação natural e acelerada no concreto com escória granulada de alto-forno sob diferentes condições de exposição. In: CONGRESSO BRASILEIRO DO CONCRETO, 48, 2006, Rio de Janeiro. Anais: IBRACON, 2006.

BRITISH STANDARD INSTITUTE. BS EN 7543: Guide to durability of buildings elements, products and elements. 1992.

.BS EN 8110: Strucutural use and construction concrete code for design. 1997.

.BS EN 12350-4: Testing fresh concrete. Degree of compactability, 2008.

BOLINA, C. C.; ANDRADE, M. A. S.; HASPARYK, N. P.; CASCUDO, O.; FERREIRA, R. B. Inibidores de corrosão: Comportamento frente à corrosão do aço induzida por carbonatação em meio aquoso. In: CONGRESSO BRASILEIRO DO CONCRETO, 51, 2009, Curitiba. Anais: IBRACON, 2009.

CAFANGE, D.M.P.J. Estudo de propriedades auxiliares no controle tecnológico dos concretos de cimento Portland com vistas à resistência à carbonatação. 2009. Qualificação (Mestrado) - Escola Politécnica da Universidade de São Paulo, São Paulo, 2009.

CAMPOS, R.R. A durabilidade das estruturas de concreto armado - Critérios e diretrizes. 2006. Dissertação (Mestrado) - Universidade Federal Fluminense, Niterói. Rio de Janeiro, 2006.

CARMONA, T. G. Modelos de previsão da despassivação das armaduras em estruturas de concreto sujeitas a carbonatação. 2005. Dissertação (Mestrado) - Escola Politécnica da Universidade de São Paulo, São Paulo, 2005.

CASCUDO, O. Contribuição ao estudo e emprego de técnicas eletroquímicos no controle da corrosão de armaduras em concreto armado. 1991. Dissertação (Mestrado) - Escola Politécnica da Universidade de São Paulo, 1991.

- O controle da corrosão de armaduras de concreto: inspeção e técnicas eletroquímicas. São Paulo, Pini, 1997. 
Influência das características do aço carbono destinado ao uso como armaduras para concreto armado no comportamento frente à corrosão. 2000. Tese (Doutorado) - Escola Politécnica da Universidade de São Paulo, 2000.

CAVALCANTI FILHO, A.N.; CAVALCANTI, G.A.A.; SELMO, S.M.S. Estudo de propriedades mecânicas de concretos estruturais em cura acelerada com temperatura moderada. In: CONGRESSO BRASILEIRO DO CONCRETO, 51, 2009, Curiti ba. Anais: IBRACON. Curitiba, 2009.

CHANG, C.F; CHENG, J.W. The experimental investigation of concrete carbonation depth. Cement Concrete Research, v.36, July 2004.

CAMPOS, R. R. A durabilidade das estruturas de concreto armado - critérios e diretrizes. 2006. Dissertação (Mestrado) - Universidade Federal Fluminense, Rio de Janeiro, 2006.

COSTA JR. M.; BOURGUIGNON, K.M.; SILVA, M.G. Avaliação da carbonatação natural e acelerada no concreto com escória granulada de alto-forno sob diferentes condições de exposição. In: CONGRESSO BRASILEIRO DO CONCRETO, 48, 2006, Rio de Janeiro. Anais: IBRACON. Rio de Janeiro, 2006.

CUNHA, A. C. Q. Despassivação das armaduras de concreto por ação da carbonatação. 2001. Dissertação (Mestrado) - Escola Politécnica da Universidade de São Paulo, São Paulo, 2001.

DAL MOLIN, D.C.C. Fissuras em estruturas de concreto armado: análise das manifestações típicas e levantamento de casos ocorridos no estado do Rio Grande do Sul. 1995. Dissertação (Mestrado) - Universidade Federal do Rio Grande do Sul, Porto Alegre. Rio Grande do Sul, 1995.

DHIR, R. K.; JONES, M.R.; ELEGHALY, S. L. D. Concrete: exposure temperature effects on chloride diffusion. Cement and Concrete Research, v. 23, n. 5, p. $1105-1114,1993$.

DIAZ, N. B. Avaliação do grau de corrosão das armaduras em estruturas com concreto carbonatado. 1997. Dissertação (Mestrado) - Escola Politécnica da Universidade de São Paulo, São Paulo, 1997.

FIGUEIREDO, E. P. Efeitos da carbonatação e cloretos no concreto. In: ISAIA, G. C. Concreto - Ensino, pesquisa e realizações. São Paulo, 2005.

FUSCO, P. B. Tecnologia do Concreto Estrutural. São Paulo: Pini, 2008, 
GOMES, N. A. Estruturas de Concreto Armado em Ambiente Urbano: Avaliação da Carbonatação à Luz das Recomendações da NBR 6118 (2003). 2006. Dissertação (Mestrado) - Universidade Federal de São Carlos, São Carlos. São Paulo, 2006.

GUIMARAES, A. T. C. Vida útil das estruturas de concreto armado em ambientes marítimos. 2000. Tese (Doutorado) - Escola Politécnica da Universidade de São Paulo, São Paulo, 2000.

HELENE, P.R.L. Controle de Qualidade do Concreto. 1981. Dissertação (Mestrado) - Escola Politécnica da Universidade de São Paulo, São Paulo, 1981

Corrosão em armaduras para concreto armado. São Paulo, IPT, Pini, 1986.

. Contribuição ao estudo da corrosão em armaduras de concreto armado. 1993. Tese

(Livre Docência) - Escola Politécnica da Universidade de São Paulo, São Paulo, 1993.

Introdução à Prevenção da Corrosão das Armaduras no Projeto das Estruturas de Concreto - Avanços e Recuos. Simpósio sobre Durabilidade do Concreto. São Paulo, 1998. Escola Politécnica da Universidade de São Paulo, São Paulo, 1998.

HELENE, P.R.L.; TERZIAN, P.R. Manual de dosagem e controle do concreto. São Paulo: Pini, 1993.

HOOTON, R.D; MINDESS, S.; ROUMAIN, J.C.; BOYD, A.J.; REAR, K.B. Proportioning and Testing Concrete for Durability. Concrete International. August, 2006. p. $38-41$.

HOPPE FILHO, J. Efeitos da adição de cal hidratada sobre a permeabilidade ao oxigênio e absorção capilar de concretos com altos teores de adições minerais. 2002. Dissertação (Mestrado) - Universidade Federal de Santa Maria, Santa Maria. Rio Grande do Sul, 2002.

ISAIA, G. C. Efeitos de misturas binárias e ternárias de pozolanas em concretos de alto desempenho: um estudo de durabilidade com vistas a corrosão da armadura. 1995. Tese (Doutorado) - Escola Politécnica da Universidade de São Paulo, São Paulo, 1995.

ISAIA, G. C. Carbonatação do concreto: uma revisão. Departamento de Estruturas e Construção Civil - Universidade Federal de Santa Maria, Rio Grande do Sul, 1999.

O concreto: da Era clássica à contemporânea. In: ISAIA, G. C. Concreto - Ensino, pesquisa e realizações. São Paulo: IBRACON, 2005.

JACINTHO, A.E.P.G.A.; GIONGO, J.S. Resistência Mecânica do Concreto. Concreto. Ensino, Pesquisa e Realizações. São Paulo, Pini, 2005, c. 20, pag. 605-632. 
JOHN, V.M.; Resíduos na construção civil: Contribuição a metodologia e desenvolvimento. 2000. Tese (Livre-docência) - Escola Politécnica da Universidade de São Paulo, São Paulo, 2000.

JUCÁ, T. R. P. Avaliação de cloretos livres em concretos e argamassas de cimento portland pelo método de aspersão de solução de nitrato de prata. 2002. Dissertação (Mestrado) - Universidade Federal de Goiás, Goiânia. Goiás, 2002.

LIBORIO, J.B.L. Patologia das construções. EESC - USP, 1998/ Notas de aulas.

LIMA, M.G. Ação do meio ambiente sobre as estruturas de concreto. Concreto - Ensino, pesquisa e realizações. São Paulo, Pini, 2005, v. 1, c. 24, pag. $713-751$.

MALHOTRA, V. M. Making concrete "greener" with fly ash. Concrete International. 1999. v.21, n.5, p.61-66.

MATHER B. Owner Responsability in quality verification?. Concrete International. 2002. v2. p. $70-72$.

MEDEIROS, M.H.F. Estruturas de concreto armado com corrosão de armaduras causada por carbonatação: estudo comparativo de argamassa de reparo quanto à penetração do aço. 2002. Dissertação (Mestrado) - Escola Politécnica da Universidade de São Paulo, São Paulo, 2002.

MEDEIROS, M.H.F. Contribuição ao estudo da durabilidade de concretos com proteção superficial frente à ação de íons cloretos. 2007. Tese (Doutorado) - Escola Politécnica da Universidade de São Paulo, São Paulo, 2007

MEDEIROS, M.H.F.; HELENE, P. R. L. Migração de íons cloretos no concreto - influência da consistência, relação água/cimento e consumo de cimento. Revista Ibracon. São Paulo, IBRACON, nํㅜ 32, 2003.

MEHTA, P.K.; MONTEIRO, P.J.M. Concreto: Estrutura, Propriedades e Materiais. São PAULO, 1994, Pini.

MEHTA, P.K.; MONTEIRO, P.J.M. Concreto: Estrutura, Propriedades e Materiais. São Paulo, 2008, Pini.

MEIRA, G. R. Agressividade por cloretos em zona de atmosfera marinha frente ao problema da corrosão em estruturas de concreto armado. Tese (Doutorado) - Universidade Federal de Santa Catarina, Santa Catarina, 2004 
MEIRA, G.R.; PADARATZ, I. J.; BORBA, J.C.J. Carbonatação natural de concretos: Resultados de cerca de quatro anos de monitoramento. 2006. Anais. Entac 2006.

MELO Neto, A. A.; HELenE, P. R. L. Módulo de elasticidade: Dosagem e avaliação de modelos de previsão do módulo de elasticidade de concretos. In: CONGRESSO BRASILEIRO DO CONCRETO, 44, 2002, Minas Gerais. Anais: IBRACON. Minas Gerais, 2002.

MONÇÃO JR. A.; HELENE, P. MONTEIRO, E. PEREIRA, M. Análise da carbonatação ao natural com diferentes traços. In: CONGRESSO BRASILEIRO DO CONCRETO, 48, 2006, Rio de Janeiro. Anais: IBRACON. Rio de Janeiro, 2006.

MONTIJA, F. C. Aspecto da variabilidade experimental do ensaio de módulo de deformação do concreto. 2007. Dissertação (Mestrado) - Escola Politécnica da Universidade de São Paulo, São Paulo, 2007.

MONTEIRO, E.C.B. Estudo da capacidade de proteção de alguns tipos de cimentos nacionais, em relação à corrosão de armaduras sob a ação conjunta de $\mathrm{CO}_{2}$ e íons cloretos. 1996. Dissertação (Mestrado) - Universidade de Brasília, Brasília, 1996.

Avaliação do método de extração eletroquímica de cloretos para reabilitação de estruturas de concreto com problemas de corrosão de armaduras. Tese (Doutorado) Escola Politécnica da Universidade de São Paulo, São Paulo, 2002.

NAKAMURA, J. Gerenciamento e controle de concretagens. Téchne. São Paulo: Pini, 2008.

NEPOMUCENO, A. A. Comportamiento de morteros de reparacion frente a la carbonatacion y la penetracion de cloruros em estructuras de hormogon armado danados por corrosion de armaduras. Estúdio mediant la resitencia de polarizasion. 1992. Tese (Doutorado) - Universida Politécnica de Madrid, Instituto de Ciências de la Construcion "Eduardo Torroja" - CSIC. Madrid.

NEVILLE, A. M. Propriedades do concreto. São Paulo, Pini, 2ª Ed., 828p, 1997.

NILSSON, L.O.; TANG, L. Transporte mechanisms in porous materials, an introduction to their basic laws and correlations. In: THE MODELLING OF MICROSTRUCTURE AND ITS POTENTIAL FOR STUDYING TRANSPORT PROPERTIES AND DURABILITY. Proccedings...Saint-Rémy - lés Chevreuse, 1996.

NINCE, A.A. Levantamento de dados sobre a deterioração de estruturas na região CentroOeste. 1996. Dissertação (Mestrado) - Universidade de Brasília, Brasília, 1996. 
NUNES, F. LYRA. Influência da Dosagem na Carbonatação dos Concretos. 1998. Dissertação (Mestrado) - Escola Politécnica da Universidade de São Paulo, São Paulo, 1998. OBLA, K. H.; LOBO, C. L. Acceptance criteria for durability tests. Concrete International. v. 29, n. 5 , May 2007 , p. $43-48$.

O’DOWD, C. D.; SMITH, M. H.; CONSTERDINE, I. A.; LOWE, J. Marine aerosol, sea-salt, and the marine sulphur cycle: a short review. Atmospheric Environment, v. 31, n.1, p. 73-80, 1997. PAGE, C.L.; SHORT, N.R.; EI TARRAS, A. Diffusion of chloride ions in hardened cement pastes. Cement and Concrete research. V. 11. 1981. p. $395-406$.

PAULETTI, C.; DAL MOLIN, D. C. C.; KAZMIERCZAK, C. S; BREZEZINSKI, D. Profundidade de carbonatação em ensaios acelerados com diferentes percentuais de $\mathrm{CO}_{2}$. In: CONGRESSO BRASILEIRO DO CONCRETO, 47, 2005, Recife. Anais: IBRACON 2005. p. 1076-1087.

PEREIRA, V. G. A. Avaliação do coeficiente de difusão de cloretos em concretos: influência do tipo de cimento, da relação água/cimento, da temperatura e do tempo de cura. 2001. Dissertação (Mestrado) - Universidade Federal do Rio Grande do Sul, Porto Alegre. Rio Grande do Sul, 2001.

POSSAN, E.; DAL MOLIN, D.C.C.; ANDRADE, J.J; KULAKOWSKI, M.P. Carbonatação em ambiente urbano: correlação entre ensaios acelerados e não acelerados. In. VIII Congreso Latinoamericano de Patologia de La Construción. Paraguai, 2005.

REGATTIERI, C. E. X. Contribuição ao estudo da influência da dosagem do concreto na absorção capilar e penetração de íons cloreto. 1998. Dissertação (Mestrado) - Escola Politécnica da Universidade de São Paulo, São Paulo, 1998.

SELMO, S. M. S. ; BUONAPANE, R. S. B. ; RIBEIRO, J. L. S. ; MEDEIROS, Marcelo Henrique Farias de ; GALENI, Patricia Castanho ; SILVA, T. F. . Contribution to the macro and microstructure analysis of repair mortars for corroded reinforced concrete structures. In: 5th International Essen Workshop Transport ind Concrete: Nano-to Macrostructure - TRANSCON 07, 2007, Essen. Proceedings of 5th International Essen Workshop Transport ind Concrete: Nano-to Macrostructure - TRANSCON 07. Freiburg : Aedificatio Publishers, 2007. p. 241-250.

SILVA, F. G.; HELENE, P. R. L. A necessidade de padronização da medida de carbonatação em concretos. In: Congresso Nacional Construção 2007. 3, Coimbra. Congresso Construção 2007. Coimbra: Centro de Investigação em Ciências da Construção - CICC, 2007. v. 1. p. 48-59 
SILVA, F. T., PIMENTEL, R. L., BARBOSA, N. P. Análise de patologias em estruturas de edificações da cidade de João Pessoa. In: CONGRESSO BRASILEIRO DO CONCRETO, 45\%, 2003, Vitória. Anais: IBRACON 2003.

SILVA, V. M. Ação da carbonatação em vigas de concreto armado em serviço, construídas em escala real e reduzida. 2007. Tese (Doutorado) - Escola Politécnica da Universidade de São Paulo, São Carlos. São Paulo, 2007.

SOUZA, R. Avaliação de desempenho aplicada a novos componentes e sistemas construtivos para habitação. São Paulo: Instituto de Pesquisas Tecnológicas. Divisão Edificações. Tecnologia de edificações, 1988. p. 529-532

THOMAZ, E. Requisitos técnicos e operacionais visando a qualidade na construção de edificios. 1999. Tese (Doutorado) - Escola Politécnica da Universidade de São Paulo, São Paulo, 1999.

TULA, L. S. Contribuição ao estudo da resistência à corrosão de armaduras de aço inoxidável. 2000. Tese (Doutorado) - Escola Politécnica da Universidade de São Paulo, São Paulo, 2000.

TUUTTI, K. "Corrosion of steel in concrete". Cement and Concrete Research Institute, Stockholm, 469p, 1982.

VIEIRA, G.L. Estudo do processo de corrosão sob a ação de íons cloreto em concretos obtidos a partir de agregados reciclados de resíduos de construção e demolições. 2003. Dissertação (Mestrado) - Universidade Federal do Rio Grande do Sul, Porto Alegre, 2003.

VIERA, R.M.S.; MARQUES, V.C.; MEIRA, G.R.; PADILHA JR. M. Carbonatação natural de concretos - influência de características dos materiais e de fatores ambientais. In: CONGRESSO BRASILEIRO DO CONCRETO, 51, 2009, Curiti ba. Anais: IBRACON, 2009.

VILASBOAS, J. M. L.; MACHADO, S. L. Durabilidade das edificações de concreto armado em Salvador: Uma contribuição para a implantação da NBR 6118:2003. In: CONGRESSO BRASILEIRO DO CONCRETO, 47, 2005, Recife . Anais: IBRACON, 2005 


\section{APÊNDICE A}

\section{Características dos materiais coletados nas centrais dosadoras de concreto}

A seguir estão apresentadas as características dos materiais utilizados na produção dos concretos, segundo informações das duas centrais dosadoras.

\section{1 - Obra 1}

A caracterização dos agregados foi realizada pelo laboratório que deu suporte a esse trabalho em campo.

\section{a) Agregado Graúdo do lote 1}

- ABNT NBR 7251 (1982): Massa unitária em estado solto $1,39 \mathrm{~g} / \mathrm{dm}^{3}$

- ABNT NBR 9776 (1987): Massa específica $2630 \mathrm{~kg} / \mathrm{m}^{3}$

- ABNT NBR 7217 (1987): Dimensão máxima característica. $19 \mathrm{~mm}$

- ABNT NBR 7217 (1987): Módulo de finura. 7,01

- ABNT NBR 7809 (1983): Índice de Forma Médio 2,29

\section{b) Agregado Miúdo do lote 1}

- ABNT NBR 7251 (1982): Massa unitária em estado solto. $1,56 \mathrm{~g} / \mathrm{dm} 3$

- ABNT NBR 9776 (1987): Massa específica $2630 \mathrm{~kg} / \mathrm{m}^{3}$

- ABNT NBR 7217 (1987): Dimensão máxima característica. $2,40 \mathrm{~mm}$

- ABNT NBR 7217 (1987): Módulo de finura. 2,34

- ABNT NBR 7218 (1982): Teor de argila em torrões e materiais friáveis.....0,6\%

- ABNT NBR 7219 (1987): Teor de materiais pulverulentos. $4,0 \%$ 


\section{APÊNDICE A}

\section{Características dos materiais coletados nas centrais dosadoras de concreto}

\section{c) Tipo de cimento}

O Cimento CP V ARI RS, da marca Mizu, fabricado pela Pacatuba Cimentos e procedente da fábrica de Sergipe;

As propriedades químicas deste cimento foram fornecidas pelas centrais dosadoras e estão resumidas a seguir:

Tabela 90 - Propriedades químicas, físicas e mecânicas do CP V ARI RS do concreto da obra 1 mês de Agosto/08

\begin{tabular}{|c|c|c|}
\hline \multicolumn{3}{|c|}{ Propriedades químicas do CP V ARI RS } \\
\hline & & Médias \\
\hline \multicolumn{2}{|l|}{ Trioxido de enxofre $\left(\mathrm{SO}_{3}\right)(\%)$} & 3,30 \\
\hline \multicolumn{2}{|l|}{ Oxido de cálcio livre $(\mathrm{CaO})(\%)$} & 1,70 \\
\hline \multicolumn{2}{|l|}{ Resíduos insolúveis (\%) } & 0,79 \\
\hline \multicolumn{2}{|l|}{ Perda ao fogo (\%) } & 2,26 \\
\hline \multicolumn{3}{|c|}{ Propriedades físicas e mecânicas do CP V ARI RS } \\
\hline \multicolumn{2}{|l|}{ Expansibilidade a quente $(\mathrm{mm})$} & 1,0 \\
\hline \multirow{2}{*}{ Tempo de pega (min) } & inicio & 150 \\
\hline & fim & 165 \\
\hline \multicolumn{2}{|l|}{ Blaine $\left(\mathrm{cm}^{2} / \mathrm{g}\right)$} & 4090 \\
\hline \multicolumn{2}{|l|}{ \#325(\%) } & 1,70 \\
\hline \multicolumn{2}{|l|}{ \#200 (\%) } & 0,15 \\
\hline \multicolumn{2}{|l|}{ Massa especifica $\left(\mathrm{g} / \mathrm{cm}^{3}\right)$} & 3,10 \\
\hline \multirow{3}{*}{ Resistência à compressão (MPa) } & 3 dias & 28,73 \\
\hline & 7 dias & 37,69 \\
\hline & 28 dias & 45,90 \\
\hline
\end{tabular}




\section{APÊNDICE A}

\section{Relatório de caracterização das amostras dos materiais coletados nas datas de amostragem dos concretos}

\section{2- Obra 2}

A caracterização dos agregados foi realizada pelo laboratório que deu suporte a esse trabalho em campo.

\section{a) Agregado Graúdo do lote 2}

- ABNT NBR 7251 (1982): Massa unitária em estado solto $1,33 \mathrm{~g} / \mathrm{dm}^{3}$

- ABNT NBR 9776 (1987): Massa específica. $2630 \mathrm{~kg} / \mathrm{m}^{3}$

- ABNT NBR 7217 (1987): Dimensão máxima característica. $19 \mathrm{~mm}$

- ABNT NBR 7217 (1987): Módulo de finura......................................... 7,01

- ABNT NBR 7809 (2006): Índice de Forma Médio. 1,89

b) Agregado Miúdo do lote 2

- ABNT NBR 7251 (1982): Massa unitária em estado solto. $1,52 \mathrm{~g} / \mathrm{dm} 3$

- ABNT NBR 9776 (1987): Massa específica $2630 \mathrm{~kg} / \mathrm{m}^{3}$

- ABNT NBR 7217 (1987): Dimensão máxima característica $2,40 \mathrm{~mm}$

- ABNT NBR 7217 (1987): Módulo de finura. 1,92

- ABNT NBR 7218 (1987): Teor de argila em torrões e materiais friáveis.....0,45\%

- ABNT NBR 7219 (1987): Teor de materiais pulverulentos. $4,0 \%$ 


\section{APÊNDICE A}

\section{Relatório de caracterização das amostras dos materiais coletados nas datas de} amostragem dos concretos

\section{c) Tipo de cimento}

Cimento CPII F 32, da marca Zebu, fabricado pela Cimpor Cimentos e procedente da fábrica de João Pessoa-PB.

As propriedades químicas deste cimento foram fornecidas pelas centrais dosadoras e estão resumidas a seguir:

Tabela 91 - Propriedades químicas, tisicas e mecânicas do CP IIF 32 do concreto da obra 2

\begin{tabular}{|c|c|c|}
\hline \multicolumn{3}{|c|}{ Propriedades químicas do CP II F 32} \\
\hline & & Médias (\%) \\
\hline \multicolumn{2}{|l|}{ Trioxido de enxofre $\left(\mathrm{SO}_{3}\right)(\%)$} & 2,77 \\
\hline \multicolumn{2}{|l|}{ Oxido de magnésio (MgO) (\%) } & 4,25 \\
\hline \multicolumn{2}{|l|}{ Dióxido de silício $\left(\mathrm{SiO}_{2}\right)(\%)$} & 18,78 \\
\hline \multicolumn{2}{|l|}{ Óxido de ferro $\left(\mathrm{Fe}_{2} \mathrm{O}_{3}\right)(\%)$} & 2,34 \\
\hline \multicolumn{2}{|l|}{ Oxido de cálcio total (CaO) (\%) } & 59,63 \\
\hline \multicolumn{2}{|l|}{ Óxido de alumínio $\left(\mathrm{Al}_{2} \mathrm{O}_{3}\right)(\%)$} & 4,27 \\
\hline \multicolumn{2}{|l|}{ Óxido de cálcio livre (CaO) (\%) } & - \\
\hline \multicolumn{2}{|l|}{ Resíduos insolúveis (\%) } & 1,33 \\
\hline \multicolumn{2}{|l|}{ Perda ao fogo (\%) } & 4,35 \\
\hline \multicolumn{3}{|c|}{ Propriedades físicas e mecânicas do CP II F 32} \\
\hline \multicolumn{2}{|l|}{ Expansibilidade a quente $(\mathrm{mm})$} & 0,3 \\
\hline \multirow{2}{*}{ Tempo de pega (min) } & inicio & 165 \\
\hline & fim & 265 \\
\hline \multicolumn{2}{|l|}{ Blaine $\left(\mathrm{cm}^{2} / \mathrm{g}\right)$} & 4097 \\
\hline \multicolumn{2}{|l|}{ \#325(\%) } & 1,70 \\
\hline \multicolumn{2}{|l|}{ Massa especifica $\left(\mathrm{g} / \mathrm{cm}^{3}\right)$} & 3,10 \\
\hline \multirow{3}{*}{ Resistência à compressão (MPa) } & 3 dias & 32,90 \\
\hline & 7 dias & 39,2 \\
\hline & 28 dias & 44,70 \\
\hline
\end{tabular}




\section{APÊNDICE B}

Tabelas de controle dos tanques de cura acelerada e de ciclagem de corpos-deprova do estudo

Tabela 92 - Controle de temperatura e umidade da caixa térmica 1

\begin{tabular}{|c|c|c|c|c|c|c|}
\hline \multirow{4}{*}{$\begin{array}{l}\text { Data da } \\
\text { leitura }\end{array}$} & \multicolumn{5}{|c|}{ Temperatura $\left({ }^{\circ} \mathrm{C}\right)$} & \multirow{4}{*}{$\begin{array}{c}\text { Umidade } \\
\text { Relativa } \\
\text { (\%) }\end{array}$} \\
\hline & \multicolumn{5}{|c|}{ Condições de leitura e horario } & \\
\hline & $\begin{array}{l}\text { Após a abertura } \\
\text { da tampa da } \\
\text { estufa para } \\
\text { circulção do ar }\end{array}$ & $\begin{array}{c}\text { Após } 4 \text { horas } \\
\text { da abertura } \\
\text { da tampa }\end{array}$ & $\begin{array}{c}\text { Fim da } \\
\text { incidência } \\
\text { do sol }\end{array}$ & $\begin{array}{c}\text { Após } \\
\text { colocação } \\
\text { da tampa }\end{array}$ & \multirow[t]{2}{*}{$\begin{array}{l}\text { Média do } \\
\text { dia }\left({ }^{\circ} \mathrm{C}\right)\end{array}$} & \\
\hline & 8 horas & 12 horas & 14 horas & 17 horas & & \\
\hline $15 / 11 / 2008$ & 50 & 45 & 32 & 55 & 46 & - \\
\hline $17 / 11 / 2008$ & 45 & 50 & 50 & 60 & 51 & - \\
\hline $19 / 11 / 2008$ & 38 & 42 & 30 & 55 & 41 & - \\
\hline $20 / 11 / 2008$ & 45 & 51 & 38 & 47 & 45 & - \\
\hline $22 / 11 / 2008$ & 50 & 50 & 38 & 45 & 46 & - \\
\hline $24 / 11 / 2008$ & 46 & 42 & 36 & 47 & 43 & - \\
\hline $25 / 11 / 2008$ & 45 & 38 & 30 & 45 & 40 & 52 \\
\hline $26 / 11 / 2008$ & 50 & 38 & 40 & 45 & 43 & 50 \\
\hline $28 / 11 / 2008$ & 36 & 35 & 30 & 45 & 37 & 48 \\
\hline $01 / 12 / 2008$ & 45 & 43,5 & 38 & 45,5 & 43 & 40 \\
\hline $03 / 12 / 2008$ & 50,2 & 45,7 & 38,5 & 55,0 & 47 & - \\
\hline $05 / 12 / 2008$ & 55,5 & 45,7 & 45 & 55 & 50 & - \\
\hline $08 / 12 / 2008$ & 45 & 43,4 & 40,2 & 45,5 & 44 & 25 \\
\hline $08 / 12 / 2008$ & 45 & 43,4 & 40,2 & 45,5 & 44 & 32 \\
\hline $08 / 12 / 2008$ & 45 & 43,4 & 40,2 & 45,5 & 44 & 35 \\
\hline $08 / 12 / 2008$ & 45 & 43,4 & 40,2 & 45,5 & 44 & 32 \\
\hline $09 / 12 / 2008$ & 45 & 44,5 & 39,8 & 46,0 & 44 & 32 \\
\hline $10 / 12 / 2008$ & 45 & 35 & 30 & 40 & 38 & 30 \\
\hline $11 / 12 / 2008$ & 40 & 38 & 28 & 25 & 33 & 33 \\
\hline $12 / 12 / 2008$ & 55 & 45 & 42,8 & 60 & 51 & 28 \\
\hline $15 / 12 / 2008$ & 60 & 48 & 34,7 & 50,1 & 48 & 28 \\
\hline $16 / 12 / 2008$ & 45 & 50 & 38 & 50 & 46 & 30 \\
\hline $17 / 12 / 2008$ & 46 & 44,6 & 40,5 & 48,5 & 45 & 32 \\
\hline $18 / 12 / 2008$ & 45,5 & 42,1 & 43,2 & 47,2 & 45 & 30 \\
\hline $19 / 12 / 2008$ & 45 & 42,0 & 36 & 40 & 41 & 35 \\
\hline $20 / 12 / 2008$ & 48 & 48 & 35 & 45 & 44 & 38 \\
\hline $22 / 12 / 2008$ & 60 & 38 & 32 & 50 & 45 & 35 \\
\hline $23 / 12 / 2008$ & 45 & 34 & 32 & 50 & 40 & 32 \\
\hline $24 / 12 / 2008$ & 45 & 43,8 & 38,5 & 45,5 & 43 & 30 \\
\hline $26 / 12 / 2008$ & 38 & 45 & 37 & 48,2 & 42 & 31 \\
\hline $27 / 12 / 2008$ & 45,5 & 50 & 55 & 45,7 & 49 & 38 \\
\hline $29 / 12 / 2008$ & 46,3 & 40,3 & 38,7 & 41,2 & 42 & 32 \\
\hline $30 / 12 / 2008$ & 45,5 & 42 & 38 & 42 & 42 & 35 \\
\hline $31 / 12 / 2008$ & 38 & 40 & - & - & 39 & 38 \\
\hline $01 / 01 / 2009$ & 45 & 45 & 40 & 42 & 43 & 33 \\
\hline $02 / 01 / 2009$ & 40 & 40 & 34 & 45 & 40 & 32 \\
\hline $05 / 01 / 2009$ & 44 & 42 & 36 & 50 & 43 & 34 \\
\hline $06 / 01 / 2009$ & 48 & 46 & 38 & 46 & 45 & 32 \\
\hline $07 / 01 / 2009$ & 48 & 40 & 32 & 40 & 40 & 34 \\
\hline $08 / 01 / 2009$ & 50 & 40 & 36 & 42 & 42 & 38 \\
\hline $09 / 01 / 2009$ & 58 & 42 & 38 & 55 & 48 & 42 \\
\hline $12 / 01 / 2009$ & 48 & 46 & 40 & 46 & 45 & 38 \\
\hline $13 / 01 / 2009$ & 50 & 43 & 40,1 & 45 & 45 & 32 \\
\hline $14 / 01 / 2009$ & 55 & 55 & 55 & 55 & 55 & 36 \\
\hline $15 / 01 / 2009$ & 56,5 & 55 & 55 & 50,5 & 54 & 38 \\
\hline $16 / 01 / 2009$ & 56,0 & 46,5 & 40,0 & 55 & 49 & 38 \\
\hline 19/01/2009 & 52,5 & 43 & 40 & 52 & 47 & 36 \\
\hline $20 / 01 / 2009$ & 50 & 42 & 38 & 50 & 45 & 36 \\
\hline $21 / 01 / 2009$ & 49 & 40 & 40 & 50 & 45 & 40 \\
\hline $22 / 01 / 2009$ & 45 & 40 & 39 & 48 & 43 & 42 \\
\hline $23 / 01 / 2009$ & 44 & 38 & 35 & 45 & 41 & 42 \\
\hline $24 / 01 / 2009$ & 45 & 40 & 40 & 45 & 43 & 40 \\
\hline $26 / 01 / 2009$ & 55 & 47 & 45 & 50 & 49 & 32 \\
\hline $27 / 01 / 2009$ & 55 & 45 & 45 & 52 & 49 & 32 \\
\hline $28 / 01 / 2009$ & 55 & 42 & 40 & 56 & 48 & 32 \\
\hline $29 / 01 / 2009$ & 54,5 & 48,5 & 45 & 50 & 50 & 34 \\
\hline $30 / 01 / 2009$ & 49 & 45 & 43 & 46 & 46 & 34 \\
\hline $31 / 01 / 2009$ & 50 & 47 & 47 & 50 & 49 & 38 \\
\hline
\end{tabular}




\section{APÊNDICE B}

Tabelas de controle dos tanques de cura acelerada e de ciclagem de corpos-deprova do estudo

Tabela 93 - Controle de temperatura e umidade da caixa térmica 2

\begin{tabular}{|c|c|c|c|c|c|c|}
\hline \multirow{4}{*}{$\begin{array}{l}\text { Data da } \\
\text { leitura }\end{array}$} & \multicolumn{5}{|c|}{ Temperatura $\left({ }^{\circ} \mathrm{C}\right)$} & \multirow{4}{*}{$\begin{array}{c}\text { Umidade } \\
\text { Relativa } \\
\text { (\%) }\end{array}$} \\
\hline & \multicolumn{5}{|c|}{ Condições de leitura e horario } & \\
\hline & $\begin{array}{l}\text { Após a abertura } \\
\text { da tampa da } \\
\text { estufa para } \\
\text { circulção do ar }\end{array}$ & $\begin{array}{l}\text { Após } 4 \text { horas } \\
\text { da abertura } \\
\text { da tampa }\end{array}$ & $\begin{array}{c}\text { Fim da } \\
\text { incidência } \\
\text { do sol }\end{array}$ & $\begin{array}{c}\text { Após } \\
\text { colocação } \\
\text { da tampa }\end{array}$ & \multirow[t]{2}{*}{$\begin{array}{l}\text { Média do } \\
\text { dia }\left({ }^{\circ} \mathrm{C}\right)\end{array}$} & \\
\hline & 8 horas & 12 horas & 14 horas & 17 horas & & \\
\hline $23 / 12 / 2008$ & 38 & 40 & 38,9 & 40 & 39,23 & 32 \\
\hline $24 / 12 / 2008$ & 40 & 38 & 35 & 38,1 & 38 & 30 \\
\hline 26/12/2008 & 42,3 & 40 & 38 & 40 & 40 & 31 \\
\hline $27 / 12 / 2008$ & 40 & 38 & 38 & 50 & 42 & 38 \\
\hline $29 / 12 / 2008$ & 40 & 40 & 38 & 45 & 41 & 32 \\
\hline $30 / 12 / 2008$ & 38 & 42 & 44 & 40 & 41 & 35 \\
\hline $31 / 12 / 2008$ & 36 & 42 & - & - & 39 & 38 \\
\hline $01 / 01 / 2009$ & 45 & 47 & 43 & 40 & 44 & 32 \\
\hline $02 / 01 / 2009$ & 42 & 42 & 38 & 48 & 43 & 30 \\
\hline $05 / 01 / 2009$ & 46 & 40 & 38 & 48 & 43 & 34 \\
\hline $06 / 01 / 2009$ & 44 & 42 & 38 & 50,0 & 44 & 32 \\
\hline $07 / 01 / 2009$ & 50 & 42 & 38 & 42 & 43 & 34 \\
\hline $08 / 01 / 2009$ & 48 & 40 & 40 & 40 & 42 & 30 \\
\hline $09 / 01 / 2009$ & 50 & 46 & 40 & 50 & 47 & 28 \\
\hline $12 / 01 / 2009$ & 50 & 48 & 42 & 48 & 47 & 38 \\
\hline $13 / 01 / 2009$ & 45,6 & 42,5 & 39,7 & 50 & 44 & 32 \\
\hline $14 / 01 / 2009$ & 45,5 & 42 & 39 & 50,0 & 44 & 36 \\
\hline $15 / 01 / 2009$ & 45 & 37,5 & 35,5 & 42 & 40 & 38 \\
\hline $16 / 01 / 2009$ & 47 & 42 & 39,5 & 45 & 43 & 38 \\
\hline $19 / 01 / 2009$ & 50 & 40 & 35 & 46 & 43 & 36 \\
\hline $20 / 01 / 2009$ & 50 & 42 & 37 & 45 & 44 & 36 \\
\hline $21 / 01 / 2009$ & 50 & 40 & 40 & 45 & 44 & 40 \\
\hline $22 / 01 / 2009$ & 55 & 55,0 & 55 & 54,5 & 55 & 42 \\
\hline $23 / 01 / 2009$ & 55 & 55 & 55 & 55 & 55 & 42 \\
\hline $24 / 01 / 2009$ & 55 & 52,5 & 50 & 55 & 53 & 40 \\
\hline $26 / 01 / 2009$ & 55 & 45 & 40 & 53 & 48 & 32 \\
\hline $27 / 01 / 2009$ & 50 & 50 & 50 & 50 & 50 & 32 \\
\hline $28 / 01 / 2009$ & 50 & 45 & 40,5 & 48 & 46 & 32 \\
\hline $29 / 01 / 2009$ & 49 & 40 & 37,5 & 45 & 43 & 34 \\
\hline $30 / 01 / 2009$ & 49,5 & 39,5 & 35 & 45 & 42 & 34 \\
\hline $31 / 01 / 2009$ & 50 & 50 & 50 & 50 & 50 & 38 \\
\hline $02 / 02 / 2009$ & 52 & 48 & 39 & 45 & 46 & 40 \\
\hline $03 / 02 / 2009$ & 52 & 50 & 50 & 50 & 51 & 40 \\
\hline $04 / 02 / 2009$ & 48 & 40 & 35 & 45 & 42 & 40 \\
\hline $05 / 02 / 2009$ & 48,5 & 42 & 37 & 40 & 42 & 40 \\
\hline $06 / 02 / 2009$ & 50 & 45 & 40 & 48 & 46 & 43 \\
\hline $09 / 02 / 2009$ & 50 & 50 & 53 & 55 & 52 & 40 \\
\hline $10 / 02 / 2009$ & 48 & 45 & 43,5 & 45 & 45 & 38 \\
\hline $11 / 02 / 2009$ & 45 & 40 & 33 & 45 & 41 & 36 \\
\hline $12 / 02 / 2009$ & 42 & 36 & 30,5 & 45 & 38 & 32 \\
\hline $13 / 02 / 2009$ & 48 & 45 & 45 & 45 & 46 & 32 \\
\hline $16 / 02 / 2009$ & 55 & 51 & 54 & 55 & 54 & 34 \\
\hline $17 / 02 / 2009$ & 50 & 49 & 46 & 46 & 48 & 38 \\
\hline $18 / 02 / 2009$ & 50 & 50 & 50 & 50 & 50 & 37 \\
\hline $19 / 02 / 2009$ & 50 & 50 & 50 & 50 & 50 & 37 \\
\hline $20 / 02 / 2009$ & 46 & 46 & 44 & 45 & 45 & 40 \\
\hline $26 / 02 / 2009$ & 45 & 43 & 40 & 40 & 42 & 40 \\
\hline $27 / 02 / 2009$ & 45 & 45 & 45 & 45 & 45 & 42 \\
\hline $28 / 02 / 2009$ & 45 & 44 & 40 & 46 & 44 & 42 \\
\hline $02 / 03 / 2009$ & 45 & 45 & 45 & 45 & 45 & 42 \\
\hline $03 / 03 / 2009$ & 45 & 38 & 35 & 47 & 41 & 44 \\
\hline $04 / 03 / 2009$ & 44 & 40 & 36 & 45 & 41 & 44 \\
\hline $05 / 03 / 2009$ & 45 & 45 & 45 & 45 & 45 & 40 \\
\hline $06 / 03 / 2009$ & 45 & 45 & 45 & 45 & 45 & 38 \\
\hline $09 / 03 / 2009$ & 45 & 45 & 45 & 45 & 45 & 38 \\
\hline $10 / 03 / 2009$ & 45 & 40 & 35,5 & 45 & 41 & 38 \\
\hline $11 / 03 / 2009$ & 48 & 42 & 36 & 46 & 43 & 36 \\
\hline $12 / 03 / 2009$ & 50 & 40 & 35 & 47 & 43 & 35 \\
\hline $13 / 03 / 2009$ & 50 & 50 & 50 & 50 & 50 & 37 \\
\hline $16 / 03 / 2009$ & 45 & 45 & 45,5 & 46 & 45 & 45 \\
\hline $17 / 03 / 2009$ & 48 & 46 & 46 & 48 & 47 & 43 \\
\hline $18 / 03 / 2009$ & 47 & 35 & 35 & 40,5 & 39 & 43 \\
\hline $19 / 03 / 2009$ & 50 & 38 & 36 & 50 & 44 & 43 \\
\hline $20 / 03 / 2009$ & 50 & 40,5 & 38 & 44 & 43 & 43 \\
\hline
\end{tabular}




\section{APÊNDICE B}

Tabelas de controle dos tanques de cura acelerada e de ciclagem de corpos-deprova do estudo

Tabela 94 - Controle de temperatura do tanque de cura no lote treinamento

\begin{tabular}{|c|c|c|c|c|c|}
\hline Lote & $\begin{array}{c}\text { Data de } \\
\text { moldagem }\end{array}$ & $\begin{array}{c}\text { Cura } \\
\text { acelerada }\end{array}$ & Data & Horario & $\begin{array}{c}\text { Temperatura } \\
\left({ }^{\circ} \mathrm{C}\right)\end{array}$ \\
\hline \multirow{9}{*}{ treinamento } & \multirow{9}{*}{ 07/11/2008 } & \multirow{9}{*}{$24 / 48$ horas } & \multirow{5}{*}{$08 / 11 / 2008$} & $15: 00$ & 42 \\
\hline & & & & $17: 00$ & 39 \\
\hline & & & & 19:00 & 38 \\
\hline & & & & $21: 00$ & 39 \\
\hline & & & & $23: 00$ & 40 \\
\hline & & & \multirow{4}{*}{$09 / 11 / 2008$} & 07:00 & 41 \\
\hline & & & & 09:00 & 41 \\
\hline & & & & 11:00 & 40 \\
\hline & & & & $15: 00$ & 40 \\
\hline
\end{tabular}

Tabela 95 - Controle de temperatura do tanque de cura no lote 1

\begin{tabular}{|c|c|c|c|c|c|}
\hline Lote & $\begin{array}{c}\text { Data de } \\
\text { moldagem }\end{array}$ & $\begin{array}{c}\text { Cura } \\
\text { acelerada }\end{array}$ & Data & Horario & $\begin{array}{c}\text { Temperatura } \\
\left({ }^{\circ} \mathrm{C}\right)\end{array}$ \\
\hline \multirow{17}{*}{1} & \multirow{17}{*}{ 14/01/2009 } & \multirow{17}{*}{$\begin{array}{c}\text { 0/24 horas } \\
\text { e } 24 / 48 \\
\text { horas }\end{array}$} & \multirow{5}{*}{ 14/01/2009 } & $13: 00$ & 39 \\
\hline & & & & $16: 00$ & 39 \\
\hline & & & & $18: 00$ & 38 \\
\hline & & & & $20: 00$ & 40 \\
\hline & & & & $22: 00$ & 40 \\
\hline & & & \multirow{8}{*}{ 15/01/2009 } & $07: 00$ & 39 \\
\hline & & & & 09:00 & 39 \\
\hline & & & & 11:00 & 39 \\
\hline & & & & $13: 00$ & 38 \\
\hline & & & & $16: 00$ & 39 \\
\hline & & & & 19:00 & 40 \\
\hline & & & & $21: 00$ & 40 \\
\hline & & & & $22: 00$ & 41 \\
\hline & & & \multirow{4}{*}{$16 / 01 / 2009$} & $07: 00$ & 39 \\
\hline & & & & 09:00 & 38 \\
\hline & & & & $11: 00$ & 38 \\
\hline & & & & $13: 00$ & 39 \\
\hline
\end{tabular}




\section{APÊNDICE B}

Tabelas de controle dos tanques de cura acelerada e de ciclagem de corpos-deprova do estudo

Tabela 96 - Controle de temperatura do tanque de cura no lote 2

\begin{tabular}{|c|c|c|c|c|c|}
\hline Lote & \begin{tabular}{|c|} 
Data de \\
moldagem
\end{tabular} & $\begin{array}{c}\text { Cura } \\
\text { acelerada }\end{array}$ & Data & Horario & $\begin{array}{c}\text { Temperatura } \\
(\mathrm{C})\end{array}$ \\
\hline \multirow{17}{*}{2} & \multirow{17}{*}{ 27/11/2008 } & \multirow{17}{*}{$\begin{array}{c}0 / 24 \text { horas } \\
\text { e } 24 / 48 \\
\text { horas }\end{array}$} & \multirow{5}{*}{$27 / 11 / 2008$} & $15: 00$ & 40 \\
\hline & & & & $17: 00$ & 41 \\
\hline & & & & $20: 00$ & 40 \\
\hline & & & & $21: 00$ & 40 \\
\hline & & & & $22: 00$ & 39 \\
\hline & & & \multirow{8}{*}{$28 / 11 / 2008$} & 07:00 & 38 \\
\hline & & & & 09:00 & 38 \\
\hline & & & & $11: 00$ & 39 \\
\hline & & & & $15: 00$ & 38 \\
\hline & & & & $16: 00$ & 38 \\
\hline & & & & 19:00 & 40 \\
\hline & & & & $21: 00$ & 39 \\
\hline & & & & $22: 00$ & 40 \\
\hline & & & \multirow{4}{*}{$29 / 11 / 2008$} & $07: 00$ & 39 \\
\hline & & & & 09:00 & 40 \\
\hline & & & & $12: 00$ & 40 \\
\hline & & & & $15: 00$ & 39 \\
\hline
\end{tabular}




\section{APÊNDICE C \\ Resultados da caracterização dos lotes}

\section{1) Lote 1}

$\mathrm{Na}$ Tabela 97 são apresentados os tempos de descarga de cada caminhão, com os respectivos resultados do abatimento do tronco de cone, com a média, desvio padrão e o coeficiente de variação do lote 1 .

Tabela 97 - Tempo de descarga dos caminhões e resultados dos ensaios de abatimento do tronco de cone nos concretos do lote 1

\begin{tabular}{|c|c|c|c|c|c|c|c|c|c|c|}
\hline \multirow{3}{*}{ 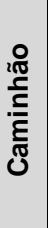 } & \multirow{2}{*}{\multicolumn{4}{|c|}{$\begin{array}{l}\text { Tempo de descarga do caminhão } \\
\text { (min) }\end{array}$}} & \multicolumn{6}{|c|}{ Abatimento do tronco de cone $(\mathrm{cm})$} \\
\hline & & & & & \multicolumn{3}{|c|}{ Medidas (cm) } & \multirow{2}{*}{$\begin{array}{c}\text { Média } \\
(\mathrm{cm})\end{array}$} & \multirow{2}{*}{$\begin{array}{c}\text { Desvio } \\
\text { Padrão } \\
(\mathrm{cm})\end{array}$} & \multirow{2}{*}{$\begin{array}{c}\text { Coeficiente } \\
\text { de variação } \\
(\%)\end{array}$} \\
\hline & inicio & termino & $\begin{array}{l}\text { Tempo - } \\
\text { descarga }\end{array}$ & Média & 1 & 2 & Média & & & \\
\hline 1 & $11: 50$ & $12: 15$ & $00: 25$ & \multirow{6}{*}{$00: 18$} & 9 & 9 & 9 & \multirow{6}{*}{12} & \multirow{6}{*}{2,74} & \multirow{6}{*}{$23 \%$} \\
\hline 2 & $12: 20$ & $12: 33$ & $00: 13$ & & 8 & 12 & 10 & & & \\
\hline 3 & $12: 55$ & $13: 08$ & $00: 13$ & & 11 & 13 & 12 & & & \\
\hline 4 & $13: 10$ & $13: 27$ & $00: 17$ & & 12 & 17 & 15 & & & \\
\hline 5 & $13: 30$ & $13: 45$ & $00: 15$ & & 15 & 17 & 16 & & & \\
\hline 6 & $13: 50$ & $14: 15$ & $00: 25$ & & 9 & 12 & 11 & & & \\
\hline
\end{tabular}

Na Tabela 98 são apresentados os resultados dos ensaios de massa específica de cada caminhão amostrado, com a média, desvio padrão e o coeficiente de variação do lote 1 .

Tabela 98 - Resultados dos ensaios de densidade específica do concreto fresco amostrado do lote 1

\begin{tabular}{|c|c|c|c|c|c|c|c|c|c|c|}
\hline \multirow[b]{2}{*}{ 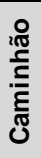 } & \multirow[b]{2}{*}{$\begin{array}{l}\text { Massa do } \\
\text { recipiente } \\
\text { (kg) }\end{array}$} & \multirow[b]{2}{*}{$\begin{array}{l}\text { Volume do } \\
\text { recipiente } \\
\left(\mathrm{cm}^{3}\right)\end{array}$} & \multicolumn{2}{|c|}{ Medidas (kg) } & \multicolumn{3}{|c|}{ Densidade $\left(\mathrm{kg} / \mathrm{m}^{3}\right)$} & \multicolumn{3}{|c|}{ Lote 1} \\
\hline & & & 1 & 2 & 1 & 2 & Média & $\begin{array}{l}\text { Média } \\
\left(\mathrm{kg} / \mathrm{m}^{3}\right)\end{array}$ & $\begin{array}{l}\text { Desvio } \\
\text { Padrão } \\
\left(\mathrm{kg} / \mathrm{m}^{3}\right)\end{array}$ & $\begin{array}{c}\text { Coeficiante } \\
\text { de variação } \\
(\%)\end{array}$ \\
\hline 1 & 9,20 & \multirow{6}{*}{13,744} & 41,70 & 41,50 & 2360 & 2350 & 2355 & \multirow{6}{*}{2348} & \multirow{6}{*}{27} & \multirow{6}{*}{$1 \%$} \\
\hline 2 & 9,20 & & 41,20 & 41,20 & 2330 & 2330 & 2330 & & & \\
\hline 3 & 9,20 & & 41,60 & 40,20 & 2360 & 2260 & 2310 & & & \\
\hline 4 & 9,20 & & 42,20 & 41,80 & 2400 & 2370 & 2385 & & & \\
\hline 5 & 9,20 & & 41,40 & 41,40 & 2340 & 2340 & 2340 & & & \\
\hline 6 & 9,20 & & 41,60 & 41,80 & 2360 & 2370 & 2365 & & & \\
\hline
\end{tabular}




\section{APÊNCIDE C}

\section{Resultados dos Ensaios Individuais, com duas repetições por concreto de cada caminhão amostrado}

$\mathrm{Na}$ Tabela 99 são apresentados os resultados dos ensaios compactabilidade adensado e não adensado de cada caminhão amostrado, com a média, desvio padrão e o coeficiente de variação do lote 1 .

Tabela 99 - Resultados dos ensaios de compactabilidade do concreto fresco adensado e não adensado dos concretos amostrados do lote 1

\begin{tabular}{|c|c|c|c|c|c|c|c|c|c|c|c|c|}
\hline \multirow{3}{*}{ 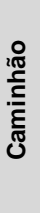 } & \multicolumn{6}{|c|}{ Compactabilidade sem adensamento $(\mathrm{cm})$} & \multicolumn{6}{|c|}{ Compactabilidade com adensamento $(\mathrm{cm})$} \\
\hline & \multicolumn{3}{|c|}{ Medidas (cm) } & \multicolumn{3}{|c|}{ Lote 1} & \multicolumn{3}{|c|}{ Medidas $(\mathrm{cm})$} & \multicolumn{3}{|c|}{ Lote 1} \\
\hline & 1 & 2 & Média & $\begin{array}{c}\text { Média } \\
(\mathrm{cm})\end{array}$ & $\begin{array}{l}\text { Desvio } \\
\text { padrão } \\
\text { (cm) }\end{array}$ & $\begin{array}{c}\text { Coeficiente } \\
\text { de variação } \\
(\%)\end{array}$ & 1 & 2 & Média & $\begin{array}{l}\text { Média } \\
\text { (cm) }\end{array}$ & $\begin{array}{l}\text { Desvio } \\
\text { padrão } \\
(\mathrm{cm})\end{array}$ & $\begin{array}{c}\text { Coeficiente } \\
\text { de variação } \\
\text { (\%) }\end{array}$ \\
\hline 1 & 0,7 & 0,7 & 0,70 & \multirow{6}{*}{0,74} & \multirow{6}{*}{0,10} & \multirow{6}{*}{$14 \%$} & 0,8 & 0,7 & 0,75 & \multirow{6}{*}{0,66} & \multirow{6}{*}{0,17} & \multirow{6}{*}{$26 \%$} \\
\hline 2 & 0,9 & 0,6 & 0,75 & & & & 0,8 & 0,5 & 0,65 & & & \\
\hline 3 & 0,8 & 0,8 & 0,8 & & & & 0,6 & 0,4 & 0,5 & & & \\
\hline 4 & 0,6 & 0,6 & 0,60 & & & & 0,5 & 0,6 & 0,55 & & & \\
\hline 5 & 0,8 & 0,6 & 0,70 & & & & 0,6 & 0,5 & 0,55 & & & \\
\hline 6 & 1,2 & 0,6 & 0,90 & & & & 0,9 & 1,0 & 0,95 & & & \\
\hline
\end{tabular}

$\mathrm{Na}$ Tabela 100 são apresentados os resultados dos ensaios de teor de ar e umidade do concreto fresco de cada caminhão amostrado e a média, desvio padrão e coeficiente de variação do lote 1 .

Tabela 100 - Resultados dos ensaios de teor de ar pelo método pressométrico e umidade do concreto fresco nos concretos amostrados do lote 1

\begin{tabular}{|c|c|c|c|c|c|c|c|c|c|c|c|c|}
\hline \multirow{3}{*}{ 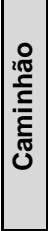 } & \multicolumn{6}{|c|}{ Teor de ar pelo método pressométrico (\%) } & \multicolumn{6}{|c|}{ Umidade (\%) } \\
\hline & \multicolumn{3}{|c|}{ Medidas } & \multicolumn{3}{|c|}{ Lote 1} & \multicolumn{3}{|c|}{ Medidas } & \multicolumn{3}{|c|}{ Lote 1} \\
\hline & 1 & 2 & $\begin{array}{c}\text { Média } \\
\text { (\%) }\end{array}$ & $\begin{array}{c}\text { Média } \\
\text { (\%) }\end{array}$ & $\begin{array}{c}\text { Desvio } \\
\text { Padrão } \\
\text { (\%) }\end{array}$ & $\begin{array}{c}\text { Coeficiente } \\
\text { de variação } \\
\text { (\%) }\end{array}$ & 1 & 2 & $\begin{array}{c}\text { Média } \\
\text { (\%) }\end{array}$ & $\begin{array}{c}\text { Média } \\
\text { (\%) }\end{array}$ & $\begin{array}{c}\text { Desvio } \\
\text { Padrão } \\
(\%)\end{array}$ & $\begin{array}{c}\text { Coeficiente } \\
\text { de variação } \\
(\%)\end{array}$ \\
\hline 1 & 2,82 & 3,21 & 3,02 & \multirow{6}{*}{3,3} & \multirow{6}{*}{0,2} & \multirow{6}{*}{$6 \%$} & 5 & 2 & 4 & \multirow{6}{*}{5} & \multirow{6}{*}{1,9} & \multirow{6}{*}{$42 \%$} \\
\hline 2 & 3,10 & 3,17 & 3,14 & & & & 3 & 3 & 3 & & & \\
\hline 3 & 3,35 & 3,38 & $\begin{array}{ll}3,37 \\
\end{array}$ & & & & 6 & 10 & 8 & & & \\
\hline 4 & 3,29 & 3,31 & 3,30 & & & & 4 & 3 & 4 & & & \\
\hline 5 & 3,55 & 3,60 & 3,58 & & & & 4 & 3 & 3 & & & \\
\hline 6 & 3,50 & 3,50 & 3,50 & & & & 6 & 5 & 6 & & & \\
\hline
\end{tabular}




\section{APÊNDICE C}

\section{Resultados dos Ensaios Individuais, com duas repetições por concreto de cada caminhão amostrado}

Na Tabela 101 são apresentados os resultados dos ensaios de absorção de água total e índice de vazios nos corpos-de-prova amostrados do lote 1.

$\mathrm{Na}$ Tabela 102 são apresentados os resultados dos ensaios de absorção de água por capilaridade nos corpos-de-prova amostrados do lote 1.

Na Tabela 103 são apresentados os resultados dos ensaios mecânicos realizados nos corpos-de-prova amostrados do lote 1 , com suas respectivas médias, os desvio padrão, os coeficiente de variação e os valores máximos e mínimos.

Na Tabela 104 são apresentados os resultados dos ensaios de tração por compressão diametral nos corpos-de-prova destinados a ciclagem do lote 1.

\begin{tabular}{|c|c|c|c|c|c|c|c|}
\hline 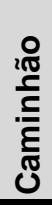 & 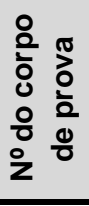 & 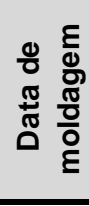 & 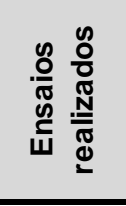 & $\begin{array}{c}\text { Resistência à } \\
\text { tração aos } 91 \\
\text { dias (MPa) }\end{array}$ & $\begin{array}{l}\text { Média } \\
(\mathrm{MPa})\end{array}$ & $\begin{array}{c}\text { Desvio } \\
\text { Padrão } \\
\text { (MPa) }\end{array}$ & \begin{tabular}{|c} 
Coeficiente \\
de \\
Variação \\
$(\%)$ \\
\end{tabular} \\
\hline \multirow{2}{*}{1} & 441 & \multirow{12}{*}{ 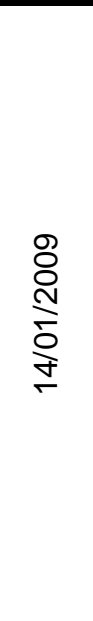 } & \multirow{5}{*}{ 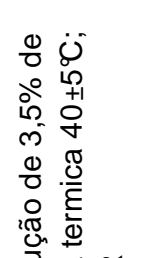 } & 5,60 & \multirow{2}{*}{5,37} & \multirow{2}{*}{0,33} & \multirow{2}{*}{$6 \%$} \\
\hline & 442 & & & 5,14 & & & \\
\hline \multirow{2}{*}{2} & 443 & & & 4,41 & 537 & 136 & $25 \%$ \\
\hline & 444 & & & 6,33 & I & 促 & 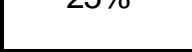 \\
\hline 3 & 445 & & & 4,42 & \multirow{2}{*}{4,89} & \multirow{2}{*}{0,66} & \multirow{2}{*}{$13 \%$} \\
\hline & 446 & & \multirow{7}{*}{ 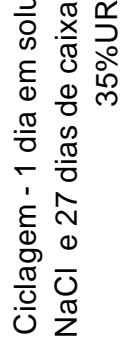 } & 5,35 & & & \\
\hline \multirow{2}{*}{4} & 447 & & & 4,35 & \multirow{2}{*}{4,75} & \multirow{2}{*}{0,56} & \multirow{2}{*}{$12 \%$} \\
\hline & 448 & & & 5,14 & & & \\
\hline \multirow{2}{*}{5} & 449 & & & 5,03 & \multirow{2}{*}{5,39} & \multirow{2}{*}{0,50} & \multirow{2}{*}{$9 \%$} \\
\hline & 450 & & & 5,74 & & & \\
\hline \multirow{2}{*}{6} & 451 & & & 5,04 & \multirow{2}{*}{4,13} & \multirow{2}{*}{1,29} & \multirow{2}{*}{$31 \%$} \\
\hline & 452 & & & 3,21 & & & \\
\hline
\end{tabular}




\section{APÊNDICE C}

\section{Resultados dos Ensaios Individuais, com duas repetições por concreto de cada caminhão amostrado}

Tabela 101 - Resultados dos ensaios de absorção de água total nos corpos-de-prova do lote 1

\begin{tabular}{|c|c|c|c|c|c|c|c|c|c|c|c|c|}
\hline 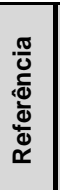 & 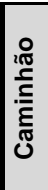 & 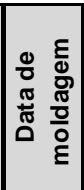 & Cura & $\begin{array}{c}\text { Massa } \\
\text { saturada } \\
\text { após cura } \\
\text { (g) }\end{array}$ & \begin{tabular}{|c|} 
Massa \\
saturada (g) \\
após \\
fervura a \\
$100^{\circ} \mathrm{C}$
\end{tabular} & $\begin{array}{c}\text { Massa } \\
\text { submers } \\
\text { a em } \\
\text { água (g) }\end{array}$ & \begin{tabular}{|c|} 
Massa \\
seca a \\
$100^{\circ} \mathrm{C}$ após \\
$72 \mathrm{hs}$ na \\
estufa
\end{tabular} & $\begin{array}{c}\text { Absorçã } \\
\text { o de } \\
\text { água } \\
\text { total (\%) }\end{array}$ & $\begin{array}{c}\text { Indice } \\
\text { de } \\
\text { vazios } \\
(\%)\end{array}$ & $\begin{array}{c}\text { Massa } \\
\text { especifica } \\
\text { da amostra } \\
\text { seca } \\
\left(\mathrm{g} / \mathrm{cm}^{3}\right)\end{array}$ & \begin{tabular}{|c|} 
Massa \\
especifica \\
da amostra \\
saturada \\
$\left(\mathrm{g} / \mathrm{cm}^{3}\right)$
\end{tabular} & $\begin{array}{c}\text { Massa } \\
\text { especific } \\
\text { a real } \\
\left(\mathrm{g} / \mathrm{cm}^{3}\right)\end{array}$ \\
\hline 381 & 1 & \multirow{24}{*}{ 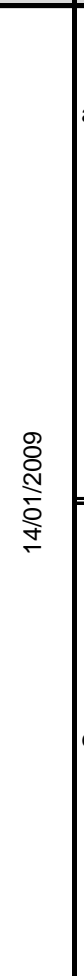 } & \multirow{12}{*}{$\begin{array}{c}\text { Cura } \\
\text { acelerad } \\
\text { a 24/48 } \\
\text { horas - } \\
\text { ASTM } \\
\mathrm{A} ; \mathrm{e} \\
\text { cura } \\
\text { imersa } \\
\text { em água } \\
\text { até } 7 \\
\text { dias }\end{array}$} & 3689,7 & 3694,7 & 2146,2 & 3493,6 & 5,76 & 12,99 & 2,26 & 2,39 & 2,59 \\
\hline 382 & & & & 3715,8 & 3720,2 & 2170,9 & 3538,1 & 5,15 & 11,75 & 2,28 & 2,40 & 2,59 \\
\hline 383 & 2 & & & 3719,7 & 3723,3 & 2150,6 & 3523,4 & 5,67 & 12,71 & 2,24 & 2,37 & 2,57 \\
\hline 384 & & & & 3711,0 & 3718,2 & 2158,7 & 3523,4 & 5,53 & 12,49 & 2,26 & 2,38 & 2,58 \\
\hline 385 & 3 & & & 3680,4 & 3688,2 & 2146,5 & 3487,9 & 5,74 & 12,99 & 2,26 & 2,39 & 2,60 \\
\hline 386 & 3 & & & 3627,1 & 3633,9 & 2104,9 & 3435,5 & 5,77 & 12,98 & 2,25 & 2,38 & 2,58 \\
\hline 387 & 4 & & & 3642,7 & 3648,0 & 2100,2 & 3429,2 & 6,38 & 14,14 & 2,22 & 2,36 & 2,58 \\
\hline 388 & & & & 3638,1 & 3644,8 & 2106,6 & 3437,1 & 6,04 & 13,50 & 2,23 & 2,37 & 2,58 \\
\hline 389 & 5 & & & 3690,9 & 3645,8 & 2145,3 & 3482,6 & 4,69 & 10,88 & 2,32 & 2,43 & 2,60 \\
\hline 390 & & & & 3685,3 & 3689,4 & 2135,4 & 3479,9 & 6,02 & 13,48 & 2,24 & 2,37 & 2,59 \\
\hline 391 & 6 & & & 3678,5 & 3681,5 & 2132,7 & 3473,9 & 5,98 & 13,40 & 2,24 & 2,38 & 2,59 \\
\hline 392 & & & & 3622,5 & 3629,6 & 2101,4 & 3422,6 & 6,05 & 13,55 & 2,24 & 2,38 & 2,59 \\
\hline 393 & 1 & & \multirow{12}{*}{$\begin{array}{c}\text { Cura } \\
\text { imersa } \\
\text { em água } \\
\text { por } 28 \\
\text { dias }\end{array}$} & 3667,2 & 3663,7 & 2143,5 & 3483,8 & 5,16 & 11,83 & 2,29 & 2,41 & 2,60 \\
\hline 394 & & & & 3696,0 & 3697,4 & 2145,6 & 3503,0 & 5,55 & 12,53 & 2,26 & 2,38 & 2,58 \\
\hline 395 & 2 & & & 3708,7 & 3704,0 & 2149,3 & 3513,8 & 5,41 & 12,23 & 2,26 & 2,38 & 2,58 \\
\hline 396 & & & & 3710,2 & 3705,5 & 2149,5 & 3517 & 5,36 & 12,11 & 2,26 & 2,38 & 2,57 \\
\hline 397 & 3 & & & 3648,0 & 3644,5 & 2116,6 & 3446,5 & 5,74 & 12,96 & 2,26 & 2,39 & 2,59 \\
\hline 398 & 3 & & & 3656,1 & 3650,9 & 2110,4 & 3451,7 & 5,77 & 12,93 & 2,24 & 2,37 & 2,57 \\
\hline 399 & 4 & & & 3653,9 & 3648,1 & 2107,7 & 3429,1 & 6,39 & 14,22 & 2,23 & 2,37 & 2,60 \\
\hline 400 & & & & 3676,4 & 3673,3 & 2131,0 & 3472,7 & 5,78 & 13,01 & 2,25 & 2,38 & 2,59 \\
\hline 401 & 5 & & & 3651,5 & 3648,8 & 2106,5 & 3430,7 & 6,36 & 14,14 & 2,22 & 2,37 & 2,59 \\
\hline 402 & & & & 3738,9 & 3736,7 & 2166,7 & 3518,4 & 6,20 & 13,90 & 2,24 & 2,38 & 2,60 \\
\hline 403 & 6 & & & 3735,8 & 3732,5 & 2168,3 & 3531,2 & 5,70 & 12,87 & 2,26 & 2,39 & 2,59 \\
\hline 404 & & & & 3667,8 & 3660,2 & 2115,0 & 3459,2 & 5,81 & 13,01 & 2,24 & 2,37 & 2,57 \\
\hline
\end{tabular}




\section{APÊNDICE C}

\section{Resultados dos Ensaios Individuais, com duas repetições por concreto de cada caminhão amostrado}

Tabela 102 - Resultados dos ensaios de absorção de água por capilaridade nos corpos-de-prova do lote 1

\begin{tabular}{|c|c|c|c|c|c|c|c|c|c|c|c|c|c|c|c|c|c|c|c|c|c|c|c|c|c|}
\hline \multirow[b]{2}{*}{ 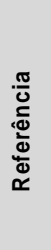 } & \multirow[b]{2}{*}{ 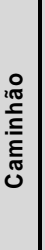 } & \multirow{2}{*}{ 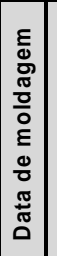 } & \multirow[b]{2}{*}{ Cura } & \multirow[b]{2}{*}{$\begin{array}{c}\text { Massa } \\
\text { após } \\
\text { cura } \\
(\mathrm{g})\end{array}$} & \multirow[b]{2}{*}{$\mid \begin{array}{c}\text { Massa (g) } \\
\text { após } 24 \\
\text { horas na } \\
\text { estufa a } \\
100^{\circ} \mathrm{C}\end{array}$} & \multirow[b]{2}{*}{$\mid \begin{array}{c}\text { Massa (g) } \\
\text { após } 48 \\
\text { horas na } \\
\text { estufa a } \\
100^{\circ} \mathrm{C}\end{array}$} & \multirow[b]{2}{*}{$\begin{array}{c}\text { Massa } \\
\text { (g) após } \\
72 \text { horas } \\
\text { na estufa } \\
\text { a } 100^{\circ} \mathrm{C}\end{array}$} & \multicolumn{9}{|c|}{ Massa Adquirida na absorção de água por capilaridade (g) } & \multicolumn{9}{|c|}{ Absorção de água por capilaridade $\left(\mathrm{g} / \mathrm{cm}^{2}\right)$} \\
\hline & & & & & & & & 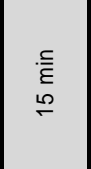 & $\begin{array}{l}\text { 高 } \\
\text { 品 }\end{array}$ & 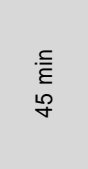 & ๕̋ & $\begin{array}{l}\frac{\pi}{\pi} \\
\frac{\pi}{0} \\
\frac{0}{m}\end{array}$ & $\begin{array}{l}\frac{1}{\pi} \\
\frac{\pi}{0} \\
\frac{0}{6}\end{array}$ & 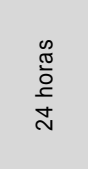 & 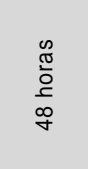 & $\begin{array}{l}\mathbb{N} \\
\stackrel{\pi}{0} \\
\stackrel{2}{N} \\
\text { N }\end{array}$ & 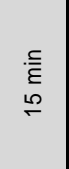 & 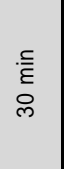 & 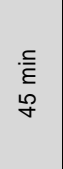 & $\begin{array}{l}\frac{\sigma}{0} \\
\frac{0}{\check{c}}\end{array}$ & $\begin{array}{l}\frac{\pi}{\pi} \\
\frac{\pi}{0} \\
\frac{0}{m}\end{array}$ & $\begin{array}{l}\frac{\pi}{\pi} \\
\frac{\pi}{0} \\
0\end{array}$ & 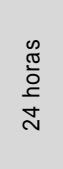 & 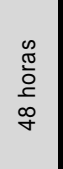 & 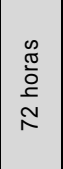 \\
\hline 381 & \multirow{4}{*}{2} & \multirow{12}{*}{\multicolumn{2}{|c|}{$\begin{array}{c}\text { Cura } \\
\text { acelerad } \\
\text { a } 24 / 48 \\
\text { horas - } \\
\text { ASTM A; } \\
\text { e cura } \\
\text { imersa } \\
\text { em água } \\
\text { até } 7 \\
\text { dias }\end{array}$}} & 89,7 & 3529,7 & 3510,7 & 3493,6 & 3503,4 & 3510,7 & $\overline{513,2}$ & \begin{tabular}{|l|l|}
3517,6 \\
\end{tabular} & 3530,3 & 3538,4 & 3564,4 & 3580,0 & 3589,1 & 0,12 & 0,22 & 0,25 & 0,31 & 0,47 & 0,57 & 0,90 & 1,10 & 1,22 \\
\hline 382 & & & & 3715,8 & 3558,4 & 3543,3 & 3538,1 & 3548,0 & 3553,6 & 3557,7 & 3560,3 & 3573,1 & 3579,4 & 3600,1 & 3612,7 & 3622,0 & 0,13 & 0,20 & 0,25 & 0,28 & 0,45 & 0,53 & 0,79 & 0,95 & \begin{tabular}{|l|}
1,07 \\
\end{tabular} \\
\hline 383 & & & & \begin{tabular}{|l|}
3719,7 \\
\end{tabular} & 3567,4 & 3548,9 & 3523,4 & 3533,6 & 3537,9 & 3540,4 & \begin{tabular}{|l|}
3543,0 \\
\end{tabular} & 3555,7 & 3562,8 & 3588,8 & 3602,5 & 3608,5 & 0,13 & 0,18 & 0,22 & 0,25 & 0,41 & 0,50 & 0,83 & 1,01 & \begin{tabular}{|l|}
1,08 \\
\end{tabular} \\
\hline 384 & & & & 3711,0 & 3559,1 & 3537,4 & 3523,6 & 3532,6 & 3536,2 & 3540,2 & \begin{tabular}{|l|}
3541,9 \\
\end{tabular} & 3551,3 & \begin{tabular}{|l|}
3558,4 \\
\end{tabular} & 3580,3 & \begin{tabular}{|l|l|}
3594,4 \\
\end{tabular} & 3608,0 & 0,11 & 0,16 & 0,21 & 0,23 & 0,35 & 0,44 & 0,72 & 0,90 & 1,07 \\
\hline 385 & \multirow[t]{2}{*}{3} & & & 3680,4 & 3509,0 & 3498,2 & 3487,9 & 3498,3 & 3503,5 & 3508,3 & 3511,1 & 3521,1 & 3529,6 & 3555,7 & 3570,2 & 3579,3 & 0,13 & 0,20 & 0,26 & 0,30 & 0,42 & 0,53 & 0,86 & 1,05 & \begin{tabular}{|l|}
1,16 \\
\end{tabular} \\
\hline 386 & & & & 3627,1 & 3460,1 & 3445,7 & 3435,5 & 3448,4 & 3454,8 & 3459,9 & \begin{tabular}{|l|}
3463,4 \\
\end{tabular} & 3481,6 & 3490,3 & 3519,5 & 3531,6 & 3541,9 & 0,16 & 0,25 & 0,31 & 0,36 & 0,59 & 0,70 & 1,07 & 1,22 & 1,35 \\
\hline 387 & & & & 3642,7 & 3463,8 & 3443,8 & 3429,2 & 3439,2 & 3444,2 & \begin{tabular}{|l|l}
3448,8 \\
\end{tabular} & 3450,7 & 3464,3 & 3473,0 & 3502,4 & 3519,3 & 3530,0 & 0,13 & 0,19 & 0,25 & 0,27 & 0,45 & 0,56 & 0,93 & 1,15 & 1,28 \\
\hline 388 & & & & 3638,1 & 3480,2 & 3459,8 & 3437,1 & 3446,4 & 3450,3 & 3453,6 & 3455,8 & 3469,5 & 3479,1 & 3507,0 & 3519,1 & 3529,2 & 0,12 & 0,17 & 0,21 & 0,24 & 0,41 & 0,53 & 0,89 & 1,04 & 1,17 \\
\hline 389 & & & & 3690,9 & 3518,8 & 3495,4 & 3482,6 & \begin{tabular}{|l|}
3493,5 \\
\end{tabular} & \begin{tabular}{|l|}
3498,7 \\
\end{tabular} & 3502,9 & 3505,0 & 3520,5 & 3528,7 & 3560,0 & 3580,2 & \begin{tabular}{|l|}
3593,4 \\
\end{tabular} & 0,14 & 0,20 & 0,26 & 0,29 & 0,48 & 0,59 & 0,99 & 1,24 & \begin{tabular}{|l|}
1,41 \\
\end{tabular} \\
\hline 390 & & & & 3685,3 & 3530,7 & 3515,1 & 3479,9 & 3489,0 & 3492,9 & 3495,8 & 3498,4 & 3511,0 & 3516,9 & 3544,2 & 3561,6 & 3572,1 & 0,12 & 0,17 & 0,20 & 0,24 & 0,40 & 0,47 & 0,82 & 1,04 & \begin{tabular}{|l|}
1,17 \\
\end{tabular} \\
\hline 391 & & & & 3678,5 & 3509,3 & 3490,3 & 3473,9 & 3484,0 & 3489,4 & 3492,9 & 3498,3 & 3515,0 & 3520,2 & 3548,0 & 3560,1 & 3571,3 & 0,13 & 0,20 & 0,24 & 0,31 & 0,52 & 0,59 & 0,94 & 1,10 & \begin{tabular}{|l|}
1,24 \\
\end{tabular} \\
\hline 392 & & & & 3622,5 & 3463,3 & 3437,5 & 3422,6 & 3433,7 & 3438,8 & 3442,9 & 3444,2 & 3460,8 & 3467,5 & 3494,6 & 3511,3 & 3522,5 & 0,14 & 0,21 & 0,26 & 0,28 & 0,49 & 0,57 & 0,92 & 1,13 & \begin{tabular}{|l|}
1,27 \\
\end{tabular} \\
\hline 393 & \multirow{4}{*}{15} & 잏 & \multirow{12}{*}{$\begin{array}{c}\text { Cura } \\
\text { imersa } \\
\text { emágua } \\
\text { por } 28 \\
\text { dias }\end{array}$} & \begin{tabular}{|l|l|}
3667,2 \\
\end{tabular} & $\begin{array}{l}3524,9 \\
\end{array}$ & $\begin{array}{l}3504,3 \\
\end{array}$ & $\begin{array}{l}3483,8 \\
\end{array}$ & \begin{tabular}{|l|l|}
3486,4 \\
\end{tabular} & 3490,9 & \begin{tabular}{|c|}
3493,8 \\
\end{tabular} & \begin{tabular}{|c|}
3496,7 \\
\end{tabular} & \begin{tabular}{|c|}
3509,0 \\
\end{tabular} & \begin{tabular}{|c|}
3513,8 \\
\end{tabular} & $\begin{array}{c}3539,1 \\
\end{array}$ & \begin{tabular}{|c|}
3555,4 \\
\end{tabular} & 3565,6 & \begin{tabular}{|l|l|}
0,03 \\
\end{tabular} & 0,09 & $\overline{0,13}$ & 0,16 & 0,32 & 0,38 & 0,70 & \begin{tabular}{|c|}
0,91 \\
\end{tabular} & \begin{tabular}{|l|l|}
1,04 \\
\end{tabular} \\
\hline 394 & & & & 3696,0 & 3552,4 & \begin{tabular}{|l|}
3528,8 \\
\end{tabular} & 3503,0 & 3507,4 & 3513,1 & 3516,7 & \begin{tabular}{|l|}
3519,8 \\
\end{tabular} & 3534,6 & 3549,9 & 3588,6 & 3605,9 & 3614,1 & 0,06 & 0,13 & 0,17 & \begin{tabular}{|l|l|}
0,21 \\
\end{tabular} & 0,40 & 0,60 & 1,09 & 1,31 & \begin{tabular}{|l|}
1,41 \\
\end{tabular} \\
\hline 395 & & & & 3708,7 & 3556,8 & 3537,1 & 3513,8 & \begin{tabular}{|l|}
3516,9 \\
\end{tabular} & 3522,6 & 3527,3 & \begin{tabular}{|l|}
3531,8 \\
\end{tabular} & 3540,5 & 3556,5 & 3588,1 & 3603,5 & 3612,5 & 0,04 & 0,11 & 0,17 & 0,23 & 0,34 & 0,54 & 0,95 & 1,14 & 1,26 \\
\hline 396 & & & & 3710,2 & 3557,2 & 3536,1 & 3517,0 & \begin{tabular}{|l|}
3522,3 \\
\end{tabular} & 3528,9 & 3533,5 & \begin{tabular}{|l|}
3538,3 \\
\end{tabular} & 3557,8 & 3565,0 & 3595,0 & 3609,5 & 3616,2 & 0,07 & 0,15 & 0,21 & 0,27 & 0,52 & 0,61 & 0,99 & 1,18 & 1,26 \\
\hline 397 & & & & 3648,0 & 3475,1 & 3454,4 & 3446,5 & 3455,4 & 3462,2 & 3466,8 & 3470,9 & 3489,0 & 3496,6 & 3528,6 & 3544,2 & 3553,8 & 0,11 & 0,20 & 0,26 & 0,31 & 0,54 & 0,64 & 1,05 & 1,24 & 1,37 \\
\hline 398 & & & & 3656,1 & 3493,2 & 3471,9 & 3451,7 & 3455,1 & 3461,6 & 3465,5 & 3469,4 & 3486,4 & 3492,3 & 3525,8 & 3544,5 & 3554,1 & 0,04 & 0,13 & 0,18 & 0,23 & 0,44 & 0,52 & 0,94 & 1,18 & \begin{tabular}{|l|}
1,30 \\
\end{tabular} \\
\hline 399 & \multirow[t]{2}{*}{4} & & & 3653,9 & 3471,6 & 3446,0 & 3429,1 & \begin{tabular}{|l|}
3436,1 \\
\end{tabular} & 3442,4 & 3446,5 & 3450,3 & 3469,5 & 3476,5 & 3512,0 & 3532,1 & 3543,4 & 0,09 & 0,17 & 0,22 & 0,27 & 0,51 & 0,60 & 1,06 & 1,31 & 1,46 \\
\hline 400 & & & & 3676,4 & $\begin{array}{l}3522,2 \\
\end{array}$ & 3492,1 & 3472,7 & \begin{tabular}{|l|}
3479,6 \\
\end{tabular} & 3488,0 & \begin{tabular}{|l|l|}
3494,8 \\
\end{tabular} & \begin{tabular}{|l|}
3500,3 \\
\end{tabular} & 3523,2 & 3530,9 & 3563,0 & 3580,0 & 3588,9 & 0,09 & 0,19 & 0,28 & 0,35 & 0,64 & 0,74 & 1,15 & 1,37 & \begin{tabular}{|l|}
1,48 \\
\end{tabular} \\
\hline 401 & \multirow[t]{2}{*}{5} & & & 3651,5 & 3477,2 & 3451,7 & 3430,7 & \begin{tabular}{|l|}
3439,6 \\
\end{tabular} & 3449,6 & 3455,0 & \begin{tabular}{|l|}
3462,9 \\
\end{tabular} & 3487,5 & 3469,3 & 3536,9 & 3554,3 & 3564,2 & 0,11 & 0,24 & 0,31 & 0,41 & 0,72 & 0,49 & 1,35 & 1,57 & \begin{tabular}{|l|}
1,70 \\
\end{tabular} \\
\hline 402 & & & & 3738,9 & 3568,3 & 3532,6 & 3518,4 & \begin{tabular}{|l|}
3525,3 \\
\end{tabular} & 3531,6 & 3535,5 & 3540 & 3558,1 & 3564,8 & 3600,6 & 3620,4 & 3631,2 & 0,09 & 0,17 & 0,22 & 0,28 & 0,51 & 0,59 & 1,05 & 1,30 & 1,44 \\
\hline 403 & \multirow[t]{2}{*}{6} & & & 3735,8 & 3582,0 & 3555,5 & & 3536,0 & 3541,4 & 3545,4 & 3549,1 & 3564,8 & 3571,5 & 3603,9 & 3622,7 & 3633,0 & 0,06 & 0,13 & 0,18 & 23 & 43 & 0,51 & 0,93 & 1,17 & 1,30 \\
\hline 404 & & & & \begin{tabular}{|l|}
3667,8 \\
\end{tabular} & 3481,2 & 3459,2 & 3440,5 & \begin{tabular}{|l|}
3449,0 \\
\end{tabular} & 3456,7 & 3461,1 & 3465,5 & 3483,7 & 3490,1 & 3521,8 & \begin{tabular}{|l|l|}
3538,8 \\
\end{tabular} & 3548,4 & 0,11 & 0,21 & 0,26 & 0,32 & 0,55 & 0,63 & 1,04 & 1,25 & \begin{tabular}{|l|}
1,37 \\
\end{tabular} \\
\hline
\end{tabular}




\section{APÊNDICE C}

\section{Resultados dos Ensaios Individuais, com duas repetições por concreto de cada caminhão amostrado}

Tabela 103 - Resultados dos ensaios mecânicos nos corpos-de-prova amostrados dos caminhões do lote 1

\begin{tabular}{|c|c|c|c|c|c|c|c|c|c|c|c|c|c|c|c|c|c|c|c|c|c|c|c|c|c|c|c|c|c|c|c|}
\hline \multirow{3}{*}{$\mid \mathrm{NO}^{\circ}$} & \multirow{3}{*}{$\begin{array}{c}\text { Porpriedadel } \\
\text { Caminhão }\end{array}$} & \multirow{2}{*}{\multicolumn{6}{|c|}{$\begin{array}{l}\text { Média } \\
\end{array}$}} & \multirow{2}{*}{\multicolumn{6}{|c|}{ Desvio Padrão }} & \multicolumn{6}{|c|}{ Coeficiente de variação } & \multirow{2}{*}{\multicolumn{6}{|c|}{$\frac{\text { Valor maximo }}{\text { Caminhão }}$}} & \multirow{2}{*}{\multicolumn{6}{|c|}{$\frac{\text { Valor minimo }}{\text { Caminhão }}$}} \\
\hline & & & & & & & & & & & & & & & & $\mathrm{Cam}$ & nhão & & & & & & & & & & & & & & \\
\hline & & 1 & 2 & 3 & 4 & \begin{tabular}{|l|}
5 \\
\end{tabular} & 6 & 1 & \begin{tabular}{|l|}
2 \\
\end{tabular} & 3 & 4 & 5 & 6 & 1 & 2 & 3 & 4 & 5 & 6 & 1 & 2 & 3 & 4 & 5 & 6 & 1 & 2 & 3 & 4 & 5 & 6 \\
\hline & $\begin{array}{c}\text { Resistência à } \\
\text { compressão }-f_{\mathrm{c}} 1 \\
\text { (MPa) }\end{array}$ & 18,85 & $\mid 19,60$ & 17,45 & 16,90 & 14,75 & \begin{tabular}{|l|l} 
& 18,80 \\
\end{tabular} & 0,6 & 0,6 & 1,5 & \begin{tabular}{|l|l|} 
& 0,4 \\
\end{tabular} & 0,5 & 0,3 & $3 \%$ & $3 \%$ & $9 \%$ & $3 \%$ & $3 \%$ & $2 \%$ & 19,3 & 20,0 & 18,5 & 17,2 & 15,1 & 19,0 & 18,40 & 19,20 & 16,40 & 16,60 & 14,40 & 18,60 \\
\hline & 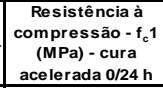 & 28,10 & 30,85 & \begin{tabular}{|l}
27,85 \\
\end{tabular} & 23,55 & 21,95 & 25,25 & 0,6 & 0,5 & 0,5 & \begin{tabular}{|l|}
0,6 \\
\end{tabular} & \begin{tabular}{|l|}
2,1 \\
\end{tabular} & 0,6 & $2 \%$ & $2 \%$ & $2 \%$ & $3 \%$ & $9 \%$ & $3 \%$ & 28,5 & 31,2 & 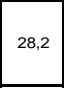 & 24,0 & 23,4 & 25,7 & 27,10 & 30,50 & 27,50 & 23,10 & 20,50 & 24,80 \\
\hline & $\begin{array}{c}\text { Resistên ncia à } \\
\text { compressão - } f_{\mathrm{c}} 7 \\
\text { (MPa) - cura } \\
\text { acelerada 24/48 } \\
\text { e imersãa em } \\
\text { água até } 7 \text { dias }\end{array}$ & $34,20 \mid$ & 29,40 & \begin{tabular}{|l}
29,20 \\
\end{tabular} & 29,85 & 29,15 & 30,00 & $\begin{array}{l}0,14 \\
\end{array}$ & 1,273 & 0,990 & $\mid 1,626]$ & \begin{tabular}{|l|l}
1,20 \\
\end{tabular} & 0,28 & $0 \%$ & $4 \%$ & $3 \%$ & $5 \%$ & $4 \%$ & $1 \%$ & 34,3 & 30,3 & \begin{tabular}{|l|}
29,9 \\
\end{tabular} & 31,0 & 30,0 & 30,2 & 34,10 & 28,50 & 28,50 & 28,70 & 28,30 & | 29,80 \\
\hline 16 & 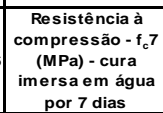 & 23,65 & 23,75 & $\mid 28,35$ & 28,60 & 27,10 & 26,40 & $\begin{array}{l}0,07 \\
\end{array}$ & 0,92 & 1,91 & 3,25 & \begin{tabular}{|l|l|} 
\\
\end{tabular} & 0,14 & $0 \%$ & $4 \%$ & $7 \%$ & $11 \%$ & $2 \%$ & $1 \%$ & 23,7 & 24,4 & 29,7 & 30,9 & 27,4 & 26,5 & 23,60 & 23,10 & 27,00 & 26,30 & 26,80 & 26,30 \\
\hline 17 & 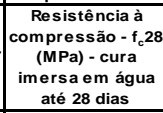 & 32,00 & 36,35 & \begin{tabular}{|l|}
29,55 \\
\end{tabular} & 31,00 & 32,55 & 29,55 & 0,6 & 1,1 & 4,0 & \begin{tabular}{|l|l|}
1,1 \\
\end{tabular} & 4,0 & 2,1 & $2 \%$ & $3 \%$ & $14 \%$ & $4 \%$ & $12 \%$ & $7 \%$ & 32,4 & 37,1 & 32,4 & 31,8 & 35,4 & 31,0 & 31,60 & 35,60 & 26,70 & 30,20 & \begin{tabular}{|l}
29,70 \\
\end{tabular} & 28,10 \\
\hline 18 & \begin{tabular}{|c|} 
Resistência à \\
compressấ- $\mathrm{f}_{6} 63$ \\
(MPa) - cura \\
imersa em água \\
até 63 dias
\end{tabular} & $|40,05|$ & 40,70 & $\mid 40,40$ & 32,80 & 36,00 & 42,3 & 0,2 & 0,3 & 2,0 & 8,2 & 0,8 & 1,3 & $1 \%$ & $1 \%$ & $5 \%$ & $25 \%$ & $2 \%$ & $3 \%$ & 40,2 & 40,9 & 41,8 & 38,6 & 36,6 & 43,2 & 39,90 & 40,50 & 39,00 & 27,00 & 35,40 & 41,30 \\
\hline 19 & \begin{tabular}{|c|} 
Resistência à \\
compressáo- foc \\
91 (MPa)-- cura \\
imersa em água \\
até 91 dias \\
\end{tabular} & 41,10 & 39,05 & 40,35 & 36,50 & 38,15 & $\mid 43,10$ & 2,3 & 2,3 & 0,5 & \begin{tabular}{|l|l|} 
& 0,7 \\
\end{tabular} & 0,9 & 0,8 & $6 \%$ & $6 \%$ & $1 \%$ & $2 \%$ & $2 \%$ & $2 \%$ & 42,70 & 40,70 & 40,70 & 37,00 & 38,80 & 43,70 & 39,50 & 37,40 & 40,00 & 36,00 & 37,50 & 42,50 \\
\hline 0 & 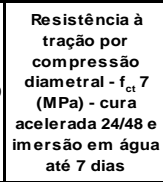 & 2,85 & $\mid 2,77$ & 2,85 & 2,64 & 2,88 & \begin{tabular}{|l|l}
2,68 \\
\end{tabular} & \begin{tabular}{|l|} 
\\
0,06
\end{tabular} & 0,23 & 0,42 & \begin{tabular}{|l|l|} 
\\
\end{tabular} & \begin{tabular}{|l|l} 
\\
\end{tabular} & 0,25 & $2 \%$ & $8 \%$ & $15 \%$ & $26 \%$ & $16 \%$ & $9 \%$ & 2,9 & 2,9 & 3,2 & 3,1 & 3,2 & 2,9 & 2,80 & 2,61 & 2,55 & 2,16 & 2,54 & 2,50 \\
\hline & 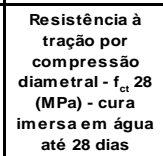 & 3,08 & 3,41 & \begin{tabular}{|l|}
3,14 \\
\end{tabular} & 3,12 & 3,41 & 3,12 & $0,0,23$ & 0,13 & 1,01 & $\mid 0,09$ & $\mid 0,32$ & 0,36 & $7 \%$ & $4 \%$ & $32 \%$ & $3 \%$ & $9 \%$ & $12 \%$ & 3,2 & 3,5 & 3,9 & 3,2 & 3,6 & 3,4 & 2,92 & 2,92 & 2,42 & 3,05 & 3,18 & 2,86 \\
\hline
\end{tabular}




\section{APÊNDICE C}

\section{Resultados dos Ensaios Individuais, com duas repetições por concreto de cada caminhão amostrado}

Tabela 104 - Resultados dos ensaios de tração por compressão diametral nos corpos-de-prova ciclados do lote 1.

\begin{tabular}{|c|c|c|c|c|c|c|c|}
\hline 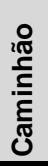 & 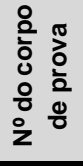 & 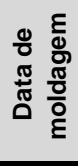 & 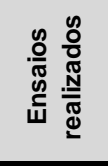 & $\begin{array}{c}\text { Resistência à } \\
\text { tração aos } 91 \\
\text { dias (MPa) }\end{array}$ & $\begin{array}{r}\text { Média } \\
(\mathrm{MPa})\end{array}$ & $\begin{array}{c}\text { Desvio } \\
\text { Padrão } \\
\text { (MPa) }\end{array}$ & $\begin{array}{c}\text { Coeficiente } \\
\text { de } \\
\text { Variação } \\
(\%)\end{array}$ \\
\hline \multirow{2}{*}{1} & 441 & \multirow{12}{*}{ 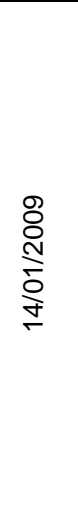 } & \multirow{3}{*}{ 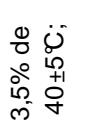 } & 5,60 & \multirow{2}{*}{5,37} & \multirow{2}{*}{0,33} & \multirow{2}{*}{$6 \%$} \\
\hline & 442 & & & 5,14 & & & \\
\hline \multirow{2}{*}{2} & 443 & & & 4,41 & \multirow{2}{*}{5,37} & \multirow{2}{*}{1,36} & \multirow{2}{*}{$25 \%$} \\
\hline & 444 & & \multirow{9}{*}{ 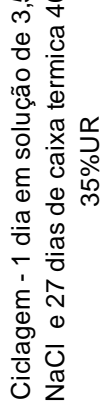 } & 6,33 & & & \\
\hline \multirow{2}{*}{3} & 445 & & & 4,42 & \multirow{2}{*}{4,89} & \multirow{2}{*}{0,66} & \multirow{2}{*}{$13 \%$} \\
\hline & 446 & & & 5,35 & & & \\
\hline \multirow{2}{*}{4} & 447 & & & 4,35 & \multirow{2}{*}{4,75} & \multirow{2}{*}{0,56} & \multirow{2}{*}{$12 \%$} \\
\hline & 448 & & & 5,14 & & & \\
\hline \multirow{2}{*}{5} & 449 & & & 5,03 & \multirow{2}{*}{5,39} & \multirow{2}{*}{0,50} & \multirow{2}{*}{$9 \%$} \\
\hline & 450 & & & 5,74 & & & \\
\hline \multirow{2}{*}{6} & 451 & & & 5,04 & \multirow{2}{*}{4,13} & \multirow{2}{*}{1,29} & \multirow{2}{*}{$31 \%$} \\
\hline & 452 & & & 3,21 & & & \\
\hline
\end{tabular}

$\mathrm{Na}$ Tabela 105 são apresentadas todas as medidas dos ensaios de carbonatação realizados em câmara de $\mathrm{CO}_{2}$, por fenolftaleína.

Tabela 105 - Resultados dos ensaios de carbonatação por câmara de $\mathrm{CO}_{2}$ ( $5 \%$; 7 dias) nos corposde-prova por fenolftaleína, submetidos a cura acelerada 24/48 horas mais imersão em água até 7 dias, do lote 1

\begin{tabular}{|c|c|c|c|c|c|c|c|c|c|c|c|}
\hline \multirow{3}{*}{ 选 } & \multirow{3}{*}{ 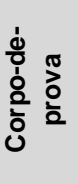 } & \multicolumn{9}{|c|}{ Metade A (fenol) } & \multirow{3}{*}{$\begin{array}{l}\text { Coeficiente de } \\
\text { carbonatação } \\
\qquad \begin{array}{c}(x=k \text { vt }) \\
\mathrm{mm} / \mathrm{ano}^{-1 / 2}\end{array}\end{array}$} \\
\hline & & \multicolumn{6}{|c|}{ Medidas (mm) } & \multirow{2}{*}{$\begin{array}{l}\text { Média } \\
(\mathrm{mm})\end{array}$} & \multirow{2}{*}{$\begin{array}{l}\text { Desvio } \\
\text { padrão } \\
(\mathrm{mm})\end{array}$} & \multirow{2}{*}{$\begin{array}{l}\text { Coeficiente } \\
\text { de variação } \\
\text { (\%) }\end{array}$} & \\
\hline & & Topo & Meio & Fundo & Topo & Meio & Fundo & & & & \\
\hline \multirow{2}{*}{1} & 429 & 5,12 & 7,74 & 7,34 & 5,10 & 6,83 & 8,51 & 6,8 & 1,4 & $21 \%$ & 48,9 \\
\hline & 430 & 7,74 & 7,85 & 9,26 & 8,00 & 8,03 & 7,30 & 8,0 & 0,7 & $8 \%$ & 58,0 \\
\hline \multirow{2}{*}{2} & 431 & 5,79 & 6,70 & 5,63 & 9,30 & 6,35 & 6,92 & 6,8 & 1,3 & $20 \%$ & 49,0 \\
\hline & 432 & 4,68 & 5,06 & 5,75 & 7,34 & 9,37 & 8,56 & 6,8 & 1,9 & $28 \%$ & 49,1 \\
\hline \multirow{2}{*}{3} & 433 & 10,71 & 9,27 & 7,87 & 7,99 & 9,46 & 5,52 & 8,5 & 1,8 & $21 \%$ & 61,2 \\
\hline & 434 & 7,38 & 11,70 & 14,15 & 7,60 & 12,77 & 10,91 & 10,8 & 2,8 & $26 \%$ & 77,6 \\
\hline \multirow{2}{*}{4} & 435 & 10,96 & 11,11 & 9,64 & 13,22 & 11,77 & 10,20 & 11,2 & 1,3 & $11 \%$ & 80,5 \\
\hline & 436 & 8,30 & 11,02 & 13,42 & 4,71 & 11,03 & 9,16 & 9,6 & 3,0 & $31 \%$ & 69,4 \\
\hline \multirow{2}{*}{5} & 437 & 9,27 & 6,97 & 6,89 & 4,94 & 5,75 & 4,87 & 6,4 & 1,7 & $26 \%$ & 46,6 \\
\hline & 438 & 17,45 & 13,44 & 14,79 & 10,64 & 14,62 & 11,85 & 13,8 & 2,4 & $17 \%$ & 99,6 \\
\hline \multirow{2}{*}{6} & 439 & 11,80 & 12,48 & 10,90 & 11,89 & 10,15 & 12,25 & 11,6 & 0,9 & $8 \%$ & 83,6 \\
\hline & 440 & 11,17 & 10,66 & 7,25 & 6,03 & 8,17 & 5,00 & 8,0 & 2,5 & $31 \%$ & 58,1 \\
\hline
\end{tabular}


$\mathrm{Na}$ Tabela 106 são apresentadas todas as medidas dos ensaios de carbonatação realizados em câmara de $\mathrm{CO}_{2}$, por timolftaleína.

Tabela 106 - Resultados dos ensaios de carbonatação por câmara de $\mathrm{CO}_{2}$ (5\%; 7 dias) nos corposde-prova por timolftaleína, submetidos a cura acelerada 24/48 horas mais imersão em água até 7 dias, do lote 1

\begin{tabular}{|c|c|c|c|c|c|c|c|c|c|c|c|}
\hline \multirow{3}{*}{ 迹 } & \multirow{3}{*}{ 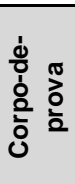 } & \multicolumn{9}{|c|}{ Metade B (timol) } & \multirow{3}{*}{$\begin{array}{c}\text { Coeficiente de } \\
\text { carbonatação } \\
(\mathbf{x}=\mathbf{k} \text { vt }) \\
\mathrm{mm} / \mathrm{ano}^{-1 / 2}\end{array}$} \\
\hline & & \multicolumn{6}{|c|}{ Medidas (mm) } & \multirow{2}{*}{$\begin{array}{l}\text { Média } \\
(\mathrm{mm})\end{array}$} & \multirow{2}{*}{$\begin{array}{c}\text { Desvio } \\
\text { padrão } \\
(\mathrm{mm})\end{array}$} & \multirow{2}{*}{$\begin{array}{c}\text { Coeficiente } \\
\text { de } \\
\text { variação } \\
\text { (\%) }\end{array}$} & \\
\hline & & Topo & Meio & Fundo & Topo & Meio & Fundo & & & & \\
\hline \multirow{2}{*}{1} & 429 & 13,61 & 16,66 & 12,62 & 8,53 & 14,67 & 10,55 & $\overline{12,8}$ & 2,9 & $23 \%$ & 92,2 \\
\hline & 430 & 11,18 & 13,2 & 23,08 & 9,13 & 9,83 & 16,13 & 13,8 & 5,2 & $38 \%$ & 99,3 \\
\hline \multirow{2}{*}{2} & 431 & 18,87 & 7,36 & 12,03 & 15,09 & 8,70 & 8,31 & 11,7 & 4,5 & $39 \%$ & 84,7 \\
\hline & 432 & 9,72 & 14,61 & 15,87 & 9,91 & 10,73 & 9,96 & 11,8 & 2,7 & $23 \%$ & 85,2 \\
\hline \multirow{2}{*}{3} & 433 & 10,35 & 22,56 & 12,75 & 14,7 & 8,30 & 13,90 & 13,8 & 4,9 & $36 \%$ & 99,4 \\
\hline & 434 & 12,06 & 21,42 & 20,63 & 10,89 & 14,50 & 12,32 & 15,3 & 4,6 & $30 \%$ & 110,5 \\
\hline \multirow{2}{*}{4} & 435 & 11,43 & 11,40 & 8,40 & 11,02 & 9,00 & 9,90 & 10,2 & 1,3 & $13 \%$ & 73,6 \\
\hline & 436 & 8,34 & 12,02 & 10,01 & 12,09 & 20,40 & 18,60 & 13,6 & 4,8 & $36 \%$ & 98,0 \\
\hline \multirow{2}{*}{5} & 437 & 14,18 & 12,20 & 10,87 & 14,55 & 13,80 & 10,72 & 12,7 & 1,7 & $13 \%$ & 91,9 \\
\hline & 438 & 35,57 & 26,35 & 26,50 & 30,00 & 23,60 & 12,14 & 25,7 & 7,8 & $30 \%$ & 185,5 \\
\hline \multirow{2}{*}{6} & 439 & 19,79 & 20,44 & 12,00 & 14,60 & 12,36 & 10,55 & 15,0 & 4,2 & $28 \%$ & 108,0 \\
\hline & 440 & 8,04 & 13,43 & 17,96 & 17,07 & 18,53 & 18,11 & 15,5 & 4,1 & $26 \%$ & 112,1 \\
\hline
\end{tabular}




\section{APÊNDICE C}

\section{Resultados dos Ensaios Individuais, com duas repetições por concreto de cada caminhão amostrado}

A Figura 77 ilustra a variação de massa nos corpos-de-prova, submetidos a três ciclos de imersão e secagem, dos ensaios de penetração de cloretos, amostrados dos caminhões do lote 1.

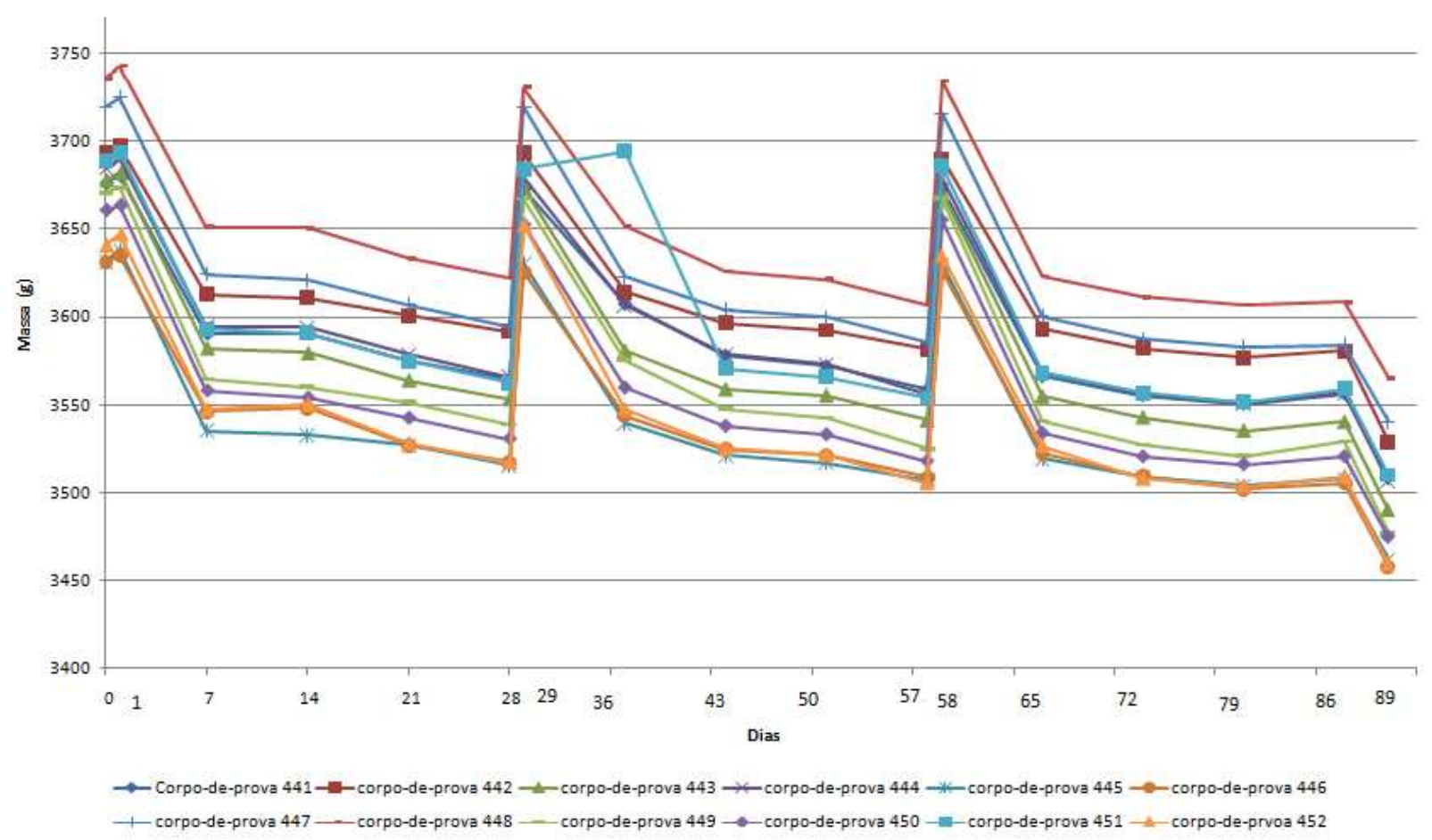

Figura 77 - Acompanhamento de massa dos corpos-de-prova, expostos a três ciclos de imersão e secagem, amostrados do lote 1.

A Tabela 107 ilustra a variação de massa nos corpos-de-prova, submetidos a três ciclos de imersão e secagem, dos ensaios de penetração de cloretos e carbonatação, amostrados dos caminhões do lote 1. 


\section{APÊNDICE C}

\section{Resultados dos Ensaios Individuais, com duas repetições por concreto de cada caminhão amostrado}

\begin{tabular}{|c|c|c|c|c|c|c|c|c|c|c|c|c|c|c|c|c|c|c|c|c|c|}
\hline \multirow{3}{*}{$\ddot{\bar{\omega}}$} & \multirow{3}{*}{$\mid$} & \multirow{3}{*}{ 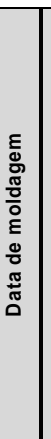 } & \multirow{3}{*}{ 气ूّ } & \multirow{3}{*}{ 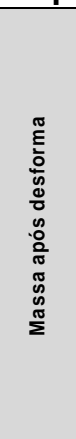 } & \multirow[b]{2}{*}{\begin{tabular}{|c|} 
Peso \\
saturado \\
após a 7 \\
dias de \\
cura \\
(antes do \\
inicio da \\
ciclagem) \\
4/12/08
\end{tabular}} & \multicolumn{5}{|c|}{$1^{a^{3}}$ Ciclagem (inicio de 21/01 a 18/02/09) - 24 horas } & \multicolumn{5}{|c|}{$2^{2^{\mathrm{C}}}$ Ciclagem (inicio em 19/02 a 18/03/09) - 24 horas } & \multicolumn{5}{|c|}{$3^{a}$ Ciclagem (inicio em 19/03 a 16/04/09) - 24 horas imerso } & \multirow[b]{2}{*}{$\begin{array}{l}\text { Massa após } \\
72 \text { horas na } \\
\text { estufa a } \\
\text { 100c }\end{array}$} \\
\hline & & & & & & \begin{tabular}{|c} 
Massa \\
úmida \\
saturada \\
(g) após \\
24 horas \\
em \\
solução \\
de NaCL \\
(22/01/09)
\end{tabular} & \begin{tabular}{|c|} 
Massa \\
seca (g) \\
apos 7 \\
dias na \\
estufa \\
artificial a \\
$50^{\circ} \pm 5^{\circ} \mathrm{C}$ \\
(energia \\
solar e \\
elétrica); \\
UR 40\% \pm 5 \\
$(29 / 1 / 109)$
\end{tabular} & \begin{tabular}{|l} 
Massa \\
seca (g) \\
após 14 \\
dias na \\
estufa \\
artificiala \\
$50^{\circ} \pm 5^{\circ} \mathrm{C}$ \\
(energia \\
solar e \\
elétrica); \\
UR 40\%+5 \\
(5502/096)
\end{tabular} & \begin{tabular}{|c|} 
Massa \\
seca $(g)$ \\
após 21 \\
dias na \\
estufa \\
artificial a \\
$50^{\circ} \pm 5^{\circ} \mathrm{C}$ \\
(energia \\
solar e \\
elétrica); \\
UR 40\% 45 \\
$(12 / 02 / 09)$ \\
\end{tabular} & \begin{tabular}{|c|} 
Massa \\
seca (g) \\
após 27 \\
dias na \\
estufa \\
artificial a \\
$50^{\circ} \pm 5^{\circ} \mathrm{C}$ \\
(energia \\
solar e \\
elétrica); \\
UR 40\%+5 \\
$(18 / 02 / 200$ \\
$9)$
\end{tabular} & \begin{tabular}{|c} 
Massa \\
úmida \\
saturada \\
(g) após \\
24 horas \\
em \\
solução \\
de NaCL \\
$(19 / 02 / 09)$
\end{tabular} & \begin{tabular}{|c|} 
Massa \\
seca (g) \\
apos 7 \\
dias na \\
estufa \\
artificial a \\
$50^{\circ} \pm 5^{\circ} \mathrm{C}$ \\
(energia \\
solar e \\
elétrica); \\
UR 40\% \pm 5 \\
$(26 / 02 / 09)$ \\
\end{tabular} & \begin{tabular}{|l} 
Massa \\
seca (g) \\
apos 14 \\
dias na \\
estufa \\
artificiala a \\
$50^{\circ} \pm 5^{\circ} \mathrm{C}$ \\
(energia \\
solar e \\
elétrica); \\
UR 40\%+5 \\
$(5 / 03 / 09)$
\end{tabular} & \begin{tabular}{|l|} 
Massa \\
seca (g) \\
após 21 \\
dias na \\
estufa \\
artificial a \\
$50^{\circ} \pm 5^{\circ} \mathrm{C}$ \\
(energia \\
solar e \\
elétrica); \\
UR 40\% \pm 5 \\
$(12 / 03 / 09)$
\end{tabular} & \begin{tabular}{|c|} 
Massa \\
seca (g) \\
após 27 \\
dias na \\
estufa \\
artificial a \\
$50^{\circ} \pm 5^{\circ} \mathrm{C}$ \\
(energia \\
solar e \\
elétrica); \\
UR 40\% 45 \\
$(18 / 03 / 09)$
\end{tabular} & \begin{tabular}{|c} 
Massa \\
úmida \\
saturada \\
(g) após \\
24 horas \\
em \\
solução \\
de NaCL \\
$(19 / 03 / 09)$
\end{tabular} & \begin{tabular}{|c|} 
Massa \\
seca (g) \\
apos 7 \\
dias na \\
estufa \\
artificial a \\
$50^{\circ} \pm 5^{\circ} \mathrm{C}$ \\
(energia \\
solar e \\
elétrica); \\
UR 40\% \pm 5 \\
$(26 / 03 / 09)$ \\
\end{tabular} & \begin{tabular}{|c|} 
Massa \\
seca (g) \\
após 14 \\
dias na \\
estufa \\
artificiala a \\
$50^{\circ} \pm 5^{\circ} \mathrm{C}$ \\
(energia \\
solar e \\
elétrica); \\
UR 40\%+5 \\
(2/04/09)
\end{tabular} & \begin{tabular}{|c|} 
Massa \\
seca (g) \\
apó 21 \\
dias na \\
estufa \\
artificial a \\
$50^{\circ} \pm 5^{\circ} \mathrm{C}$ \\
(energia \\
solar e \\
elétrica); \\
UR 40\% 45 \\
$(09 / 04 / 09)$ \\
\end{tabular} & \begin{tabular}{|c|} 
Massa seca \\
(g) após 27 \\
dias na \\
estufa \\
artificial a \\
$50^{\circ} \pm 5^{\circ} \mathrm{C}$ \\
(energia \\
solar e \\
elétrica); UR \\
$40 \% \pm 5$ \\
$(16 / 04 / 09)$
\end{tabular} & \\
\hline & & & & & 0 & 1 & 7 & 14 & 21 & 28 & 29 & 36 & 43 & 50 & 57 & 58 & 65 & 72 & 79 & 86 & 89 \\
\hline 441 & 1 & & & 3635,0 & 3676,8 & 3680,6 & 3590,5 & 3590,7 & 3575,4 & 3564,8 & 3673,1 & 07,5 & 3577,9 & 3571,7 & 3558,3 & 3672,7 & 3566,2 & 3555,3 & 3550,5 & 56,2 & 507,9 \\
\hline 442 & & & & 3652,8 & 3693,5 & 3697,4 & 3612,8 & 3610,9 & 3600,7 & 3591,7 & 3693,2 & 3614,0 & 3596,5 & 3592,3 & 3581,6 & 3689,8 & 3593,0 & 3582,2 & 3576,5 & 880,7 & 528,9 \\
\hline 443 & م & & & 3634,7 & 3678,1 & 3682,4 & 3582,1 & 3579,4 & 3563,8 & 3553,3 & 3673,9 & 3580,7 & 3558,8 & 3555,3 & 3541,1 & 3671,2 & 3554,6 & 3542,7 & 3535,2 & 3540,2 & 3489,9 \\
\hline $\begin{array}{lll}444 \\
\end{array}$ & & & $4 / 48$ & 3640,7 & 3684,7 & 3690,0 & \begin{tabular}{|l|}
3594,4 \\
\end{tabular} & 3594,0 & 3578,8 & 3565,9 & 3679,4 & 3606,5 & \begin{tabular}{|l|}
3578,7 \\
\end{tabular} & 3573,0 & 3556,2 & 3678,7 & 3568,1 & 3556,2 & 3550,8 & 3556,4 & 5506,0 \\
\hline 445 & 3 & & & 3598,7 & 3631,5 & 3638,1 & 3535,1 & 3532,7 & 3526,9 & 3515,1 & 3630,3 & 3539,4 & 3521,0 & 3516,9 & 3506,9 & 3629,7 & 3519,0 & 3508,4 & 3504,0 & 3507,8 & 3461,8 \\
\hline 446 & & 8 & & 3591,5 & 3631,3 & 3635,0 & 3546,0 & 3547,8 & 3526,9 & 3517,0 & 3625,8 & 3543,5 & 3524,3 & 3521,1 & 3508,7 & 3625,7 & 3522,2 & 3509,3 & 3501,9 & 3505,4 & 3457,7 \\
\hline 447 & & $\stackrel{\Gamma}{5}$ & $e$ & 3682,1 & 3719,9 & 3725,1 & 3624,1 & 3620,9 & 3607,1 & 3594,2 & 3719,7 & 3622,7 & 3604,2 & 3599,6 & 3585,6 & 3715,8 & 3600,4 & 3587,3 & 3583,2 & 3584,0 & 3540,1 \\
\hline $\begin{array}{ll}448 \\
\end{array}$ & & $\hat{\sim}$ & imers & 3694,1 & 3735,8 & 3742,8 & 3651,1 & 3650,5 & 3633,2 & 3622,0 & $\begin{array}{ll}3730,8 \\
\end{array}$ & 3652,0 & 3626,1 & 3621,4 & 3607,1 & $\begin{array}{l}3734,3 \\
\end{array}$ & 3623,0 & 3611,1 & 3606,6 & 3608,3 & 3565,1 \\
\hline 449 & 5 & & a em & 3635,3 & 3670,6 & 3673,5 & 3564,5 & 3560,0 & 3551,3 & 3538,4 & 3667,1 & 3575,4 & 3547,6 & 3542,3 & 3524,9 & 3667,6 & 3540,7 & 3527,0 & 3520,7 & 3529,0 & 3476,8 \\
\hline 450 & & & & 3625,3 & 3660,7 & 3663,6 & $\begin{array}{l}3557,9 \\
\end{array}$ & 3553,8 & 3542,3 & 3530,4 & 3652,5 & 3559,5 & 3537,7 & 3532,9 & 3517,8 & 3655,1 & 3533,7 & 3520,3 & 3515,9 & 3520,5 & 3474,5 \\
\hline 451 & Jo & & dias & 3651,4 & 3689,1 & 3693,6 & 3593,2 & 3590,5 & 3574,7 & 3562,4 & 3684,4 & 3694,3 & 3570,3 & 3565,5 & 3553,8 & 3685,5 & 3568,0 & 3556,5 & 3551,3 & 3558,9 & 3509,8 \\
\hline 452 & & & & 3598,4 & 3640,8 & 3647,1 & 3547,1 & 3550,0 & 3527,8 & 3516,9 & 3652,4 & 3547,2 & 3524,8 & 3521,4 & 3505,1 & 3634,8 & 3526,4 & 3507,6 & 3503,5 & 3508,9 & 3459,0 \\
\hline
\end{tabular}




\section{APÊNDICE C}

\section{Resultados dos Ensaios Individuais, com duas repetições por concreto de cada caminhão amostrado}

$\mathrm{Na}$ Tabela 108 são apresentadas as medidas dos ensaios de profundidade de carbonatação nos corpos-de-prova submetidos a ciclos de molhagem e secagem, amostrados dos caminhões do lote 1.

Tabela 108 - Resultados do ensaio de profundidade de carbonatação em corpos-de-prova, submetidos a três ciclos de molhagem e secagem, dos caminhões amostrados do lote 1

\begin{tabular}{|c|c|c|c|c|c|c|c|c|c|c|c|}
\hline \multirow{4}{*}{ 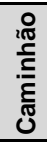 } & \multirow{4}{*}{ 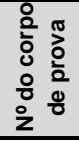 } & \multicolumn{9}{|c|}{ Penetração de $\mathrm{CO}_{2}(\mathrm{~mm})$} & \multirow{4}{*}{$\begin{array}{c}\text { Coeficiente de } \\
\text { carbonatação }(x= \\
\mathrm{k} \text { vt) } \mathrm{mm} / \mathrm{ano}^{-1 / 2}\end{array}$} \\
\hline & & \multicolumn{6}{|c|}{ Posição do corpo de prova } & \multirow{3}{*}{$\begin{array}{c}\text { Mádia } \\
(\mathrm{mm})\end{array}$} & \multirow{3}{*}{$\begin{array}{c}\text { Desvio } \\
\text { padrão } \\
(\mathrm{mm})\end{array}$} & \multirow{3}{*}{$\begin{array}{c}\text { Coeficiente } \\
\text { de variação } \\
(\%)\end{array}$} & \\
\hline & & Fundo & Meio & Topo & Fundo & Meio & Topo & & & & \\
\hline & & 1 & 2 & 3 & 4 & 5 & 6 & & & & \\
\hline \multirow{2}{*}{1} & 441 & 0,0 & 0,0 & 0,0 & 0,0 & 0,0 & 0,0 & 0,0 & 0,0 & $0 \%$ & 0,0 \\
\hline & 442 & 0,0 & 0,0 & 0,0 & 0,0 & 0,0 & 0,0 & 0,0 & 0,0 & $0 \%$ & 0,0 \\
\hline \multirow{2}{*}{2} & 443 & 0,0 & 0,0 & 0,0 & 0,0 & 0,0 & 0,0 & 0,0 & 0,0 & $0 \%$ & 0,0 \\
\hline & 444 & 3,40 & 1,90 & 2,55 & 3,56 & 2,06 & 1,66 & 2,5 & 0,8 & $32 \%$ & 5,1 \\
\hline \multirow{2}{*}{3} & 445 & 2,10 & 1,89 & 2,14 & 2,30 & 3,30 & 2,28 & 2,3 & 0,5 & $21 \%$ & 4,7 \\
\hline & 446 & 0,0 & 2,36 & 3,35 & 2,06 & 0,0 & 2,39 & 1,7 & 1,4 & $82 \%$ & 3,4 \\
\hline \multirow{2}{*}{4} & 447 & 2,80 & 1,90 & 2,64 & 3,00 & 3,34 & 3,40 & 2,8 & 0,6 & $19 \%$ & 5,7 \\
\hline & 448 & 0,0 & 0,0 & 0,0 & 0,0 & 0,0 & 0,0 & 0,0 & 0,0 & $0 \%$ & 0,0 \\
\hline \multirow{2}{*}{5} & 449 & 2,76 & 3,40 & 5,70 & 4,72 & 3,17 & 4,64 & 4,1 & 1,1 & $28 \%$ & 8,1 \\
\hline & 450 & 3,27 & 3,45 & 2,06 & 2,91 & 2,07 & 2,74 & 2,8 & 0,6 & $21 \%$ & 5,5 \\
\hline \multirow{2}{*}{6} & 451 & 0,0 & 0,0 & 0,0 & 0,0 & 0,0 & 0,0 & 0,0 & 0,0 & $0 \%$ & 0,0 \\
\hline & 452 & 2,46 & 2,55 & 2,80 & 2,73 & 2,66 & 3,47 & 2,8 & 0,36 & $13 \%$ & 5,6 \\
\hline
\end{tabular}

Na Tabela 109 são apresentadas as medidas dos ensaios de penetração de cloretos nos corpos-de-prova, rompidos na diametral, submetidos a três ciclos de molhagem e secagem, amostrados dos caminhões do lote 1 . 


\section{APÊNDICE C}

\section{Resultados dos Ensaios Individuais, com duas repetições por concreto de cada caminhão amostrado}

Tabela 109 - Resultados do ensaio de penetração de cloretos em corpos-de-prova rompidos na diametral, submetidos a ciclos de molhagem e secagem, dos caminhões amostrados do lote 1

\begin{tabular}{|c|c|c|c|c|c|c|c|c|c|c|c|}
\hline \multirow{4}{*}{ 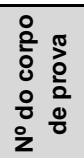 } & \multirow{4}{*}{ 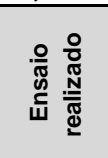 } & \multirow{4}{*}{$\stackrel{\frac{\pi}{3}}{0}$} & \multirow{2}{*}{\multicolumn{6}{|c|}{$\begin{array}{l}\text { Profundidade da penetração de cloretos }(\mathrm{mm}) \\
\text { Posição do corpo de prova }\end{array}$}} & \multirow{4}{*}{$\begin{array}{c}\text { Média } \\
(\mathrm{mm})\end{array}$} & \multirow{4}{*}{$\begin{array}{c}\text { Desvio } \\
\text { padrão } \\
(\mathrm{mm})\end{array}$} & \multirow{4}{*}{$\begin{array}{c}\text { Coeficiente } \\
\text { de variação } \\
(\%)\end{array}$} \\
\hline & & & & & & & & & & & \\
\hline & & & Fundo & Meio & Topo & Fundo & Meio & Topo & & & \\
\hline & & & 1 & 2 & 3 & 4 & 5 & 6 & & & \\
\hline 441 & \multirow{12}{*}{ 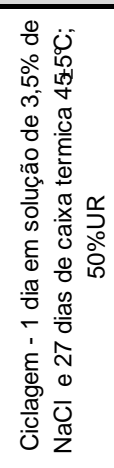 } & \multirow{12}{*}{$\begin{array}{c}\text { Acelerada } \\
24 / 48 \mathrm{hs}, \\
38 \pm 3{ }^{\circ} \mathrm{C} \\
\text { (adaptada } \\
\text { do método } \\
\text { A da ASTM } \\
684 \mathrm{C} \text { ) }+ \\
\text { imersão em } \\
\text { água até } 7 \\
\text { dias }\end{array}$} & 10,45 & 9,40 & 11,23 & 9,63 & 8,70 & 12,7 & 10,4 & 1,5 & $0 \%$ \\
\hline 442 & & & 8,07 & 5,43 & 4,70 & 6,91 & 5,03 & 9,13 & 6,5 & 1,8 & $0 \%$ \\
\hline 443 & & & 5,05 & 3,68 & 5,09 & 6,85 & 4,42 & 4,67 & 5,0 & 1,1 & $0 \%$ \\
\hline 444 & & & 7,27 & 3,46 & 4,8 & 4,16 & 4,05 & 5,62 & 4,89 & 1,4 & $28 \%$ \\
\hline 445 & & & 10,43 & 9,90 & 6,87 & 9,78 & 8,86 & 8,36 & 9,03 & 1,3 & $14 \%$ \\
\hline 446 & & & 5,31 & 3,24 & 7,51 & 4,84 & 2,80 & 5,78 & 4,91 & 1,7 & $35 \%$ \\
\hline 447 & & & 6,05 & 4,02 & 4,08 & 7,11 & 4,40 & 4,47 & 5,02 & 1,3 & $0 \%$ \\
\hline 448 & & & 11,0 & 7,98 & 11,20 & 9,32 & 10,20 & 9,56 & 9,87 & 1,2 & $0 \%$ \\
\hline 449 & & & 8,15 & 8,19 & 9,27 & 6,92 & 8,33 & 9,01 & 8,31 & 0,8 & $10 \%$ \\
\hline 450 & & & 4,46 & 4,22 & 5,57 & 4,29 & 5,05 & 8,90 & 5,42 & 1,8 & $33 \%$ \\
\hline 451 & & & 11,04 & 7,03 & 8,28 & 12,9 & 7,16 & 8,60 & 9,17 & 0,0 & $0 \%$ \\
\hline 452 & & & 5,51 & 4,78 & 10,05 & 5,31 & 6,30 & 8,89 & 6,81 & 2,2 & $32 \%$ \\
\hline
\end{tabular}

Na Tabela 110 são apresentadas as medidas dos ensaios de penetração de cloretos nos corpos-de-prova, rompidos na diametral, submetidos a três ciclos de molhagem e secagem, amostrados dos caminhões do lote 1.

Tabela 110 - Resultados do ensaio de penetração de cloretos em corpos-de-prova rompidos nos terços médios, submetidos a ciclos de molhagem e secagem, dos caminhões amostrados do lote 2

\begin{tabular}{|c|c|c|c|c|c|c|c|c|c|c|c|}
\hline \multirow{3}{*}{$\begin{array}{c}\text { Corpo- } \\
\text { de- } \\
\text { prova }\end{array}$} & \multirow{3}{*}{ 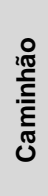 } & \multirow{3}{*}{ 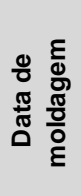 } & \multicolumn{6}{|c|}{$\begin{array}{l}\text { Medidas da penetração de clorestos nos terços } \\
\text { médios }(\mathrm{mm})\end{array}$} & \multirow{3}{*}{$\begin{array}{l}\text { Média } \\
(\mathrm{mm})\end{array}$} & \multirow{3}{*}{$\begin{array}{l}\text { Desvio } \\
\text { padrão } \\
(\mathrm{mm})\end{array}$} & \multirow{3}{*}{$\begin{array}{l}\text { Coeficiente } \\
\text { de variação } \\
\text { (\%) }\end{array}$} \\
\hline & & & \multicolumn{3}{|c|}{ Terço Superior (TS) } & \multicolumn{3}{|c|}{ Terço Inferior (TI) } & & & \\
\hline & & & 1 & 2 & 3 & 1 & 2 & 3 & & & \\
\hline 441 & \multirow{4}{*}{1} & \multirow{12}{*}{ 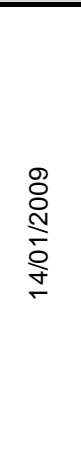 } & 5,37 & 3,07 & 3,42 & 3,52 & 3,61 & 3,07 & 3,68 & 0,86 & $23 \%$ \\
\hline 442 & & & 5,35 & 4,41 & 4,14 & 5,42 & 3,78 & 6,22 & 4,89 & 0,93 & $19 \%$ \\
\hline 443 & & & 5,72 & 4,62 & 3,55 & 6,02 & 4,04 & 4,14 & 4,68 & 0,99 & $21 \%$ \\
\hline 444 & & & 4,83 & 4,81 & 4,31 & 3,93 & 4,15 & 4,44 & 4,41 & 0,36 & $8 \%$ \\
\hline 445 & \multirow{2}{*}{3} & & 4,66 & 4,22 & 4,73 & 3,32 & 4,05 & 3,91 & 4,15 & 0,52 & $13 \%$ \\
\hline 446 & & & 3,30 & 3,73 & 3,56 & 3,25 & 2,32 & 2,61 & 3,13 & 0,55 & $18 \%$ \\
\hline 447 & \multirow[b]{2}{*}{4} & & 6,18 & 5,94 & 5,19 & 7,00 & 6,13 & 5,98 & 6,07 & 0,58 & $10 \%$ \\
\hline 448 & & & 3,23 & 4,80 & 4,11 & 5,41 & 3,98 & 4,47 & 4,33 & 0,75 & $17 \%$ \\
\hline 449 & \multirow{2}{*}{5} & & 4,53 & 4,70 & 4,02 & 4,55 & 3,53 & 3,93 & 4,21 & 0,45 & $11 \%$ \\
\hline 450 & & & 4,66 & 5,02 & 4,62 & 3,84 & 4,33 & 4,25 & 4,45 & 0,41 & $9 \%$ \\
\hline 451 & \multirow{2}{*}{6} & & 5,11 & 5,80 & 5,32 & 5,66 & 5,23 & 4,70 & 5,30 & 0,40 & $7 \%$ \\
\hline 452 & & & 6,72 & 4,91 & 4,31 & 5,08 & 4,06 & 6,03 & 5,19 & 1,02 & $20 \%$ \\
\hline
\end{tabular}




\section{APÊNDICE C}

Resultados dos Ensaios Individuais, com duas repetições por concreto de cada caminhão amostrado

Tabela 111 - Valores do potencia de corrosão no potenciostato modelo 273 (mV,ECS), nos corpos-de-prova com cobrimento de $2,5 \mathrm{~cm}$ do lote 1

\begin{tabular}{|c|c|c|c|c|c|c|c|}
\hline \multirow{2}{*}{ 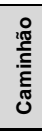 } & \multirow{2}{*}{$\begin{array}{c}\begin{array}{c}\text { Nodo } \\
\text { corpo de } \\
\text { prova }\end{array} \\
\end{array}$} & \multirow{2}{*}{ 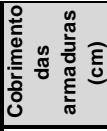 } & \multirow[t]{2}{*}{$\begin{array}{l}\text { Identificação } \\
\text { barra no cp }\end{array}$} & $\begin{array}{c}\text { Valores de potencial no potenciostato } \\
\text { mod } 273 \text { (mVvsECS em pte sal KCl } 3 \\
\text { mol) } \\
\end{array}$ & \multirow[t]{2}{*}{ Media } & \multirow[t]{2}{*}{$\begin{array}{l}\text { Desvio } \\
\text { padrão }\end{array}$} & \multirow[t]{2}{*}{$\begin{array}{l}\text { Coeficiente } \\
\text { de variação }\end{array}$} \\
\hline & & & & 600 segundos & & & \\
\hline \multirow{8}{*}{1} & \multirow{4}{*}{453} & \multirow{8}{*}{2,5} & $A$ & -388 & \multirow{4}{*}{-314} & \multirow{4}{*}{118} & \multirow{4}{*}{$-37 \%$} \\
\hline & & & B & -263 & & & \\
\hline & & & $\mathrm{C}$ & -174 & & & \\
\hline & & & $\mathrm{D}$ & -432 & & & \\
\hline & \multirow{4}{*}{454} & & A & -352 & \multirow{4}{*}{-224} & \multirow{4}{*}{137} & \multirow{4}{*}{$-61 \%$} \\
\hline & & & $B$ & -153 & & & \\
\hline & & & C & -67 & & & \\
\hline & & & $\mathrm{D}$ & -324 & & & \\
\hline \multirow{8}{*}{2} & \multirow{4}{*}{456} & & $\mathrm{~A}$ & -64 & \multirow{4}{*}{-190} & & \\
\hline & & & B & -72 & & 154 & $-81 \%$ \\
\hline & & & $\mathrm{C}$ & -389 & & 154 & $-01 \%$ \\
\hline & & 25 & D & -236 & & & \\
\hline & & $2, \sigma$ & A & -89 & & & \\
\hline & 457 & & $\mathrm{~B}$ & -87 & & & \\
\hline & $45 r$ & & C & -106 & -96 & 9 & $-10 \%$ \\
\hline & & & $\mathrm{D}$ & -102 & & & \\
\hline & & & A & -119 & & & \\
\hline & 458 & & $B$ & -88 & -107 & 13 & $120 \%$ \\
\hline & 470 & & C & -106 & -101 & 13 & $-13 \%$ \\
\hline 3 & & 25 & $D$ & -113 & & & \\
\hline 3 & & 2,0 & A & -249 & & & \\
\hline & 459 & & B & -88 & -275 & 235 & $-86 \%$ \\
\hline & & & C & -149 & -213 & 205 & $00 \%$ \\
\hline & & & $D$ & -613 & & & \\
\hline & & & A & -60 & & & \\
\hline & 460 & & B & -277 & -279 & 155 & $-56 \%$ \\
\hline & 400 & & $\mathrm{C}$ & -385 & -279 & 135 & $-30 \%$ \\
\hline 4 & & 2.5 & $\mathrm{D}$ & -394 & & & \\
\hline 4 & & & A & -164 & & & \\
\hline & 461 & & B & -82 & -172 & 117 & $-68 \%$ \\
\hline & & & $\mathrm{C}$ & -103 & $1 / 2$ & $1+1$ & -0010 \\
\hline & & & D & -340 & & & \\
\hline & & & A & -126 & & & \\
\hline & 462 & & $B$ & -102 & -133 & 32 & $-24 \%$ \\
\hline & & & $\mathrm{C}$ & -177 & -133 & 32 & 2410 \\
\hline 5 & & 2.5 & D & -127 & & & \\
\hline & & & A & -103 & & & \\
\hline & 463 & & B & -143 & -149 & 46 & $-31 \%$ \\
\hline & 405 & & $\mathrm{C}$ & -213 & -145 & 40 & (3110 \\
\hline & & & D & -136 & & & \\
\hline & & & A & -82 & & & \\
\hline & 464 & & B & -79 & -94 & 19 & $-20 \%$ \\
\hline & 404 & & C & -121 & -94 & 19 & $-20 \%$ \\
\hline 6 & & 25 & D & -94 & & & \\
\hline 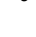 & & & A & -215 & & & \\
\hline & 465 & & B & -89 & -140 & 57 & $-41 \%$ \\
\hline & 700 & & c & -154 & -140 & נו & $-41 \%$ \\
\hline & & & D & -103 & & & \\
\hline
\end{tabular}




\section{APÊNDICE C}

\section{Resultados dos Ensaios Individuais, com duas repetições por concreto de cada caminhão amostrado}

A Tabela 112 apresenta os valores do potencial de corrosão nos corpos-de-prova do lote 1 , com cobrimentos de $3,5 \mathrm{~cm}$ e $1,5 \mathrm{~cm}$.

Tabela 112 - Valores do potencia de corrosão no potenciostato modelo 273 (mV,ECS), nos corposde-prova com cobrimento de 3,5 e 1,5 cm do lote 1

\begin{tabular}{|c|c|c|c|c|c|c|c|}
\hline \multirow{2}{*}{ 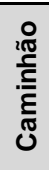 } & \multirow[t]{2}{*}{$\begin{array}{l}\mathrm{N}^{\circ} \text { do } \\
\text { corpo de } \\
\text { prova }\end{array}$} & \multirow{2}{*}{ 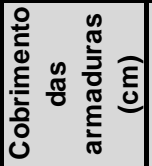 } & \multirow[t]{2}{*}{$\begin{array}{c}\text { Identificaç } \\
\text { ão barra } \\
\text { no cp }\end{array}$} & $\begin{array}{c}\text { Valores de potencial no } \\
\text { potenciostato mod } 273 \text { ( } \mathrm{mVvsECS} \\
\text { em pte sal } \mathrm{KCl} 3 \mathrm{~mol} \text { ) }\end{array}$ & \multirow[t]{2}{*}{ Media } & \multirow[t]{2}{*}{$\begin{array}{l}\text { Desvio } \\
\text { padrão }\end{array}$} & \multirow[t]{2}{*}{$\begin{array}{l}\text { Coeficiente } \\
\text { de variação }\end{array}$} \\
\hline & & & & 600 segundos & & & \\
\hline \multirow{4}{*}{1} & \multirow{4}{*}{466} & \multirow{12}{*}{3,5} & A & -95 & \multirow{4}{*}{-103} & \multirow{4}{*}{21} & \multirow{4}{*}{$-21 \%$} \\
\hline & & & B & -91 & & & \\
\hline & & & C & -135 & & & \\
\hline & & & D & -92 & & & \\
\hline \multirow{4}{*}{3} & \multirow{4}{*}{467} & & A & -122 & \multirow{4}{*}{-110} & \multirow{4}{*}{14} & \multirow{4}{*}{$-13 \%$} \\
\hline & & & $B$ & -90 & & & \\
\hline & & & $\mathrm{C}$ & -119 & & & \\
\hline & & & $\bar{D}$ & -109 & & & \\
\hline \multirow{4}{*}{6} & \multirow{4}{*}{566} & & A & -111 & \multirow{4}{*}{-100} & \multirow{4}{*}{8} & \multirow{4}{*}{$-8 \%$} \\
\hline & & & B & -91 & & & \\
\hline & & & C & -98 & & & \\
\hline & & & D & -101 & & & \\
\hline \multirow{4}{*}{1} & \multirow{4}{*}{468} & \multirow{8}{*}{1,5} & A & -80 & \multirow{4}{*}{-90} & \multirow{4}{*}{11} & \multirow{4}{*}{$-12 \%$} \\
\hline & & & $B$ & -83 & & & \\
\hline & & & $\mathrm{C}$ & -104 & & & \\
\hline & & & D & -93 & & & \\
\hline \multirow{4}{*}{6} & \multirow{4}{*}{567} & & A & -92 & \multirow{4}{*}{-257} & \multirow{4}{*}{118} & \multirow{4}{*}{$-46 \%$} \\
\hline & & & $B$ & -251 & & & \\
\hline & & & C & -348 & & & \\
\hline & & & $D$ & -337 & & & \\
\hline
\end{tabular}




\section{APÊNDICE C}

\section{Resultados dos Ensaios Individuais, com duas repetições por concreto de cada caminhão amostrado}

\section{2) Lote 2}

Na Tabela 113 são apresentados os tempos de descarga de cada caminhão, com os respectivos resultados do abatimento do tronco de cone, com a média, desvio padrão e o coeficiente de variação do lote 2 .

Tabela 113 - Tempo de descarga de cada caminhão e os resultados dos ensaios de abatimento do tronco de cone dos concretos amostrados do lote 2

\begin{tabular}{|c|c|c|c|c|c|c|c|c|c|c|c|}
\hline \multirow{3}{*}{ 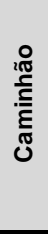 } & \multirow{3}{*}{$\begin{array}{c}\text { № da } \\
\text { nota } \\
\text { fiscal }\end{array}$} & \multirow{2}{*}{\multicolumn{4}{|c|}{ Tempo de descagra do caminhão (min) }} & \multicolumn{6}{|c|}{ Abatiemnto do tronco de cone $(\mathrm{cm})$} \\
\hline & & & & & & \multicolumn{3}{|c|}{ Medidas (cm) } & \multicolumn{3}{|c|}{ Lote 2} \\
\hline & & Ínicio & Termino & $\begin{array}{l}\text { Tempo de } \\
\text { descarga }\end{array}$ & Média (min) & 1 & 2 & Média & $\begin{array}{c}\text { Média } \\
(\mathrm{cm})\end{array}$ & $\begin{array}{c}\text { Desvio } \\
\text { padrão } \\
(\mathrm{cm})\end{array}$ & $\begin{array}{c}\text { Coeficiente } \\
\text { de variação } \\
(\%)\end{array}$ \\
\hline 1 & 9853 & $09: 30$ & $10: 00$ & $00: 30$ & \multirow{5}{*}{$00: 27$} & 10 & 9 & 9 & \multirow{5}{*}{10} & \multirow{5}{*}{1,1} & \multirow{5}{*}{$12 \%$} \\
\hline 2 & 9854 & $10: 05$ & $10: 35$ & $00: 30$ & & 10 & 10 & 10 & & & \\
\hline 3 & 9859 & $11: 35$ & $11: 50$ & $00: 15$ & & 10 & 12 & 11 & & & \\
\hline 4 & 9860 & $12: 10$ & $12: 40$ & $00: 30$ & & 6 & 10 & 8 & & & \\
\hline 5 & 9863 & $13: 15$ & $13: 45$ & $00: 30$ & & 10 & 11 & 10 & & & \\
\hline
\end{tabular}

$\mathrm{Na}$ Tabela 114 são apresentados os resultados dos ensaios de massa específica de cada caminhão amostrado, com a média, desvio padrão e o coeficiente de variação do lote 2.

Tabela 114 - Resultados dos ensaios de densidade de massa específica do concreto fresco amostrado dos caminhões do lote 2

\begin{tabular}{|c|c|c|c|c|c|c|c|c|c|c|}
\hline \multirow{2}{*}{ 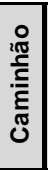 } & \multirow{2}{*}{$\begin{array}{l}\text { Massa do } \\
\text { recipiente } \\
(\mathbf{k g})\end{array}$} & \multirow{2}{*}{$\begin{array}{l}\text { Volume do } \\
\text { recipiente } \\
\quad\left(\mathrm{cm}^{3}\right)\end{array}$} & \multicolumn{2}{|c|}{ Medidas (kg) } & \multicolumn{3}{|c|}{ Densidade $\left(\mathrm{kg} / \mathrm{m}^{3}\right)$} & \multicolumn{3}{|c|}{ Lote 2} \\
\hline & & & 1 & 2 & 1 & 2 & Média & $\begin{array}{c}\text { Média } \\
\left(\mathrm{kg} / \mathrm{m}^{3}\right)\end{array}$ & $\begin{array}{l}\text { Desvio } \\
\text { padrão } \\
\left(\mathrm{kg} / \mathrm{m}^{3}\right)\end{array}$ & \begin{tabular}{|c|}
$\begin{array}{c}\text { Coeficiente } \\
\text { de variação } \\
(\%)\end{array}$ \\
\end{tabular} \\
\hline 1 & 9,20 & \multirow{5}{*}{13,744} & 42,0 & 41,5 & 2390 & 2350 & 2370 & \multirow{5}{*}{2380} & \multirow{5}{*}{33} & \multirow{5}{*}{$1 \%$} \\
\hline 2 & 9,20 & & 41,9 & 43,3 & 2380 & 2480 & 2430 & & & \\
\hline 3 & 9,20 & & 42,0 & 41,6 & 2380 & 2360 & 2370 & & & \\
\hline 4 & 9,20 & & 41,4 & 41,3 & 2340 & 2340 & 2340 & & & \\
\hline 5 & 9,20 & & 41,9 & 42,2 & 2380 & 2400 & 2390 & & & \\
\hline
\end{tabular}




\section{APÊNDICE C}

\section{Resultados dos Ensaios Individuais, com duas repetições por concreto de cada caminhão amostrado}

Na Tabela 115 são apresentados os resultados dos ensaios compactabilidade adensado e não adensado de cada caminhão amostrado, com a média, desvio padrão e o coeficiente de variação do lote 2 .

Tabela 115 - Resultados dos ensaios de compactabilidade do concreto fresco adensado e não adensado amostrado dos caminhões do lote 2

\begin{tabular}{|c|c|c|c|c|c|c|c|c|c|c|c|c|}
\hline \multicolumn{7}{|c|}{ Compactabilidade do concreto adensado (cm) } & \multicolumn{6}{|c|}{ Compactabilidade do concreto não adensado $(\mathrm{cm})$} \\
\hline \multirow{2}{*}{$\frac{O}{\frac{2}{\frac{2}{5}}}$} & \multicolumn{3}{|c|}{ Medidas (cm) } & \multicolumn{3}{|c|}{ Lote 2} & \multicolumn{3}{|c|}{ Medidas (cm) } & \multicolumn{3}{|c|}{ Lote 2} \\
\hline & 1 & 2 & Média & $\begin{array}{c}\text { Média } \\
(\mathrm{cm})\end{array}$ & $\begin{array}{c}\text { Desvio } \\
\text { padrão } \\
(\mathrm{cm})\end{array}$ & $\begin{array}{c}\text { Coeficiente } \\
\text { de variação } \\
(\%)\end{array}$ & 1 & 2 & Média & $\begin{array}{c}\text { Média } \\
\text { (cm) }\end{array}$ & $\begin{array}{l}\text { Desvio } \\
\text { padrão } \\
(\mathrm{cm})\end{array}$ & $\begin{array}{c}\text { Coeficiente } \\
\text { de variação } \\
(\%)\end{array}$ \\
\hline 1 & 0,4 & 0,4 & 0,40 & \multirow{5}{*}{0,42} & \multirow{5}{*}{0,06} & \multirow{5}{*}{$14 \%$} & 0,5 & 0,6 & 0,55 & \multirow{5}{*}{0,66} & \multirow{5}{*}{0,07} & \multirow{5}{*}{$10 \%$} \\
\hline 2 & 0,3 & 0,5 & 0,40 & & & & 0,7 & 0,7 & 0,70 & & & \\
\hline 3 & 0,5 & 0,4 & 0,45 & & & & 0,8 & 0,6 & 0,70 & & & \\
\hline 4 & 0,5 & 0,5 & 0,50 & & & & 0,6 & 0,7 & 0,65 & & & \\
\hline 5 & 0,3 & 0,4 & 0,35 & & & & 0,6 & 0,8 & 0,70 & & & \\
\hline
\end{tabular}

Na Tabela 116 são apresentados os resultados dos ensaios de teor de ar e umidade do concreto fresco de cada caminhão amostrado e a média, desvio padrão e coeficiente de variação do lote 2 .

Tabela 116 - Resultados dos ensaios de teor de ar pelo método pressométrico e umidade do concreto fresco dos concretos de cada caminhão amostrados do lote 2

\begin{tabular}{|c|c|c|c|c|c|c|c|c|c|c|c|c|}
\hline \multicolumn{7}{|c|}{ Teor de ar pelo metodo pressométrico (\%) } & \multicolumn{6}{|c|}{ Umidade (\%) } \\
\hline \multirow{2}{*}{ 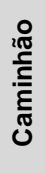 } & \multicolumn{3}{|c|}{ Medidas (\%) } & \multicolumn{3}{|c|}{ Lote 2} & \multicolumn{3}{|c|}{ Medidas (\%) } & \multicolumn{3}{|c|}{ Lote 2} \\
\hline & 1 & 2 & Média & $\begin{array}{c}\text { Média } \\
(\%\end{array}$ & $\begin{array}{c}\text { Desvio } \\
\text { padrão (\%) }\end{array}$ & $\begin{array}{l}\text { Coeficiente } \\
\text { de variação } \\
(\%)\end{array}$ & 1 & 2 & Média & $\begin{array}{c}\text { Média } \\
\text { (\% }\end{array}$ & $\begin{array}{c}\text { Desvio } \\
\text { padrão } \\
\text { (\%) }\end{array}$ & \begin{tabular}{|c} 
Coeficiente \\
de variação \\
(\%)
\end{tabular} \\
\hline 1 & 2,8 & 2,7 & 2,75 & \multirow{5}{*}{2,85} & \multirow{5}{*}{0,43} & \multirow{5}{*}{$15 \%$} & 10 & 6 & 8 & \multirow{5}{*}{10} & \multirow{5}{*}{6} & \multirow{5}{*}{$63 \%$} \\
\hline 2 & 3,8 & $\overline{3,4}$ & 3,60 & & & & 20 & 22 & 21 & & & \\
\hline 3 & 2,5 & 2,5 & 2,50 & & & & 8 & 6 & 7 & & & \\
\hline 4 & 2,8 & $\overline{2,5}$ & 2,65 & & & & 7 & 7 & 7 & & & \\
\hline 5 & 2,8 & 2,7 & 2,75 & & & & 6 & 7 & 6 & & & \\
\hline
\end{tabular}




\section{APÊNDICE C \\ Resultados dos Ensaios Individuais, com duas repetições por concreto de cada caminhão amostrado}

Na Tabela 117 são apresentados os resultados dos ensaios de absorção de água total do lote 2.

$\mathrm{Na}$ Tabela 118 são apresentados os resultados dos ensaios de absorção de água por capilaridade, nos corpos-de-prova amostrados do lote 2.

$\mathrm{Na}$ Tabela 119 são apresentados todos os resultados dos ensaios de resistência à compressão realizados nos concretos dos caminhões amostrados do lote 2, com suas respectivas médias, desvio padrão, coeficiente de variação, valores máximos e mínimos.

Na tabela 120 e 121 são apresentados os resultados do ensaio de resistência à tração por compressão diametral nos concretos dos caminhões amostrados no lote 2 , com suas respectivas médias, desvios padrão, coeficientes de variação e valores máximos e mínimos. 


\section{APÊNDICE C}

\section{Resultados dos Ensaios Individuais, com duas repetições por concreto de cada caminhão amostrado}

Tabela 117 - Resultados do ensaio de absorção de água total nos corpos-de-prova do lote 2

\begin{tabular}{|c|c|c|c|c|c|c|c|c|c|c|c|c|}
\hline 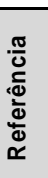 & 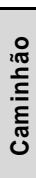 & 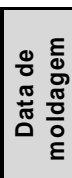 & Cura & $\begin{array}{c}\text { Massa } \\
\text { saturada } \\
\text { após cura } \\
\text { (g) }\end{array}$ & $\begin{array}{c}\text { Massa } \\
\text { seca a } \\
100^{\circ} \mathrm{C}\end{array}$ & $\begin{array}{c}\text { Massa } \\
\text { saturada }(\mathrm{g}) \\
\text { após } \\
\text { fervura a } \\
100^{\circ} \mathrm{C}\end{array}$ & $\begin{array}{c}\text { Massa } \\
\text { imersa }(\mathrm{g}) \\
\text { em água }\end{array}$ & $\begin{array}{c}\text { Absorção } \\
\text { de água } \\
\text { total (\%) }\end{array}$ & $\begin{array}{l}\text { Indice } \\
\text { de } \\
\text { vazios } \\
(\%)\end{array}$ & $\begin{array}{c}\text { Massa } \\
\text { especifica } \\
\text { da amostra } \\
\text { seca } \\
\left(\mathrm{g} / \mathrm{cm}^{3}\right)\end{array}$ & \begin{tabular}{|c|} 
Massa \\
especifica \\
da amostra \\
saturada \\
$\left(\mathrm{g} / \mathrm{cm}^{3}\right)$
\end{tabular} & $\begin{array}{c}\text { Massa } \\
\text { especifica } \\
\text { real } \\
\left(\mathrm{g} / \mathrm{cm}^{3}\right)\end{array}$ \\
\hline 177 & 1 & \multirow{20}{*}{ 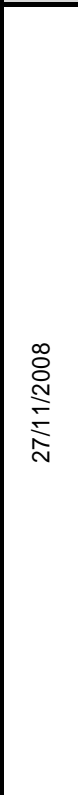 } & \multirow{10}{*}{$\begin{array}{c}\text { Cura } \\
\text { acelerada } \\
24 / 48 \text { horas } \\
\text { - ASTM A; e } \\
\text { cura imersa } \\
\text { em água até } \\
7 \text { dias }\end{array}$} & 3689,0 & 3483,3 & 3665,9 & 2129,8 & 5,24 & 11,89 & 2,27 & 2,39 & 2,57 \\
\hline 178 & & & & 3711,5 & 3520,6 & 3709,4 & 2154,9 & 5,36 & 12,15 & 2,26 & 2,39 & 2,58 \\
\hline 179 & 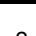 & & & 3699,6 & 3479,8 & 3692,9 & 2135,1 & 6,12 & 13,68 & 2,23 & 2,37 & 2,59 \\
\hline 180 & & & & 3702,0 & 3489,6 & 3697,6 & 2134,2 & 5,96 & 13,30 & 2,23 & 2,37 & 2,57 \\
\hline 181 & 3 & & & 3692,3 & 3507,5 & 3687,0 & 2145,7 & 5,12 & 11,65 & 2,28 & 2,39 & 2,58 \\
\hline 182 & & & & 3660,1 & 3470,7 & 3651,7 & 2119,3 & 5,22 & 11,81 & 2,26 & 2,38 & 2,57 \\
\hline 183 & 4 & & & 3716,7 & 3510,7 & 3709,3 & 2147,0 & 5,66 & 12,71 & 2,25 & 2,37 & 2,57 \\
\hline 184 & & & & 3704,5 & 3495,9 & 3700,2 & 2142,0 & 5,84 & 13,11 & 2,24 & 2,37 & 2,58 \\
\hline 185 & 5 & & & 3696,4 & 3484,2 & 3690,0 & 2141,5 & 5,91 & 13,29 & 2,25 & 2,38 & 2,59 \\
\hline 186 & & & & 3689,0 & 3484,7 & 3685,2 & 2136,6 & 5,75 & 12,95 & 2,25 & 2,38 & 2,58 \\
\hline 187 & 1 & & \multirow{10}{*}{$\begin{array}{c}\text { Cura imersa } \\
\text { em água por } \\
28 \text { dias }\end{array}$} & $\begin{array}{l}3682,3 \\
\end{array}$ & 3486,8 & $\begin{array}{l}3674,8 \\
\end{array}$ & $\begin{array}{l}2132,4 \\
\end{array}$ & 5,39 & $\begin{array}{l}12,19 \\
\end{array}$ & 2,26 & 2,38 & 2,57 \\
\hline 188 & & & & 3723,8 & 3529,9 & 3717,4 & 2156,0 & 5,31 & 12,01 & 2,26 & 2,38 & 2,57 \\
\hline 189 & 2 & & & 3697,9 & 3479,6 & 3689,7 & 2134,5 & 6,04 & 13,51 & 2,24 & 2,37 & 2,59 \\
\hline 190 & & & & 3709,9 & 3491,2 & 3704,4 & 2142,9 & 6,11 & 13,65 & 2,24 & 2,37 & 2,59 \\
\hline 191 & 3 & & & 3689,1 & 3501,8 & 3683,7 & 2136,8 & 5,19 & 11,76 & 2,26 & 2,38 & 2,57 \\
\hline 192 & & & & 3681,4 & 3485,0 & 3676,5 & 2132,6 & 5,49 & 12,40 & 2,26 & 2,38 & 2,58 \\
\hline 193 & 4 & & & 3681,6 & 3465,3 & 3674,9 & 2120,4 & 6,05 & 13,48 & 2,23 & 2,36 & 2,58 \\
\hline 194 & & & & 3698,9 & 3483,6 & 3692,7 & 2135,4 & 6,00 & 13,43 & 2,24 & 2,37 & 2,58 \\
\hline 195 & 5 & & & 3708,0 & 3501,8 & 3702,5 & 2145,2 & 5,73 & 12,89 & 2,25 & 2,38 & 2,58 \\
\hline 196 & & & & 3672,6 & 3451,4 & 3665,3 & 2130,0 & 6,20 & 13,93 & 2,25 & 2,39 & 2,61 \\
\hline
\end{tabular}




\section{APÊNDICE C}

Resultados dos Ensaios Individuais, com duas repetições por concreto de cada caminhão amostrado

Tabela 118 - Resultados dos ensaios de absorção de água por capilaridade nos corpos-de-prova do lote 2

\begin{tabular}{|c|c|c|c|c|c|c|c|c|c|c|c|c|c|c|c|c|c|c|c|c|c|c|c|c|c|}
\hline \multirow[b]{2}{*}{ 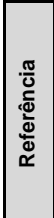 } & \multirow[b]{2}{*}{ 选 } & \multirow{2}{*}{ 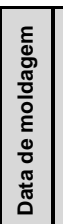 } & \multirow[b]{2}{*}{ Cura } & \multirow[b]{2}{*}{$\begin{array}{c}\text { Massa } \\
\text { após } \\
\text { cura }(\mathrm{g})\end{array}$} & \multirow{2}{*}{$\begin{array}{c}\text { Massa (g) } \\
\text { após 24 } \\
\text { horas na } \\
\text { estufa a } \\
100^{\circ} \mathrm{C}\end{array}$} & \multirow{2}{*}{$\begin{array}{c}\text { Massa }(\mathrm{g}) \\
\text { após } 48 \\
\text { horas na } \\
\text { estufa a } \\
100^{\circ} \mathrm{C}\end{array}$} & \multirow{2}{*}{$\begin{array}{c}\text { Massa }(\mathrm{g}) \\
\text { após } 72 \\
\text { horas na } \\
\text { estufa a } \\
100^{\circ} \mathrm{C}\end{array}$} & \multicolumn{9}{|c|}{ Massa Adquirida na absorção de água por capilaridade (g) } & \multicolumn{9}{|c|}{ Absorção de água por capilaridade $\left(\mathrm{g} / \mathrm{cm}^{2}\right)$} \\
\hline & & & & & & & & 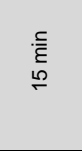 & $\begin{array}{l}\text { 点 } \\
\text { ह }\end{array}$ & $\begin{array}{l}\text { 产 } \\
\& \text { \& }\end{array}$ & 离 & $\begin{array}{l}\frac{\pi}{\pi} \\
\frac{\pi}{0} \\
\frac{0}{m}\end{array}$ & $\begin{array}{l}\frac{\pi}{\pi} \\
\frac{\pi}{0} \\
\frac{0}{6}\end{array}$ & 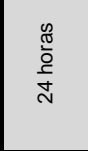 & 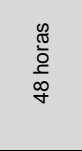 & $\begin{array}{l}\frac{\pi}{\pi} \\
\frac{\pi}{N} \\
\frac{0}{N}\end{array}$ & 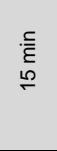 & $\begin{array}{l}\text { 高 } \\
\text { ह }\end{array}$ & $\begin{array}{l}\text { 亮 } \\
\text { \& }\end{array}$ & $\begin{array}{l}\frac{\pi}{0} \\
\frac{0}{2} \\
\end{array}$ & $\begin{array}{l}\frac{g}{0} \\
\frac{\pi}{0} \\
\frac{c}{m}\end{array}$ & $\begin{array}{l}\frac{\pi}{0} \\
\frac{\pi}{0} \\
0\end{array}$ & 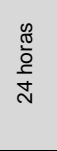 & 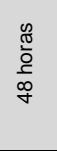 & 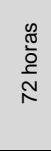 \\
\hline 177 & & \multirow{10}{*}{\multicolumn{2}{|c|}{$\begin{array}{c}\text { Cura } \\
\text { acelerad } \\
\text { a 24/48 } \\
\text { horas - } \\
\text { ASTM A; } \\
\text { e cura } \\
\text { imersa } \\
\text { em água } \\
\text { até } 7 \text { dias }\end{array}$}} & 89,0 & $\overline{05,4}$ & 899,1 & 83,3 & 98,0 & 03,8 & 08,0 & 3511,8 & 3515,0 & 3522,2 & 3548,9 & 563,8 & 571,9 & $\overline{0,19}$ & 0,26 & 0.31 & 0,3 & 0,40 & 0,50 & 0,84 & 1,02 & 1,13 \\
\hline 178 & & & & 3711,5 & 3552,4 & 3528,0 & 20,6 & 3539,4 & 3543,9 & 3547,3 & 3552,5 & 3560,0 & 3569,9 & 3598,0 & 3611,7 & 3620,1 & 0,24 & 0,30 & 0,34 & 0,41 & 0,50 & 0,63 & 0,99 & 1,16 & 1,27 \\
\hline 179 & 2 & & & 3699,6 & 3506,0 & 3485,2 & 3479, & 3493,1 & 3498,0 & 3501,4 & 3502,8 & 3518,4 & 3528,5 & 3561,7 & 3580,3 & 3592,0 & 0,17 & \begin{tabular}{|l}
0,23 \\
\end{tabular} & 0,28 & 0,29 & 0,49 & 0,62 & 1,04 & 1,28 & 1,43 \\
\hline \begin{tabular}{|l|}
180 \\
\end{tabular} & & & & 3702,0 & 3525,0 & 500,8 & 3489,9 & 3500,2 & 3508,0 & 3513,0 & 3519,0 & 3525,2 & 3535,0 & 3565,8 & 3582,0 & 3593,1 & 0,13 & \begin{tabular}{|l|l|}
0,23 \\
\end{tabular} & 0,29 & 0,37 & 0,45 & 0,57 & 0,97 & 1,17 & 1,31 \\
\hline \begin{tabular}{|l|}
181 \\
\end{tabular} & 3 & & & 3692,3 & 3538,8 & 518, & 507, & 3525,4 & 3529,0 & 3535,0 & 3538,4 & 3544,1 & 3553,2 & 3579,8 & 3592,5 & 3600,3 & 0,2 & \begin{tabular}{|l|l}
0,27 \\
\end{tabular} & 0,3 & 0,3 & 0,47 & 0,58 & 0,9 & 1,08 & 1,18 \\
\hline \begin{tabular}{|l|}
182 \\
\end{tabular} & & & & 3660,1 & 5503, & 180,4 & 170, & 3483,1 & 3487,9 & 3490,5 & 3493,2 & 3508,3 & 3519,0 & 3548,9 & 3563,2 & \begin{tabular}{|l|l}
3574,1 \\
\end{tabular} & 0,16 & 22 & 0,25 & 0,29 & 0,48 & 0,61 & 1,00 & ,18 & 1,32 \\
\hline \begin{tabular}{|l|}
183 \\
\end{tabular} & 4 & & & 3716 , & 3 & 20, & 3 & 3520,0 & 525,5 & 3527,9 & 3530,7 & 3543,2 & 3551,8 & 3579,8 & 3596,4 & 3608,9 & 0,1 & 0,19 & 0,2 & 0,2 & 0,41 & $\leq$ & 88 & 9 & 1,25 \\
\hline \begin{tabular}{|l|}
184 \\
\end{tabular} & & & & 3704,5 & 626,0 & $0,0,0$ & 3495 , & 3510,3 & 3514 & 3519,7 & 3521,0 & 3527,0 & 3537,0 & 3567,4 & 3584,2 & 3595,6 & - & \begin{tabular}{|l}
0,23 \\
\end{tabular} & 0,3 & 0, & 0,40 & 0,52 & 0 & 1,12 & 1,27 \\
\hline \begin{tabular}{|l|}
185 \\
\end{tabular} & 5 & & & 3696,4 & 3511,3 & 492,5 & 484 & 3501,5 & $\begin{array}{l}3507,7 \\
\end{array}$ & 3512,2 & 3515,1 & 3524,9 & 3535,3 & 3568,0 & 3585,8 & 3597,3 & 0,22 & \begin{tabular}{|l|l}
0,30 \\
\end{tabular} & 0,3 & 0,39 & 0,52 & 0,65 & 1,07 & 1,29 & 1,44 \\
\hline \begin{tabular}{|l|}
186 \\
\end{tabular} & & & & 3689,0 & 3523,0 & 3500,6 & 3484,7 & 3501,0 & 3506,2 & 3509,2 & 3511,5 & \begin{tabular}{|l}
3527,8 \\
\end{tabular} & 3538,8 & 3567,7 & 3583,4 & 3593,6 & 0,21 & \begin{tabular}{|l}
0,27 \\
\end{tabular} & 0,3 & 0,34 & 0,55 & 0,69 & 1,06 & 1,26 & 1,39 \\
\hline \begin{tabular}{|l|}
187 \\
\end{tabular} & & \multirow{10}{*}{\multicolumn{2}{|c|}{$\begin{array}{c}\text { Cura } \\
\text { imersa } \\
\text { em água } \\
\text { por } 28 \\
\text { dias }\end{array}$}} & 3682,3 & 3533,2 & 3507,7 & 3486,8 & 3497,7 & 3503,0 & 3506,4 & 3511,1 & 3526,6 & 3535,6 & \begin{tabular}{|l|l|l}
3568,8 \\
\end{tabular} & 3585,7 & \begin{tabular}{l|l}
3598,3 \\
\end{tabular} & 0,14 & 21 & 0,25 & 0,31 & 0,51 & 52 & 1,04 & 26 & 1,42 \\
\hline \begin{tabular}{|l|}
188 \\
\end{tabular} & & & & 372 & & & 3529,9 & 3540,4 & 3547,8 & 3548,0 & 3550,4 & 3563,0 & 3570,2 & \begin{tabular}{|l|l}
3598,7 \\
\end{tabular} & 3615,5 & 3626,8 & 0,1 & 23 & 0,2 & 0,26 & 0,42 & 51 & 0,00 & 09 & 1,23 \\
\hline \begin{tabular}{|l|}
189 \\
\end{tabular} & \multirow{8}{*}{3} & & & 3697,9 & 3536,2 & 4964 & 34796 & 3491,1 & 3494,8 & 3498,8 & 3508,2 & 3519,9 & 3531,0 & 3569,4 & 3593,3 & 3610,2 & 01 & 19 & 0,24 & 0,3 & 0,51 & 0,65 & 1 & 45 & 1,66 \\
\hline \begin{tabular}{|l|}
190 \\
\end{tabular} & & & & 3709,9 & 3550,8 & 523,1 & 3491,2 & 3501,7 & 3505,6 & 3509,6 & 3512,9 & \begin{tabular}{|l}
3527,4 \\
\end{tabular} & 3537,2 & \begin{tabular}{|l|l}
3577,2 \\
\end{tabular} & 3600,3 & 3615,4 & 0,13 & \begin{tabular}{|l|l|}
0,18 \\
\end{tabular} & 0,23 & 0,28 & 0,46 & 0,59 & 1,09 & 1,39 & 1,58 \\
\hline \begin{tabular}{|l|}
191 \\
\end{tabular} & & & & 3689,1 & 3539,7 & 35 & 3501,8 & 3510,9 & 3515,8 & 3519,8 & \begin{tabular}{|l|}
3522,4 \\
\end{tabular} & 3535,2 & $\begin{array}{l}3543,1 \\
\end{array}$ & 3575,6 & 3592,5 & 3603,8 & 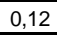 & 18 & 0,2 & 0,2 & 0,43 & 53 & 0,94 & 15 & 1,30 \\
\hline \begin{tabular}{|l|l|l|}
192 \\
\end{tabular} & & & & 3681,4 & 3525,4 & 3506, & 3485,0 & 3495,3 & 3500,4 & 3505,5 & 3506,2 & 3519,4 & 3526,6 & 3557,8 & 3575,0 & 3588,7 & 0,13 & \begin{tabular}{|l}
0,20 \\
\end{tabular} & 0,2 & 0,27 & 0,44 & 53 &, 93 & 15 & 1,32 \\
\hline \begin{tabular}{|l|}
193 \\
\end{tabular} & & & & 3681 & & & & 3475,7 & 318 & 34848 & 3488,4 & 3504,4 & 3514,2 & 3550,0 & 3569 & 25021 & & 0,19 & & & 50 & 62 & 10 & 33 & 1,50 \\
\hline \begin{tabular}{|l|}
194 \\
\end{tabular} & & & & 3698,9 & 3538,1 & 3510,5 & 3483,6 & 3493,4 & 3498,0 & 3501,4 & \begin{tabular}{|l|l}
3504,6 \\
\end{tabular} & 3519,3 & 3528,6 & \begin{tabular}{|l|l}
3563,8 \\
\end{tabular} & 3583,2 & 3598,0 & 0,12 & 0,18 & 0,23 & 0,27 & 0,45 & 0,57 & 1,02 & 1,27 & 1,46 \\
\hline \begin{tabular}{|l|}
195 \\
\end{tabular} & & & & 3708,0 & 3554,5 & 3523,7 & 3501,8 & 3513,1 & $\begin{array}{l}3518,3 \\
\end{array}$ & 3522,2 & \begin{tabular}{|l}
3526,4 \\
\end{tabular} & 3544,5 & 3554,7 & 3593,4 & 3612,4 & 3625,6 & 0,14 & \begin{tabular}{|l|l|}
0,21 \\
\end{tabular} & 0,26 & 0,3 & 0,54 &, 67 & 1,17 & 41 & 1,58 \\
\hline 10 & & & & 3672,6 & 3521,2 & 3479,4 & 3451,4 & 3461,4 & 3465,7 & 3469,0 & 3471,7 & \begin{tabular}{|l}
3484,8 \\
\end{tabular} & 3493,1 & \begin{tabular}{|l|l}
3530,4 \\
\end{tabular} & 3552,7 & 3566,4 & 0,13 & \begin{tabular}{|l|l|}
0,18 \\
\end{tabular} & 0,22 & 0,26 & 0,43 & 0,53 & 1,01 & 1,29 & 1,46 \\
\hline
\end{tabular}




\section{APÊNDICE C}

Resultados dos Ensaios Individuais, com duas repetições por concreto de cada caminhão amostrado

\begin{tabular}{|c|c|c|c|c|c|c|c|c|c|c|c|c|c|c|c|c|c|c|c|c|c|c|c|c|c|c|}
\hline \multirow{3}{*}{$\mathbf{N}^{\circ}$} & \multirow{3}{*}{$\begin{array}{l}\text { Porpriedadel } \\
\text { Caminhão }\end{array}$} & \multirow{2}{*}{\multicolumn{5}{|c|}{$\begin{array}{l}\text { Média } \\
\text { Caminhão }\end{array}$}} & \multirow{2}{*}{\multicolumn{5}{|c|}{$\begin{array}{l}\text { Desvio Padrão } \\
\text { Cam inhão }\end{array}$}} & \multirow{2}{*}{\multicolumn{5}{|c|}{$\begin{array}{c}\text { Coeficiente de variação } \\
\text { Caminhão }\end{array}$}} & \multirow{2}{*}{\multicolumn{5}{|c|}{$\frac{\text { Valor maximo }}{\text { Caminhão }}$}} & \multirow{2}{*}{\multicolumn{5}{|c|}{$\frac{\text { Valor minimo }}{\text { Caminhão }}$}} \\
\hline & & & & & & & & & & & & & & & & & & & & & & & & & & \\
\hline & & 1 & 2 & 3 & 4 & 5 & 1 & 2 & 3 & 4 & 5 & 1 & 2 & 3 & 4 & 5 & 1 & 2 & 3 & 4 & 5 & 1 & 2 & 3 & 4 & 5 \\
\hline 13 & \begin{tabular}{|c}
$\begin{array}{c}\text { Resistência à } \\
\text { compressão- }-f_{c} 1 \\
\text { (MPa) }\end{array}$ \\
\end{tabular} & 14,3 & 13,1 & 2,9 & 15,4 & 14,8 & 0,00 & 1,34 & 0,07 & 0,21 & 1,27 & $0 \%$ & $10 \%$ & $2 \%$ & $1 \%$ & $9 \%$ & 14,3 & 14,0 & 2,9 & 15,5 & 15,7 & 14,3 & 12,1 & 2,8 & 15,2 & 13,9 \\
\hline 14 & \begin{tabular}{|c} 
Resistência à \\
compressão - $\mathrm{f}_{\mathrm{c}} 1$ \\
(MPa) - cura \\
acelerada 0/24 $\mathrm{h}$ \\
\end{tabular} & 29,7 & 31,8 & 29,9 & 30,3 & 32,5 & 0,85 & 0,00 & 4,10 & 1,56 & 1,98 & $3 \%$ & $0 \%$ & $14 \%$ & $10 \%$ & $6 \%$ & 30,3 & 31,8 & 32,8 & 31,4 & 33,9 & 29,1 & 31,8 & 27,0 & 29,2 & 31,1 \\
\hline 15 & \begin{tabular}{|c|} 
Resistência à \\
compressão - $\mathrm{f}_{\mathrm{c}} 7$ \\
(MPa) - cura \\
acelerada 24/48 $\mathrm{h}$ e \\
imersão em água \\
até 7 dias \\
\end{tabular} & 30,2 & 32,9 & 33,3 & 30,4 & 31,3 & 0,14 & 0,49 & 0,42 & 1,91 & 1,20 & $0 \%$ & $2 \%$ & $1 \%$ & $6 \%$ & $4 \%$ & 30,3 & 33,2 & 33,6 & 31,7 & 32,1 & 30,1 & 32,5 & 33,0 & 29,0 & 30,4 \\
\hline 16 & $\begin{array}{c}\text { Resistência à } \\
\text { compressão - } \mathrm{f}_{\mathrm{c}} 7 \\
\text { (MPa) - cura } \\
\text { imersa em água } \\
\text { por } 7 \text { dias }\end{array}$ & 25,1 & 27,8 & 28,9 & 26,5 & 23,5 & 1,34 & 0,78 & 0,07 & 2,62 & 0,21 & $5 \%$ & $3 \%$ & $0 \%$ & $10 \%$ & $1 \%$ & 26,0 & 28,3 & 28,9 & 28,3 & 23,6 & 24,1 & 27,2 & 28,8 & 24,6 & 23,6 \\
\hline 17 & $\begin{array}{c}\text { Resistência à } \\
\text { compressão - } \mathrm{f}_{\mathrm{c}} 28 \\
\text { (MPa) - cura } \\
\text { imersa em água }\end{array}$ & 34,9 & 31,4 & 38,7 & 37,3 & 30,9 & 5,30 & 1,63 & 3,04 & 4,31 & 2,12 & $15 \%$ & $5 \%$ & $8 \%$ & $12 \%$ & $7 \%$ & 38,6 & 32,5 & 40,8 & 40,3 & 32,4 & 31,1 & 30,2 & 36,5 & 34,2 & 29,4 \\
\hline 18 & $\begin{array}{c}\text { Resistência à } \\
\text { compressão }-\mathrm{f}_{6} 63 \\
(\mathrm{MPa}) \text { - cura } \\
\text { imersa em água } \\
\text { até } 63 \text { dias }\end{array}$ & 39,4 & 38,3 & 39,1 & 37,6 & 37,5 & 1,13 & 0,35 & 1,27 & 1,63 & 2,33 & $3 \%$ & $1 \%$ & $3 \%$ & $4 \%$ & $6 \%$ & 40,2 & 38,5 & 40,0 & 38,7 & 39,1 & 38,6 & 38,0 & 38,2 & 36,4 & 35,8 \\
\hline 19 & $\begin{array}{c}\text { Resistência à } \\
\text { compressão- } f_{c} 91 \\
(\mathrm{MPa}) \text { - cura } \\
\text { imersa em água } \\
\end{array}$ & 37,9 & 39,0 & 41,1 & 39,6 & 37,2 & 3,96 & 0,57 & 1,84 & 0,14 & 1,13 & $10 \%$ & $1 \%$ & $4 \%$ & $0 \%$ & $3 \%$ & 40,7 & 39,4 & 42,4 & 39,7 & 38,0 & 35,1 & 38,6 & 39,8 & 39,5 & 36,4 \\
\hline
\end{tabular}




\section{APÊNDICE C}

\section{Resultados dos Ensaios Individuais, com duas repetições por concreto de cada caminhão amostrado}

\begin{tabular}{|c|c|c|c|c|c|c|c|c|c|c|c|c|c|c|c|c|c|c|c|c|c|c|c|c|c|}
\hline \multirow{3}{*}{$\mathbf{N}^{\circ}$} & \multirow{3}{*}{$\begin{array}{l}\text { Porpriedadel } \\
\text { Caminhão }\end{array}$} & \multirow{2}{*}{\multicolumn{5}{|c|}{$\begin{array}{l}\text { Média } \\
\text { Caminhão }\end{array}$}} & \multirow{2}{*}{\multicolumn{5}{|c|}{$\begin{array}{c}\text { Desvio Padrão } \\
\text { Caminhão }\end{array}$}} & \multirow{2}{*}{\multicolumn{4}{|c|}{$\frac{\text { Coeficiente de variação }}{\text { Caminhão }}$}} & \multirow{2}{*}{\multicolumn{5}{|c|}{$\begin{array}{c}\text { Valor maximo } \\
\text { Caminhão }\end{array}$}} & \multirow{2}{*}{\multicolumn{5}{|c|}{ Valor minimo }} \\
\hline & & & & & & & & & & & & & & & & & & & & & & & & & \\
\hline & & 1 & 2 & 3 & 4 & 5 & 1 & 2 & 3 & 4 & 5 & 1 & 2 & 4 & 5 & 1 & 2 & 3 & 4 & 5 & 1 & 2 & 3 & 4 & 5 \\
\hline 20 & \begin{tabular}{|c|} 
Resistência à \\
tração por \\
compressão \\
diametral $-\mathrm{f}_{\mathrm{cta}} 7$ \\
$(\mathrm{MPa})-$ cura \\
acelerada $24 / 48 \mathrm{e}$ \\
imersão em água
\end{tabular} & 4,0 & 3,1 & 4,2 & 3,5 & 3,9 & | 0,23 & 0,07 & 0,37 & 0,13 & 0,72 & $6 \%$ & $2 \%$ & $9 \%$ & $4 \%$ & $18 \%$ & 4,1 & 3,1 & 4,5 & 3,6 & 4,5 & 3,8 & 3,0 & 3,9 & 3,4 \\
\hline 21 & \begin{tabular}{|c|} 
Resistência à \\
tração por \\
compressão \\
diametral - $f_{c t} 28$ \\
(MPa) - cura \\
imersa em água
\end{tabular} & 3,1 & 2,7 & 3,5 & 2,8 & 2,9 & | 0,28 & 0,18 & 0,49 & 0,22 & 0,45 & $9 \%$ & $6 \%$ & $14 \%$ & $8 \%$ & $16 \%$ & 3,3 & 2,9 & 3,9 & 2,9 & 3,2 & 2,9 & 2,6 & 3,2 & 2,6 \\
\hline
\end{tabular}

Tabela 121 - Resultados dos ensaios de resistência à tração por compressão diametral nos corpos-de-prova ciclados do lote 2

\begin{tabular}{|c|c|c|c|c|c|c|c|}
\hline 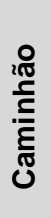 & 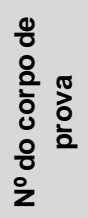 & 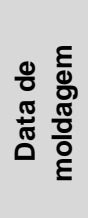 & 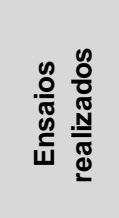 & $\begin{array}{c}\text { Resistência à } \\
\text { tração aos } 91 \\
\text { dias (MPa) }\end{array}$ & $\begin{array}{r}\text { Média } \\
(\mathrm{MPa})\end{array}$ & $\begin{array}{c}\text { Desvio } \\
\text { Padrão } \\
\text { (MPa) }\end{array}$ & $\begin{array}{c}\text { Coeficiente } \\
\text { de } \\
\text { Variação } \\
(\%)\end{array}$ \\
\hline \multirow{2}{*}{1} & 227 & \multirow{10}{*}{ 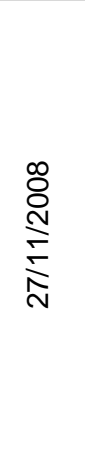 } & \multirow{10}{*}{ 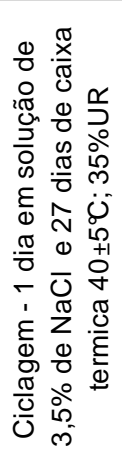 } & 3,75 & \multirow{2}{*}{4,39} & \multirow{2}{*}{0,91} & \multirow{2}{*}{$21 \%$} \\
\hline & 228 & & & 5,03 & & & \\
\hline \multirow{2}{*}{2} & 229 & & & 2,55 & \multirow{2}{*}{2,96} & \multirow{2}{*}{0,58} & \multirow{2}{*}{$20 \%$} \\
\hline & 230 & & & 3,37 & & & \\
\hline \multirow{2}{*}{3} & 231 & & & 3,40 & \multirow{2}{*}{3,82} & \multirow{2}{*}{0,59} & \multirow{2}{*}{$15 \%$} \\
\hline & 232 & & & 4,23 & & & \\
\hline \multirow{2}{*}{4} & 233 & & & 4,80 & \multirow{2}{*}{4,65} & \multirow{2}{*}{0,22} & \multirow{2}{*}{$5 \%$} \\
\hline & 234 & & & 4,49 & & & \\
\hline \multirow{2}{*}{5} & 235 & & & 3,95 & \multirow{2}{*}{4,14} & \multirow{2}{*}{0,27} & \multirow{2}{*}{$6 \%$} \\
\hline & 236 & & & 4,33 & & & \\
\hline
\end{tabular}




\section{APÊNDICE C}

\section{Resultados dos Ensaios Individuais, com duas repetições por concreto de cada caminhão amostrado}

$\mathrm{Na}$ Tabela 122 são apresentadas todas as medidas dos ensaios de carbonatação realizados em câmara de $\mathrm{CO}_{2}$ ( $5 \% ; 7$ dias), por fenolftaleína, nos corpos-de-prova do lote 2 .

Tabela 122 - Resultados dos ensaios de carbonatação por câmara de $\mathrm{CO}_{2}$ ( $5 \%$; 7 dias) nos corposde-prova por fenolftaleína, submetidos a cura acelerada 24/48 horas mais imersão em água até 7 dias, do lote 2

\begin{tabular}{|c|c|c|c|c|c|c|c|c|c|c|c|}
\hline \multicolumn{11}{|c|}{ Penetração de $\mathrm{CO}_{2}(\mathrm{~mm})$} & \multirow{4}{*}{$\begin{array}{l}\text { Coeficiente de } \\
\text { carbonataçãc } \\
(\mathrm{x}=\mathrm{k} \text { vt) } \\
\mathrm{mm} / \mathrm{ano}^{-1 / 2}\end{array}$} \\
\hline \multirow{3}{*}{ 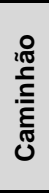 } & \multirow{3}{*}{ 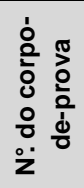 } & \multicolumn{9}{|c|}{ Lado A (fenol) } & \\
\hline & & \multicolumn{6}{|c|}{ Medidas $(\mathrm{m} \mathrm{m})$} & \multirow{2}{*}{$\begin{array}{r}\text { Média } \\
(\mathrm{mm})\end{array}$} & \multirow{2}{*}{$\begin{array}{c}\text { Desvio } \\
\text { padrão } \\
(\mathrm{mm})\end{array}$} & \multirow{2}{*}{$\begin{array}{c}\text { Coef. De } \\
\text { variação } \\
(\%)\end{array}$} & \\
\hline & & topo & meio & fundo & topo & meio & fundo & & & & \\
\hline \multirow{2}{*}{1} & 217 & 6,70 & 6,84 & 6,52 & 6,66 & 5,30 & 6,65 & 6,4 & 0,6 & $9 \%$ & 46,5 \\
\hline & 218 & 7,43 & 8,32 & 5,60 & 7,06 & 7,62 & 4,97 & 6,8 & 1,3 & $19 \%$ & 49,3 \\
\hline \multirow{2}{*}{2} & 219 & 8,17 & 6,60 & 7,63 & 7,19 & 7,06 & 6,06 & 7,1 & 0,7 & $10 \%$ & 51,4 \\
\hline & 220 & 6,83 & 6,09 & 8,23 & 5,77 & 7,47 & 6,36 & 6,8 & 0,9 & $14 \%$ & 49,0 \\
\hline \multirow{2}{*}{3} & 221 & 0,0 & 0,0 & 0,0 & 0,0 & 0,0 & 0,0 & 0,0 & 0,0 & $0 \%$ & 0,0 \\
\hline & 222 & 5,52 & 6,37 & 6,50 & 4,83 & 5,70 & 4,47 & 5,6 & 0,8 & $15 \%$ & 40,2 \\
\hline \multirow{2}{*}{4} & 223 & 6,07 & 7,25 & 7,42 & 5,26 & 7,63 & 7,97 & 6,9 & 1,0 & $15 \%$ & 50,1 \\
\hline & 224 & 7,76 & 7,64 & 7,55 & 8,40 & 7,42 & 7,60 & 7,7 & 0,3 & $4 \%$ & 55,8 \\
\hline \multirow{2}{*}{5} & 225 & 0,0 & 0,0 & 0,0 & 0,0 & 0,0 & 0,0 & 0,0 & 0,0 & $0 \%$ & 0,0 \\
\hline & 226 & 0,0 & 0,0 & 0,0 & 0,0 & 0,0 & 0,0 & 0,0 & 0,0 & $0 \%$ & 0,0 \\
\hline
\end{tabular}




\section{APÊNDICE C}

\section{Resultados dos Ensaios Individuais, com duas repetições por concreto de cada caminhão amostrado}

$\mathrm{Na}$ Tabela 123 são apresentadas todas as medidas dos ensaios de carbonatação realizados em câmara de $\mathrm{CO}_{2}$ ( $5 \% ; 7$ dias), por timolftaleína, nos corpos-de-prova do lote 2 .

Tabela 123 - Resultados dos ensaios de carbonatação por câmara de $\mathrm{CO}_{2}$ (5\%; 7 dias) nos corposde-prova por timolftaleína, submetidos a cura acelerada 24/48 horas mais imersão em água até 7 dias, do lote 2

\begin{tabular}{|c|c|c|c|c|c|c|c|c|c|c|c|}
\hline \multicolumn{11}{|c|}{ Penetração de $\mathrm{CO}_{2}(\mathrm{~mm})$} & \multirow{4}{*}{$\begin{array}{l}\text { Coeficiente de } \\
\text { carbonatação } \\
(\mathrm{x}=\mathrm{k} \mathrm{vt}) \\
\mathrm{mm} / \mathrm{ano}^{-1 / 2}\end{array}$} \\
\hline \multirow{3}{*}{ 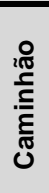 } & \multirow{3}{*}{ 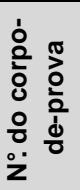 } & \multicolumn{9}{|c|}{ Lado B (timol) } & \\
\hline & & \multicolumn{6}{|c|}{ Medidas ( $\mathrm{mm}$ ) } & \multirow{2}{*}{$\begin{array}{l}\text { Média } \\
(\mathrm{mm})\end{array}$} & \multirow{2}{*}{$\begin{array}{l}\text { Desvio } \\
\text { padrão } \\
(\mathrm{mm})\end{array}$} & \multirow{2}{*}{$\begin{array}{c}\text { Coeficiente } \\
\text { de variação } \\
(\%)\end{array}$} & \\
\hline & & 1 & 2 & 3 & 4 & 5 & 6 & & & & \\
\hline \multirow{2}{*}{1} & 217 & 6,91 & 5,75 & 7,00 & 5,30 & 6,60 & 6,46 & $\overline{6,3}$ & $\overline{0,7}$ & $11 \%$ & 45,8 \\
\hline & 218 & 6,86 & 12,95 & 7,84 & 7,86 & 6,88 & 6,92 & 8,2 & 2,4 & $29 \%$ & 59,3 \\
\hline \multirow{2}{*}{2} & 219 & 6,30 & 7,13 & 10,31 & 7,70 & 11,40 & 7,16 & 8,3 & 2,0 & $24 \%$ & 60,2 \\
\hline & 220 & 8,19 & 12,21 & 8,78 & 6,09 & 9,54 & 7,45 & 8,7 & 2,1 & $24 \%$ & 62,9 \\
\hline \multirow{2}{*}{3} & 221 & 2,65 & 4,11 & 2,27 & 2,84 & 2,50 & 2,42 & 2,8 & 0,7 & $24 \%$ & 20,2 \\
\hline & 222 & 5,56 & 7,62 & 6,67 & 4,74 & 8,60 & 6,75 & 6,7 & 1,4 & $21 \%$ & 48,1 \\
\hline \multirow{2}{*}{4} & 223 & 7,95 & 11,18 & 9,61 & 8,78 & 7,26 & 7,44 & 8,7 & 1,5 & $17 \%$ & 62,8 \\
\hline & 224 & 9,53 & 7,95 & 7,70 & 8,83 & 7,08 & 6,61 & 8,0 & 1,1 & $14 \%$ & 57,4 \\
\hline \multirow{2}{*}{5} & 225 & 0,0 & 0,0 & 0,0 & 0,0 & 0,0 & 0,0 & 0,0 & 0,0 & $0 \%$ & 0,0 \\
\hline & 226 & 0,0 & 0,0 & 0,0 & 0,0 & 0,0 & 0,0 & 0,0 & 0,0 & $0 \%$ & 0,0 \\
\hline
\end{tabular}




\section{APÊNDICE C}

\section{Resultados dos Ensaios Individuais, com duas repetições por concreto de cada} caminhão amostrado

A Figura 76 ilustra a variação de massa nos corpos-de-prova, submetidos a três ciclos de imersão e secagem, dos ensaios de penetração de cloretos, amostrados dos caminhões do lote 2.

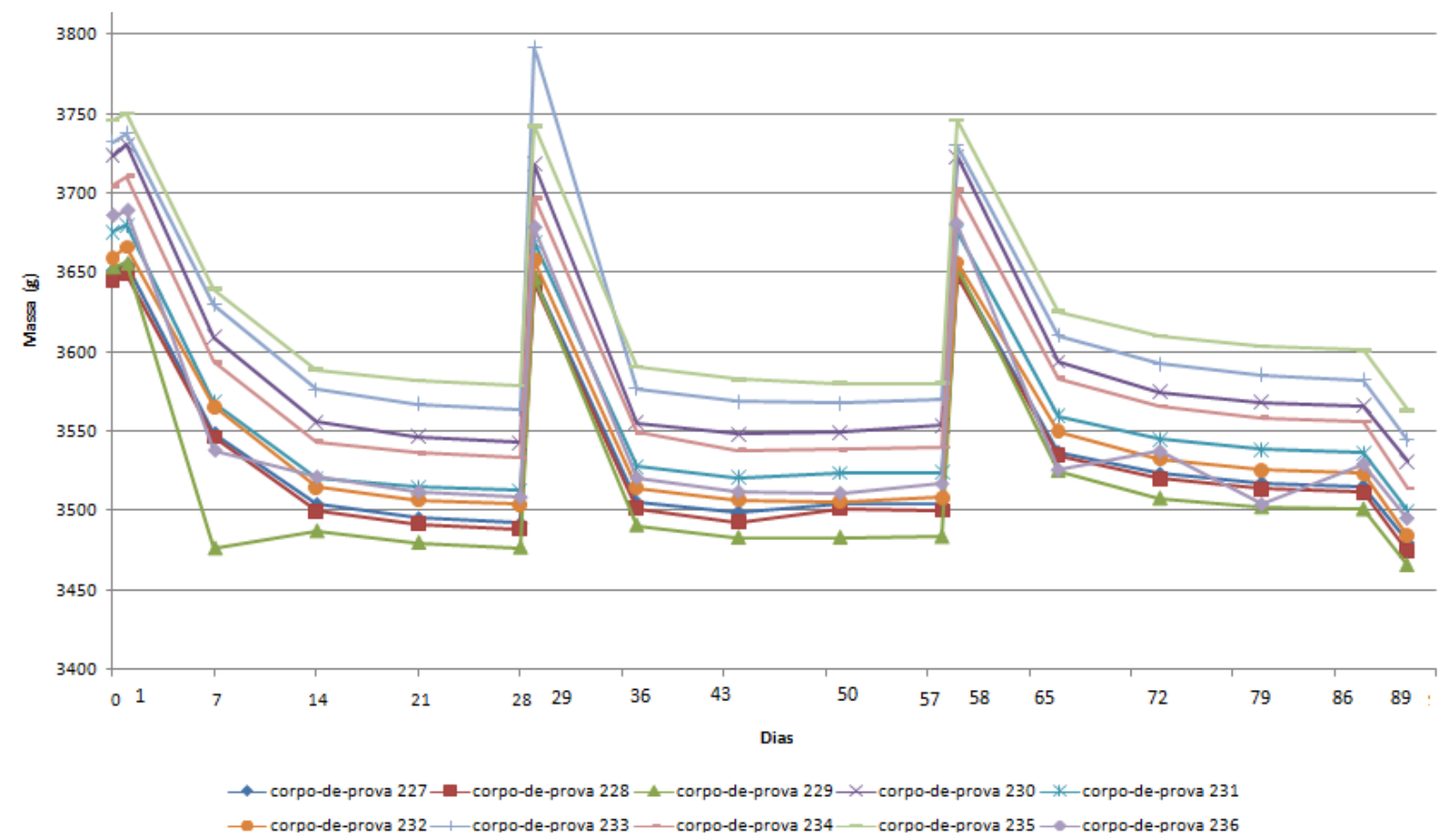

Figura 76 - Acompanhamento de massa dos corpos-de-prova, expostos a três ciclos de imersão e secagem, amostrados do lote 2.

A Tabela 124 ilustra a variação de massa nos corpos-de-prova, submetidos a três ciclos de imersão e secagem, dos ensaios de penetração de cloretos e carbonatação, amostrados dos caminhões do lote 2 . 


\section{APÊNDICE C}

\section{Resultados dos Ensaios Individuais, com duas repetições por concreto de cada caminhão amostrado}

Tabela 124 - Acompanhamento de massa dos corpos-de-prova submetidos a três ciclos de imersão e secagem, amostrados do lote 2

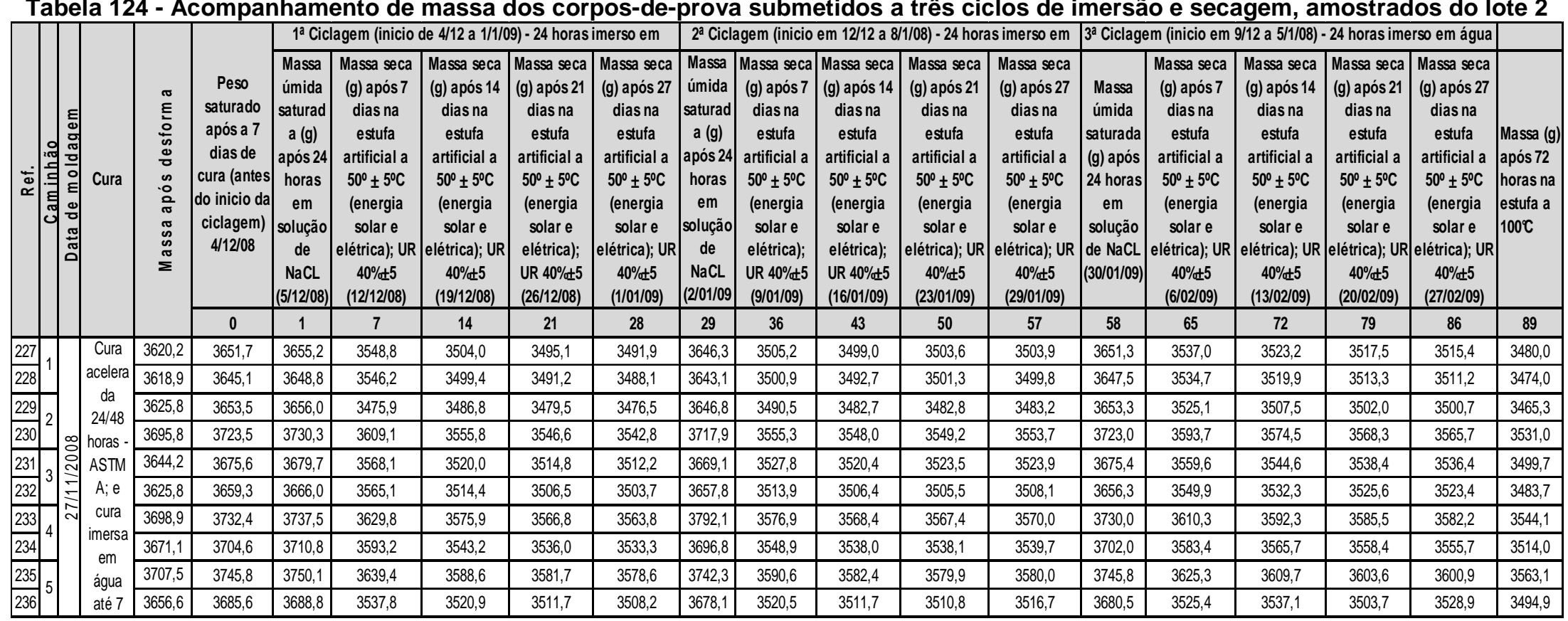




\section{APÊNDICE C}

\section{Resultados dos Ensaios Individuais, com duas repetições por concreto de cada caminhão amostrado}

$\mathrm{Na}$ Tabela 125 são apresentadas as medidas dos ensaios de profundidade de carbonatação nos corpos-de-prova submetidos a ciclos de molhagem e secagem, amostrados dos caminhões do lote 2 .

Tabela 125 - Resultados das medidas dos ensaios de carbonatação em corpos-de-prova, submetidos a 3 ciclos de imersão e secagem, por cura acelerada 24/48 horas mais imersão em água até 7 dias, amostrados do lote 2.

\begin{tabular}{|c|c|c|c|c|c|c|c|c|c|c|c|}
\hline \multirow{4}{*}{ 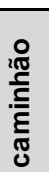 } & \multirow{4}{*}{ 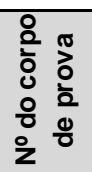 } & \multicolumn{9}{|c|}{ Penetração de $\mathrm{CO}_{2}(\mathrm{~mm})$} & \multirow{4}{*}{$\begin{array}{c}\text { Coeficiente de } \\
\text { carbonatação } \\
(\mathrm{x}=\mathrm{k} \text { vt) } \\
\mathrm{mm} / \mathrm{ano}^{-1 / 2}\end{array}$} \\
\hline & & \multicolumn{6}{|c|}{ Medidas (mm) } & \multirow{3}{*}{$\begin{array}{l}\text { Média } \\
(\mathrm{mm})\end{array}$} & \multirow{3}{*}{$\begin{array}{c}\text { Desvio } \\
\text { padrão } \\
(\mathrm{mm})\end{array}$} & \multirow{3}{*}{$\begin{array}{c}\text { Coeficiente } \\
\text { de variação } \\
(\%)\end{array}$} & \\
\hline & & Fundo & Meio & Topo & Fundo & Meio & Topo & & & & \\
\hline & & 1 & 2 & 3 & 4 & 5 & 6 & & & & \\
\hline \multirow{2}{*}{1} & 227 & 2,34 & 2,33 & 2,8 & 1,75 & 3,57 & 1,84 & 2,4 & 0,67 & $28 \%$ & 4,88 \\
\hline & 228 & 2,61 & 1,10 & 2,53 & 1,61 & 1,12 & 0,0 & $\overline{1,5}$ & 0,99 & $66 \%$ & 2,99 \\
\hline \multirow{2}{*}{2} & 229 & 2,55 & $\overline{0,0}$ & 2,18 & 2,91 & 3,26 & 1,63 & $\overline{2,1}$ & 1,17 & $56 \%$ & 4,18 \\
\hline & 230 & 5,58 & 2,78 & 2,37 & 2,52 & 4,87 & 4,00 & 3,7 & 1,34 & $36 \%$ & 7,38 \\
\hline \multirow{2}{*}{3} & 231 & 2,22 & 1,65 & 1,75 & 3,18 & 2,45 & 1,53 & 2,1 & 0,62 & $29 \%$ & 4,27 \\
\hline & 232 & 1,02 & 1,10 & 1,35 & 2,00 & 1,78 & 1,00 & 1,4 & 0,42 & $31 \%$ & 2,75 \\
\hline \multirow{2}{*}{4} & 233 & 1,00 & 1,00 & 1,00 & 1,00 & 1,00 & 1,00 & 1,0 & 0,00 & $0 \%$ & 2,00 \\
\hline & 234 & 2,87 & 2,81 & 2,78 & 2,47 & 6,42 & 2,57 & 3,3 & 1,53 & $46 \%$ & 6,65 \\
\hline \multirow{2}{*}{5} & 235 & 3,18 & 3,86 & 2,48 & 2,75 & 2,69 & 3,78 & 3,1 & 0,59 & $19 \%$ & 6,26 \\
\hline & 236 & 2,70 & 3,80 & 2,15 & 1,90 & 2,41 & 1,85 & 2,5 & 0,73 & $29 \%$ & 4,94 \\
\hline
\end{tabular}

Na Tabela 126 são apresentadas as medidas dos ensaios de penetração de cloretos nos corpos-de-prova, rompidos na diametral, submetidos a ciclos de molhagem e secagem, amostrados dos caminhões do lote 2. 


\section{APÊNDICE C}

\section{Resultados dos Ensaios Individuais, com duas repetições por concreto de cada caminhão amostrado}

Tabela 126 - Resultados do ensaio de penetração de cloretos em corpos-de-prova rompidos na diametral, submetidos a ciclos de molhagem e secagem, dos caminhões amostrados do lote 2

\begin{tabular}{|c|c|c|c|c|c|c|c|c|c|c|c|}
\hline \multirow{3}{*}{ 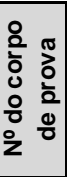 } & \multirow{3}{*}{ 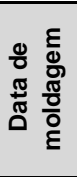 } & \multirow{3}{*}{ 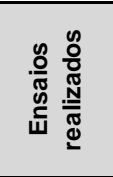 } & \multicolumn{9}{|c|}{ Penetração de cloretos (mm) } \\
\hline & & & \multicolumn{6}{|c|}{ Posição do corpo de prova } & \multirow{2}{*}{$\begin{array}{c}\text { média } \\
(\mathrm{mm})\end{array}$} & \multirow{2}{*}{$\begin{array}{c}\text { Desvio } \\
\text { padrão } \\
(\mathrm{mm})\end{array}$} & \multirow{2}{*}{$\begin{array}{c}\text { Coeficiente de } \\
\text { variação (\%) }\end{array}$} \\
\hline & & & Fundo & Meio & Topo & Fundo & Meio & Topo & & & \\
\hline 227 & \multirow{7}{*}{ 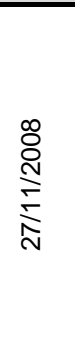 } & \multirow{7}{*}{ 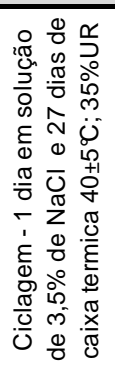 } & 5,73 & 3,75 & 4,39 & 3,50 & 2,84 & 5,02 & 4,21 & 1,1 & $25 \%$ \\
\hline 228 & & & 3,14 & 4,66 & 3,09 & 3,78 & 4,54 & 5,56 & 4,13 & 1,0 & $23 \%$ \\
\hline 231 & & & 5,06 & 4,93 & 4,30 & 3,82 & 3,19 & 4,45 & 4,29 & 0,7 & $16 \%$ \\
\hline 232 & & & 3,71 & 7,11 & 4,90 & 3,50 & 4,13 & 3,46 & 4,47 & 1,4 & $31 \%$ \\
\hline 233 & & & 3,22 & 3,24 & 4,16 & 3,91 & 3,42 & 3,40 & 3,56 & 0,4 & $11 \%$ \\
\hline 234 & & & 2,15 & 2,80 & 3,30 & 3,05 & 2,50 & 3,96 & 2,96 & 0,6 & $21 \%$ \\
\hline 235 & & & 4,55 & 3,39 & 3,21 & 3,32 & 3,56 & 2,56 & 3,43 & 0,6 & $19 \%$ \\
\hline
\end{tabular}

$\mathrm{Na}$ Tabela 127 são apresentadas as medidas dos ensaios de penetração de cloretos nos corpos-de-prova, rompidos nos terços médios, submetidos a ciclos de molhagem e secagem, amostrados dos caminhões do lote 2 .

Tabela 127 - Resultados do ensaio de penetração de cloretos em corpos-de-prova rompidos nos terços médios, submetidos a ciclos de molhagem e secagem, dos caminhões amostrados do lote

\begin{tabular}{|c|c|c|c|c|c|c|c|c|c|c|c|c|}
\hline \multirow{3}{*}{ 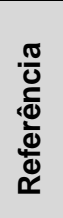 } & \multirow{3}{*}{ } & \multirow{3}{*}{ 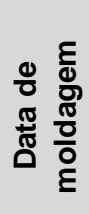 } & \multirow{3}{*}{$\begin{array}{l}\frac{0}{\bar{\Phi}} \\
\stackrel{\omega}{\tilde{W}}\end{array}$} & Terçc & Super & $r(T S)$ & Ter & Infer & ( $(\mathrm{TI})$ & \multirow{3}{*}{$\begin{array}{l}\text { Média } \\
(\mathrm{mm})\end{array}$} & \multirow{3}{*}{$\begin{array}{c}\text { Desvio } \\
\text { padrão } \\
(\mathrm{mm})\end{array}$} & \multirow{3}{*}{$\begin{array}{l}\text { Coeficiente } \\
\text { de variação } \\
\text { (\%) }\end{array}$} \\
\hline & & & & \multicolumn{6}{|c|}{ Medidas (mm) } & & & \\
\hline & & & & 1 & 2 & 3 & 1 & 2 & 3 & & & \\
\hline \multirow{2}{*}{\begin{tabular}{|l|}
227 \\
228 \\
\end{tabular}} & \multirow{2}{*}{1} & & \multirow{10}{*}{ 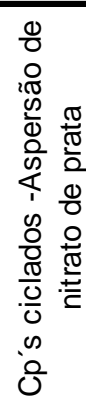 } & 4,20 & 4,10 & 4,20 & 5,30 & 5,15 & 5,20 & 4,7 & 0,6 & $12 \%$ \\
\hline & & & & 4,11 & 3,15 & 3,85 & 4,31 & 4,40 & 4,64 & 4,1 & 0,5 & $13 \%$ \\
\hline 222 & \multirow{2}{*}{2} & & & 5,36 & 4,36 & 3,43 & 5,80 & 6,00 & 5,60 & 5,1 & 1,0 & $20 \%$ \\
\hline \begin{tabular}{|l|}
230 \\
\end{tabular} & & & & \begin{tabular}{|l|}
5,74 \\
\end{tabular} & 4,25 & 4,02 & 5,00 & 3,70 & 5,0 & 4,6 & 0,8 & $16 \%$ \\
\hline 23 & \multirow[t]{2}{*}{3} & & & 4,51 & 4,15 & 3,97 & 4,66 & 3,60 & 3,40 & 4,0 & 0,5 & $12 \%$ \\
\hline 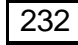 & & & & 4,50 & 3,61 & 3,50 & 3,75 & 3,60 & 4,80 & 4,0 & 0,5 & $14 \%$ \\
\hline 20 & \multirow[t]{2}{*}{4} & & & 4,02 & 4,33 & 4,21 & 3,72 & 4,00 & 3,56 & 4,0 & 0,3 & $7 \%$ \\
\hline 234 & & & & 3,30 & 3,31 & 3,55 & 4,15 & 3,60 & 4,2 & 3,7 & 0,4 & $11 \%$ \\
\hline 235 & \multirow{2}{*}{5} & & & 4,50 & 5,05 & 5,42 & 4,10 & 3,96 & 4,23 & 4,5 & 0,6 & $13 \%$ \\
\hline 236 & & & & 5,17 & 4,65 & 4,40 & 5,24 & 5,32 & 5,36 & 5,0 & 0,4 & $8 \%$ \\
\hline
\end{tabular}




\section{APÊNDICE C}

Resultados dos Ensaios Individuais, com duas repetições por concreto de cada caminhão amostrado

Tabela 128 - Valores do potencia de corrosão no potenciostato modelo 273 (mV,ECS), nos corposde-prova com cobrimento de $2,5 \mathrm{~cm}$ do lote 2

\begin{tabular}{|c|c|c|c|c|c|c|c|}
\hline \multirow[t]{2}{*}{$\frac{80}{2}$} & \multirow[t]{2}{*}{$\begin{array}{c}\mathbf{N}^{\circ} \text { do } \\
\text { corpo de } \\
\text { prova }\end{array}$} & \multirow{2}{*}{ 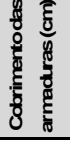 } & \multirow[t]{2}{*}{$\begin{array}{c}\text { Identificação } \\
\text { barra no cp }\end{array}$} & $\begin{array}{c}\text { Valores de potencial no } \\
\text { potenciostato mod } 273 \\
\text { (mVvsECS em pte sal KCl } 3 \\
\text { mol) }\end{array}$ & \multirow[t]{2}{*}{ Media } & \multirow[t]{2}{*}{$\begin{array}{l}\text { Desvio } \\
\text { padrão }\end{array}$} & \multirow[t]{2}{*}{$\begin{array}{l}\text { Coeficiente } \\
\text { de variação }\end{array}$} \\
\hline & & & & 600 segundos & & & \\
\hline \multirow{8}{*}{1} & \multirow{4}{*}{237} & \multirow{8}{*}{2,5} & $\mathrm{~A}$ & -81 & \multirow{4}{*}{-27} & \multirow{4}{*}{51} & \multirow{4}{*}{$-188 \%$} \\
\hline & & & $\mathrm{B}$ & 32 & & & \\
\hline & & & C & -55 & & & \\
\hline & & & D & -4 & & & \\
\hline & \multirow{4}{*}{238} & & $A$ & -80 & \multirow{4}{*}{-59} & \multirow{4}{*}{15} & \multirow{4}{*}{$-26 \%$} \\
\hline & & & $\mathrm{B}$ & -47 & & & \\
\hline & & & $\mathrm{C}$ & -59 & & & \\
\hline & & & $\mathrm{D}$ & -49 & & & \\
\hline \multirow{8}{*}{2} & \multirow{4}{*}{239} & \multirow{8}{*}{2,5} & A & -86 & & & \\
\hline & & & B & -107 & -107 & 43 & $-40 \%$ \\
\hline & & & C & -166 & -108 & 43 & $-40 \%$ \\
\hline & & & D & -67 & & & \\
\hline & & & $\mathrm{A}$ & -13 & & & \\
\hline & 240 & & $\mathrm{~B}$ & -187 & -42 & 100 & $-239 \%$ \\
\hline & 240 & & $\mathrm{C}$ & -7 & -42 & 100 & $-239 \%$ \\
\hline & & & $\mathrm{D}$ & 40 & & & \\
\hline & & & A & -66 & & & \\
\hline & 241 & & B & -67 & & & \\
\hline & 241 & & $\mathrm{C}$ & -84 & -74 & 8,7 & $-12 \%$ \\
\hline & & & $\mathrm{D}$ & -78 & & & \\
\hline & & & $\mathrm{A}$ & -36 & & & \\
\hline & 242 & & $\mathrm{~B}$ & -162 & & & \\
\hline & 242 & & $\mathrm{C}$ & 28 & -118 & 145 & $-124 \%$ \\
\hline & & 2,5 & $\mathrm{D}$ & -301 & & & \\
\hline 3 & & & $\mathrm{~A}$ & -72 & & & \\
\hline & & & $B$ & -51 & & & \\
\hline & 331 & & $\mathrm{C}$ & -251 & -158 & 112 & $-71 \%$ \\
\hline & & & $\mathrm{D}$ & -259 & & & \\
\hline & & & $\mathrm{A}$ & -147 & & & \\
\hline & 332 & & $\mathrm{~B}$ & 12 & -59 & 69 & $-116 \%$ \\
\hline & & & $C$ & -43 & -59 & 69 & $-110 \%$ \\
\hline & & & $\mathrm{D}$ & -97 & & & \\
\hline & & & A & 65 & & & \\
\hline & 243 & & B & 59 & 58 & 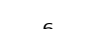 & $10 \%$ \\
\hline & 240 & & $\mathrm{C}$ & 55 & 58 & 6 & $10 \%$ \\
\hline 4 & & 2,5 & $\mathrm{D}$ & 52 & & & \\
\hline 4 & & & A & 68 & & & \\
\hline & 244 & & $\mathrm{~B}$ & 92 & & & \\
\hline & 244 & & $\mathrm{C}$ & -66 & -7 & 103 & $-1581 \%$ \\
\hline & & & $\mathrm{D}$ & -120 & & & \\
\hline & & & $\mathrm{A}$ & 35 & & & \\
\hline & & & $\mathrm{B}$ & 64 & & & \\
\hline & 245 & & $\mathrm{C}$ & -143 & 2 & 98 & $4336 \%$ \\
\hline & & 25 & $\mathrm{D}$ & 53 & & & \\
\hline 5 & & & $\mathrm{~A}$ & 40 & & & \\
\hline & & & $\mathrm{B}$ & -15 & & & \\
\hline & 246 & & C & 28 & -19 & 76 & $-411 \%$ \\
\hline & & & $\mathrm{D}$ & -127 & & & \\
\hline
\end{tabular}




\section{APÊNDICE C}

Resultados dos Ensaios Individuais, com duas repetições por concreto de cada caminhão amostrado

Tabela 129 - Valores do potencia de corrosão no potenciostato modelo 273 (mV,ECS), nos corpos-

\begin{tabular}{|c|c|c|c|c|c|c|c|}
\hline \multirow{2}{*}{ 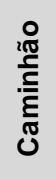 } & \multirow[t]{2}{*}{$\begin{array}{l}\mathrm{N}^{\circ} \text { do } \\
\text { corpo de } \\
\text { prova }\end{array}$} & \multirow{2}{*}{ 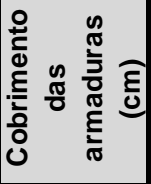 } & \multirow[t]{2}{*}{$\begin{array}{l}\text { Identificação } \\
\text { barra no cp }\end{array}$} & $\begin{array}{c}\text { Valores de potencial no } \\
\text { potenciostato mod } 273 \text { ( } \mathrm{mVvsECS} \\
\text { em pte sal KCl } 3 \mathrm{~mol} \text { ) }\end{array}$ & \multirow[t]{2}{*}{ Media } & \multirow[t]{2}{*}{$\begin{array}{l}\text { Desvio } \\
\text { padrão }\end{array}$} & \multirow[t]{2}{*}{$\begin{array}{l}\text { Coeficiente } \\
\text { de variaçãc }\end{array}$} \\
\hline & & & & 600 segundos & & & \\
\hline \multirow{8}{*}{1} & \multirow{4}{*}{247} & \multirow{8}{*}{3,5} & $A$ & -106 & \multirow{4}{*}{-139} & \multirow{4}{*}{31} & \multirow{4}{*}{$-22 \%$} \\
\hline & & & B & -119 & & & \\
\hline & & & C & -166 & & & \\
\hline & & & $D$ & -164 & & & \\
\hline & \multirow{4}{*}{248} & & A & 100 & \multirow{4}{*}{40} & \multirow{4}{*}{66} & \multirow{4}{*}{$166 \%$} \\
\hline & & & $B$ & 92 & & & \\
\hline & & & C & -34 & & & \\
\hline & & & $\mathrm{D}$ & 2 & & & \\
\hline \multirow{8}{*}{2} & \multirow{4}{*}{249} & & A & -200 & \multirow{4}{*}{-259} & \multirow{4}{*}{90} & \multirow{4}{*}{$-35 \%$} \\
\hline & & & $B$ & -273 & & & \\
\hline & & & $C$ & -381 & & & \\
\hline & & 15 & $D$ & -183 & & & \\
\hline & \multirow{4}{*}{250} & & A & -86 & \multirow{4}{*}{-18} & \multirow{4}{*}{53} & \multirow{4}{*}{$-300 \%$} \\
\hline & & & $B$ & 35 & & & \\
\hline & & & $C$ & -32 & & & \\
\hline & & & D & 12 & & & \\
\hline
\end{tabular}




\section{APÊNDICE C}

\section{Resultados dos Ensaios Individuais, com duas repetições por concreto de cada caminhão amostrado}

\section{3) Lote treinamento}

Na Tabela 130 são apresentados os respectivos resultados do abatimento do tronco de cone, com a média, desvio padrão e o coeficiente de variação do lote treinamento.

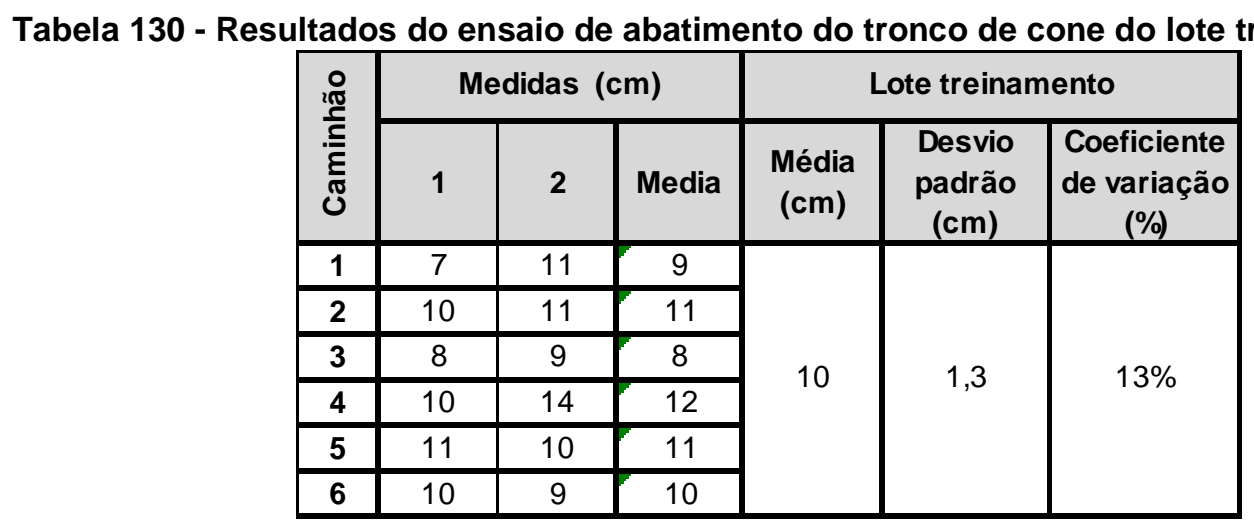

Na Tabela 131 são apresentados os resultados dos ensaios de massa específica de cada caminhão amostrado, com a média, desvio padrão e o coeficiente de variação do lote treinamento.

Tabela 131 - Resultados dos ensaios de massa especifica do concreto fresco do lote treinamento

\begin{tabular}{|c|c|c|c|c|c|c|c|c|c|c|}
\hline \multirow{3}{*}{ 迹 } & \multirow{3}{*}{$\begin{array}{l}\text { Massa do } \\
\text { recipiente } \\
\text { (g) }\end{array}$} & \multirow{3}{*}{$\begin{array}{c}\text { Volume } \\
\text { do } \\
\text { recipiente } \\
\left(\mathrm{cm}^{3}\right)\end{array}$} & \multicolumn{2}{|c|}{$\begin{array}{c}\text { Massa do recipiente + } \\
\text { concreto }(\mathbf{k g})\end{array}$} & \multicolumn{6}{|c|}{ Massa especifica $\left(\mathrm{kg} / \mathrm{m}^{3}\right)$} \\
\hline & & & \multirow[b]{2}{*}{$\begin{array}{l}\text { Medida } 1 \\
\text { (kg) }\end{array}$} & \multirow[b]{2}{*}{$\begin{array}{l}\text { Medida } 2 \\
(\mathbf{k g})\end{array}$} & \multicolumn{3}{|c|}{ Medidas $\left(\mathrm{kg} / \mathrm{m}^{3}\right)$} & \multicolumn{3}{|c|}{ Lote treinamento } \\
\hline & & & & & Medida 1 & Medida 2 & Média & $\begin{array}{l}\text { Média } \\
\left(\mathbf{k g} / \mathbf{m}^{3}\right)\end{array}$ & $\begin{array}{c}\text { Desvio padrão } \\
\left(\mathbf{k g} / \mathbf{m}^{3}\right)\end{array}$ & $\begin{array}{c}\text { Coeficiente } \\
\text { de variação } \\
(\%)\end{array}$ \\
\hline 1 & $\overline{9200}$ & 13,744 & 41200 & 41100 & 2328 & 2321 & 2325 & \multirow{6}{*}{2314} & \multirow{6}{*}{18} & \multirow{6}{*}{$1 \%$} \\
\hline 2 & 9200 & 13,744 & 41200 & 41100 & 2328 & 2321 & 2325 & & & \\
\hline 3 & 9200 & 13,744 & 41000 & 41100 & 2314 & 2321 & 2317 & & & \\
\hline 4 & 9200 & 13,744 & 41100 & 41100 & 2321 & 2321 & 2321 & & & \\
\hline 5 & 9200 & 13,744 & 40600 & 40400 & 2285 & 2270 & 2277 & & & \\
\hline 6 & 9200 & 13,744 & 41100 & 41100 & 2321 & 2321 & 2321 & & & \\
\hline
\end{tabular}




\section{APÊNDICE C}

\section{Resultados dos Ensaios Individuais, com duas repetições por concreto de cada caminhão amostrado}

$\mathrm{Na}$ Tabela 132 são apresentados os resultados dos ensaios compactabilidade do concreto adensado de cada caminhão amostrado, com a média, desvio padrão e o coeficiente de variação do lote treinamento.

Tabela 132 - Resultados do ensaio de compactabilidade com adensamento prévio do concreto amostrado do lote treinamento

\begin{tabular}{|c|c|c|c|c|c|c|}
\hline \multirow{2}{*}{ Uి } & \multicolumn{3}{|c|}{ Medidas $(\mathrm{cm})$} & \multicolumn{3}{|c|}{ Lote treinamento } \\
\hline & 1 & 2 & Média & $\begin{array}{c}\text { Média } \\
\text { (cm) }\end{array}$ & $\begin{array}{c}\text { Desvio } \\
\text { padrão } \\
\text { (cm) }\end{array}$ & $\begin{array}{c}\text { Coeficiente } \\
\text { de variação } \\
(\%)\end{array}$ \\
\hline 1 & 0,5 & 0,0 & 0,25 & \multirow{6}{*}{0,36} & \multirow{6}{*}{0,10} & \multirow{6}{*}{$28 \%$} \\
\hline 2 & 0,4 & 0,3 & 0,35 & & & \\
\hline 3 & 0,7 & 0,2 & 0,45 & & & \\
\hline 4 & 0,5 & 0,2 & 0,35 & & & \\
\hline 5 & 0,3 & 0,2 & 0,25 & & & \\
\hline 6 & 0,6 & 0,4 & 0,50 & & & \\
\hline
\end{tabular}

$\mathrm{Na}$ Tabela 133 são apresentados os resultados dos ensaios de teor de ar e umidade do concreto fresco de cada caminhão amostrado e a média, desvio padrão e coeficiente de variação do lote 2 .

Tabela 133 - Resultados dos ensaios de teor de ar e umidade do lote treinamento

\begin{tabular}{|c|c|c|c|c|c|c|c|c|}
\hline \multirow{3}{*}{ 选 } & \multicolumn{4}{|c|}{ Teor de ar pressométrico (\%) } & \multicolumn{4}{|c|}{ Umidade (\%) } \\
\hline & \multirow[b]{2}{*}{ Medida } & \multicolumn{3}{|c|}{ Lote treinamento } & \multirow[b]{2}{*}{ Medida } & \multicolumn{3}{|c|}{ Lote treinamento } \\
\hline & & $\begin{array}{l}\text { Média } \\
(\%)\end{array}$ & \begin{tabular}{|c} 
Desvio \\
padrão (\%)
\end{tabular} & $\begin{array}{c}\text { Coeficiente de } \\
\text { variação (\%) }\end{array}$ & & Média (\%) & \begin{tabular}{|c|} 
Desvio \\
padrão (\%)
\end{tabular} & $\begin{array}{c}\text { Coeficiente } \\
\text { de variação } \\
(\%)\end{array}$ \\
\hline 1 & 2,7 & \multirow{6}{*}{2,8} & \multirow{6}{*}{0,2} & \multirow{6}{*}{$8 \%$} & - & \multirow{6}{*}{11} & \multirow{6}{*}{0,6} & \multirow{6}{*}{$6 \%$} \\
\hline 2 & 2,5 & & & & - & & & \\
\hline 3 & 2,9 & & & & - & & & \\
\hline 4 & 3,0 & & & & 11 & & & \\
\hline 5 & - & & & & 11 & & & \\
\hline 6 & - & & & & 10 & & & \\
\hline
\end{tabular}




\section{APÊNDICE C}

\section{Resultados dos Ensaios Individuais, com duas repetições por concreto de cada caminhão amostrado}

Na Tabela 134 são apresentados os resultados dos ensaios de absorção de água total nos concretos dos caminhões amostrados no lote treinamento.

Tabela 134 - Resultados dos ensaios de absorção de água total do lote treinamento

\begin{tabular}{|c|c|c|c|c|c|c|c|c|c|c|c|c|}
\hline 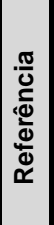 & 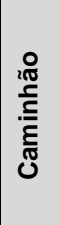 & 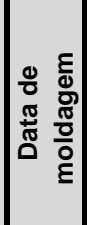 & Cura & $\begin{array}{c}\text { Massa } \\
\text { saturada } \\
\text { após cura } \\
\text { (g) }\end{array}$ & $\begin{array}{c}\text { Mass } \\
\text { seca a } \\
100^{\circ} \mathrm{C}\end{array}$ & $\begin{array}{c}\text { Maassa } \\
\text { saturada } \\
\text { (g) após } \\
\text { fervura a } \\
100^{\circ} \mathrm{C}\end{array}$ & $\begin{array}{c}\text { Massa } \\
\text { imersa } \\
\text { (g) em } \\
\text { água }\end{array}$ & $\begin{array}{c}\text { Absorção } \\
\text { de água } \\
\text { total }\end{array}$ & $\begin{array}{c}\text { Indice } \\
\text { de } \\
\text { vazios } \\
(\%)\end{array}$ & \begin{tabular}{|c} 
Massa \\
especifica \\
da \\
amostra \\
seca \\
$\left(\mathrm{g} / \mathrm{cm}^{3}\right)$
\end{tabular} & $\begin{array}{c}\text { Massa } \\
\text { especific } \\
\text { a da } \\
\text { amostra } \\
\text { saturada } \\
\left(\mathrm{g} / \mathrm{cm}^{3}\right)\end{array}$ & $\begin{array}{c}\text { Massa } \\
\text { especifi } \\
\text { ca real } \\
\left(\mathrm{g} / \mathrm{cm}^{3}\right)\end{array}$ \\
\hline 49 & \multirow{2}{*}{1} & \multirow{12}{*}{ 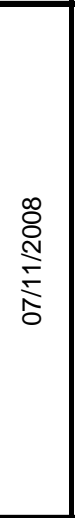 } & \multirow{12}{*}{$\begin{array}{c}\text { Cura } \\
\text { acelerada } \\
24 / 48 \\
\text { horas - } \\
\text { ASTM A; } \\
\text { e cura } \\
\text { imersa em } \\
\text { água até } \\
7 \text { dias }\end{array}$} & 3695,2 & 3518,9 & 3690,7 & 2144,60 & 4,88 & 11,11 & 2,28 & 2,39 & 2,56 \\
\hline 50 & & & & 3651,7 & 3465,2 & 3645,0 & 2097,50 & 5,19 & 11,62 & 2,24 & 2,36 & 2,53 \\
\hline 51 & ? & & & 3671,6 & 3468,1 & 3662,0 & 2109,30 & 5,59 & 12,49 & 2,23 & 2,36 & 2,55 \\
\hline \begin{tabular}{|l|}
52 \\
\end{tabular} & 2 & & & 3661,5 & 3479,2 & 3651,7 & 2111,70 & 4,96 & 11,20 & 2,26 & 2,37 & 2,54 \\
\hline 53 & \multirow{2}{*}{3} & & & 3632,9 & 3438,8 & 3621,7 & 2083,40 & 5,32 & 11,89 & 2,24 & 2,35 & 2,54 \\
\hline 54 & & & & 3636,1 & 3439,7 & 3625,2 & 2085,10 & 5,39 & 12,04 & 2,23 & 2,35 & 2,54 \\
\hline 55 & \multirow{2}{*}{4} & & & 3641,2 & 3456,4 & 3631,4 & 2102,20 & 5,06 & 11,44 & 2,26 & 2,37 & 2,55 \\
\hline 56 & & & & 3606,6 & 3411,1 & 3596,8 & 2074,50 & 5,44 & 12,20 & 2,24 & 2,36 & 2,55 \\
\hline 57 & \multirow{2}{*}{5} & & & 3635,8 & 3449,6 & 3625,0 & 2099,00 & 5,08 & 11,49 & 2,26 & 2,38 & 2,55 \\
\hline 58 & & & & 3647,3 & 3455,3 & 3638,3 & 2100,60 & 5,30 & 11,90 & 2,25 & 2,37 & 2,55 \\
\hline 59 & \multirow{2}{*}{6} & & & 3625,3 & 3436,6 & 3616,4 & 2079,30 & 5,23 & 11,70 & 2,24 & 2,35 & 2,53 \\
\hline 60 & & & & 3627,7 & 3441,5 & 3619,0 & 2087,00 & 5,16 & 11,59 & 2,25 & 2,36 & 2,54 \\
\hline 61 & \multirow{2}{*}{1} & \multirow{12}{*}{ 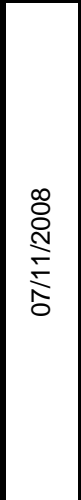 } & \multirow{12}{*}{$\begin{array}{c}\text { Cura } \\
\text { imersa em } \\
\text { água por } \\
28 \text { dias }\end{array}$} & 3661,1 & 3483,3 & 3654,6 & 2111,3 & 4,92 & 11,10 & 2,26 & 2,37 & 2,54 \\
\hline 62 & & & & 3645,1 & 3469,7 & 3645,1 & 2105,2 & 5,06 & 11,39 & 2,25 & 2,37 & 2,54 \\
\hline 63 & 2 & & & 3660,4 & 3490,0 & 3659,9 & 2116,3 & 4,87 & 11,01 & 2,26 & 2,37 & 2,54 \\
\hline 64 & & & & 3630,3 & 3447,1 & 3628,6 & 2073,6 & 5,27 & 11,67 & 2,22 & 2,33 & 2,51 \\
\hline 65 & \multirow{2}{*}{3} & & & 3643,7 & 3460,2 & 3636,2 & 2098,1 & 5,09 & 11,44 & 2,25 & 2,36 & 2,54 \\
\hline 66 & & & & 3626,1 & 3442,9 & 3618,3 & 2086,7 & 5,09 & 11,45 & 2,25 & 2,36 & 2,54 \\
\hline 67 & \multirow{2}{*}{4} & & & 3635,7 & 3469,0 & 3635,7 & 2105,0 & 4,81 & 10,89 & 2,27 & 2,38 & 2,54 \\
\hline 68 & & & & 3676,5 & 3497,7 & 3677,2 & 2116,8 & 5,13 & 11,50 & 2,24 & 2,36 & 2,53 \\
\hline 69 & \multirow{2}{*}{$\frac{9}{9}$} & & & 3633,9 & 3450,3 & 3633,1 & 2096,0 & 5,30 & 11,89 & 2,24 & 2,36 & 2,55 \\
\hline 70 & & & & 3629,2 & 3442,9 & 3629,3 & 2096,0 & 5,41 & 12,16 & 2,25 & 2,37 & 2,56 \\
\hline 71 & \multirow{2}{*}{6} & & & 3641,2 & 3470,3 & 3638,0 & 2097,3 & 4,83 & 10,88 & 2,25 & 2,36 & 2,53 \\
\hline 72 & & & & 3660,8 & 3492,3 & 3660,3 & 2113,1 & 4,81 & 10,86 & 2,26 & 2,37 & 2,53 \\
\hline
\end{tabular}




\section{APÊNDICE C}

\section{Resultados dos Ensaios Individuais, com duas repetições por concreto de cada caminhão amostrado}

Na Tabela 135 são apresentados os resultados dos ensaios de absorção de água por capilaridade nos concretos amostrados no lote treinamento.

$\mathrm{Na}$ Tabela 136 são apresentados os resultados dos ensaios mecânicos e de durabilidade realizados nos concretos amostrados no lote treinamento, com suas respectivas médias, desvio padrão, coeficiente de variação, valor máximo e mínimo. 
Tabela 135 - Resultados dos ensaios de absorção de água por capilaridade do lote treinamento

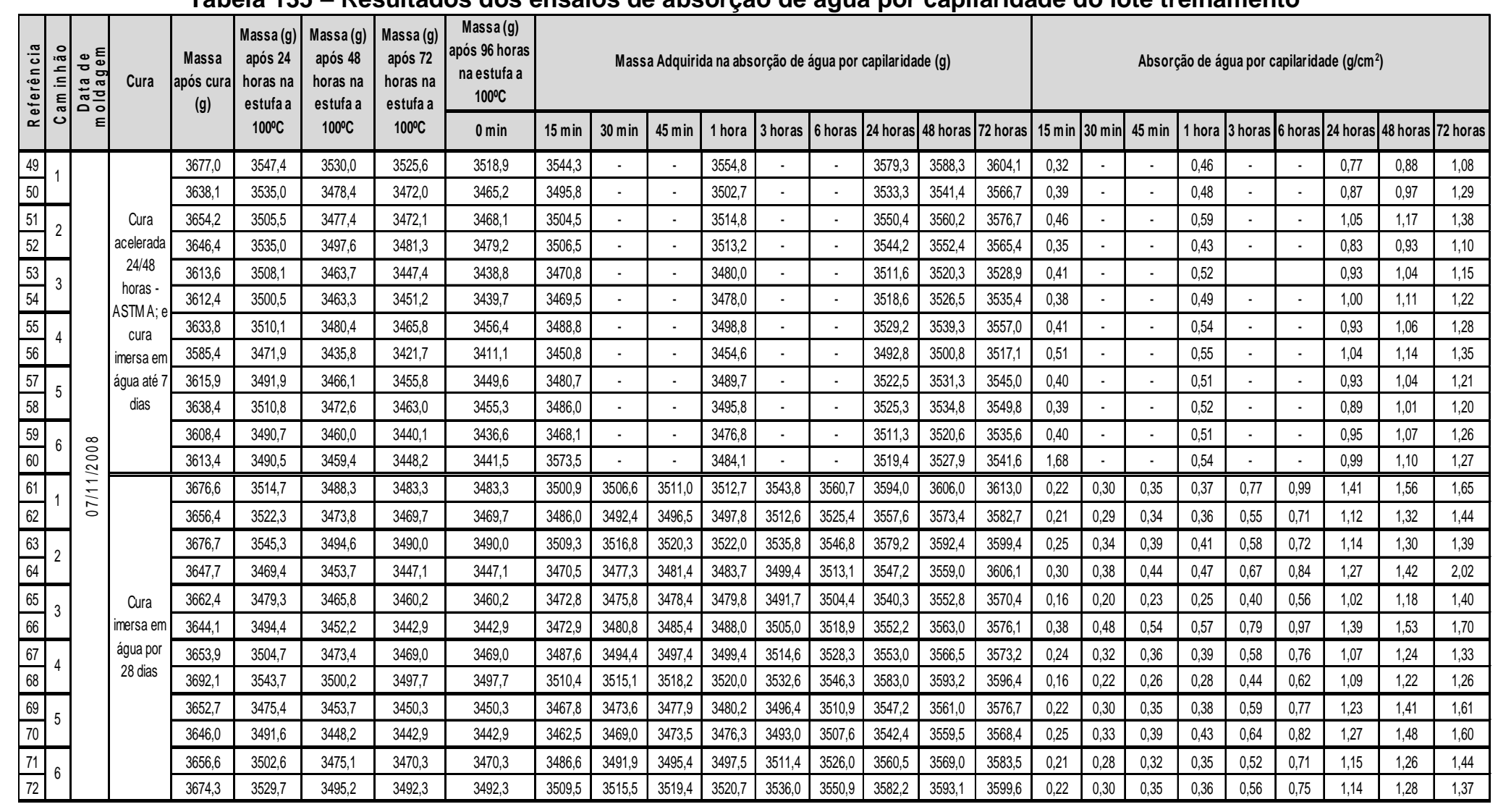


Tabela 136 - Resultados dos ensaios mecânicos e acelerados do lote treinamento

\begin{tabular}{|c|c|c|c|c|c|c|c|c|c|c|c|c|c|c|c|c|c|c|c|c|c|c|c|c|c|c|c|c|c|c|c|}
\hline \multirow{2}{*}{$\mathrm{N}^{0}$} & \multirow{2}{*}{$\begin{array}{l}\text { Porpriedadel } \\
\text { Caminhão }\end{array}$} & \multicolumn{6}{|c|}{ Média } & \multicolumn{6}{|c|}{ Desvio Padrão } & \multicolumn{6}{|c|}{ Coeficiente de variação } & \multicolumn{6}{|c|}{ Valor máximo } & \multicolumn{6}{|c|}{ Valor mínimo } \\
\hline & & C1 & C2 & C2 & $\mathrm{C4}$ & $\mathrm{C} 5$ & $\mathrm{C} 6$ & C1 & $\mathrm{C2}$ & $\mathrm{C3}$ & $\mathrm{C4}$ & $\mathrm{C5}$ & $\mathrm{C6}$ & C1 & $\mathrm{C2}$ & $\mathrm{C} 3$ & $\mathrm{C4}$ & $\mathrm{C5}$ & $\mathrm{C6}$ & $\mathrm{C} 1$ & C2 & C3 & $\mathrm{C} 4$ & $\mathrm{C5}$ & $\mathrm{C} 6$ & $\mathrm{C1}$ & C2 & C3 & $\mathrm{C4}$ & $\mathrm{C5}$ & $\mathrm{C6}$ \\
\hline 9 & \begin{tabular}{|c|} 
Resistência à \\
compressão - $\mathrm{f}_{\mathrm{c}} \mathbf{}$ \\
(MPa) - cura
\end{tabular} & 30,2 & 31,3 & 33,3 & 28,9 & 32,4 & 34,8 & 0,1 & 0,1 & 0,4 & 0,1 & 0,9 & 0,2 & $1 \%$ & $1 \%$ & $1 \%$ & $0 \%$ & $3 \%$ & $1 \%$ & 30,3 & 31,4 & 33,6 & 28,9 & 33,0 & 34,9 & 30,1 & 31,2 & 33,0 & 28,8 & 31,7 & 34,6 \\
\hline 10 & \begin{tabular}{|c} 
Resistência à \\
compressão - $\mathrm{f}_{c} 28$ \\
(MPa)
\end{tabular} & 39,5 & 32,7 & 38,7 & 34,5 & 30,2 & 37,5 & 4,0 & 3,9 & 1,1 & 3,8 & 2,5 & 1,0 & $10 \%$ & $12 \%$ & $3 \%$ & $11 \%$ & $8 \%$ & $3 \%$ & 42,3 & 35,4 & 39,4 & 37,2 & 31,9 & 38,2 & 36,6 & 29,9 & 37,9 & 31,8 & \begin{tabular}{|l|}
28,4 \\
\end{tabular} & 36,8 \\
\hline 11 & $\begin{array}{c}\text { Resistência à } \\
\text { tração por } \\
\text { compressão } \\
\text { diametral - } \mathrm{f}_{\mathrm{ct}} 7 \\
\text { (MPa) - cura } \\
\end{array}$ & 3,7 & 3,9 & 3,7 & 3,5 & 3,5 & 3,5 & 0,1 & 0,5 & 0,2 & 0,9 & 0,2 & 1,0 & $4 \%$ & $13 \%$ & $5 \%$ & $25 \%$ & $5 \%$ & $27 \%$ & 3,8 & 4,2 & 3,8 & 4,1 & 3,6 & 4,2 & 3,6 & 3,5 & 3,6 & 2,9 & 3,4 & 2,9 \\
\hline 12 & $\begin{array}{c}\text { Resistência à } \\
\text { tração por } \\
\text { compressão } \\
\text { diametral }-f_{\mathrm{ct}} 28 \\
(\mathrm{MPa})\end{array}$ & 3,0 & 3,9 & 3,6 & 3,0 & 3,3 & 3,7 & 0,8 & 0,0 & 0,1 & 0,0 & 0,6 & 0,8 & $25 \%$ & $1 \%$ & $4 \%$ & $2 \%$ & $17 \%$ & $21 \%$ & 3,6 & 3,9 & 3,7 & 3,0 & \begin{tabular}{|l|}
3,7 \\
\end{tabular} & 4,2 & 2,5 & 3,8 & 3,5 & 3,0 & 2,9 & 3,1 \\
\hline 13 & \begin{tabular}{|c} 
Resistência à \\
penetraçăo de $\mathrm{CO}_{2}$ \\
por ciclagem $(\mathrm{mm})$
\end{tabular} & 3,1 & 2,4 & 4,1 & 4,2 & 4,1 & 4,1 & 2,0 & 2,2 & 0,1 & 2,1 & 1,2 & 0,7 & $65 \%$ & $90 \%$ & $1 \%$ & $51 \%$ & $28 \%$ & $17 \%$ & 4,5 & 3,9 & 4,1 & 5,7 & 4,9 & 4,5 & 1,6 & 0,9 & 4,1 & 2,7 & 3,3 & 3,6 \\
\hline 14 & $\begin{array}{c}\text { Profundidade de } \\
\text { penetração de } \\
\text { cloretos }(\mathrm{mm}) \text { por } \\
\text { ciclagem }\end{array}$ & 6,5 & 1,9 & 4,3 & 1,6 & 5,4 & 3,3 & 4,9 & 2,0 & 0,8 & 2,3 & 6,2 & 4,7 & $74 \%$ & $104 \%$ & $19 \%$ & $141 \%$ & $116 \%$ & $141 \%$ & 10,0 & 3,3 & 4,8 & 3,2 & 9,8 & 6,6 & 3,1 & 0,5 & 3,7 & 0,0 & 1,0 & 0,0 \\
\hline 15 & \begin{tabular}{|c|} 
Resistência à \\
carbonatacacão por \\
secagem e $5 \% \mathrm{CO}_{2}$ \\
(91998 dias) $(\mathrm{mm}$ )
\end{tabular} & 11,1 & 10,2 & 11,4 & 10,1 & 5,7 & 0,0 & 0,1 & 0,8 & 0,2 & 0,1 & 0,7 & 0,0 & $1 \%$ & $8 \%$ & $2 \%$ & $1 \%$ & $12 \%$ & $0 \%$ & 11,2 & 10,8 & 11,6 & 10,2 & 6,2 & 0,0 & 11,1 & 9,6 & 11,3 & 10,0 & 5,2 & 0,0 \\
\hline 16 & $\begin{array}{c}\text { Resistência à } \\
\text { carbonatacăão por } \\
\text { secagem e 5\% } \mathrm{CO}_{2} \\
(\mathrm{~mm})\end{array}$ & 10,5 & 9,6 & 9,6 & 8,3 & 4,3 & 0,0 & 0,7 & 0,9 & 0,6 & 0,4 & 1,6 & 0,0 & $6 \%$ & $10 \%$ & $6 \%$ & $5 \%$ & $38 \%$ & $0 \%$ & 11,0 & 10,3 & 10,0 & 8,6 & 5,5 & 0,0 & 10,0 & 8,9 & 9,2 & 8,0 & 3,2 & 0,0 \\
\hline
\end{tabular}




\section{APÊNDICE C}

\section{Resultados dos Ensaios Individuais, com duas repetições por concreto de cada caminhão amostrado}

$\mathrm{Na}$ Tabela 137 são apresentadas todas as medidas dos ensaios de carbonatação realizados em câmara de $\mathrm{CO}_{2}$ (5\%; 7 dias), por fenolftaleína, nos corpos-de-prova do lote treinamento.

Tabela 137 - Resultados dos ensaios de carbonatação por câmara de $\mathrm{CO}_{2}$ ( $5 \%$; 7 dias) nos corposde-prova por fenolftaleína, submetidos a cura acelerada 24/48 horas mais imersão em água até 7 dias, do treinamento

\begin{tabular}{|c|c|c|c|c|c|c|c|c|c|c|c|}
\hline \multirow{4}{*}{$\frac{20}{\frac{2 \pi}{c}}$} & \multirow{4}{*}{$\begin{array}{l}\frac{\pi}{0} \\
\frac{\mathbb{U}}{\mathbb{N}} \\
\frac{\bar{d}}{\mathbb{J}} \\
\widetilde{I}\end{array}$} & \multicolumn{9}{|c|}{ Profundidade de carbonatação } & \multirow{4}{*}{$\begin{array}{c}\text { Coeficiente de } \\
\text { carbonatação } \\
(x=k \text { vt }) \\
\mathrm{mm} / \mathrm{ano}^{-1 / 2}\end{array}$} \\
\hline & & \multicolumn{9}{|c|}{ Lado A (fenol) } & \\
\hline & & \multicolumn{6}{|c|}{ Medidas (mm) } & \multirow{2}{*}{$\begin{array}{r}\text { Média } \\
(\mathrm{mm})\end{array}$} & \multirow{2}{*}{$\begin{array}{c}\text { Desvio } \\
\text { padrão } \\
(\mathrm{mm})\end{array}$} & \multirow{2}{*}{$\begin{array}{c}\text { Coeficiente de } \\
\text { variação (\%) }\end{array}$} & \\
\hline & & topo & meio & fundo & topo & meio & fundo & & & & \\
\hline \multirow{2}{*}{1} & 97 & 12,45 & 10,49 & 14,27 & 10,00 & 8,58 & 11,27 & 11,18 & 1,990 & $18 \%$ & 80,7 \\
\hline & 98 & 10,08 & 14,16 & 9,36 & 10,22 & 12,72 & 9,79 & 11,06 & 1,93 & $17 \%$ & 79,8 \\
\hline \multirow{2}{*}{2} & 99 & 10,07 & 10,81 & 8,70 & 8,79 & 8,87 & 10,55 & 9,63 & 0,96 & $10 \%$ & 69,6 \\
\hline & 100 & 10,43 & 11,34 & 10,54 & 11,03 & 11,9 & 9,28 & 10,75 & 0,90 & $8 \%$ & 77,6 \\
\hline \multirow{2}{*}{3} & 101 & 12,21 & 11,80 & 11,27 & 12,06 & 10,73 & 9,79 & 11,31 & 0,92 & $8 \%$ & 81,7 \\
\hline & 102 & 9,33 & 9,77 & 11,87 & 9,70 & 12,71 & 16,10 & 11,58 & 2,59 & $22 \%$ & 83,6 \\
\hline \multirow{2}{*}{4} & 103 & 12,86 & 9,16 & 9,78 & 10,37 & 6,70 & 11,23 & 10,02 & 2,07 & $21 \%$ & 72,3 \\
\hline & 104 & 8,35 & 11,49 & 10,4 & 7,61 & 12,65 & 10,86 & 10,23 & 1,91 & $19 \%$ & 73,8 \\
\hline \multirow{2}{*}{5} & 105 & 7,00 & 6,00 & 6,00 & 7,00 & 6,00 & 5,00 & 6,17 & 0,75 & $12 \%$ & 44,5 \\
\hline & 106 & 0,0 & 4,0 & 6,0 & 8,0 & 7,0 & 6,0 & 5,17 & 2,86 & $55 \%$ & 37,3 \\
\hline \multirow{2}{*}{6} & 107 & 0,0 & 0,0 & 0,0 & 0,0 & 0,0 & 0,0 & 0,00 & 0,0 & $0 \%$ & 0,0 \\
\hline & 108 & 0,0 & 0,0 & 0,0 & 0,0 & 0,0 & 0,0 & 0,00 & 0,0 & $0 \%$ & 0,0 \\
\hline
\end{tabular}

$\mathrm{Na}$ Tabela 138 são apresentadas todas as medidas dos ensaios de carbonatação realizados em câmara de $\mathrm{CO}_{2}$ ( $5 \% ; 7$ dias), por timolftaleína, nos corpos-de-prova do lote treinamento. 


\section{APÊNDICE C}

\section{Resultados dos Ensaios Individuais, com duas repetições por concreto de cada caminhão amostrado}

Tabela 138 - Resultados dos ensaios de profundidade de carbonatação em câmara de $\mathrm{CO}_{2}(5 \% ; 7$ dias), por timolftaleina nos corpos-de-prova do lote treinamento

\begin{tabular}{|c|c|c|c|c|c|c|c|c|c|c|c|}
\hline \multirow{4}{*}{ 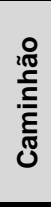 } & \multirow{4}{*}{ 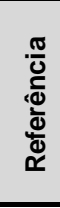 } & \multicolumn{9}{|c|}{ Profundidade de carbonatação } & \multirow{4}{*}{$\begin{array}{l}\text { Coeficiente de } \\
\text { carbonatação } \\
(x=k \text { v7t) } \\
\mathrm{mm} / \mathrm{ano}^{-1 / 2}\end{array}$} \\
\hline & & \multicolumn{9}{|c|}{ Lado B (timol) } & \\
\hline & & \multicolumn{6}{|c|}{ Medidas (mm) } & \multirow{2}{*}{$\begin{array}{r}\text { Média } \\
(\mathrm{mm})\end{array}$} & \multirow{2}{*}{$\begin{array}{c}\text { Desvio } \\
\text { padrão } \\
(\mathrm{mm}) \\
\end{array}$} & \multirow{2}{*}{$\begin{array}{c}\text { Coeficiente } \\
\text { de variação } \\
\text { (\%) }\end{array}$} & \\
\hline & & topo & meio & fundo & topo & meio & fundo & & & & \\
\hline \multirow{2}{*}{1} & 97 & 10,4 & 11,04 & 11,05 & 7,77 & 12,36 & 11,87 & 10,75 & 1,614 & $15 \%$ & 77,6 \\
\hline & 98 & 9,57 & 11,04 & 10,94 & 10,83 & 10,13 & 13,43 & 10,99 & 1,32 & $12 \%$ & 79,4 \\
\hline \multirow{2}{*}{2} & 99 & 9,84 & 11,77 & 13,93 & 10,67 & 11,86 & 9,66 & 11,29 & 1,59 & $14 \%$ & 81,5 \\
\hline & 100 & 11,55 & 11,51 & 12,67 & 10,49 & 11,40 & 10,73 & 11,39 & 0,76 & $7 \%$ & 82,3 \\
\hline \multirow{2}{*}{3} & 101 & 12,41 & 11,72 & 11,64 & 14,64 & 15,78 & 12,20 & 13,07 & 1,72 & $13 \%$ & 94,3 \\
\hline & 102 & 11,74 & 10,93 & 14,27 & 11,93 & 12,09 & 15,17 & 12,69 & 1,65 & $13 \%$ & 91,6 \\
\hline \multirow{2}{*}{4} & 103 & 9,46 & 13,69 & 10,47 & 12,59 & 8,82 & 9,99 & 10,84 & 1,90 & $18 \%$ & 78,3 \\
\hline & 104 & 12,43 & 11,36 & 10,65 & 9,91 & 11,06 & 11,38 & 11,13 & 0,84 & $8 \%$ & 80,4 \\
\hline \multirow{2}{*}{5} & 105 & 8,0 & 8,0 & 5,0 & 7,0 & 7,0 & 5,0 & 6,67 & 1,37 & $20 \%$ & 48,1 \\
\hline & 106 & 10,0 & 8,0 & 7,0 & 4,0 & 7,0 & 4,0 & 6,67 & 2,34 & $35 \%$ & 48,1 \\
\hline \multirow{2}{*}{6} & 107 & 0,0 & 0,0 & 0,0 & 0,0 & 0,0 & 0,0 & 0,00 & 0,0 & $0 \%$ & 0,0 \\
\hline & 108 & 3,0 & 4,0 & 3,0 & 0,0 & 2,0 & 2,0 & 2,33 & 1,4 & $0 \%$ & 16,8 \\
\hline
\end{tabular}

A Figura 77 ilustra a variação de massa nos corpos-de-prova, submetidos a três ciclos de imersão e secagem, dos ensaios de penetração de cloretos, amostrados dos caminhões do lote treinamento. 


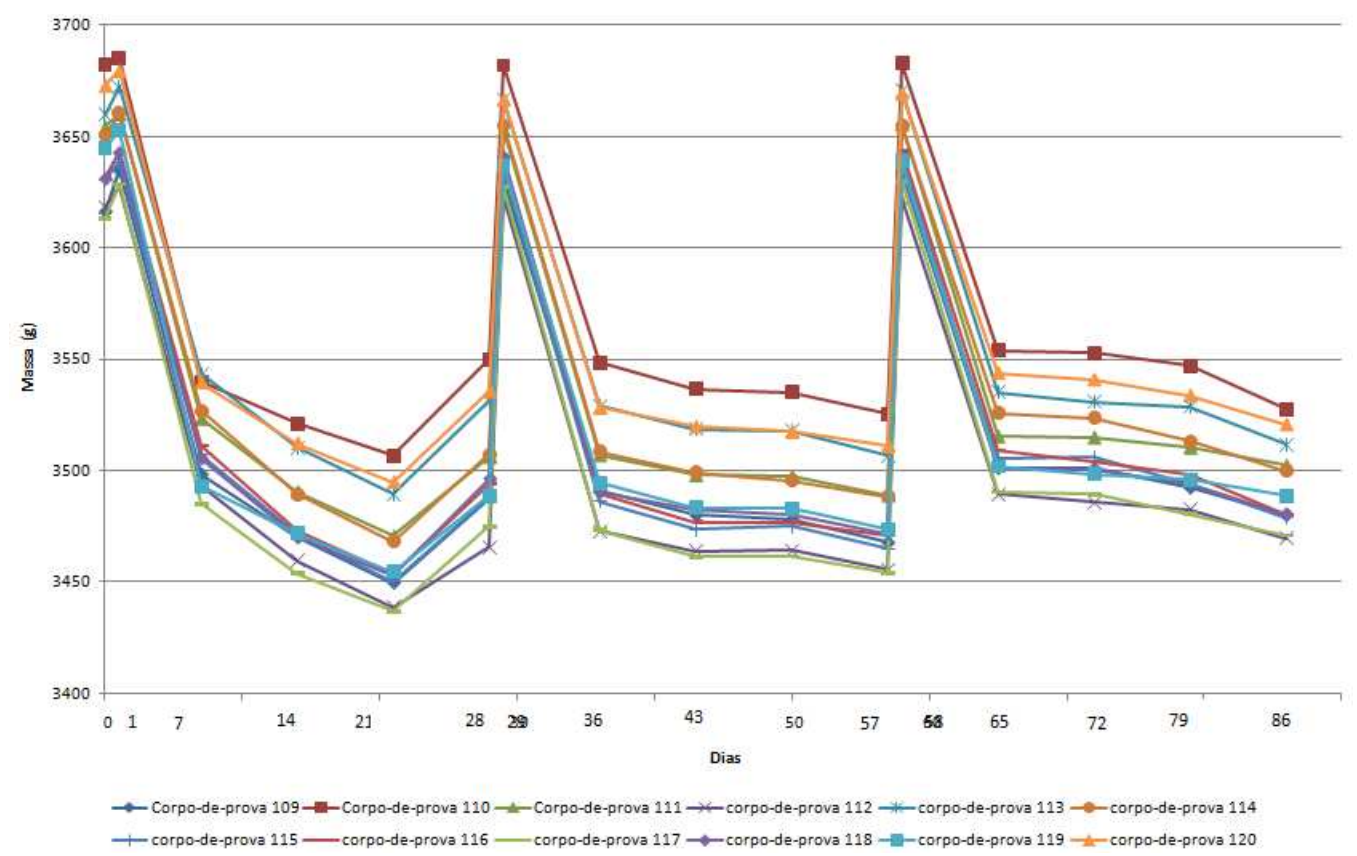

Figura 77 - Acompanhamento de massa dos corpos-de-prova, expostos a três ciclos de imersão e secagem, amostrados do lote treinamento.

$\mathrm{Na}$ Tabela 139 são apresentadas as medidas dos ensaios de profundidade de carbonatação em corpos-de-prova submetidos a três ciclos de imersão e secagem, do lote treinamento.

Tabela 139 - Resultados dos ensaios de carbonatação nos corpos-de-prova submetidos a três ciclos de imersão em solução de $3,5 \%$ de $\mathrm{NaCl}$ e secagem em caixa térmica ventilada, do lote treinamento

\begin{tabular}{|c|c|c|c|c|c|c|c|c|c|c|c|c|}
\hline \multirow{4}{*}{ 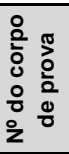 } & \multirow{4}{*}{ 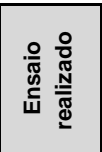 } & \multirow{4}{*}{ 苟 } & \multirow{2}{*}{\multicolumn{6}{|c|}{$\begin{array}{c}\text { Profundidade de carbonatação }(\mathrm{mm}) \\
\text { Posicão do corpo de prova }\end{array}$}} & \multirow{4}{*}{$\begin{array}{r}\text { Média } \\
(\mathrm{mm})\end{array}$} & \multirow{4}{*}{$\begin{array}{c}\text { Desvio } \\
\text { padrão } \\
(\mathrm{mm})\end{array}$} & \multirow{4}{*}{$\begin{array}{c}\text { Coeficiente } \\
\text { de variação } \\
(\%)\end{array}$} & \multirow{4}{*}{$\begin{array}{l}\text { Coeficiente de } \\
\text { carbonatação (x } \\
=\mathrm{kvt}) \mathrm{mm} / \mathrm{ano}^{-1 / 2}\end{array}$} \\
\hline & & & & & & & & & & & & \\
\hline & & & Fundo & Meio & Topo & Fundo & Meio & Topo & & & & \\
\hline & & & 1 & 2 & 3 & 4 & 5 & 6 & & & & \\
\hline 109 & \multirow{12}{*}{ 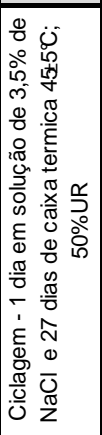 } & \multirow{12}{*}{$\begin{array}{c}\text { Acelerada } \\
24 / 48 \mathrm{hs}, \\
38 \pm 3 \mathrm{C} \\
\text { (adaptada } \\
\text { do método } \\
\text { A da ASTM } \\
684 \mathrm{C} \text { ) } \\
\text { imersão em } \\
\text { água até } 7 \\
\text { dias }\end{array}$} & 4,4 & 3,19 & 4,77 & 3,02 & 2,47 & 9,03 & 4,5 & 2,4 & $53 \%$ & 8,96 \\
\hline 110 & & & 0,0 & 2,6 & 2,81 & 0,0 & 1,9 & 2,56 & 1,6 & 1,3 & $80 \%$ & 3,29 \\
\hline 111 & & & 0,0 & 0,0 & 13,0 & 0,0 & 2,05 & 8,60 & 3,9 & 5,5 & $141 \%$ & 7,88 \\
\hline 112 & & & 0,0 & 1,15 & 2,01 & 0,0 & 0,0 & 2,1 & 0,9 & 1,0 & $116 \%$ & 1,75 \\
\hline 113 & & & 4,36 & 2,26 & 6,95 & 3,43 & 2,44 & 5,01 & 4,1 & 1,8 & $43 \%$ & 8,15 \\
\hline 114 & & & 3,91 & 3,15 & 4,84 & 3,48 & 4,68 & 4,8 & 4,1 & 0,7 & $18 \%$ & 8,29 \\
\hline 115 & & & 8,12 & 3,37 & 5,55 & 9,55 & 3,47 & 4,01 & 5,7 & 2,6 & $0 \%$ & 11,36 \\
\hline 116 & & & 3,46 & 3,08 & 2,75 & 2,1 & 1,75 & 2,91 & 2,7 & 0,6 & $24 \%$ & 5,35 \\
\hline 117 & & & 2,71 & 2,37 & 1,24 & 6,11 & 3,42 & 4,00 & 3,3 & 1,7 & $50 \%$ & 6,62 \\
\hline 118 & & & 3,81 & 3,35 & 7,17 & 3,09 & 6,60 & 5,64 & 4,9 & 1,8 & $36 \%$ & 9,89 \\
\hline 119 & & & 4,90 & 3,95 & 3,08 & 3,99 & 2,30 & 3,27 & 3,6 & 0,9 & $0 \%$ & 7,16 \\
\hline 120 & & & 4,26 & 3,54 & 6,90 & 3,18 & 4,25 & 5,08 & 4,5 & 1,3 & $29 \%$ & 9,07 \\
\hline
\end{tabular}




\section{APÊNDICE C}

\section{Resultados dos Ensaios Individuais, com duas repetições por concreto de cada caminhão amostrado}

Na Tabela 140 são apresentadas as medidas dos ensaios de penetração de cloretos nos corpos-de-prova, rompidos na diametral, submetidos a três ciclos de molhagem e secagem, amostrados dos caminhões do lote treinamento.

Tabela 140 - Resultados do ensaio de penetração de cloretos em corpos-de-prova rompidos na diametral, submetidos a ciclos de molhagem e secagem, dos caminhões amostrados do lote treinamento

\begin{tabular}{|c|c|c|c|c|c|c|c|c|c|c|c|c|}
\hline \multirow{4}{*}{$\begin{array}{ll} & \\
\text { 운 } & \frac{\pi}{2} \\
0 & 0 \\
0 & 0 \\
0 & 0 \\
2 & 0\end{array}$} & \multirow{4}{*}{ 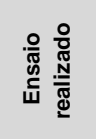 } & \multirow{4}{*}{ 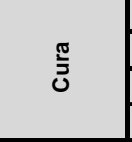 } & \multicolumn{6}{|c|}{ Profundidade de penetração de cloretos $(\mathrm{mm})$} & \multirow{4}{*}{$\begin{array}{r}\text { Média } \\
(\mathrm{mm})\end{array}$} & \multirow{4}{*}{$\begin{array}{l}\text { Desvio } \\
\text { padrão } \\
(\mathrm{mm})\end{array}$} & \multirow{4}{*}{$\begin{array}{c}\text { Coeficiente } \\
\text { de variação } \\
(\%)\end{array}$} & \multirow{4}{*}{$\begin{array}{c}\text { Valor } \\
\text { caracteristic } \\
\text { o da } \\
\text { profundidad }\end{array}$} \\
\hline & & & \multicolumn{6}{|c|}{ Posição do corpo de prova } & & & & \\
\hline & & & Fundo & Meio & Topo & Fundo & Meio & Topo & & & & \\
\hline & & & 1 & 2 & 3 & 4 & 5 & 6 & & & & \\
\hline 109 & \multirow{12}{*}{ 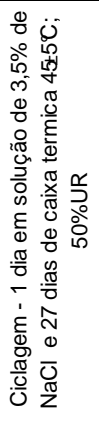 } & \multirow{12}{*}{$\begin{array}{c}\text { Acelerada } \\
24 / 48 \mathrm{hs}, \\
38 \pm 3^{C} \mathrm{C} \\
\text { (adaptada } \\
\text { do método } \\
\text { A da ASTM } \\
684 \text { C) + } \\
\text { imersão em } \\
\text { água até } 7 \\
\text { dias }\end{array}$} & 4,08 & 0 & 4,94 & 6,02 & 0 & 3,55 & 3,1 & 2,5 & $82 \%$ & \multirow{2}{*}{10,0} \\
\hline 110 & & & 4,85 & 2,82 & 9,41 & 16,45 & 14,65 & 11,60 & 10,0 & 5,4 & $54 \%$ & \\
\hline 111 & & & 0,0 & 0,0 & 3,05 & 0,0 & 0,0 & 0,0 & 0,5 & 1,2 & $245 \%$ & \multirow{2}{*}{3,3} \\
\hline 112 & & & 2,34 & 3,57 & 2,63 & 5,09 & 3,50 & 2,67 & 3,3 & 1,0 & $31 \%$ & \\
\hline 113 & & & 3,07 & 2,66 & 2,80 & 2,20 & 5,80 & 5,65 & 3,7 & 1,6 & $43 \%$ & \multirow{2}{*}{4,8} \\
\hline 114 & & & 5,04 & 5,01 & 7,8 & 2,56 & 2,98 & 5,52 & 4,8 & 1,9 & $39 \%$ & \\
\hline 115 & & & 0,0 & 0,0 & 0,0 & 0,0 & 0,0 & 0,0 & 0,0 & 0,0 & $0 \%$ & \multirow{2}{*}{3,2} \\
\hline 116 & & & 5,0 & 4,0 & 0,0 & 6,5 & 3,70 & 0,0 & 3,2 & 2,7 & $83 \%$ & \\
\hline 117 & & & 13,45 & 12,21 & 12,96 & 9,25 & 3,10 & 7,80 & 9,8 & 4,0 & $40 \%$ & \multirow{2}{*}{9,8} \\
\hline 118 & & & 3,60 & 0,00 & 0,00 & 2,31 & 0,00 & 0,00 & 1,0 & 1,6 & $160 \%$ & \\
\hline 119 & & & 0,0 & 0,0 & 0,0 & 0,0 & 0,0 & 0,0 & 0,0 & 0,0 & $0 \%$ & \multirow{2}{*}{6,6} \\
\hline 120 & & & 6,85 & 4,84 & 3,78 & 11,10 & 7,54 & 5,44 & 6,6 & 2,6 & $39 \%$ & \\
\hline
\end{tabular}




\section{APÊNDICE C}

\section{Resultados dos Ensaios Individuais, com duas repetições por concreto de cada caminhão amostrado}

$\mathrm{Na}$ Tabela 141 são apresentadas todas as medidas dos ensaios acelerados de cloretos feitos após a ruptura nos terços.

Tabela 141 - Resultados dos ensaios da penetração de cloretos nos terços médios dos corpos-deprova do lote treinamento

\begin{tabular}{|c|c|c|c|c|c|c|c|c|c|c|}
\hline \multirow{2}{*}{ 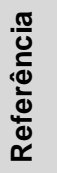 } & \multirow{2}{*}{ 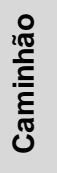 } & \multicolumn{3}{|c|}{ Terço } & \multicolumn{3}{|c|}{ Terço } & \multirow{2}{*}{$\begin{array}{l}\text { Média } \\
(\mathrm{mm})\end{array}$} & \multirow{2}{*}{$\begin{array}{c}\text { Desvio } \\
\text { Padrão }(\mathrm{mm})\end{array}$} & \multirow{2}{*}{$\begin{array}{c}\text { Coeficiente de } \\
\text { variação (\%) }\end{array}$} \\
\hline & & \multicolumn{3}{|c|}{ Terço Superior (TS) } & \multicolumn{3}{|c|}{ Terço Inferior (TI) } & & & \\
\hline 109 & 1 & 2,81 & 4,50 & 3,76 & 3,12 & 4,83 & 4,48 & 3,7 & 0,8 & $23 \%$ \\
\hline 110 & 1 & 3,16 & 3,87 & 3,21 & - & - & - & 3,4 & 0,4 & $12 \%$ \\
\hline 111 & 2 & 4,33 & 4,14 & 3,68 & - & - & - & 4,1 & 0,3 & $8 \%$ \\
\hline 112 & 2 & 2,70 & 2,72 & 3,15 & 3,87 & 5,80 & 4,76 & 2,9 & 0,3 & $9 \%$ \\
\hline 113 & 3 & 3,27 & 3,60 & 3,36 & 5,98 & 4,55 & 4,90 & 3,4 & 0,2 & $5 \%$ \\
\hline 114 & 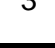 & 3,18 & 5,38 & 4,10 & 4,02 & 3,40 & 3,60 & 4,2 & 1,1 & $26 \%$ \\
\hline 115 & 4 & 4,88 & 3,42 & 4,20 & 4,22 & 4,30 & 4,03 & 4,2 & 0,7 & $18 \%$ \\
\hline 116 & & - & - & - & 3,31 & 4,11 & 4,05 & 3,8 & 0,4 & - \\
\hline 117 & 5 & 3,37 & 3,30 & 3,06 & 3,33 & 2,85 & 4,03 & 3,2 & 0,2 & $5 \%$ \\
\hline 118 & & - & - & - & - & - & - & - & - & - \\
\hline 119 & 6 & 3,66 & 3,04 & 3,86 & 3,47 & 4,31 & 4,60 & 3,5 & 0,4 & $12 \%$ \\
\hline 120 & 0 & 1,97 & 1,56 & 1,94 & 2,25 & 2,41 & 2,14 & 1,8 & 0,2 & $13 \%$ \\
\hline
\end{tabular}

A Tabela 142 apresenta os valores de potencial de corrosão dos corpos-de-prova do lote treinamento com $2,5 \mathrm{~cm}$ de cobrimento. 


\section{APÊNDICE C}

Resultados dos Ensaios Individuais, com duas repetições por concreto de cada caminhão amostrado

Tabela 142 - Valores do potencia de corrosão no potenciostato modelo 273 (mV,ECS), nos corposde-prova com cobrimento de $2,5 \mathrm{~cm}$ do lote treinamento

\begin{tabular}{|c|c|c|c|c|c|c|c|}
\hline \multirow{2}{*}{ 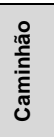 } & \multirow[t]{2}{*}{$\begin{array}{c}\text { Nodo } \\
\text { corpo de } \\
\text { prova }\end{array}$} & \multirow{2}{*}{ 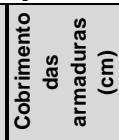 } & \multirow[t]{2}{*}{$\begin{array}{l}\text { Identificação } \\
\text { barra no cp }\end{array}$} & $\begin{array}{l}\text { Valores de potencial no potenciostato mod } \\
273 \text { ( } \mathrm{mV} \text {, ECS em pte sal KCI } 3 \mathrm{~mol})\end{array}$ & \multirow[t]{2}{*}{ Media } & \multirow[t]{2}{*}{$\begin{array}{l}\text { Desvio } \\
\text { padrão }\end{array}$} & \multirow{2}{*}{$\begin{array}{c}\text { Coeficiente } \\
\text { de } \\
\text { variação }\end{array}$} \\
\hline & & & & 600 segundos & & & \\
\hline \multirow{8}{*}{1} & \multirow{4}{*}{121} & \multirow{8}{*}{2,5} & $\mathrm{~A}$ & -500 & \multirow{4}{*}{$-435,3$} & \multirow{4}{*}{44,0} & \multirow{4}{*}{$-10 \%$} \\
\hline & & & $B$ & -402 & & & \\
\hline & & & $\mathrm{C}$ & -422 & & & \\
\hline & & & $\mathrm{D}$ & -417 & & & \\
\hline & \multirow{4}{*}{122} & & $\bar{A}$ & -471 & \multirow{4}{*}{$-485,5$} & \multirow{4}{*}{64,0} & \multirow{4}{*}{$-13 \%$} \\
\hline & & & $B$ & -401 & & & \\
\hline & & & $\mathrm{C}$ & -540 & & & \\
\hline & & & $\mathrm{D}$ & -530 & & & \\
\hline \multirow{8}{*}{2} & \multirow{4}{*}{123} & & $\mathrm{~A}$ & -390 & \multirow{4}{*}{$-405,3$} & \multirow{4}{*}{17,6} & \multirow{4}{*}{$-4 \%$} \\
\hline & & & $B$ & -396 & & & \\
\hline & & & c & -430 & & & \\
\hline & & 25 & $\mathrm{D}$ & -405 & & & \\
\hline & & 2,5 & $\bar{A}$ & -528 & & & \\
\hline & 10 & & B & -500 & 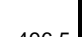 & 200 & 70 \\
\hline & 124 & & C & -508 & $\mid-496,5$ & 33,2 & $-1 \%$ \\
\hline & & & $\mathrm{D}$ & -450 & & & \\
\hline & & & $\mathrm{A}$ & -432 & & & \\
\hline & 105 & & $B$ & -450 & 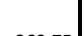 & 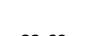 & 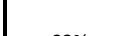 \\
\hline & 125 & & $\mathrm{C}$ & -315 & $-369,75$ & 83,69 & $-23 \%$ \\
\hline 2 & & 25 & $\mathrm{D}$ & -282 & & & \\
\hline 3 & & 2,0 & $\bar{A}$ & \begin{tabular}{ll|}
-437 \\
\end{tabular} & & & \\
\hline & 126 & & B & -520 & 1 & 5122 & 110 \\
\hline & 126 & & C & -445 & $-449,75$ & 51,32 & $-11 \%$ \\
\hline & & & $\mathrm{D}$ & -397 & & & \\
\hline & & & A & -561 & & & \\
\hline 4 & 128 & 25 & B & -526 & 505 & 6622 & $13 \%$ \\
\hline 4 & & & C & -409 & -505 & 66,22 & $-13 \%$ \\
\hline & & & $\mathrm{D}$ & -524 & & & \\
\hline & & & $\mathrm{A}$ & -415 & & & \\
\hline & 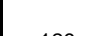 & & $B$ & -413 & & & 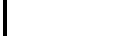 \\
\hline & 129 & & C & -411 & $-394,5$ & 37,04 & $-9 \%$ \\
\hline- & & 25 & $\mathrm{D}$ & -339 & & & \\
\hline 5 & & 2,5 & $\bar{A}$ & -459 & & & \\
\hline & 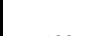 & & B & -181 & 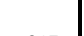 & 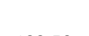 & \\
\hline & 130 & & $\mathrm{c}$ & -400 & -317 & 133,50 & $-42 \%$ \\
\hline & & & $\mathrm{D}$ & -228 & & & \\
\hline & & & A & -469 & & & \\
\hline & 131 & & B & -158 & | & 10 & 11\% \\
\hline & 131 & & $\mathrm{C}$ & -319 & $-311,75$ & 127,19 & $-41 \%$ \\
\hline & & 25 & $\mathrm{D}$ & -301 & & & \\
\hline 6 & & & $\bar{A}$ & -484 & & & \\
\hline & 132 & & B & -468 & 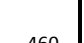 & & \\
\hline & & & C & -425 & -460 & 24,99 & $-5 \%$ \\
\hline & & & $\mathrm{D}$ & -463 & & & \\
\hline
\end{tabular}


A Tabela 143 apresenta os valores de potencial de corrosão dos corpos-de-prova do lote treinamento com $1,5 \mathrm{~cm}$ e $3,5 \mathrm{~cm}$ de cobrimento.

Tabela 143 - Valores do potencia de corrosão no potenciostato modelo 273 (mV,ECS), nos corposde-prova com cobrimento de $3,5 \mathrm{~cm}$ e $1,5 \mathrm{~cm}$ do lote treinamento

\begin{tabular}{|c|c|c|c|c|c|c|c|}
\hline \multirow{2}{*}{ 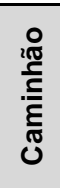 } & \multirow[t]{2}{*}{$\begin{array}{l}N^{\circ} \text { do } \\
\text { corpo de } \\
\text { prova }\end{array}$} & \multirow{2}{*}{ 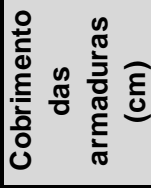 } & \multirow[t]{2}{*}{$\begin{array}{c}\text { Identificaç } \\
\text { ão barra no } \\
\text { cp }\end{array}$} & $\begin{array}{c}\text { Valores de potencial no } \\
\text { potenciostato mod } 273(\mathrm{mVvsECS} \\
\text { em pte sal } \mathrm{KCl} 3 \mathrm{~mol})\end{array}$ & \multirow[t]{2}{*}{ Media } & \multirow[t]{2}{*}{$\begin{array}{l}\text { Desvio } \\
\text { padrão }\end{array}$} & \multirow[t]{2}{*}{$\begin{array}{l}\text { Coeficiente } \\
\text { de variação }\end{array}$} \\
\hline & & & & 600 segundos & & & \\
\hline \multirow{8}{*}{1} & \multirow{4}{*}{133} & \multirow{8}{*}{3,5} & $A$ & -398 & \multirow{4}{*}{$-467,0$} & \multirow{4}{*}{92,2} & \multirow{4}{*}{$-20 \%$} \\
\hline & & & $B$ & -377 & & & \\
\hline & & & C & -545 & & & \\
\hline & & & D & -548 & & & \\
\hline & \multirow{4}{*}{134} & & A & -367 & \multirow{4}{*}{$-402,8$} & \multirow{4}{*}{61,0} & \multirow{4}{*}{$-15 \%$} \\
\hline & & & $B$ & -407 & & & \\
\hline & & & C & -350 & & & \\
\hline & & & $D$ & -487 & & & \\
\hline \multirow{8}{*}{2} & \multirow{4}{*}{135} & \multirow{8}{*}{1,5} & A & -409 & \multirow{4}{*}{$-408,3$} & \multirow{4}{*}{37,5} & \multirow{4}{*}{$-9 \%$} \\
\hline & & & $B$ & -434 & & & \\
\hline & & & $C$ & -355 & & & \\
\hline & & & $D$ & -435 & & & \\
\hline & \multirow{4}{*}{136} & & $A$ & -434 & \multirow{4}{*}{$-441,0$} & \multirow{4}{*}{28,4} & \multirow{4}{*}{$-6 \%$} \\
\hline & & & $B$ & -414 & & & \\
\hline & & & C & -435 & & & \\
\hline & & & $\mathrm{D}$ & -481 & & & \\
\hline
\end{tabular}




\section{APÊNDICE D}

\section{Registro fotográfico das seções dos corpos-de-prova e medidas quanto à penetração de cloretos e profundidade de carbonatação}

\section{1) Lote 1}

1.1) Profundidade de Penetração de cloretos por três ciclos de imersão e secagem

As Figuras 78, 79, 80 81, 82, 83 apresentam as fotos das metades de corpos-de-prova do lote 1, com fratura nos terços médios (TS = terço superior; $\mathrm{TI}=$ terço inferior), após ensaio inicial de compressão diametral.

Abaixo de cada foto consta o número do caminhão, do corpo-de-prova, o terço ensaiado e a profundidade média de penetração de cloretos, nas respectivas seções.

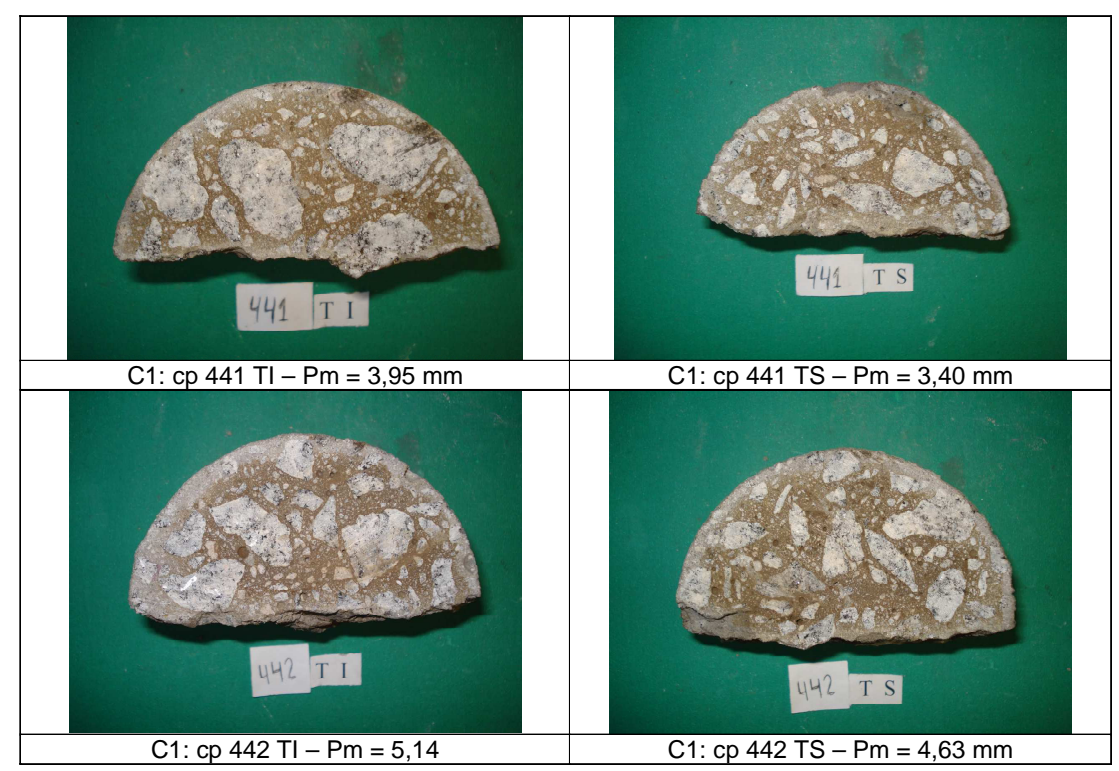

Figura 78 - Seções de medida da penetração de cloretos nos corpos-de-prova 441 e 442 do lote 1, após cura acelerada (24/48 h) e três ciclos de imersão e secagem, entre 7 e 91 dias. 


\section{APÊNDICE D}

Registro fotográfico das seções dos corpos-de-prova e medidas quanto à penetração de cloretos e profundidade de carbonatação

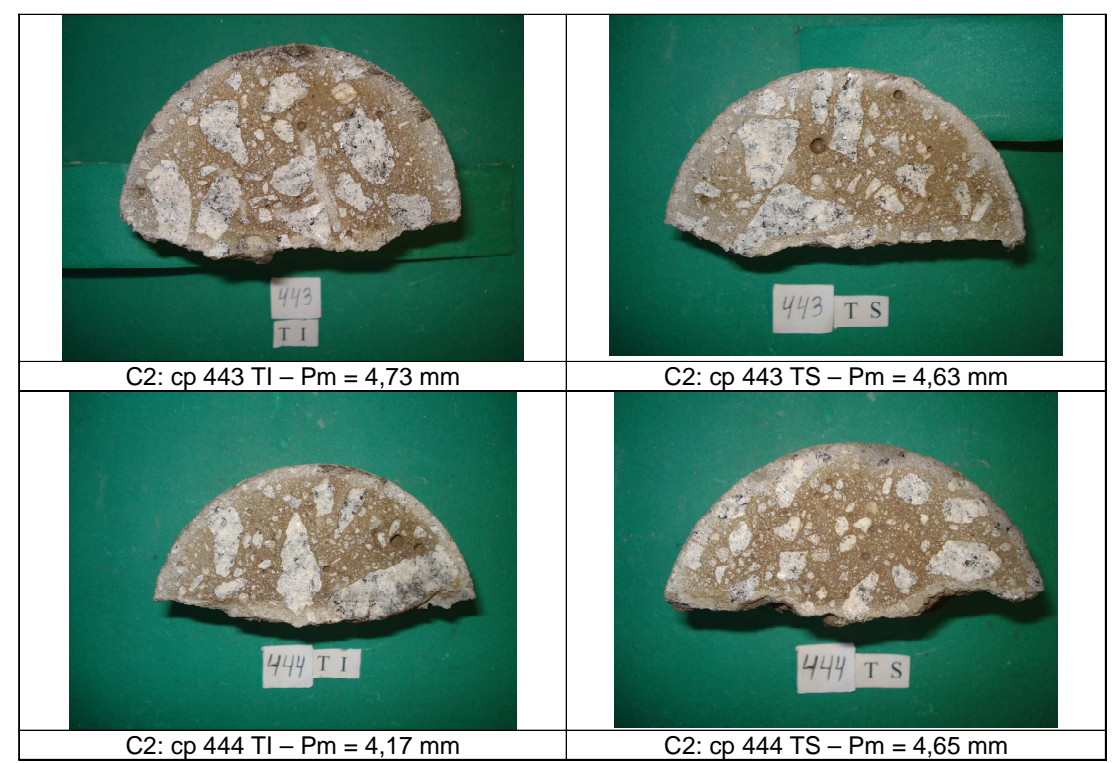

Figura 79 - Seções de medida da penetração de cloretos nos corpos-de-prova 443 e 444, com cura acelerada $24 / 48$ h, do lote 1 , após três ciclos de imersão e secagem entre 7 e 91 dias.

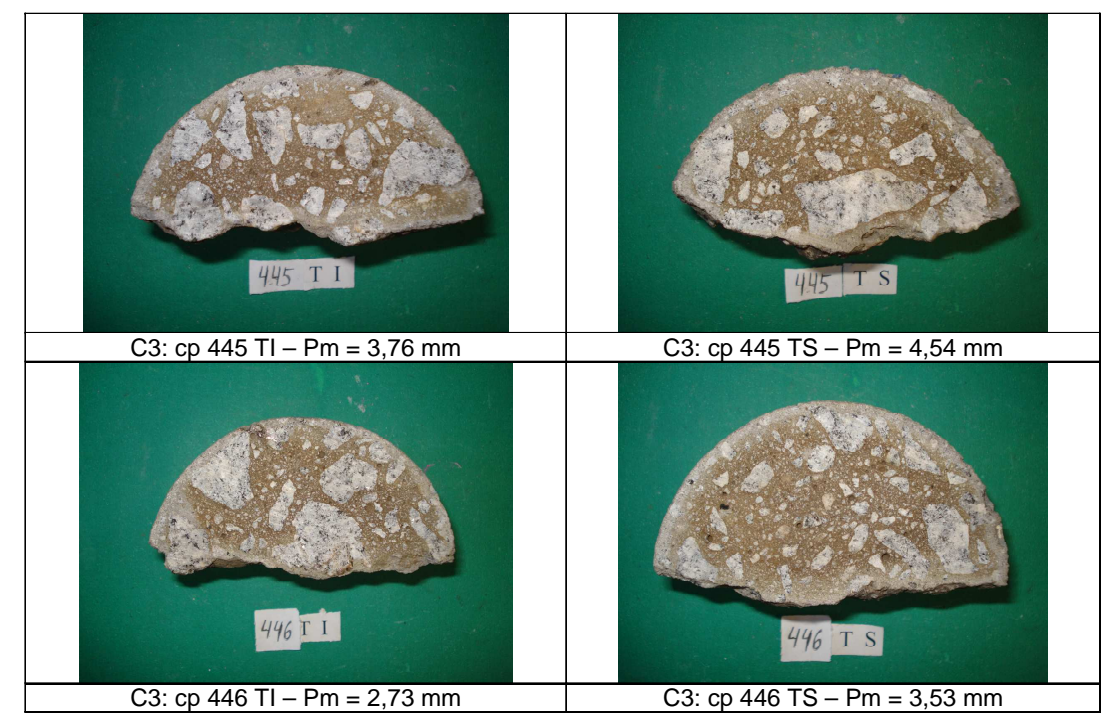

Figura 80 - Seções de medida da penetração de cloretos nos corpos-de-prova 445 e 446 do lote 1, após cura acelerada $(24 / 48$ h) e três ciclos de imersão e secagem, entre 7 e 91 dias. 


\section{APÊNDICE D}

Registro fotográfico das seções dos corpos-de-prova e medidas quanto à penetração de cloretos e profundidade de carbonatação

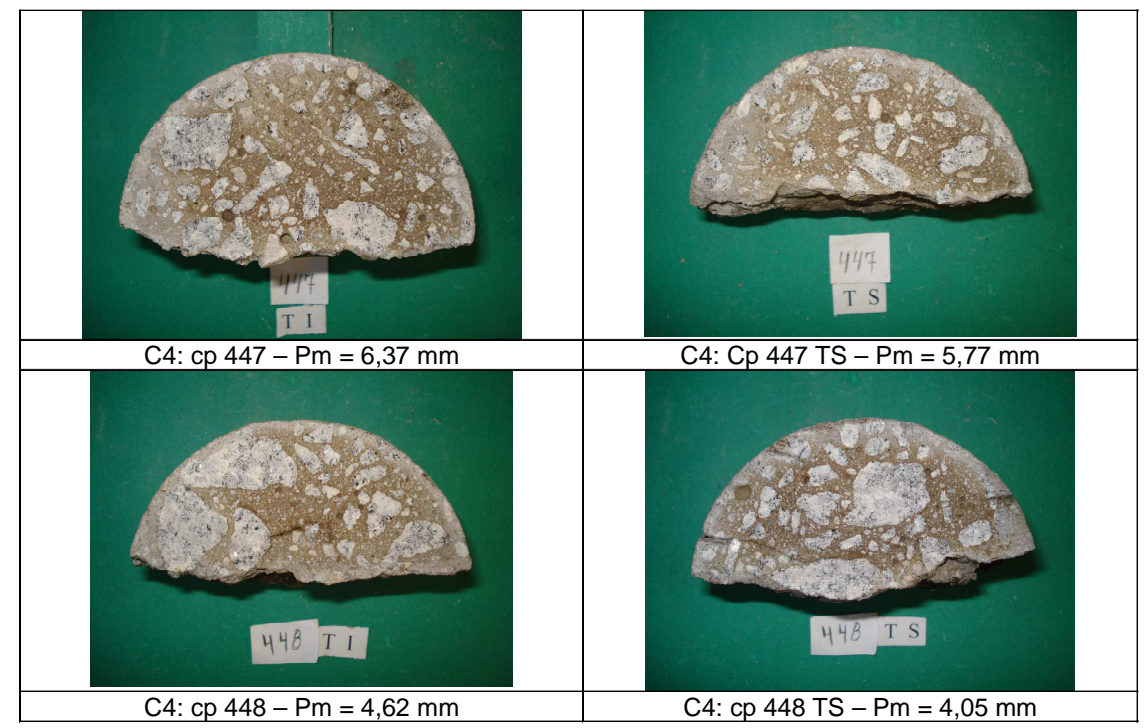

Figura 81 - Seções de medida da penetração de cloretos nos corpos-de-prova 447 e 448 do lote 1, após cura acelerada $(24 / 48 \mathrm{~h})$ e três ciclos de imersão e secagem entre 7 e 91 dias.

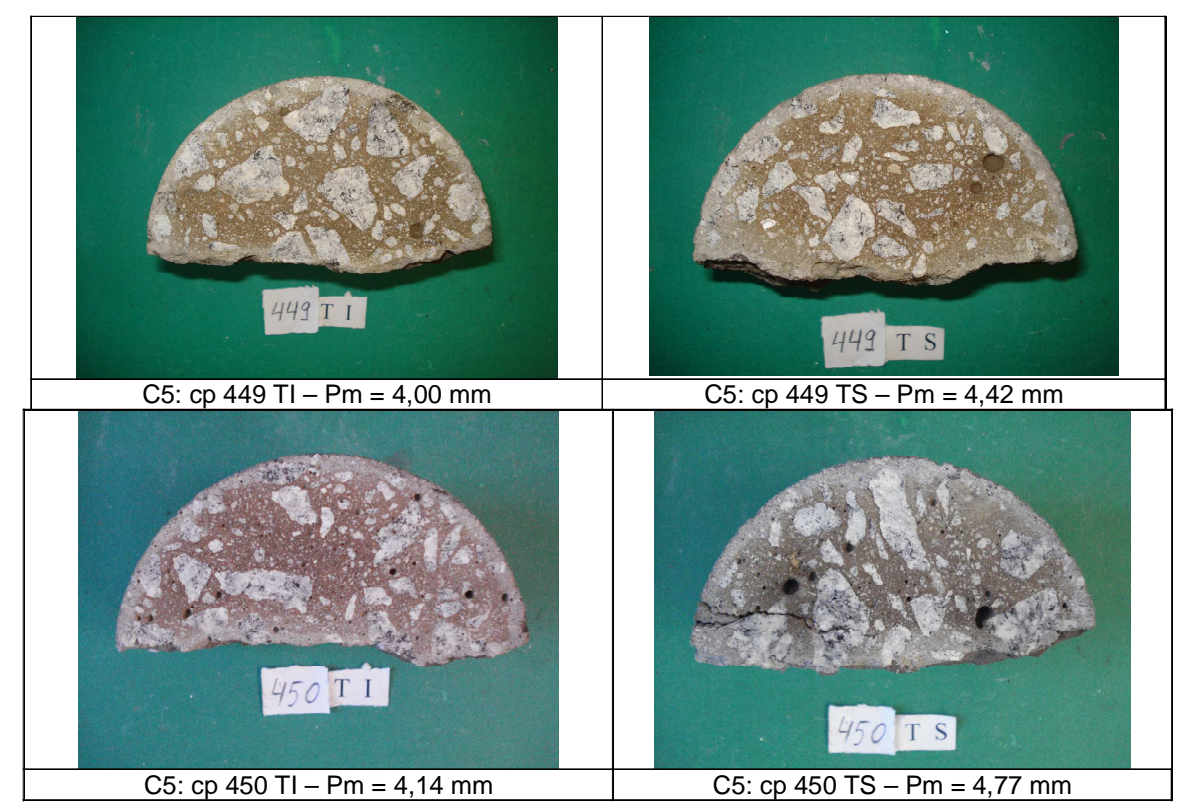

Figura 82 - Seções de medida da penetração de cloretos nos corpos-de-prova 449 e 450 do lote 1 , após cura acelerada $(24 / 48$ h) e três ciclos de imersão e secagem entre 7 e 91 dias. 


\section{APÊNDICE D}

Registro fotográfico das seções dos corpos-de-prova e medidas quanto à penetração de cloretos e profundidade de carbonatação

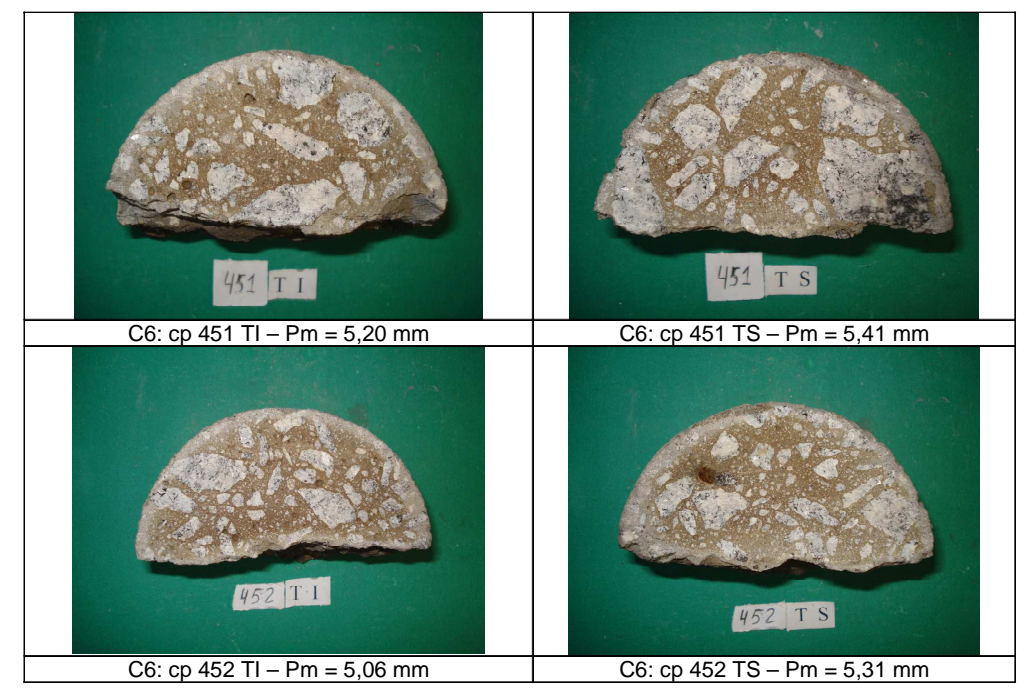

Figura 83 - Seções de medida da penetração de cloretos nos corpos-de-prova 451 e 452 do lote 1, após cura acelerada $(24 / 48 \mathrm{~h})$ e três ciclos de imersão e secagem entre 7 e 91 dias. 


\section{APÊNDICE D \\ Registro fotográfico das seções dos corpos-de-prova e medidas quanto à penetração de cloretos e profundidade de carbonatação}

1.2) Profundidade de carbonatação por três ciclos de imersão e secagem

As Figuras 84, 85 e 86 apresentam as fotos dos corpos-de-prova do lote 1.

Abaixo de cada foto consta o número do caminhão, do corpo-de-prova e a profundidade média de carbonatação.

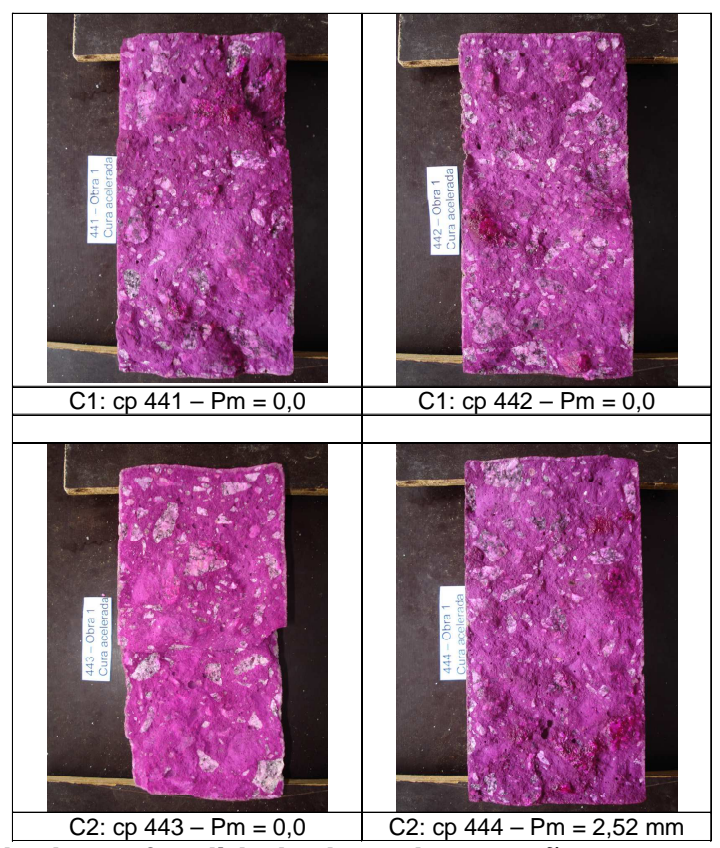

Figura 84 - Seções de medida da profundidade de carbonatação nos corpos-de-prova 441,442 , 443 e 444 dos caminhões 1 e 2 do lote 1 , após cura acelerada $(24 / 48$ h) e três ciclos de imersão e secagem entre 7 e 91 dias. 


\section{APÊNDICE D}

Registro fotográfico das seções dos corpos-de-prova e medidas quanto à penetração de cloretos e profundidade de carbonatação

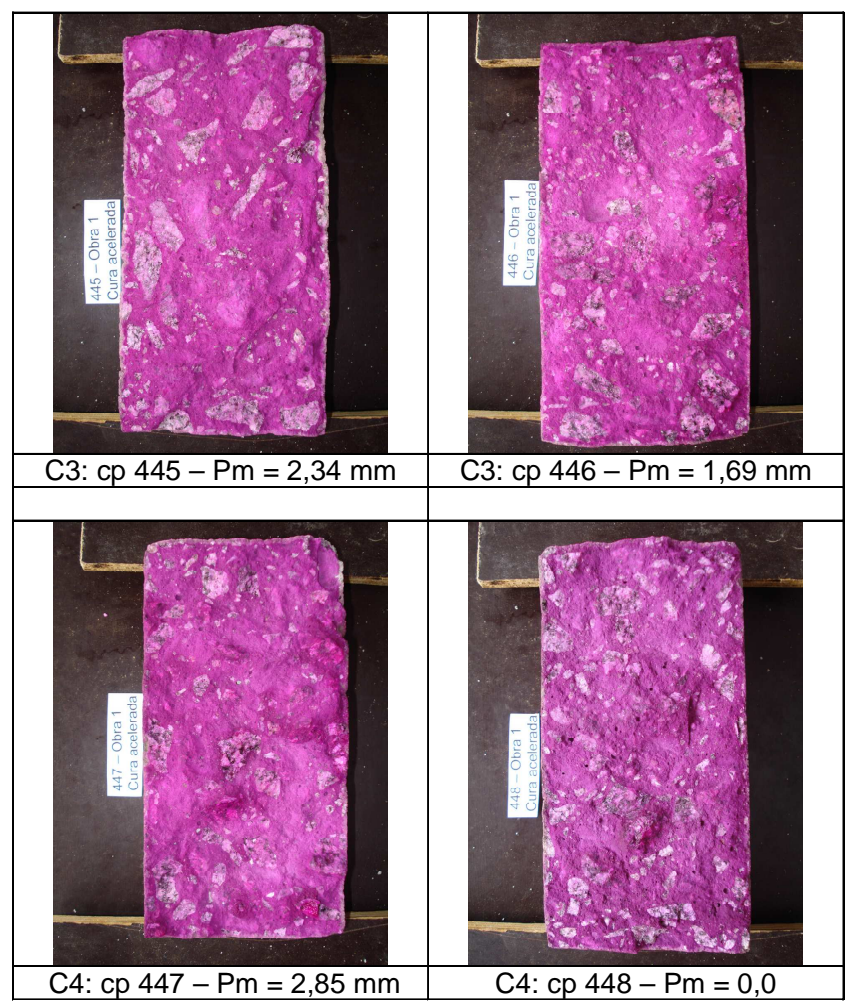

Figura 85 - Seções de medida da profundidade de carbonatação nos corpos-de-prova 445, 446, 447 e 448 dos caminhões 3 e 4, do lote 1 , após cura acelerada (24/48 h) e três ciclos de imersão e secagem entre 7 e 91 dias. 


\section{APÊNDICE D}

Registro fotográfico das seções dos corpos-de-prova e medidas quanto à penetração de cloretos e profundidade de carbonatação

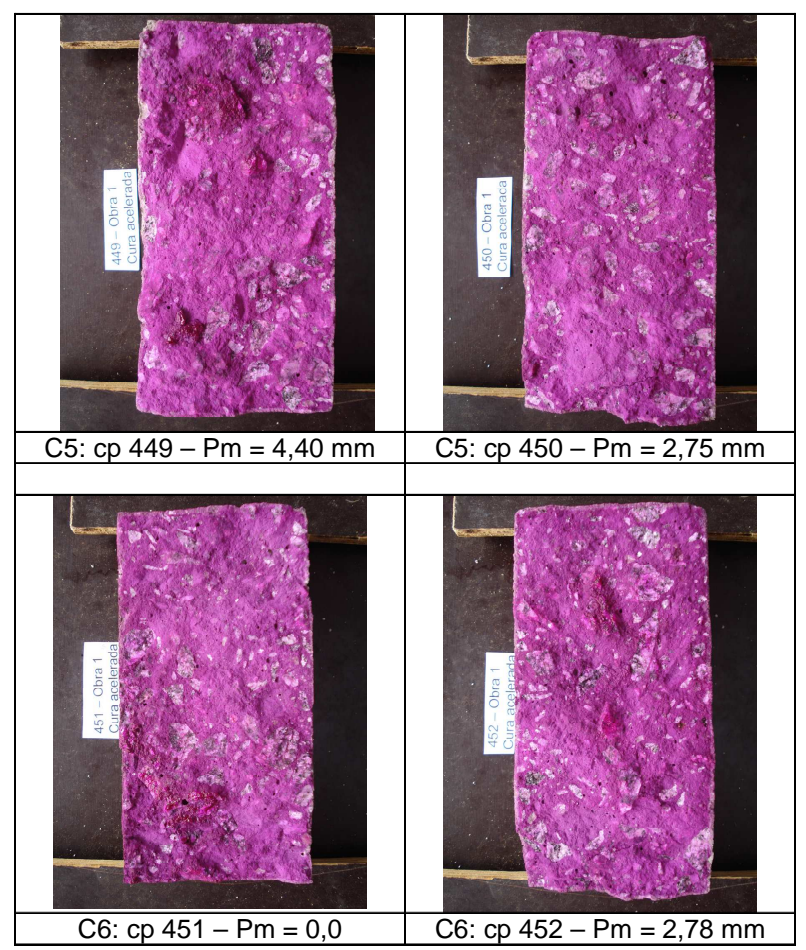

Figura 86 - Seções de medida da profundidade de carbonatação nos corpos-de-prova 449, 450 , 451 e 452 dos caminhões 5 e 6 , do lote 1 , após cura acelerada $(24 / 48$ h) e três ciclos de imersão e secagem entre 7 e 91 dias. 


\section{APÊNDICE D}

\section{Registro fotográfico das seções dos corpos-de-prova e medidas quanto à penetração de cloretos e profundidade de carbonatação}

\section{3) Profundidade de carbonatação por exposição em câmara com $\mathrm{CO}_{2}$ sob pressão}

As Figuras 87, 88 e 89 apresentam as fotos dos perfis de penetração de $\mathrm{CO}_{2}$, indicados por fenolftaleína e timolftaleina, nos corpos-de-prova do lote 1.

Abaixo de cada foto consta o número do caminhão, do corpo-de-prova e a profundidade média de carbonatação por secagem prolongada em estufa ventilada a $45 \pm 5^{\circ} \mathrm{C}$ seguida de exposição por sete dias em câmara com $5 \%$ de $\mathrm{CO}_{2}$ sob pressão.

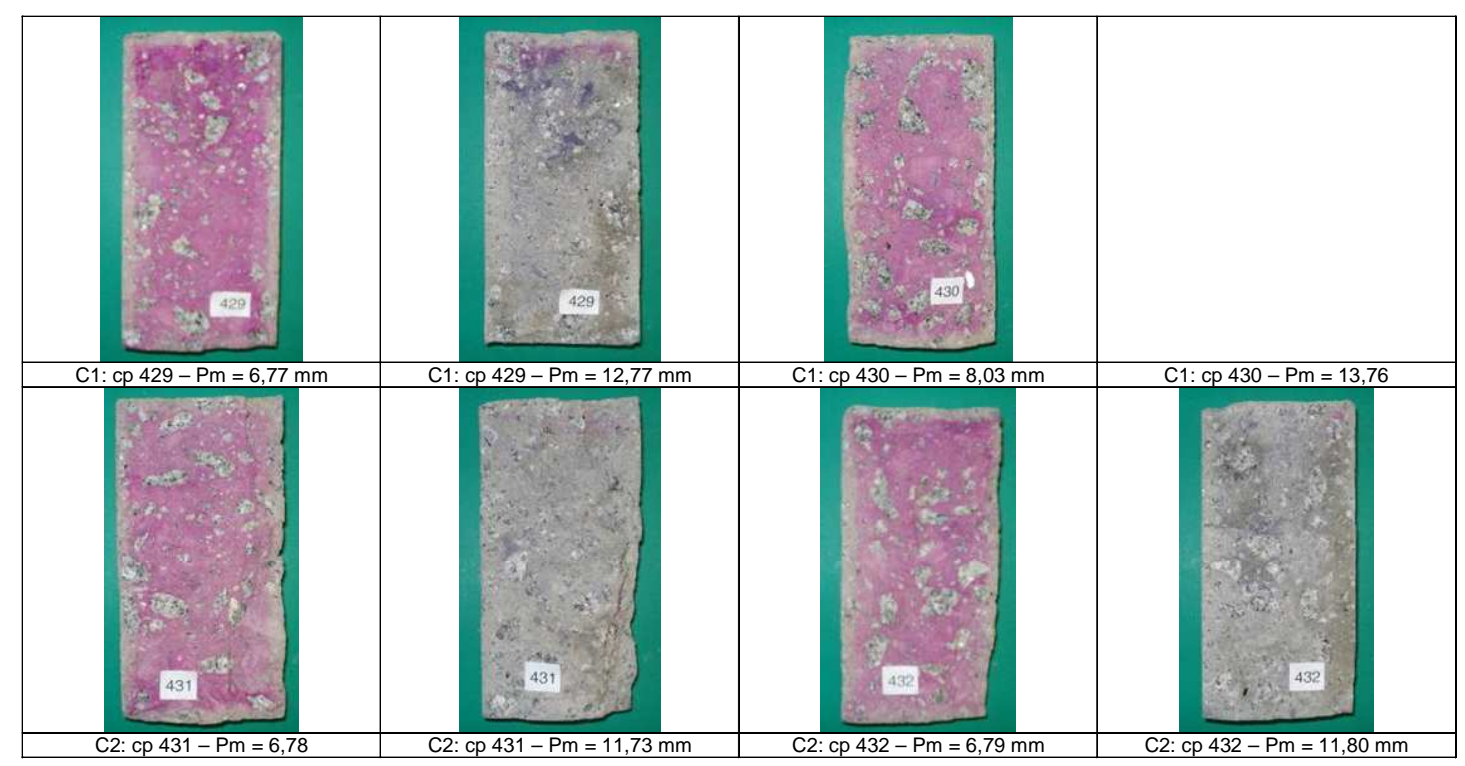

Figura 87 - Seções de medida da profundidade de carbonatação nos corpos-de-prova 429, 430, 431 e 432, após secagem prolongada em estufa ventilada e sete dias em câmara com $\mathrm{CO}_{2}$ a $5 \%$. 


\section{APÊNDICE D}

Registro fotográfico das seções dos corpos-de-prova e medidas quanto à penetração de cloretos e profundidade de carbonatação
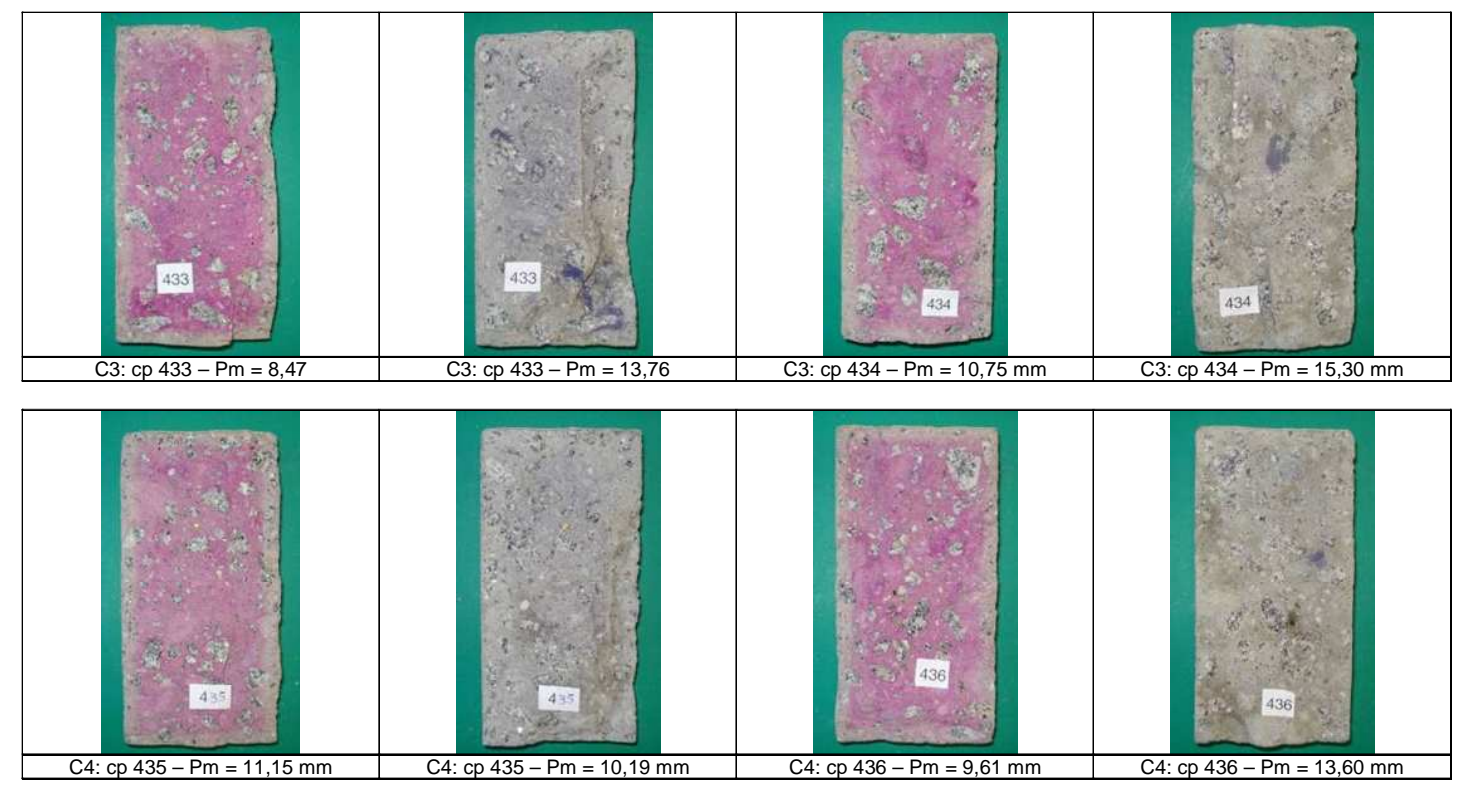

Figura 88 - Seções de medida da profundidade de carbonatação nos corpos-de-prova 433, 434, 435 e 436, após secagem prolongada em estufa ventilada e sete dias em câmara com $\mathrm{CO}_{2}$ a $5 \%$.

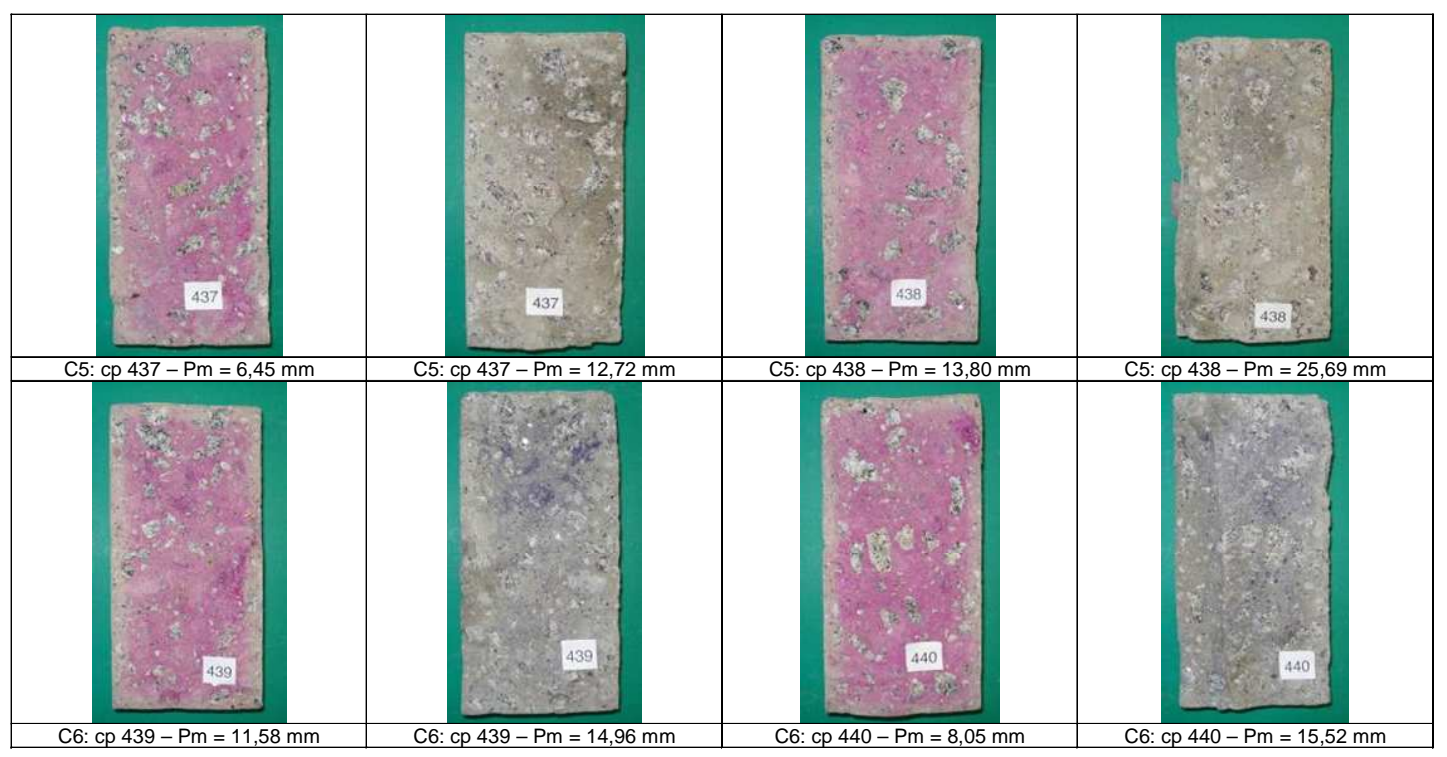

Figura 89 - Seções de medida da profundidade de carbonatação nos corpos-de-prova 437, 438, 439 e 440, após secagem prolongada em estufa ventilada e sete dias em câmara com $\mathrm{CO}_{2}$ a $5 \%$. 


\section{APÊNDICE D}

\section{Registro fotográfico das seções dos corpos-de-prova e medidas quanto à penetração de cloretos e profundidade de carbonatação}

As Figuras 90, 91, 92, 93, 94 e 95 apresentam as fotos das metades de corpos-de-prova do lote 2 , com fratura nos terços médios ( $\mathrm{TS}=$ terço superior; $\mathrm{TI}=$ terço inferior), após ensaio inicial de compressão diametral.

Abaixo de cada foto consta o número do caminhão, do corpo-de-prova, o terço ensaiado e a profundidade média de penetração de cloretos, nas respectivas seções.

\section{2) Lote 2}

1.1) Profundidade de penetração de cloretos por três ciclos de imersão e secagem

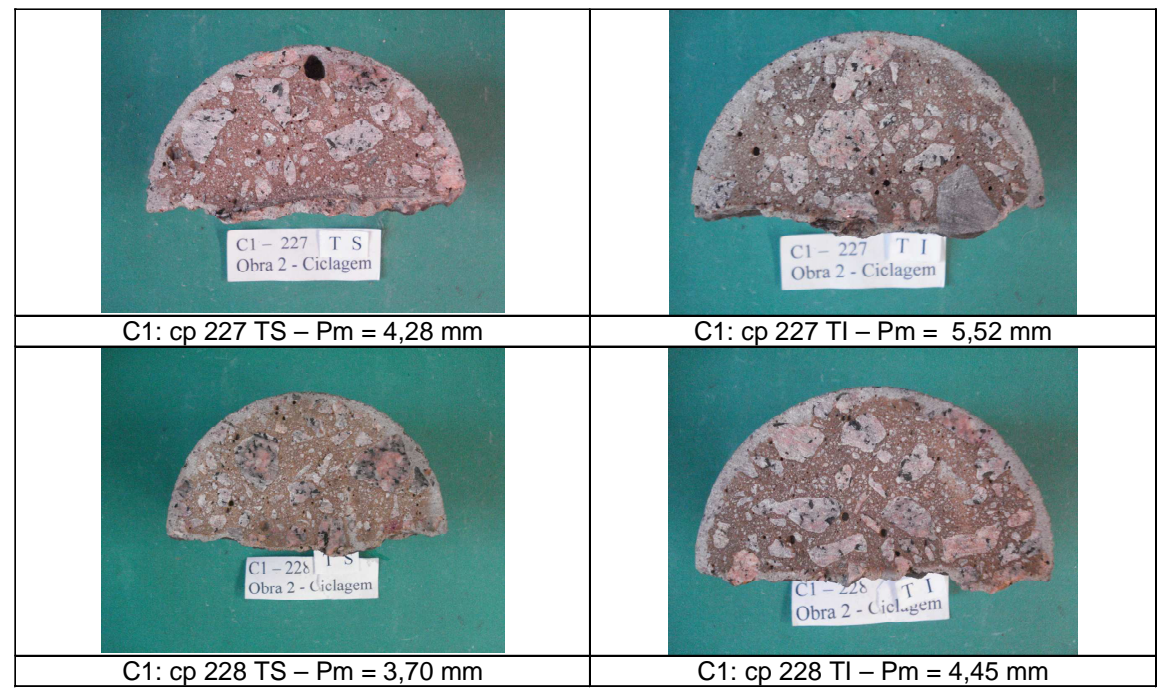

Figura 91 - Seções de medida da penetração de cloretos nos corpos-de-prova 227 e 228 do lote 2 , após cura acelerada $(24 / 48 \mathrm{~h})$ e três ciclos de imersão e secagem entre 7 e 91 dias. 


\section{APÊNDICE D}

Registro fotográfico das seções dos corpos-de-prova e medidas quanto à penetração de cloretos e profundidade de carbonatação

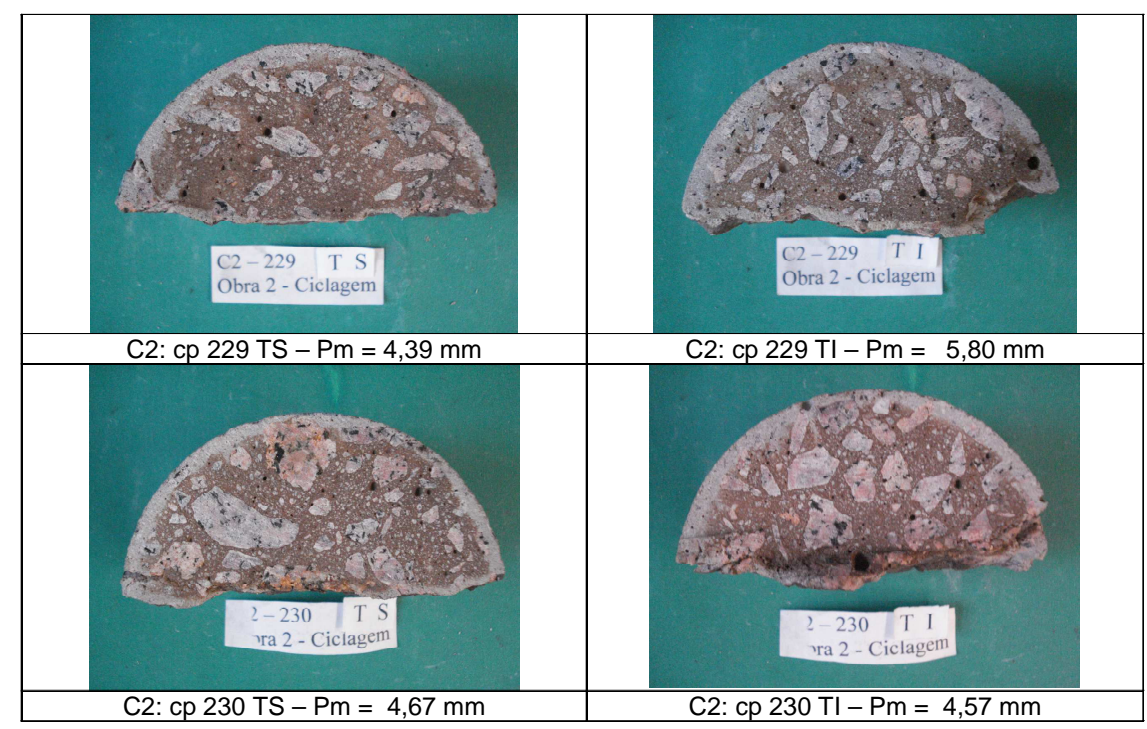

Figura 92 - Seções de medida da penetração de cloretos nos corpos-de-prova 229 e 230 do lote 2, após cura acelerada (24/48 h) e três ciclos de imersão e secagem entre 7 e 91 dias.

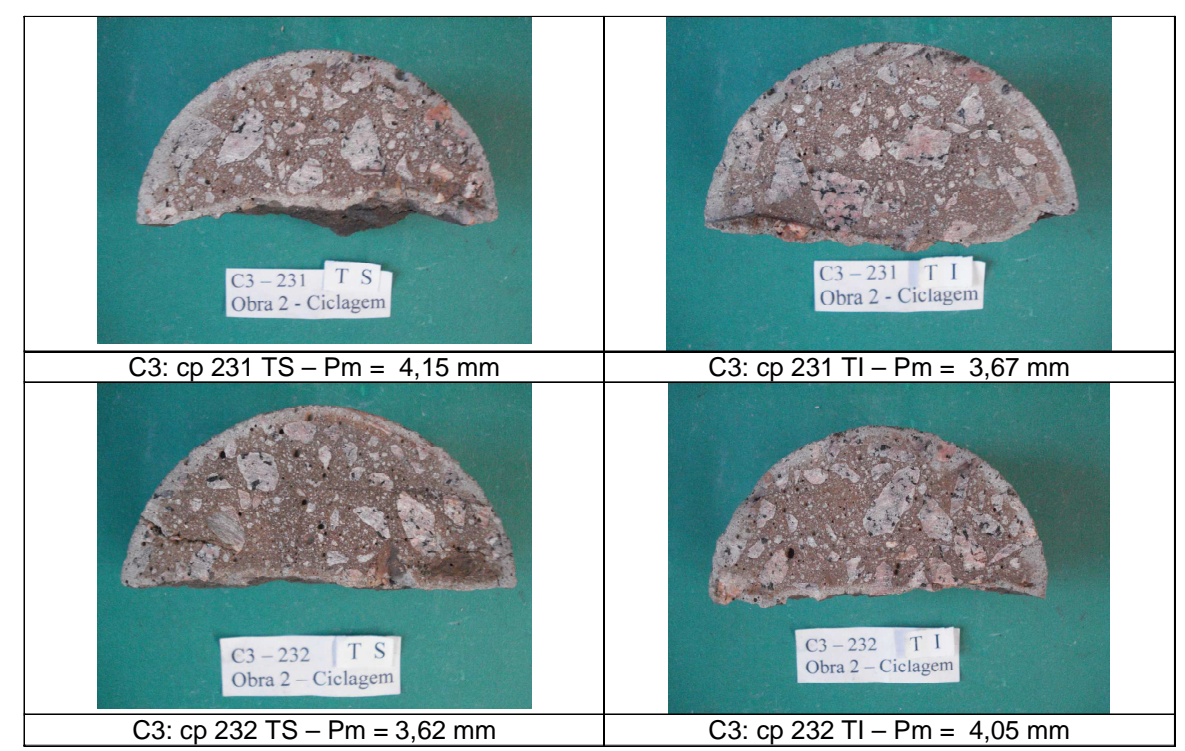

Figura 93 - Seções de medida da penetração de cloretos nos corpos-de-prova 231 e 232 do lote 2 , após cura acelerada (24/48 h) e três ciclos de imersão e secagem entre 7 e 91 dias. 


\section{APÊNDICE D}

Registro fotográfico das seções dos corpos-de-prova e medidas quanto à penetração de cloretos e profundidade de carbonatação

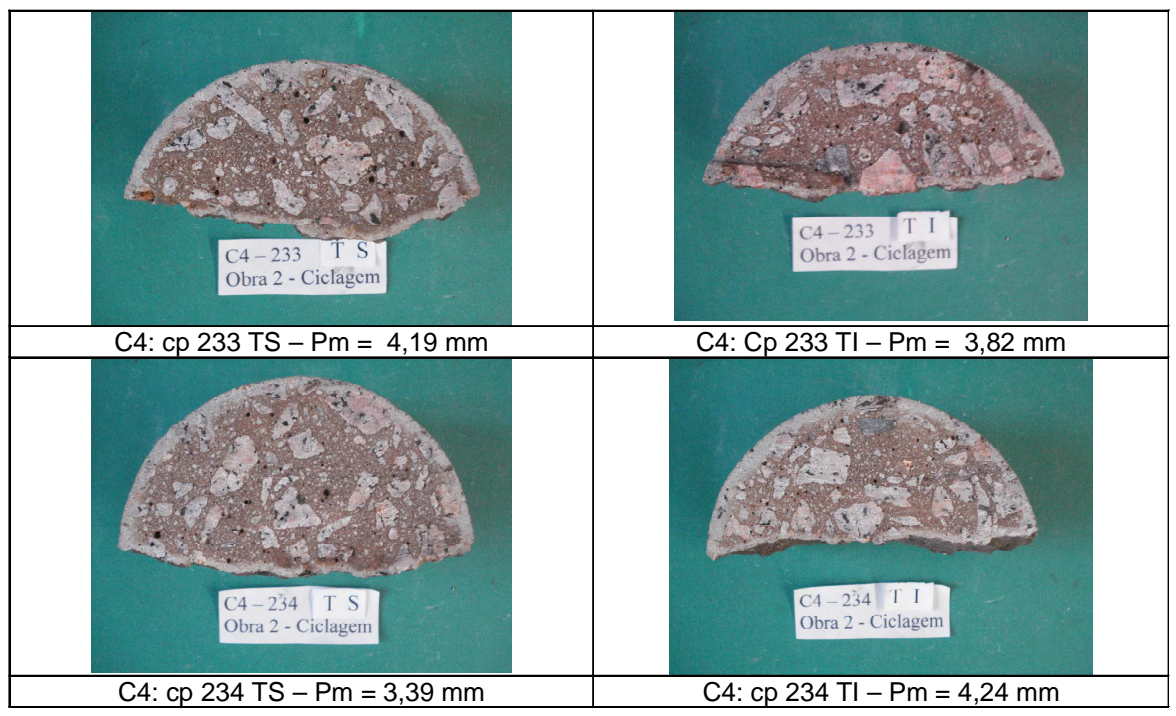

Figura 94 - Seções de medida da penetração de cloretos nos corpos-de-prova 233 e 234 do lote 2, após cura acelerada $(24 / 48 \mathrm{~h})$ e três ciclos de imersão e secagem entre 7 e 91 dias.

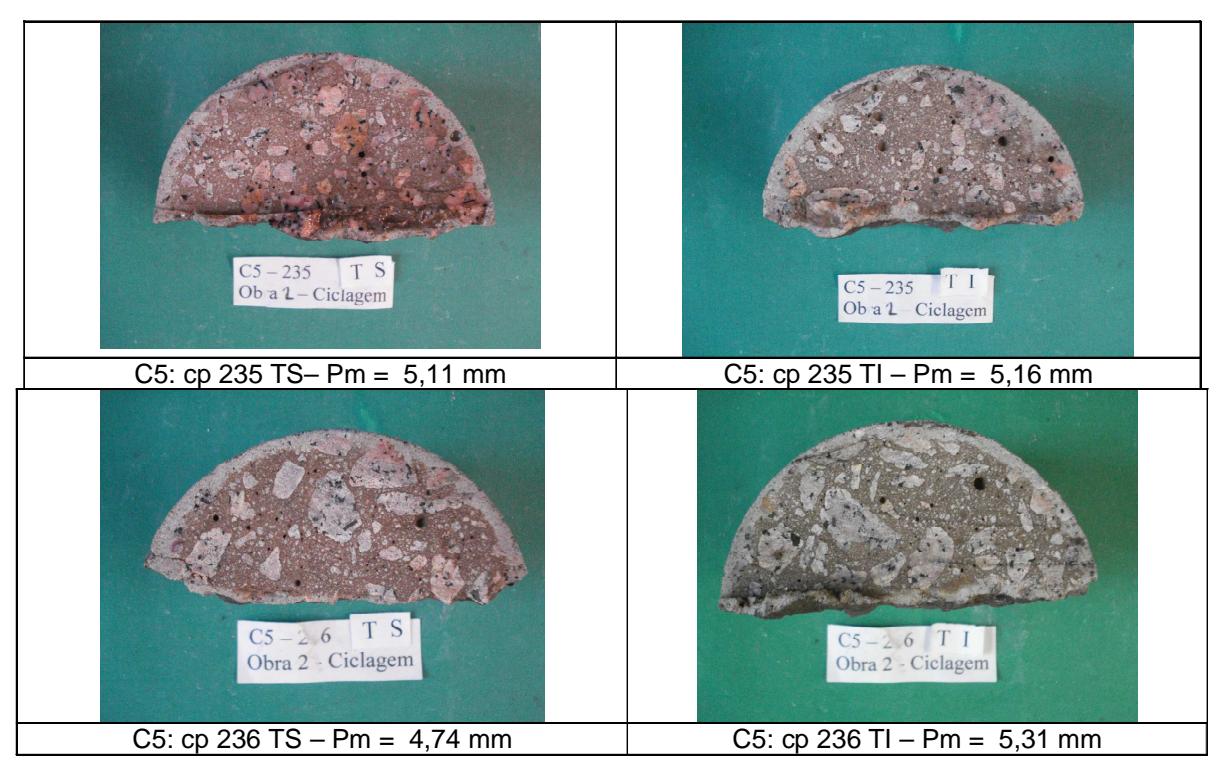

Figura 95 - Seções de medida da penetração de cloretos nos corpos-de-prova 235 e 236 do lote 2, após cura acelerada $(24 / 48 \mathrm{~h})$ e três ciclos de imersão e secagem entre 7 e 91 dias. 


\section{APÊNDICE D}

\section{Registro fotográfico das seções dos corpos-de-prova e medidas quanto à penetração de cloretos e profundidade de carbonatação}

\section{2) Profundidade de carbonatação por três ciclos de imersão e secagem}

As Figuras 96, 97 e 98 apresentam as fotos de metades dos corpos-de-prova do lote 2, ensaiados à compressão diametral após três ciclos de imersão e secagem.

Abaixo de cada foto consta o número do caminhão, do corpo-de-prova e a profundidade média de carbonatação.

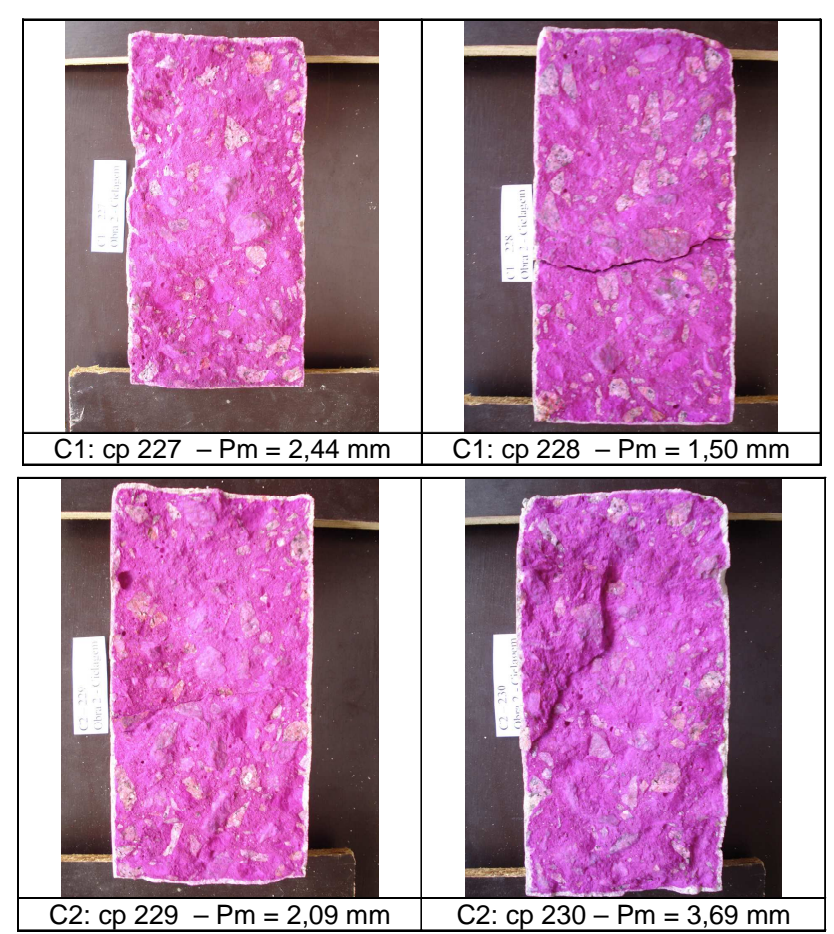

Figura 96 - Seções de medida da profundidade de carbonatação nos corpos-de-prova 227, 228, 229 e 230 dos caminhões 1 e 2, do lote 1 , após cura acelerada $(24 / 48$ h) e três ciclos de imersão e secagem entre 7 e 91 dias. 


\section{APÊNDICE D}

Registro fotográfico das seções dos corpos-de-prova e medidas quanto à penetração de cloretos e profundidade de carbonatação

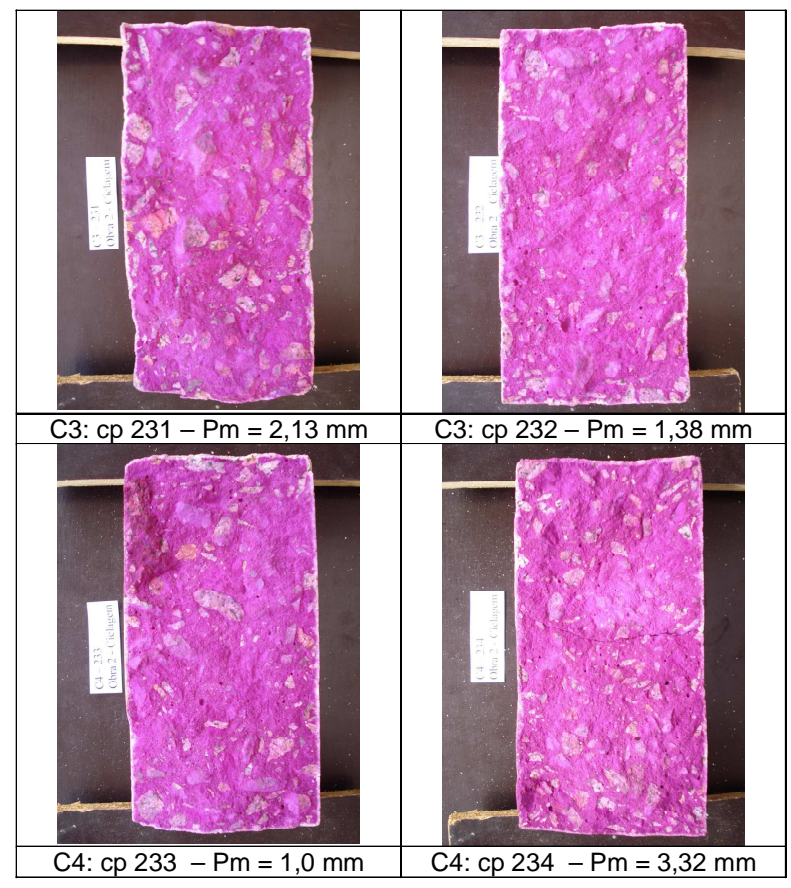

Figura 97 - Seções de medida da profundidade de carbonatação nos corpos-de-prova 231, 232, 233 e 234 dos caminhões 3 e 4, do lote 1 , após cura acelerada $(24 / 48$ h) e três ciclos de imersão e secagem entre 7 e 91 dias.

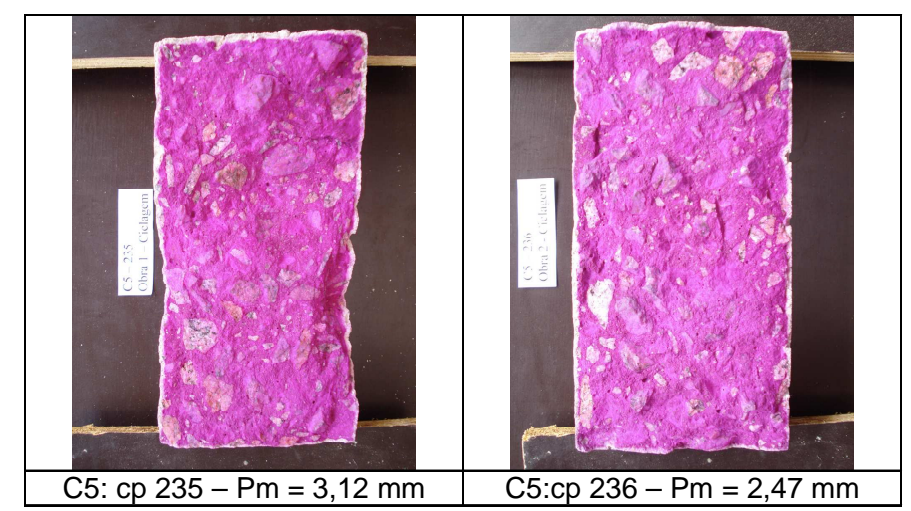

Figura 98 - Seções de medida da profundidade de carbonatação nos corpos-de-prova 235 e 236 do caminhão 5 , do lote 1 , após cura acelerada $(24 / 48$ h) e três ciclos de imersão e secagem entre 7 e 91 dias. 


\section{APÊNDICE D}

\section{Registro fotográfico das seções dos corpos-de-prova e medidas quanto à penetração de cloretos e profundidade de carbonatação}

\section{3) Profundidade de carbonatação por exposição em câmara de $\mathrm{CO}_{2}$ sob pressão}

As Figuras 99 e 100 apresentam as fotos dos perfis de penetração de $\mathrm{CO}_{2}$, indicados por fenolftaleína e timolftaleina, nos corpos-de-prova do lote 2.

Abaixo de cada foto consta o número do caminhão, do corpo-de-prova e a profundidade média de carbonatação por secagem prolongada em estufa ventilada a $45 \pm 5^{\circ} \mathrm{C}$ seguida de exposição por sete dias em câmara com $5 \%$ de $\mathrm{CO}_{2}$ sob pressão.

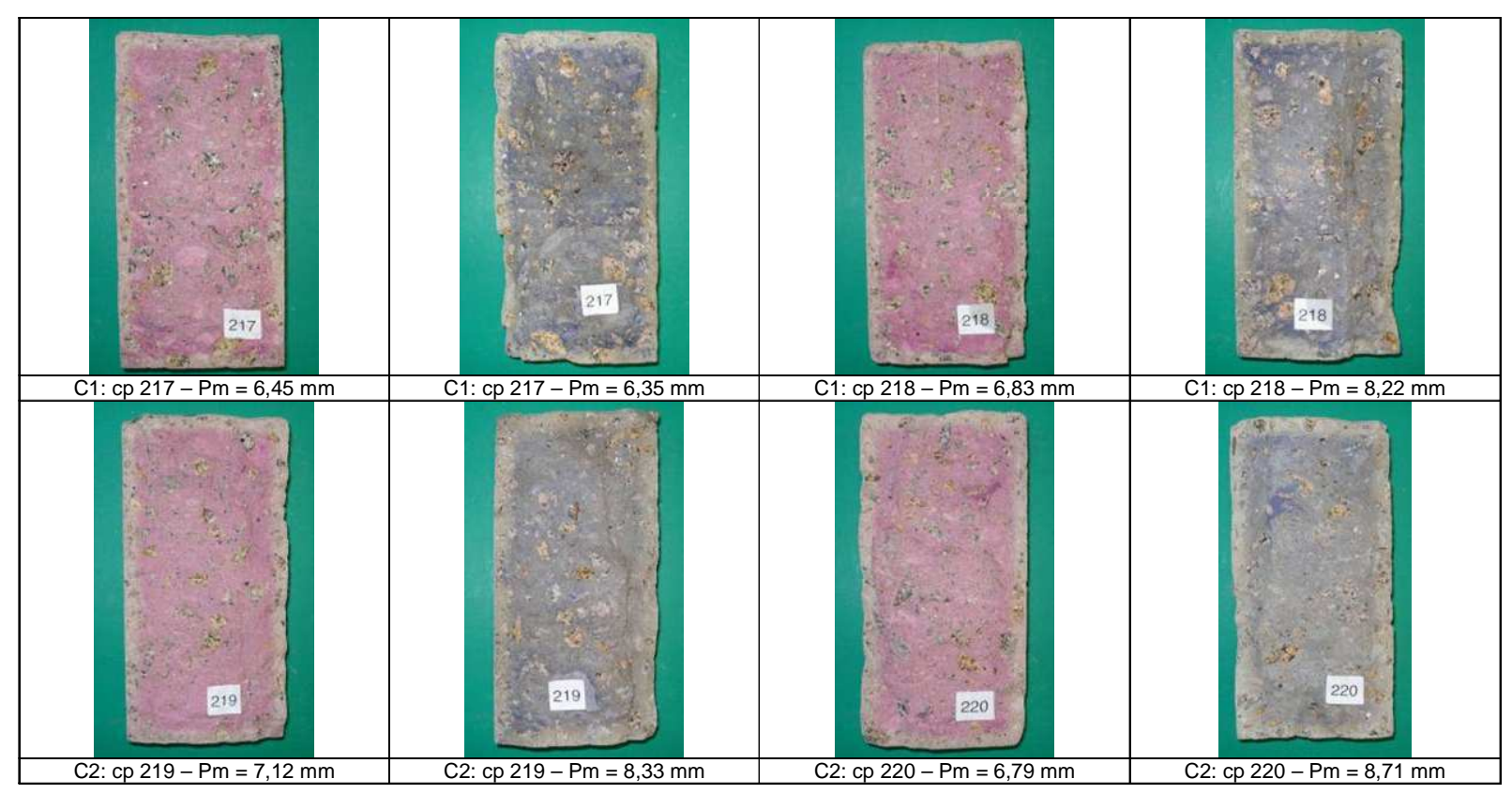

Figura 99 - Seções de medida da profundidade de carbonatação nos corpos-de-prova 217, 218, 219 e 220, do lote 2, após secagem prolongada em estufa ventilada e sete dias em câmara com $\mathrm{CO}_{2}$ a $5 \%$. 


\section{APÊNDICE D}

Registro fotográfico das seções dos corpos-de-prova e medidas quanto à penetração de cloretos e profundidade de carbonatação
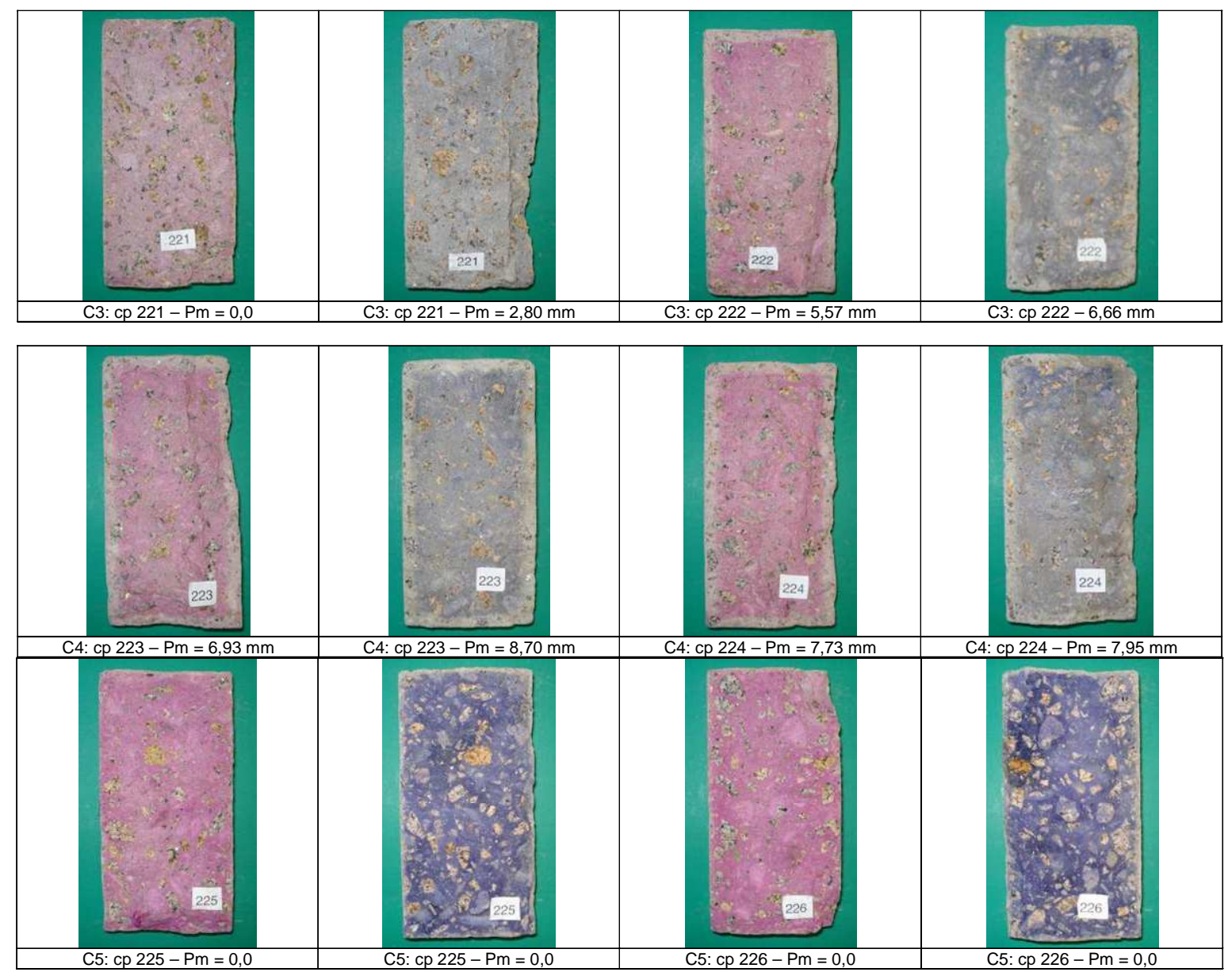

Figura 100 - Seções de medida da profundidade de carbonatação nos corpos-de-prova 221, 222, 223, 224 e 225, do lote 2, após secagem prolongada em estufa ventilada e sete dias em câmara com $\mathrm{CO}_{2}$ a $5 \%$. 


\section{APÊNCIDE D}

\section{Registro fotográfico das seções dos corpos-de-prova e medidas quanto à penetração de cloretos e profundidade de carbonatação}

\section{3) Lote treinamento}

3.1) Profundidade de Penetração de cloretos por três ciclos de imersão e secagem

As Figuras 101, 102 e 103 apresentam as fotos das metades de corpos-de-prova do lote treinamento, com fratura nos terços médios (TS = terço superior; $\mathrm{TI}=$ terço inferior), após ensaio inicial de compressão diametral.

Abaixo de cada foto consta o número do caminhão, do corpo-de-prova, o terço ensaiado e a profundidade média de penetração de cloretos, nas respectivas seções.

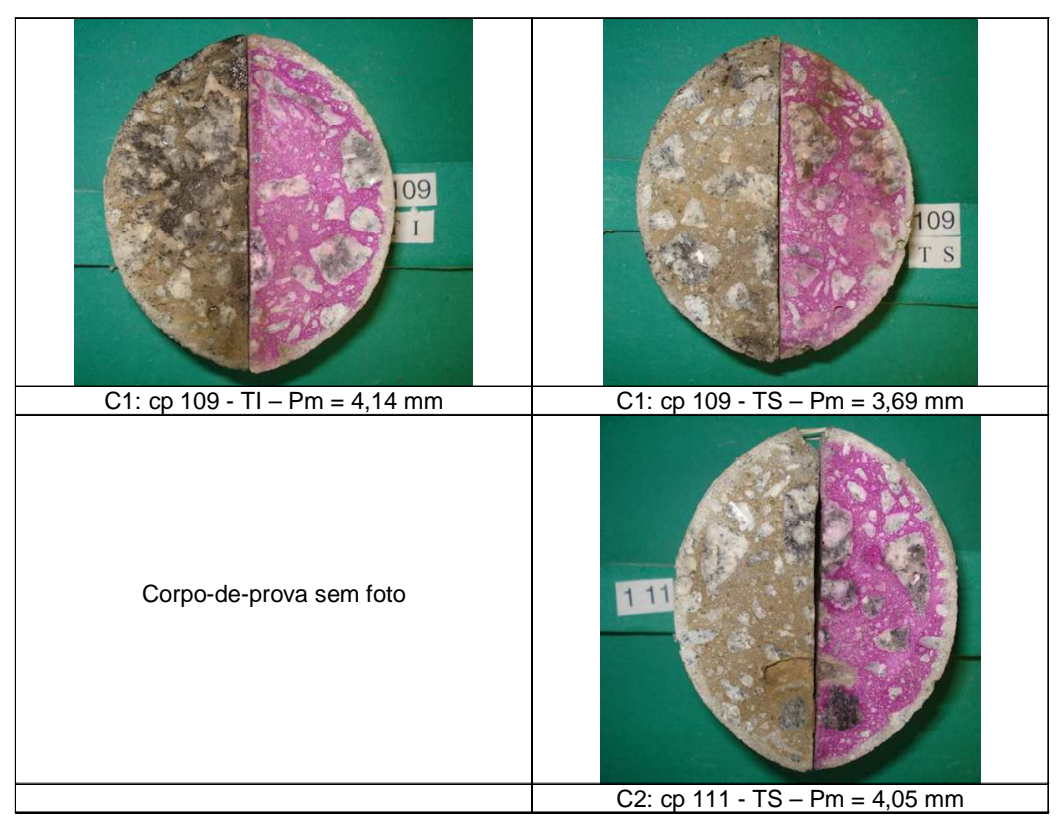

Figura 101 - Seções de medida da penetração de cloretos nos corpos-de-prova 109 e 111 do lote treinamento, após cura acelerada $(24 / 48$ h) e três ciclos de imersão e secagem, entre 7 e 91 dias. 


\section{APÊNDICE D}

Registro fotográfico das seções dos corpos-de-prova e medidas quanto à penetração de cloretos e profundidade de carbonatação

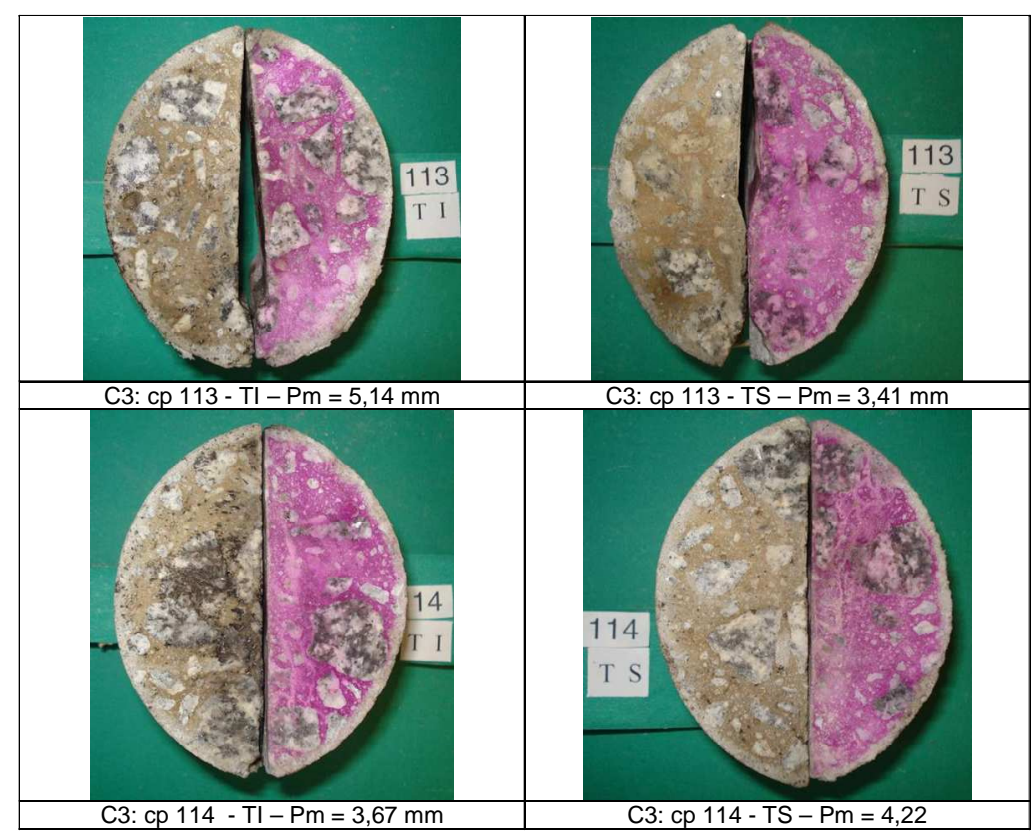

Figura 102 - Seções de medida da penetração de cloretos nos corpos-de-prova 113 e 114 do lote treinamento, após cura acelerada $(24 / 48$ h) e três ciclos de imersão e secagem, entre 7 e 91 dias. 


\section{APÊNDICE D}

Registro fotográfico das seções dos corpos-de-prova e medidas quanto à penetração de cloretos e profundidade de carbonatação

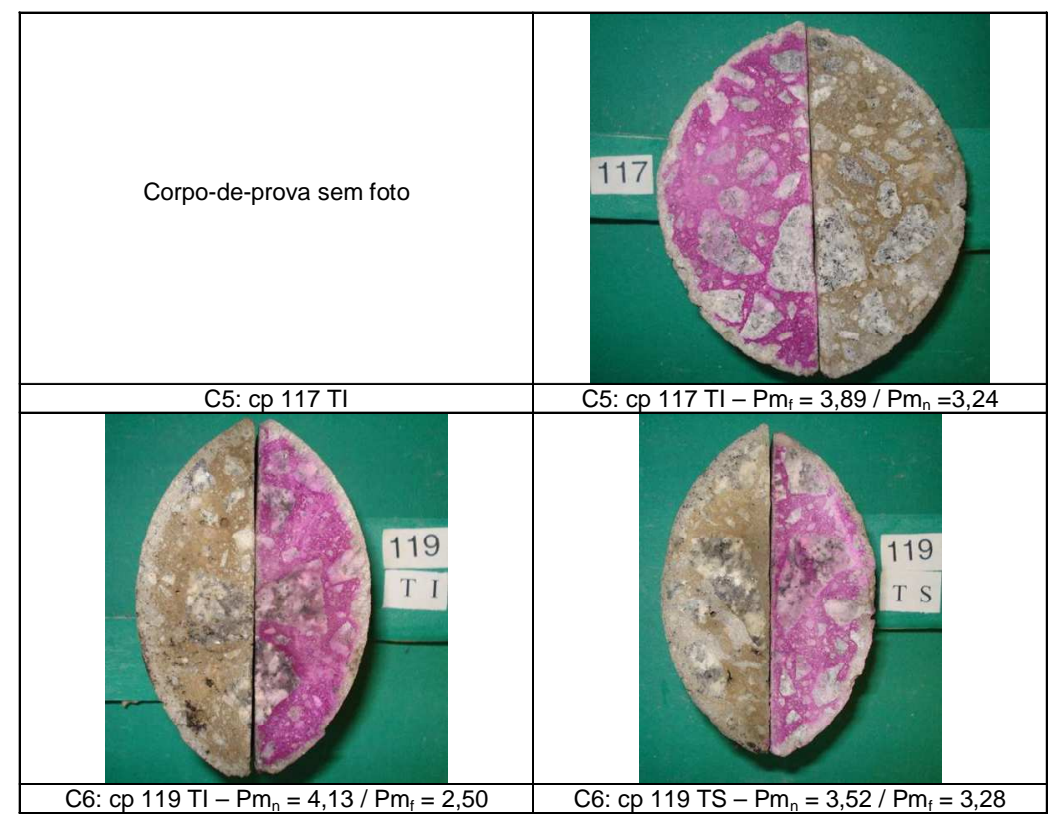

Figura 103 - Seções de medida da penetração de cloretos nos corpos-de-prova 117 e 119 do lote treinamento, após cura acelerada $(24 / 48$ h) e três ciclos de imersão e secagem, entre 7 e 91 dias. 


\section{APÊNDICE D}

Registro fotográfico das seções dos corpos-de-prova e medidas quanto à penetração de cloretos e profundidade de carbonatação

\section{2) Profundidade de carbonatação por três ciclos de imersão e secagem}

As Figuras 104, 105 e 106 apresentam as fotos dos corpos-de-prova do lote treinamento.

Abaixo de cada foto consta o número do caminhão, do corpo-de-prova e a profundidade média de carbonatação.

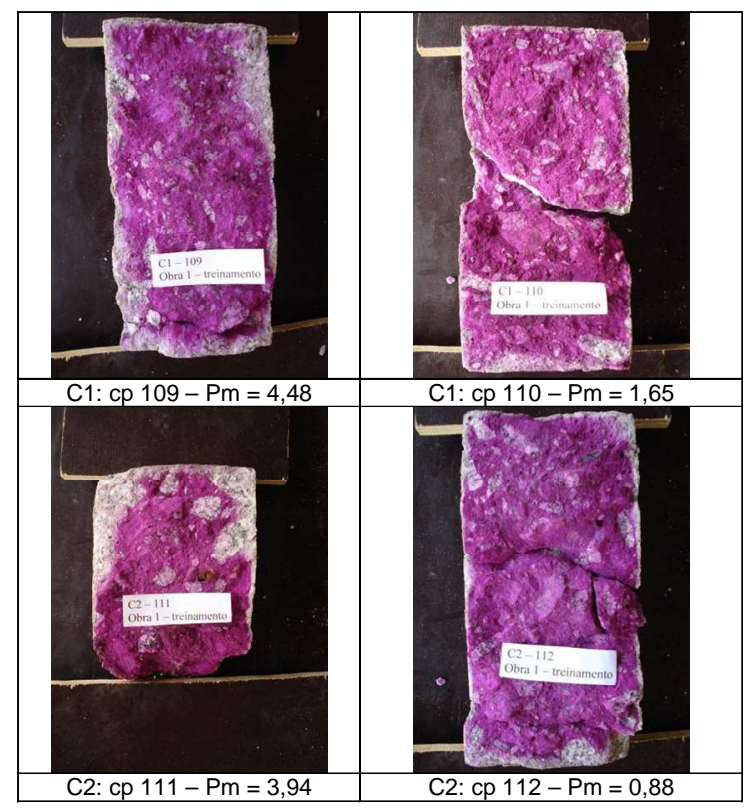

Figura 104 - Seções de medida da profundidade de carbonatação nos corpos-de-prova 109, 110, 111 e 112 dos caminhões 1 e 2, do lote treinamento, após cura acelerada $(24 / 48$ h) e três ciclos de imersão e secagem entre 7 e 91 dias. 


\section{APÊNDICE D}

Registro fotográfico das seções dos corpos-de-prova e medidas quanto à penetração de cloretos e profundidade de carbonatação

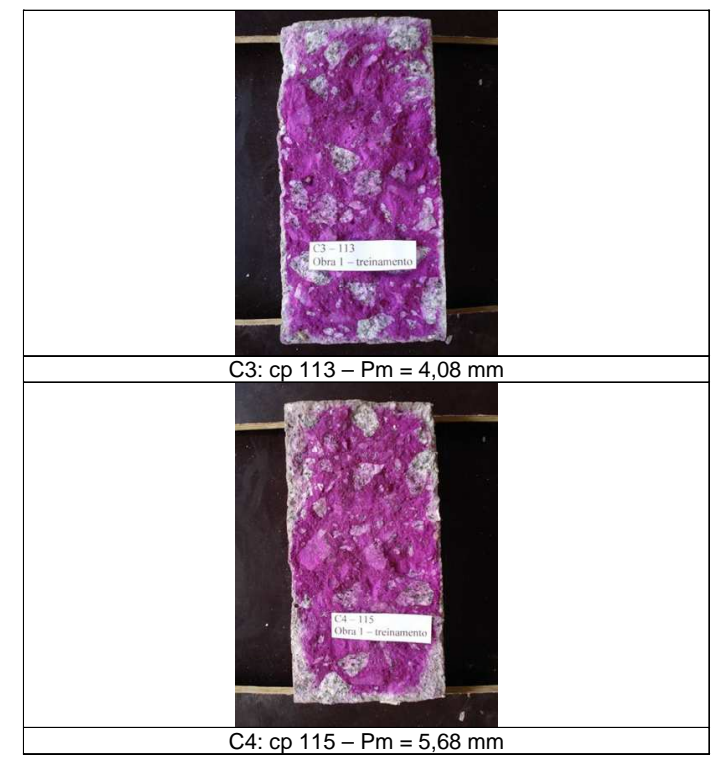

Figura 105 - Seções de medida da profundidade de carbonatação nos corpos-de-prova 113 e 115 dos caminhões 3 e 5 , do lote treinamento, após cura acelerada $(24 / 48$ h) e três ciclos de imersão e secagem entre 7 e 91 dias.

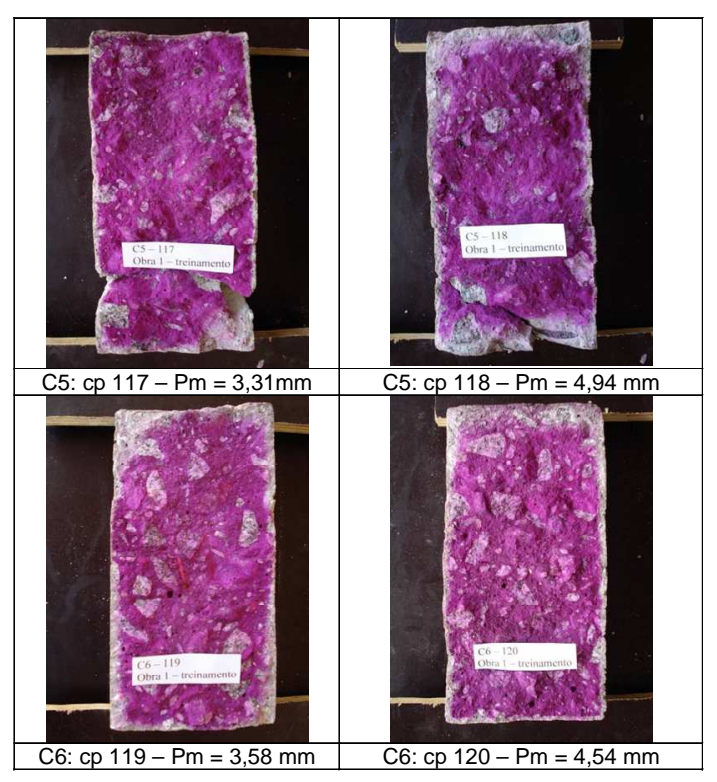

Figura 106 - Seções de medida da profundidade de carbonatação nos corpos-de-prova 117, 118, 119 e 120 dos caminhões 5 e 6, do lote treinamento, após cura acelerada $(24 / 48$ h) e três ciclos de imersão e secagem entre 7 e 91 dias. 


\section{APÊNDICE D}

\section{Registro fotográfico das seções dos corpos-de-prova e medidas quanto à} penetração de cloretos e profundidade de carbonatação

\section{3) Profundidade de carbonatação por exposição em câmara de $\mathrm{CO}_{2}$ sob pressão}

As Figuras 107 e 108 apresentam as fotos dos perfis de penetração de $\mathrm{CO}_{2}$, indicados por fenolftaleína e timolftaleina, nos corpos-de-prova do lote treinamento.

Abaixo de cada foto consta o número do caminhão, do corpo-de-prova e a profundidade média de carbonatação por secagem prolongada em estufa ventilada a $40 \pm 5^{\circ} \mathrm{C}$ seguida de exposição por sete dias em câmara com $5 \%$ de $\mathrm{CO}_{2}$ sob pressão, conforme item 5.3.3.3. 


\section{APÊNDICE D}

Registro fotográfico das seções dos corpos-de-prova e medidas quanto à penetração de cloretos e profundidade de carbonatação

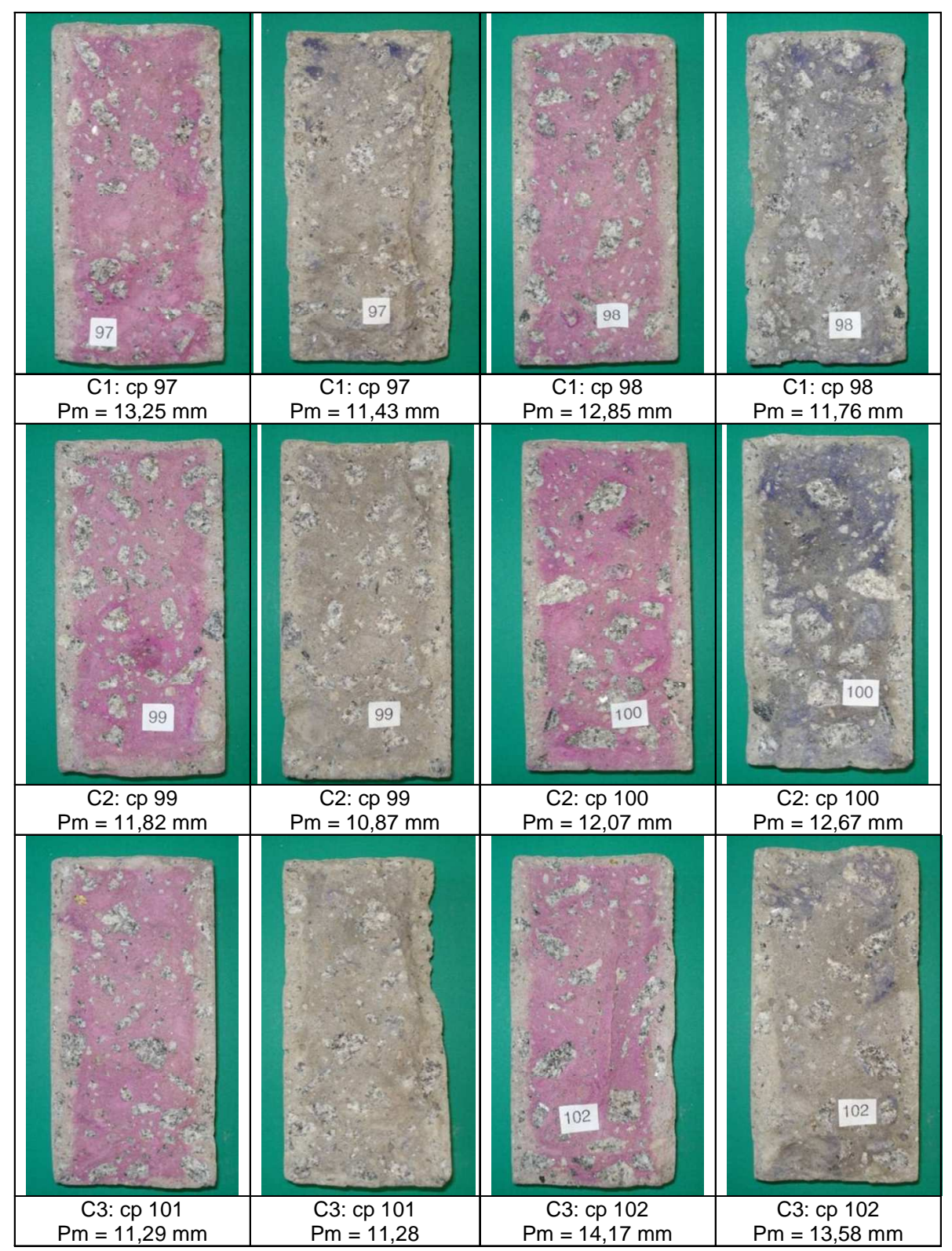

Figura 107 - Seções de medida da profundidade de carbonatação nos corpos-de-prova 99, 100, 101 e 102 do lote treinamento, após secagem prolongada e sete dias em câmara com $5 \%$ de $\mathrm{CO}_{2}$. 


\section{APÊNDICE D}

Registro fotográfico das seções dos corpos-de-prova e medidas quanto à penetração de cloretos e profundidade de carbonatação

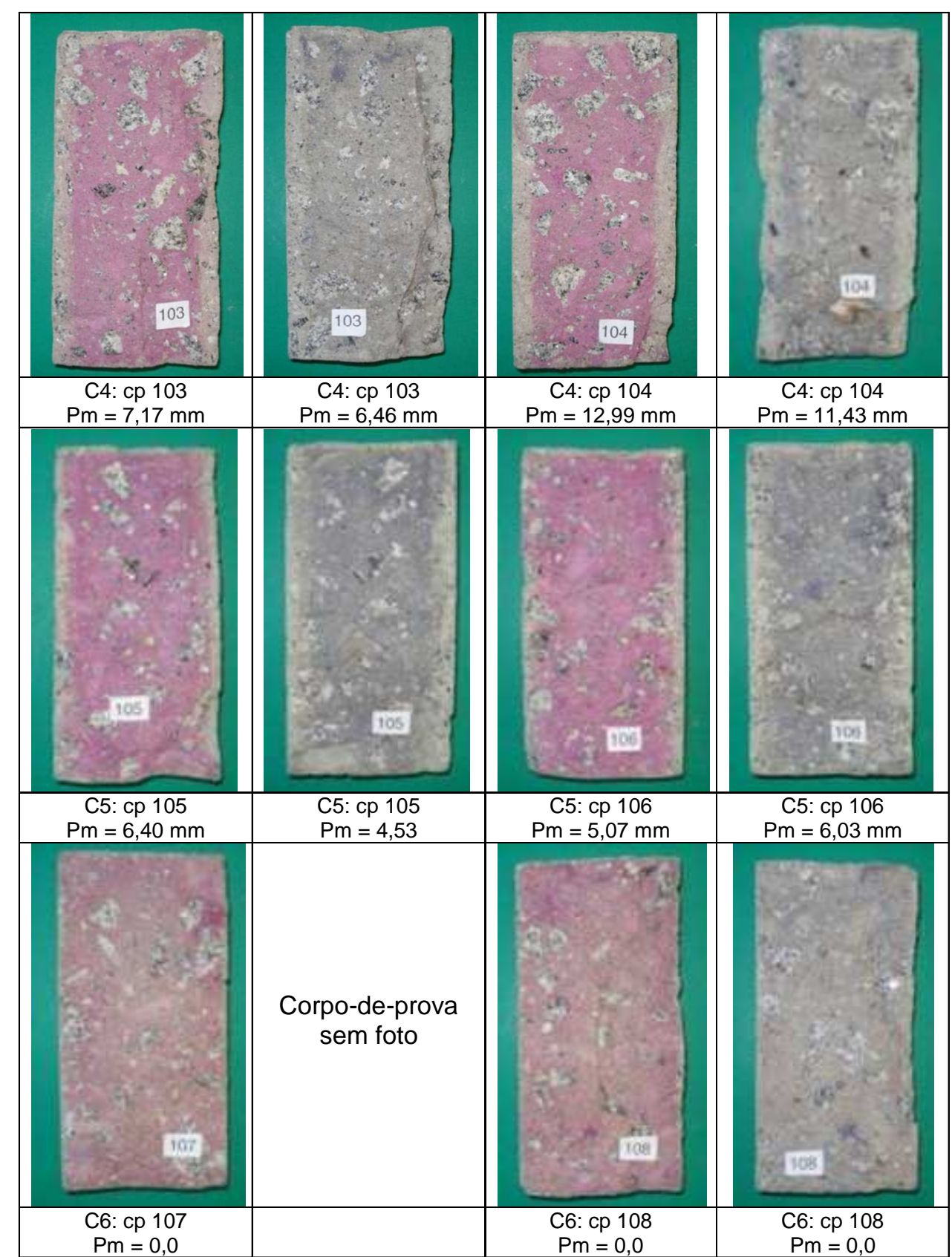

Figura 108 - Seções de medida da profundidade de carbonatação nos corpos-de-prova 103, 104, $105,106,107$ e 108 do lote treinamento, após secagem prolongada e sete dias em câmara com $5 \%$ de $\mathrm{CO}_{2}$. 


\section{APÊNDICE E}

\section{Relatório do CEA}

\section{CENTRO DE ESTATÍSTICA APLICADA - IME/USP \\ Relatório de Consulta revisado pelo graduando Márcio Eduardo Maciel}

Título: Contribuição ao controle tecnológico de concretos estruturais de cimento Portland.

Pesquisador: Professora Doutora Silvia Maria de Souza Selmo

Instituição: Escola Politécnica da Universidade de São Paulo

Finalidade: Sugestões para análise

Participantes da entrevista: Prof ${ }^{-a}$ Dra Júlia Maria Pavan Soler

Márcio Eduardo Maciel

Karina Paula Santos Silva

Data: 30/10/200919

Alunos Responsáveis pela Análise: Karina Paula Santos Silva

Márcio Eduardo Maciel

19 Nesta edição revisada da dissertação, este Relatório CEA foi acrescido de algumas análises complementares e pequenas revisões de digitação, realizadas em conjunto pelo Graduando Marcio Eduardo Maciel, este autor e sua orientadora, conforme correspondência principais de 12/03/2010 e 20/04/2010. 


\section{APÊNDICE E}

\section{Relatório do CEA}

\section{Índice}

Introdução 297

Descrição das variáveis 299

Análise estatística 300

\section{Introdução}

A padronização de procedimentos de controle tecnológico do concreto armado de cimento Portland permite a verificação de qualidade do produto na proteção de armaduras e modelagem da vida útil de projeto das estruturas. O presente estudo experimental propõe a comparação de duas diferentes composições de concreto estrutural, identificando comportamentos e padrões em suas propriedades, para que critérios relacionados à proteção de armaduras e durabilidade de edifícios possam ser estabelecidos, bem como sua aplicação futura em estudos de dosagem ou no controle tecnológico de concretos estruturais. 


\section{APÊNDICE E}

\section{Relatório do CEA}

\section{Descrição do estudo}

O estudo foi realizado em concretos estruturais de cimento Portland produzidos em centrais dosadoras, na cidade de João Pessoa-PB.

Foram escolhidas duas obras ( 1 e 2), cada uma abastecida por uma diferente central dosadora de concreto. A especificação do concreto estrutural nessas obras era semelhante, em termos de abatimento $(10 \mathrm{~cm}+1 \mathrm{~cm})$ e de resistência característica à 28 dias (fck) de $30 \mathrm{MPa}$. Foram analisadas certas propriedades do estado fresco e endurecido do concreto com maturação acelerada e natural para observações de algumas características a 7, 28 e 91 dias.

$\mathrm{Na}$ primeira obra (obra 1) foram considerados dois lotes (treinamento e lote 1), provenientes da mesma central dosadora. Cada lote era constituído de 10 caminhões betoneiras $\left(71 \mathrm{~m}^{3}\right)$ e foram amostrados 6 caminhões betoneira/lote. Na obra 2 foi possível apenas a amostragem de um lote de 5 caminhões (lote 2), oriundo de outra central dosadora, por razão de ser um volume menor de concretagem $\left(40 \mathrm{~m}^{3}\right)$. Seguindo a NBR 12655:2006, as variáveis de interesse foram mensuradas a partir de dois carrinhos de 90L por caminhão. Como não há interesse em avaliar possíveis erros de medida, foram consideradas as médias dessas avaliações como os valores da variável para o caminhão em questão.

O método de coleta das amostras e as especificações básicas do concreto de cada central dosadora seguiram as normas ABNT NBR 6118 (2003) e ABNT NBR 12655 (2006), tanto no estado fresco, como nas observações em corpos de prova no concreto endurecido. 


\section{APÊNDICE E}

\section{Relatório do CEA}

\section{Objetivo}

O objetivo do estudo é, a partir de três lotes de concreto estrutural de cimento Portland extraídos de duas centrais dosadoras, realizar comparações de variáveis físicas entre os lotes 1 (obra 1) e 2 (obra 2), bem como entre os dois lotes da obra 1.

A unidade amostral considerada foi o concreto contido no carrinho de 90L, extraído de um caminhão betoneira. A população à qual se deseja inferir são os lotes treinamento e 1, produzidos em uma mesma central dosadora, e o lote 2 , vindo de outra central.

\section{Descrição das variáveis}

As variáveis de interesse medidas no concreto amostrado foram:

1. Abatimento de tronco de cone $(\mathrm{cm})$;

2. Densidade de massa especifica aparente $(\mathrm{kg} / \mathrm{L})$;

3. Índice de compactabilidade com adensamento $(\mathrm{cm})$;

4. Índice de compactabilidade sem adensamento $(\mathrm{cm})$;

5. Teor de ar pressométrico (\%);

6. Umidade (\%);

7. Absorção de água por capilaridade $(\mathrm{g} / \mathrm{cm} 2)$ - cura acelerada $24 / 48 \mathrm{~h}+$ imersão em água até 7 dias;

8. Absorção de água por capilaridade $(\mathrm{g} / \mathrm{cm} 2)$ - cura imersa em água por 28 dias;

9. Absorção de água total (\%) - cura acelerada $24 / 48 \mathrm{~h}+$ imersão em água até 7 dias;

10. Índice de vazios (\%) - cura acelerada 24/48 h + imersão em água até 7 dias;

11. Absorção de água total (\%) - cura imersa em água por 28 dias;

12. Índice de vazios (\%) - cura imersa em água por 28 dias;

13. Resistência à compressão - fc1 (MPa); 


\section{APÊNDICE E}

\section{Relatório do CEA}

14. Resistência à compressão - fc $1(\mathrm{MPa})$ - cura acelerada $0 / 24 \mathrm{~h}$;

15. Resistência à compressão - fc7 (MPa) - cura acelerada 24/48 h e imersão em água até 7 dias;

16. Resistência à compressão - fc7 (MPa) - cura imersa em água por 7 dias;

17. Resistência à compressão - fc28 (MPa) - cura imersa em água até 28 dias;

18. Resistência à compressão - fc63 (MPa) - cura imersa em água até 63 dias;

19. Resistência à compressão - fc 91 (MPa) - cura imersa em água até 91 dias;

20. Resistência à tração por compressão diametral - fct $7(\mathrm{MPa})$ - cura acelerada 24/48 e imersão em água até 7 dias;

21. Resistência à tração por compressão diametral - fct 28 (MPa) - cura imersa em água até 28 dias;

22. Resistência à tração por compressão diametral - fct 91 (MPa) - cura imersa em água até 91 dias;

23. Profundidade de carbonatação por ciclagem $(\mathrm{mm})$;

24. Profundidade de carbonatação em câmara de $\mathrm{CO} 2(\mathrm{~mm})$;

25. Profundidade de penetração de cloretos $(\mathrm{mm})$.

\section{Análise estatística}

Os gráficos A.1 e A.2 ilustram a dispersão de valores das variáveis 17 (resistência à compressão - $f c 28(\mathrm{MPa})$ ) e 8 (absorção de água por capilaridade (g/cm2) - cura imersa em água por 28 dias), respectivamente. Pode-se observar que, para a variável 17 , os três lotes apresentam uma distribuição semelhante, enquanto que, para a variável 8 , os valores dos lotes 1 e 2 são inferiores aos do lote treinamento. Os gráficos para as demais variáveis e suas medidas descritivas encontram-se no Apêndice. É possível observar semelhanças entre os lotes 1 e 2 para as variáveis 2, 4, $8,9,10,11,12,14,16,19$ e 23 . Entre os lotes 1 e treinamento, foi observada uma ligeira semelhança somente na variável 17. 


\section{APÊNDICE E}

\section{Relatório do CEA}

Gráfico A.1

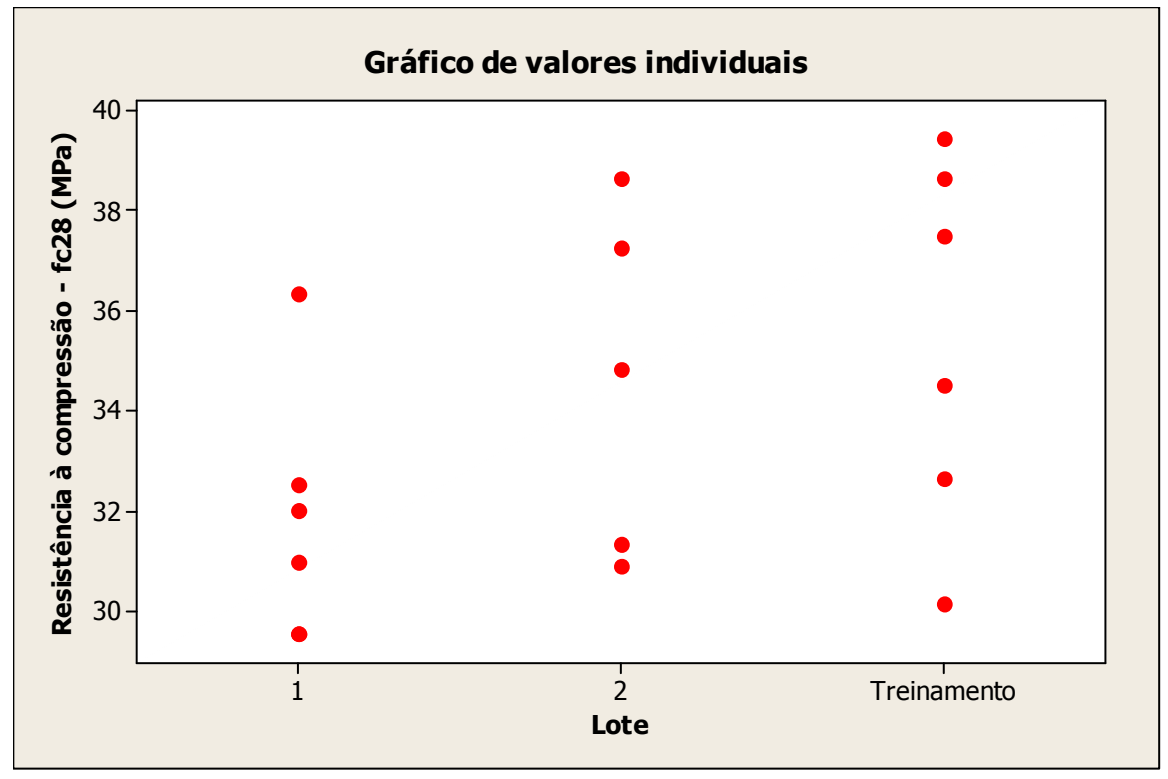

Gráfico A.2

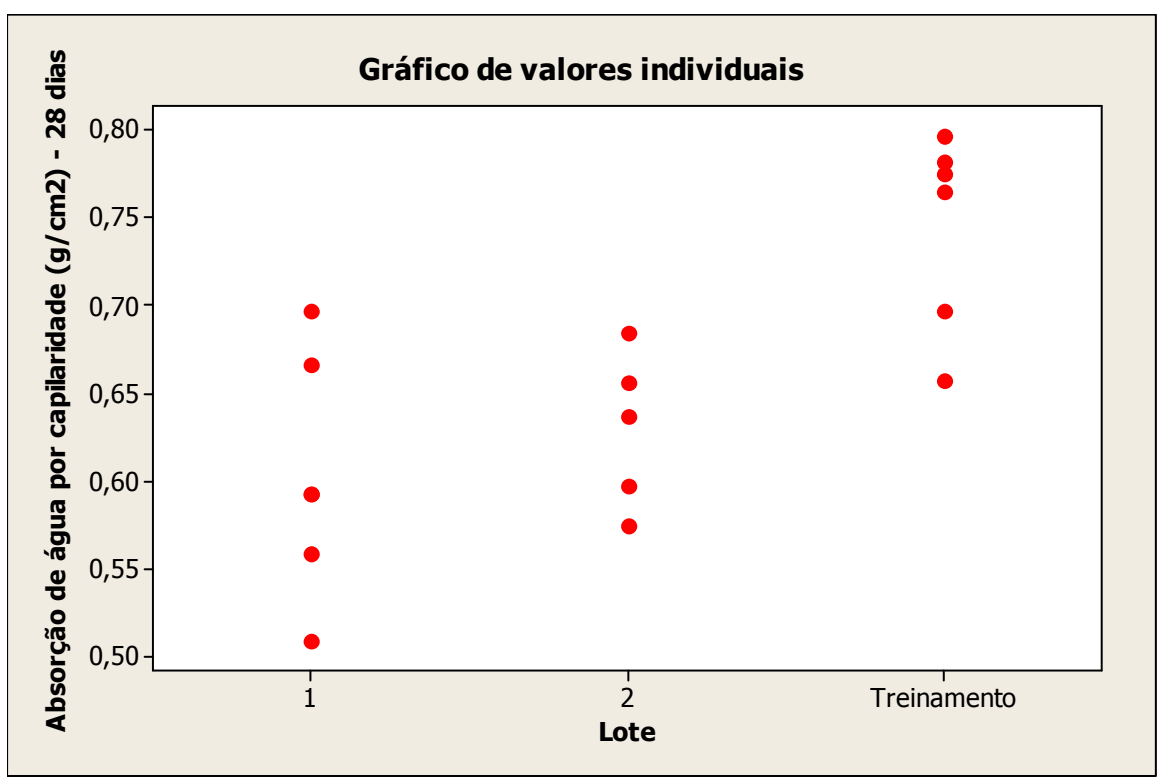




\section{APÊNDICE E}

\section{Relatório do CEA}

Como as variáveis de interesse são de caráter físico, é usual assumir que as observações seguem uma distribuição normal de probabilidade. Assim, foram realizados testes t para verificar a igualdade de médias entre as variáveis dos lotes 1 e 2 e dos lotes 1 e treinamento. Dado o número restrito de observações em cada amostra é pouco razoável assumir igualdade entre as variâncias populacionais, de forma que os testes efetuados consideraram diferença entre as mesmas.

- Lote treinamento $\mathrm{x}$ Lote 1 :

A Tabela B.1 apresenta os valores médios e seus respectivos erros padrão para as variáveis do estudo, além dos níveis descritivos dos testes de diferenças de médias entre os lotes treinamento e 1. A um nível de significância de $5 \%$, não se verificaram diferenças significativas nas variáveis 1, 10, 15, 17, 21 e 24. Observa-se também que os valores médios das variáveis 8 e 20 são significantemente menores no lote 1 , enquanto o lote treinamento apresenta valores menores para as variáveis $2,3,4,9,11$, 12,23 e 25.

- Lote1 x Lote2:

Tratando-se das comparações entre os lotes 1 e 2, os valores médios observados junto com seus respectivos erros padrão encontram-se relacionados na Tabela B.2, além dos níveis descritivos dos testes de diferenças de médias. Assumindose um nível de significância de 5\%, é possível observar que os valores do lote 1 são, em média, superiores aos do lote 2 nas variáveis 3, 24 e 25, e inferiores em 7,14 e 20. Para as demais variáveis, a hipótese de igualdade de médias não foi rejeitada, ao nível de $5 \%$. 


\section{APÊNDICE E}

\section{Relatório do CEA}

Dessa forma, as variáveis 3 (Índice de compactabilidade com adensamento (cm)), 20 (Resistência à tração por compressão diametral - fct 7 (MPa) - cura acelerada 24/48 e imersão em água até 7 dias) e 25 (Profundidade de penetração de cloretos $(\mathrm{mm})$ ) apresentaram diferença, em média, tanto no concreto produzido pela mesma central, quanto por centrais diferentes.

- Correlações entre as variáveis do estudo:

A Tabela B.4 traz as correlações observadas entre as variáveis do estudo, de forma que altas correlações estão destacados em cores mais fortes, sendo que o vermelho representa correlações negativas e o azul as correlações positivas.

Assim, observa-se que a variável 8 é positivamente correlacionada com as variáveis 11,12 e 23 . O mesmo se observa entre as variáveis 9 e 10 e entre as variáveis 11 e 12.

Ainda, é possível observar que a variável 22 é correlacionada de forma negativa com as variáveis 2, 5, 6 e 15, assim como a variável 20 com as variáveis 5,25 e 24. A variável 14 também apresenta altos valores de correlação negativa quando estudada em conjunto com as variáveis 1 e 24 .

- Normalidade das variáveis 23, 24 e 25:

Ao analisar os gráficos A.27-A.32 e os valores da estatística de Anderson-Darling para teste de normalidade, é possível concluir que:

- Ao nível de $5 \%$, não há evidências para se rejeitar a suposição de normalidade para a variável 23 quando se avaliam os valores independentemente do lote. Entretanto, quando os valores são analisados dentro de cada lote, os dados aparentam não apresentar normalidade no lote treinamento. 


\section{APÊNDICE E}

\section{Relatório do CEA}

- Para a variável 24, a suposição de normalidade parece se satisfazer, ao nível de $5 \%$, para os lotes 1 e 2 . Para o lote treinamento, o nível descritivo do teste foi de 0,49 , bem próximo ao nível de significância estabelecido, de forma que não haveria grande problema em aceitar a suposição de normalidade também para este lote. No entanto, quando não se consideram os lotes e realiza-se o teste para todas as observações do estudo, a hipótese de normalidade é rejeitada. Os valores médios de cada lote são também indicativos de que os dados não vêm de uma única distribuição.

- Considerando-se a estratificação por lote, a suposição de normalidade não é rejeitada, ao nível de $5 \%$, para a variável 25 . O mesmo ocorre quando analisamse os dados conjuntamente.

Bibliografia

- Magalhães, M. N. e Pedroso de Lima, A. C. (2006), Noções de Probabilidade e Estatística. 6ª Ed. São Paulo: Edusp.

- Morettin, P. A. e Bussab, W. O. (2005), Estatística Básica. 2a Ed. São Paulo: Atual.

- Neter, J., Kutner, M. H., Nachtshem, C. J. \& Wasserman, W. (2005). Applied Linear Statistical Models, 5th Ed., Homewood: Chicago. 


\section{APÊNDICE E}

\section{Relatório do CEA}

Gráfico A.3 - Gráfico de valores individuais: 1. Abatimento de tronco de cone $(\mathrm{cm})$.

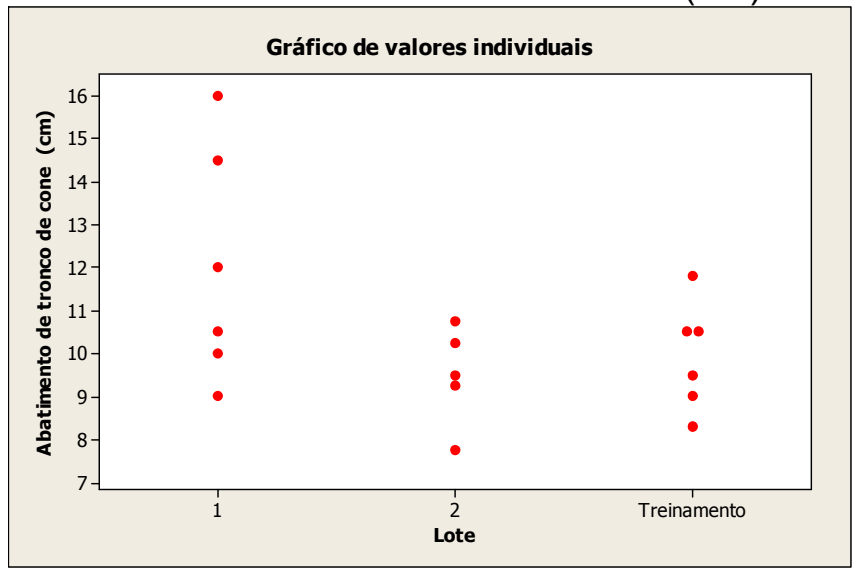

Gráfico A.4 - Gráfico de valores individuais:

2. Densidade de massa específica aparente $\left(\mathrm{kg} / \mathrm{m}^{3}\right)$.

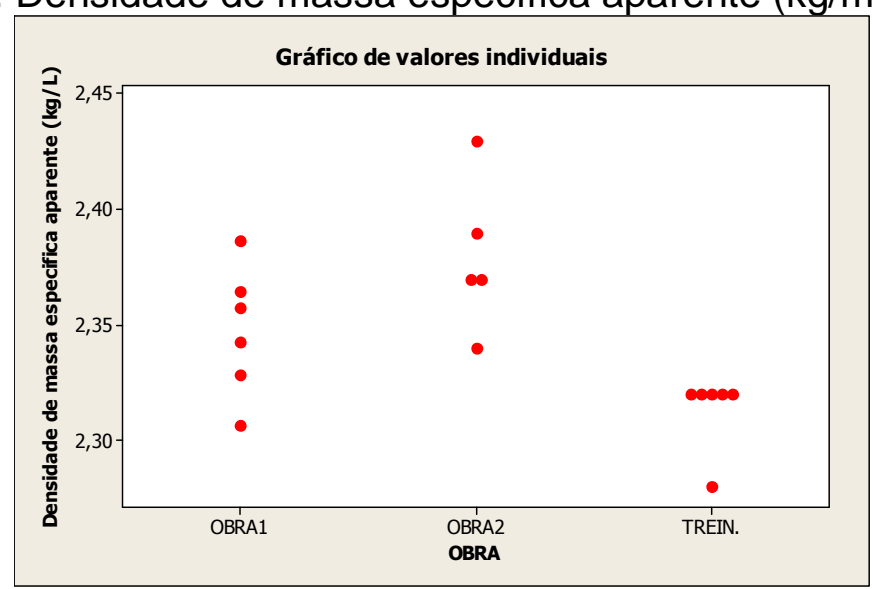




\section{APÊNDICE E}

\section{Relatório do CEA}

Gráfico A.5 - Gráfico de valores individuais:

3. Índice de compactabilidade com adensamento $(\mathrm{cm})$.

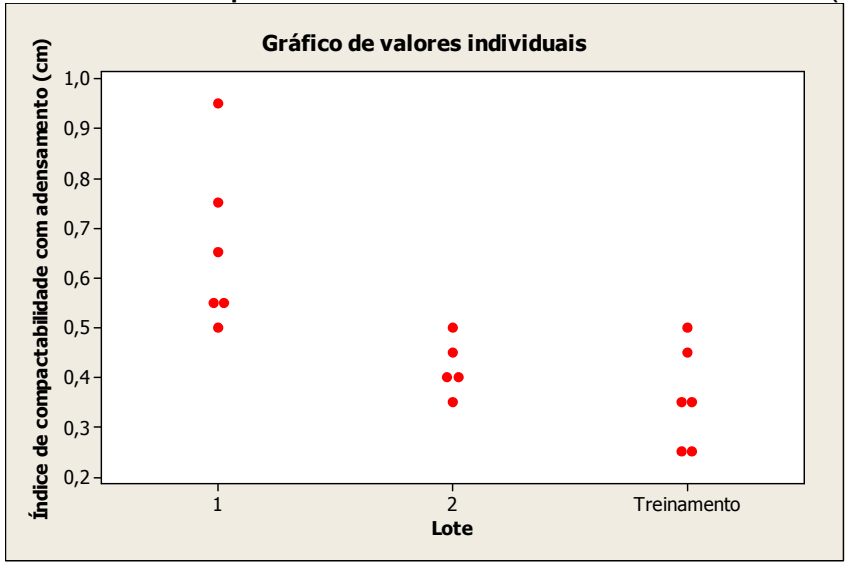

Gráfico A.6 - Gráfico de valores individuais:

4. Índice de compactabilidade sem adensamento (cm).

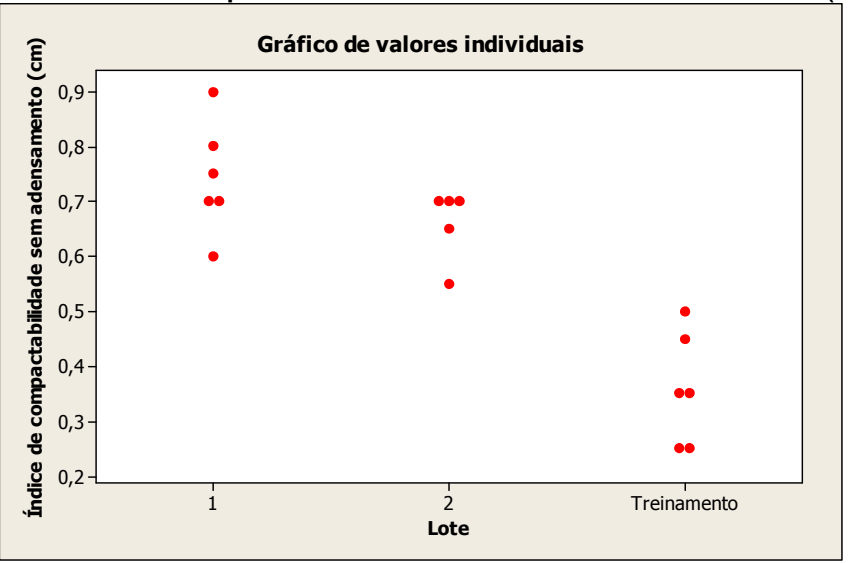




\section{APÊNDICE E}

\section{Relatório do CEA}

Gráfico A.7 - Gráfico de valores individuais:

5. Teor de ar pressometrico (\%).

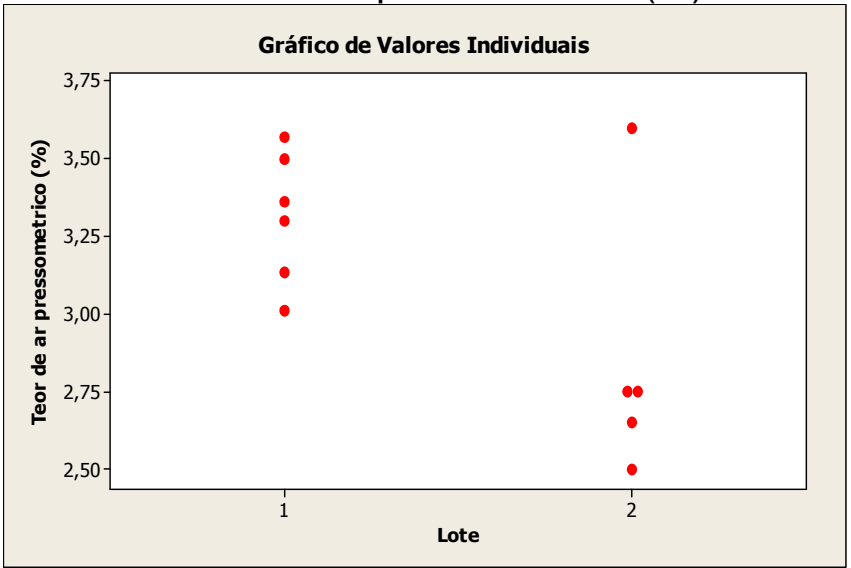

Gráfico A.8 - Gráfico de valores individuais:

6 . Umidade (\%).

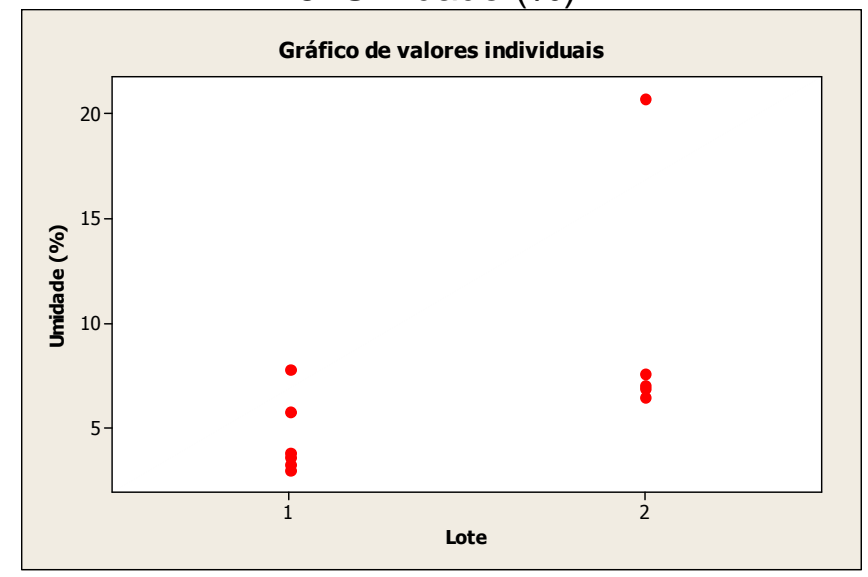




\section{APÊNDICE E}

\section{Relatório do CEA}

Gráfico A.9 - Gráfico de valores individuais:

7. Absorção de água por capilaridade $(\mathrm{g} / \mathrm{cm} 2)$ - cura acelerada $24 / 48 \mathrm{~h}+$ imersão em água até 7 dias.

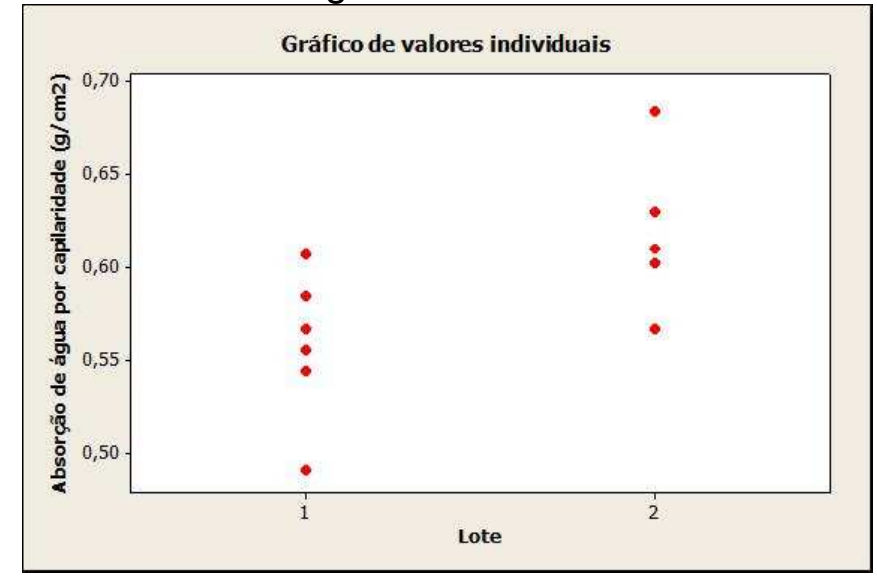

Gráfico A.10 - Gráfico de valores individuais:

8. Absorção de água por capilaridade $(\mathrm{g} / \mathrm{cm} 2)$ - cura acelerada imersa em água por 28 dias.

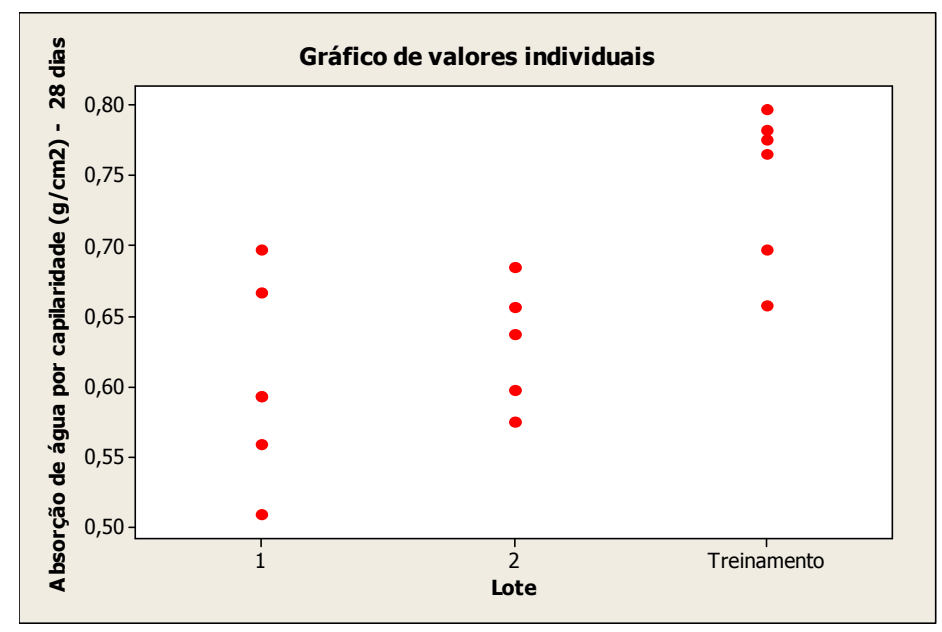




\section{APÊNDICE E}

\section{Relatório do CEA}

Gráfico A.11 - Gráfico de valores individuais:

9. Absorção de água total (\%) - cura acelerada 24/48 $\mathrm{h}+$ imersão em água até 7 dias.

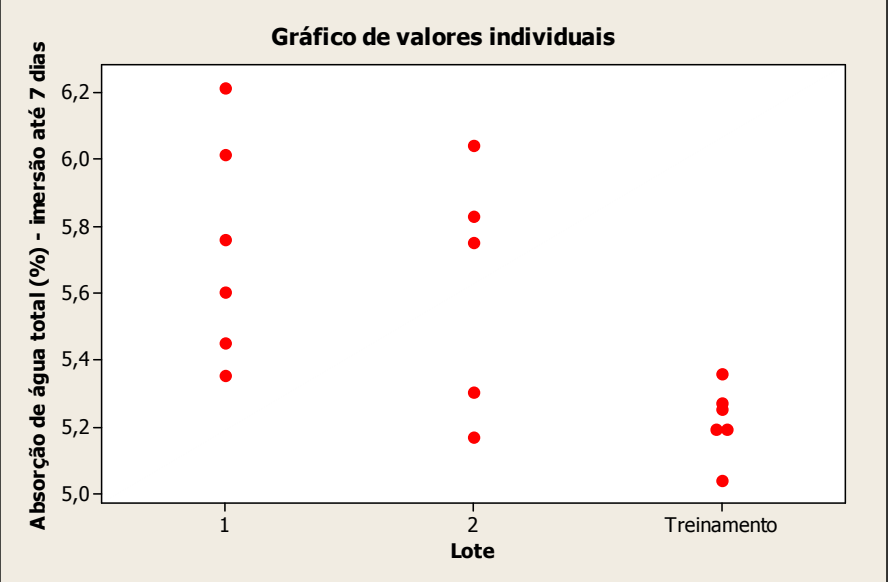

Gráfico A.12 - Gráfico de valores individuais:

10. Índice de vazios (\%) - cura acelerada $24 / 48$ h + imersão em água até 7 dias.

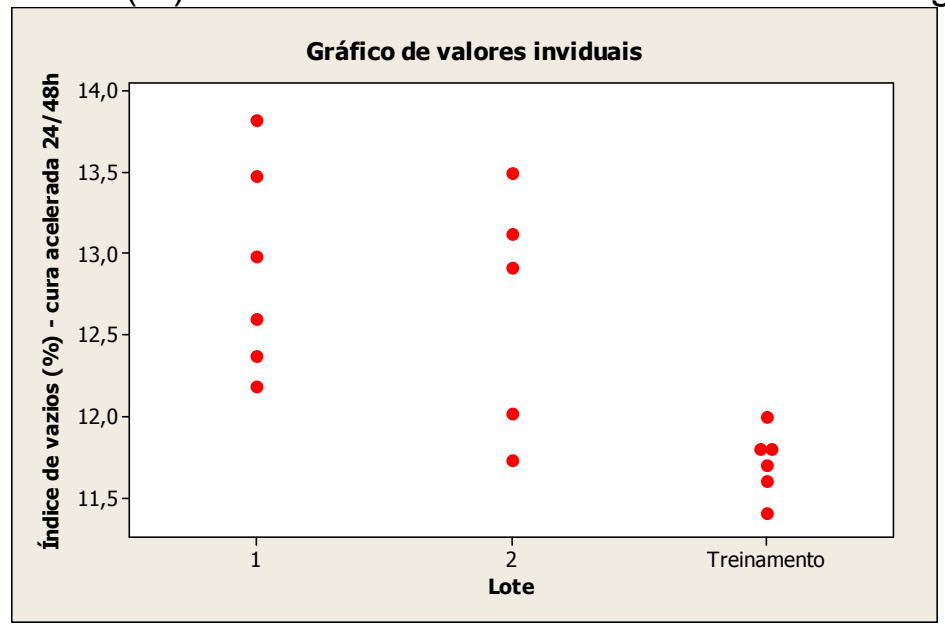




\section{APÊNDICE E}

\section{Relatório do CEA}

Gráfico A.13 - Gráfico de valores individuais:

11. Absorção de água total (\%) - cura imersa em água por 28 dias.

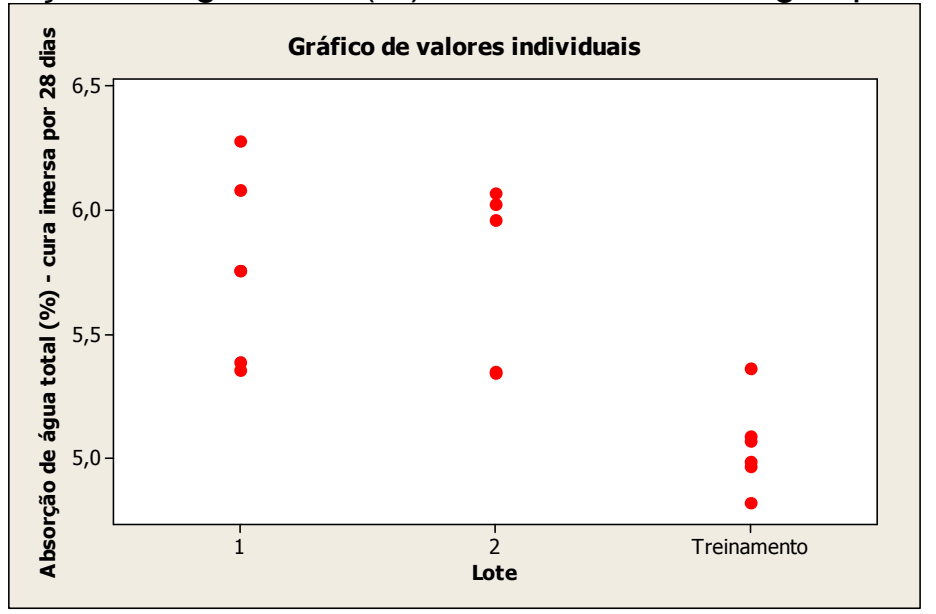

Gráfico A.14 - Gráfico de valores individuais:

12. Índice de vazios (\%) - cura imersa em água por 28 dias.

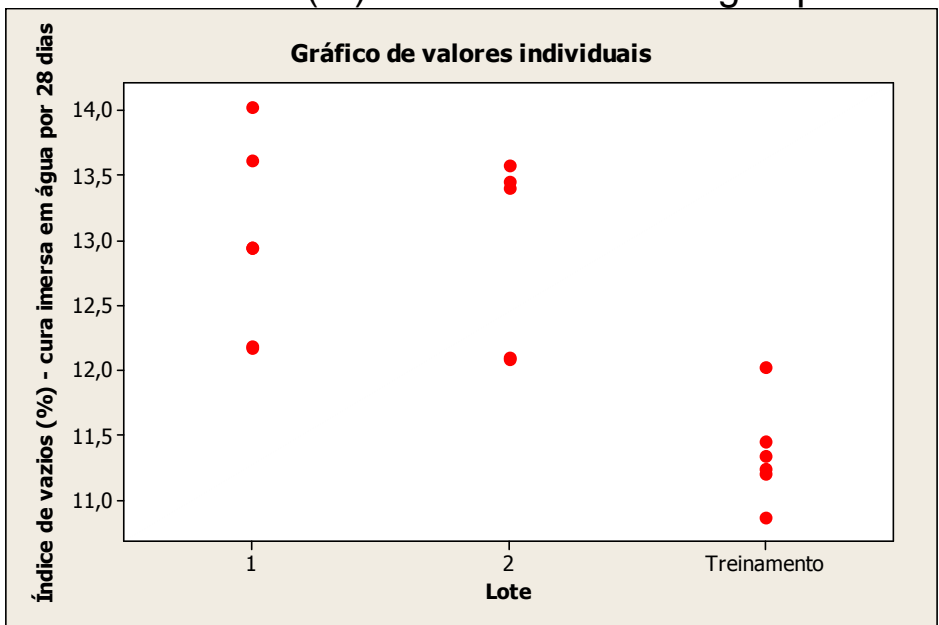




\section{APÊNDICE E}

\section{Relatório do CEA}

Gráfico A.15 - Gráfico de valores individuais:

13. Resistência à compressão - fc1 (MPa).

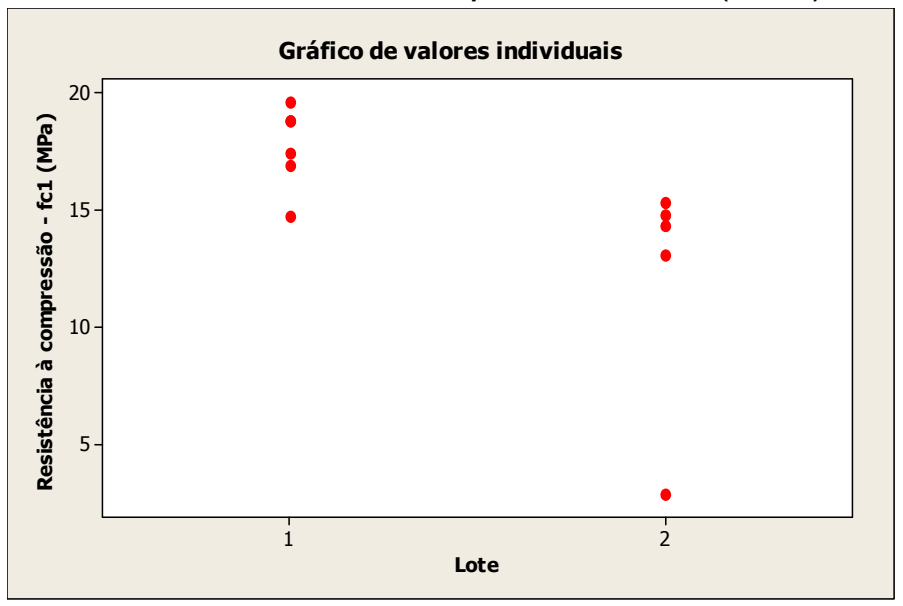

Gráfico A.16 - Gráfico de valores individuais:

14. Resistência à compressão - fc1 (MPa) - cura acelerada 0/24 h.

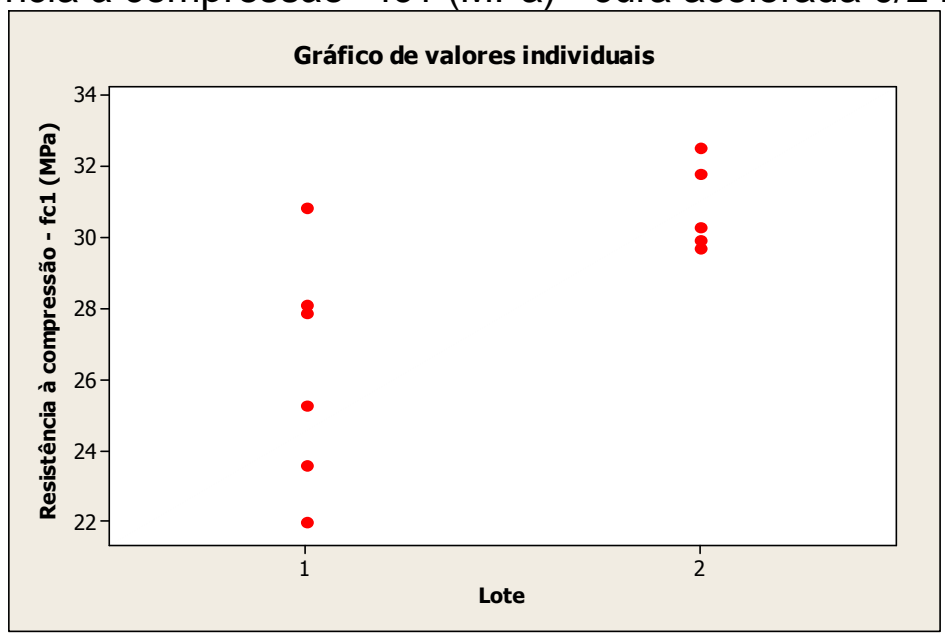




\section{APÊNDICE E}

\section{Relatório do CEA}

Gráfico A.17 - Gráfico de valores individuais:

15. Resistência à compressão - fc7 (MPa) - cura acelerada $24 / 48$ h e imersão em água até 7 dias.

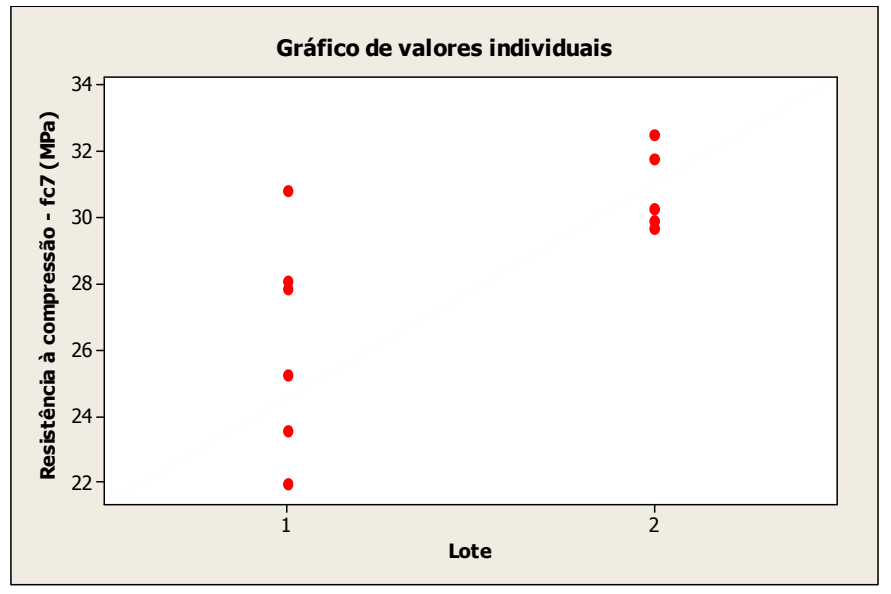

Gráfico A.18 - Gráfico de valores individuais:

16. Resistência à compressão - fc7 (MPa) - cura imersa em água por 7 dias.

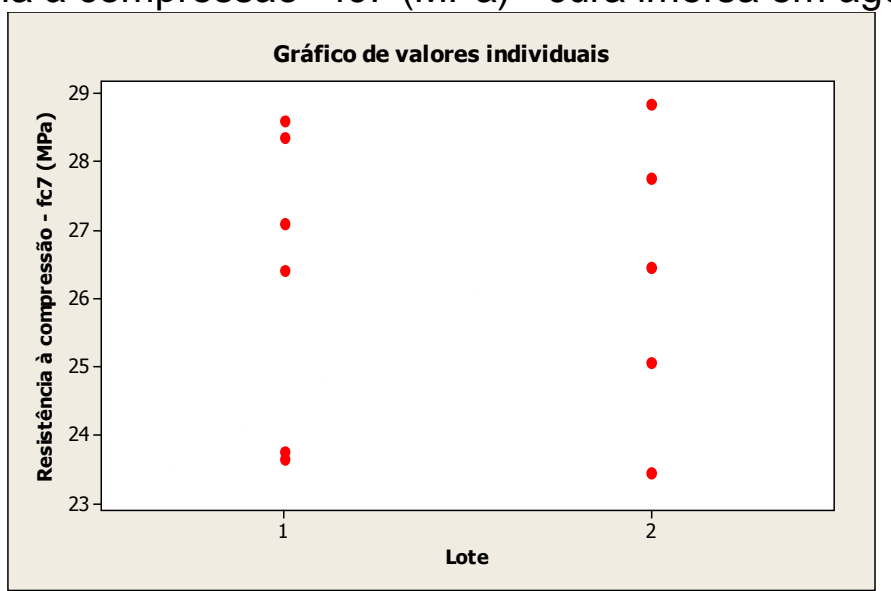




\section{APÊNDICE E}

\section{Relatório do CEA}

Gráfico A.19 - Gráfico de valores individuais:

17. Resistência à compressão - fc28 $(\mathrm{MPa})$ - cura imersa em água até 28 dias

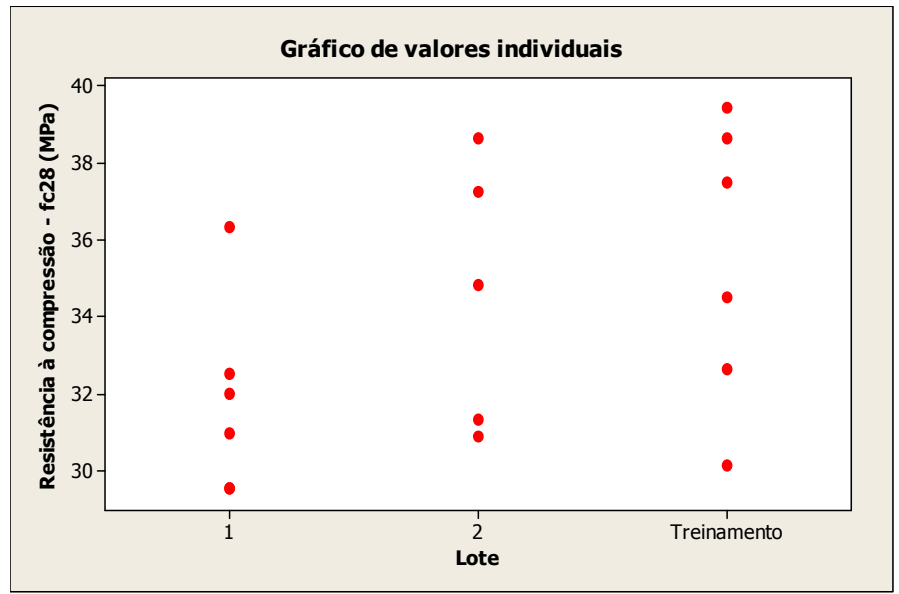

Gráfico A.20 - Gráfico de valores individuais:

18. Resistência à compressão - fc63 (MPa) - cura imersa em água até 63 dias.

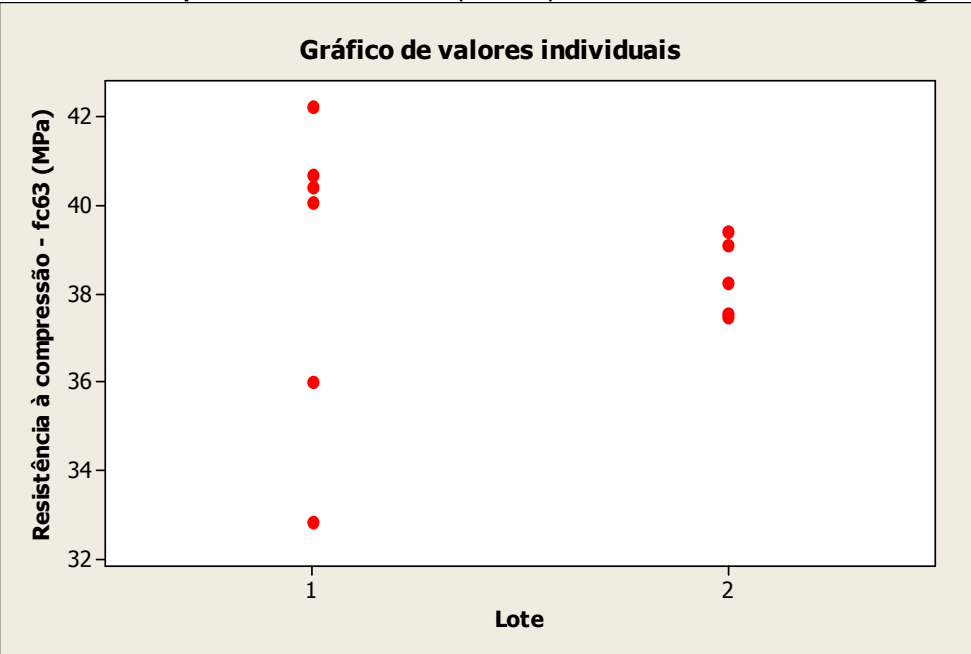




\section{APÊNDICE E}

\section{Relatório do CEA}

Gráfico A.21 - Gráfico de valores individuais:

19. Resistência à compressão - fc91 (MPa) - cura imersa em água até 91 dias.

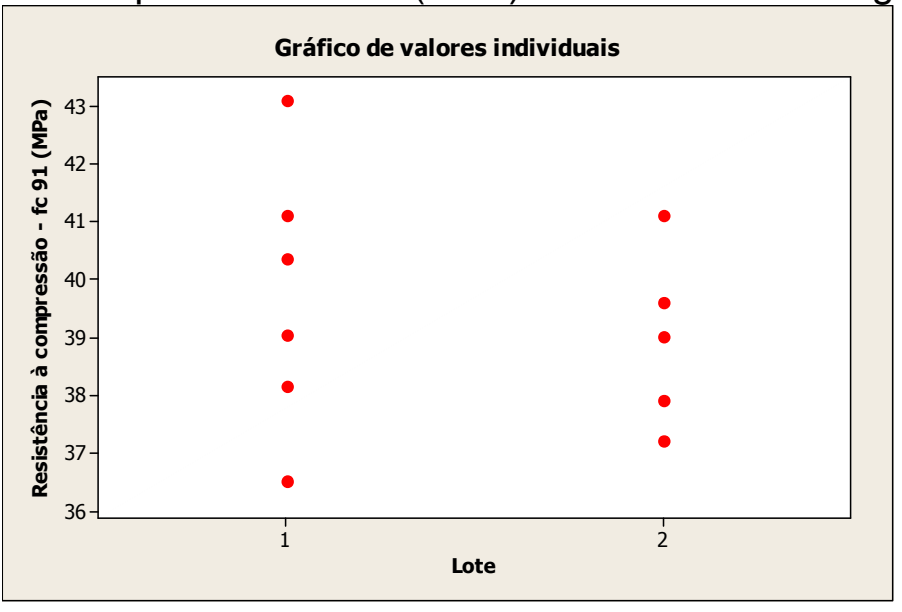

Gráfico A.22 - Gráfico de valores individuais:

20. Resistência à tração por compressão diametral - fct $7(\mathrm{MPa})$ - cura acelerada $24 / 48$ $\mathrm{h}+$ imersão em água até 7 dias.

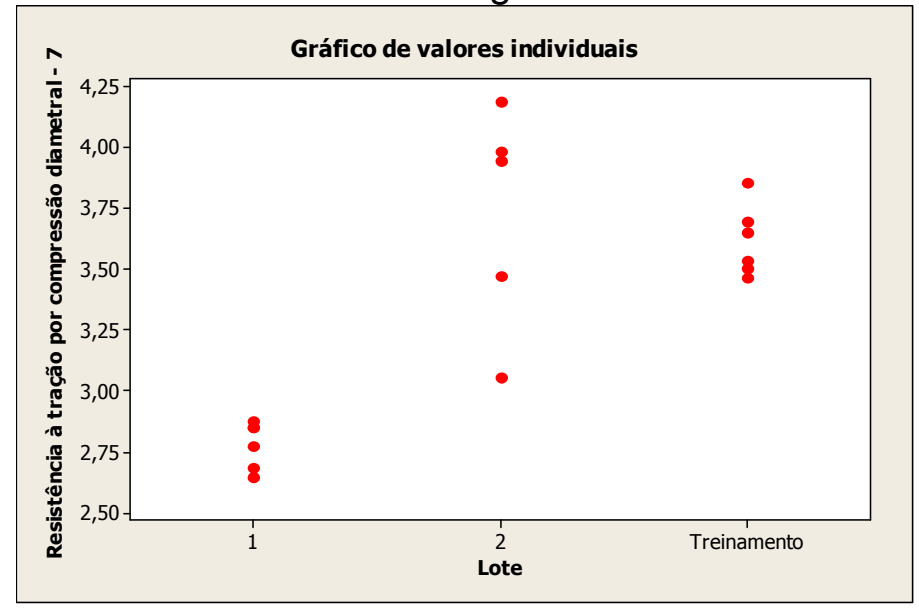




\section{APÊNDICE E}

\section{Relatório do CEA}

Gráfico A.23 - Gráfico de valores individuais:

21. Resistência à tração por compressão diametral - fct $28(\mathrm{MPa})$ - cura imersa em água até 28 dias.

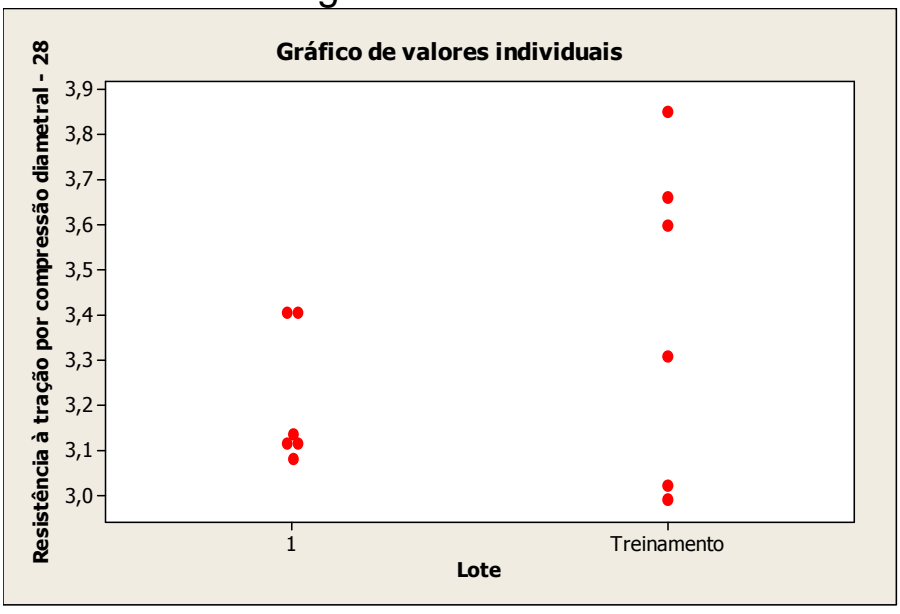

Gráfico A.24 - Gráfico de valores individuais:

23. Profundidade de carbonatação por ciclagem ( $\mathrm{mm})$.

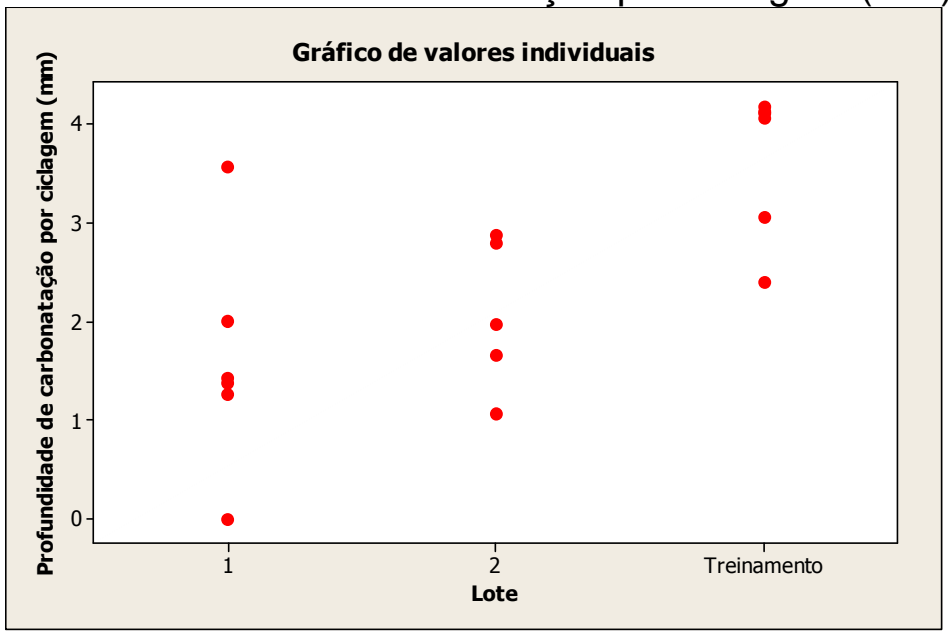




\section{APÊNDICE E}

\section{Relatório do CEA}

Gráfico A.25 - Gráfico de valores individuais:

24. Profundidade de carbonatação em câmara de CO2 ( $\mathrm{mm})$.

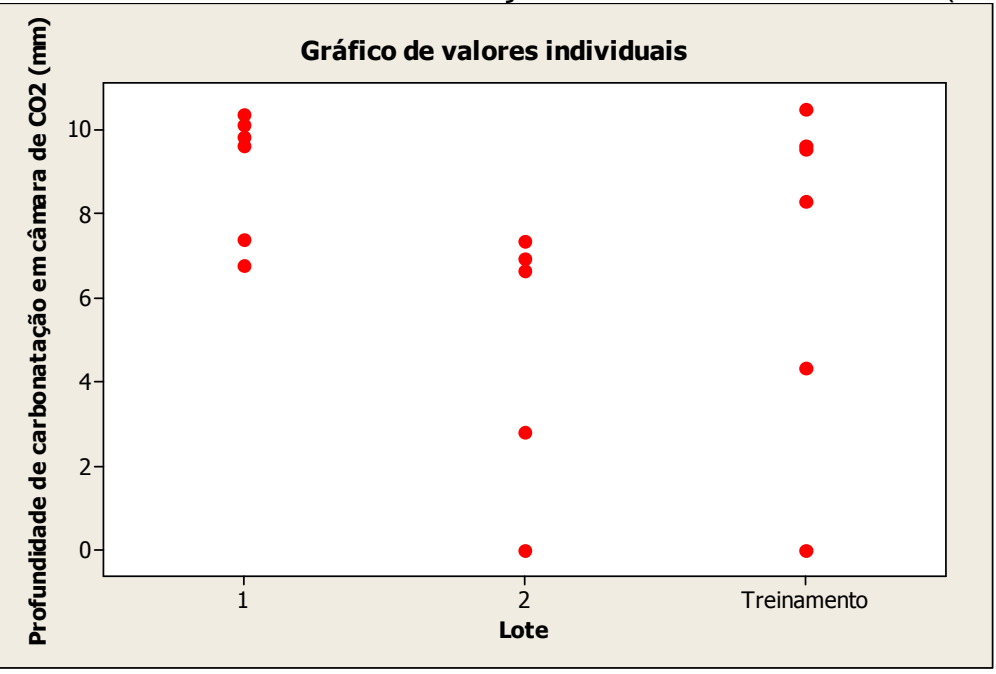

Gráfico A.26 - Gráfico de valores individuais:

25. Profundidade de penetração de cloretos ( $\mathrm{mm}$ ).

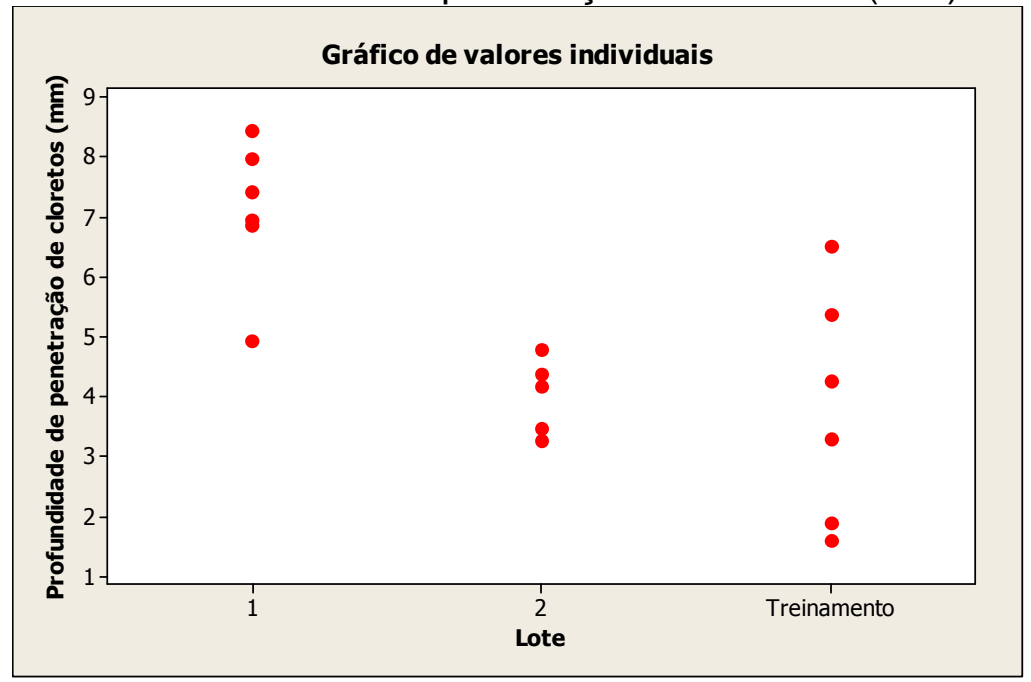




\section{APÊNDICE E}

\section{Relatório do CEA}

Gráfico A.27 - Gráfico de probabilidade normal: 23. Profundidade de carbonatação por ciclagem ( $\mathrm{mm}$ ).

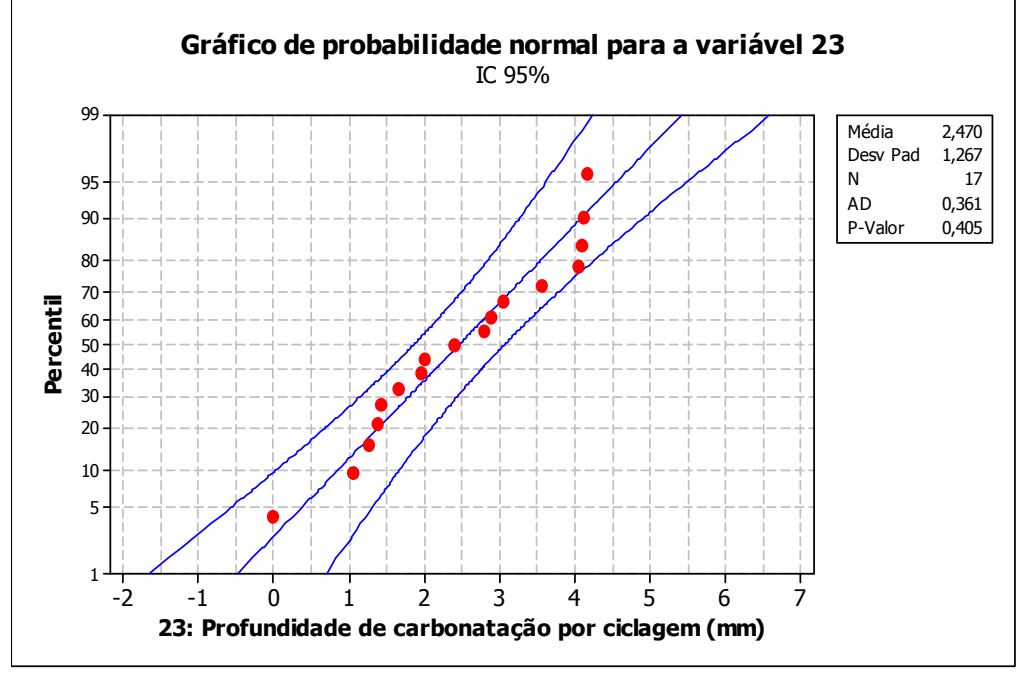

Gráfico A.28 - Gráfico de probabilidade normal: 24. Profundidade de carbonatação em câmara de $\mathrm{CO} 2(\mathrm{~mm})$.

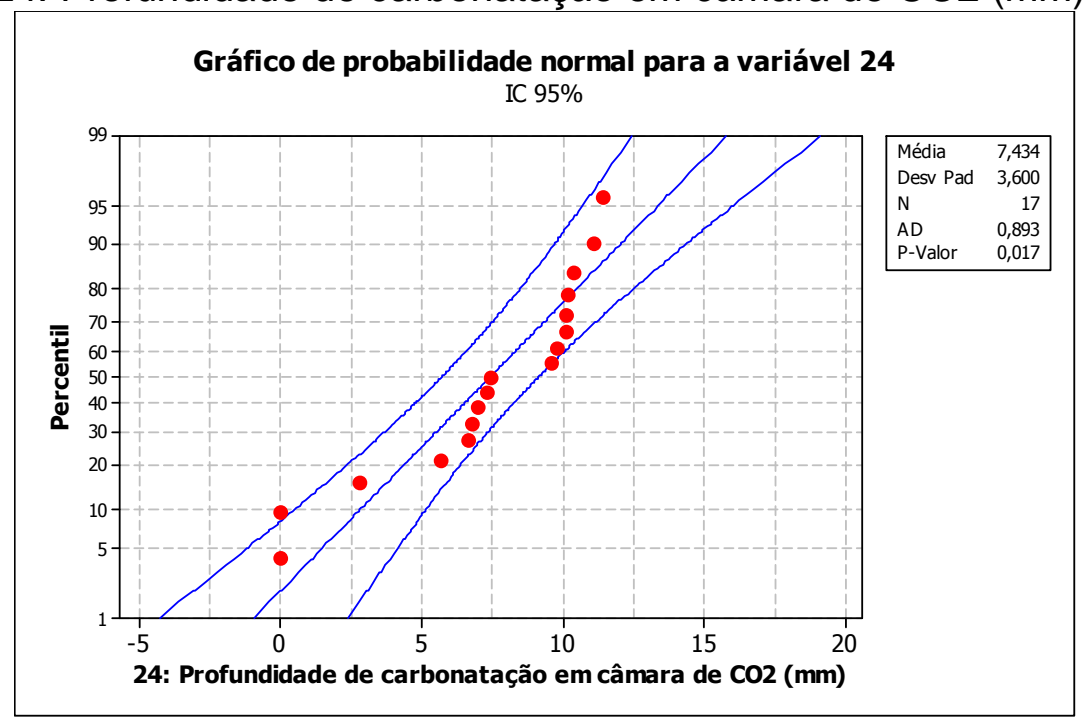




\section{APÊNDICE E}

\section{Relatório do CEA}

Gráfico A.29 - Gráfico de probabilidade normal: 25. Profundidade de penetração de cloretos $(\mathrm{mm})$.

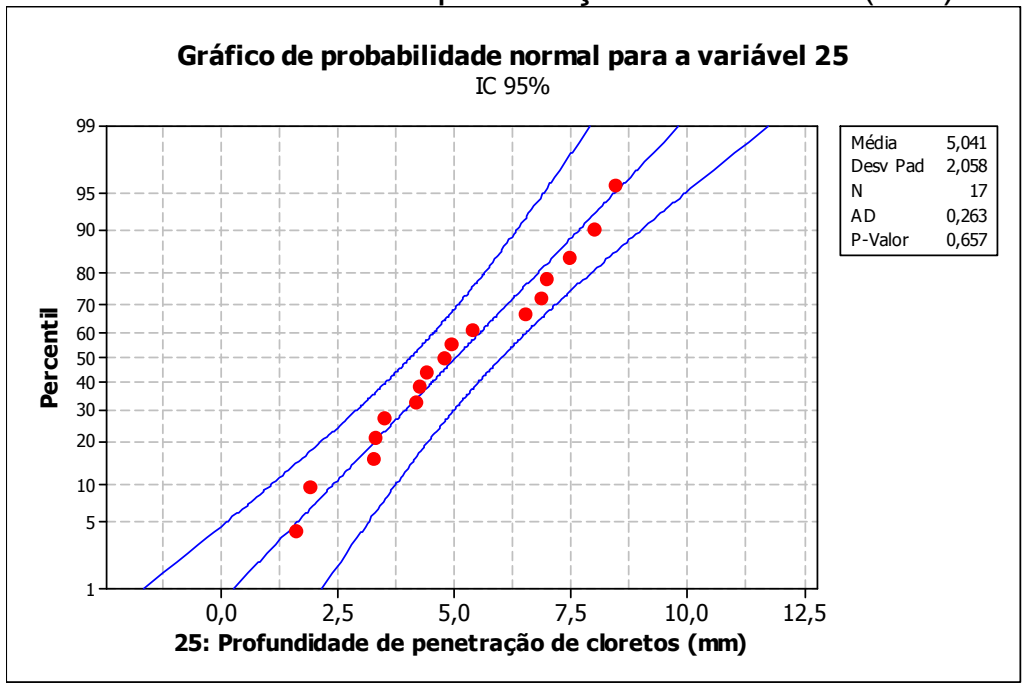

Gráfico A.30 - Gráficos de probabilidade normal por lote: 23. Profundidade de carbonatação por ciclagem $(\mathrm{mm})$.

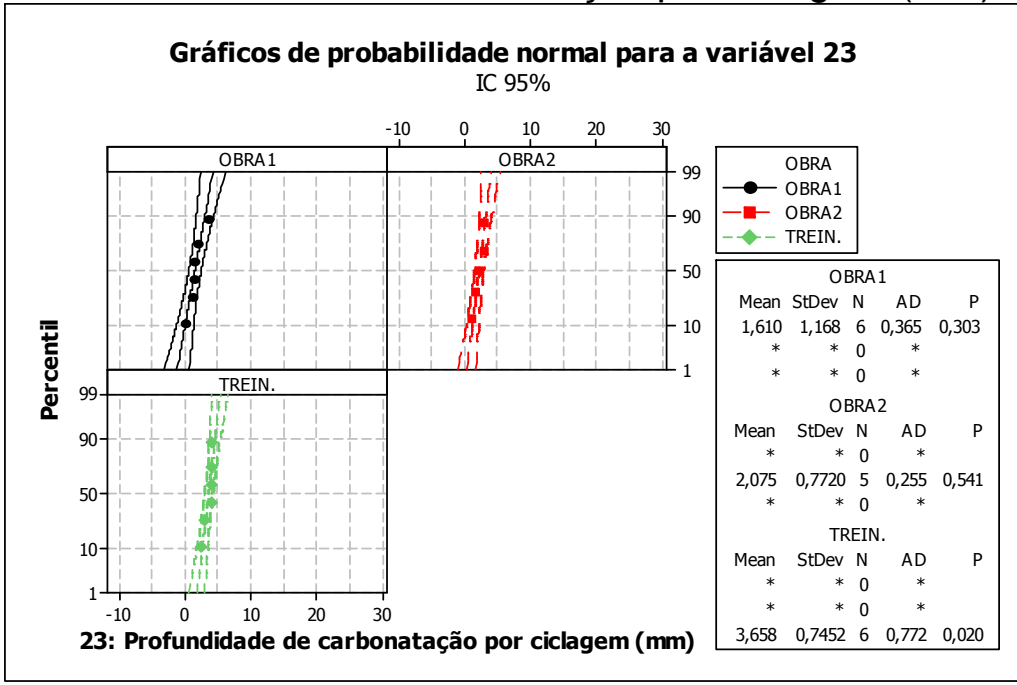




\section{APÊNDICE E}

\section{Relatório do CEA}

Gráfico A.31 - Gráficos de probabilidade normal por lote: 24. Profundidade de carbonatação em câmara de CO2 (mm).

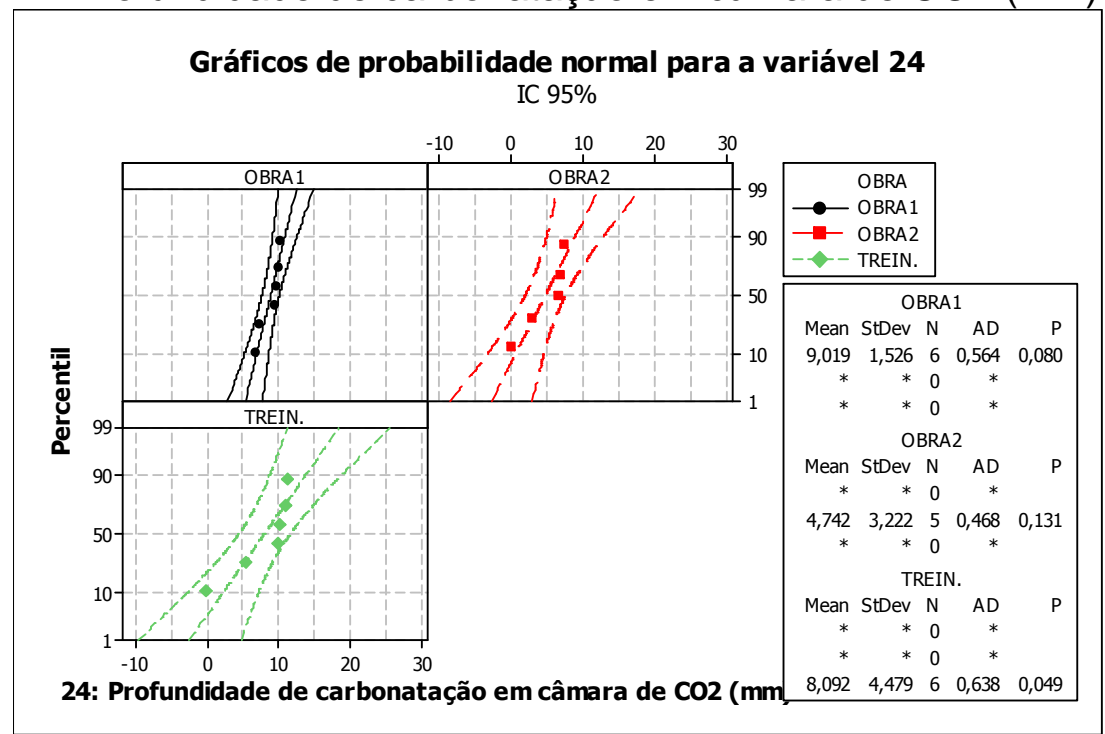

Gráfico A.32 - Gráficos de probabilidade normal por lote: 25. Profundidade de penetração de cloretos $(\mathrm{mm})$.

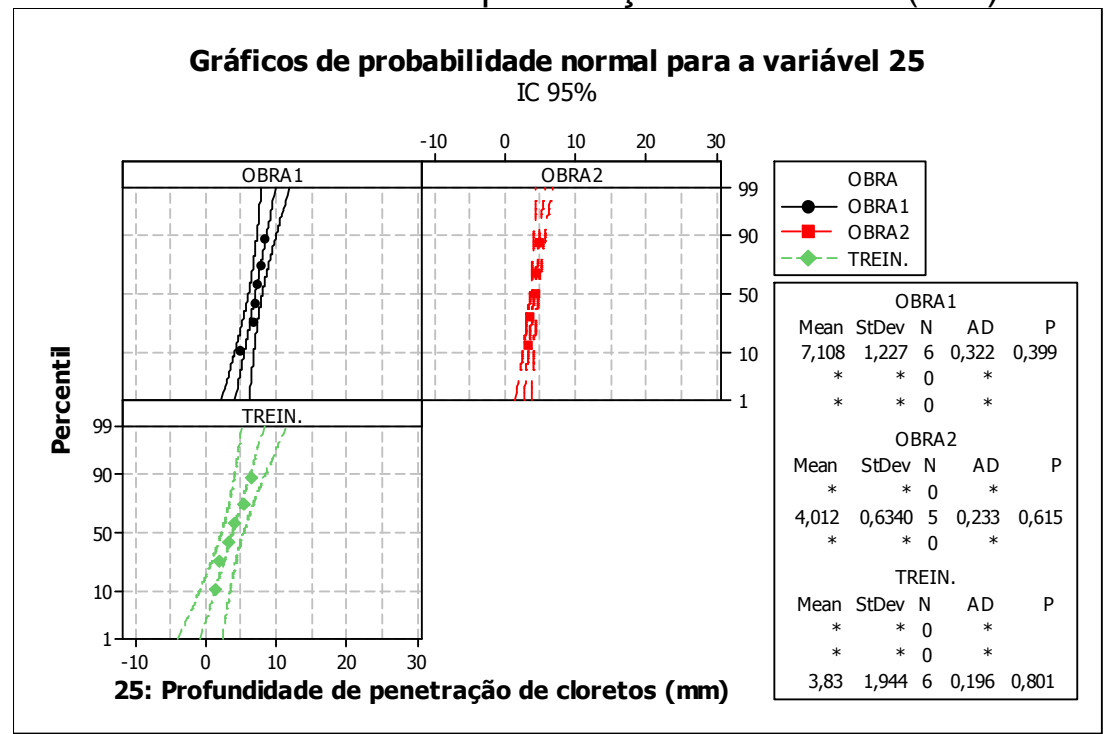




\section{APÊNDICE E}

\section{Relatório do CEA}

Tabela B.1 - Resultados das Comparações entre lote treinamento e lote 1

\begin{tabular}{|c|c|c|c|}
\hline Variável & $\begin{array}{l}\text { Lote } \\
\text { Trein. }\end{array}$ & Lote 1 & P-valor \\
\hline 1. Abatimento de tronco de cone $(\mathrm{cm})$ & $\begin{array}{c}9,930 \\
(0,510)\end{array}$ & $\begin{array}{l}12,000 \\
(1,100)\end{array}$ & 0,137 \\
\hline 2. Densidade de massa especifica aparente $(\mathrm{kg} / \mathrm{L})$ & $\begin{array}{c}2,313 \\
(0,007)\end{array}$ & $\begin{array}{c}2,348 \\
(0,012)\end{array}$ & 0,033 \\
\hline $\begin{array}{l}\text { 3. Indice de compactabilidade com adensamento } \\
(\mathrm{cm})\end{array}$ & $\begin{array}{c}0,358 \\
(0,042)\end{array}$ & $\begin{array}{c}0,658 \\
(0,069)\end{array}$ & 0,006 \\
\hline $\begin{array}{l}\text { 4. Índice de compactabilidade sem adensamento } \\
(\mathrm{cm})\end{array}$ & $\begin{array}{c}0,358 \\
(0,042)\end{array}$ & $\begin{array}{c}0,742 \\
(0,042)\end{array}$ & $<0,001$ \\
\hline $\begin{array}{l}\text { 8. Absorção de água por capilaridade }(\mathrm{g} / \mathrm{cm} 2) \text { - cura } \\
\text { acelerada imersa em água por } 28 \text { dias }\end{array}$ & $\begin{array}{c}0,745 \\
(0,023)\end{array}$ & $\begin{array}{c}0,602 \\
(0,028)\end{array}$ & 0,003 \\
\hline $\begin{array}{l}\text { 9. Absorção de água total (\%) - cura acelerada } \\
24 / 48 \mathrm{~h}+\text { imersão em água até } 7 \text { dias }\end{array}$ & $\begin{array}{l}0,217 \\
5,044)\end{array}$ & $\begin{array}{c}5,731 \\
(0,140)\end{array}$ & 0,011 \\
\hline $\begin{array}{l}\text { 10. İndice de vazios (\%) - cura acelerada } 24 / 48 \text { h + } \\
\text { imersão em água até } 7 \text { dias }\end{array}$ & $\begin{array}{l}11,717 \\
(0,083)\end{array}$ & $\begin{array}{l}12,905 \\
(0,260)\end{array}$ & 0,008 \\
\hline $\begin{array}{l}\text { 11. Absorção de água total (\%) - cura imersa em } \\
\text { água por } 28 \text { dias }\end{array}$ & $\begin{array}{l}5,050 \\
(0,073)\end{array}$ & $\begin{array}{c}5,770 \\
(0,150)\end{array}$ & 0,004 \\
\hline $\begin{array}{l}\text { 12. Índice de vazios (\%) - cura imersa em água por } \\
28 \text { dias }\end{array}$ & $\begin{array}{l}11,353 \\
(0,160)\end{array}$ & $\begin{array}{l}12,979 \\
(0,300)\end{array}$ & 0,002 \\
\hline $\begin{array}{l}\text { 15. Resistência à compressão - fc7 (MPa) - cura } \\
\text { acelerada } 24 / 48 \text { h e imersão em água até } 7 \text { dias }\end{array}$ & $\begin{array}{l}31,790 \\
(0,870)\end{array}$ & $\begin{array}{l}30,300 \\
(0,790)\end{array}$ & 0,237 \\
\hline $\begin{array}{l}\text { 17. Resistência à compressão - fc28 (MPa) - cura } \\
\text { imersa em água até } 28 \text { dias }\end{array}$ & $\begin{array}{l}35,480 \\
(1,500)\end{array}$ & $\begin{array}{l}31,830 \\
(1,000)\end{array}$ & 0,080 \\
\hline $\begin{array}{l}\text { 20. Resistência à tração por compressão diametral } \\
\text { - fct } 7 \text { (MPa) - cura acelerada } 24 / 48 \text { e imersão em } \\
\text { água até } 7 \text { dias }\end{array}$ & $\begin{array}{l}3,613 \\
(0,060)\end{array}$ & $\begin{array}{c}2,777 \\
(0,040)\end{array}$ & $<0,001$ \\
\hline $\begin{array}{l}\text { 21. Resistência à tração por compressão diametral } \\
\text { - fct } 28(\mathrm{MPa}) \text { - cura imersa em água até } 28 \text { dias }\end{array}$ & $\begin{array}{c}3,405 \\
(0,140)\end{array}$ & $\begin{array}{c}3,209 \\
(0,062)\end{array}$ & 0,261 \\
\hline $\begin{array}{l}\text { 23. Profundidade de carbonataçã̃o por ciclagem } \\
(\mathrm{mm})\end{array}$ & $\begin{array}{l}1,610 \\
(0,480) \\
\end{array}$ & $\begin{array}{c}3,658 \\
(0,300)\end{array}$ & 0,007 \\
\hline $\begin{array}{l}\text { 24. Profundidade de carbonatação em câmara de } \\
\mathrm{CO}_{2}(\mathrm{~mm})\end{array}$ & $\begin{array}{l}8,090 \\
(1,800)\end{array}$ & $\begin{array}{c}9,020 \\
(0,620)\end{array}$ & 0,648 \\
\hline 25. Profundidade de penetração de cl & $\begin{array}{l}3,830 \\
(0,790)\end{array}$ & $\begin{array}{l}7,110 \\
(0,500)\end{array}$ & 0,008 \\
\hline
\end{tabular}




\section{APÊNDICE E}

\section{Relatório do CEA}

Tabela B.2 - Resultados das Comparações entre lote 1 e lote 2

\begin{tabular}{|c|c|c|c|}
\hline Variável & Lote 1 & Lote 2 & P-valo \\
\hline 1. Abatimento de tronco de cone $(\mathrm{cm})$ & $\begin{array}{l}12,000 \\
(1,100)\end{array}$ & $\begin{array}{c}9,500 \\
(0,510)\end{array}$ & 0,088 \\
\hline $\begin{array}{l}\text { 2. Densidade de massa especifica aparente } \\
\text { (kg/L) }\end{array}$ & $\begin{array}{c}2,348 \\
(0,012)\end{array}$ & $\begin{array}{l}2,380 \\
(0,015)\end{array}$ & 0,129 \\
\hline $\begin{array}{l}\text { 3. İndice de compactabilidade com adensamento } \\
(\mathrm{cm})\end{array}$ & $\begin{array}{c}0,658 \\
(0,069)\end{array}$ & $\begin{array}{c}0,420 \\
(0,025)\end{array}$ & 0,018 \\
\hline $\begin{array}{l}\text { 4. Índice de compactabilidade sem adensamento } \\
(\mathrm{cm})\end{array}$ & $\begin{array}{c}0,742 \\
(0,042)\end{array}$ & $\begin{array}{c}0,660 \\
(0,029)\end{array}$ & 0,147 \\
\hline 5. Teor de ar pressométrico (\%) & $\begin{array}{c}3,315 \\
(0,087)\end{array}$ & $\begin{array}{c}2,850 \\
(0,019)\end{array}$ & 0,079 \\
\hline 6. Umidade (\%) & $\begin{array}{c}4,510 \\
(0,077)\end{array}$ & $\begin{array}{l}9,730 \\
(2,700)\end{array}$ & 0,142 \\
\hline $\begin{array}{l}\text { 7. Absorção de água por capilaridade }(\mathrm{g} / \mathrm{cm} 2) \text { - } \\
\text { cura acelerada } 24 / 48 \mathrm{~h}+\text { imersão em água até } 7 \\
\text { dias }\end{array}$ & $\begin{array}{c}0,558 \\
(0,016)\end{array}$ & $\begin{array}{c}0,618 \\
(0,019)\end{array}$ & 0,044 \\
\hline $\begin{array}{l}\text { 8. Absorção de água por capilaridade }(\mathrm{g} / \mathrm{cm} 2) \\
\text { cura acelerada imersa em água por } 28 \text { dias }\end{array}$ & $\begin{array}{c}0,602 \\
(0,028)\end{array}$ & $\begin{array}{c}0,630 \\
(0,020)\end{array}$ & 0,453 \\
\hline $\begin{array}{l}\text { 9. Absorção de água total (\%) - cura acelerada } \\
24 / 48 \mathrm{~h}+\text { imersão em água até } 7 \text { dias }\end{array}$ & $\begin{array}{c}5,731 \\
(0,140)\end{array}$ & $\begin{array}{c}5,618 \\
(0,170)\end{array}$ & 0,611 \\
\hline $\begin{array}{l}\text { 10. Índice de vazios (\%) - cura acelerada } 24 / 48 \mathrm{~h} \\
+ \text { imersão em água até } 7 \text { dias }\end{array}$ & $\begin{array}{l}12,905 \\
(0,260) \\
\end{array}$ & $\begin{array}{l}12,653 \\
(0,340) \\
\end{array}$ & 0,572 \\
\hline $\begin{array}{l}\text { 11. Absorção de água total (\%) - cura imersa em } \\
\text { água por } 28 \text { dias }\end{array}$ & $\begin{array}{c}5,770 \\
(0,150) \\
\end{array}$ & $\begin{array}{c}5,752 \\
(0,170) \\
\end{array}$ & 0,938 \\
\hline $\begin{array}{l}\text { 12. Índice de vazios (\%) - cura imersa em água } \\
\text { por } 28 \text { dias }\end{array}$ & $\begin{array}{l}12,979 \\
(0,300)\end{array}$ & $\begin{array}{c}12,925 \\
(0,34)\end{array}$ & 0,910 \\
\hline 13. Resistência à compressão - fc1 $(\mathrm{MPa})$ & $\begin{array}{l}17,720 \\
(0,720)\end{array}$ & $\begin{array}{l}12,070 \\
(2,300)\end{array}$ & 0,082 \\
\hline $\begin{array}{l}\text { 14. Resistência à compressão - fc1 (MPa) - cura } \\
\text { acelerada } 0 / 24 \mathrm{~h}\end{array}$ & $\begin{array}{l}26,260 \\
(1,300)\end{array}$ & $\begin{array}{l}30,840 \\
(0,550)\end{array}$ & 0,020 \\
\hline $\begin{array}{l}\text { 15. Resistência à compressão - fc7 (MPa) - cura } \\
\text { acelerada } 24 / 48 \text { h e imersão em água até } 7 \text { dias }\end{array}$ & $\begin{array}{l}30,300 \\
(0,790) \\
\end{array}$ & $\begin{array}{l}31,590 \\
(0,640) \\
\end{array}$ & 0,240 \\
\hline $\begin{array}{l}\text { 16. Resistência à compressão - fc7 (MPa) - cura } \\
\text { imersa em água por } 28 \text { dias }\end{array}$ & $\begin{array}{l}26,310 \\
(0,890)\end{array}$ & $\begin{array}{l}26,310 \\
(0,960)\end{array}$ & 0,999 \\
\hline $\begin{array}{l}\text { 17. Resistência à compressão - fc28 (MPa) - } \\
\text { cura imersa em água até } 28 \text { dias }\end{array}$ & $\begin{array}{l}31,830 \\
(1,000)\end{array}$ & $\begin{array}{l}34,600 \\
(1,500)\end{array}$ & 0,180 \\
\hline $\begin{array}{l}\text { 18. Resistência à compressão - fc63 (MPa) - } \\
\text { cura imersa em água até } 63 \text { dias }\end{array}$ & $\begin{array}{l}38,700 \\
(1,500)\end{array}$ & $\begin{array}{l}38,350 \\
(0,400)\end{array}$ & 0,826 \\
\hline
\end{tabular}




\section{APÊNDICE E}

Relatório do CEA

Tabela B.2 - Resultados das Comparações entre lote 1 e lote 2

Continuação

\begin{tabular}{|c|c|c|c|}
\hline $\begin{array}{l}\text { 19. Resistência à compressão }-f_{c} 91(\mathrm{MPa})- \\
\text { cura imersa em água até } 91 \text { dias }\end{array}$ & $\begin{array}{l}39,710 \\
(0,950)\end{array}$ & $\begin{array}{l}38,960 \\
(0,680) \\
\end{array}$ & 0,539 \\
\hline $\begin{array}{l}\text { 20. Resistência à tração por compressão } \\
\text { diametral - fct } 7 \text { (MPa) - cura acelerada } 24 / 48 \text { e } \\
\text { imersão em água até } 7 \text { dias }\end{array}$ & $\begin{array}{c}2,777 \\
(0,040)\end{array}$ & $\begin{array}{c}3,724 \\
(0,210)\end{array}$ & 0,011 \\
\hline $\begin{array}{l}\text { 21. Resistência à tração por compressão } \\
\text { diametral - fct } 28(\mathrm{MPa}) \text { - cura imersa em água } \\
\text { até } 28 \text { dias }\end{array}$ & $\begin{array}{l}3,209 \\
(0,062)\end{array}$ & $\begin{array}{c}3,000 \\
(0,140)\end{array}$ & 0,234 \\
\hline $\begin{array}{l}\text { 23. Profundidade de carbonatação por ciclagem } \\
(\mathrm{mm})\end{array}$ & $\begin{array}{c}1,610 \\
(0,480)\end{array}$ & $\begin{array}{c}2,312 \\
(0,230)\end{array}$ & 0,225 \\
\hline $\begin{array}{l}\text { 24. Profundidade de carbonatação em câmara } \\
\text { de } \mathrm{CO}_{2}(\mathrm{~mm})\end{array}$ & $\begin{array}{c}9,020 \\
(0,620) \\
\end{array}$ & $\begin{array}{c}4,740 \\
(1,400)\end{array}$ & 0,042 \\
\hline $\begin{array}{l}\text { 25. Profundidade de penetração de cloretos } \\
\text { (mm) }\end{array}$ & $\begin{array}{c}7,110 \\
(0,500)\end{array}$ & $\begin{array}{l}4,012 \\
(0,280)\end{array}$ & 0,001 \\
\hline
\end{tabular}


Tabela B.3 - Medidas descritivas das variáveis.

\begin{tabular}{|c|c|c|c|}
\hline Variável & Lote & Média & $\begin{array}{l}\text { Desvio } \\
\text { Padrão }\end{array}$ \\
\hline \multirow{3}{*}{$\begin{array}{l}\text { 1. Abatimento de tronco de } \\
\text { cone }(\mathrm{cm})\end{array}$} & Lote 1 & 12,000 & 2,740 \\
\hline & Lote 2 & 9,500 & 1,146 \\
\hline & Lote Trein. & 9,933 & 1,253 \\
\hline \multirow{3}{*}{$\begin{array}{l}\text { 2. Densidade de massa } \\
\text { especifica aparente }(\mathrm{kg} / \mathrm{L})\end{array}$} & Lote 1 & 2,348 & 0,028 \\
\hline & Lote 2 & 2,38 & 0,033 \\
\hline & Lote Trein. & 2,313 & 0,016 \\
\hline \multirow{3}{*}{$\begin{array}{l}\text { 3. Índice de compactabilidade } \\
\text { com adensamento }(\mathrm{cm})\end{array}$} & Lote 1 & 0,658 & 0,169 \\
\hline & Lote 2 & 0,420 & 0,057 \\
\hline & Lote Trein. & 0,358 & 0,102 \\
\hline \multirow{3}{*}{$\begin{array}{l}\text { 4. Índice de compactabilidade } \\
\text { sem adensamento }(\mathrm{cm})\end{array}$} & Lote 1 & 0,742 & 0,102 \\
\hline & Lote 2 & 0,660 & 0,065 \\
\hline & Lote Trein. & 0,358 & 0,102 \\
\hline \multirow{3}{*}{$\begin{array}{l}\text { 5. Teor de ar pressometrico } \\
(\%)\end{array}$} & Lote 1 & 3,315 & 0,213 \\
\hline & Lote 2 & 2,850 & 0,432 \\
\hline & Lote Trein. & * & * \\
\hline \multirow{3}{*}{ 6. Umidade (\%) } & Lote 1 & 4,513 & 1,883 \\
\hline & Lote 2 & 9,730 & 6,150 \\
\hline & Lote Trein. & * & * \\
\hline \multirow{3}{*}{$\begin{array}{l}\text { 7. Absorção de água por } \\
\text { capilaridade }(\mathrm{g} / \mathrm{cm} 2) \text { - cura } \\
\text { acelerada } 24 / 48 \mathrm{~h}+\text { imersão } \\
\text { em água até } 7 \text { dias }\end{array}$} & Lote 1 & 0,558 & 0,040 \\
\hline & Lote 2 & 0,618 & 0,043 \\
\hline & Lote Trein. & * & * \\
\hline \multirow{3}{*}{$\begin{array}{l}\text { 8. Absorção de água por } \\
\text { capilaridade }(\mathrm{g} / \mathrm{cm} 2) \text { - cura } \\
\text { acelerada imersa em água por } \\
28 \text { dias }\end{array}$} & Lote 1 & 0,603 & 0,069 \\
\hline & Lote 2 & 0,630 & 0,044 \\
\hline & Lote Trein. & 0,745 & 0,055 \\
\hline \multirow{3}{*}{$\begin{array}{l}\text { 9. Absorção de água total (\%) } \\
\text { - cura acelerada } 24 / 48 \text { h + } \\
\text { imersão em água até } 7 \text { dias }\end{array}$} & Lote 1 & 5,731 & 0,331 \\
\hline & Lote 2 & 5,618 & 0,370 \\
\hline & Lote Trein. & 5,217 & 0,107 \\
\hline \multirow{3}{*}{$\begin{array}{l}\text { 10. Índice de vazios (\%) - cura } \\
\text { acelerada } 24 / 48 \text { h + imersão } \\
\text { em água até } 7 \text { dias }\end{array}$} & Lote 1 & 12,905 & 0,644 \\
\hline & Lote 2 & 12,653 & 0,750 \\
\hline & Lote Trein. & 11,717 & 0,204 \\
\hline \multirow{2}{*}{$\begin{array}{l}\text { 11. Absorção de água total } \\
\text { (\%) - cura imersa em água por }\end{array}$} & Lote 1 & 5,770 & 0,368 \\
\hline & Lote 2 & 5,752 & 0,370 \\
\hline
\end{tabular}


Tabela B.3 - Medidas descritivas das variáveis.

\begin{tabular}{|c|c|c|c|}
\hline & & \multicolumn{2}{|c|}{ Continuaçãc } \\
\hline \multirow{3}{*}{$\begin{array}{l}\text { 12. Índice de vazios (\%) - cura } \\
\text { imersa em água por } 28 \text { dias }\end{array}$} & Lote 1 & 12,979 & 0,745 \\
\hline & Lote 2 & 12,925 & 0,765 \\
\hline & Lote Trein. & 11,353 & 0,381 \\
\hline \multirow{3}{*}{$\begin{array}{l}\text { 13. Resistência à compressão } \\
\text { - fc1 (MPa) }\end{array}$} & Lote 1 & 17,725 & 1,763 \\
\hline & Lote 2 & 12,070 & 5,220 \\
\hline & Lote Trein. & * & * \\
\hline \multirow{3}{*}{$\begin{array}{l}\text { 14. Resistência à compressão } \\
\text { - fc1 (MPa) - cura acelerada } \\
0 / 24 \mathrm{~h}\end{array}$} & Lote 1 & 26,260 & 3,280 \\
\hline & Lote 2 & 30,840 & 1,240 \\
\hline & Lote Trein. & * & * \\
\hline \multirow{3}{*}{$\begin{array}{l}\text { 15. Resistência à compressão } \\
\text { - fc7 (MPa) - cura acelerada } \\
24 / 48 \mathrm{~h} \text { e imersão em água } \\
\text { até } 7 \text { dias }\end{array}$} & Lote 1 & 30,300 & 1,941 \\
\hline & Lote 2 & 31,590 & 1,423 \\
\hline & Lote Trein. & 31,792 & 2,134 \\
\hline \multirow{3}{*}{$\begin{array}{l}\text { 16. Resistência à compressão } \\
\text { - fc7 (MPa) - cura imersa em } \\
\text { água por } 7 \text { dias }\end{array}$} & Lote 1 & 26,308 & 2,176 \\
\hline & Lote 2 & 26,310 & 2,140 \\
\hline & Lote Trein. & * & * \\
\hline
\end{tabular}

\begin{tabular}{|c|c|c|c|}
\hline \multicolumn{4}{|c|}{20} \\
\hline \multirow{3}{*}{$\begin{array}{l}\text { 17. Resistência à compressão } \\
\text { - fc28 (MPa) - cura imersa em } \\
\text { água até } 28 \text { dias }\end{array}$} & Lote 1 & 31,830 & 2,530 \\
\hline & Lote 2 & 34,600 & 3,450 \\
\hline & Lote Trein. & 35,480 & 3,670 \\
\hline \multirow{3}{*}{$\begin{array}{l}\text { 18. Resistência à compressão } \\
\text { - fc63 (MPa) - cura imersa em } \\
\text { água até } 63 \text { dias }\end{array}$} & Lote 1 & 38,700 & 3,560 \\
\hline & Lote 2 & 38,350 & 0,884 \\
\hline & Lote Trein. & * & * \\
\hline \multirow{3}{*}{$\begin{array}{l}\text { 19. Resistência à compressão } \\
\text { - fc } 91(\mathrm{MPa}) \text { - cura imersa } \\
\text { em água até } 91 \text { dias }\end{array}$} & Lote 1 & 39,708 & 2,324 \\
\hline & Lote 2 & 38,960 & 1,518 \\
\hline & Lote Trein. & * & * \\
\hline \multirow{3}{*}{$\begin{array}{l}\text { 20. Resistência à tração por } \\
\text { compressão diametral - fct } 7 \\
\text { (MPa) - cura acelerada } 24 / 48\end{array}$} & Lote 1 & 2,777 & 0,098 \\
\hline & Lote 2 & 3,724 & 0,460 \\
\hline & Lote Trein. & 3,613 & 0,146 \\
\hline \multirow{3}{*}{$\begin{array}{l}\text { 21. Resistência à tração por } \\
\text { compressão diametral - fct } 28 \\
\text { (MPa) - cura imersa em água } \\
\text { até } 28 \text { dias }\end{array}$} & Lote 1 & 3,209 & 0,153 \\
\hline & Lote 2 & 3,000 & 0,316 \\
\hline & Lote Trein. & 3,405 & 0,355 \\
\hline
\end{tabular}

Continua

20 As propriedades marcadas com * não foram medidas. No caso do lote treinamento, o asterisco (*) é referente às seguintes: umidade, compactabilidade sem adensamento (o CEA por engano aplicou os valores da propriedade 3), absorção de água por capilaridade a 7 dias com cura acelerada, resistências à compressão a 1 dia e resistência à compressão a 63 dias, resistência à tração por compressão diametral a 91 dias e o teor de ar pelo método gravimétrico (medido apenas para 3 dos 6 caminhões e por isto esta propriedade foi considerada posteriormente pelo CEA apenas na Tabela B4-2). Para o lote 1, o asterisco (*) diz respeito apenas à resistência à tração por compressão diametral a 91 dias. 


\begin{tabular}{|c|c|c|c|}
\hline \multirow{3}{*}{$\begin{array}{l}\text { 22. Resistência à tração por } \\
\text { compressão diametral - fct } 91 \\
\text { (MPa) - cura imersa em água } \\
\text { até } 91 \text { dias }\end{array}$} & Lote 1 & * & * \\
\hline & Lote 2 & 3,990 & 0,653 \\
\hline & Lote Trein. & * & * \\
\hline $\begin{array}{l}\text { 23. Profundidade de } \\
\text { carbonatação por ciclagem } \\
(\mathrm{mm})\end{array}$ & $\begin{array}{l}\text { Lote } 1 \\
\text { Lote } 2 \\
\text { Lote Trein. }\end{array}$ & $\begin{array}{l}1,610 \\
2,312 \\
*\end{array}$ & $\begin{array}{l}1,168 \\
0,506 \\
\star\end{array}$ \\
\hline $\begin{array}{l}\text { 24. Profundidade de } \\
\text { carbonatação em câmara de } \\
\text { CO2 }(\mathrm{mm})\end{array}$ & $\begin{array}{c}\text { Lote } 1 \\
\text { Lote } 2 \\
\text { Lote Trein. }\end{array}$ & $\begin{array}{l}9,019 \\
4,740 \\
8,090 \\
\end{array}$ & $\begin{array}{l}1,526 \\
3,220 \\
4,480 \\
\end{array}$ \\
\hline $\begin{array}{l}\text { 25. Profundidade de } \\
\text { penetração de cloretos }(\mathrm{mm})\end{array}$ & $\begin{array}{l}\text { Lote } 1 \\
\text { Lote } 2 \\
\text { Lote Trein. }\end{array}$ & $\begin{array}{l}7,108 \\
4,012 \\
3,830\end{array}$ & $\begin{array}{l}1,227 \\
0,634 \\
1,944\end{array}$ \\
\hline
\end{tabular}


Tabela B4-1. Matriz das correlações entre dois lotes de diferentes centrais dosadoras (Lotes 1 e 2)

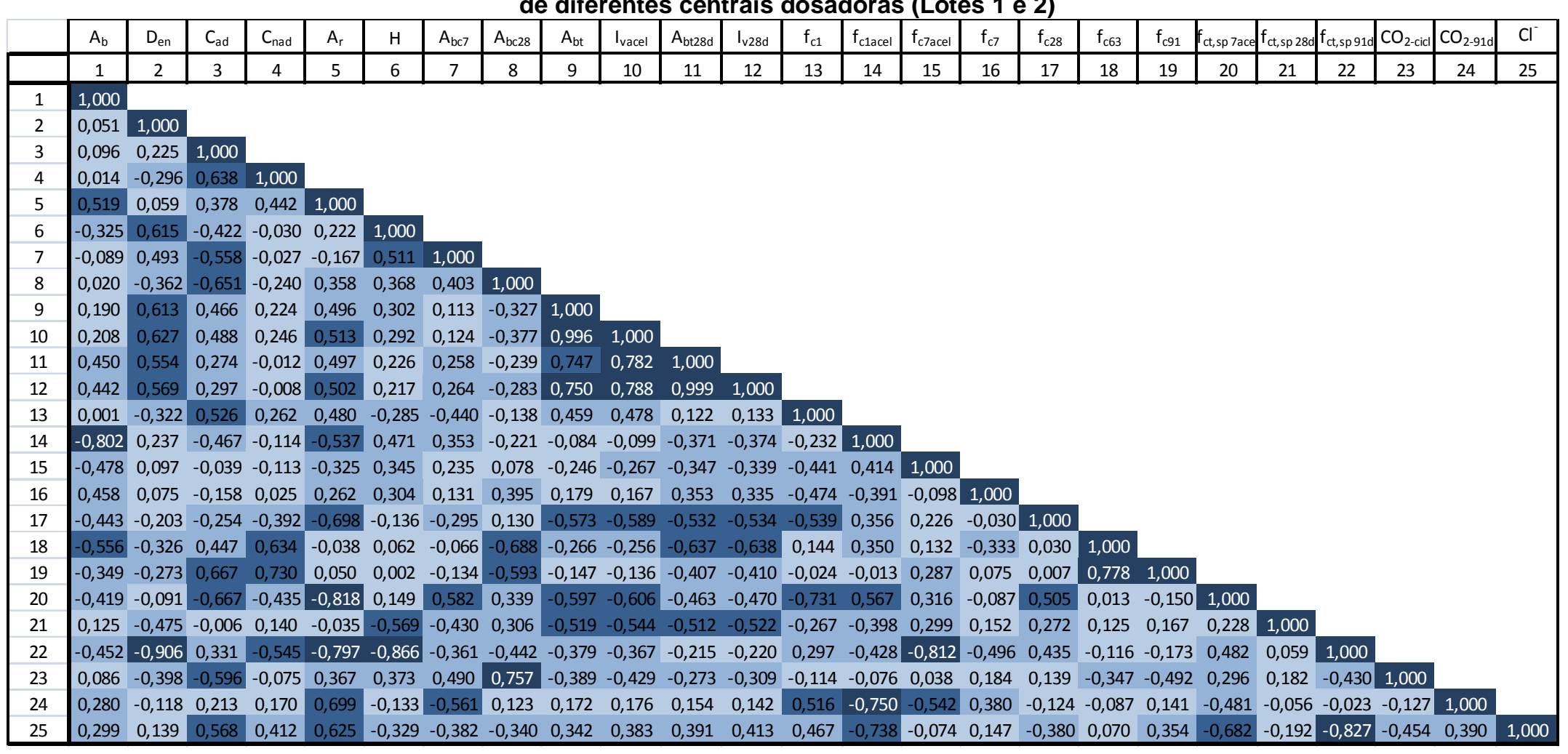


Tabela B4-2. Matriz das correlações entre os três lotes

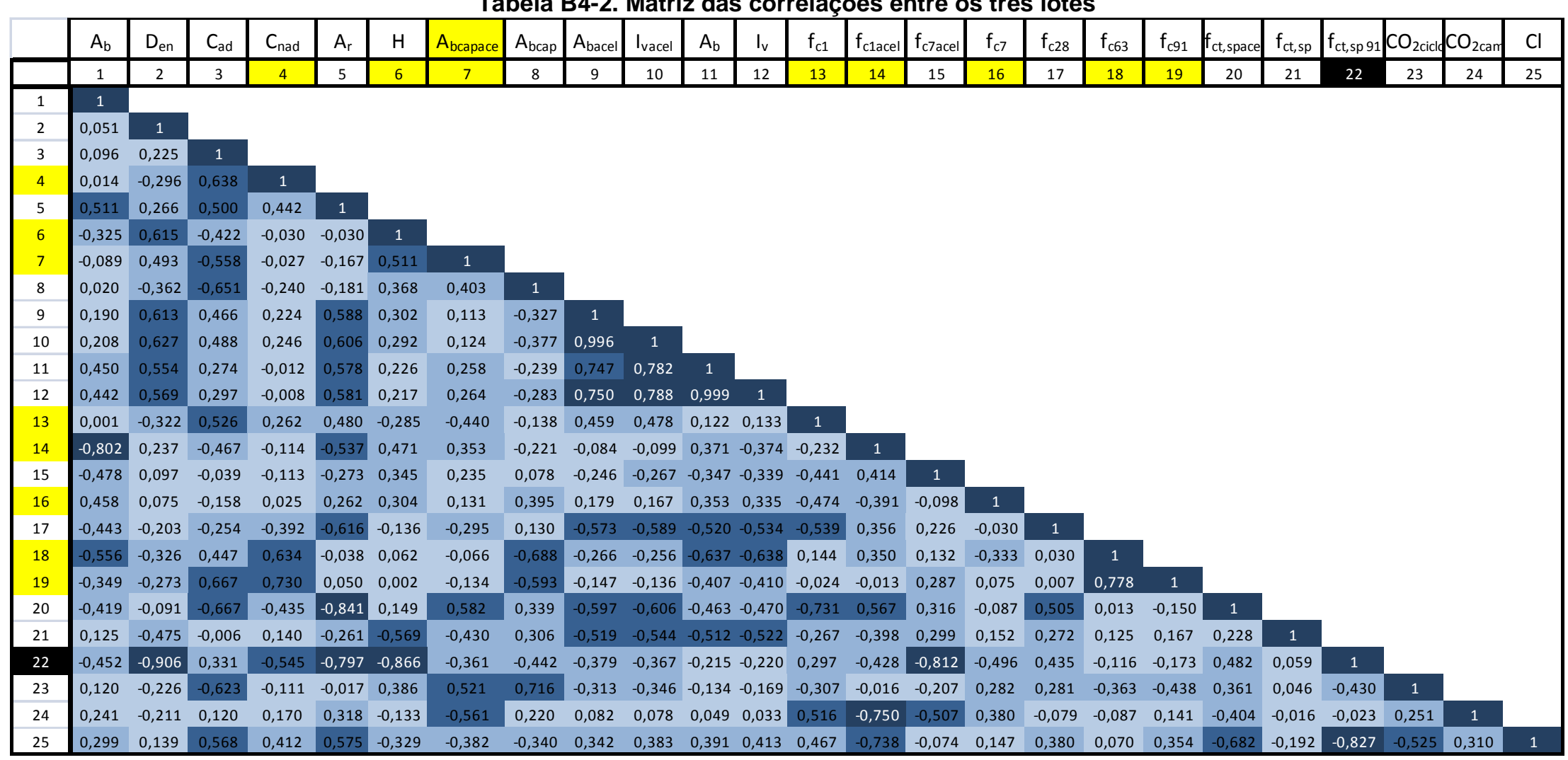

21

21 As células de identificação e de numeração das propriedades em cor branca dizem respeito a propriedades analisadas para os três lotes (1, 2 e treinamento); As células de identificação e de numeração das propriedades em cor amarela, ou seja as de número 4, 6, 7, 13,14,16, 18 e 19, dizem respeito a correlações analisadas apenas para os dois lotes principais do trabalho $(1,2)$, pois não foram medidas no lote treinamento; A propriedade 22 , indicada pelas células de ordem da matriz assinaladas em preto, foi analisada apenas para o lote 2 e isto em parte explica os valores de forte correlação que apresentou com as demais propriedades 


\section{ANEXO A \\ Caracterização das obras que participaram do estudo}

A seguir é apresentada a caracterização das estruturas de concreto armado das obras selecionadas para o estudo.

Edifício Residencial Chateau de Montparnasse - Lote treinamento e lote 1

i. Endereço: Rua Poeta Geraldo Alverga com rua João B. Fernandes Oceania IV - Bessa ( próximo ao aeroclube - 400 metros do mar)

ii. Projeto Estrutural: Tecncon - Tecnologia do Concreto e Engenharia Ltda.

iii. Construtora: HEMA LTDA

iv. Pavimentos: Duas torres com 17 pavimentos, estando a estrutura de uma já concluída.

v. Resistência característica à compressão do concreto nos pavimentos tipos $f_{c k}: 30 \mathrm{MPa}$

vi. Classe de agressividade ambiental: III (zona de atmosfera marinha)

vii. Relação água/cimento: $\leq 0,55$

viii. Dados relativos às armaduras

a) Aços: Aço CA 50 e aço CA 60

b) Marca do aço: Companhia Siderúrgica Belgo Mineira

c) Fábrica de procedência: Companhia Siderúrgica Belgo Mineira

d) Fornecedora da obra: O Vergalhão Materiais de Construção

i. Cobrimentos:

- Fundação: 3,0 cm

- Pilares: $3,5 \mathrm{~cm}$

- Vigas: $3,5 \mathrm{~cm}$

- Lajes: $3,0 \mathrm{~cm}$

- Escada: 2,5 cm

- Reservatório elevado: $3,0 \mathrm{~cm}$

ii. Tipo de lançamento: por bombeamento

iii. Abatimento de tronco de cone, NBR NM 067: $10 \pm 2 \mathrm{~cm}$ 


\begin{abstract}
ANEXO A
Caracterização das obras que participaram do estudo

iv. Tipo de adensamento: por vibradores de imersão

v. Fornecedora de concreto: Polimix

vi. Data da concretagem dos lotes em estudo: 7/11/08 (6ำ pavimento tipo - Lote treinamento) para treinamento da equipe e 14/01/2009 (10 pavimento tipo - Lote 1$)$
\end{abstract}

Nas Figuras 110 (a) e (b) são apresentados os desenhos do corte esquemático e planta baixa do pavimento tipo da Obra 1, respectivamente. 


\section{ANEXO A}

Caracterização das obras que participaram do estudo

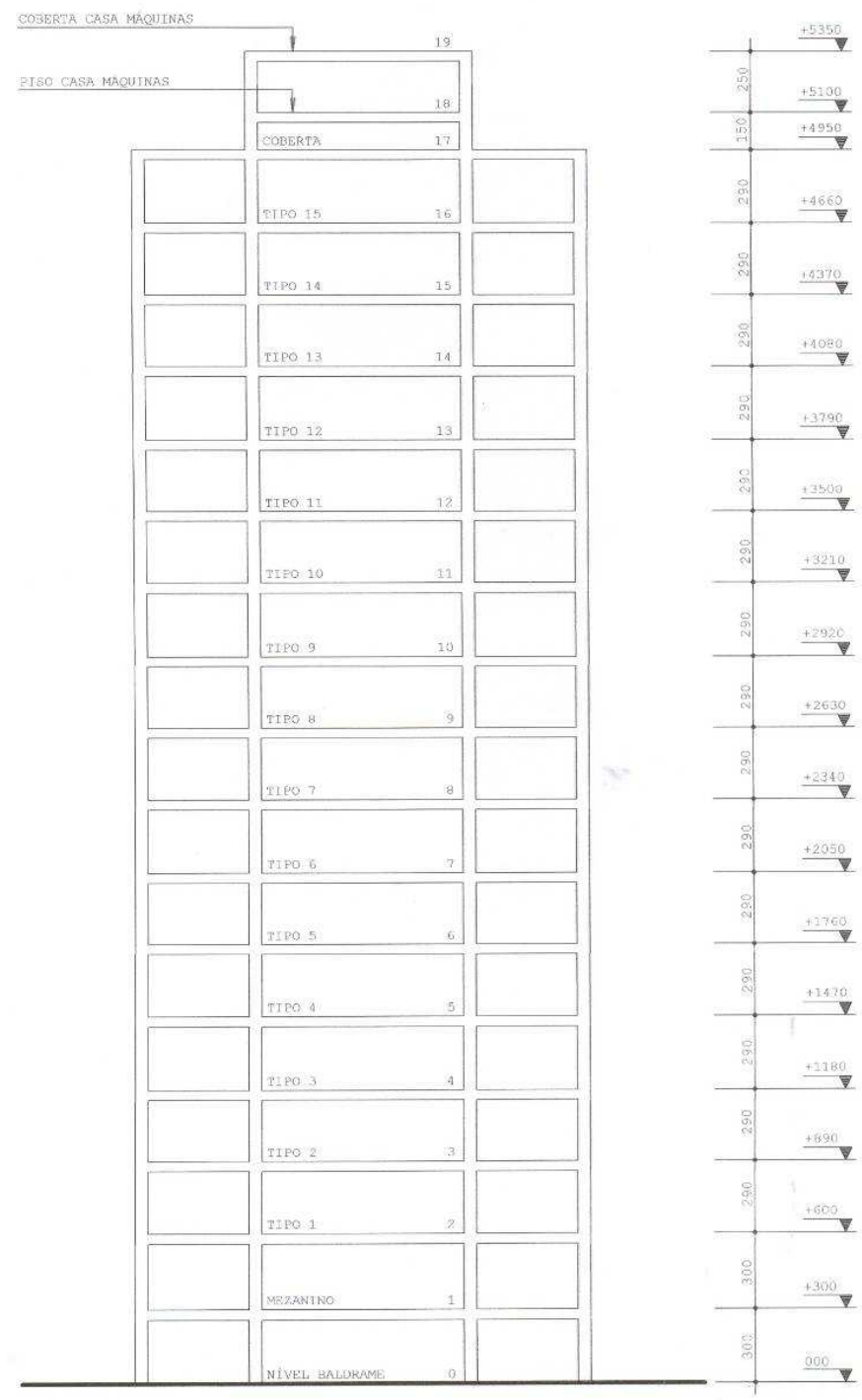

(a) 


\section{ANEXO A}

Caracterização das obras que participaram do estudo

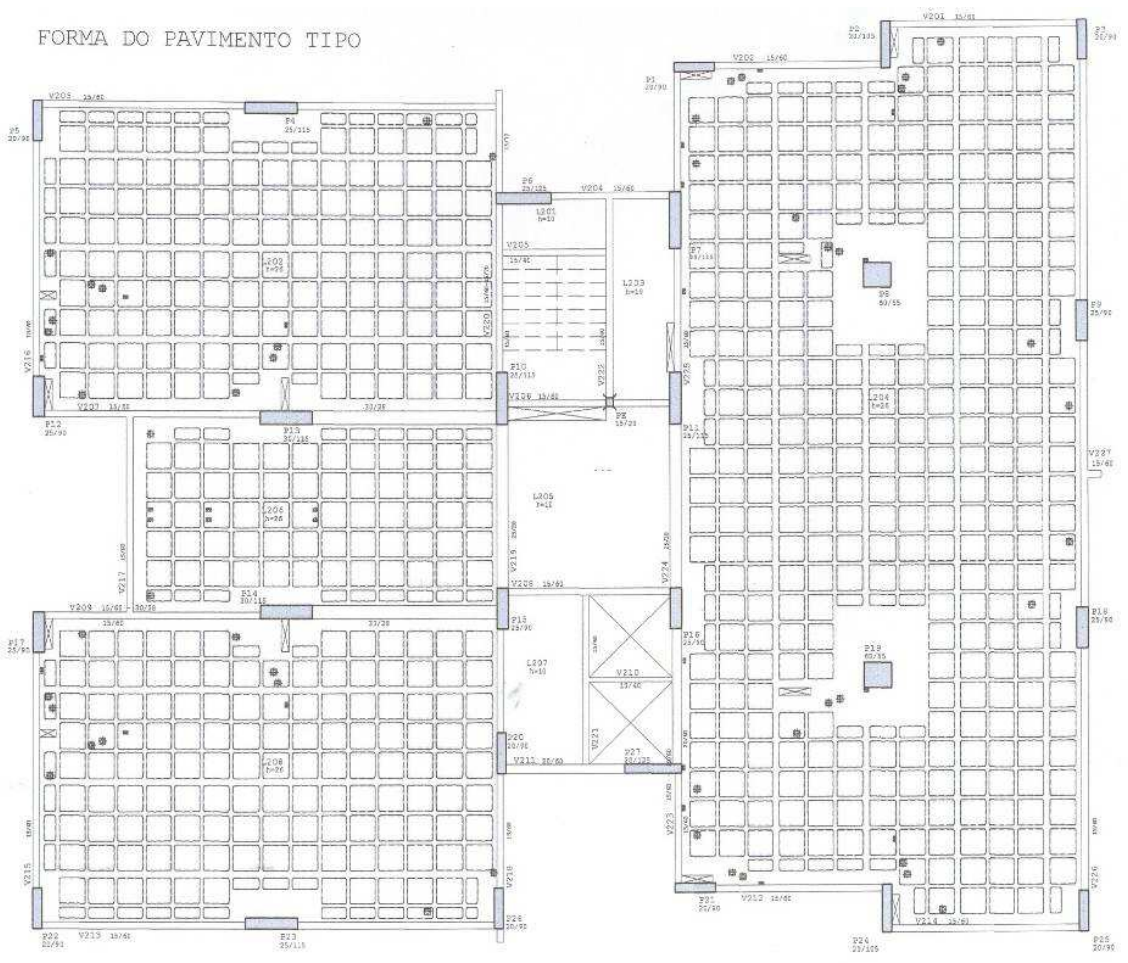

(b)

Figura 110- (a) Corte esquemático da obra 1; (b) Planta baixa do pavimento-tipo da obra 1

\section{Obra 2- Edifício Alameda}

1) Endereço: Rua Helena Meira Lima - Tambaú (800 metros do mar);

2) Projeto estrutural: Tecncon - Tecnologia do Concreto e Engenharia Ltda;

3) Construtora: ENGER ENGENHARIA DA CONSTRUÇÃO LTDA;

4) Pavimentos: Uma torre com 19 pavimentos;

5) Resistência característica à compressão do concreto nos pavimentos tipos $\mathrm{f}_{\mathrm{ck}}$ : 30 e $35 \mathrm{MPa}$ (Fundações);

6) Classe de agressividade ambiental: classe III (zona de atmosfera marinha);

7) Relação água/cimento: $\leq 0,55$;

8) Dados relativos à armadura: 


\section{ANEXO A}

\section{Caracterização das obras que participaram do estudo}

a) Aços: Aço CA 50 e aço CA 60;

b) Marca do aço: Companhia Siderúrgica Belgo Mineira;

c) Fabrica da procedência: Companhia Siderúrgica Belgo Mineira;

d) Fornecedora da obra: O Vergalhão Materiais de Construção;

e) Cobrimentos:

- Fundação: 3,0 cm;

- Pilares: $3,5 \mathrm{~cm}$;

- Vigas: $3,5 \mathrm{~cm}$;

- Lajes: 3,0 cm;

- Escada: 2,5 cm;

- Reservatório elevado: 3,0 cm;

9) Tipo de lançamento: por bombeamento;

10) Abatimento de tronco de cone NBR NM 067: $10 \pm 1 \mathrm{~cm}$;

11) Tipo de Adensamento: por vibrador de imersão;

12) Fornecedora de concreto: Cimpor Concreto;

13) Data da concretagem do lote em estudo: $27 / 11 / 2008$ (Laje do Mezanino);

14) Controle tecnológico: Tecncon - Tecnologia do Concreto e Engenharia Ltda. Resultado dos últimos cinco lotes consta no anexo $\mathrm{C}$. 
Nas Figuras 111 (a) e (b) são apresentados o corte esquemático e planta baixa do pavimento-tipo da obra 2 respectivamente.

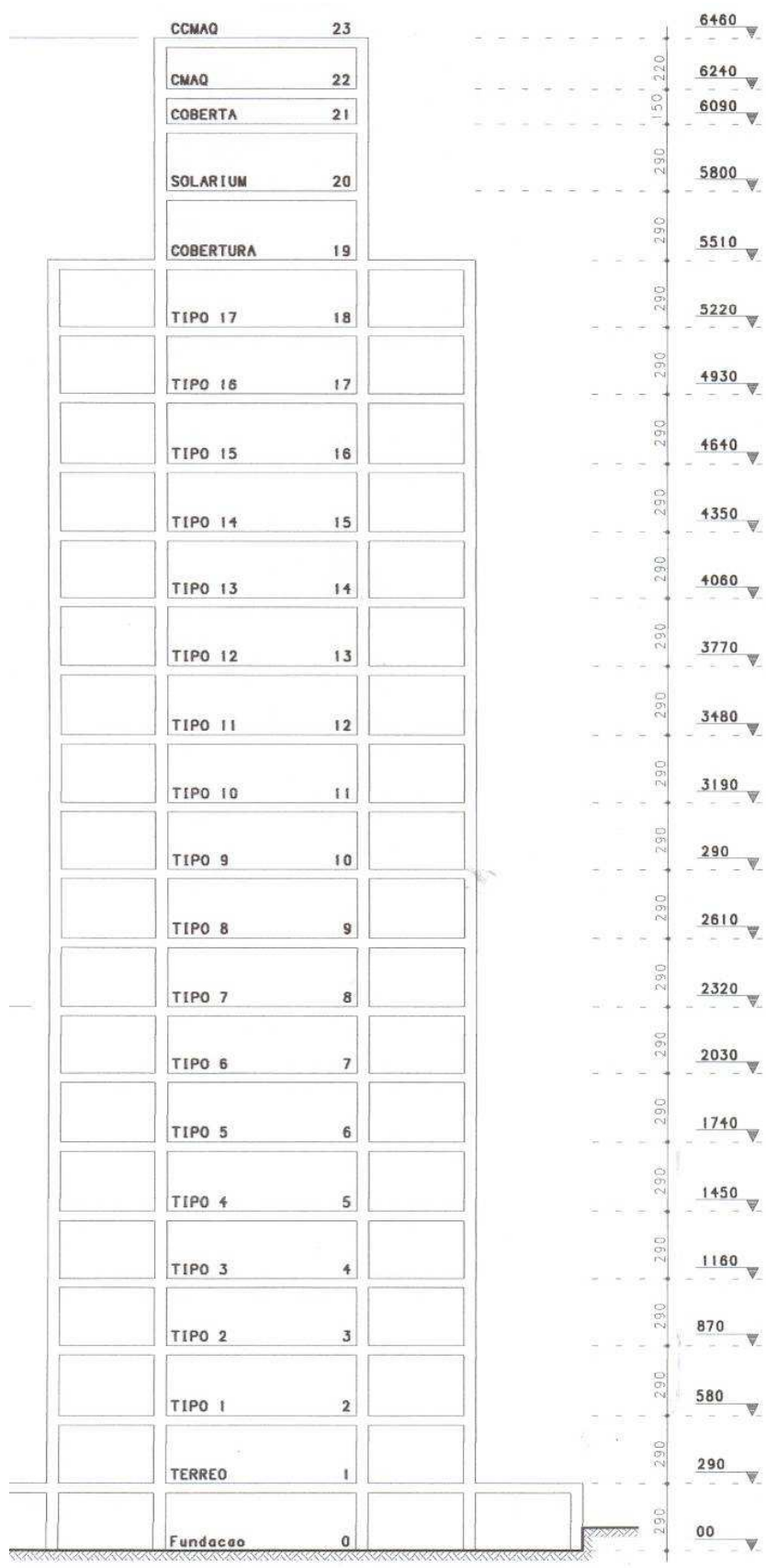

(a) 


\section{ANEXO A}

\section{Caracterização das obras que participaram do estudo}

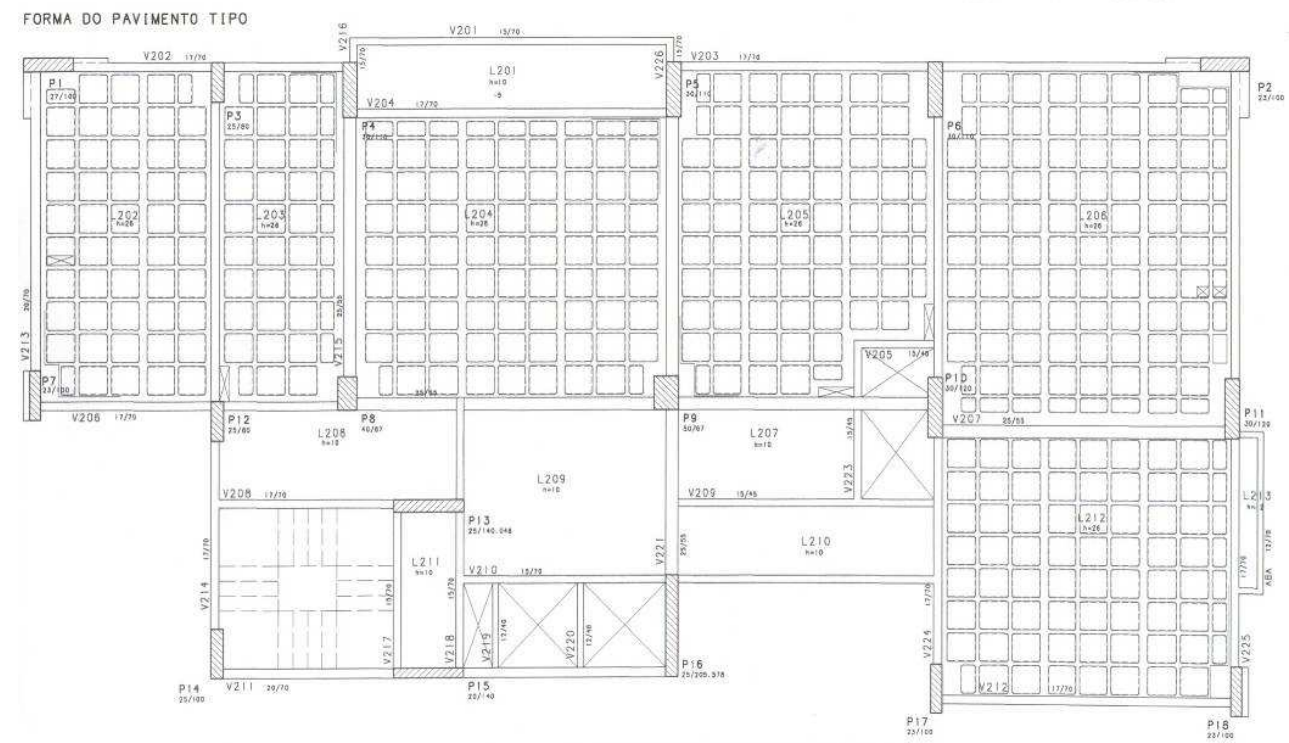

(b)

Figura 111 - (a) Corte esquemático da obra 2; (b) Planta Baixa do pavimento tipo da obra 2 